Biogeochemical Characterization of a Wetland Impacted by Alkaline Mine Tailings Located in North Cobalt, Ontario

\author{
Submitted by \\ Jenifer Kelly, B.Eng.
}

A thesis submitted to the Faculty of Graduate

Studies and Research in partial fulfillment of the requirements for the degree of Master of Science

Department of Earth Sciences

\author{
Carleton University \\ Ottawa, Ontario
}

January 2006

(a) copyright

2006, Jenifer Kelly 


$\begin{array}{ll}\begin{array}{l}\text { Library and } \\ \text { Archives Canada }\end{array} & \begin{array}{l}\text { Bibliothèque et } \\ \text { Archives Canada }\end{array} \\ \begin{array}{l}\text { Published Heritage } \\ \text { Branch }\end{array} & \begin{array}{l}\text { Direction du } \\ \text { Patrimoine de l'édition }\end{array} \\ \begin{array}{l}\text { 395 Wellington Street } \\ \text { Ottawa ON K1A ON4 }\end{array} & \begin{array}{l}\text { 395, rue Wellington } \\ \text { Ottawa ON K1A ON4 } \\ \text { Canada }\end{array}\end{array}$

Your file Votre référence

ISBN: 0-494-13467-4

Ourfile Notre référence

ISBN: 0-494-13467-4

NOTICE:

The author has granted a nonexclusive license allowing Library and Archives Canada to reproduce, publish, archive, preserve, conserve, communicate to the public by telecommunication or on the Internet, loan, distribute and sell theses worldwide, for commercial or noncommercial purposes, in microform, paper, electronic and/or any other formats.

The author retains copyright ownership and moral rights in this thesis. Neither the thesis nor substantial extracts from it may be printed or otherwise reproduced without the author's permission.
AVIS:

L'auteur a accordé une licence non exclusive permettant à la Bibliothèque et Archives Canada de reproduire, publier, archiver, sauvegarder, conserver, transmettre au public par télécommunication ou par l'Internet, prêter, distribuer et vendre des thèses partout dans le monde, à des fins commerciales ou autres, sur support microforme, papier, électronique et/ou autres formats.

L'auteur conserve la propriété du droit d'auteur et des droits moraux qui protège cette thèse. $\mathrm{Ni}$ la thèse ni des extraits substantiels de celle-ci ne doivent être imprimés ou autrement reproduits sans son autorisation.
In compliance with the Canadian

Privacy Act some supporting forms may have been removed from this thesis.

While these forms may be included in the document page count, their removal does not represent any loss of content from the thesis.
Conformément à la loi canadienne sur la protection de la vie privée, quelques formulaires secondaires ont été enlevés de cette thèse.

Bien que ces formulaires aient inclus dans la pagination, il n'y aura aucun contenu manquant.

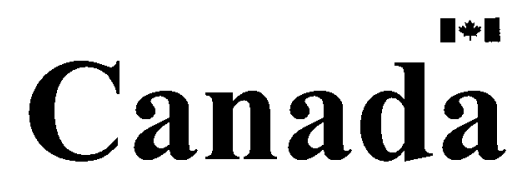




\section{ABSTRACT}

The wetland area studied in the Farr Creek drainage basin in North Cobalt is entirely floored with alkaline mine tailings containing elevated concentration levels of metals including $\mathrm{As}, \mathrm{Co}, \mathrm{Cu}, \mathrm{Zn}, \mathrm{Pb}$, and $\mathrm{Sb}$. The results from this study clearly indicate that this wetland is a net sink for metals, with over $75 \%$ (by mass) of the metals being retained in the sediments. Also, up to $25 \%$ (by mass) of the metals were retained in the leaves of Typha latfolia. Both oxidizing and reducing bacteria were quantified throughout the wetland and it was found that both types of bacteria were prevalent throughout the wetland at similar population levels. This would suggest that both oxic and anoxic geochemical processes are prevalent throughout this system. It is likely that the presence of localized oxic zones in the vicinity of root zones of Typha latfolia, supported the APB populations observed. The sequentially extracted metals (SEM) results indicated that much of the metals retained in the sediments are associated with the residual and organic matter $(\mathrm{OM})$ fractions. These results have highlighted the geochemical processes prevalent in Alkaline drainage systems which are quite different from those observed in acid drainage systems. These results indicate the importance in considering both the geochemical conditions of the wetland or system being used to treat the mine drainage, as well as to have a detailed understanding of the metals of concern within the mining waste because different metals will have different geochemical interactions based on redox conditions, presence of sulfides, Fe and $\mathrm{Mn}$ oxides, and organic matter. 


\section{ACKNOWLEDGEMENTS}

I would like to extend thanks to my supervisors, Dr. Fred Michel and Dr. Pascale Champagne for their guidance, supervision and support throughout this project. I would also like to thank Dr. Nimal De Silva for conducting my metals analysis in such a timely fashion and Lyne Lortie and Doug Gould of CANMET who helped me a great deal with my microbiological analyses.

This project was funded by NSERC Discovery Grant (through Dr. Pascale Champagne) and Natural Resources Canada by providing direct and in-kind funding contributions. 


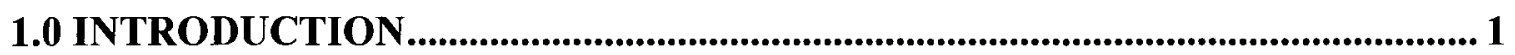

1.1 Study Area

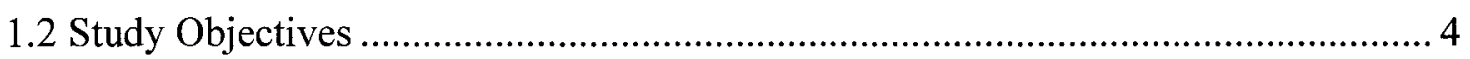

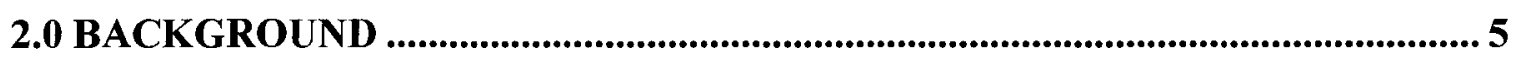

2.1 Literature Review...................................................................................... 5

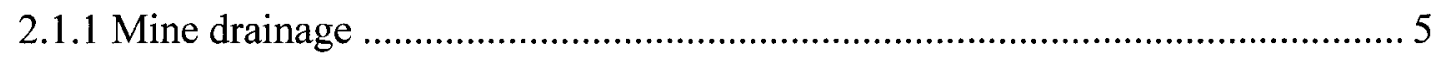

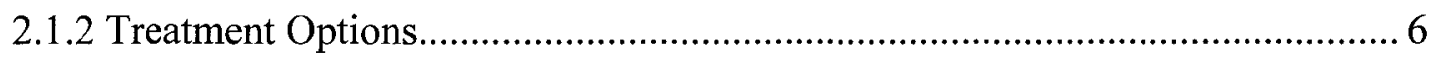

2.1.3 Geochemical Processes in Freshwater Aquatic Environments .......................... 7

2.1.4 Previous Studies on the Use of Wetlands for Treating NAMD ...................... 13

2.2 Site Background Information.......................................................................... 19

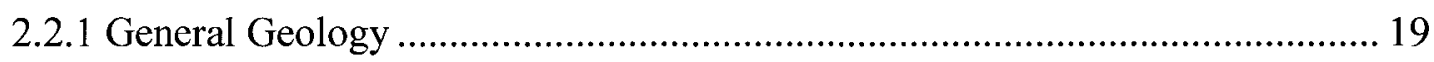

2.2.2 Silver Vein Occurrence and Geochemistry................................................... 20

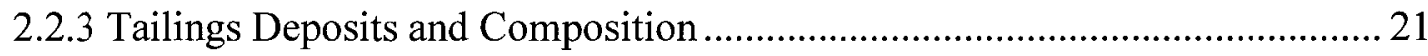

2.2.4 Farr Creek Tailings Deposit Geochemistry .................................................... 39

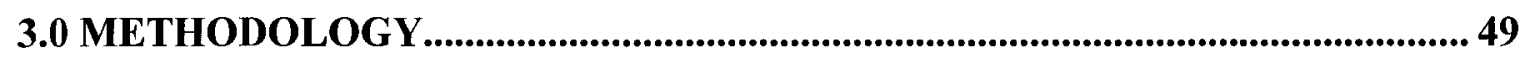

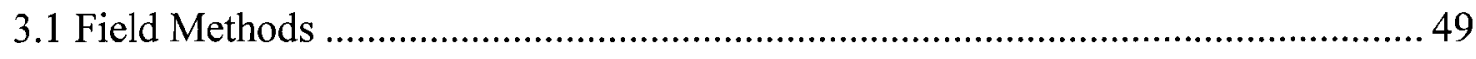

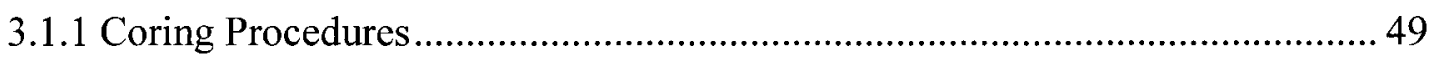

3.1.2 Monitoring Well Installation and Sampling.................................................. 52

3.1.3 Surface Water Sampling and Flow Measurement........................................... 54

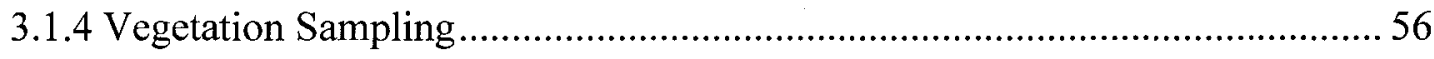

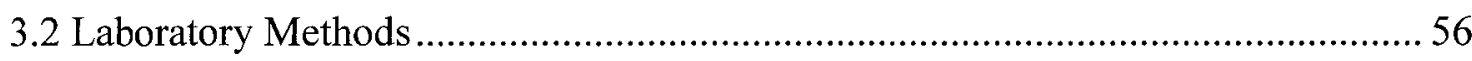


3.2.1 Water Contents and Organic Matter Determinations................................... 56

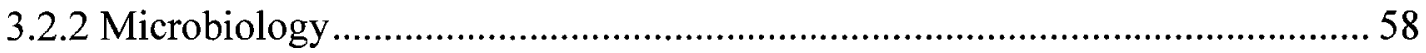

3.2.3 Acid Volatile Sulfides (AVS) and Chromium Reducible Sulfides (CRS)

Sequential Extraction Procedure ...................................................................6 60

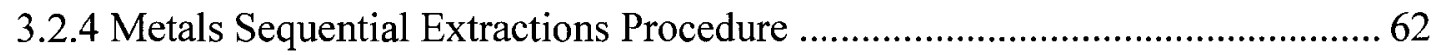

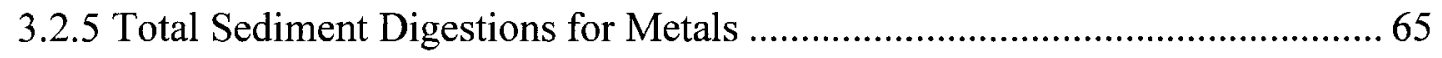

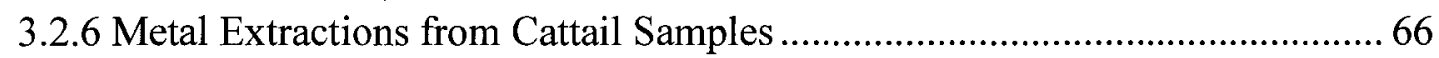

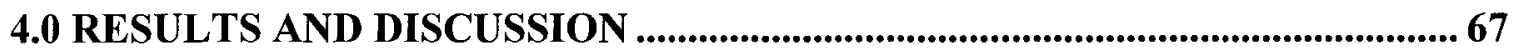

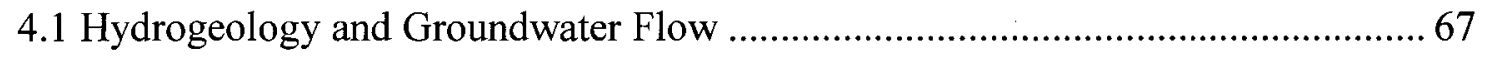

4.2 Sediment Metal Concentrations, Organic Matter and Water Contents.................. 71

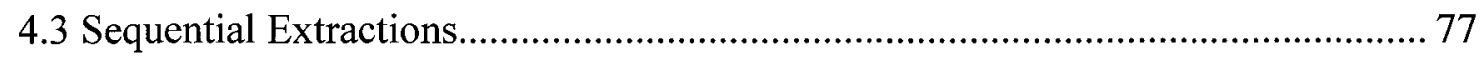

4.4 Acid Volatile Sulfides (AVS) and Chromium Reducible Sulfides (CRS)

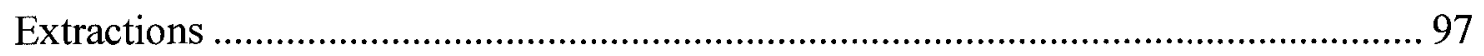

4.5 Porewater Metal Concentrations ............................................................ 100

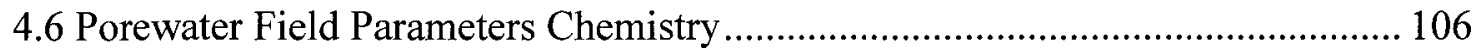

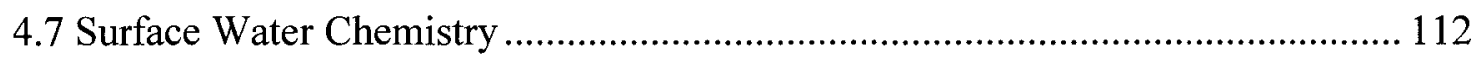

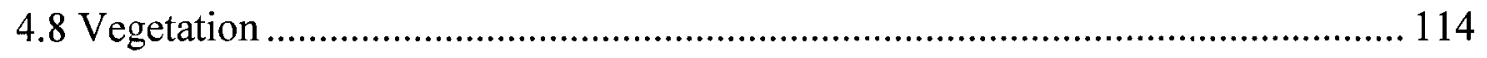

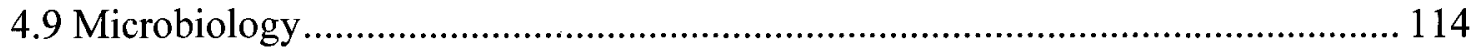

4.10 Mass distribution of metals between phases ............................................... 119

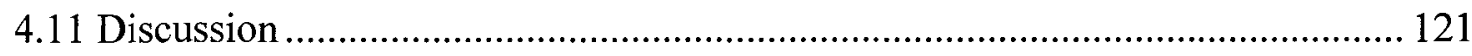

5.0 GEOCHEMICAL SPECIATION MODELLING ......................................... 126

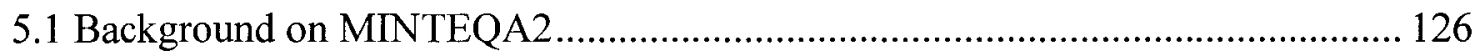

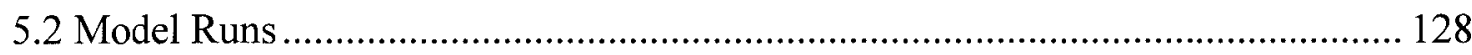




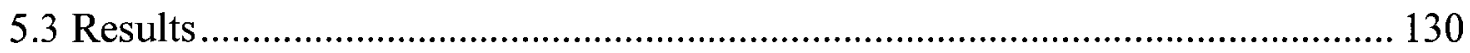

5.3.1 Modeled Runs without Adsorption ............................................................ 130

5.3.2 Modeled runs with Adsorption ................................................................ 132

5.4 Discussion of Modeling Results from Each Core Location.................................... 133

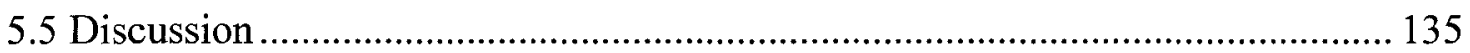

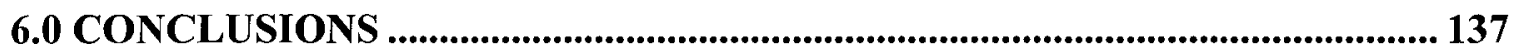

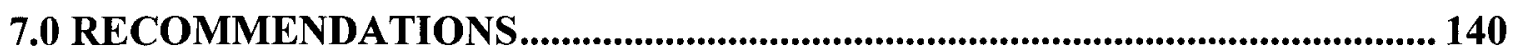

8.0 REFERENCES........................................................................................................... 142

\section{APPENDICES}

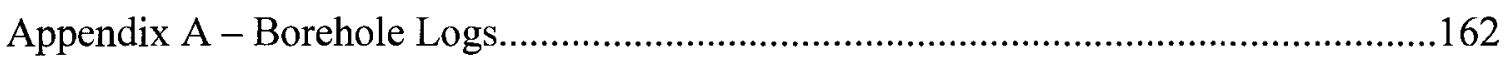

Appendix B - Summary of Field and Laboratory Chemical Analysis Results............165

Appendix C - Modeling Results Raw Data........................................212 


\section{LIST OF TABLES}

Table 2-1: Oxidation of Organic Compounds (Chemoorganotrophs, All Heterotrophs) (Morel and Hering, 1993).

Table 2-2: Ore-bearing minerals in Cobalt Veins (Petruk, 1971b and Boyle and Dass, 1971).

Table 2-3: Vein Composition from Cobalt Area (Petruk, 1071b).................................23

Table 2-4: Average metal concentrations in native bedrock units from the Cobalt area (Boyle et al., 1967).

Table 2-5: Trace metal concentrations in tailings samples collected from the Cobalt area (taken from Dumaresq, 1993).

Table 2-6: Major components from core samples collected from Farr Creek and Mill Creek (Percival et al., 2004).

Table 2-7: Trace metal concentrations from core samples collected from Farr Creek and Mill Creek (Percival et al., 2004).

Table 2-8: Trace metal concentrations from core pore water samples collected from Farr Creek and Mill Creek (Percival et al., 2004).....

Table 2-9: Trace metal concentrations from surface water samples collected from Farr Creek and Mill Creek (Percival et al., 2004).................................................................36

Table 2-10: Anion concentrations from surface water samples collected from Farr Creek and Mill Creek (Percival et al., 2004).

Table 2-11: Maximum allowable concentrations (MAC) for Ni based on water hardness (taken from Dumaresq, 1993).

Table 4-1: Sediment metal concentrations for June and September 2004 cores using aqua regia digestions and ICP MS.

Table 4-2: Porewater dissolved metals concentrations. 101

Table 4-3: Monitoring wells groundwater field chemistry. 107

Table 4-4: Surface water chemistry for selected parameters. 113

Table 4-5: Extracted metal concentrations from cattail samples. 115

viii 
Table 4-6: Mass Distribution of heavy metals between solid, dissolved and vegetative uptake phases......................................................................................................120

Table 5-1: Location and depth for each modeled run.....................................................128

Table 5-2: Percent difference of $\mathrm{pH}$ values for modeled runs without adsorption...........132 


\section{LIST OF FIGURES}

Figure 1-1: Location of Cobalt, Ontario (Taken from Dumaresq, 1993)........................2

Figure 1-2: Study Area.......................................................................................

Figure 2-1: Typical pore water profile (Fortin, 2003) ..............................................

Figure 2-2: Locations of tailings deposits in the Cobalt area (Dumaresq, 1993)............27

Figure 2-3: Location of core samples collected from Farr Creek and Mill Creek by

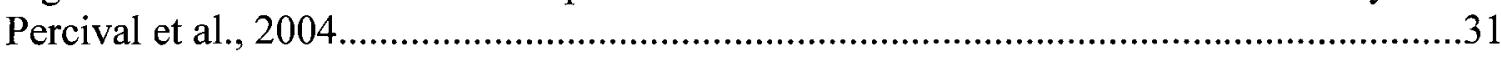

Figure 2-4: Location of surface water samples collected from Farr Creek and Mill Creek

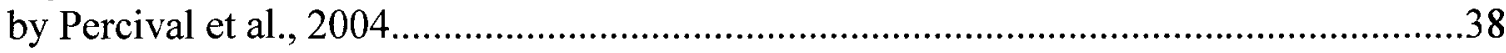

Figure 3-1: Location of June and September Core Samples.......................................51

Figure 3-2: Location of groundwater monitoring wells installed in June 2004...............53

Figure 3-3: Location of surface water samples collected in June 2004.........................55

Figure 4-1: Groundwater elevation measurements collected in September 2004 for all

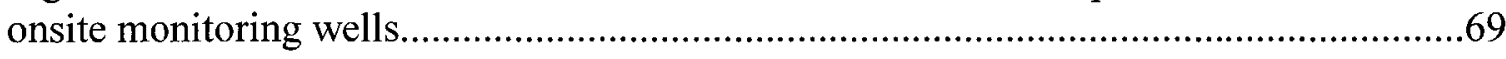

Figure 4-2: Vertical gradients calculated from September hydraulic head measurements from selected onsite monitoring wells..................................................................... 70

Figure 4-3a: Core J1 - water and organic matter content......................................... 72

Figure 4-3b: Core J2 - water and organic matter content.......................................... 72

Figure 4-3c: Core J3 - water and organic matter content........................................ 72

Figure 4-3d: Core J4 - water and organic matter content......................................... 72

Figure 4-3e: Core J5 - water and organic matter content......................................... 72

Figure 4-3f: Core J7 - water and organic matter content.......................................72

Figure 4-3g: Core J8 - water and organic matter content...................................... 73

Figure 4-3h: Core J9 - water and organic matter content....................................... 73 
Figure 4-3i: Core J10 - water and organic matter content..........................................73

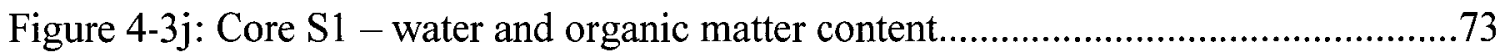

Figure 4-3k: Core $\mathrm{S} 2$ - water and organic matter content......................................

Figure 4-31: Core S3 - water and organic matter content.......................................73

Figure 4-3m: Core S4 - water and organic matter content........................................74

Figure 4-3n: Core S5 - water and organic matter content...................................... 74

Figure 4-4a(i): Core J1 - As, Co, Cu, Zn Sediment Concentrations.............................78

Figure 4-4a(ii): Core J1 - Ni, Pb, Sb Sediment Concentrations...................................78

Figure 4-4b(i): Core J2 - As, Co, Cu, Zn Sediment Concentrations.............................79

Figure 4-4b(ii): Core J2 - Ni, Pb, Sb Sediment Concentrations....................................79

Figure 4-4c(i): Core J3 - As, Co, Cu, Zn Sediment Concentrations.............................80

Figure 4-4c(ii): Core J3 - Ni, Pb, Sb Sediment Concentrations...................................80

Figure 4-4d(i): Core J4 - As, Co, Cu, Zn Sediment Concentrations.............................81

Figure 4-4d(ii): Core J4 - Ni, Pb, Sb Sediment Concentrations...................................81

Figure 4-4e(i): Core J5 - As, Co, Cu, Zn Sediment Concentrations................................82

Figure 4-4e(ii): Core J5 - Ni, Pb, Sb Sediment Concentrations..................................82

Figure 4-4f(i): Core J7 - As, Co, Cu, Zn Sediment Concentrations.............................83

Figure 4-4f(ii): Core J7 - Ni, Pb, Sb Sediment Concentrations.................................83

Figure 4-4g(i): Core J8 - As, Co, Cu, Zn Sediment Concentrations..............................84

Figure 4-4g(ii): Core J8 - Ni, Pb, Sb Sediment Concentrations................................84

Figure 4-4h(i): Core J9 - As, Co, Cu, Zn Sediment Concentrations.............................85

Figure 4-4h(ii): Core J9 - Ni, Pb, Sb Sediment Concentrations..................................85

Figure 4-4i(i): Core J10 - As, Co, Cu, Zn Sediment Concentrations..............................86 
Figure 4-4i(ii): Core J10 - Ni, Pb, Sb Sediment Concentrations...................................86

Figure 4-5a: Sequential extractions results for Arsenic.........................................8

Figure 4-5b: Sequential extractions results for Cobalt...........................................89

Figure 4-5c: Sequential extractions results for Zinc............................................90

Figure 4-5d: Sequential extractions results for Copper..........................................90

Figure 4-5e: Sequential extractions results for Nickel............................................91

Figure 4-5f: Sequential extractions results for Lead..............................................91

Figure 4-5g: Sequential extractions results for Antimony.....................................92

Figure 4-6a: Core S1 - AVS and CRS Concentrations........................................99

Figure 4-6a: Core S2 - AVS and CRS Concentrations...........................................99

Figure 4-6a: Core S3 - AVS and CRS Concentrations..........................................99

Figure 4-6a: Core S4 - AVS and CRS Concentrations.........................................99

Figure 4-6a: Core S5 - AVS and CRS Concentrations.........................................99

Figure 4-7a: Core S1 - Al, Fe porewater concentrations..........................................103

Figure 4-7b: Core $\mathrm{S} 1$ - Pb, Ti, Zn porewater concentrations...................................103

Figure 4-7c: Core S1 - As, Co, Sb porewater concentrations...............................103

Figure 4-7d: Core S2 - Al, Fe porewater concentrations.....................................103

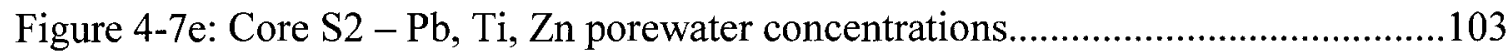

Figure 4-7f: Core S2 - As, Co, Sb porewater concentrations.....................................103

Figure 4-7g: Core S3 - Al, Fe porewater concentrations.........................................104

Figure 4-7h: Core S3 - $\mathrm{Pb}, \mathrm{Ti}, \mathrm{Zn}$ porewater concentrations.....................................104

Figure 4-7i: Core S3 - As, Co, Sb porewater concentrations.................................104

Figure 4-7j: Core S4 - Al, Fe porewater concentrations...................................... 104 


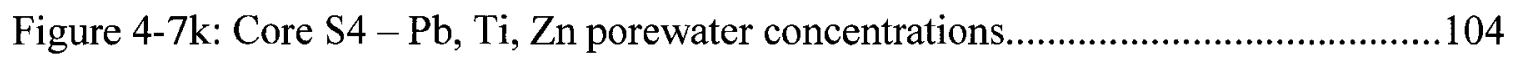

Figure 4-71: Core S4 - As, Co, Sb porewater concentrations.......................................104

Figure 4-7m: Core S5 - Al, Fe porewater concentrations......................................... 105

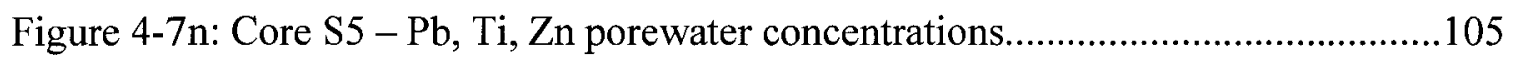

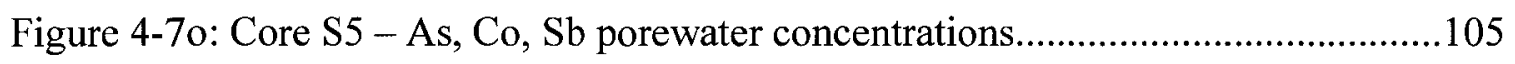

Figure 4-8a: Core S1 - Porewater sulfate and alkalinity concentrations......................108

Figure 4-8b: Core S1 - Porewater sulfide and Fe(II) concentrations...........................108

Figure 4-8c: Core $\mathrm{S} 1$ - Porewater $\mathrm{pH}$ and dissolved oxygen concentrations..................108

Figure 4-8d: Core S2 - Porewater sulfate and alkalinity concentrations.......................108

Figure 4-8e: Core S2 - Porewater sulfide and Fe(II) concentrations..........................108

Figure 4-8f: Core S2 - Porewater $\mathrm{pH}$ and dissolved oxygen concentrations.................108

Figure 4-8g: Core S3 - Porewater sulfate and alkalinity concentrations.......................109

Figure 4-8h: Core S3 - Porewater sulfide and Fe(II) concentrations...........................109

Figure 4-8i: Core S3 - Porewater $\mathrm{pH}$ and dissolved oxygen concentrations.................109

Figure 4-8j: Core S4 - Porewater sulfate and alkalinity concentrations........................109

Figure 4-8k: Core S4 - Porewater sulfide and Fe(II) concentrations...........................109

Figure 4-81: Core S4 - Porewater $\mathrm{pH}$ and dissolved oxygen concentrations.................109

Figure 4-8m: Core S5 - Porewater sulfate and alkalinity concentrations....................110

Figure 4-8n: Core S5 - Porewater sulfide and Fe(II) concentrations..........................110

Figure 4-8o: Core S5 - Porewater $\mathrm{pH}$ and dissolved oxygen concentrations.................110

Figure 4-9a: Core S1 - Microbial populations with depth.......................................116

Figure 4-9b: Core S2 - Microbial populations with depth......................................116

Figure 4-9c: Core S3 - Microbial populations with depth......................................116

xiii 
Figure 4-9d: Core S4 - Microbial populations with depth...

Figure 4-9e: Core S5 - Microbial populations with depth............................................117 


\subsection{INTRODUCTION}

All sediments contain natural background concentrations of trace metals from the surrounding bedrock material (Gambrell, 1991). Anthropogenic sources of metals, including mining wastes, runoff waste streams, and air fall deposition from industrial operations, are becoming increasingly an issue for contamination of downstream environments and health impacts to aquatic species and humans. As a result, it is important to characterize metal distributions and transformations in aquatic environments to better understand the geochemical and biological processes regulating these transformations.

This section gives a brief introduction to the study area (Section 1.1) and provides the study objectives (Section 1.2).

\subsection{Study Area}

The study area is located in the Farr Creek drainage area, in Cobalt, ON. Cobalt is located on Highway 11B, approximately $130 \mathrm{~km}$ north of North Bay, ON (Figure 1-1). The wetland area investigated in this study is confined to a relatively narrow northeast oriented valley that is bounded to the south by Crosswise Lake and the remnants of a gravel dam, and bounded to the north by a water level control dam. Tailings underlie the entire study area as well as both upgradient and downgradient of the study area. Farr Creek flows northeast through the study area (Figure 1-2). Mill Creek, which transports 
Figure 1-1: Location of Cobalt, Ontario (Taken from Dumaresq, 1993)

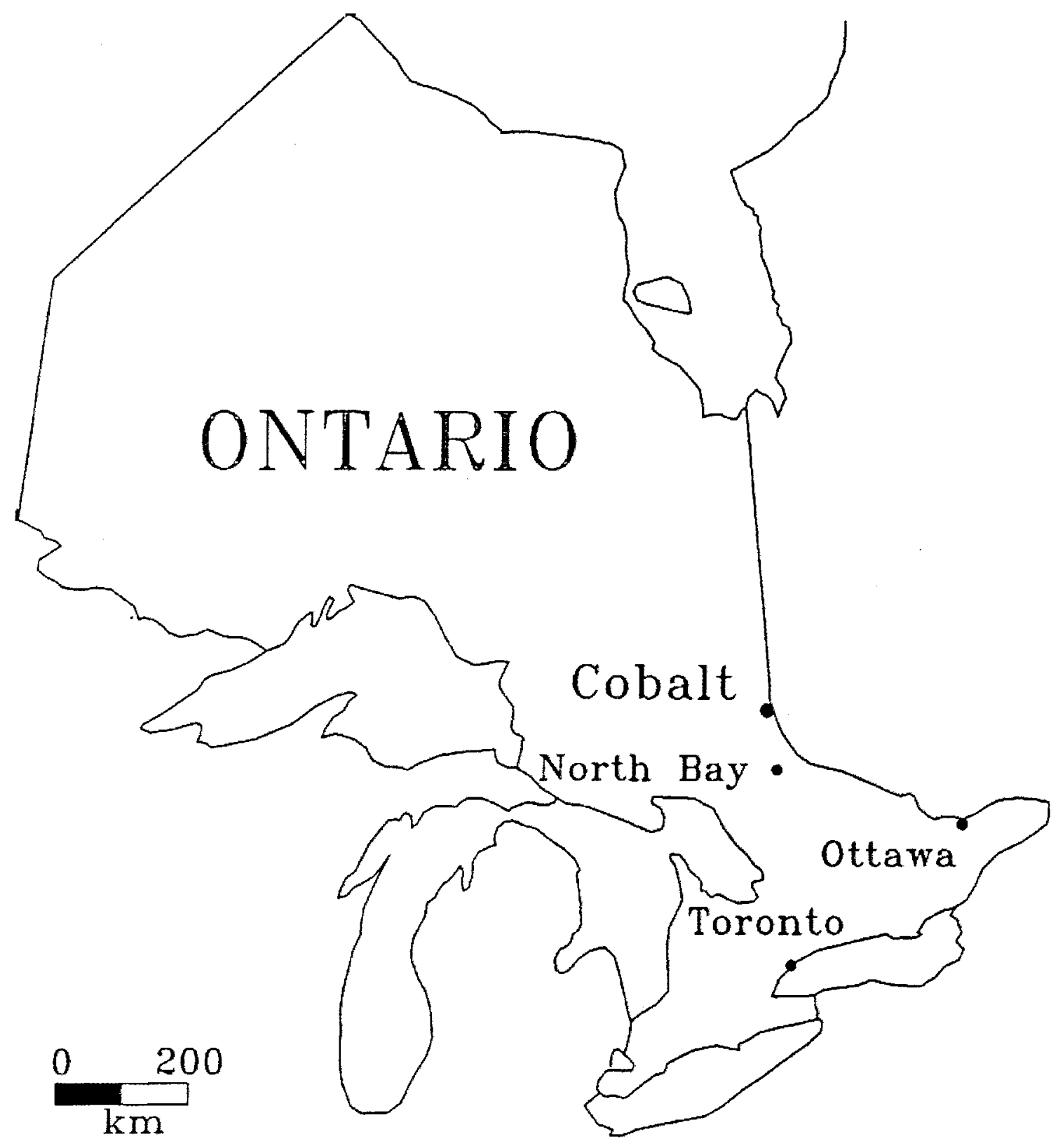


Figure 1-2: Study Area

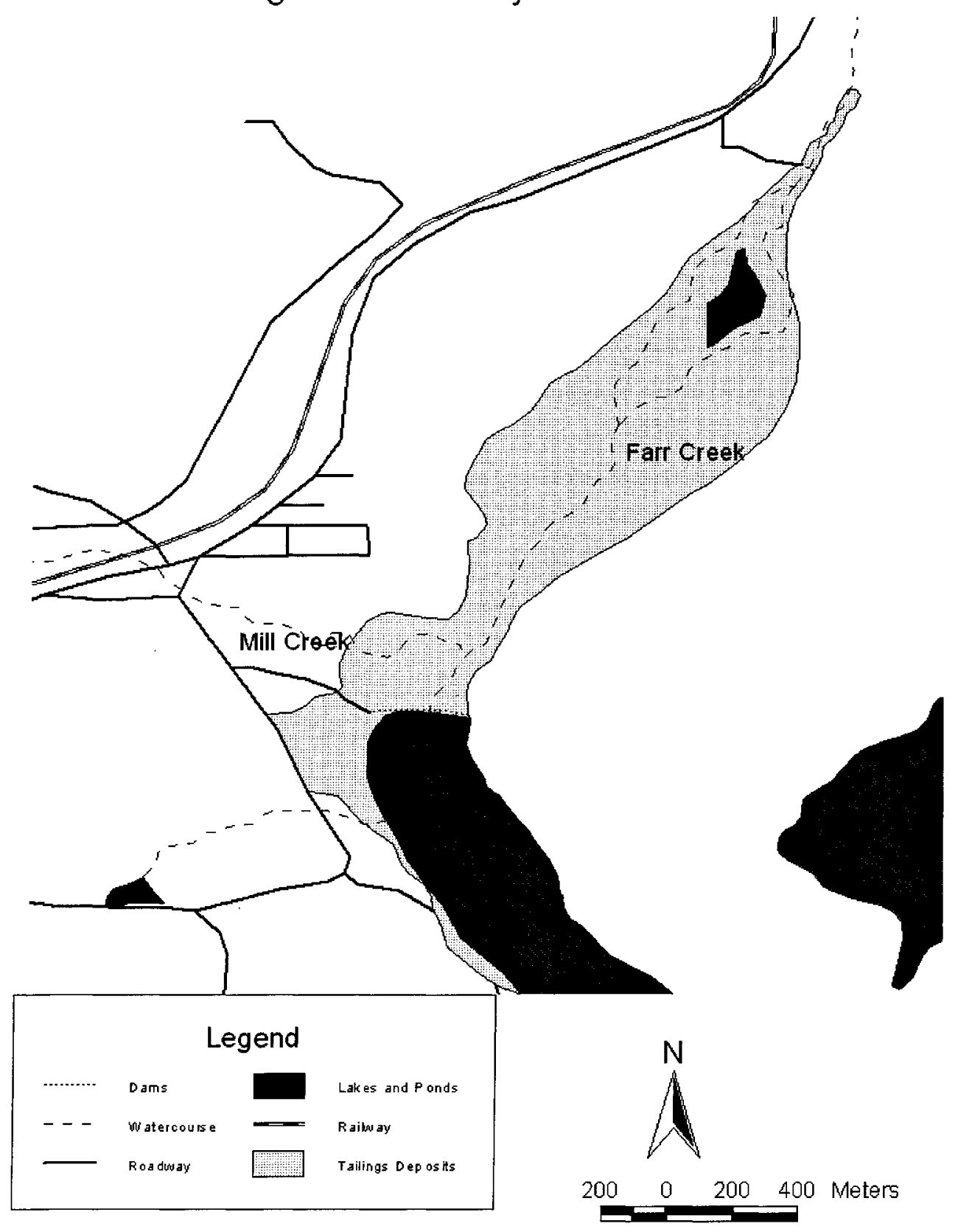


metal loadings from several upstream tailings deposits and organic loadings from the municipal wastewater lagoon flows into Farr Creek as shown on Figure 1-2. The northern portion of the area is maintained under a water cover for much of the open water season, whereas the southern portion of the area is relatively dry throughout the summer and fall. This is further evidenced by the establishment of grasses and sedges in the drier areas, while waterlogged areas are primarily populated with cattails.

\subsection{Study Objectives}

The main objectives of this research were to characterize the biogeochemical interactions occurring throughout the wetland and to evaluate the wetland's ability to effectively attenuate heavy metals. This was accomplished by:

- Determining the magnitude and distribution of acid producing bacteria (APB), iron reducing bacteria (IRB), and sulfate reducing bacteria (SRB) populations throughout the wetland;

- Characterizing the abundance and distribution of geochemical species in the sediment, porewater, and surface water;

- Correlating microbial population results with porewater chemistry and sediment metals concentrations; and

- Conducting geochemical speciation modeling and adsorption modeling to determine the role precipitation and adsorption reactions have on metal immobilization throughout the wetland. 


\subsection{BACKGROUND}

The environmental disturbance resulting from mining wastes has become a well documented problem. Drainages and/or seepages from mine adits, waste rock piles, and tailings impoundments containing elevated, and in many cases toxic concentrations of heavy metals, can have deleterious effects on the receiving environments. The following section will provide a literature review of the problems associated with mine drainage, the geochemical processes that are occurring in aquatic environments, the applicability of wetlands as passive treatment options for mining wastes (Section 2.1), and a summary of background geology and tailings geochemistry from the study area (Section 2.2).

\subsection{Literature Review}

\subsubsection{Mine drainage}

The most studied mine waste problem is acid mine drainage (AMD). This occurs when sulfide bearing material is exposed to the atmosphere and undergoes oxidation. The oxidation of sulfides, which may be catalyzed by microbial populations, produces sulfuric acid. This can result in extremely low $\mathrm{pH}$ waters, depending on the amount of sulfides in the waste rock or tailings. The highly acidic conditions produced enhance heavy metal dissolution. Metals are typically more soluble under low $\mathrm{pH}$ conditions due to the increased competition between protons and metal cations for organic ligands 
(Schnoor, 1996). The dissolved metals have the potential to migrate offsite resulting in potential negative impacts to both humans and aquatic organisms.

The acidity produced from the oxidation reactions can potentially become neutralized if there is adequate carbonate minerals present in the tailings and mixing waters. This can result in net neutral or alkaline mine drainage (NAMD). NAMD can also be produced from mining wastes containing little to no sulfides. Such drainage, although non-acidic, can also contain elevated dissolved metal concentrations, which can potentially impact receiving environments.

\subsubsection{Treatment Options}

Historically several mining companies have used active treatment options for mitigating impacts to the environment as a result of acid mine drainage. These options typically involved chemical additions of neutralizing agents such as lime, which was quite expensive. This sparked the movement towards passive treatment options, one of which is the use of constructed or natural wetlands to attenuate the metals. Currently, two types of treatment wetlands are used: aerobic wetlands and anaerobic wetlands.

Aerobic wetlands typically have a large surface area pond with horizontal surface flow and aquatic vegetation such as cattails (Typha latfolia). The typical water cover should be maintained between 15 to $45 \mathrm{~cm}$ in depth (Berghorn and Hunzeker, 2001). Shallower areas may enhance the oxygenation of surficial sediments and oxidizing reactions. 
Deeper areas generally decrease the vegetative diversity in the wetland (Berghorn and Hunzeker, 2001). These wetlands are only effective for NAMD because the predominant metal removal/immobilization pathway is via oxidation reactions. As such, the operational $\mathrm{pH}$ should be maintained above 5.5. Under oxic conditions $\mathrm{Fe}$ and $\mathrm{Mn}$ form amorphous Fe and Mn oxides, hydroxides and oxyhydroxides, which contain prime adsorption sites where metals can be bound. It has also been shown that selected metals, such as As, can coprecipitate with Fe oxides and/or hydroxides (Gambrell et al., 1994).

Anaerobic wetlands typically consist of a large pond with an organic substrate layer which is typically 30 to $60 \mathrm{~cm}$ thick (Berghorn and Hunzeker, 2001). Vegetation may help stabilize the organic layer and provide additional substrate to perpetuate sulfate reduction. The organic substrate stimulates chemical and microbial reduction reactions which generate alkalinity and increase solution $\mathrm{pH}$. The organic matter removes any oxygen which allows for iron and sulfate reduction. Anaerobic wetlands are better suited for AMD waste streams because the prime method of metal removal is through iron and sulfate reduction. This results in the precipitation of metal sulfides. Sulfate reducing bacteria typically thrive in relatively neutral environments, however, Fortin et al. (1996) have reported active SRB populations in waters with $\mathrm{pH}$ values of less than 4 .

\subsubsection{Geochemical Processes in Freshwater Aquatic Environments}

Redox condition and $\mathrm{pH}$ are the two most important parameters used to characterize geochemical interactions. Microbial populations play a vital role in the cycling of 
geochemical species. Organic substrates, nutrients and terminal electron acceptors are required by microbial populations to survive. Variations in these geochemical species will dictate the dominance of certain microbial populations. Microorganisms will derive their energy from the breakdown of organic substrates by sequentially using electron acceptors in the most energetically favourable order (Hunter, et al., 1998). Table 2-1 lists the chemical equations for the sequential oxidation of organic compounds by microorganisms.

Table 2-1: Oxidation of Organic Compounds (Chemoorganotrophs, All Heterotrophs) (Morel and Hering, 1993)

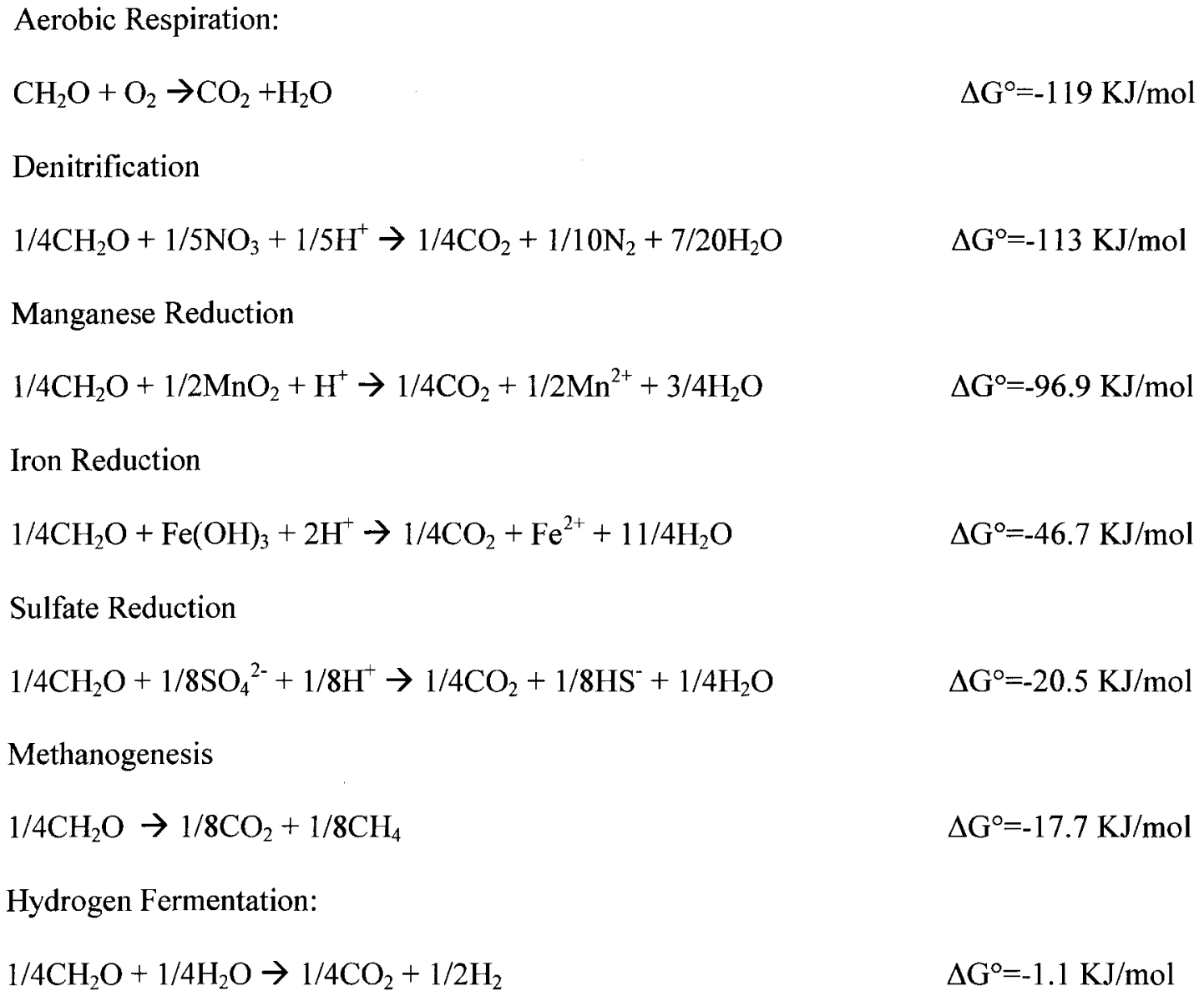


The Gibbs free energy of formation values for each reaction is included in Table 2-1. Microorganisms will typically favour the reactions with the highest Gibbs free energy value (aerobic respiration) and sequentially move down the chain once electron acceptors become consumed. It is important to note that these reactions are competitive between different microbial populations (Hunter et al., 1998).

In the oxic zone of the sediments, aerobic respiration is prevalent. Arsenopyrite (FeAsS), which is a relatively common sulfide mineral found in mine tailings, would undergo oxidation as shown by the reaction shown in equation $2-1$, when present in the oxic zone of the tailings(Boyle and Dass, 1971):

$2 \mathrm{FeAsS}+7 \mathrm{O}_{2}+2 \mathrm{H}_{2} \mathrm{O} \rightarrow 2 \mathrm{FeAsO}_{4}+2 \mathrm{H}_{2} \mathrm{SO}_{4}$ (Equation 2-1)

The sulfuric acid produced from this reaction immediately reacts with carbonates present in the tailings to produce soluble sulfates. The reaction of $\mathrm{FeCO}_{3}$ with sulfuric acid is presented in equation 2-2 ( Boyle and Dass, 1971):

$\mathrm{FeCO}_{3}+\mathrm{H}_{2} \mathrm{SO}_{4} \rightarrow \mathrm{FeSO}_{4}+\mathrm{H}_{2} \mathrm{CO}_{3}$ (Equation 2-2)

Fe is further oxidized to Fe(III) as ferric sulfates and hydrous ferric oxides and/or oxyhydroxides as shown in equation 2-3 (Boyle and Dass, 197.1):

$12 \mathrm{FeSO}_{4}+6 \mathrm{O}_{2}+\mathrm{xH}_{2} \mathrm{O} \rightarrow \mathrm{Fe}_{2}\left(\mathrm{SO}_{4}\right)_{3}+4 \mathrm{Fe}_{2} \mathrm{O}_{3} \bullet \mathrm{xH}_{2} \mathrm{O}$ (Equation 2-3) 
These oxidation reactions may be catalyzed by a wide range of acidophilic and neutrophilic microorganisms. Figure 2-1 presents a typical pore water redox zonation profile for submerged sediments.

Figure 2-1: Typical pore water profile (Fortin, 2003)

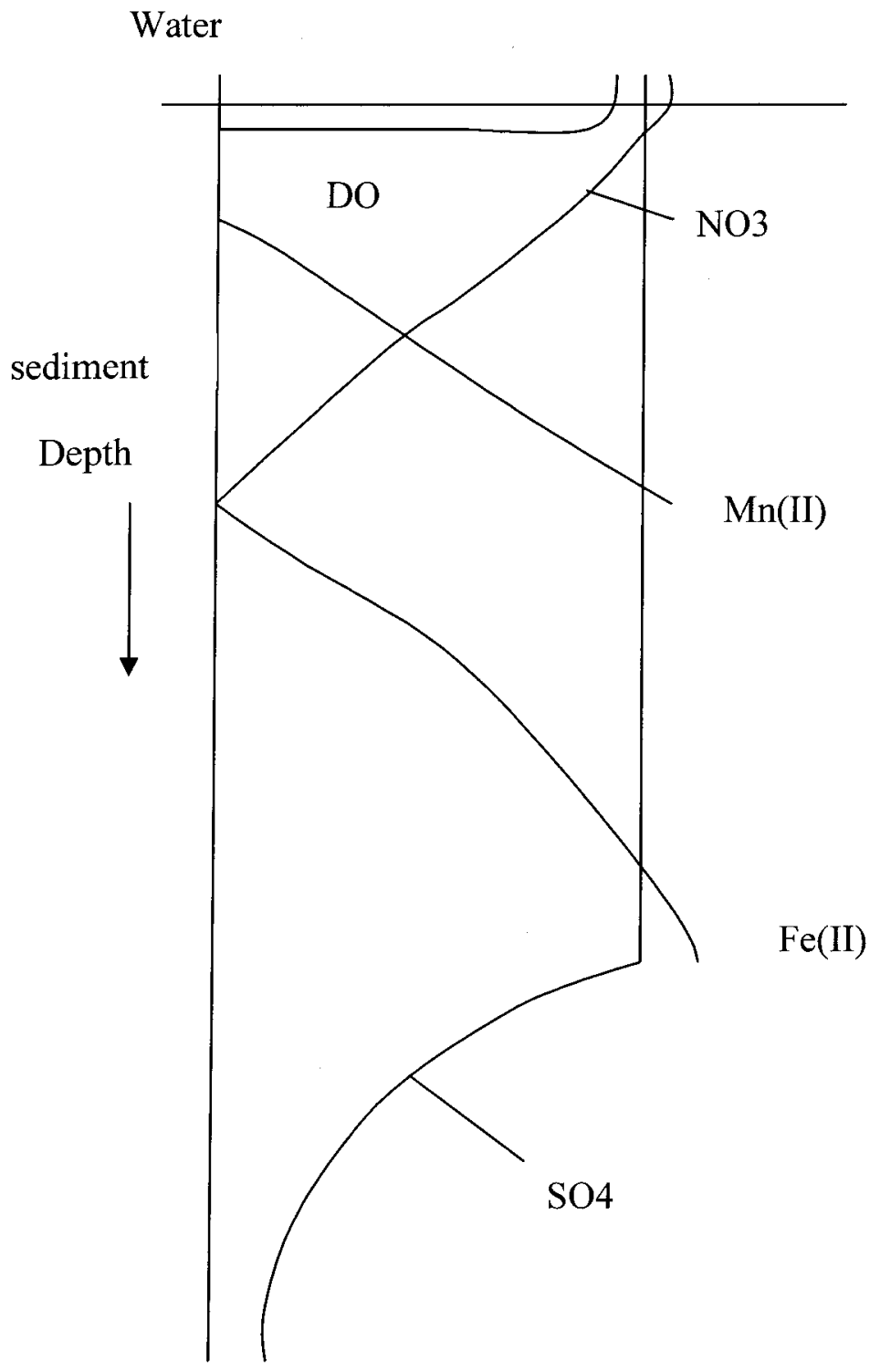


Immediately below the sediment-water interface there is a rapid reduction in the dissolved oxygen concentration, indicating the development of anoxia, followed by the reduction of nitrate concentration. The end product of nitrate reduction is nitrogen gas, which may either be converted to organic nitrogen by nitrogen fixating bacteria or released to the atmosphere. This process generates permanent alkalinity by removing one equivalent $\mathrm{H}^{+}$ion per ion of nitrate reduced (Rudd et al., 1986). As such, if acidic conditions persist in the oxic zone of sediments or the water column, there will be a shift towards increasing $\mathrm{pH}$ with depth. Deeper into the sediments there is a measurable increase in reduced manganese, followed by an increase in reduced iron. Both $\mathrm{Mn}$ and Fe reduction may generate alkalinity. For each equivalent $\mathrm{H}^{+}$ion two Fe or $\mathrm{Mn}$ ions are reduced. Further in depth within the pore water profile there will be a reduction in sulfate concentrations. Sulfate reduction converts sulfate to sulfides. If there is a significant concentration of dissolved metals, such as reduced Mn, iron and other metal sulfide precipitates may form. Sulfate reduction also generates alkalinity. For each equivalent $\mathrm{H}^{+}$ion two sulfate ions are reduced. The alkalinity produced from $\mathrm{Mn}, \mathrm{Fe}$ and sulfate reduction is not permanent. Should the sediments become reoxidized, the reduced Mn, $\mathrm{Fe}$ and sulfide are converted back to their oxidized forms of manganese oxides, iron oxides and sulfate respectively, thereby consuming the alkalinity produced by the reduction processes (Rudd et al., 1986). This is typical in hypolimnetic lakes during fall overturn where the lake completely mixes resulting in oxic conditions throughout the entire depth of the lake. In the absence of adequate nitrate, $\mathrm{Mn}$ or $\mathrm{Fe}$ oxides, and sulfate, methanogenesis and hydrogen fermentation will proceed where an external organic substrate is converted directly to carbon dioxide and methane during methanogenesis and 
to carbon dioxide and hydrogen gas during hydrogen fermentation. These processes do not add to the alkalinity budget.

The most common chemical species contributing to alkalinity in fresh waters are shown in equation 2-4 (Cook et al., 1986):

$\mathrm{Alk}=2 \mathrm{CO}_{3}{ }^{2-}+\mathrm{HCO}_{3}^{-}-\mathrm{H}^{+}+2 \mathrm{~S}^{2-}+\mathrm{HS}^{-}+\mathrm{NH}_{3}$ (Equation 2-4)

At neutral to slightly acidic $\mathrm{pH}$ values, the contribution of $\mathrm{CO}_{3}{ }^{2-}, 2 \mathrm{~S}^{2-}$ and $\mathrm{NH}_{3}$ to the overall alkalinity are negligible and the dissolution of carbonates in water adds equal amounts of $\mathrm{H}^{+}$and $\mathrm{HCO}_{3}{ }^{-}$(Cook et al., 1986). Therefore the overall reaction can be rewritten in terms of the redox species produced, as shown in equation 2-5 (Cook et al., 1986):

$\Delta \mathrm{Alk}=\Delta \mathrm{Fe}(\mathrm{II})+\Delta \mathrm{Mn}(\mathrm{II})-\Delta \mathrm{NO}_{3}{ }^{-}-2 \Delta \mathrm{SO}_{4}{ }^{2-}$ (Equation 2-5)

This production of alkalinity during nitrate, $\mathrm{Mn}$ and Fe reduction may help insure adequate $\mathrm{pH}$ values for sulfate reduction. Microorganisms involved in sulfate reduction cannot survive in pH less than 5 (Fortin et al., 1996).

It is important to note, that all of the above redox reactions are catalyzed by microorganisms. Only oxidation and reduction of Fe and $\mathrm{Mn}$ can occur abiotically as well as mediated by microorganisms (Fortin, 2003). Several studies have been conducted 
to determine under what circumstances iron and manganese oxidation occur abiotically versus biotically. The results of these studies have indicated that iron oxidation is catalyzed more strongly by bacteria under lower $\mathrm{pH}$ conditions where abiotic controls may take over at circumneutral pH's (Kirby et al., 1999). It is also speculated that because both iron and manganese oxides tend to remain as amorphous solids, bacteria growth onto these surfaces may stimulate further growth, indicating an autocatalytic process (Tessier et al., 1996; Tipping et al., 1984).

\subsubsection{Previous Studies on the Use of Wetlands for Treating NAMD}

\section{Metal Immobilization in Soils}

Metal contamination in soils is a cumulative process. Retention of metals within substrates results from Van der Waals interactions between particulate matter and metal cations, adsorption to organic matter via lewis acid base reactions and precipitation reactions due to oxidation, hydrolysis, and bacteria catalyzed reactions (Gamrell et al., 1991). These reactions are influenced by sediment $\mathrm{pH}$, redox condition, and chelating agents released during decomposition of organic matter (Gambrell et al., 1991).

Microbial biomass and $\mathrm{pH}$ are the dominant parameters which control metal adsorption in sediments. Metal adsorption increases with $\mathrm{pH}$ and is quite active under circumneutral to alkaline conditions and becomes reduced under acidic conditions. Organic matter is typically negatively charged under the $\mathrm{pH}$ conditions of most aquatic environments. 
Bacterial surfaces become neutral at $\mathrm{pH}$ values approaching 2 (Yee et al, 2001). As the $\mathrm{pH}$ increases, the bacterial cell walls become increasingly negatively charged due to deprotonation reactions of surface functional groups such as carboxyl, hydroxyl and phosphate functional groups (Yee et al., 2000). The negative charge on the bacteria surface and the positively charged dissolved metal ions generates an electric field where positively charged ions diffuse towards the negatively charged organic matter surfaces.

Sequential extractions have been used to quantify the forms in which metals are bound in the sediment substrate. This can give an indication of the metal's availability for uptake by organisms. There are five major fractions of sediments: residual fraction, exchangeable fraction, carbonate fraction, $\mathrm{Fe}$ and $\mathrm{Mn}$ oxides fraction, and organic matter fraction. Metals retained in the residual fraction of the soil are usually in the form of metal sulfides or adsorbed to clay minerals and are considered relatively unavailable for uptake by organisms (Grambrell et al., 1991). Exchangeable metal fractions adsorb onto substrate surfaces but these forms are easily exchangeable with other cations depending on adsorption kinetics and equilibria (Miller et al., 1983). In high alkalinity waters, carbonates could bind metals as well (Miller et al., 1983). Metals adsorbed and/or coprecipitated with the Fe and Mn oxides fraction of the sediments are relatively immobile assuming that redox conditions do not change to reducing conditions. This would result in the dissolution of Fe and Mn oxides, thereby releasing the metals back into the porewater. 
In a complex aquatic system, there are numerous different types of microorganisms which may be associated with specific chemical species such as iron oxides. It has also been suggested that adsorption of metal species to microorganism surfaces may promote further metal precipitations or enhance the formation of metal complexes, resulting in the generation of large molecular weight organic complexes. A classic example of this is the adsorption of metals to Fe-humic substance complexes, which form under predominantly acidic conditions. This results in enhanced metal adsorption to these reactive surfaces under reduced $\mathrm{pH}$ conditions. As a metal-organic matter complex grows, the molecule may become folded resulting in the permanent adsorption of metals to the structure.

Fitch and Buken (2003) reported that the main removal mechanism regulating metal immobilization at a constructed wetland in Trail $\mathrm{BC}$ were:

1) adsorption, predominantly to organic matter;

2) coprecipitation with iron oxyhydroxides; and

3) precipitation as metal sulfides.

They also noted that the bulk of the removal was due to coprecipitative adsorption onto growing Fe oxide particles. There were concerns, however, that metals adsorbed onto dissolved organic matter molecules could potentially migrate outside of the wetland.

It has been suggested that adsorbed metals can remobilize easier than metals associated with sulfide precipitate lattices. A number of studies have shown that longer residence 
times in constructed wetlands can enhance the probability of forming metal sulfides (Machemer and Wildeman, 1992; Sobolewski, 1996; Chague-Goff and Rosen, 2001).

\section{$\underline{\text { Role of Wetland Plants on Metal Immobilizations }}$}

Wetland plants play an important role in metal removal. Metals may be absorbed directly into the plant tissue via the shoot system and they enhance filtration and cation exchange reactions (Deng et al., 2004). The degree to which plant species can retain metals, either through their root system or through absorption and translocation, is dependent not only on the specific plant species, but also on its growth stage, and the specific metal characteristics (Deng et al., 2004). A study was conducted by Deng et al. (2004) where metal accumulations were tested in both the root zones and the shoots of 12 different wetland plant species, one of which was cattails (Typha latfolia). The results indicated that much higher metal concentrations were retained in the root zone of the plants as compared to the amount of metals in the plant shoots and leaves. The metals investigated were $\mathrm{Pb}, \mathrm{Cu}, \mathrm{Cd}, \mathrm{Zn}$. Jackson et al. (1993) demonstrated that under mildly oxidizing conditions in the root zone, lower concentrations of metals were reported in the shoot as opposed to the root zone. This was attributed to the formation of amorphous $\mathrm{Fe}$ and $\mathrm{Al}$ oxide precipitates to which metals would be adsorbed. It was suggested that the formation of $\mathrm{Fe}$ and $\mathrm{Al}$ oxides in the root zones prevented high concentrations of metals from being taken up into the plants, thereby helping to regulate the internal metal transport under contaminated conditions. 
Wetland plants transport oxygen to the root system, also known as the rhizosphere, generating a zone of radial oxygen loss (ROL) in an otherwise predominantly anoxic environment. The total volume of ROL is dependent on several factors including the root biomass, location along the root, root age, time of day, season, and soil oxygen demand (Jacob and Otte, 2003). Thus, even though roots diffuse oxygen into the sediment, whole root systems may consume this oxygen immediately due to soil and or respiratory demands. Engler and Patrick (1979) and Trolldenier (1988) showed that in the root zone there was an increase in sulfide oxidation leading to increased concentrations of soluble ferric iron, and a reduction in the $\mathrm{pH}$. Fe may also become oxidized, forming Fe oxide and oxyhydroxide precipitates, as evidenced by iron plaques observed in the rhizosphere of some wetland plants (Jacob and Otte, 2003). These plaques can act as adsorption sites for selected metals, including As, Co, Ni. This oxygen-rich rhizosphere may cycle to anoxic conditions during the winter months when plants die. Weise et al. (2001) found that both iron oxidizing bacteria and iron reducing bacteria were present in the rhizosphere. Sulfides are generally oxidized before Fe. Therefore, it would be expected that some distance away from the root surface sulfides would be abundant while near the roots ferric oxide precipitates would be plentiful. Between these zones would be an area where sulfides have oxidized to sulfates but where iron still exists in its reduced form. This is the zone where metals which were in the form of metal sulfides such as ZnS would have optimal mobility, provided no organic matter is present to facilitate adsorption (Jacob and Otte, 2003). 
Vegetation also contributes to the organic matter content of the sediment through senescence, root tissue sloughing and the release of organic acids (Jacob and Otte, 2003). Through the process of senescence, metals can be immobilized temporarily, however, they may become redistributed into the water column or surficial sediments (Jacob and Otte, 2003). The presence of dissolved organic acids in the rhizosphere can enhance the formation of soluble metal -organic complexes under oxidizing conditions, thereby further increasing metal mobility.

\section{$\underline{\text { Seasonal Influences }}$}

Seasonal influences on metal attenuation in natural and constructed wetlands appear to be site specific. Faulkner and Skousen (1994) found that climate, season, and nutrient availability in the winter months dramatically reduced sulfate reduction and thus metal retention. Ye et al. (2001) noted that in the presence of live vegetation there appeared to be no effect of season on metal retention. They attributed this to the fact that sulfate reduction was not the main removal mechanism for this treatment wetland. Adsorption onto iron hydroxides and plant uptake were noted as the main removal pathways. August et al. (2002) studied an older treatment wetland that has been receiving mining wastewater since the early 1900 's. They found that the wetland shifted from a net sink for metals in the summer to a net source for metals in the winter months. During the winter months, the plants would die, fall into the water column and release metals, particularly $\mathrm{Mn}$, back into the water column. Other factors that contributed to the release of metals back to the water column include the change in redox condition, flow paths, 
and decreases in microbial activity. This was one of the few studies on an aged wetland. It was speculated that perhaps this wetland was initially a sink for metals throughout all seasons and at some point there was a shift due to metal accumulations over several years.

\subsection{Site Background Information}

The following sections summarize the local geology, provide a summary of the ore deposits geochemistry, a brief history of mining and milling activities, a brief description of the tailings deposits in the area and at the study site, and give a brief description of geochemical properties and interactions of metals of interest. The objective of these discussions is to provide the reader with an idea as to the complexity of the tailings at the study site.

\subsubsection{General Geology}

The geology of the Cobalt Mining Camp has been investigated by numerous government, corporate and independent academic geologists since the discovery of silver in 1903. The following section gives a brief summary of the findings of Jambor (1971).

The basic geology of the area consists of Archean volcanic basement rocks and interflow sediments overlain by Proterozoic rocks. The oldest Proterozoic rocks deposited in the area are the Coleman member of the Gowganda Formation. These rocks consist 
predominantly of conglomerates with variable amounts of argillite, quartzite, and arkose. Overlying the Coleman member is the Firstbrook member of the Gowganda Formation. Typically well bedded, fine grained greywacke and argillite rock units are associated with the Firstbrook member. The Lorraine Formation overlies the Gowganda Formation. The rock units in this formation consist of pink arkose and white quartzite.

Both the Archean and Proterozoic rocks were intruded by a sill-like sheet of the Nipissing diabase and later dikes of olivine and quartz diabase. Paleozoic shales, sandstones and limestones of Silurian and Ordovician age unconformably overlie the Proterozoic formations in the northeastern portion of the region. Pleistocene sand, gravel and clay deposits unconformably overlie much of the lowlying area. These sediment deposits can vary in thickness from a few millimeters to over $90 \mathrm{~m}$.

\subsubsection{Silver Vein Occurrence and Geochemistry}

Silver deposits in the Cobalt area occur as veins in the fractures, joints, and faults within the Archean and Proterozoic rocks and the Nipissing diabase. These veins vary in width from a few millimeters to over $30 \mathrm{~cm}$ (Dumaresq, 1993).

The vein mineralogy is quite complex. The gangue minerals include calcite, dolomite, quartz, and chlorite (Dumaresq, 1993). Other minerals associated with the silver deposits include arsenides, sulfarsenides, antimonides, arsenates, sulfates, carbonates, silicates, 
oxides, and sulfides. A complete list of ore minerals with their chemical formulae are presented in Table 2-2.

Petruk (1971b) analyzed four rock samples from the silver veins and also presented ore geochemical data collected from other sources. These data are presented in Table 2-3. As can be seen from these tables, the major components of the ore materials include carbonate minerals plus $\mathrm{Ni}, \mathrm{As}, \mathrm{Ag}, \mathrm{Co}$, and $\mathrm{S}$.

Boyle et al. (1967) analyzed samples collected from local rock units located away from areas of mineralization to determine background trace metal concentrations. Table 2-4 summarizes his results. The data indicate that significantly elevated concentrations of $\mathrm{As}, \mathrm{Sb}, \mathrm{Ni}, \mathrm{Co}, \mathrm{Pb}, \mathrm{Zn}, \mathrm{Cu}$, and $\mathrm{Mn}$ occur predominantly in the Archean rock units. Interestingly, $\mathrm{Ni}, \mathrm{Co}, \mathrm{Cu}$, and $\mathrm{Mn}$ were found to have elevated concentrations throughout all the rock units, with the exception of the granite and the Lorraine sandstone.

\subsubsection{Tailings Deposits and Composition}

Tailings consist of crushed waste rock and any residues or chemicals used in the milling and refining processes. Therefore it is important to understand the procedures and processes used in the milling and refining processes to fully characterize the geochemical reactions with the tailings and surrounding porewater. 
Table 2-2: Ore-bearing Minerals in Cobalt Veins (Petruk, 1971b and Boyle and Dass, (1971)

\begin{tabular}{|c|c|c|}
\hline Mineral Group & Mineral Name & Chemical Formula \\
\hline Arsenides & $\begin{array}{c}\text { Nickeline } \\
\text { Langisite } \\
\text { Safflorite } \\
\text { Loellingite } \\
\text { Rammelsbergite, pararammelsbergite } \\
\text { Skutterite } \\
\end{array}$ & $\begin{array}{c}\mathrm{NiAs} \\
(\mathrm{Co}, \mathrm{Ni}) \mathrm{As} \\
(\mathrm{Co}, \mathrm{Fe}, \mathrm{Ni}) \mathrm{As} \\
\mathrm{FeAs}_{2} \\
\mathrm{NiAs}_{2} \\
(\mathrm{Co}, \mathrm{Fe}, \mathrm{Ni}) \mathrm{As}_{3-\mathrm{x}}\end{array}$ \\
\hline Sulfarsenides & $\begin{array}{c}\text { Cobaltite } \\
\text { Gerdorffite } \\
\text { Arsenopyrite } \\
\text { Alloclatite } \\
\end{array}$ & $\begin{array}{c}\text { (Co,Fe,Ni)AsS } \\
\text { NiAsS } \\
\text { FeAsS } \\
(\mathrm{Fe}, \mathrm{Co}) \mathrm{AsS} \\
\end{array}$ \\
\hline Antimonides & $\begin{array}{l}\text { Breithauptite } \\
\text { Ullmannite } \\
\text { Allargentum }\end{array}$ & $\begin{array}{c}\mathrm{NiSb} \\
\mathrm{NiSbS} \\
\mathrm{Ag}_{1-\mathrm{x}} \mathrm{Sb}_{\mathrm{x}}\end{array}$ \\
\hline Arsenates & $\begin{array}{l}\text { Erythrite } \\
\text { Annabergite } \\
\text { Scordite }\end{array}$ & $\begin{array}{c}\mathrm{Co}_{3}\left(\mathrm{AsO}_{4}\right)_{2} \cdot 8 \mathrm{H}_{2} \mathrm{O} \\
\mathrm{Ni}_{3}\left(\mathrm{AsO}_{4}\right)_{2} \cdot 8 \mathrm{H}_{2} \mathrm{O} \\
(\mathrm{Fe}, \mathrm{Al}) \mathrm{AsO}_{4} \cdot 2 \mathrm{H}_{2} \mathrm{O}\end{array}$ \\
\hline Sulfides & $\begin{array}{c}\text { Pyrargyrite } \\
\text { Tetrahedrite } \\
\text { Chalcopyrite } \\
\text { Bornite } \\
\text { Galena } \\
\text { Marcasite, pyrite } \\
\text { Sphalerite } \\
\text { Pyrrhotite } \\
\text { Molybdenite } \\
\end{array}$ & $\begin{array}{c}\mathrm{Ag}_{3} \mathrm{SbS}_{3} \\
(\mathrm{Cu}, \mathrm{Fe})_{12} \mathrm{Sb}_{4} \mathrm{~S}_{13} \\
\mathrm{CuFeS}_{2} \\
\mathrm{Cu}_{5} \mathrm{FeS}_{4} \\
\mathrm{PbS} \\
\mathrm{FeS}_{2} \\
(\mathrm{Zn}, \mathrm{Fe}, \mathrm{Mn}) \mathrm{S} \\
\mathrm{Fe}_{1-\mathrm{x}} \mathrm{S} \\
\mathrm{MoS}_{2}\end{array}$ \\
\hline Oxides & $\begin{array}{c}\text { Rutile } \\
\text { Hematite } \\
\text { Magnetite } \\
\text { Anatase } \\
\text { Illmenite }\end{array}$ & $\begin{array}{c}\mathrm{TiO}_{2} \\
\mathrm{Fe}_{2} \mathrm{O}_{3} \\
\mathrm{Fe}_{3} \mathrm{O}_{4} \\
\mathrm{TiO}_{2} \\
\mathrm{FeTiO}_{3}\end{array}$ \\
\hline Sulfates & $\begin{array}{c}\text { Melanterite } \\
\text { Gypsum }\end{array}$ & $\begin{array}{l}\mathrm{FeSO}_{4} \cdot 7 \mathrm{H}_{2} \mathrm{O} \\
\mathrm{CaSO}_{4} \cdot 2 \mathrm{H}_{2} \mathrm{O}\end{array}$ \\
\hline Silicates & $\begin{array}{c}\text { Quartz } \\
\text { Chlorite } \\
\text { Albite } \\
\end{array}$ & $\begin{array}{c}\mathrm{SiO}_{2} \\
(\mathrm{Mg}, \mathrm{Fe})_{10} \mathrm{Al}_{2}(\mathrm{SiAl})_{8} \mathrm{O}_{20}(\mathrm{OH}, \mathrm{F})_{16} \\
(\mathrm{Na}, \mathrm{Ca})(\mathrm{Al}, \mathrm{Si})_{4} \mathrm{O}_{8}\end{array}$ \\
\hline Carbonates & $\begin{array}{c}\text { Calcite } \\
\text { Dolomite } \\
\text { Malachite }\end{array}$ & $\begin{array}{c}\mathrm{CaCO}_{3} \\
\mathrm{CaMg}\left(\mathrm{CO}_{3}\right)_{2} \\
\mathrm{Cu}_{2}\left(\mathrm{CO}_{3}\right)(\mathrm{OH})_{2} \\
\end{array}$ \\
\hline Hydroxides & $\begin{array}{l}\text { Limonite } \\
\text { Wad }\end{array}$ & $\begin{array}{c}\mathrm{FeO}(\mathrm{OH}) \cdot \mathrm{nH}_{2} \mathrm{O} \\
\text { hydrated } \mathrm{MnO}_{2} \text { mixtures }\end{array}$ \\
\hline
\end{tabular}


Table 2-3: Vein Composition from Cobalt area (Petruk, 1971b)

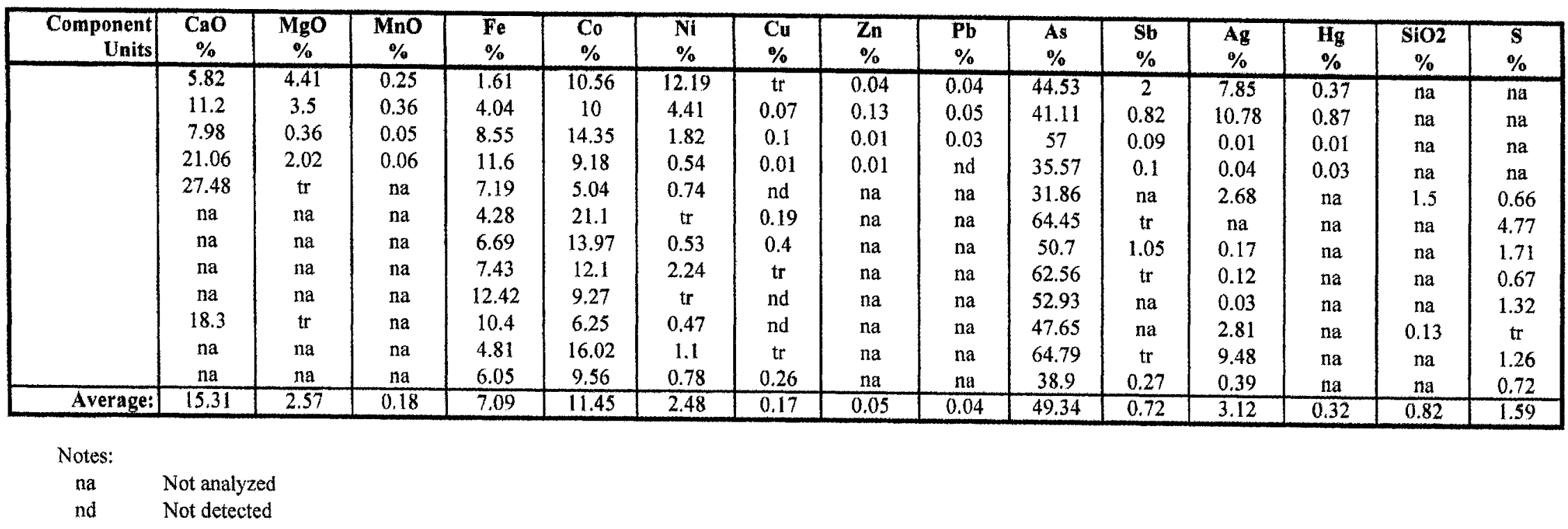


Table 2-4: Average metal concentrations in native bedrock units from the cobalt area (Boyle et al, 1967)

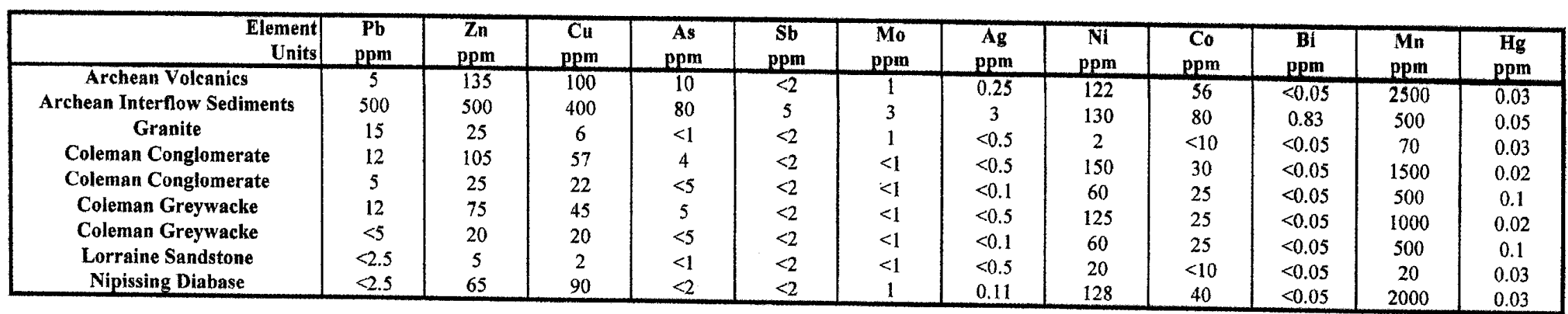




\section{Milling and Refining Processes}

Milling and refining processes that were employed throughout the entire Cobalt Camp have been summarized in great detail by Dumaresq (1993). The following section gives a brief description of the milling and refining processes.

The first mining operations began in 1904 using hand sorting or gravity separation of the ore. The first cyanide mill began operation in 1909. This process involved mixing the crushed ore with $\mathrm{KCN}$ to dissolve the Ag. Powdered $\mathrm{Al}$ was then added to the mixture to form Ag precipitates. The precipitate was melted down in a furnace to produce a final bullion of approximately 960 fine. One negative aspect of using cyanide was the formation of cyanide complexes (cyanicides) with base metals such as $\mathrm{Ni}$ and Co present in the ore.

In 1911, the Nipissing high grade mill began adding $\mathrm{Hg}$ to its cyanide milling process. The revised protocol involved mixing the crushed ore with $\mathrm{Hg}$ and $\mathrm{KCN}$. Chert pebbles were also added as grinding agents. After approximately 10 hours of milling the $\mathrm{Ag}$ became amalgamated with Hg. The amalgam was later refined in furnaces for an end product of 999 fine. This process was discontinued in 1918 due to the increased cost of Hg. In 1918, all the high grade ores were pretreated with calcium hypochlorite prior to cyanicidation. This process oxidized the ores thereby preventing the cyanide from forming complexes with the base metals in the ore such as $\mathrm{Ni}$ and Co present in the ore. This reduced the actual amount of cyanide required in the milling process. In 1921, 
sulfuric acid replaced the calcium hypochlorite because it proved to be more efficient in oxidizing the base metals.

In 1912, the Nipissing low grade cyanide mill began operation using $\mathrm{NaCN}$ instead of KCN. During World War I, the price of Al rose significantly and as such, many of the cyanide mills switched to floatation processing. This process involved coating the finely crushed ore with a mixture of creosote, pine oil, and coal tar. The emulsified ore was then agitated in floatation cells where the Ag emulsion would float to the top of the cells and the waste material would sink to the bottom. The concentrates produced from this process were shipped elsewhere to smelters for refining.

\section{Tailings Deposits}

There were several milling operations throughout the Cobalt area. Figure 2-2 presents the locations of the major tailings deposits in the Cobalt area. The Crosswise Lake tailings deposits represent the primary source of contamination in the study area and these tailings underlie the entire study area. Small amounts of contaminants have been deposited into Farr Creek as a result of downstream transport from Mill Creek. 
Figure 2-2: Locations of tailings deposits in the Cobalt area (Dumaresq, 1993)

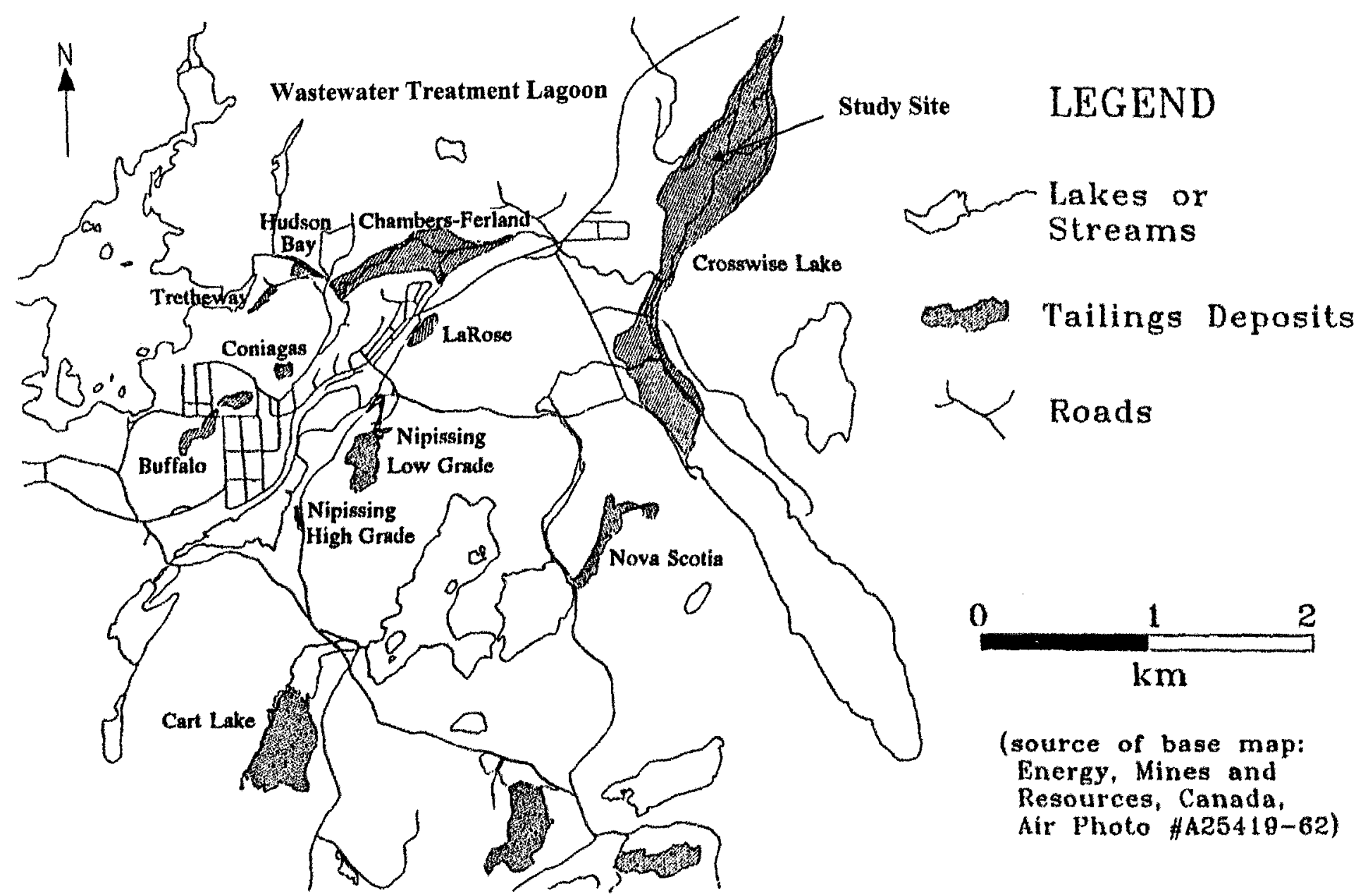




\section{Crosswise Lake Tailings Deposits}

Crosswise Lake is home to the largest tailings deposits in the area. Tailings were deposited from at least five different mills in operation from 1908 to the early 1930's and intermittently until the 1970's (Dumaresq, 1993). A dam was built at the northern limit of Crosswise Lake in order to minimize the continued migration of tailings into Farr Creek. The dam was reportedly constructed in the 1970's and failed shortly thereafter. North of this failed dam is a marshy area followed by a road with a small water level control dam and overflow weir maintained by the province of Ontario. The purpose of the water level control dam was to minimize further migration of the tailings by maintaining water cover over the tailings and enhance the wetland vegetation in the area.

\section{Tailings Composition}

Table 2-5 presents geochemical data collected from several different tailings deposits in the Cobalt area. As can be seen from the table, there is considerable geochemical variability among the different tailings deposits. The tailings samples collected from Crosswise Lake show that the tailing are elevated with respect to carbonate and sulfate minerals, as well as $\mathrm{As}, \mathrm{Al}, \mathrm{Fe}, \mathrm{Ni}, \mathrm{Sb}, \mathrm{Co}, \mathrm{Cu}, \mathrm{Hg}, \mathrm{Pb}, \mathrm{Zn}$, and $\mathrm{V}$.

The Geological Survey of Canada (GSC) Open File Report 1680 (Percival et al., 2004) summarized the results of several environmental investigations undertaken to characterize the environmental conditions of the Cobalt area. Four sediment cores were 
Table 2-5:'Trace element concentrations in tailings samples collected from the Cobalt area (Taken from Dumaresq, 1993)

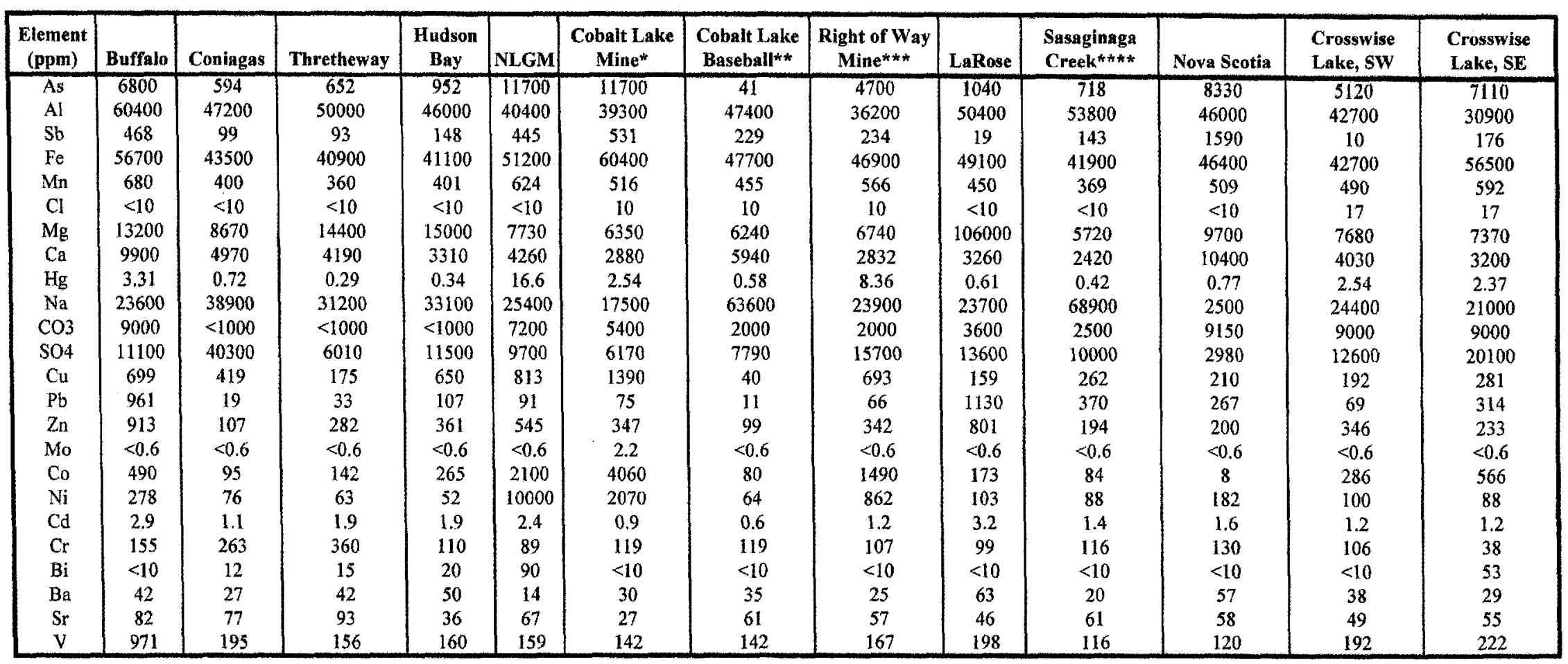

Notes:

* it is not clear the specific location of this sample since there was no on land tailings in this area

** sample was likely collected from the playing surface of the basehall diamond at the Cobalt Lion's Club Park

*** the Right of Way Mine did not produce any tailings

**** sampling location is not known. Possibly collected within the tailings on the Chamber-Ferland Pronertv. or unstream of these tailinos 
collected within 150m of the confluence of Mill Creek with Farr Creek. The report did not specify the date when these cores were collected. The specific core locations are presented on Figure 2-3. The most abundant minerals in these core samples were quartz, chlorite, and plagioclase. Table 2-6 summarizes the major constituents of these core samples and Table 2-7 presents the trace metal concentrations of the core samples. The major components of the tailings samples include approximately $60 \% \mathrm{SiO}_{2}, 15 \% \mathrm{Al}_{2} \mathrm{O}_{3}$, $8 \% \mathrm{Fe}_{2} \mathrm{O}_{3}, 5 \% \mathrm{MgO}$, and $4 \% \mathrm{CaO}$. The trace metal analytical results indicated that most of the metals were present in stable and relatively low concentrations as a function of depth. Between core samples, $\mathrm{As}, \mathrm{Co}, \mathrm{Cu}$, and $\mathrm{Pb}$ displayed elevated concentrations that increased with depth. Elevated concentrations of $\mathrm{Ni}$ were reported but did not exhibit any observable trend with depth.

Pore water was also extracted from these cores and analyzed for dissolved metals. Table 2-8 summarizes the dissolved metal concentrations in the pore water samples. In Farr Creek, upstream of the confluence with Mill Creek (Core C14) elevated concentrations of heavy metals were reported at shallow depths followed by decreases in concentrations with depth. In Core C13, located in Farr Creek, just downstream of the confluence with Mill Creek, higher concentrations were reported with depth. Similar ranges in the concentrations of heavy metals, such as $\mathrm{As}, \mathrm{Ni}, \mathrm{Co}, \mathrm{Pb}, \mathrm{Sb}$, were reported from the pore water collected from the cores in Mill Creek. However, there were not enough data available to provide a depth profile. 
Figure 2-3: Location of Core Samples collected from Farr Creek and Mill Creek by Percival et al., 2004

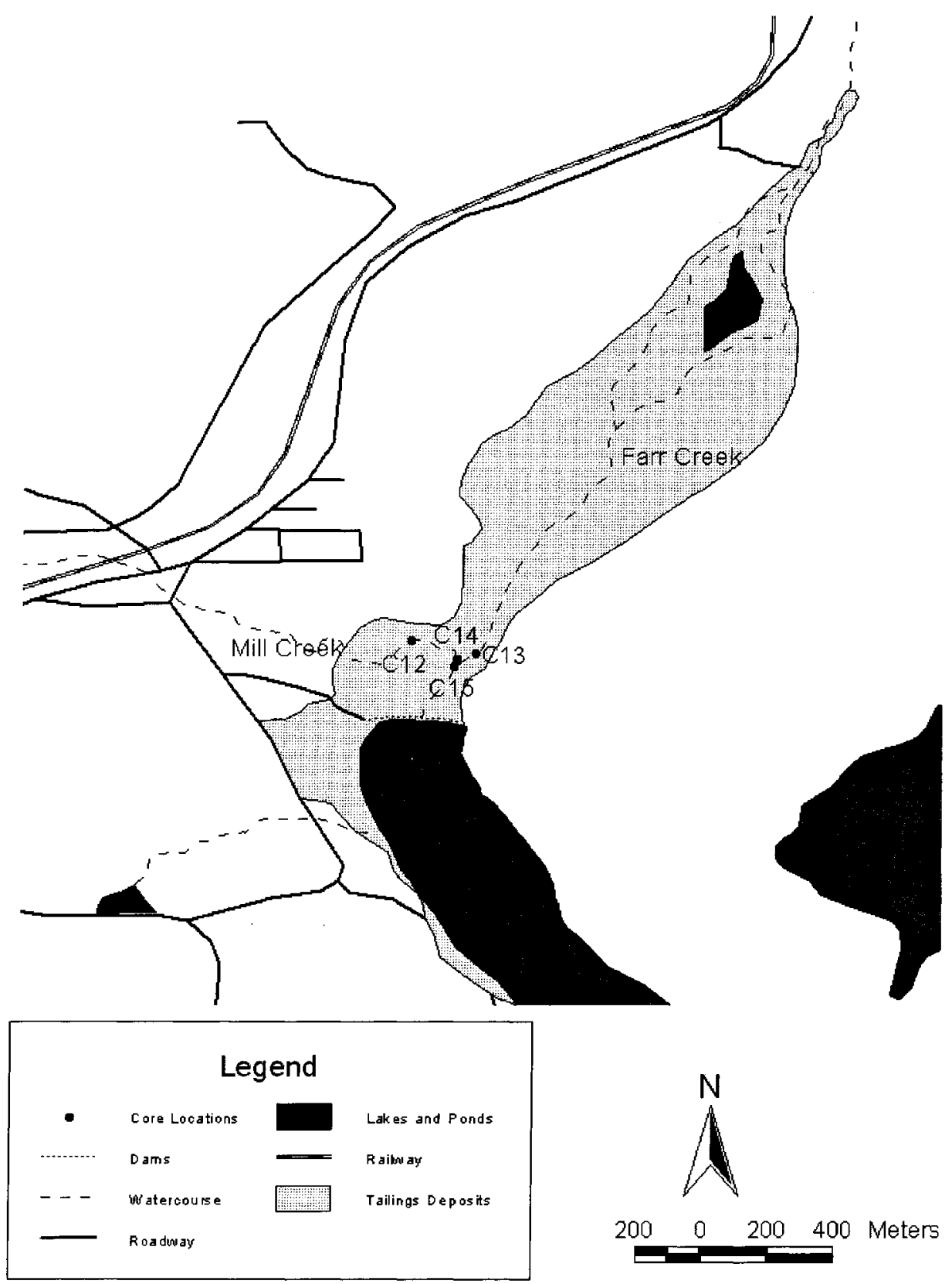


Iable 2-6: Vajor Components from core samples collected from Farr Creek and Mill Creek (Percival et al., 2004)

\begin{tabular}{|c|c|c|c|c|c|c|c|c|c|c|c|c|c|c|c|c|c|}
\hline Location & Core ID & $\begin{array}{c}\text { Variable } \\
\text { Units } \\
\text { Detection Limits } \\
\text { Depth }(\mathbf{c m}) \\
\end{array}$ & $\begin{array}{c}\mathrm{SiO} 2 \\
\text { wt } \% \\
0.5 \\
\quad(\mathrm{Fe} \\
\end{array}$ & $\begin{array}{c}\mathrm{Al} 2 \mathrm{O} \\
\mathrm{wt} \% \\
0.2\end{array}$ & $\mid \begin{array}{c}e 203(\mathrm{~T} \\
\text { wt } \% \\
0.06 \\
\text { e203T-1. }\end{array}$ & $\begin{array}{c}\mathrm{Fe} 2 \mathrm{O} 3 \\
\text { wt \% } \\
113 \times \mathrm{FeO}) \\
\end{array}$ & $\begin{array}{c}\mathrm{FeO} \\
\mathrm{wt} \% \\
0.2\end{array}$ & $\begin{array}{l}\mathrm{MnO} \\
\text { wt \% } \\
0.01\end{array}$ & $\begin{array}{c}\mathrm{MgO} \\
\mathrm{wt} \% \\
0.04\end{array}$ & $\begin{array}{c}\mathrm{CaO} \\
\mathrm{wt} \% \\
0.01\end{array}$ & $\begin{array}{c}\mathrm{H} 2 \mathrm{OT} \\
\mathrm{wt} \% \\
0.1\end{array}$ & $\begin{array}{c}\mathrm{CO} 2(\mathrm{~T}) \\
\mathrm{wt} \% \\
0.1\end{array}$ & $\begin{array}{l}\mathrm{CO} 2 \\
\mathrm{wt} \% \\
0.1 \\
\mathrm{C}=(\mathrm{Cl}\end{array}$ & $\begin{array}{c}\mathrm{C} \\
\mathrm{wt} \% \\
0.2 \\
2 \mathrm{~T}-\mathrm{CO}\end{array}$ & $\begin{array}{r}\mathrm{P} 2 \mathrm{O} 5 \\
\mathrm{wt} \% \\
0.01 \\
y / 3.66 \\
\end{array}$ & $\begin{array}{c}S(T) \\
w t \% \\
0.02\end{array}$ & $\begin{array}{l}\text { LOI } \\
0.1\end{array}$ \\
\hline \multirow{4}{*}{$\begin{array}{l}\text { Farr Creek, } 5 \mathrm{~m} \mathrm{u} / \mathrm{s} \text { of } \\
\text { confluence with Mill Creek }\end{array}$} & \multirow[t]{4}{*}{$\mathrm{C} 14$} & 2.00 & 62.6 & 15.1 & 6.65 & 2.00 & 4.2 & 0.08 & 3.66 & 2.05 & 2.8 & 0.2 & 09 & nd & 010 & 004 & 36 \\
\hline & & 12.00 & 60.3 & 15.0 & 7.63 & 1.90 & 5.2 & 0.11 & 4.70 & 3.37 & 3.1 & 0.5 & 1.2 & nd & 0.12 & 0.11 & $\begin{array}{l}3.0 \\
3.6\end{array}$ \\
\hline & & 31.00 & 53.5 & 15.0 & 8.99 & 1.70 & 6.6 & 0.14 & 4.65 & 4.66 & 4.5 & 5.7 & 3.5 & 0.6 & 0.14 & 0.14 & 7.9 \\
\hline & & 31.00 & 53.8 & 15.3 & 8.79 & 1.20 & 6.8 & 0.13 & 4.64 & 3.69 & 5.3 & 8.1 & 2.2 & 1.6 & 0.15 & 0.18 & 8.6 \\
\hline \multirow{4}{*}{$\begin{array}{l}\text { Farr Creek, } 50 \mathrm{~m} \mathrm{~d} / \mathrm{s} \text { of } \\
\text { confluence with Mill Creek }\end{array}$} & \multirow[t]{4}{*}{$\mathrm{C} 13$} & 5.00 & 56.7 & 14.4 & 8.02 & 1.50 & 5.9 & 0.12 & 4.37 & 2.74 & 4.8 & 6.4 & 1.3 & 1.4 & 0.26 & 0.24 & 7.4 \\
\hline & & 14.50 & 61.8 & 15.3 & 7.30 & 0.70 & 5.9 & 0.09 & 3.97 & 2.38 & 2.8 & 0.5 & 1.2 & nd & 0.11 & 0.17 & 2.9 \\
\hline & & 22.75 & 53.1 & 15.3 & 9.36 & 1.60 & 7.0 & 0.14 & 5.07 & nd & 4.4 & 4.2 & 2.7 & 0.4 & 0.14 & 0.17 & 6.6 \\
\hline & & 33.00 & 54.3 & 14.7 & 8.96 & 0.60 & 7.5 & 0.15 & 5.45 & 5.28 & 3.4 & 1.9 & 2.6 & nd & 0.13 & 0.19 & 5.0 \\
\hline \multirow{3}{*}{$\begin{array}{l}\text { Mill Creek, } 150 \mathrm{~m} \text { u's from } \\
\text { confluence with Farr Creek }\end{array}$} & \multirow[t]{3}{*}{$\mathrm{Cl} 2$} & 3.00 & 54.0 & 14.3 & 8.59 & 1.60 & 6.3 & 0.12 & 4.79 & 3.48 & 4.9 & 6.4 & 1.6 & 1.3 & 0.15 & 0.13 & 7.2 \\
\hline & & 26.50 & 54.2 & 14.6 & 9.24 & 1.50 & 7.0 & 0.13 & 5.24 & 4.18 & 3.2 & 1.3 & 2.0 & nd & 0.12 & 0.13 & 4.3 \\
\hline & & 26.50 & 55.7 & 15.3 & 9.60 & 1.60 & 7.2 & 0.14 & 5.52 & 4.57 & 3.2 & 1.4 & 2.1 & nd & 0.12 & 0.11 & 4.1 \\
\hline \multirow{4}{*}{$\begin{array}{l}\text { Mill Creek, } 10 \mathrm{~m} \text { u/s from } \\
\text { confluence with Farr Creek }\end{array}$} & \multirow[t]{4}{*}{$\mathrm{Cl} 5$} & 9.00 & 59.5 & \begin{tabular}{|l|}
14.7 \\
\end{tabular} & 6.75 & 0.30 & 5.8 & 0.10 & 4.01 & 2.29 & 2.8 & 0.6 & 1.3 & nd & 0.13 & 0.09 & 3.4 \\
\hline & & 26.00 & 59.9 & 15.2 & 7.33 & 1.10 & 5.6 & 0.09 & 4.08 & 2.41 & 2.8 & 0.6 & 1.3 & nd & 0.12 & 0.10 & 3.4 \\
\hline & & 26.00 & 57.9 & 14.3 & 7.38 & 0.80 & 5.9 & 0.11 & 4.18 & 2.90 & 3.5 & 4.4 & 1.8 & 0.7 & 0.19 & 0.14 & 5.4 \\
\hline & & 39.75 & 52.8 & 15.5 & 9.25 & 0.70 & 7.7 & 0.12 & 4.84 & 3.39 & 4.1 & 3.8 & 2.3 & 0.4 & 0.15 & 0.20 & 6.1 \\
\hline
\end{tabular}

Notes:

nd Not detected 
Table 2-7: Trace metal concentrations from core samples collected from Farr Creek and Mill Creek (Percival et al., 2004)

\begin{tabular}{|c|c|c|c|c|c|c|c|c|c|c|c|c|c|c|c|c|c|}
\hline Location & Core ID & $\begin{array}{c}\text { Variable } \\
\text { Units } \\
\text { Detection Limits } \\
\text { Depth }(\mathrm{cm}) \\
\end{array}$ & $\begin{array}{c}\mathrm{Ag} \\
\text { ppm } \\
0.1\end{array}$ & $\begin{array}{c}\text { As } \\
\mathrm{ppm} \\
10\end{array}$ & $\begin{array}{c}\mathrm{Ba} \\
\mathrm{ppm} \\
10\end{array}$ & $\begin{array}{c}\mathrm{Be} \\
\text { ppm } \\
0.5\end{array}$ & $\begin{array}{c}\mathrm{Bi} \\
\mathrm{ppm} \\
0.5\end{array}$ & $\begin{array}{c}\mathrm{Cd} \\
\mathrm{ppm} \\
0.2\end{array}$ & $\begin{array}{c}\mathrm{Ce} \\
\mathrm{ppm} \\
0.1\end{array}$ & $\begin{array}{c}\mathrm{Co} \\
\text { ppm } \\
5\end{array}$ & $\begin{array}{c}\mathrm{Cr} \\
\mathrm{ppm} \\
10\end{array}$ & $\begin{array}{c}\text { Cs } \\
\text { ppm } \\
0.02\end{array}$ & $\begin{array}{c}\mathrm{Cu} \\
\text { ppm } \\
10\end{array}$ & $\begin{array}{c}\text { Mo } \\
\text { ppm } \\
0.2\end{array}$ & $\begin{array}{c}\mathrm{Ni} \\
\text { ppm } \\
10\end{array}$ & $\begin{array}{c}\mathrm{Pb} \\
\mathrm{ppm} \\
10\end{array}$ & $\begin{array}{c}\mathrm{Rb} \\
\mathrm{ppm} \\
0.05\end{array}$ \\
\hline \multirow{4}{*}{$\begin{array}{l}\text { Farr Creek, } 5 \mathrm{~m} \text { u/s of } \\
\text { confluence with Mill Creek }\end{array}$} & \multirow[t]{4}{*}{ C14 } & 2.00 & 32 & 343 & 160 & 1.5 & 7.2 & $<0.2$ & 31 & 130 & 87 & 0.86 & & 32 & & & \\
\hline & & 12.00 & 30 & 1300 & 180 & 1.5 & 18 & 0.5 & 38 & 440 & 100 & 0.93 & 160 & $\begin{array}{l}3.2 \\
6.5\end{array}$ & \begin{tabular}{|c}
90 \\
170
\end{tabular} & $\begin{array}{l}110 \\
140\end{array}$ & $\begin{array}{l}23 \\
26\end{array}$ \\
\hline & & 31.00 & 210 & 1400 & 190 & 2.1 & 21 & 0.7 & 62 & 390 & 120 & 1.50 & 470 & 7.2 & 300 & 350 & $\begin{array}{l}20 \\
34\end{array}$ \\
\hline & & 31.00 & 200 & 1650 & 190 & 2.0 & 23 & 0.6 & 54 & 400 & 160 & 1.20 & 470 & 7.8 & 320 & 240 & 31 \\
\hline \multirow{4}{*}{$\begin{array}{l}\text { Farr Creek, } 50 \mathrm{~m} \mathrm{~d} / \mathrm{s} \text { of } \\
\text { confluence with Mill Creek }\end{array}$} & \multirow[t]{4}{*}{$\mathrm{C} 13$} & 5.00 & 95 & 1580 & 170 & 1.7 & 28 & 0.9 & 41 & 590 & 130 & 1.20 & 380 & 5.0 & 290 & 230 & 27 \\
\hline & & $\begin{array}{l}14.50 \\
\end{array}$ & 140 & 878 & 170 & 1.7 & 15 & 0.5 & 33 & 260 & 93 & 1.10 & 320 & 4.4 & 140 & 180 & 25 \\
\hline & & 22.75 & 220 & 1980 & 210 & 2.0 & 36 & 0.7 & 55 & 480 & 160 & 1.50 & 460 & 6.5 & 290 & 340 & 36 \\
\hline & & 33.00 & 170 & 2610 & 200 & 1.7 & 38 & 1.0 & 46 & 600 & 210 & 0.98 & 540 & 6.3 & 310 & 310 & 30 \\
\hline \multirow{3}{*}{$\begin{array}{l}\text { Mill Creek, } 150 \mathrm{~m} \mathrm{u} / \mathrm{s} \text { from } \\
\text { confluence with Farr Creek }\end{array}$} & \multirow[t]{3}{*}{$\mathrm{C} 12$} & 3.00 & 54 & 1200 & 120 & 1.5 & 25 & 1.0 & 39 & 560 & 120 & 1.20 & 440 & 3.4 & 360 & 300 & 23 \\
\hline & & 26.50 & 17 & 817 & 110 & 1.5 & 23 & 1.6 & 34 & 250 & 120 & 1.30 & 700 & 8.7 & 130 & 510 & 22 \\
\hline & & 26.50 & 17 & 876 & $\$ 10$ & 1.5 & 22 & 1.6 & 34 & 270 & 140 & 1.30 & 640 & 6.1 & 130 & 460 & 23 \\
\hline \multirow{4}{*}{$\begin{array}{l}\text { Mill Creek, } 10 \mathrm{~m} \text { ws from } \\
\text { confluence with Farr Creek }\end{array}$} & \multirow[t]{4}{*}{$\mathrm{C} 15$} & 9.00 & 48 & 451 & 160 & 1.7 & 8.2 & 0.5 & 29 & 210 & 140 & 1.10 & 290 & 4.7 & 130 & 210 & 24 \\
\hline & & 26.00 & 58 & 456 & 150 & 1.7 & 11 & 0.6 & 32 & 210 & 90 & 1.20 & 330 & 4.6 & 120 & 210 & 25 \\
\hline & & $\begin{array}{l}26.00 \\
39.75\end{array}$ & $\begin{array}{l}96 \\
930\end{array}$ & 913 & 160 & 1.6 & 21 & 0.6 & 35 & 460 & 120 & 1.00 & 340 & 4.1 & 250 & 200 & 24 \\
\hline & & 39.75 & 230 & 1720 & 140 & 2.2 & 26 & 0.7 & 54 & 420 & 130 & 0.90 & 660 & 14 & 310 & 350 & 23 \\
\hline
\end{tabular}

\begin{tabular}{|c|c|c|c|c|c|c|c|c|c|c|c|c|c|c|c|c|}
\hline Location & Core 10 & $\begin{array}{c}\text { Vartable } \\
\text { Units } \\
\text { Detection Limits } \\
\text { Depth (cm) } \\
\end{array}$ & $\begin{array}{c}\text { Sc } \\
\text { ppm } \\
0.5\end{array}$ & $\begin{array}{l}\mathrm{Sn} \\
\mathrm{pmp} \\
0.02\end{array}$ & $\begin{array}{c}\mathrm{Sn} \\
\mathrm{ppm} \\
0.5\end{array}$ & $\begin{array}{c}\mathrm{Sr} \\
\mathrm{ppm} \\
\mathrm{S}\end{array}$ & $\begin{array}{c}\mathrm{Ta} \\
\mathrm{ppm} \\
0.2\end{array}$ & $\begin{array}{l}\mathrm{Tb} \\
\mathrm{ppm} \\
0.02\end{array}$ & $\begin{array}{c}\mathrm{Th} \\
\mathrm{ppm} \\
0.02\end{array}$ & $\mid \begin{array}{c}\mathrm{Tl} \\
\mathrm{ppm} \\
0.02\end{array}$ & $\begin{array}{c}\mathrm{Tm} \\
\text { ppm } \\
0.02\end{array}$ & $\begin{array}{c}U \\
\text { ppm } \\
0.02\end{array}$ & $\begin{array}{c}\mathrm{V} \\
\mathrm{ppm} \\
5\end{array}$ & $\begin{array}{c}\mathrm{Y} \\
\mathrm{ppm} \\
0.02\end{array}$ & $\begin{array}{c}\mathrm{Zn} \\
\mathrm{ppm} \\
5\end{array}$ & $\begin{array}{c}\mathrm{Zr} \\
\text { ppm } \\
10\end{array}$ \\
\hline \multirow{4}{*}{$\begin{array}{l}\text { Farr Creek, } 5 \mathrm{~m} \text { u/s of } \\
\text { confluence with Mill Creek }\end{array}$} & \multirow[t]{4}{*}{$\mathrm{Cl} 14$} & 2.00 & 16 & 3.2 & 1.5 & 83 & 0.4 & 0.51 & 4.2 & & & & & & & \\
\hline & & 12.00 & 21 & 3.9 & 1.7 & 82 & 0.4 & 0.61 & 3.4 & 0.13 & 0.29 & 1.7 & 150 & 20 & 180 & 130 \\
\hline & & 31.00 & 18 & 5.6 & 3.8 & 94 & 0.6 & 0.75 & 6.7 & 0.31 & 0.31 & 2.5 & 130 & 26 & 400 & 100 \\
\hline & & 31.00 & 20 & 5.2 & 3.8 & 89 & 0.5 & 0.68 & 6.3 & $0.27 \mid$ & 0.30 & 2.5 & 140 & 24 & 420 & 100 \\
\hline \multirow{4}{*}{$\begin{array}{l}\text { Farr Creek, } 50 \mathrm{~m} \mathrm{~d} / \mathrm{s} \text { of } \\
\text { confluence with Mill Creek }\end{array}$} & \multirow[t]{4}{*}{$\mathrm{C} 13$} & 5.00 & 20 & 4.2 & 4.0 & 78 & 0.4 & $0.64\}$ & 4.4 & $0.17\}$ & 0.29 & 2.0 & 140 & 21 & 320 & 130 \\
\hline & & $\begin{array}{l}14.50 \\
0\end{array}$ & 18 & 3.4 & \begin{tabular}{|l|} 
\\
\end{tabular} & 85 & 0.4 & 0.56 & 4.5 & 0.15 & 0.27 & 1.8 & 130 & 19 & 200 & 120 \\
\hline & & $\begin{array}{l}22.75 \\
33.00\end{array}$ & 21 & $\begin{array}{l}5.0 \\
4.7\end{array}$ & $\begin{array}{l}3.6 \\
3.7\end{array}$ & $\begin{array}{l}87 \\
79\end{array}$ & 0.5 & 0.72 & $\begin{array}{l}6.0 \\
44\end{array}$ & $\mid \begin{array}{l}0.32 \\
0.72\end{array}$ & 0.30 & 2.3 & 150 & 25 & 470 & 110 \\
\hline & & 33.00 & 23 & 4.7 & 3.7 & 79 & 0.4 & 0.66 & 4.4 & $0.27 \mid$ & 0.29 & 2.0 & 160 & 23 & 420 & 100 \\
\hline \multirow{3}{*}{$\begin{array}{l}\text { Mill Creek, } 150 \mathrm{~m} \text { w/s from } \\
\text { confluence with Farr Creek }\end{array}$} & \multirow[t]{3}{*}{$\mathrm{C} 12$} & 3.00 & 25 & 4.1 & 1.9 & 75 & 0.3 & 0.68 & 3.2 & 0.17 & 0.33 & 1.9 & 180 & 23 & 380 & 110 \\
\hline & & 26.50 & 29 & 4.3 & 1.5 & 70 & 0.3 & 0.78 & 2.4 & 0.18 & 0.36 & 2.0 & 200 & 26 & 350 & 100 \\
\hline & & $\begin{array}{r}26.50 \\
900\end{array}$ & $\begin{array}{l}29 \\
18\end{array}$ & $\begin{array}{l}4.4 \\
3.3\end{array}$ & 1.0 & $\begin{array}{l}69 \\
79\end{array}$ & 0.3 & 0.81 & $\left|\begin{array}{|l}2.4 \\
45\end{array}\right|$ & 0.18 & 0.38 & 1.8 & 200 & 27 & 370 & 100 \\
\hline \multirow{4}{*}{$\begin{array}{l}\text { Mill Creek, } 10 \mathrm{~m} \mathrm{w} / \mathrm{s} \text { from } \\
\text { confluence with Farr Creek }\end{array}$} & \multirow[t]{4}{*}{$\mathrm{C} 15$} & 9.00 & 18 & 3.3 & 3.1 & 79 & 0.4 & 0.56 & 4.5 & 0.15 & 0.28 & 1.6 & 140 & 19 & 190 & 110 \\
\hline & & 26.00 & 18 & 3.5 & 2.0 & 79 & 0.4 & 0.57 & 4.6 & 0.17 & 0.27 & 1.7 & 140 & 19 & 200 & 110 \\
\hline & & 26.00 & 18 & 3.6 & 2.7 & 82 & 0.5 & 0.58 & 4.5 & 0.21 & 0.27 & 1.7 & 130 & 20 & 270 & 10 \\
\hline & & 39.75 & 20 & 5.3 & 3.4 & 69 & 0.5 & 0.70 & 6.4 & 0.26 & 0.30 & 2.5 & 150 & 24 & 390 & 100 \\
\hline
\end{tabular}


Table 2-8: Trace metal concentrations from core porewater samples collected from Farr Creek and Mill Creek (Percival et al., 2004)

\begin{tabular}{|c|c|c|c|c|c|c|c|c|c|c|c|c|c|c|c|c|c|c|c|}
\hline Location & Core ID & $\begin{array}{c}\text { Variable } \\
\text { Units } \\
\text { Detection Limits } \\
\text { Depth (cm) } \\
\end{array}$ & $\begin{array}{c}\mathrm{Si} \\
\mathrm{ppb} \\
10\end{array}$ & $\begin{array}{c}\mathrm{Ti} \\
\mathrm{ppb} \\
1\end{array}$ & $\begin{array}{c}\mathrm{Al} \\
\mathrm{ppb} \\
100\end{array}$ & $\begin{array}{c}\mathrm{Fe} \\
\mathrm{ppb} \\
3\end{array}$ & $\begin{array}{l}\text { Mn } \\
\text { ppb } \\
100\end{array}$ & $\begin{array}{c}\mathrm{Mg} \\
\mathrm{ppb} \\
2\end{array}$ & $\begin{array}{c}\mathrm{Ca} \\
\mathrm{ppb} \\
5\end{array}$ & $\begin{array}{c}\mathrm{Na} \\
\mathrm{ppb} \\
20\end{array}$ & $\begin{array}{c}\mathrm{K} \\
\mathrm{ppb} \\
20\end{array}$ & $\begin{array}{c}\mathrm{Ag} \\
\mathrm{ppb} \\
\mathrm{1}\end{array}$ & $\begin{array}{c}\text { As } \\
\text { ppb } \\
500\end{array}$ & $\begin{array}{c}\text { B } \\
\text { ppb } \\
16\end{array}$ & $\begin{array}{c}\mathrm{Ba} \\
\mathrm{ppb} \\
2\end{array}$ & $\begin{array}{c}\mathrm{Bc} \\
\mathrm{ppb} \\
5\end{array}$ & $\begin{array}{c}\mathrm{Bi} \\
\mathrm{ppb} \\
1\end{array}$ & $\mid \begin{array}{c}\mathrm{Cd} \\
\mathrm{ppb} \\
2\end{array}$ & $\begin{array}{l}\mathrm{Co} \\
\mathrm{ppb} \\
100\end{array}$ \\
\hline Farr Creek, $5 \mathrm{~m} \mathrm{u} / \mathrm{s}$ of & $\mathrm{C} 14$ & 2.00 & 20000 & 57 & 4800 & 11000 & 340 & 18000 & 130000 & 6500 & 4300 & 9 & 1100 & 29 & 91 & $<5$ & 11 & $<2$ & 610 \\
\hline confluence with Mill Creek & & 12.00 & 15000 & 39 & 3400 & 6100 & 480 & 38000 & 230000 & 18000 & 1600 & 15 & 1500 & 24 & 110 & $<5$ & 8 & $\mid<2$ & 870 \\
\hline & & 31.00 & 8400 & 8 & 610 & 1200 & 720 & 24000 & 130000 & 18000 & 950 & 3 & 670 & 27 & 45 & $<5$ & 1 & $<2$ & 85 \\
\hline Farr Creek, $50 \mathrm{~m} \mathrm{~d} / \mathrm{s}$ of & $\mathrm{C} 13$ & 5.00 & 14000 & 19 & 2300 & 5600 & 2500 & 21000 & 200000 & 18000 & 11000 & 6 & 1800 & 43 & 170 & $<5$ & 3 & $<2$ & 930 \\
\hline & & 14.50 & 9900 & 31 & 2100 & 4000 & 400 & 12000 & 98000 & 22000 & 8400 & 4 & 1600 & 17 & 100 & $<5$ & 3 & $<2$ & 120 \\
\hline & & $\begin{array}{l}22.75 \\
33.00\end{array}$ & 16000 & $\begin{array}{l}53 \\
80\end{array}$ & 5000 & 9000 & 640 & 17000 & 97000 & 17000 & 8600 & 32 & 1300 & 20 & 77 & $<5$ & 10 & $<2$ & 180 \\
\hline & & & & & 11000 & 19000 & 1200 & 32000 & 160000 & 19000 & 20000 & 87 & 2500 & $<16$ & 160 & $<5$ & 25 & $<2$ & 350 \\
\hline $\begin{array}{l}\text { Mill Creek, } 150 \mathrm{~m} \mathrm{u} / \mathrm{s} \text { from } \\
\text { confluence with Farr Creek }\end{array}$ & & & & & & & & & & & & & & & & & & & \\
\hline Mill Creek, $10 \mathrm{~m} \mathrm{u} / \mathrm{s}$ & $\begin{array}{l}\mathrm{C} 12 \\
\mathrm{C} 15\end{array}$ & $\begin{array}{r}3.00 \\
2600\end{array}$ & 6700 & 7 & 960 & 2000 & 200 & 16000 & 90000 & 16000 & 2900 & 6 & 1900 & 73 & 54 & $<5$ & 2 & $<2$ & 390 \\
\hline confluence with Farr Creek & $(13$ & $\begin{array}{l}26.00 \\
39.75\end{array}$ & $\begin{array}{l}14000 \\
17000\end{array}$ & $\begin{array}{l}24 \\
70\end{array}$ & $\begin{array}{l}2200 \\
6400\end{array}$ & $\begin{array}{l}4600 \\
12000\end{array}$ & $\begin{array}{l}620 \\
520\end{array}$ & $\begin{array}{l}31000 \\
35000\end{array}$ & $\begin{array}{l}360000 \\
190000\end{array}$ & $\begin{array}{l}29000 \\
24000\end{array}$ & $\begin{array}{l}4800 \\
2600\end{array}$ & $\left|\begin{array}{c}8 \\
78\end{array}\right|$ & $\begin{array}{c}900 \\
1100\end{array}$ & $\begin{array}{l}200 \\
160\end{array}$ & 220 & $\begin{array}{l}<5 \\
<5\end{array}$ & $\begin{array}{c}3 \\
14\end{array}$ & $<2$ & 2700 \\
\hline
\end{tabular}

$\breve{\not}$

\begin{tabular}{|c|c|c|c|c|c|c|c|c|c|c|c|c|c|c|c|c|c|c|}
\hline Location & Core 1D & $\begin{array}{c}\text { Variabte } \\
\text { Units } \\
\text { Detection Limits } \\
\text { Depth (cin) } \\
\end{array}$ & $\begin{array}{c}\mathrm{Cr} \\
\mathrm{ppb} \\
1\end{array}$ & $\begin{array}{c}\mathrm{Cs} \\
\mathrm{ppb} \\
1\end{array}$ & $\begin{array}{c}\mathrm{Cl} \\
\mathrm{ppb} \\
2\end{array}$ & $\begin{array}{c}\mathrm{Hg} \\
\mathrm{ppb} \\
1\end{array}$ & $\begin{array}{l}\text { Mo } \\
\text { ppb } \\
2\end{array}$ & $\begin{array}{c}\mathrm{Ni} \\
\mathrm{ppb} \\
100\end{array}$ & $\begin{array}{c}\mathrm{Pb} \\
\mathrm{ppb} \\
1\end{array}$ & $\begin{array}{c}\mathrm{Rb} \\
\mathrm{ppb} \\
1\end{array}$ & $\begin{array}{c}\mathrm{Sb} \\
\mathrm{ppb} \\
1\end{array}$ & \begin{tabular}{|c|}
$\mathrm{Sc}$ \\
$\mathrm{ppb}$ \\
1
\end{tabular} & $\begin{array}{c}\mathrm{Se} \\
\mathrm{ppb} \\
10\end{array}$ & $\begin{array}{c}\mathrm{St} \\
\mathrm{ppb} \\
1\end{array}$ & $\begin{array}{c}\mathrm{Tl} \\
\mathrm{ppb} \\
1\end{array}$ & $\begin{array}{c}\mathrm{U} \\
\mathrm{ppb} \\
1\end{array}$ & $\begin{array}{c}\mathrm{V} \\
\mathrm{ppb} \\
1\end{array}$ & $\begin{array}{c}\mathrm{Zn} \\
\mathrm{ppb} \\
10\end{array}$ \\
\hline \multirow{3}{*}{$\begin{array}{l}\text { Farr Creek, } 5 \mathrm{~m} \text { u/s of } \\
\text { confluence with Mill Creek }\end{array}$} & \multirow[t]{2}{*}{$\mathrm{Cl} 14$} & 2.00 & 67 & 1 & 130 & $<1$ & 22 & 270 & 192 & 21 & 220 & 1.3 & 10 & 180 & $<1$ & $t$ & 45 & 120 \\
\hline & & 12.00 & 53 & $<1$ & 54 & $<1$ & 42 & 540 & 108 & 10 & 1000 & 1.3 & 12 & 310 & $<1$ & 4 & 27 & 83 \\
\hline & \multirow{5}{*}{$\mathrm{Cl3}$} & 31.00 & 27 & $<1$ & 18 & $<1$ & 24 & 230 & 25 & 4 & 720 & $<1$ & 13 & 200 & $<1$ & 9 & 10 & 20 \\
\hline \multirow{4}{*}{$\begin{array}{l}\text { Farr Creek, } 50 \mathrm{~m} \mathrm{~d} / \mathrm{s} \text { of } \\
\text { confluence with Mill Creek }\end{array}$} & & 5.00 & 42 & $<1$ & 25 & $<1$ & 32 & 300 & 66 & 20 & 110 & 1.1 & 15 & 190 & $<1$ & 1 & 23 & 60 \\
\hline & & 14.50 & 38 & $<1$ & 22 & $<1$ & 51 & 130 & 72 & 13 & 310 & 2.8 & 10 & 110 & $<1$ & 3 & 17 & 40 \\
\hline & & 22.75 & 62 & $<1$ & 31 & $<!$ & 11 & 220 & 158 & 32 & 380 & 1.2 & $<10$ & 130 & $<1$ & 8 & 41 & 70 \\
\hline & & 33.00 & 120 & 1 & 150 & $<1$ & 12 & 460 & 396 & 67 & 560 & 1.2 & $<10$ & 210 & $<\mathrm{l}$ & 15 & 93 & 130 \\
\hline \multirow{3}{*}{$\begin{array}{l}\text { Mill Creek, } 150 \mathrm{~m} \text { u/s from } \\
\text { confluence with Farr Creek } \\
\text { Mill Creek, } 10 \mathrm{~m} \text { w/s from } \\
\text { confluence with Farr Creek }\end{array}$} & \multirow{3}{*}{$\begin{array}{l}\mathrm{C} 12 \\
\mathrm{C} 15\end{array}$} & 3.00 & 47 & $<1$ & 53 & $<1$ & 33 & 280 & 56 & 9 & 750 & 150 & 11 & 140 & 1 & 2 & 14 & $54]$ \\
\hline & & 26.00 & 36 & $<1$ & 65 & $<1$ & 15 & 980 & 69 & 9 & 490 & $<1$ & 15 & 390 & $<1$ & $<1$ & $\begin{array}{l}14 \\
15\end{array}$ & $\begin{array}{c}54 \\
190\end{array} \mid$ \\
\hline & & 39.75 & 79 & $<1$ & 190 & $<1$ & 28 & 290 & 158 & 8 & 890 & 1.4 & 18 & 260 & $<1$ & 2 & 47 & 180 \\
\hline
\end{tabular}


Also summarized by Percival et al. (2004) were trace metal concentrations from several surface water samples collected at various locations within the study area from 1994 to 1997. These results are presented in Table 2-9 and the sample locations are presented in Figure 2-4. Elevated concentrations were noted for the alkali earth metals as well as As, $\mathrm{Co}, \mathrm{Ni}, \mathrm{Sb}$, where more elevated concentrations were generally noted in Mill Creek. This could be attributed to two factors:

1) Mill Creek transports tailings loadings from several upstream tailings deposits and from the municipal wastewater lagoon discharge; and

2) Dilution effects from Mill Creek draining into Farr Creek resulting in lower observed concentrations in Farr Creek downstream of the confluence.

The remaining metals analyzed appeared to have relatively low and stable concentrations throughout the drainage path with only minor fluctuations. Table 2-10 presents the results from the anion surface water chemistry summarized by Percival et al. (2004). As can be seen from the table, there are elevated nitrates and phosphates in Mill Creek, with significantly lower concentrations, in most cases below the method detection limits, in Farr Creek. Municipal wastewater was released directly to Mill Creek without treatment prior to approximately 2000 , when a wastewater treatment lagoon was installed in the 
Table 2-9: Trace metal concentrations from surface water samples collected from Farr Creek and Mill Creek (Percival et al., 2004)

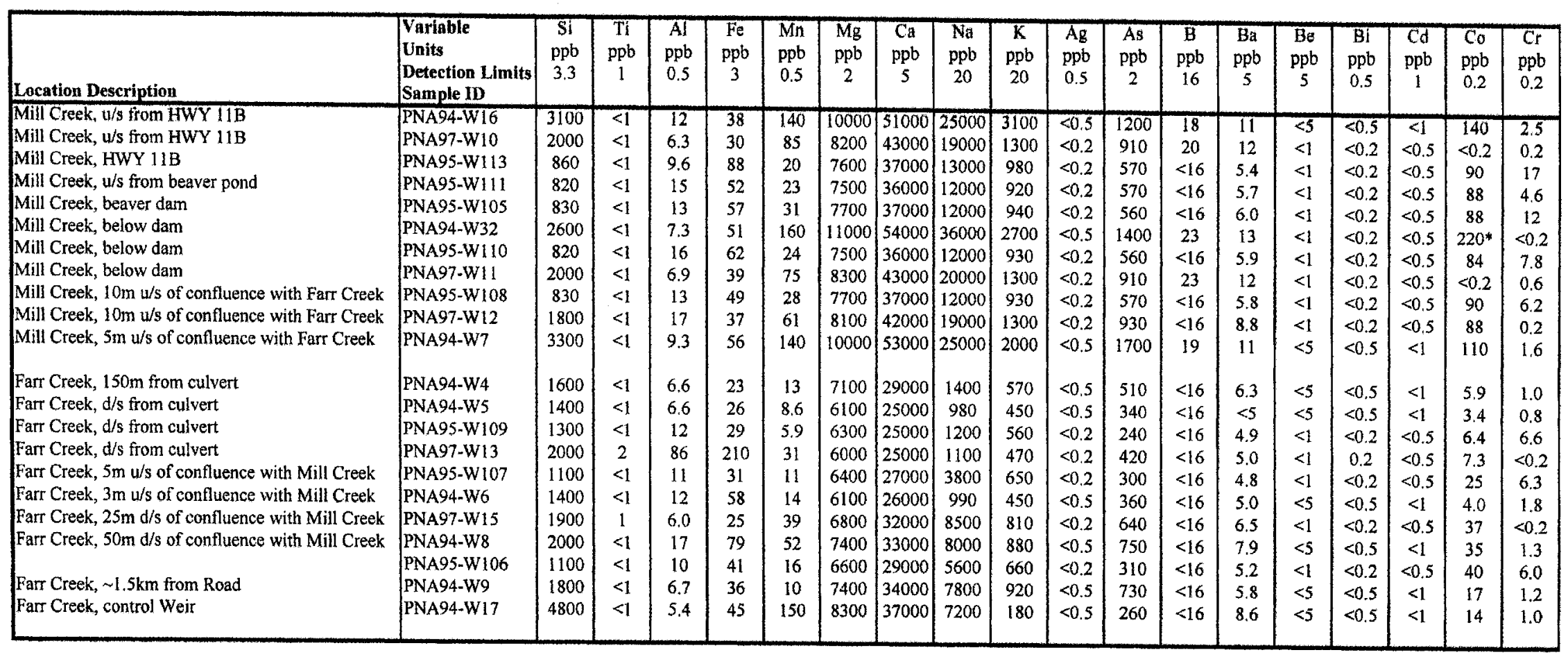


Figure 2-4: Location of Surface Water Samples Collected from Farr Creek and Mill Creek by Percival et al., 2004

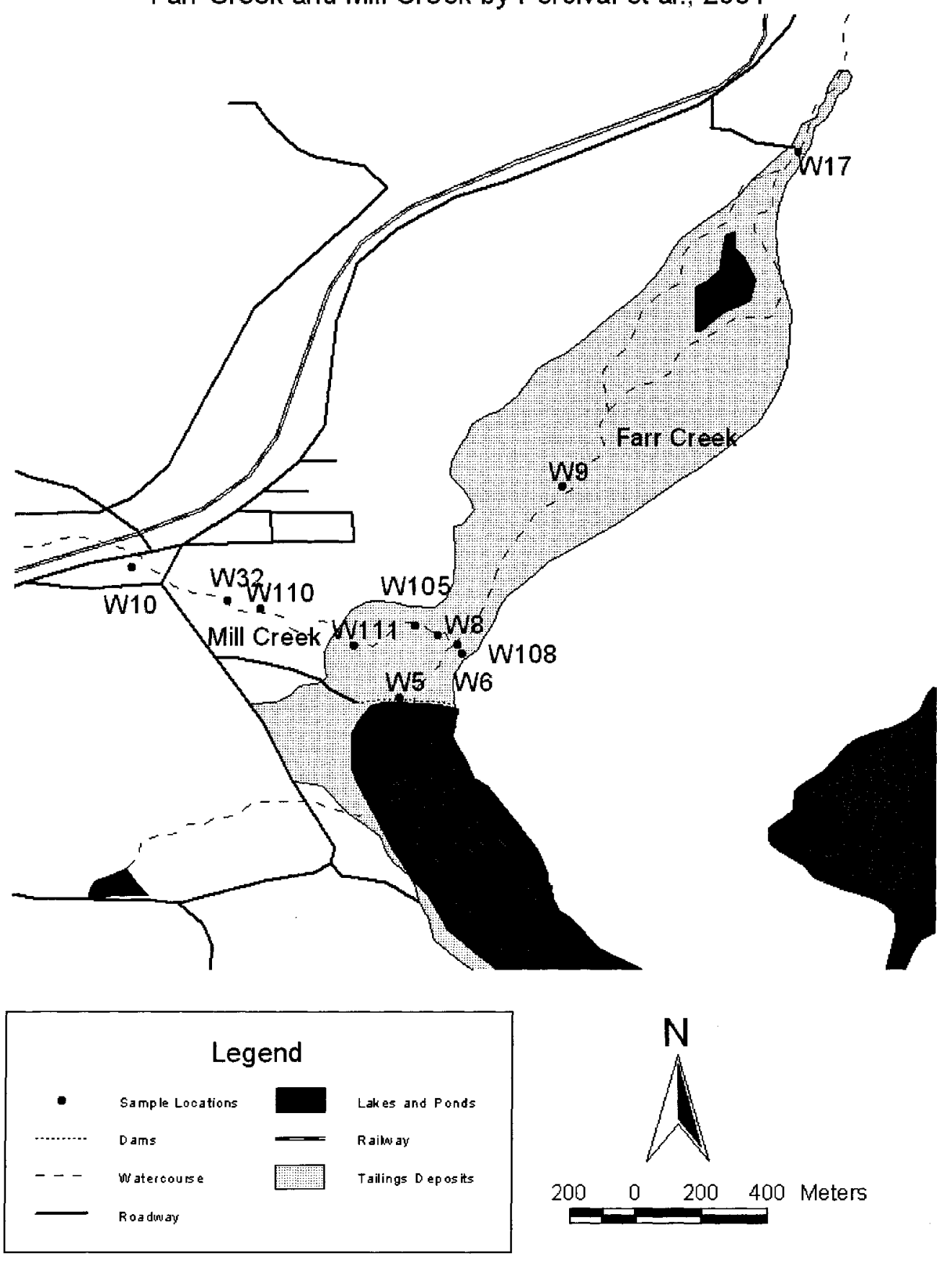


area. The lack of nutrients detected in Farr Creek is attributable to consumption of nutrients along the flow path and to dilution effects.

\subsubsection{Farr Creek Tailings Deposit Geochemistry}

The mobility of elements in subsurface systems is generally regulated by the solubility of their salts (in this case mainly their sulfates, arsenates, antimonates, or carbonate salts), and the $\mathrm{pH}$ and Eh conditions (Boyle and Dass, 1971). Near surface oxidation reactions will mobilize soluble components whereas in deeper anoxic sediments, dissolved components tend to form precipitates as a result of the strong reducing conditions.

Geochemical interactions in tailings deposits are quite complex. As a result, this discussion will be limited to elements that are components of major mineral groups within the tailings such as $\mathrm{Fe}, \mathrm{Mn}, \mathrm{Ca}, \mathrm{Mg}, \mathrm{Al}$, silicates and alkali earth metals, and to metals of significant environmental concern, which include $\mathrm{As}, \mathrm{Sb}, \mathrm{Co}, \mathrm{Ni}, \mathrm{Pb}$, and $\mathrm{Zn}$.

\section{Iron, Manganese, Calcium and Magnesium}

Primary carbonate minerals such as calcite and dolomite will react with the dissolved $\mathrm{CO}_{2}$ in the mixing water, thereby forming soluble secondary bicarbonate and carbonate minerals (Boyle and Dass, 1971). Should there be any sulfide minerals in the surficial tailings, they will become oxidized producing sulfuric acid. Considering the amount of 
Table 2-10: Anion concentrations from surface water samples collected from Farr Creek and Mill Creek (Percival et al., 2004)

\begin{tabular}{|c|c|c|c|c|c|c|c|c|}
\hline Location Description & \begin{tabular}{|l|} 
Variable \\
Units \\
Detection Limits \\
Sample ID \\
\end{tabular} & $\begin{array}{c}\mathrm{NO2} \\
\mathrm{ppb} \\
50\end{array}$ & $\begin{array}{c}\mathrm{NO} 3 \\
\mathrm{ppb} \\
50\end{array}$ & $\begin{array}{c}\mathrm{F} \\
\mathrm{ppb} \\
50\end{array}$ & $\begin{array}{c}\mathrm{PO4} \\
\mathrm{ppb} \\
50\end{array}$ & $\begin{array}{c}\mathrm{Br} \\
\mathrm{ppb} \\
50\end{array}$ & $\begin{array}{l}\mathrm{SO4} \\
\mathrm{ppm} \\
0.05\end{array}$ & $\begin{array}{c}\mathrm{Cl} \\
\mathrm{ppm} \\
0.05\end{array}$ \\
\hline Mill Creek, u/s from HWY IIB & PNA94-W16 & 180 & 4880 & 110 & 650 & $<50$ & 31.6 & 33.3 \\
\hline Mill Creek, u/s from HWY 11B & PNA97-W10 & $<50$ & 3460 & 54 & $<50$ & $<50$ & 16.9 & 25.7 \\
\hline Mill Creek, HWY 11B & PNA95-W113 & $<50$ & $<50$ & $<50$ & $<50$ & $<50$ & 17.3 & 17.5 \\
\hline Mill Creek, u/s from beaver pond & PNA95-W111 & $<50$ & $<50$ & $<50$ & $<50$ & $<50$ & 16.7 & 17.4 \\
\hline Mill Creek, beaver dam & PNA95-W105 & $<50$ & $<50$ & $<50$ & $<50$ & $<50$ & 16.0 & 17.5 \\
\hline Mill Creek, below dam & PNA94-W32 & $<50$ & 13800 & 160 & 600 & $<50$ & 25.6 & 42.9 \\
\hline Mill Creek, below dam & PNA95-W110 & $<50$ & $<50$ & 210 & $<50$ & $<50$ & 16.2 & 17.1 \\
\hline Mill Creek, below dam & PNA97-W11 & $<50$ & 3300 & 62 & $<50$ & $<50$ & 16.8 & 27.0 \\
\hline Mill Creek, $10 \mathrm{~m} \mathrm{u} / \mathrm{s}$ of confluence with Farr Creek & PNA95-W108 & $<50$ & $<50$ & $<50$ & $<50$ & $<50$ & 16.5 & 17.3 \\
\hline Mill Creek, $10 \mathrm{~m} \mathrm{u} / \mathrm{s}$ of confluence with Farr Creek & PNA97-W12 & $<50$ & 2070 & 61 & $<50$ & $<50$ & 15.8 & 25.9 \\
\hline Mill Creek, $5 \mathrm{~m} \mathrm{u} / \mathrm{s}$ of confluence with Farr Creek & PNA94-W7 & 380 & 3760 & 86 & 450 & $<50$ & 21.4 & 35.5 \\
\hline Farr Creek, $150 \mathrm{~m}$ from culvert & PNA94-W4 & $<50$ & $<50$ & $<50$ & $<50$ & $<50$ & 9.08 & 0.89 \\
\hline Farr Creek, d/s from culvert & PNA94-W5 & $<50$ & $<50$ & $<50$ & $<50$ & $<50$ & 8.43 & 0.61 \\
\hline Farr Creek, d/s from culvert & PNA95-W109 & $<50$ & $<50$ & $<50$ & $<50$ & $<50$ & 9.93 & 0.83 \\
\hline Farr Creek, d/s from culvert & PNA97-W13 & $<50$ & $<50$ & $<50$ & $<50$ & $<50$ & 7.23 & 0.72 \\
\hline Farr Creek, $5 \mathrm{~m}$ u/s of confluence with Mill Creek & PNA95-W107 & $<50$ & $<50$ & $<50$ & $<50$ & $<50$ & 10.9 & 5.03 \\
\hline Farr Creek, $3 \mathrm{~m} \mathrm{u} / \mathrm{s}$ of confluence with Mill Creek & PNA94-W6 & $<50$ & $<50$ & $<50$ & $<50$ & $<50$ & 8.45 & 0.65 \\
\hline Farr Creek, $25 \mathrm{~m} \mathrm{~d} / \mathrm{s}$ of confluence with Mill Creek & PNA97-W15 & $<50$ & 750 & $<50$ & $<50$ & $<50$ & 10.7 & 10.6 \\
\hline Farr Creek, $50 \mathrm{~m} \mathrm{~d} / \mathrm{s}$ of confluence with Mill Creek & PNA94-W8 & 140 & 830 & 92 & $<50$ & $<50$ & 12.6 & 10.2 \\
\hline Farr Creek, $50 \mathrm{~m} \mathrm{~d} / \mathrm{s}$ of confluence with Mill Creek & PNA95-W106 & $<50$ & $<50$ & $<50$ & $<50$ & $<50$ & 11.8 & 7.50 \\
\hline Farr Creek, $\sim 1.5 \mathrm{~km}$ from Road & PNA94-W9 & 69 & 747 & $<50$ & $<50$ & $<50$ & 12.0 & 9.76 \\
\hline Farr Creek, control Weir & PNA94-W17 & $<50$ & $<50$ & 100 & $<50$ & $<50$ & 2.06 & 8.54 \\
\hline
\end{tabular}


carbonate present in the tailings, the acid would be immediately neutralized and produce soluble Fe, Mn, Mg, and Ca sulfates (Boyle and Dass, 1971).

Under oxidizing conditions, $\mathrm{Fe}$ is found predominantly in the form of limonite and $\mathrm{Mn}$ as wad (Dumaresq, 1993). Wad may also coprecipitate with limonite. If arsenides are present the Fe may be bound in scordite. Under reducing conditions $\mathrm{Fe}^{2+}(\mathrm{aq})$ is the dominant Fe species, in the absence of reduced sulfur, at $\mathrm{pH}$ values below 6.8 (Brookins, 1988). If reduced sulfur is present, iron sulfide precipitates can form regardless of the $\mathrm{pH}$. Between $\mathrm{pH}$ values of $6.8-9.4, \mathrm{FeCO}_{3}$ precipitates form and at $\mathrm{pH}$ values above 9.4 reduced iron oxides are dominant (Brookins, 1988). Similar species are formed for manganese with one exception. The formation of $\mathrm{MnS}$ is dependent on $\mathrm{pH}$ and will only occur between pH levels of 8-10 (Brookins, 1988).

\section{Alkalies, Silica, and Alumina}

The oxidation of alkalies typically results in the formation of soluble carbonates, sulfates, and arsenates (Boyle and Dass, 1971). Silica is released as alkali silicates or monosilic acid (Boyle and Dass, 1971). Much of the dissolved alkalies, silica and alumina are bound up in clay minerals, limonite, and wad. It should be noted, however, that the mobilities and Eh-pH relationships of these elements are quite different. Na and $\mathrm{K}$ are quite mobile for a wide range of $\mathrm{pH}$ values. Silica only becomes $\mathrm{pH}$ dependent above $\mathrm{pH}$ 12, after which its solubility increases significantly (Brookins, 1988). The mobility of A1 is very $\mathrm{pH}$ dependent. Below $\mathrm{pH} 4, \mathrm{Al}$ is in the form of $\mathrm{Al}^{3+}{ }_{(\mathrm{aq})}$. Between $\mathrm{pH} 4-10$, 
$\mathrm{Al}_{2} \mathrm{O}_{3}$ and $\mathrm{Al}(\mathrm{OH})_{3}$ precipitates are abundant, and above $\mathrm{pH} 10$, soluble $\mathrm{AlO}_{2}{ }^{-}$is predominant (Brookins, 1988).

\section{$\underline{\text { Arsenic }}$}

Most of the arsenic in the tailings originates from arsenides and sulfarsenides (Boyle and Dass, 1971). The most common oxidation states in natural waters are As(III) and As(V). The oxidation of arsenides and sulfarsenides releases arsenious oxide and arsenic acid and its ionization products (Boyle and Dass, 1971). Dissolved Fe may react with the arsenic forming scordite or it may precipitate as limonite. Similarly, Co and Ni can react with arsenic acid forming erythrite and annabergite respectively. These three minerals are the most common secondary minerals in the tailings in general and may also adsorb to or coprecipitate with limonite and wad (Dumaresq, 1993). In the presence of reduced sulfur AsS can precipitate. Under reducing conditions, bacteria can methylate arsenic producing methylarsenic acid $\left[\left(\mathrm{CH}_{3}\right) \mathrm{H}_{2} \mathrm{AsO}_{3}\right]$, dimethyarsenic acid $\left[\left(\mathrm{CH}_{3}\right) 2 \mathrm{HAsO}_{2}\right]$, and trimethylarsine oxide $\left[\left(\mathrm{CH}_{3}\right) 3 \mathrm{AsO}\right]$ (Percival et al., 2004).

As(III) species are more toxic than As(V) species, and in general inorganic As species are more toxic than the organic forms (Percival et al., 2004). Arsenic tends to adsorb onto Fe and $\mathrm{Al}$ oxides, clay minerals and organic matter. The freshwater aquatic life discharge guideline for As is 5ppb (CCME, 2003). Chronic exposures to As may affect the central nervous system and form skin lesions which could become cancerous (Percival et al., 2004). 


\section{Antimony}

Antimony present in the tailings is associated with antimonides and arsenides. It is considered relatively mobile under oxic conditions. Similar to As, its primary oxidation states in natural waters are $\mathrm{Sb}(\mathrm{III})$ and $\mathrm{Sb}(\mathrm{V})$. Under oxic conditions, various antimony oxides are abundant such as $\mathrm{Sb}(\mathrm{OH})_{6}{ }^{-}, \mathrm{Sb}_{2} \mathrm{O}_{4}, \mathrm{Sb}_{2} \mathrm{O}_{5}$, and $\mathrm{Sb}(\mathrm{OH})_{3}$ (Krupka and Serne, 2002). Under reducing conditions and in the presence of reduced sulfur, antimony sulfides are generated at $\mathrm{pH}$ values below 6 . Above $\mathrm{pH} 6$ antimony sulfide soluble complexes such as $\mathrm{Sb}_{2} \mathrm{~S}_{4}{ }^{2-}$ form (Brookins, 1988). Also, under mildly reducing conditions at very low $\mathrm{pH}$ aqueous $\mathrm{SbO}^{+}$forms, while at very high $\mathrm{pH}$ values (above 12) $\mathrm{SbO}_{2}{ }^{-}$is formed (Krupka and Serne, 2002).

Methylated antimony species have been detected in some marine and fresh waters, comprising less than $10 \%$ of the total dissolved antimony in these waters (Krupka and Serne, 2002). Antimony is adsorbed significantly under acidic $\mathrm{pH}$ levels due to its negatively charged species surface for much of the $\mathrm{pH}$ range. It is known to adsorb and/or coprecipitate with Fe and Al oxides (Krupka and Serne, 2002). The Canadian Council of Ministers of the Environment (CCME) list the maximum allowable $\mathrm{Sb}$ concentration (MAC) for drinking water as $6 \mathrm{ppb}$. There is no reported guideline for freshwater aquatic life. Long term exposures to elevated concentrations of $\mathrm{Sb}$ may lead to irritation of the eyes, irritation of the respiratory system, and the development of skin 
lesions called antimony spots. Chronic exposure may lead to damage to the heart, lungs and liver (ASTDR, 1992).

\section{Cobalt}

The cobalt present in the tailings originate from arsenides, sulfarsenides and sulfides. Cobalt has two oxidation states, $\mathrm{Co}(\mathrm{II})$ and $\mathrm{Co}(\mathrm{III}) . \mathrm{Co}(\mathrm{III})$ is a strong oxidizing agent and chemical species containing $\mathrm{Co}(\mathrm{III})$ tend to decompose under the Eh-pH conditions of most natural waters (Krupka and Serne, 2002). However, the presence of certain complexing ligands, such as EDTA and $\mathrm{NH}_{3}$, can stabilize $\mathrm{Co}(\mathrm{III})$ and allow it to persist in aqueous solutions (Krupka and Serne, 2002).

Under oxidizing to slightly reducing conditions, $\mathrm{Co}^{2+}{ }_{(\mathrm{aq})}$ is the dominant species for $\mathrm{pH}$ values less than 9. From $\mathrm{pH} 9-13.5, \mathrm{Co}(\mathrm{OH})_{2}$ is formed and above $\mathrm{pH} 13.5$, soluble $\mathrm{Co}(\mathrm{OH})_{4}{ }^{2-}$ becomes abundant (Brookings, 1988). Under strongly oxidizing and circumneutral to alkaline conditions $\mathrm{Co}_{3} \mathrm{O}_{4}$ becomes the dominant precipitate (Brookings, 1988). In the presence of carbonates, $\mathrm{CoCO}_{3}$ may form between $\mathrm{pH}$ 7-10 under slightly oxidizing conditions (Brookings, 1988). Under reducing conditions, CoS precipitates form relatively independent of $\mathrm{pH}$.

Several adsorption studies have indicated that Co is strongly adsorbed and/or coprecipitated onto $\mathrm{Mn}$ and Fe oxide surfaces in the absence of organic ligands, with the adsorption being more strongly favoured with Mn oxides (Percival et al., 2004). Under 
neutral to basic conditions, the presence of organic ligands can significantly reduce adsorption by forming soluble complexes with Co (Krupka and Serne, 2002).

Co is considered an essential element for humans, however, it becomes toxic at doses greater than 25mg/day (Reinman and de Caritat, 1998). It causes deficiencies in Fe and $\mathrm{Cu}$ (Percival et al., 2004).

\section{Nickel}

Nickel containing compounds present in the tailings are associated with sulfides, sulfarsenides, arsenides, and a number of silicates. The most common oxidation states for $\mathrm{Ni}$ in natural systems are $\mathrm{Ni}(0)$ and $\mathrm{Ni}(\mathrm{II})$. Chemically, $\mathrm{Ni}$ is very similar to $\mathrm{Fe}$ and $\mathrm{Co}$, and as such can replace $\mathrm{Fe}$ and $\mathrm{Co}$ in primary mineral phases such as $\mathrm{FeS}_{2}$ and CoAsS (Brookings, 1988). Under oxidizing conditions, $\mathrm{Ni}$ is in the form of $\mathrm{Ni}^{2+}{ }_{(\text {aq }}$ at $\mathrm{pH}$ values less than $8 . \mathrm{Ni}(\mathrm{OH})_{2}$ becomes the dominant species at $\mathrm{pH}$ values between $8.5-11$, and $\mathrm{HNiO}_{2}{ }^{-}$predominates at $\mathrm{pH}$ values above 11 (Brookings, 1988). Under reducing conditions and in the presence of sulfides, $\mathrm{NiS}$ will form under a wide range of $\mathrm{pH}$ values. $\mathrm{NiOH}^{+}$and $\mathrm{NiCO}_{3}$ are metastable with respect to $\mathrm{Ni}^{2+}$ and $\mathrm{Ni}(\mathrm{OH})_{2}$, respectively (Brookings, 1988). Nickel does not form any stable carbonate species.

In aquatic systems, $\mathrm{Ni}$ can become adsorbed or coprecipitated with iron and manganese oxides, clay minerals and organic matter (Dumaresq, 1993). The MAC for nickel, as reported by the CCME, is related to water hardness (Table 2-11). As shown, the toxicity 
of $\mathrm{Ni}$ increases with decreasing hardness. It is suggested by the USEPA that short term exposure is not likely to cause negative health effects, however, prolonged or chronic exposure to elevated nickel concentrations may lead to reduced body weight, heart damage, liver damage, and skin irritation (Reimann and de Caritat, 1998).

Table 2-11: Maximum Allowable Concentrations (MAC) for Ni based on water hardness (taken from Dumaresq, 1993)

\begin{tabular}{|c|c|}
\hline Hardness (mg CaCO & Ni $/$ (ppm) \\
\hline $0-60$ & 0.025 \\
$60-120$ & 0.065 \\
$120-180$ & 0.11 \\
$>180$ & 0.15 \\
\hline
\end{tabular}

$\underline{\text { Zinc }}$

Zinc is present in the tailings in trace quantities and is most likely associated with sulfide deposits. The most common oxidation state for $\mathrm{Zn}$ is $\mathrm{Zn}(\mathrm{II})$ (Reimann and de Caritat, 1998). Under oxidizing conditions and $\mathrm{pH}$ values less than $7.5, \mathrm{Zn}$ is predominantly in the form $\mathrm{Zn}^{2+}{ }_{(\mathrm{aq})}$ (Brookings, 1988). At $\mathrm{pH}$ values between 7.5 and 8 and under oxidizing conditions, $\mathrm{ZnCO}_{3}$ may form (Brookings, 1988). At higher $\mathrm{pH}$ values, $\mathrm{Zn}$ oxides are dominant. Under reducing conditions the only species that is formed is $\mathrm{ZnS}$. This precipitate may form between $\mathrm{pH}$ values of 2 to 14 (Brookings, 1988). 
In aquatic systems, $\mathrm{Zn}$ can become adsorbed or coprecipitated with iron and manganese oxides, clay minerals and organic matter. Under reducing conditions and in the presence of reduced sulfur, $\mathrm{Zn}$ competitively forms $\mathrm{ZnS}$ precipitates (Brookings, 1988). The MAC for $\mathrm{Zn}$, as reported by the CCME drinking water guideline is $5 \mathrm{mg} / \mathrm{l}$. Zinc toxicity in plants results in depressed growth. This typically occurs at soil zinc concentrations in excess of $300 \mathrm{mg} / \mathrm{kg}$ (Reimann and de Caritat, 1998). Concentrations of $\mathrm{Zn}$ in drinking water in excess of $3 \mathrm{mg} / \mathrm{l}$ causes aesthetic complaints (Reimann and de Caritat, 1998).

$\underline{\text { Lead }}$

Lead is present in the tailings in trace quantities and is most likely associated with sulfide deposits. The most common oxidation states for $\mathrm{Pb}$ are $\mathrm{Pb}(\mathrm{II})$ and $\mathrm{Pb}(\mathrm{IV})$ (Reimann and de Caritat, 1998). Under oxidizing conditions and strongly acidic conditions with $\mathrm{pH}$ values less than $0.5, \mathrm{~Pb}$ is predominantly in the form was $\mathrm{Pb}^{2+}{ }_{(\mathrm{aq})}$ (Brookings, 1988). At $\mathrm{pH}$ values between 0.5 and 4.5 and under oxidizing conditions, $\mathrm{PbSO}_{4}$ may form (Brookings, 1988). At $\mathrm{pH}$ values between 4.5 and $11 \mathrm{PbCO}_{3}$ is the dominant lead species. At higher $\mathrm{pH}$ values and strong oxidizing conditions, various lead oxides may form, including $\mathrm{PbO}, \mathrm{Pb}_{3} \mathrm{O}_{4}$, and $\mathrm{PbO}_{2}$. Under reducing conditions, $\mathrm{PbS}$ is the only species that forms. This precipitate may form between $\mathrm{pH}$ values of 0.4 to 14 (Brookings, 1988). 
In aquatic systems, $\mathrm{Pb}$ is generally strongly adsorbed or coprecipitated with iron and manganese oxides, clay minerals and organic matter. Under reducing conditions and in the presence of reduced sulfur, $\mathrm{Pb}$ competitively forms $\mathrm{PbS}$ precipitates (Brookings, 1988). The MAC for $\mathrm{Pb}$, as reported by the CCME drinking water guideline, is 0.05 $\mathrm{mg} / \mathrm{l}$. Concentrations of $\mathrm{Pb}$ above the $\mathrm{MAC}$ in drinking water can result in delays of normal physical and mental development in babies and young children, increases in blood pressure to adults in the short term and can cause stroke, kidney disease, and various cancers with long term exposure (Reimann and de Caritat, 1998). 


\subsection{METHODOLOGY}

\subsection{Field Methods}

The following sections summarize the methodologies followed for the collection of sediment, surface and groundwater, and vegetation samples at the study site.

\subsubsection{Coring Procedures}

In June 2004, nine cores were collected from the Farr Creek drainage area between the south dam near Crosswise Lake and the north control dam located at $4^{\text {th }}$ Avenue. These cores were collected using a Russian Auger, which consists of a $50 \mathrm{~cm}$ half barrel capable of holding 1/2 of a $5 \mathrm{~cm}$ core diameter volume. Each barrel was opened in the field and the sediment core sample was quickly transferred onto saran wrap and sealed and wrapped again with tin foil to seal the core from the atmosphere. The core samples were placed in a cooler to ensure conditions at the time of sampling were maintained through to the time of analysis. Stratigraphic borehole logs were completed for each core and are

presented in Appendix A. The locations of the core samples collected in June 2004 are presented on Figure 3-1.

Individual soil samples were also collected upstream of the study area in Crosswise Lake. Both a submerged and an exposed sediment sample were collected in $125 \mathrm{ml}$ plastic jars. 
All the cores were stored in a refrigerator $\left(\mathrm{kept}\right.$ below $\left.4^{\circ} \mathrm{C}\right)$ during the field trip and transported in metal coolers insulated with Styrofoam and ice packs to the Earth Sciences Laboratory at Carleton University, Ottawa, ON until they were prepared for analysis. These cores were sectioned in approximately $15 \mathrm{~cm}$ intervals and analyzed for total metals, water content and organic matter content.

Five additional sediment cores were collected from the study area in September 2004. The coring was completed by pushing a $5 \mathrm{~cm}$ diameter $\mathrm{ABS}$ pipe, $1.8 \mathrm{~m}$ in length into the sediment. The locations of the cores are presented in Figure 3-1. Four of the five cores were completed in standing water and as such the pipes were pushed down below the water level. Due to the coring methodology chosen, some compression was inevitable. It is difficult to determine the exact level of compression in each core due to losses of sediment from the base of the pipe, while extracting the pipe.

Prior to pulling the core back up to the surface, a plastic cap was pushed into the end of the pipe and then covered by several pieces of duct tape to maintain adequate suction and ensure the pipe was sealed to the atmosphere. As soon as the pipe was lifted above the sediment-water interface, the lower end of the pipe was sealed with a plastic cap and duct tape to ensure only minimal sediment was lost during the extraction. Sediment samples were collected from these cores at approximately $25 \mathrm{~cm}$ intervals and analyzed for acid producing bacteria (APB), iron reducing bacteria (IRB) and sulfate reducing bacteria (SRB) sequentially extracted metals (SEM), acid volatile sulfides (AVS) and chromium 
Figure 3-1: Location of June and September Core Samples

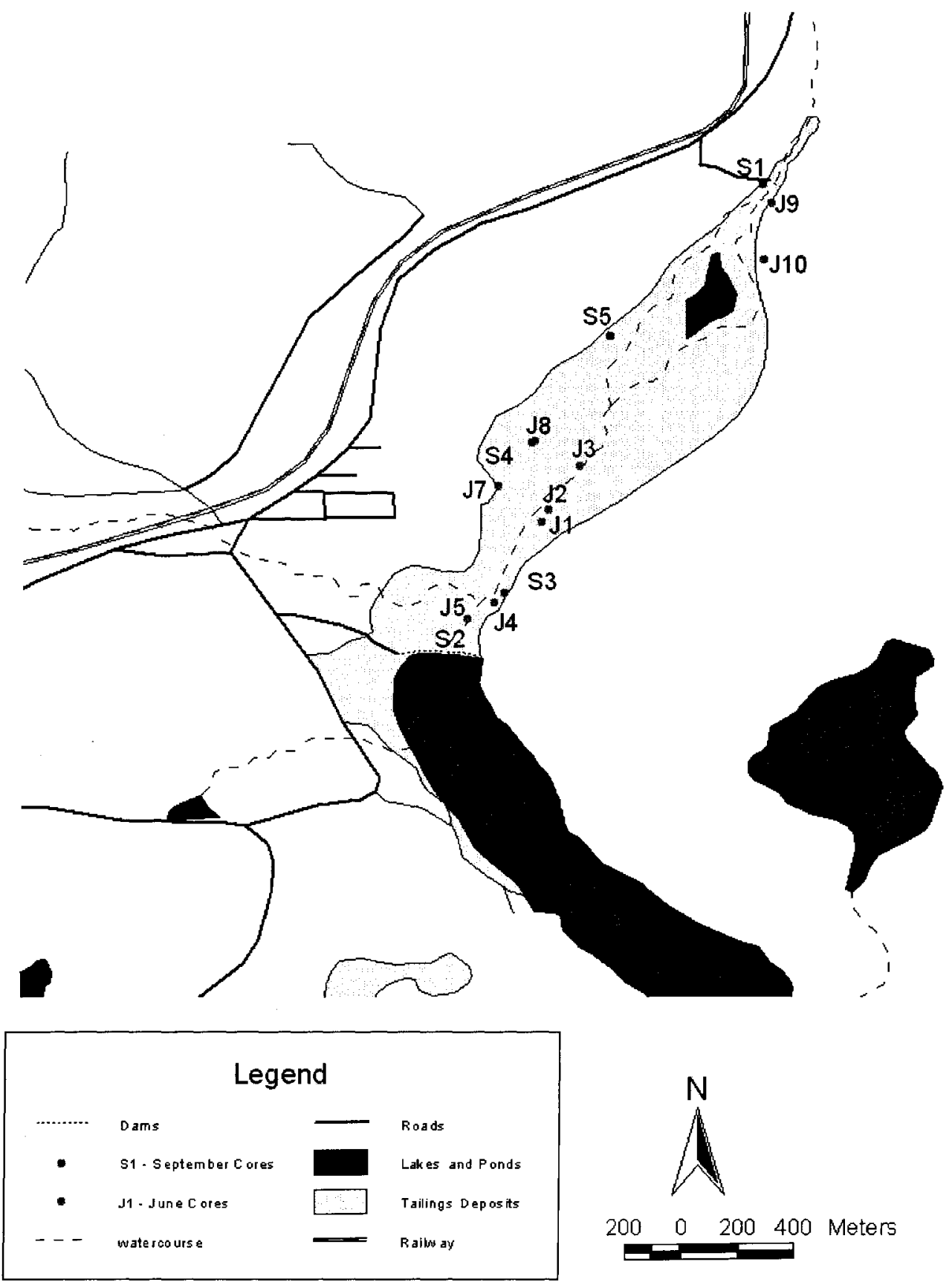


reducible sulfides (CRS), water content (WC), and organic matter content (OM). Pore water was extracted from the remaining sediment samples by ultracentrifugation and analyzed for alkalinity, pH, dissolved oxygen, $\mathrm{Fe}(\mathrm{II})$, sulfate, sulfide, and dissolved metals.

\subsubsection{Monitoring Well Installation and Sampling}

Seven monitoring wells were installed at the site in June 2004. The locations of the monitoring wells are presented in Figure 3-2. Borehole logs detailing the well installation specifications are provided in Appendix A.

All monitoring wells installed in June 2004 were monitored and sampled in September 2004. All wells were established using HDPE $1.6 \mathrm{~cm}$ ID tubing with a waterra foot valve attached to the end. Monitoring wells MW1, MW2, MW3, MW4 were purged 3 well volumes, whereas MW5, MW6, and MW7 were purged dry. These monitoring wells were located outside of standing water and as such, had slower recovery times. Two $250 \mathrm{ml}$ HDPE plastic bottles were filled at each well, one of which was filtered with a 0.45um Gelman glass microfibre filter. In situ measurements for $\mathrm{pH}, \mathrm{DO}$, conductivity, temperature, and salinity were conducted using YSI Model 85 multiprobe and an Oakton Instruments portable $\mathrm{pH}$ meter. Samples were brought back to camp, where alkalinity, $\mathrm{Fe}(\mathrm{II})$, sulfate, sulfide, ammonia, nitrate, and chloride were immediately measured using Hach field test kits. All field measurements were completed within 2 hours of arriving 
Figure 3-2: Location of Groundwater Monitoring Wells Installed in June 2004

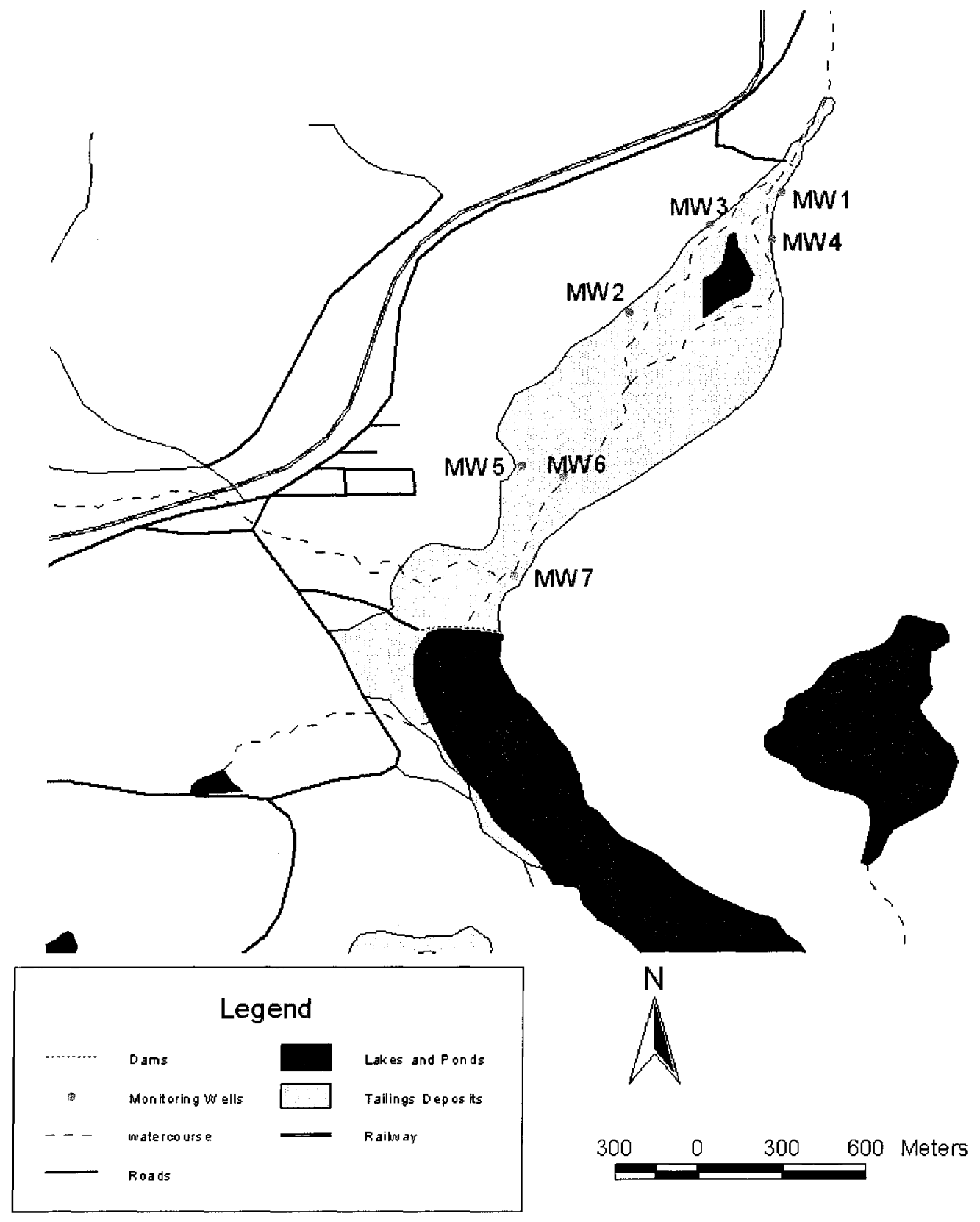


back at camp. One $125 \mathrm{ml}$ plastic bottle was filled for each monitoring well with filtered sample water and preserved with $1 \mathrm{ml}$ concentrated nitric acid for dissolved metal analysis. The water samples were kept in the fridge and transported in coolers with icepacks to ensure the samples remained below $4^{\circ} \mathrm{C}$ to the to the Earth Sciences Laboratory at Carleton University, Ottawa, ON until they were prepared for analysis.

\subsubsection{Surface Water Sampling and Flow Measurement}

Surface water samples were collected throughout the length of Farr Creek and Mill Creek, from approximately $1 \mathrm{~km}$ upstream of the confluence with Farr Creek to the control dam. The location for each of the surface water samples collected is presented in Figure 3-3. Prior to collecting the sample, each sample bottle was rinsed 3 times with stream water. Samples were collected in two $250 \mathrm{ml}$ HDPE plastic bottles. One of the bottles was later filtered using a $0.45 \mathrm{um}$ Gelman glass microfibre filter into $125 \mathrm{ml}$ plastic bottle and preserved with $1 \mathrm{ml}$ of concentrated nitric acid for dissolved metal analysis. The water samples were kept in the refrigerator and transported in coolers with icepacks to ensure the samples remained below $4^{\circ} \mathrm{C}$ to the Earth Sciences Laboratory at Carleton University, Ottawa, ON until they were prepared for analysis.

Estimates of surface water velocity were made at various locations throughout the study area by throwing twigs or leaves into the middle of the stream and timing their movement downstream. Measurements of stream width and depth were also made to determine an approximate streamflow volume. 
Figure 3-3: Location of Surface Water Samples Collected in June 2004

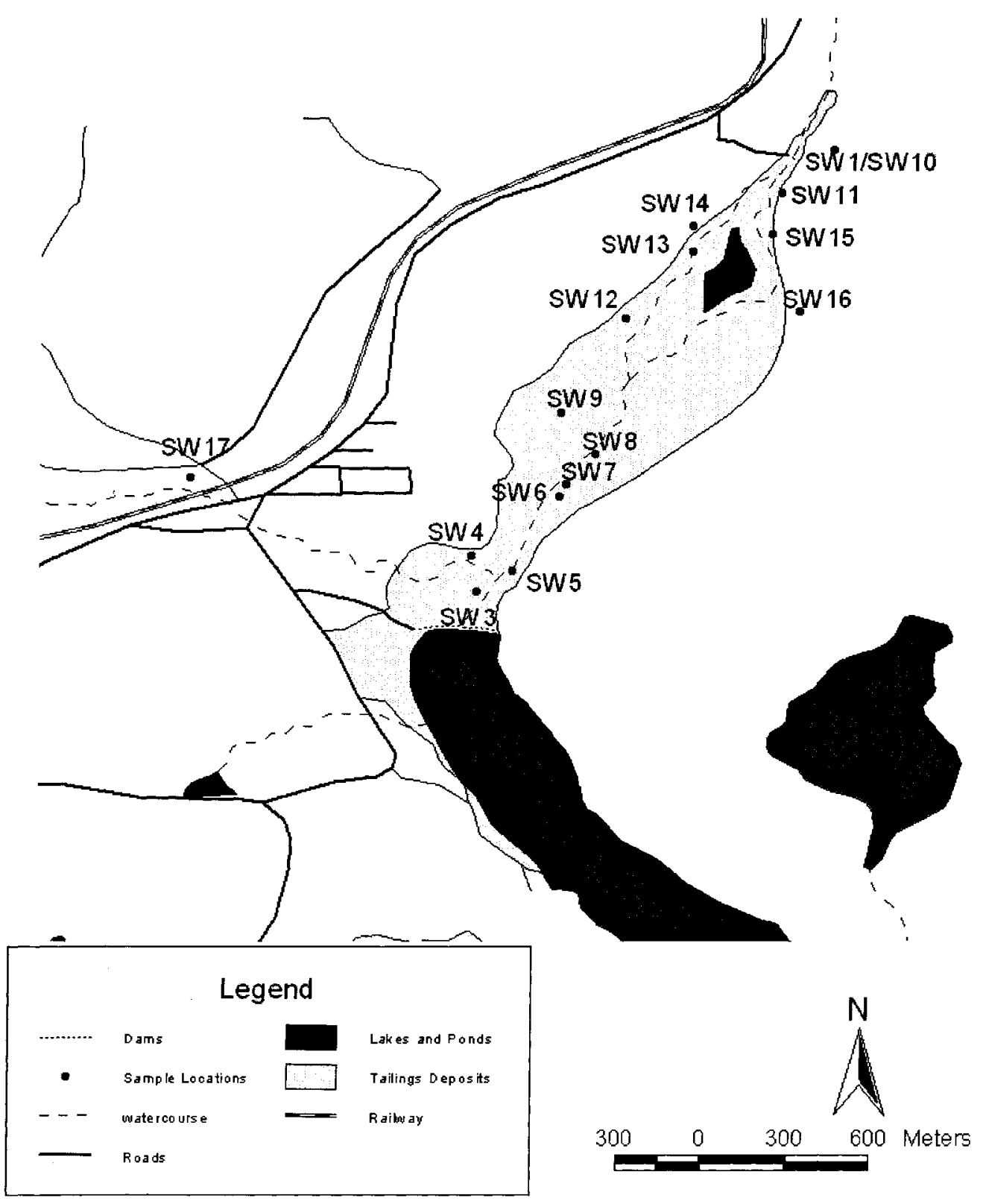




\subsubsection{Vegetation Sampling}

Cattail shoot samples were collected near each of the monitoring well locations and analyzed for total metals. Several shoot samples were cut and placed in labeled Ziplock plastic bags. They were kept in the refrigerator and transported in coolers with icepacks to ensure the samples remained below $4^{\circ} \mathrm{C}$ to the Earth Sciences Laboratory at Carleton University, Ottawa, ON until they were prepared for analysis.

\subsection{Laboratory Methods}

The following sections summarize the methodologies followed for the chemical analysis conducted on all of the samples collected in the field.

\subsubsection{Water Contents and Organic Matter Determinations}

All core samples were sectioned in 15 or $25 \mathrm{~cm}$ intervals. A composite $1 \mathrm{~g}$ sample was used for determining the water and loss on ignition (LOI) contents of the sample. Approximately $5 \mathrm{~g}$ of sediment was oven dried at $105-115^{\circ} \mathrm{C}$ overnight to determine the sediment water content. The dried sample was then ashed in a furnace at $550^{\circ} \mathrm{C}$ for 2 hours to determine the amount of organic matter as loss on ignition. The following equation was used to determine the water content of the sample:

$\mathrm{Mw}=\mathrm{Mi}-\mathrm{Md}$ 
$\mathrm{WC}=\mathrm{Mw} / \mathrm{Md}$

Where:

$\mathrm{MW}=$ mass of water $(\mathrm{g})$

$\mathrm{Mi}=$ initial mass of wet sample $(\mathrm{g})$

$\mathrm{Md}=$ mass of dried sample $(\mathrm{g})$

$\mathrm{WC}=$ water content $(\%)$

The organic matter (as LOI) content of the sample was calculated using the equations presented below:

$\mathrm{Mom}=\mathrm{Md}-\mathrm{Mf}$

$\mathrm{OM}=\mathrm{Mom} / \mathrm{Md}$

Where:

Mom $=$ mass of organic matter lost $(\mathrm{g})$

$\mathrm{Mf}=$ mass of sample after furnace $(\mathrm{g})$

$\mathrm{OM}=$ organic matter content $(\%)$ 


\subsubsection{Microbiology}

Sixteen sediment samples were analyzed for acid producing bacteria (APB), iron reducing bacteria (IRB) and sulfate reducing bacteria (SRB). The most probable number (MPN) technique was used to estimate the number of APB's, IRB, and SRB in each sample.

The growth medium used for the APB consisted of $10 \mathrm{~g}$ dextrose, $2 \mathrm{~g}$ beef extract, $20 \mathrm{~g}$ protease peptone, $20 \mathrm{~g} \mathrm{NaCl}$, and $0.2 \mathrm{~g}$ bromothymol blue. The above ingredients and $2 \mathrm{~L}$ of deionized water were measured and added to a 2L Erlenmeyer flask. The $\mathrm{pH}$ of the solution was buffered to $\mathrm{pH} 7.2$ using concentrated $\mathrm{HCl}$ and/or $\mathrm{NaOH}$. The broths were then heated to approximately $100^{\circ} \mathrm{C}$ and aerated for approximately 1 hour.

The APB growth medium was transferred to test tubes, whereas culture jars were used for the IRB and SRB enumerations. 10 different dilutions, at $1 \mathrm{ml}$ in $10 \mathrm{mls}$ were completed with 5 replicates of each dilution.

Nine $\mathrm{ml}$ of the APB growth medium was added to the test tubes using a $9 \mathrm{ml}$ pipette. Approximately $1 \mathrm{~g}$ of wet sediment was added to the five tubes containing the first dilution series. The remaining tubes were then inoculated with $1 \mathrm{ml}$ from the previous dilution set. The APB samples were incubated for 96 hours at room temperature. A blue colour indicated a positive reading. 
The growth medium containing the reducing agent, used for the IRB consisted of $5 \mathrm{~g}$ $\mathrm{NaHCO}_{3}, 3 \mathrm{~g} \mathrm{NH}_{4} \mathrm{Cl}, 1.2 \mathrm{~g} \mathrm{NaH}_{2} \mathrm{PO}_{4}, 0.2 \mathrm{~g} \mathrm{CaCL}_{2} \cdot 4 \mathrm{H}_{2} \mathrm{O}, 0.2 \mathrm{~g} \mathrm{KCl}, 0.2 \mathrm{~g} \mathrm{MgCl}_{2} 6 \mathrm{H}_{2} \mathrm{O}$, $0.01 \mathrm{~g} \mathrm{MnCl}_{2} \cdot 4 \mathrm{H} 2 \mathrm{O}, 0.002 \mathrm{~g} \mathrm{Na}_{2} \mathrm{MoO}_{4}, 3.68 \mathrm{~g}$ ferric EDTA, and $3 \mathrm{~g}$ peptone. All the above ingredients were mixed with $2 \mathrm{~L}$ of deionized water in a $2 \mathrm{~L}$ Erlenmeyer flask. All solutions were adjusted to $\mathrm{pH} 7$ with concentrated $\mathrm{HCl}$ and/or $\mathrm{NaOH}$. The broths were then heated to approximately $100^{\circ} \mathrm{C}$ and aerated for approximately 1 hour.

The Postgate growth medium was used for the SRB samples. This medium and reducing reagents consisted of $1 \mathrm{~g} \mathrm{KH}_{2} \mathrm{PO}_{4}, 2 \mathrm{~g} \mathrm{NH} 4 \mathrm{Cl}, 9 \mathrm{~g} \mathrm{Na}_{2} \mathrm{SO}_{4}, 0.08 \mathrm{~g} \mathrm{CaCL} \cdot 6 \mathrm{H}_{2} \mathrm{O}, 0.12 \mathrm{~g}$ $\mathrm{MgSO}_{4} \cdot 7 \mathrm{H}_{2} \mathrm{O}, 5.87 \mathrm{~g} \mathrm{Na}$ lactate, $2.56 \mathrm{~g} \mathrm{Na}$ acetate, $2 \mathrm{~g}$ yeast extract, $0.008 \mathrm{~g} \mathrm{FeSO} \cdot 7 \mathrm{H}_{2} \mathrm{O}$, $0.6 \mathrm{~g}$ Na citrate dihydrate, and $0.4 \%$ resazurin. All the above ingredients were mixed with 2L of deionized water in a $2 \mathrm{~L}$ Erlenmeyer flask. The $\mathrm{pH}$ of the solution was buffered to pH 7.5 with concentrated $\mathrm{H}_{2} \mathrm{SO}_{4}$ and/or $\mathrm{NaOH}$. The broths were then heated to approximately $100^{\circ} \mathrm{C}$ and aerated for approximately 1 hour.

Nine $\mathrm{ml}$ of the IRB and SRB growth mediums were each transferred to their individual culture jars via a $9 \mathrm{ml}$ pipette in an anaerobic chamber to maintain reducing conditions. Prior to inoculating the samples, the jars were sealed inside the anaerobic chamber and then autoclaved to ensure there was no oxygen in the media. Approximately $1 \mathrm{~g}$ of wet sediment was added to the five jars containing the first dilution series in the anaerobic chamber. The remaining sealed jars were then inoculated with $1 \mathrm{ml}$ from the previous dilution set. The samples were then left in the anaerobic chamber at room temperature for the four-week incubation period. 
Positive SRB counts were indicated by the formation of black FeS precipitates. For the IRB samples, $0.2 \mathrm{ml}$ of ferrazine was added to each jar after the incubation period. A positive reading was indicated by the solution colour change to pink.

MPN values were calculated for each set of samples from statistical tables (Cochran, 1950) and the results were expressed as colony forming units per gram of sediment dry weight (CFU/gdw). This method gives a rough estimate of the order of magnitude of bacterial populations and therefore the results are not indicative of absolute population numbers.

3.2.3 Acid Volatile Sulfides (AVS) and Chromium Reducible Sulfides (CRS) Sequential Extraction Procedure

Sixteen sediment samples were analyzed for AVS and CRS corresponding to the same depths as the microbiology samples.

The extraction apparatus consisted of six $250 \mathrm{ml}$ distillation flasks, $30 \mathrm{~cm}$ long condensers with water flowing through them, and six traps. This allowed for the analysis of 5 samples at a time and one blank sample for each set of five samples.

Approximately $2 \mathrm{~g}$ of dried sediment was added to the distillation flask. $10 \mathrm{ml}$ of $50 \%$ ethanol was added to the flask to remove elemental sulfur from the sediment. This was 
done for 15 minutes at room temperature under a continuous flow of $\mathrm{N}_{2}$ gas to maintain reducing conditions throughout the system. Ten $\mathrm{ml}$ of $12 \mathrm{M} \mathrm{HCl}$ was added to each flask and the AVS was extracted at room temperature for 1 hour under continuous flow of $\mathrm{N}_{2}$ carrier gas. The evolving $\mathrm{H}_{2} \mathrm{~S}$ was trapped in $10 \mathrm{ml} 20 \% \mathrm{Zn}$ acetate solution. The CRS fraction was extracted from the sediment by adding $16 \mathrm{ml}$ of $1 \mathrm{M} \mathrm{CrCl}_{2}$ to each flask. The solution was then boiled at $150-175^{\circ} \mathrm{C}$ for 1 hour. The $\mathrm{H}_{2} \mathrm{~S}$ was trapped in the same manner as the AVS. The $\mathrm{ZnS}$ precipitates were collected, diluted, and run in a Spectrophotometer at $670 \mathrm{~nm}$ wavelength under visible light. Dilutions were prepared in $50 \mathrm{ml}$ volumetric flasks. Four $\mathrm{ml}$ of Clines solution was added to each dilution to allow for the colourimetric determinations. Clines solution consists of diamine, ferric chloride and $50 \mathrm{M} \mathrm{HCl}$. Specific amounts of diamine and ferric chloride are dependent on expected sulfide range.

Prior to running the sample dilutions through the spectrophotometer, standard calibrations were made using $\mathrm{Na}_{2} \mathrm{~S} \bullet 9 \mathrm{H}_{2} \mathrm{O}$. $1.44 \mathrm{~g}$ of $\mathrm{Na}_{2} \mathrm{~S}^{*} 9 \mathrm{H}_{2} \mathrm{O}$ was added to a $40 \mathrm{ml}$ glass vial. Then, $3.2 \mathrm{ml}$ of Cline's Solution was added to each vial. The vials were then filled completely with deionized water to ensure there was no headspace. Finally, the vials were capped with a septum and plastic screw cap. Six different dilutions were made using mechanical pipettes to produce a range of sulfide concentrations from 5 to $150 \mathrm{uM}$. The samples were run in a Spectrophotometer at $670 \mathrm{~nm}$ wavelength under visible light. A calibration curve was generated with $>99 \%$ correlation. 


\subsubsection{Metals Sequential Extractions Procedure}

Sixteen sediment samples were analyzed in duplicate for metals using a sequential extraction procedure corresponding to the same depths as the microbiology samples.

The sequential extraction procedure followed was a modification of the methodology developed by Tessier et al. (1979). The procedure separates the extracted metals into five fractions: exchangeable, metals bound to carbonates, metals bound to iron and manganese oxides, metals bound to organic matter, and residual fraction. Blank samples were run for $10 \%$ of the samples.

\section{a) Exchangeable Fraction}

Approximately $1 \mathrm{~g}$ of dried sediment was mixed with $10 \mathrm{ml}$ of $1 \mathrm{M} \mathrm{MgCl}_{2}$, buffered to $\mathrm{pH}$ 7 with sodium acetate. The sample was mechanically shaken for 16 hours. The samples were then centrifuged at $3000 \mathrm{rpm}$ for 20 minutes and the supernatant was decanted into a sample bottle, preserved with $\mathrm{HNO}_{3}$ to maintain a sample $\mathrm{pH}$ of 2 . The samples were stored below $4^{\circ} \mathrm{C}$ until analysis. The residue was washed with $20 \mathrm{ml}$ of distilled water and mechanically shaken for 15 minutes, and centrifuged at $3000 \mathrm{rpm}$ for 20 minutes. The supernatant was decanted slowly to ensure that no sediment was lost and discarded. 
b) Fraction Bound to Carbonates

Twenty $\mathrm{ml}$ of sodium acetate buffered to $\mathrm{pH} 5$ with $1 \mathrm{M}$ acetic acid was added to the residue from the previous step. The mixture was mechanically shaken for 16 hours. The samples were then centrifuged at $3000 \mathrm{rpm}$ for 20 minutes and the supernatant was decanted into a sample bottle, preserved with $\mathrm{HNO}_{3}$ to maintain a sample $\mathrm{pH}$ of 2 . The samples were stored below $4^{\circ} \mathrm{C}$ until analysis. The residue was washed with $20 \mathrm{ml}$ of distilled water and mechanically shaken for 15 minutes, and centrifuged at $3000 \mathrm{rpm}$ for 20 minutes. The supernatant was decanted slowly to ensure that no sediment was lost and discarded.

c) Fraction Bound to Iron and Manganese Oxides

Twenty $\mathrm{ml}$ of $0.05 \mathrm{M}$ hydroxylamine hydrochloride buffered to $\mathrm{pH} 5$ with sodium citrate was added to the residue from the previous step. The mixture was mechanically shaken for 16 hours. The samples were then centrifuged at $3000 \mathrm{rpm}$ for 20 minutes and the supernatant was decanted into a sample bottle, preserved with $\mathrm{HNO}_{3}$ to maintain a sample $\mathrm{pH}$ of 2 . The samples were stored below $4^{\circ} \mathrm{C}$ until analysis. The residue was washed with $20 \mathrm{ml}$ of distilled water and mechanically shaken for 15 minutes, and centrifuged at $3000 \mathrm{rpm}$ for 20 minutes. The supernatant was decanted slowly to ensure that no sediment was lost and discarded. 
d) Fraction Bound to Organic Matter

Ten $\mathrm{ml}$ of $30 \% \mathrm{H}_{2} \mathrm{O}_{2}$ buffered to $\mathrm{pH} 2$ with $0.02 \mathrm{M} \mathrm{HNO}_{3}$ was slowly added to the residue from the previous step. The solution was loosely covered and digested at room temperature for 1 hour with occasional manual agitation. The solution was digested for another hour at a temperature of approximately $85^{\circ} \mathrm{C}$. The solution was then uncovered and the solution volume was reduced to approximately $3 \mathrm{ml}$ by evaporation. Another 10 $\mathrm{ml}$ of $30 \% \mathrm{H}_{2} \mathrm{O}_{2}$ buffered to $\mathrm{pH} 2$ with $0.02 \mathrm{M} \mathrm{HNO}_{3}$ was slowly added to the mixture and digested for 1 hour at $85^{\circ} \mathrm{C}$ while loosely capped. After an hour, the cap was removed and the solution was concentrated down to approximately $1 \mathrm{ml}$. The solution was allowed to cool and $50 \mathrm{ml}$ of $1 \mathrm{M}$ ammonium acetate was added to the mixture and the mixture was mechanically shaken for 16 hours. The samples were then centrifuged at $3000 \mathrm{rpm}$ for 20 minutes and the supernatant was decanted into a sample bottle. The samples were stored below $4^{\circ} \mathrm{C}$ until analysis. The residue was washed with $20 \mathrm{ml}$ of distilled water and mechanically shaken for 15 minutes, and centrifuged at $3000 \mathrm{rpm}$ for 20 minutes. The supernatant was decanted slowly to ensure that no sediment was lost and discarded.

e) Residual Fraction

Thirty $\mathrm{ml}$ of aqua regia solution $\left(3: 1 \mathrm{HCl}: \mathrm{HNO}_{3}\right.$ mixture) was added to the residue from the previous step and the mixture was digested at $100-130^{\circ} \mathrm{C}$ until the solution became clear. This varied from 2 days to 3 weeks, depending on the sample composition. 
$\mathrm{HF}$ or $\mathrm{HClO}_{4}$ was not used in the analysis for 2 reasons:

1) the ICP apparatus used to determine the metal concentrations was not equipped with the proper materials to handle HF; and

2) the complete dissolution of silicates and or clay minerals was not of the utmost importance because the metals associated with these mineral phases are considered relatively immobile compared to the metals associated with the other fractions.

Once the solution became clear the supernatant was decanted into a sample bottle. The samples were stored below $4^{\circ} \mathrm{C}$ until further analysis.

\subsubsection{Total Sediment Digestions for Metals}

Total sediment digestions were conducted on all of the sectioned core samples collected from the June and September sampling. This procedure is the same as the Residual Fraction step in the Sequential Extraction Procedure. The total digestion was completed on the September cores as a check to ensure that the total metals extracted from the total digestion sample corresponded to the total metals extracted from the sum of all the sequential extraction steps on the same sample. Sequential metal extractions were not conducted for the June cores. As such, the total digestion procedure was the only analysis used to determine metal concentrations in these samples. 
All of the metal samples were delivered to Dr. Nimal DeSilva and he completed the metal analysis via inductively couple plasma mass spectrometry (ICPMS) at the Laboratory at Health Canada.

\subsubsection{Metal Extractions from Cattail Samples}

Seven cattail (Typha latfolia) shoot samples were analyzed for metals. The samples were washed with deionized water, manually broken into small pieces and crushed using a mortar and pestle. Blank samples were run on $10 \%$ of the samples.

Thirty $\mathrm{ml}$ of $4: 1 \mathrm{HNO}_{3}: \mathrm{HCl}$ mixture was added to $200 \mathrm{mg}$ of ashed cattail shoots and the mixture was digested at $100-130^{\circ} \mathrm{C}$ until the solution became clear. This procedure varied from 1 to 2 hours. Once the solution became clear the supernatant was decanted into a sample bottle. The samples were stored below $4{ }^{\circ} \mathrm{C}$ until further analysis.

All of the metal samples were delivered to Dr. Nimal DeSilva and he completed the metal analysis via inductively couple plasma mass spectrometry (ICPMS) at the Laboratory at Health Canada. 


\subsection{RESULTS AND DISCUSSION}

The following section summarizes the results from the field work conducted in 2004 . Much of the discussion is focused on the five cores sampled in September 2004 because a more extensive analysis was completed on these cores.

\subsection{Hydrogeology and Groundwater Flow}

The locations of the 9 cores collected in June 2004 are presented in Figure 3-1. The general stratigraphy at the site, as observed from the 9 cores collected during June field sampling, is summarized below, starting at ground surface:

- Grey to brown silty tailings 60 to $100 \mathrm{~cm}$ thick;

- Layered clay tailings, 10 to $40 \mathrm{~cm}$ thick;

- An organic layer underlies the layered clay unit. The cores collected from the southern portions of the wetland $(\mathrm{J} 1, \mathrm{~J} 2, \mathrm{~J} 5)$ indicated that the organic layer was 2 to $10 \mathrm{~cm}$ thick. A thicker organic layer was observed in the northern portion of the wetland (J9, J10) where the layer extended from $20 \mathrm{~cm}$ to greater than $60 \mathrm{~cm}$ in thickness; and

- Massive brown clay was observed to underlie the layered clay and organics.

Seven monitoring wells were installed at the site to determine the direction of groundwater flow and to assess groundwater quality throughout the site. The locations of 
the groundwater monitoring wells are presented in Figure 3-2 and details of the well installations are provided in Appendix A. Figure 4-1 presents the hydraulic head measurements determined in September 2004. Six of the seven monitoring wells were installed in standing water and, therefore, vertical gradients could be calculated as shown in equation 4-1:

$\mathrm{i}=\mathrm{h}_{1}-\mathrm{h}_{2} / \mathrm{dl} \quad$ [equation $\left.4-1\right]$

Where:

$\mathrm{h}_{1}=$ water elevation in the creek (cm above arbitrary level (aal)

$\mathrm{h}_{2}=$ water elevation in the monitoring well (cm aal)

$\mathrm{dl}=$ the distance from the surface water elevation and the center of the screen in the monitoring well $(\mathrm{cm})$.

$\mathrm{i}=$ vertical hydraulic gradient $(\mathrm{cm} / \mathrm{cm})$

Positive vertical gradients are indicative of downward gradients, whereas negative vertical gradients are indicative of upward vertical gradients. The vertical gradients are shown on Figure 4-2 for all wells with the exception of MW5. All but two wells (MW1 and MW2) had upward gradients with groundwater discharging into Farr Creek and their gradients were quite small, ranging from 0.016 to 0.006 . MW1 and MW2 had downward gradients and much steeper gradients ranging from 1.08 to 0.03 . The cause of the downward gradients at these locations is most likely attributable to changes in topography, which would affect vertical groundwater movement. MW2 was located 
Figure 4-1: Groundwater Elevation Measurements Collected in September 2004 for all Onsite Monitoring Wells

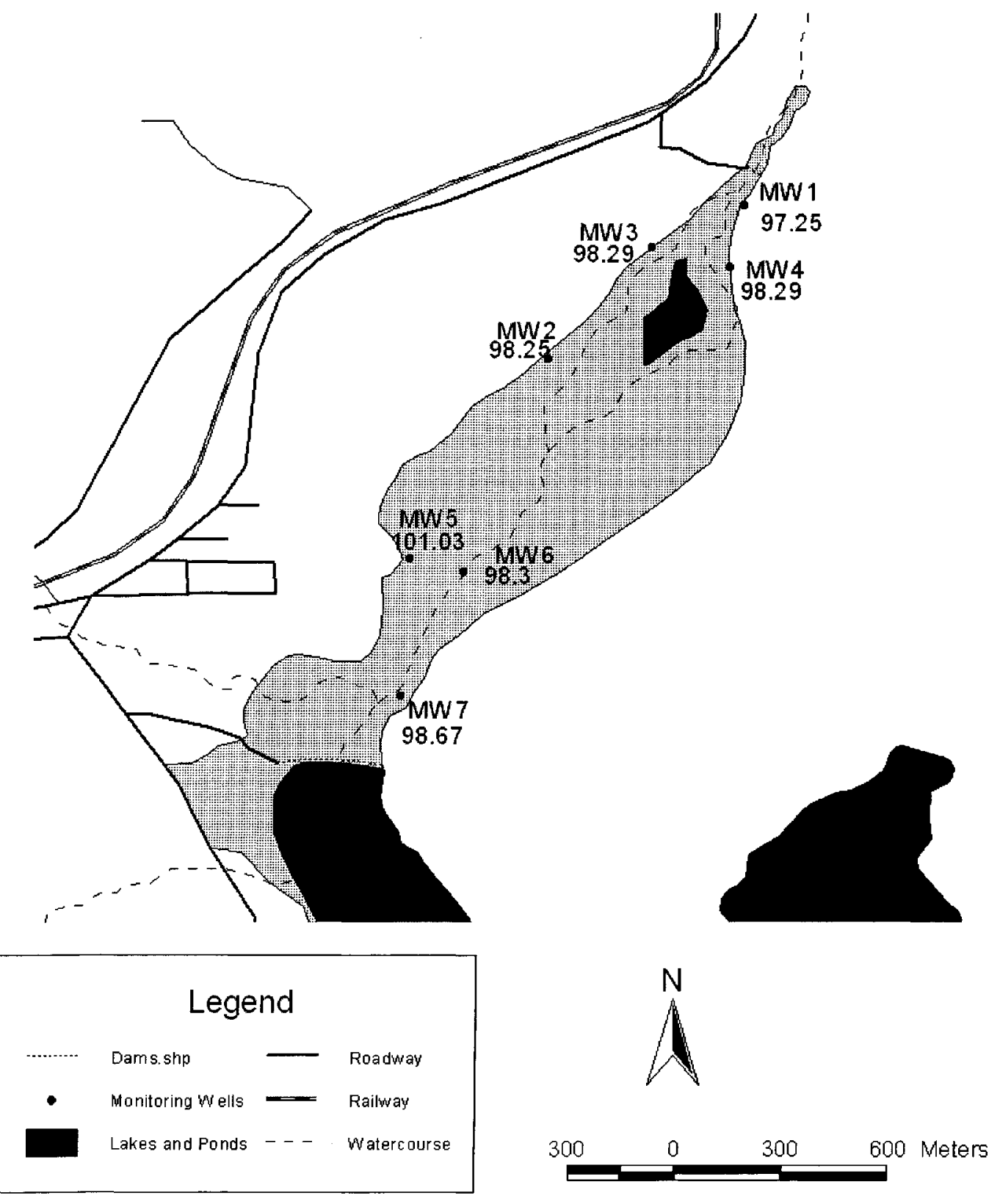


Figure 4-2: Vertical Gradients Calculated from September Hydraulic Head Measurements from Selected Onsite Monitoring Wells

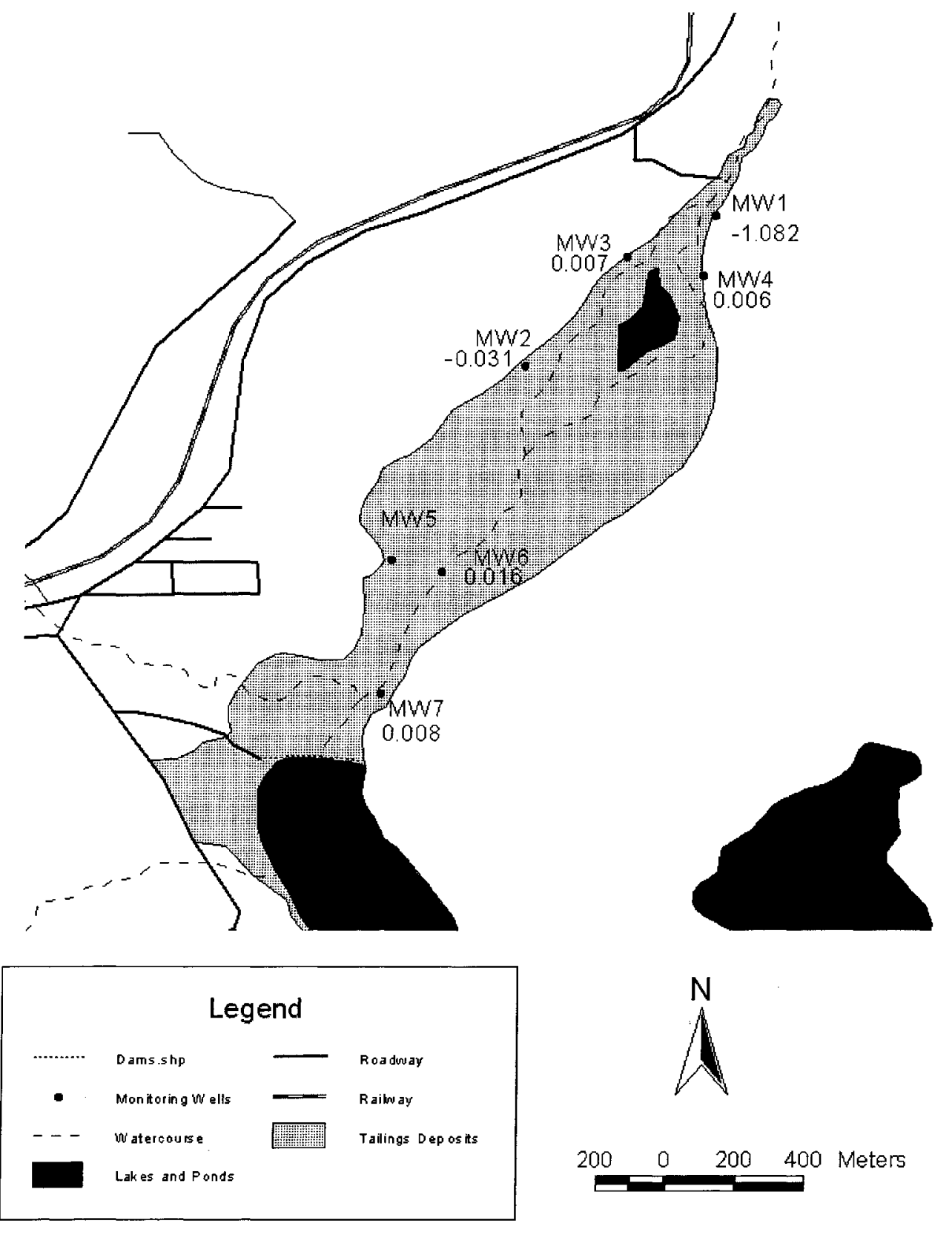


immediately west of a beaver house, which could also affect the vertical water table fluctuations.

\subsection{Sediment Metal Concentrations, Organic Matter and Water Contents}

Figures 4-3a through 4-3n present the organic matter (OM) and water content profiles

with depth for all 14 cores. The water contents were typically less than $35 \%$ at low OM values (less than 5\%). As the OM contents increased, the water contents increased substantially (up to $90 \%$ ). The OM profiles corresponded to the stratigraphy observed. Core J10 showed the highest OM layer at over $70 \%$.

Table 4-1 presents selected trace metal concentrations from the nine cores collected in June 2004 and from the 5 cores collected in September 2004. The reader is referred to Appendix B for complete chemical analysis. As shown in Table 4-1, concentrations of $\mathrm{Al}, \mathrm{Fe}, \mathrm{Ca}, \mathrm{Mg}, \mathrm{Mn}$, and $\mathrm{Na}$ were found to be relatively consistent values with depth, with the exception of core J10. Potassium demonstrated considerable variability is some cases, ranging from $2000 \mathrm{ppm}$ to $20,000 \mathrm{ppm}$ with depth. Also, Core J10 showed substantial decreasing concentrations with depth for $\mathrm{Na}, \mathrm{Mn}, \mathrm{Mg}, \mathrm{K}, \mathrm{Pb}, \mathrm{Ti}, \mathrm{Zn}, \mathrm{Fe}, \mathrm{Cu}$, $\mathrm{Co}$, As, and Al. It is possible that the enhanced organic matter content and vegetative cover of the sediments at this location act as adsorption sites for these metals, thus immobilizing them within the sediment and root zones. The results from core J10 contained elevated concentrations of several metals at $55.0 \mathrm{~cm}$ depth. This depth also 

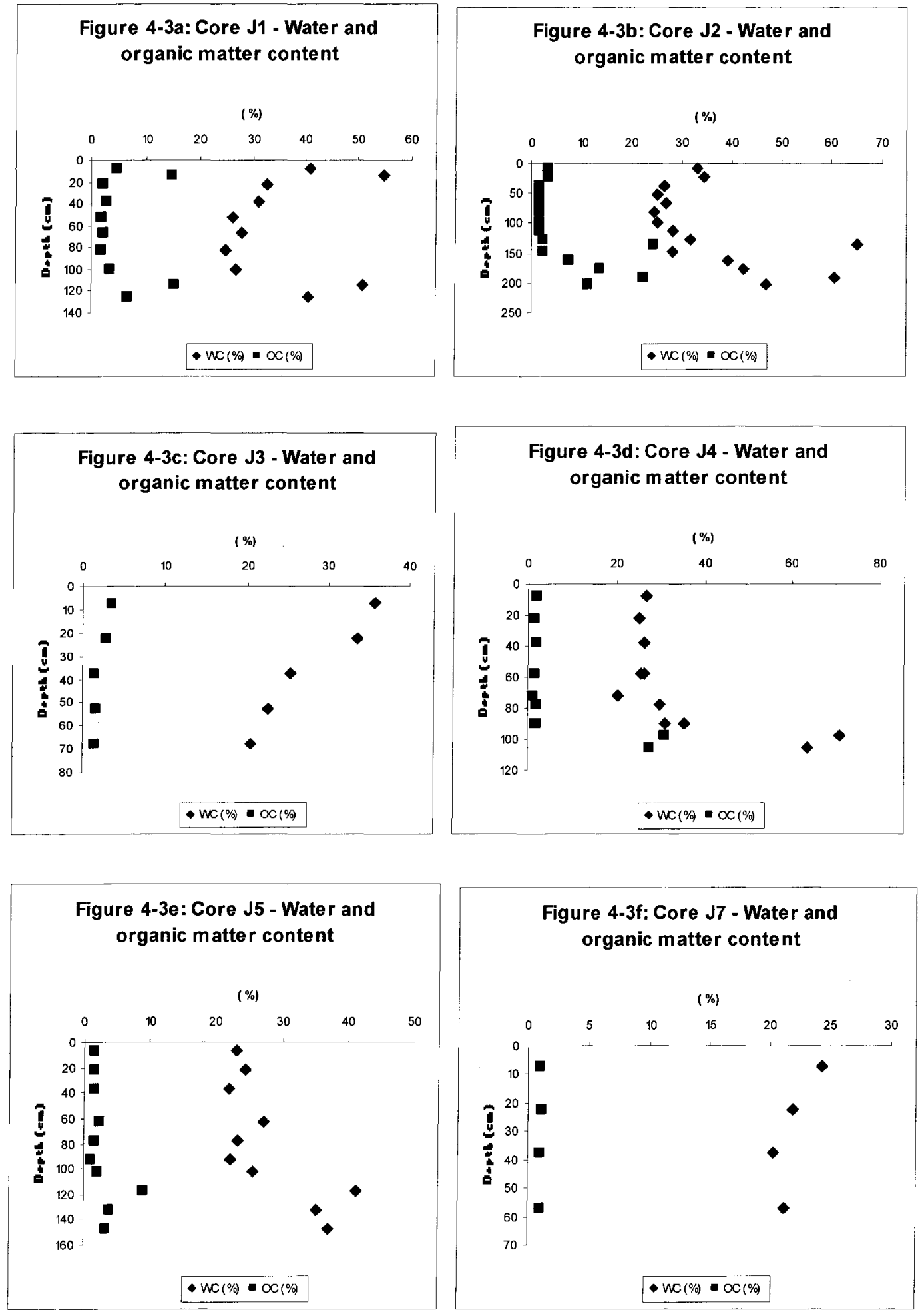

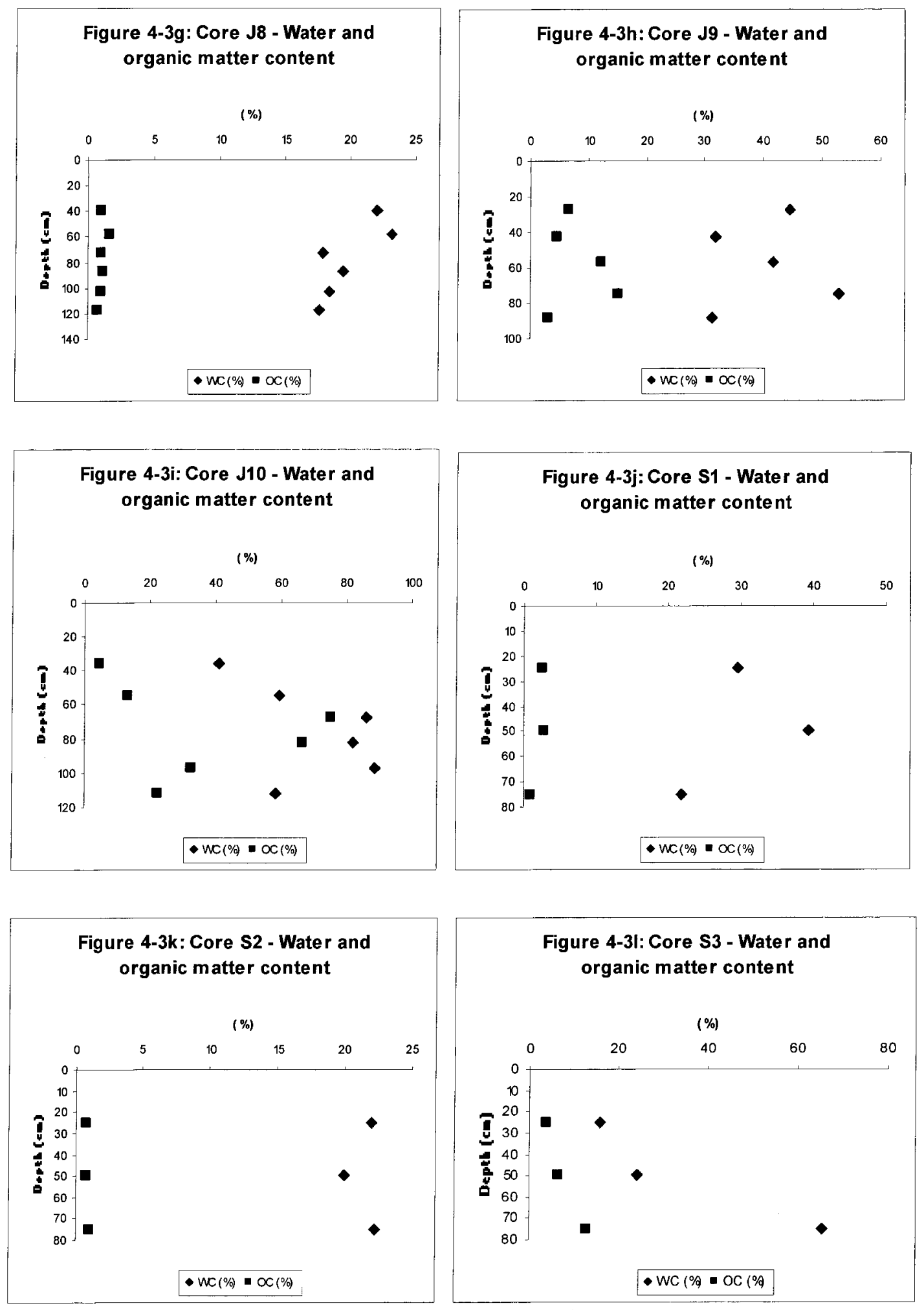

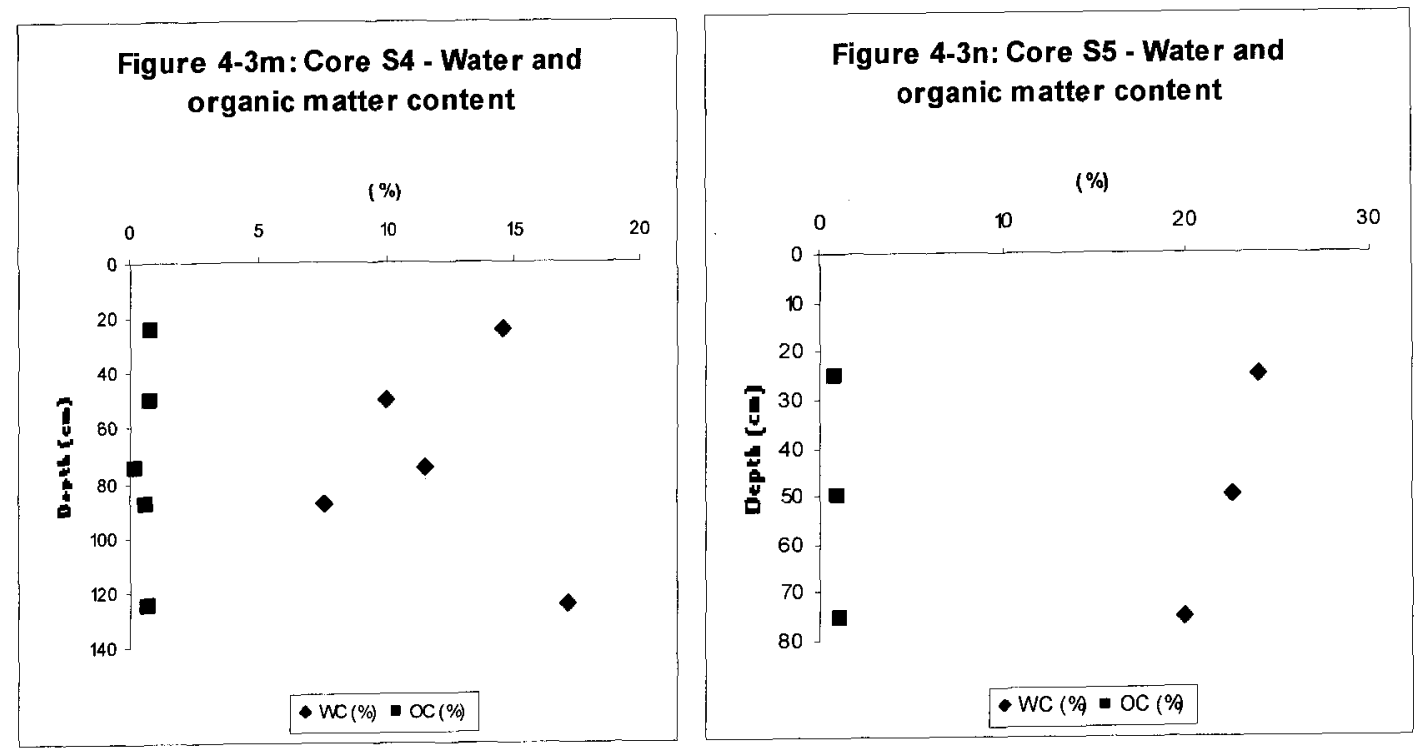


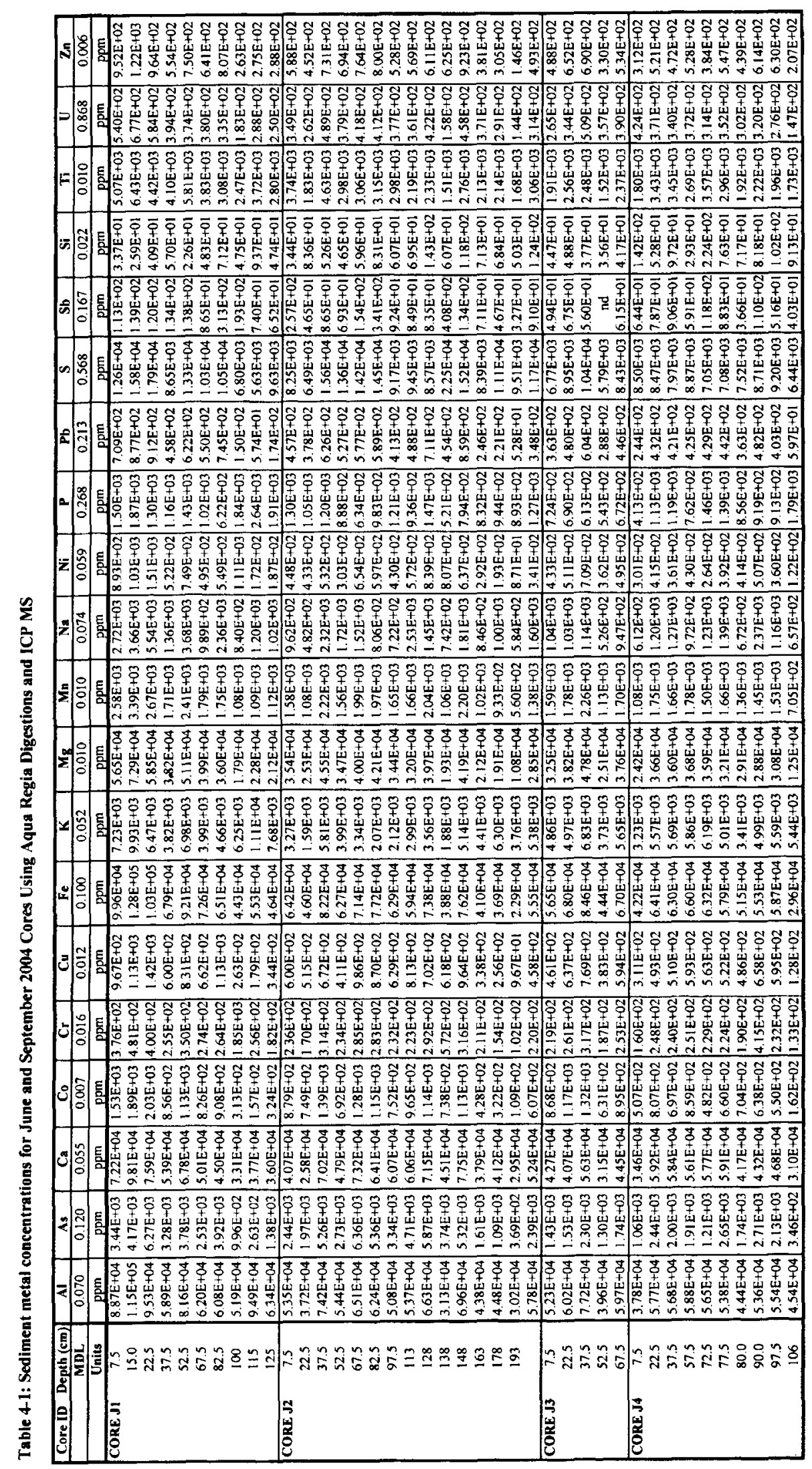




\begin{tabular}{|c|c|c|c|c|c|c|c|c|c|c|c|c|c|c|c|c|c|c|c|c|c|}
\hline D & $\overline{D_{e}}$ & & 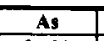 & & & cis & $\mathrm{Cu}$ & & $\mathrm{k}$ & $1 \times 8$ & $\mathbf{M n}$ & $\mathrm{Na}$ & $\mathrm{Ni}_{\mathrm{i}}$ & $P$ & 10 & $\mathbf{s}$ & Su & 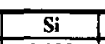 & $\mathbf{T i}$ & - & $2 n$ \\
\hline & MDL & 0.070 & 0.120 & 0.055 & 0.007 & 0.016 & 0.012 & 0.100 & 0.052 & 0.010 & 0.010 & 0.074 & 0.059 & & 0.213 & & 0.167 & & & 0.868 & \\
\hline & Enits & m & $\mathrm{ppm}$ & $\mathrm{ppm}$ & $\mathrm{ppm}$ & $\mathrm{ppm}$ & $\mathrm{ppm}$ & $\mathrm{ppm}$ & $\mathrm{ppm}$ & $\mathrm{ppm}$ & $\mathrm{ppm}$ & $\mathrm{ppm}$ & $\mathrm{ppm}$ & $\mathrm{ppm}$ & $\mathrm{ppm}$ & $\mathrm{ppm}$ & ppm & $\mathrm{ppm}$ & $\mathrm{ppm}$ & $\mathrm{ppm}$ & $\mathrm{ppm}$ \\
\hline \multirow[t]{10}{*}{$\overline{\text { ORE JS }}$} & 7.5 & & $1.72 E+03$ & .40 & $4.85 \mathrm{E}+02$ & $.78 \mathrm{E}+0$ & $2.31 \mathrm{E}+02$ & $34 E+04$ & $3.65 \mathrm{E}+03$ & $2.43 \mathrm{E}+04$ & $1.20 \mathrm{E}+03$ & $1.24 \mathrm{E}+03$ & $1.75 \mathrm{E}+0$ & $6.09 \mathrm{E}+0$ & $2.13 \mathrm{E}+02$ & $83 \mathrm{E}+0$ & $4.62 \mathrm{E}+0$ & $04 \mathrm{E}+01$ & $\frac{\mathrm{B} 0 \mathrm{E}+0}{0}$ & $\frac{16 \mathrm{E}+0}{160}$ & $\overline{E E+0}$ \\
\hline & & & $E+03$ & $E+04$ & $E+02$ & $2.46 \mathrm{E}+02$ & $\mathrm{E}+02$ & $E+04$ & $6 \mathrm{E}+03$ & $\mathrm{E}+04$ & $4 E+03$ & $1 E+03$ & $2.42 \mathrm{E}+02]$ & $8.55 \mathrm{E}+02$ & $3.32 \mathrm{E}+02$ & $5 \mathrm{E}+03$ & $6.05 \mathrm{E}+01$ & $1.15 \mathrm{E}+02$ & $3.22 \mathrm{E}+03$ & & 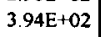 \\
\hline & 5 & 04 & $E+03$ & & $\mathrm{E}+02$ & $3.00 \mathrm{E}+02$ & $E+02$ & $E+04$ & $3 \mathrm{E}+03$ & $E+04$ & $2 E+03$ & & & $1.27 \mathrm{E}+03$ & $9 \mathrm{E}+02$ & $6=0$ & $8.95 E+01$ & & & & \\
\hline & 62.5 & $E+04$ & $9 E+03$ & $7.22 \mathrm{E}+04$ & $3 \mathrm{E}+02$ & $2.99 \mathrm{E}+02$ & $5 \mathrm{E}+02$ & $E+04$ & $2 \mathrm{E}+03$ & $6 E+04$ & $2.20 \mathrm{E}+03$ & $5+43$ & & $1.06 \mathrm{E}+03$ & $3 E+02$ & $6 \mathrm{E}+03$ & $E+C$ & $0 E+02$ & & +0 & $68 E+02$ \\
\hline & & & & $7 E+05$ & & & $4 \mathrm{E}+03$ & $9 E+05$ & $E+04$ & $0 \mathrm{E}+05$ & $50 \mathrm{E}+04$ & & & $19 \mathrm{E}+03$ & $z+02$ & & & & & & \\
\hline & 92. & & & $E+04$ & $7 E+03$ & $.99 \mathrm{E}+02$ & $7 \mathrm{E}+02$ & +04 & $5 E+03$ & -04 & 03 & 33 & 02 & & & & & +01 | & & $E+02$ & \\
\hline & & & $3 E+03$ & $6 E+04$ & +03 & $3.82 \mathrm{E}$ & 02 & & +03 & .04 & & & & & & & & & & & 02 \\
\hline & 118 & .04 & +03 & $2 E+04$ & & $|2.86 \mathrm{E}+02|$ & 02 & 04 & .04 & & & & & & & & & & & & 09 \\
\hline & & & & & & $1.95 E+$ & & 04 & 4 & & $9.64 \mathrm{I}$ & 03 & 02 & $1.01 \mathrm{E}+03$ & 01 & & & 01 & & & $1.77 \mathrm{E}+02$ \\
\hline & 148 & +04 & $\mathrm{E}+02$ & $2.79 E+04$ & $1.48 \mathrm{E}+02$ & $2.04 E+02$ & $28 \mathrm{E}+02$ & $3 E+04$ & $16 \mathrm{E}+04$ & $8 E+04$ & $1.02 \mathrm{E}+03$ & & $|1.37 E+02|$ & $8.77 \mathrm{E}+02$ & $9 \mathrm{E}+02$ & & & & & & ด \\
\hline \multirow[t]{4}{*}{ ORE J7 } & 7.5 & & & $5.29 E+C 4$ & $7.31 \mathrm{E}+02$ & $2.43 \mathrm{E}+02$ & $3.21 \mathrm{E}+02$ & $3 \mathrm{E}+04$ & $2.16 \mathrm{E}+03$ & $4.14 \mathrm{E}+04$ & $1.55 \mathrm{E}+03$ & $9.53 \mathrm{E}+02$ & $2.99 \mathrm{E}+02$ & $1.06 \mathrm{E}+03$ & $8 \mathrm{E}+02$ & $29 \mathrm{E}+03$ & $\mathrm{IE}$ & to1 & & $3.79 \mathrm{E}+$ & 02 \\
\hline & & & $\mathrm{E}+03$ & & & & $2 E+02$ & 7E+04 & $7 E+03$ & & & & & & & & & & & & \\
\hline & & & +03 & +04 & $E+02$ & $2.63 \mathrm{E}$ & +02 & -04 & & & & & & & & & & & & & \\
\hline & & & & & & & & 04 & & & & & & & & & & & & & \\
\hline \multirow[t]{6}{*}{ ORE J8 } & & & & 04 & 2 & & & & & & & & & & & & & & & & \\
\hline & & & & & & & 102 & & & & & & & & & & & & & & \\
\hline & & & $E+03$ & 04 & & 2.28 & 02 & & 03 & & & & & & & & +01 & & & & +02 \\
\hline & 87.5 & & $3 E+03$ & $8 E+04$ & $5.10 E+02$ & $2.24 \mathrm{E}+02$ & $3 E+02$ & $3 \mathbf{E}+04$ & $3.94 \mathrm{E}+03$ & & $1.52 \mathrm{E}+03$ & 33 & 2. & & & & & & & & \\
\hline & & & & & & & & & & & & & & & & & & & & & \\
\hline & & & & & & & & & & & & & & & & & & & & & \\
\hline \multirow[t]{5}{*}{ RE J } & 27. & & & & & & & & & & & & & & & & & & & & \\
\hline & & & 03 & & & & & 44 & & & & & & & & & & & & & \\
\hline & & & 03 & 4 & & & & & & & & & & & & & & & & & \\
\hline & & & 03 & & & & & & & & 8.1 & & & 1.0 & & & & & & & \\
\hline & & & 03. & 4 & $E+02$ & +02 & 02 & -04 & 04 & & & & & & & & & & & & \\
\hline \multirow[t]{6}{*}{ E. } & & & 32 & 2.5 & & & & & & & & & & & & & & & & & \\
\hline & & & & & & & & & & & & & & & & & & & & & \\
\hline & & & & 2.96 & & & & & & & & & & & & & & & & & \\
\hline & 82 & & 12 & 1.98 & & & & & & & & & & & & & & & & m & \\
\hline & & & & & & & & & & & & & & & & & & & & & \\
\hline & 1 & & & & & & & & & & & & & & & & & & & & \\
\hline \multirow[t]{3}{*}{ CORE S1 } & 25.0 & & $3.49 \mathrm{E}$ & \begin{tabular}{|l|l|}
5.53 \\
\end{tabular} & 5.7 & & & & & & & & & & & & $2.03 \mathrm{EE}+02$ & & & & \\
\hline & & & & & & & & & & & & & & & & & & & & & \\
\hline & & & & & & & & & & & & & & & & & & & & & \\
\hline \multirow[t]{3}{*}{ CORE $S 2$} & 25. & & & & & & & & & & & & & & & & & & & & \\
\hline & & & & & & & & & & & & & & & & & & & & & \\
\hline & & & & & & & & & & & & & & & & & & & & & \\
\hline \multirow{3}{*}{ CORE S3 } & 25 & & & & $6.31 \mathrm{E}+02$ & $\sqrt{3}$ & 3.5 & & & & & & & & & & & & & & \\
\hline & & & & & & & & & & & & & & & & & & & & & \\
\hline & & & & & & & & & & & & & & & & & & & & & \\
\hline \multirow[t]{4}{*}{ CORE S } & & & & & & & & & & & & & & & & & & & & & \\
\hline & & & & & & & & & & & & & & & & & & & & & \\
\hline & & & & & & & & & & & & & & & & & & & & & \\
\hline & & & & & & & & & & & & & & & & & & & & & \\
\hline \multirow[t]{2}{*}{ CORE SS } & 25. & & & & & & +02 & & & & & & & & & & & & & & \\
\hline & & & & & & & & & $83 \mathrm{E}+03$ & $333 E+05$ & $164 \mathrm{E}+03$ & & & & $393 \mathrm{E}+02$ & $36 E+05$ & & $233 \mathrm{E}+03$ & & Im & \\
\hline
\end{tabular}

Notes.

MDL Method Detection Limit

$\begin{array}{ll}\mathrm{nm} & \text { Not Measured } \\ \mathrm{nd} & \text { Not Detected }\end{array}$ 
represents the top of the tailings layer at this location which is likely the result of the higher concentrations. It should also be noted that $\mathrm{Si}, \mathrm{Mg}$, and $\mathrm{Na}$ concentrations showed notable differences between the June cores and September cores. For Si, the concentrations reported for the September cores averaged at $2500 \mathrm{ppm}$ and the highest concentration from the June cores was $402 \mathrm{ppm}$. Similarly, much higher concentrations were generally reported for $\mathrm{Mg}$ and $\mathrm{Na}$ in the September cores when compared to the reported concentrations in the June cores. The analyses for all cores were conducted at the same time and the blank samples did not indicate cross contamination (refer to Appendix B, Table B4). Thus, the reason for such large differences is not known.

Figures 4-4a through to 4-4i present sediment concentration profiles with depth for selected trace metals at each core location collected in June 2004. No observable trends were noted for any of the metal profiles from the June cores. The sediment concentration profiles for the cores collected in September 2004 (S1 to S5) are based only on three or four data points and therefore may not accurately represent any significant trends. As a result the data are not present or discussed here.

\subsection{Sequential Extractions}

Sequential extractions were completed for five separate fractions of the sediment: exchangeables, carbonates, Fe and Mn oxides (oxides), organic matter (OM), and residuals. Metals associated with the exchangeable fraction are highly mobile and are often correlated with the cation exchange capacity (CEC) of the sediment (Grambrell et 

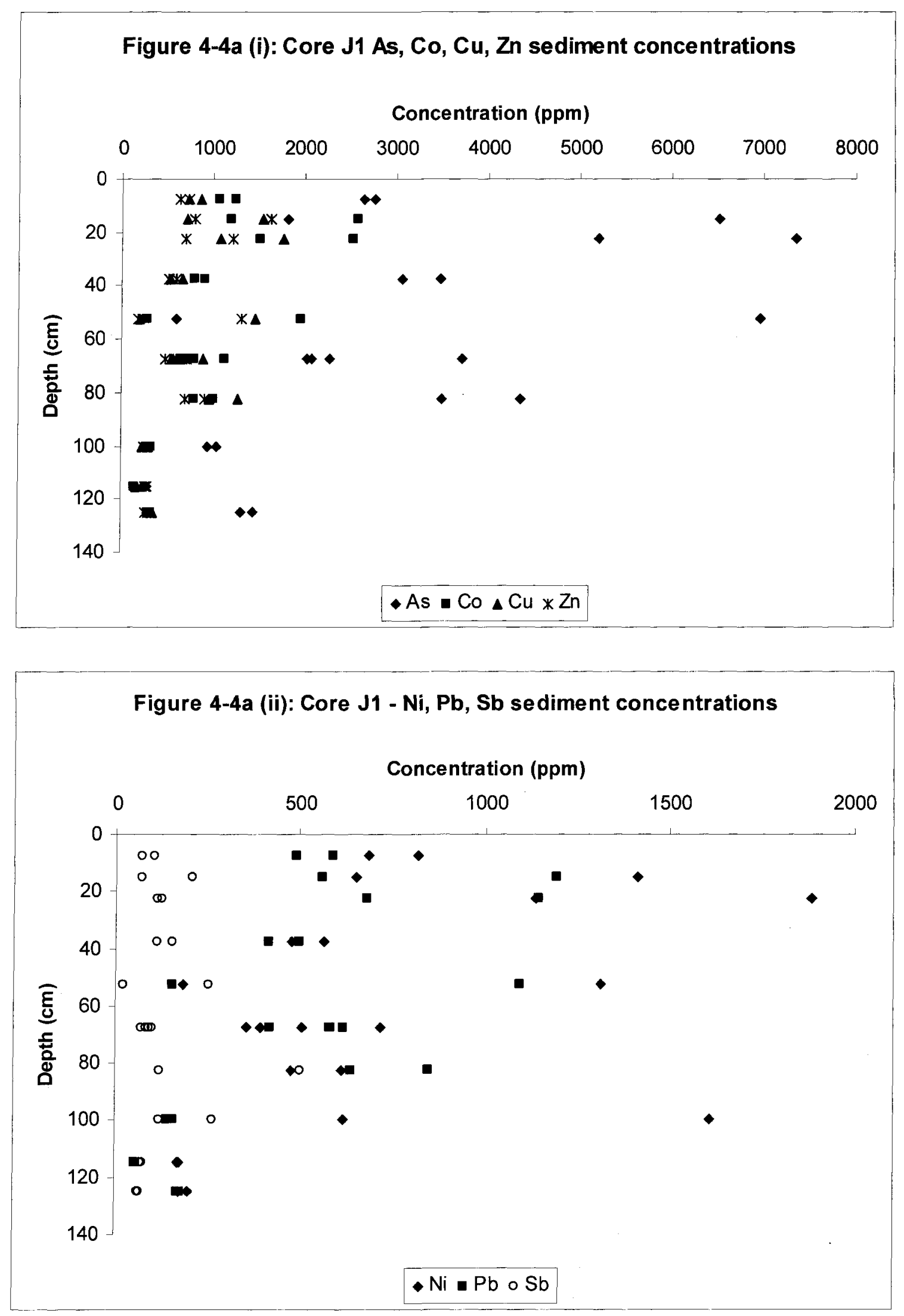

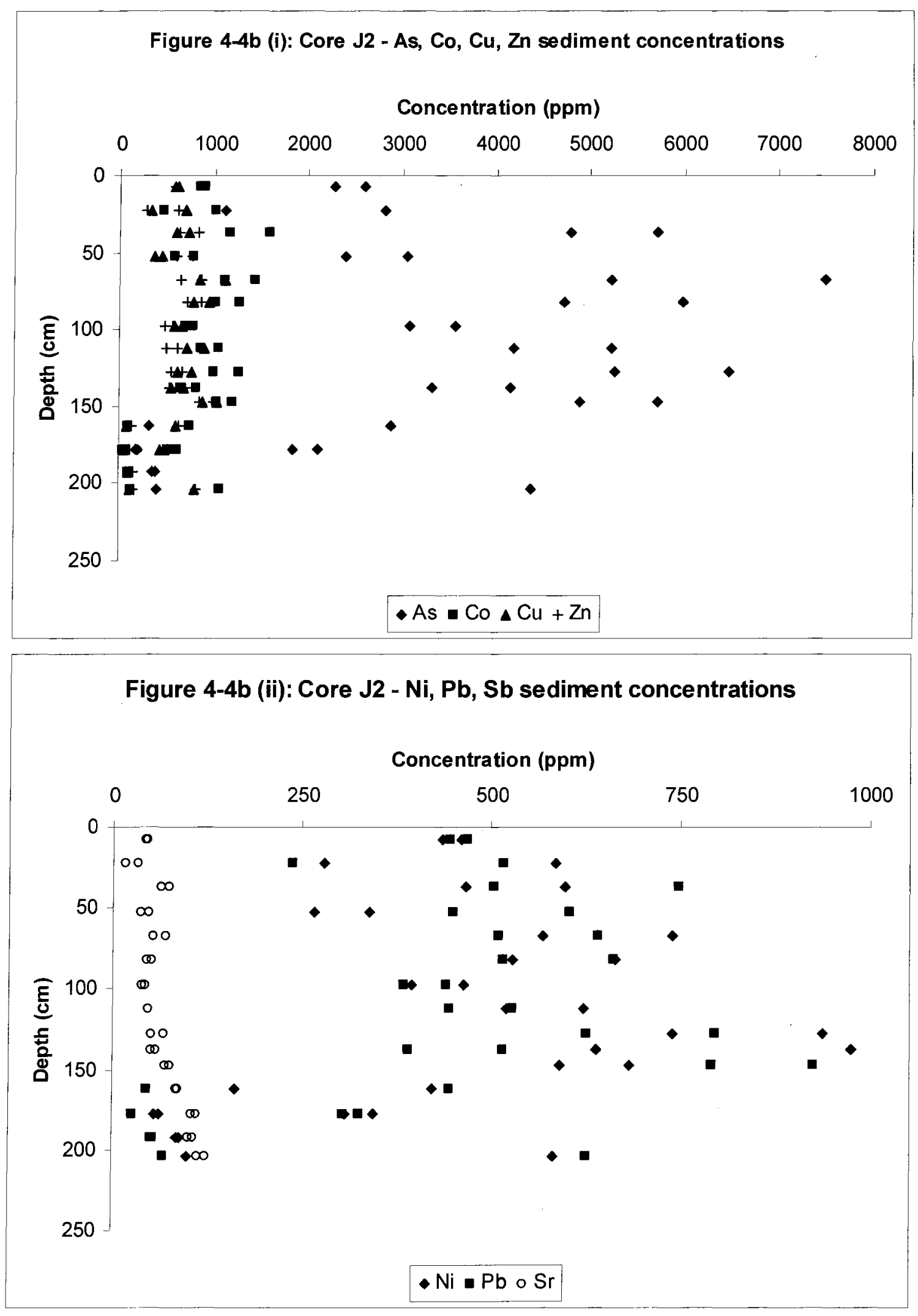

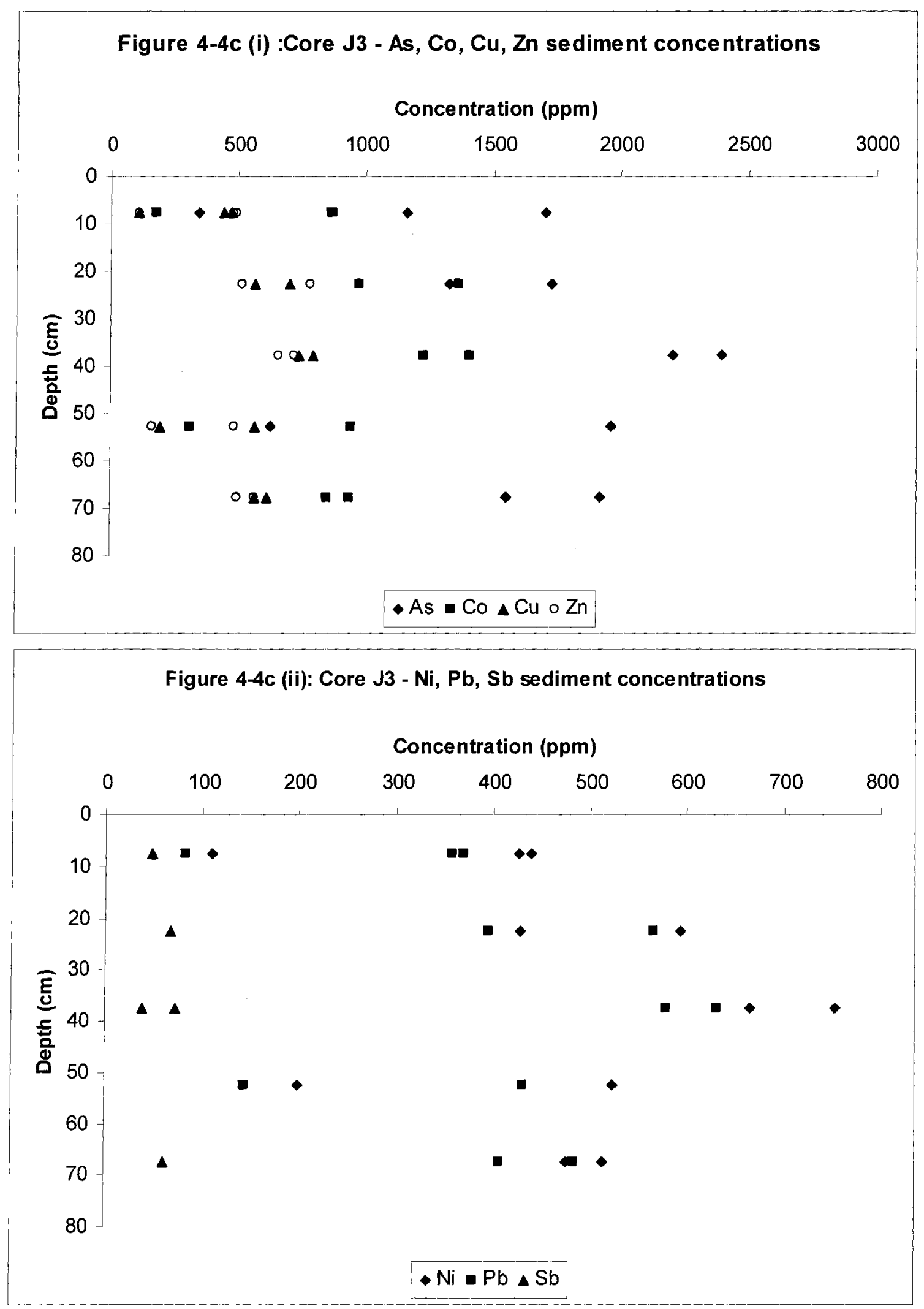

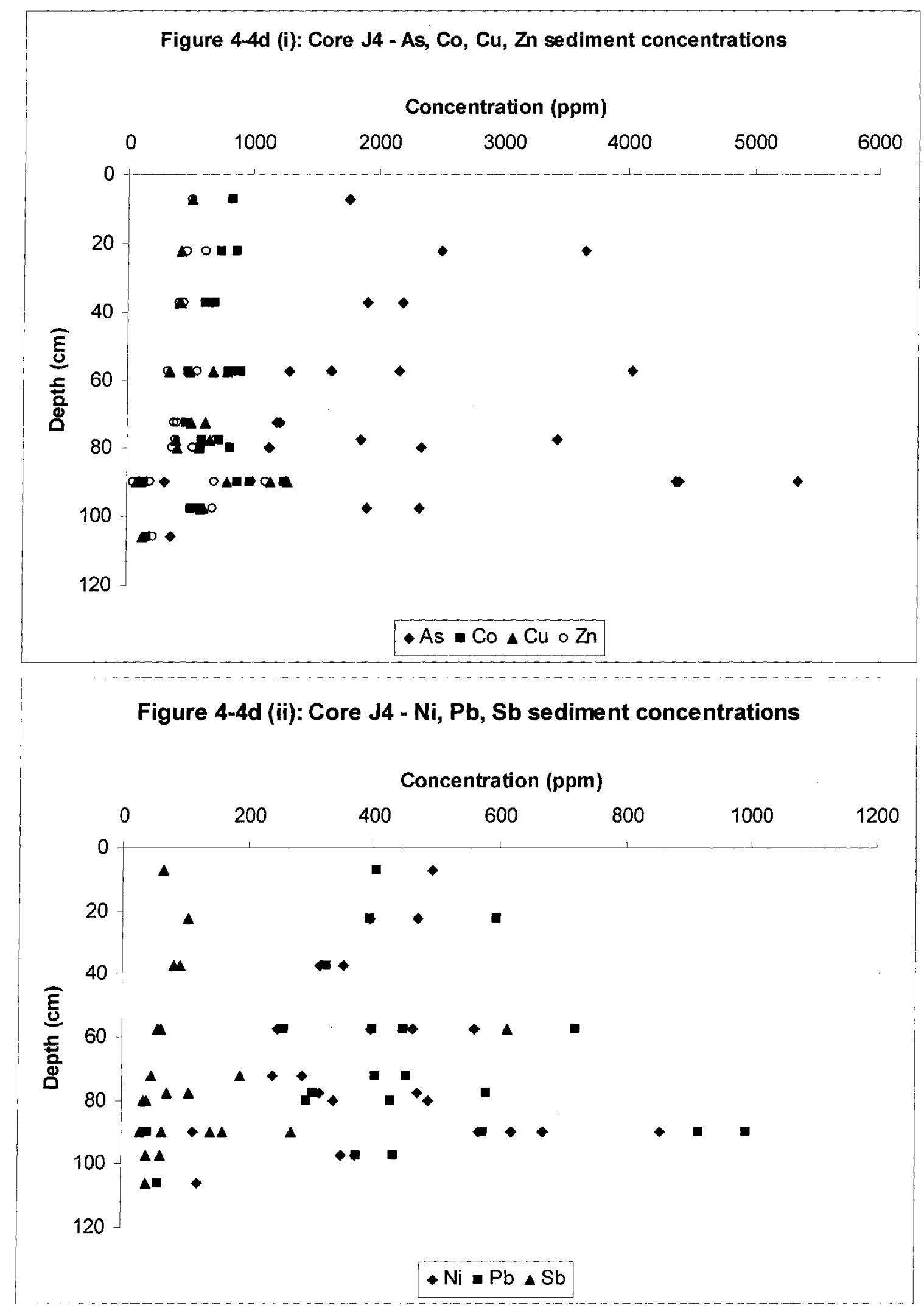

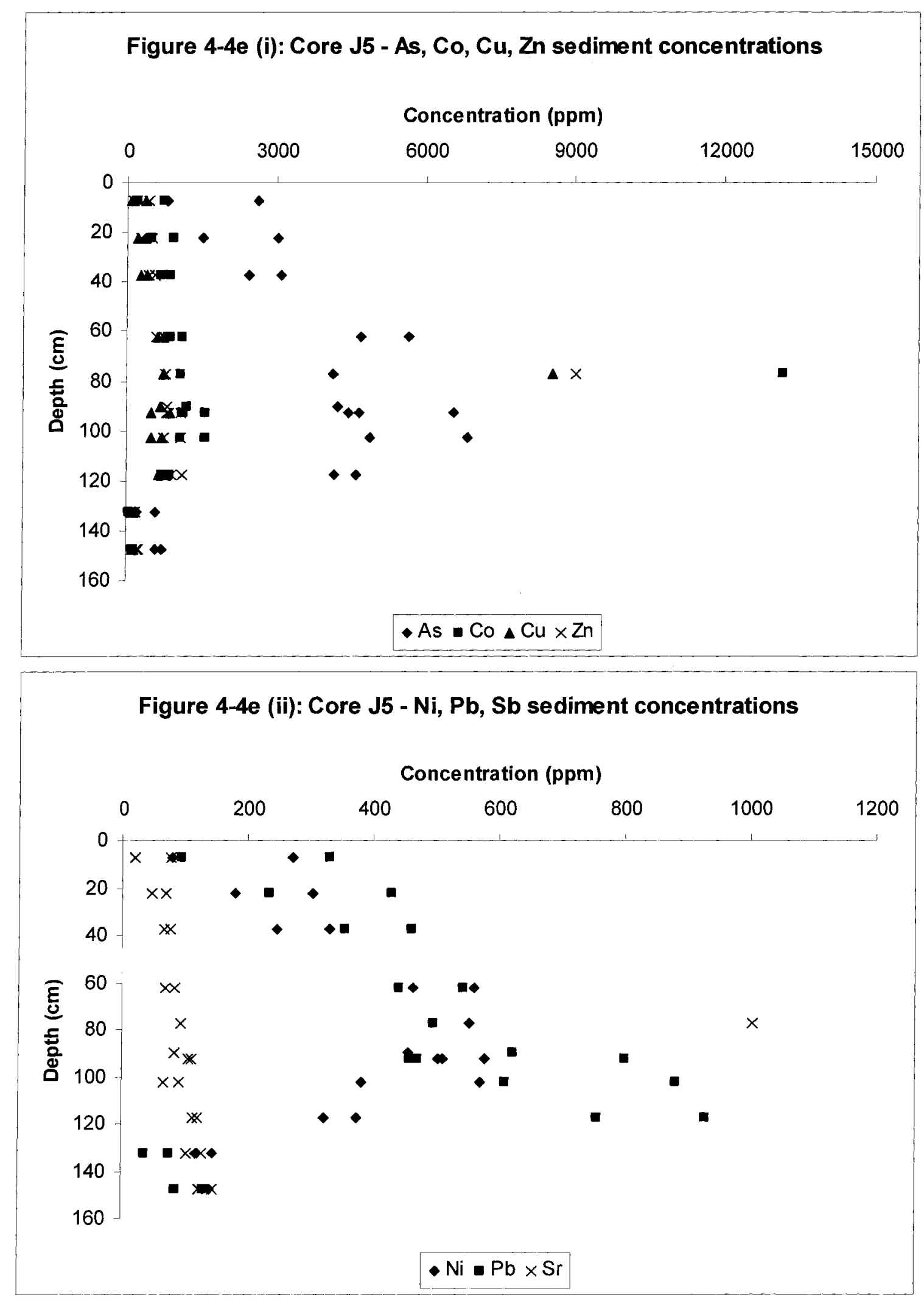

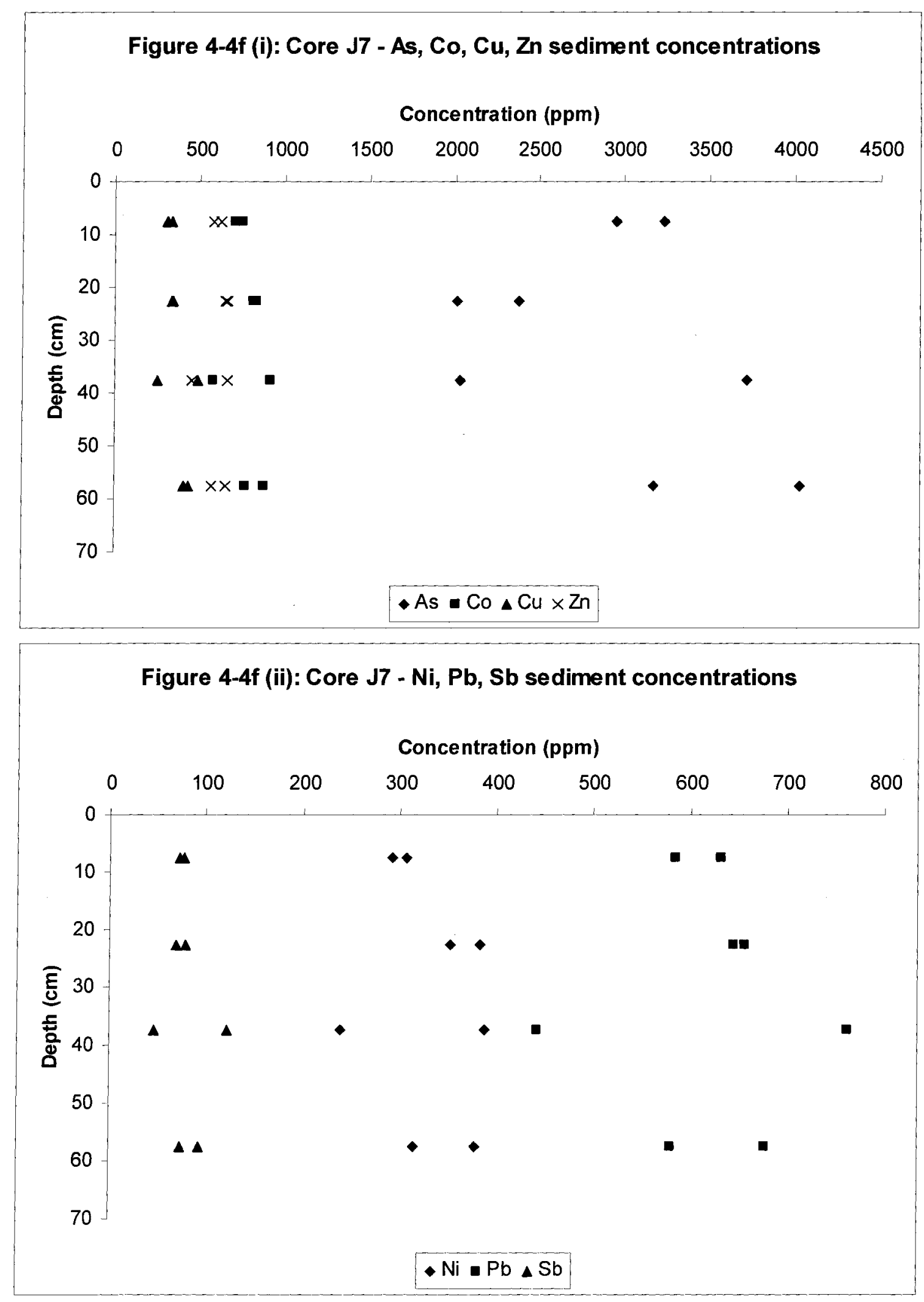

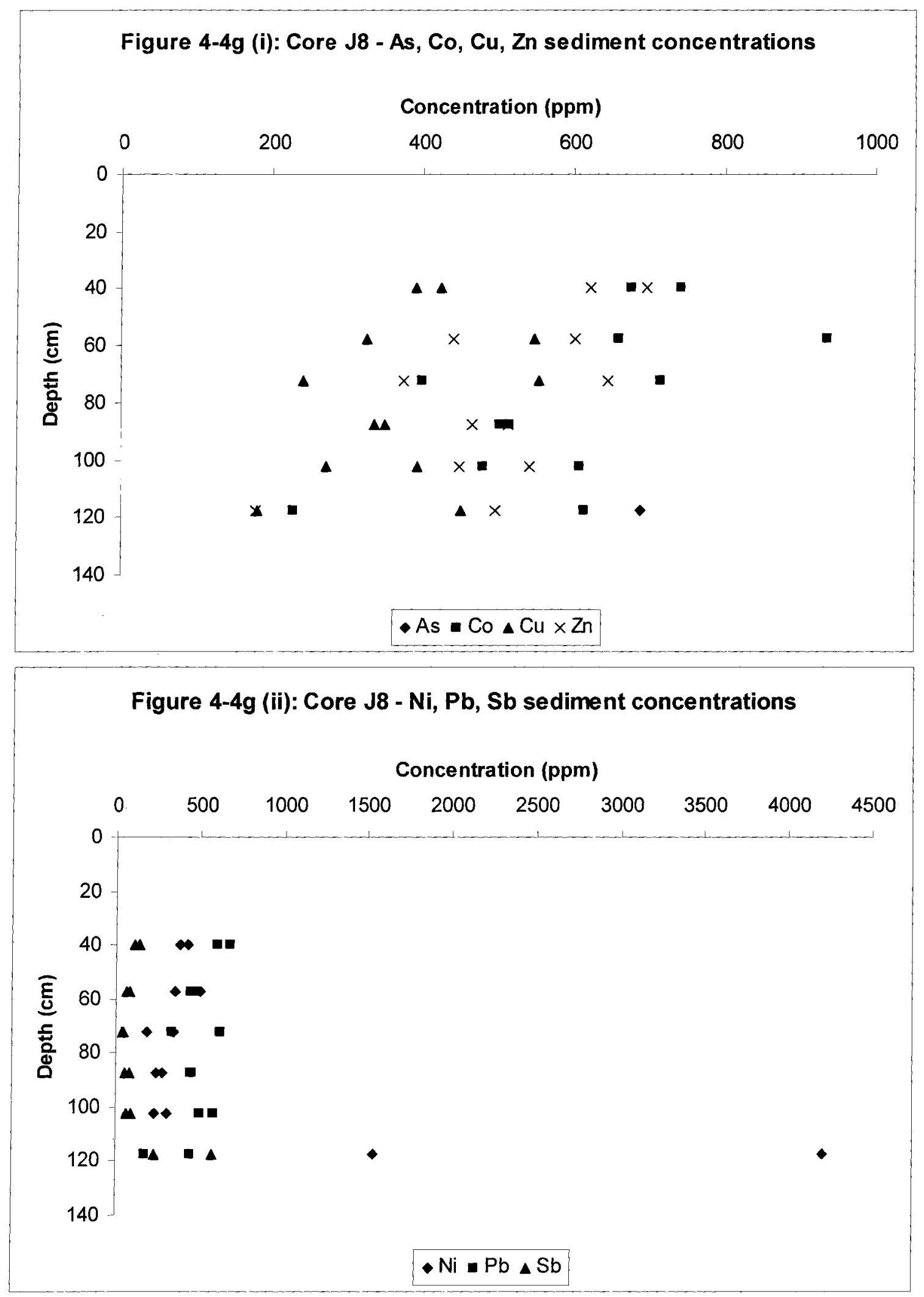

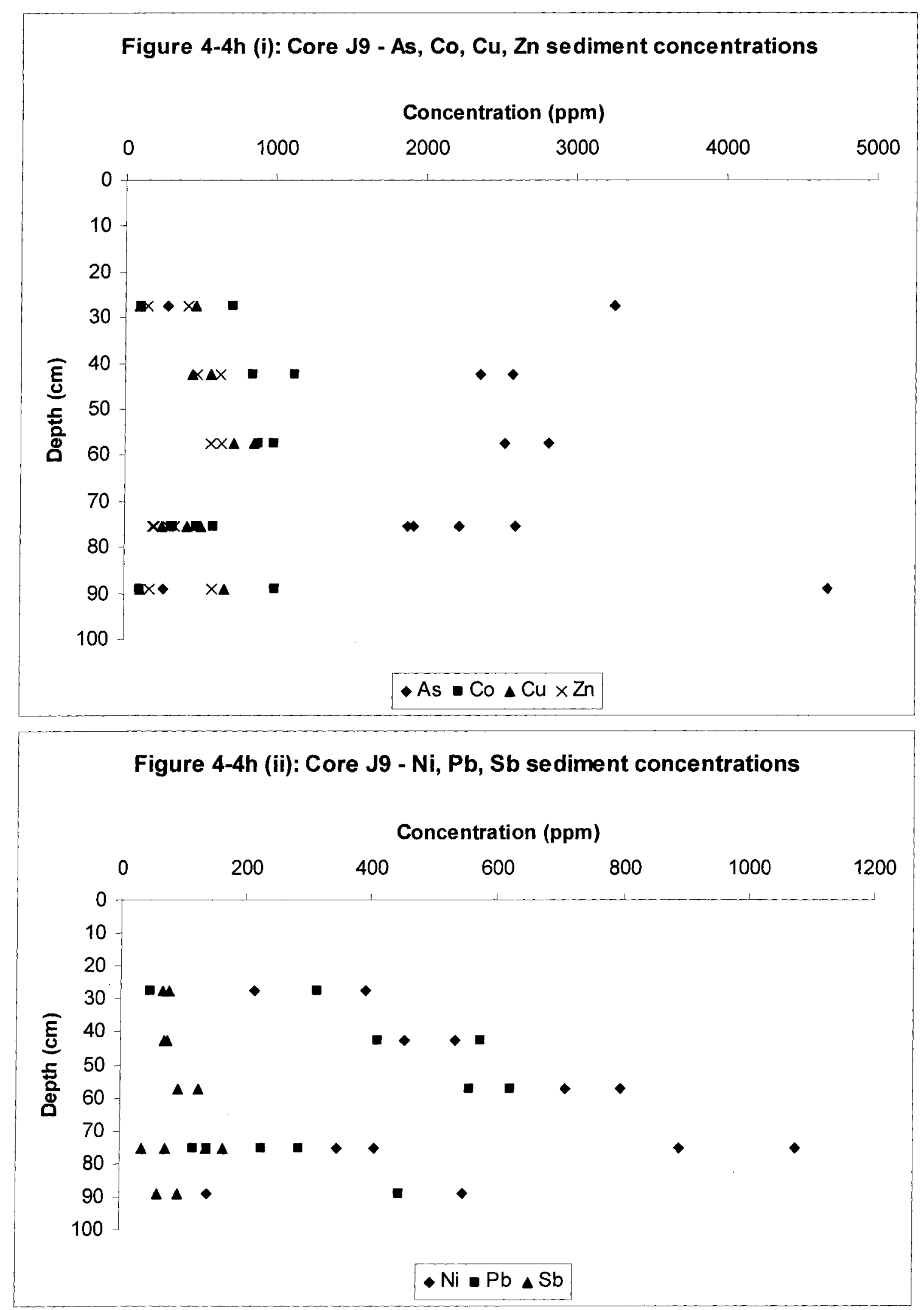

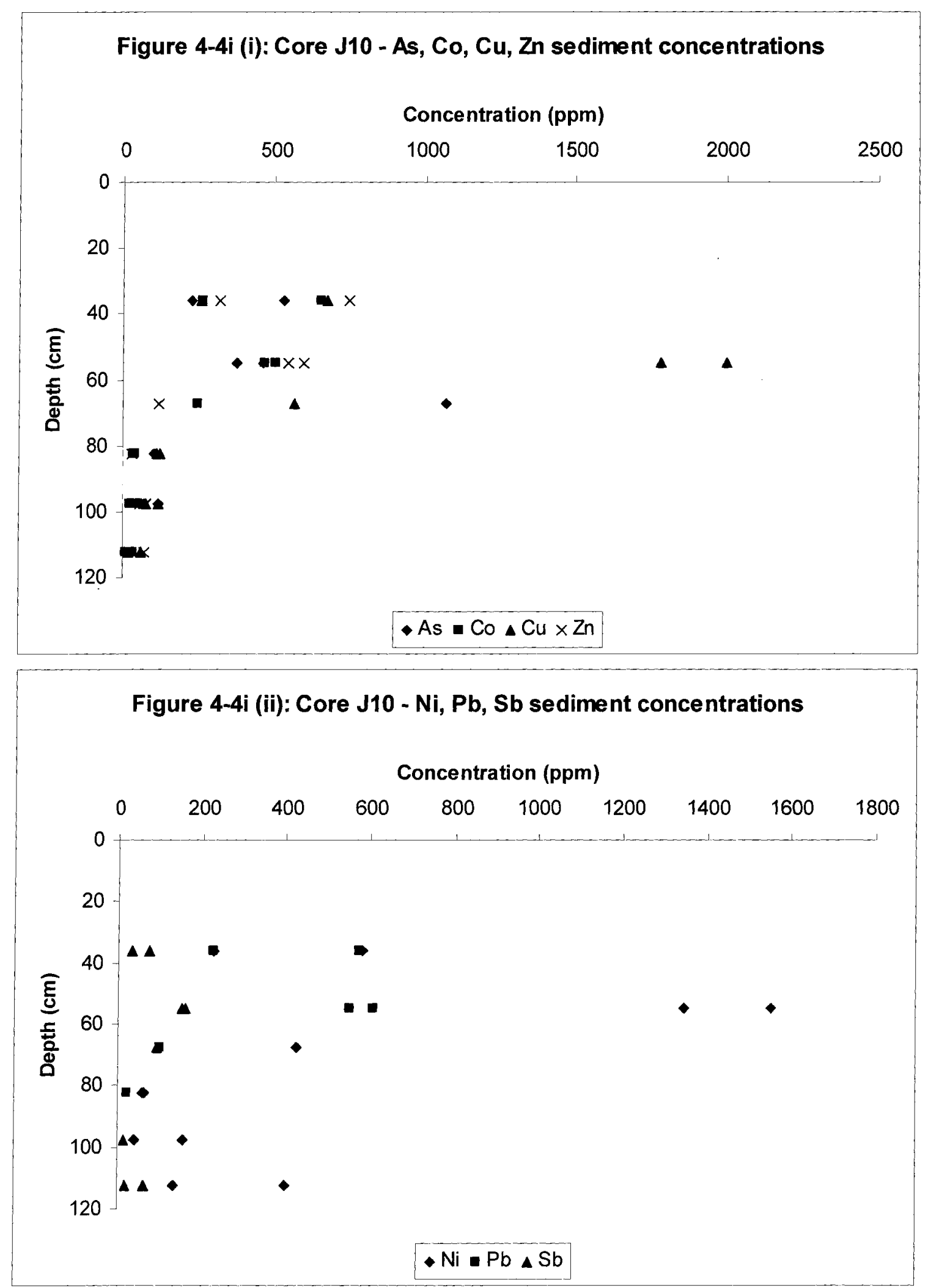
al., 1991). Some metals, such as $\mathrm{Pb}$ and $\mathrm{Co}$ are known to have an affinity for carbonate surfaces and as such it was important to include the carbonate fraction in the sequential extraction analyses. The surfaces of oxides and OM are also prime adsorption sites for metals. The residual fraction accounts for silicate minerals and sulfides. This is important since one of the sinks for select metals is the formation of metal sulfide precipitates under reducing conditions, thereby immobilizing metals.

Figures 4-5a through 4-5g present the results of the sequential extractions for selected metals from the five cores collected in September 2004. The complete set of analytical results are provided in Appendix B. For several metals, at all locations, larger (greater than $50 \%$ ) fractions of metals were associated with the residual fraction. Generally, for metals that exhibited associations with $\mathrm{Fe}$ and $\mathrm{Mn}$ oxides, there were larger percentages of metals associated with this fraction at shallow depths than at deeper depths. A brief discussion on specific metal trends observed at each core location is provided in the following sections.

\section{Arsenic}

Arsenic had relatively constant associations with the residual fraction ranging from $35 \%$ to $75 \%$. The fraction of As associated with the oxides fraction ranged from $31 \%$ to less than $5 \%$ and typically the fraction of As associated with oxides decreased with greater depths. This could be attributed to reduced anounts of Fe and Mn oxides at depth due to the development of reducing conditions. Fractions associated with $\mathrm{OM}$ increased with 
depth at Core S1. This is associated with an increase in OM content at Core S1 with depth. For the remaining cores, with the exception of S3, OM fractions seemed to be relatively constant ranging from $8 \%$ to $33 \%$. At S3, for $50 \mathrm{~cm}$ depth, a large spike in fractions associated with residuals was observed. The reason for this is not known, however, the $\mathrm{OM}$ content of this core at $50 \mathrm{~cm}$ depth was $6.6 \%$. For all locations sampled, less than $15 \%$ of the As was associated with the exchangeable or carbonate fractions

In general, As seemed to be retained predominantly in the residual fraction of the sediment as for all locations sampled, over $25 \%$ of the As was retained in this fraction. Also, As was retained significantly by OM, even under low OM contents in the sediment. This would indicate that if the OM content of the wetland increased, potentially higher associations of As could be observed with OM. It was surprising that As was not strongly associated with the Fe and Mn oxide fraction. This could be attributed to there being small quantities of oxides present in the tailings. Alternatively there could also be competition with OM for sorption sites. (Grambrell et al., 1991).

\section{Cobalt}

Cobalt associated with the OM fraction of the sediment ranged from $22 \%$ to $80 \%$. Cobalt associated with the OM fraction increased with depth at Cores S2 and S3. At Core S1, the fraction associated with OM decreased with depth. This resulted from increases in 
Figure 4-5a: Sequential Extractions Results for Arsenic

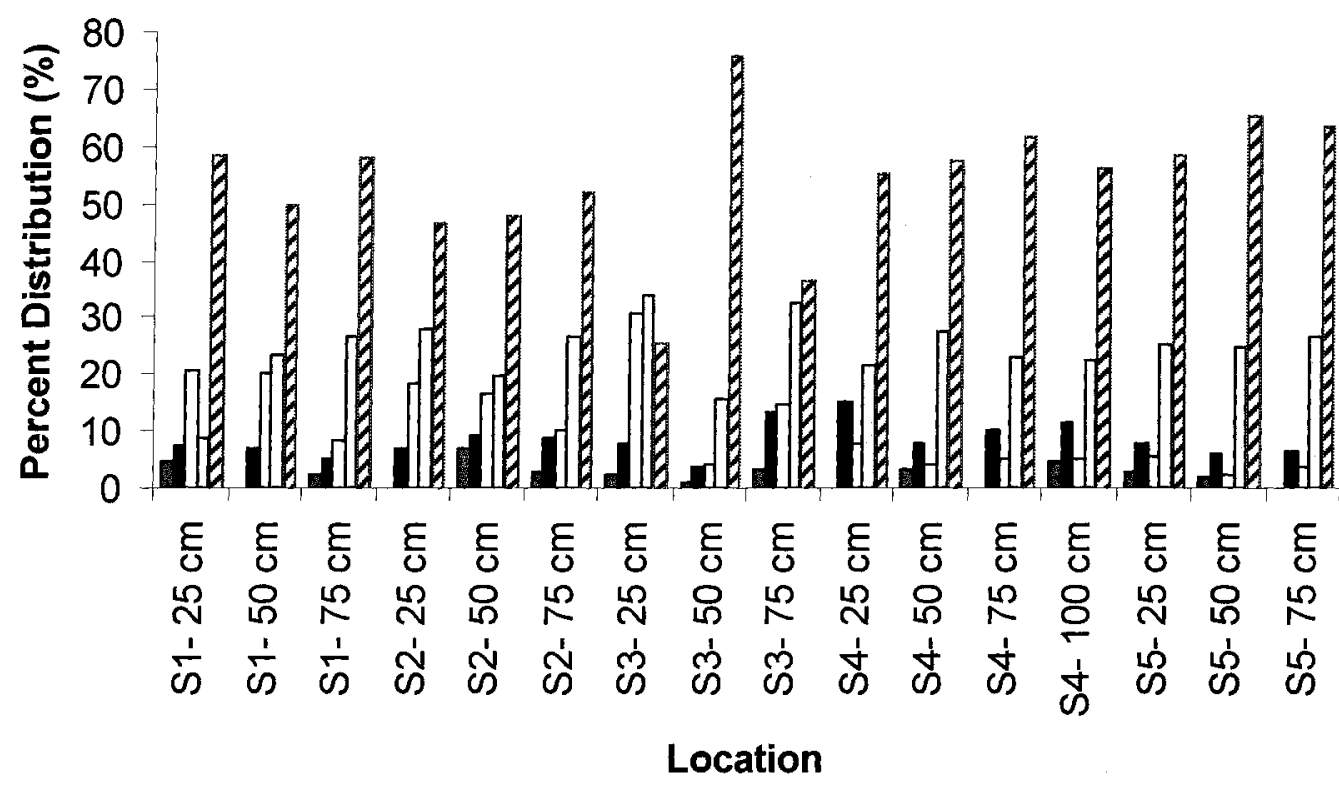

Exchangeable $\square$ Carbonates $\square$ Fe, Mn-oxides $\square$ Organic Residual

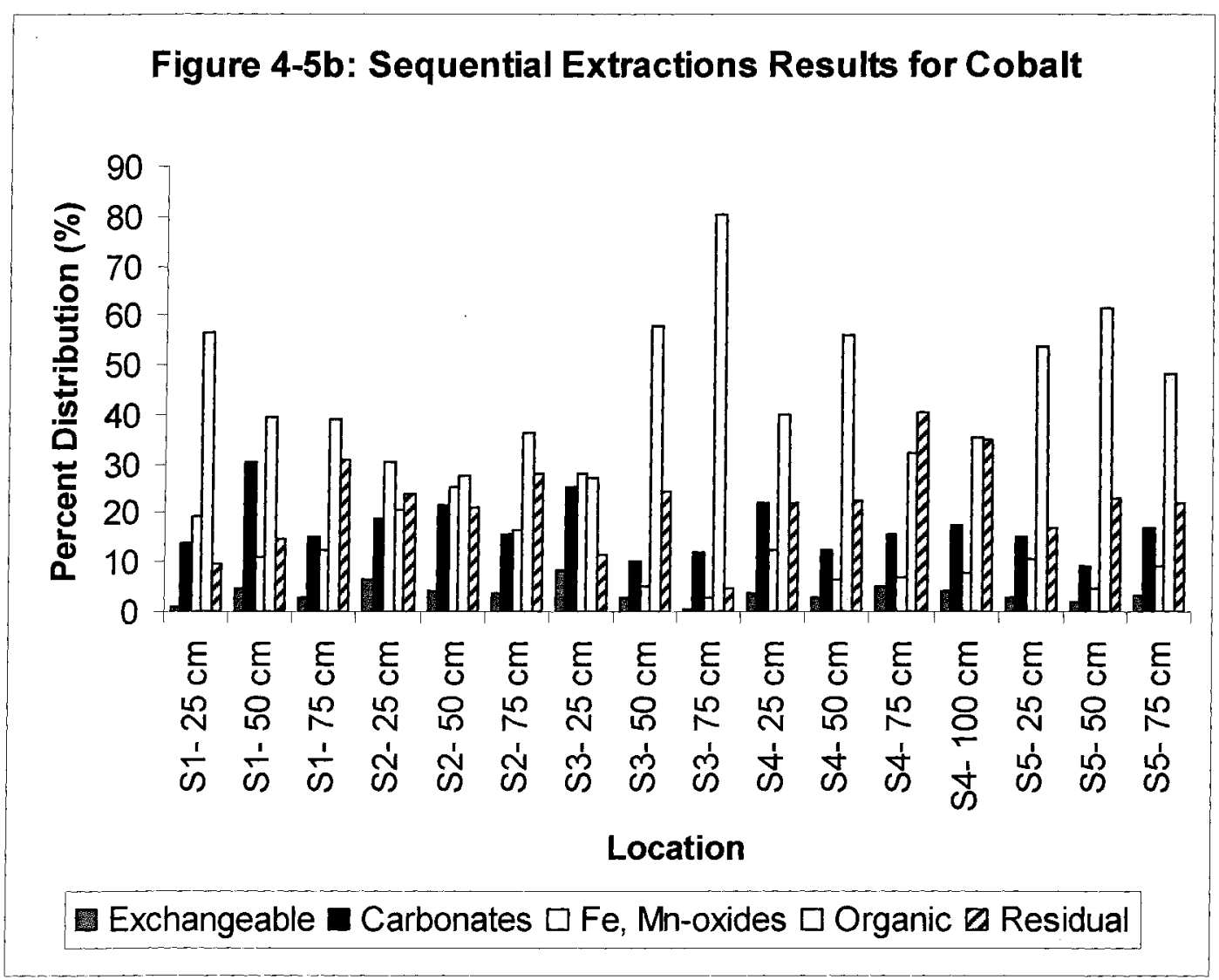


Figure 4-5c: Sequential Extraction Results for Zinc

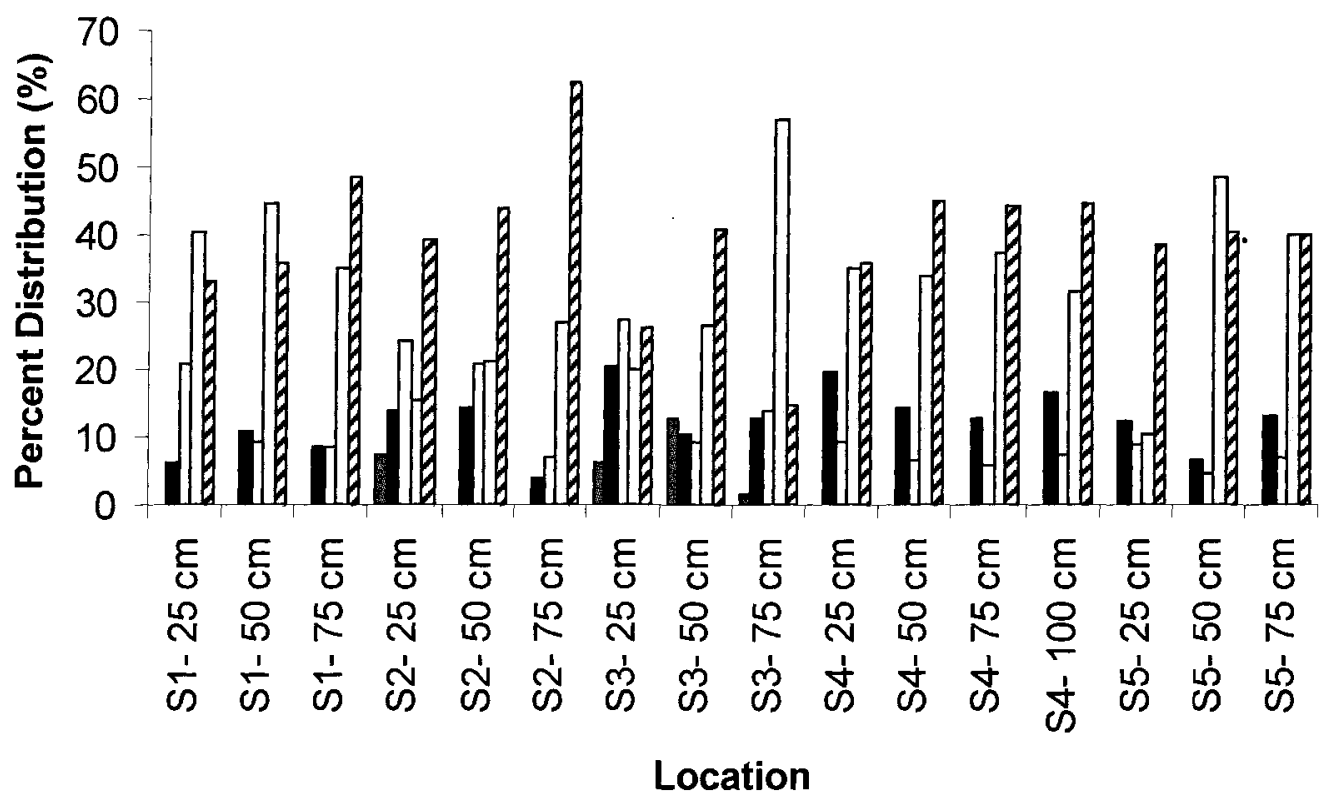

Exchangeable $\square$ Carbonates $\square \mathrm{Fe}, \mathrm{Mn}$-oxides $\square$ Organic $\square$ Residual

Figure 4-5d: Sequential Extractions Results - Copper

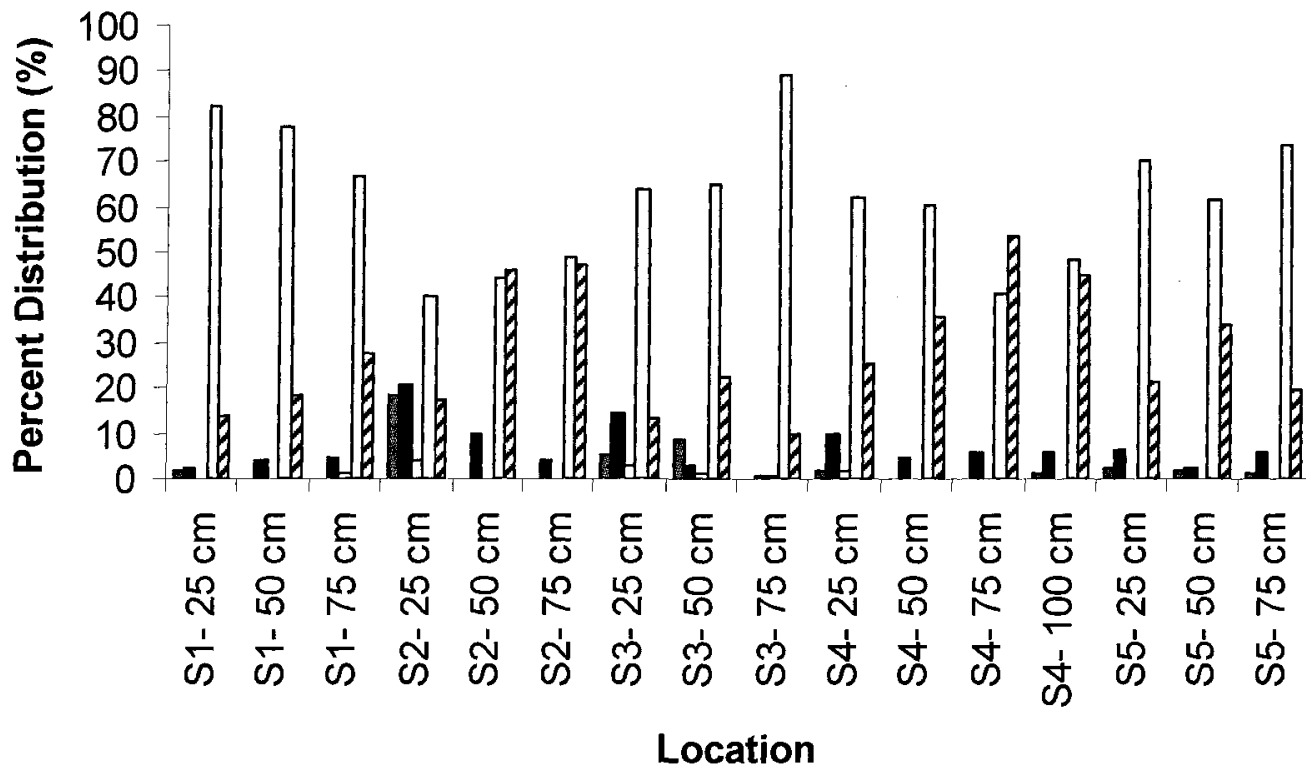

Exchangeable $\square$ Carbonates $\square \mathrm{Fe}$, Mn-oxides $\square$ Organic $\square$ Residual 
Figure 4-5e: Sequential Extractions Results for Nickel

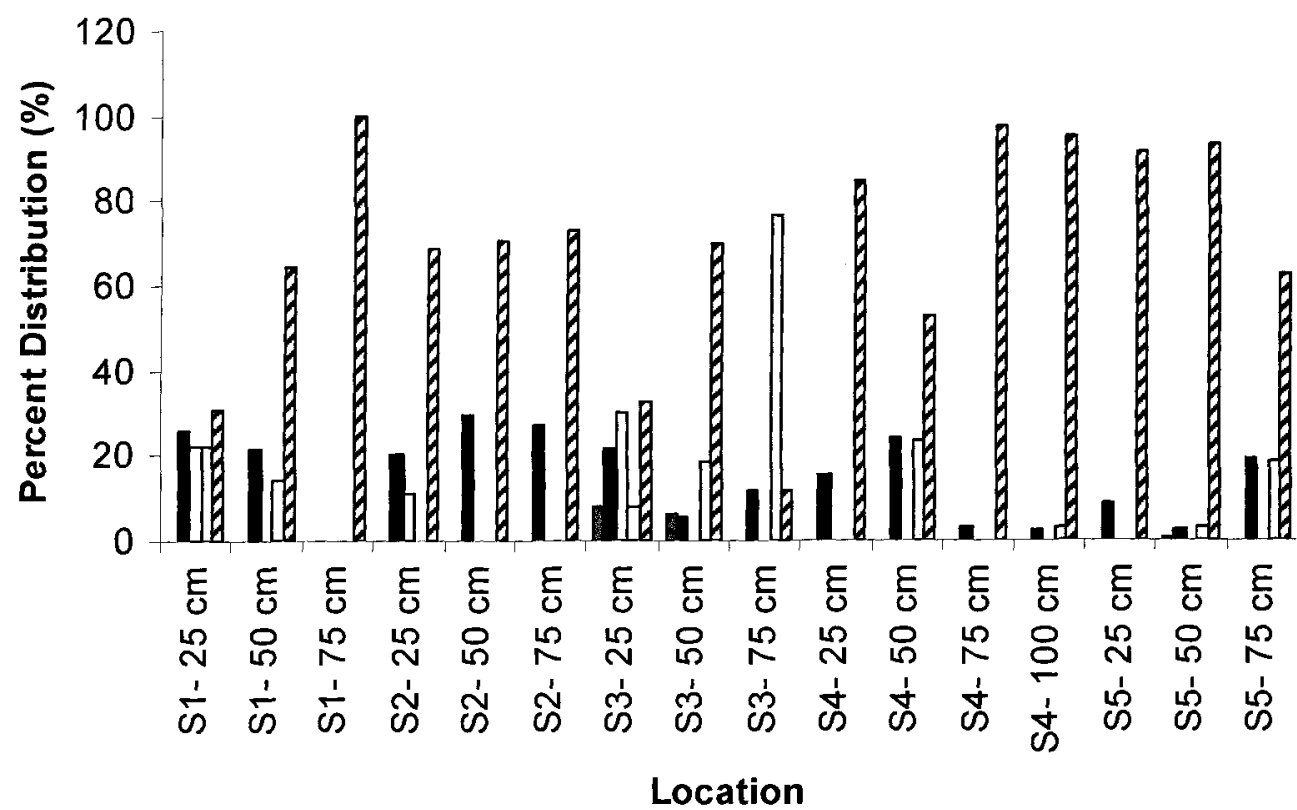

- Exchangeable $\square$ Carbonates $\square \mathrm{Fe}, \mathrm{Mn}$-oxides $\square$ Organic $\square$ Residual

Figure 4-5f: Sequential Extraction Results for Lead

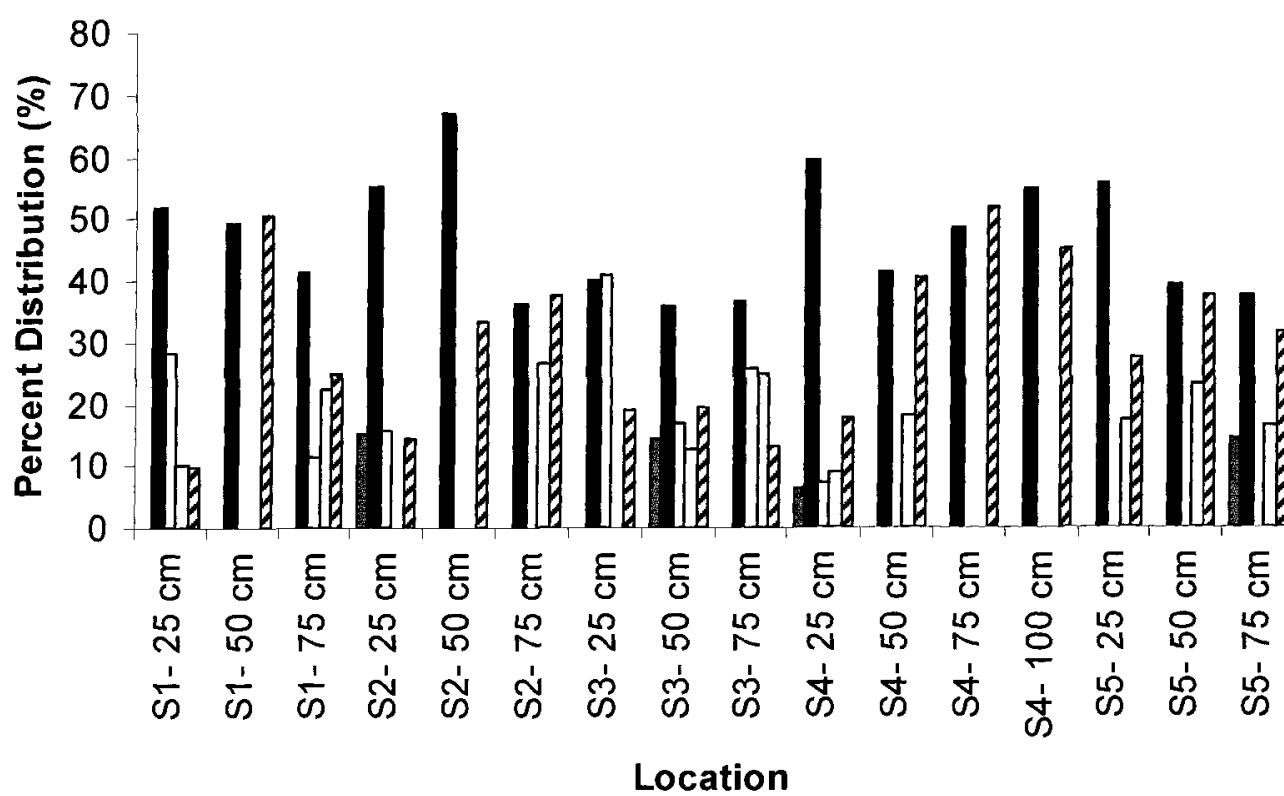

Exchangeable $\square$ Carbonates $\square \mathrm{Fe}$, Mn-oxides $\square$ Organic Residual $^{\prime}$ 
Figure 4-5g: Sequential Extraction Results for Antimony

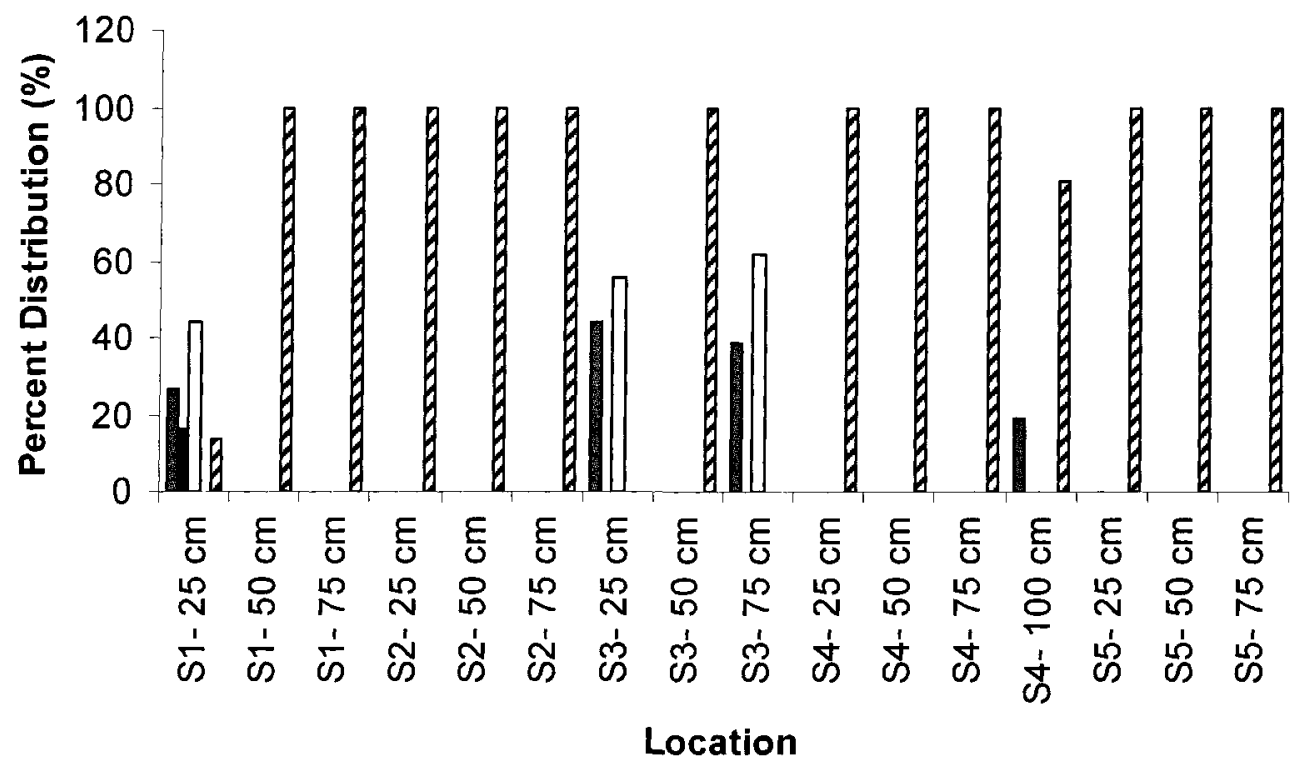

- Exchangeable $\square$ Carbonates $\square$ Fe, Mn-oxides $\square$ Organic $\square$ Residual 
carbonate and residual fractions at $50 \mathrm{~cm}$ and $75 \mathrm{~cm}$ depth, respectively. At core $\mathrm{S} 4$, the fraction of Co associated with $\mathrm{OM}$ increased from $45 \%$ at $25 \mathrm{~cm}$ depth to $60 \%$ at $50 \mathrm{~cm}$ depth and decreased to $38 \%$ at $75 \mathrm{~cm}$ depth. The decrease in Co associated with $\mathrm{OM}$ at $75 \mathrm{~cm}$ depth was attributed to an increase in Co associated with the residual fraction. Cobalt associated with the residual fraction ranged from less than $5 \%$ to $40 \%$. The fraction of Co associated with the residual fraction generally remained constant or increased with depth. Core S3 demonstrated a decrease in Co association with the residual fraction between $50 \mathrm{~cm}$ and $75 \mathrm{~cm}$ depth, which was matched with a marked increase in $\mathrm{OM}$ associations. Cobalt associated with the oxide fraction ranged from less than $5 \%$ to $32 \%$. For all core locations, the fraction of Co associated with oxides decreased with depth. Cobalt associated with the carbonate fraction of the sediment ranged from $8 \%$ to $30 \%$. The fraction of Co associated with carbonates remained relatively constant with depth at cores $\mathrm{S} 2, \mathrm{~S} 4$, and $\mathrm{S} 5$. At Core $\mathrm{S} 3$, the fraction of Co associated with carbonates decreased with depth. At core S1, there was a spike up to $30 \%$ of Co associated with carbonates. The Co associated with the exchangeable fraction of the sediment was always less than $10 \%$ for all core locations.

It is also known that Co has an affinity for carbonates and, thus, in the presence of carbonates, it is likely that there was considerable competition for sorption sites between carbonates and $\mathrm{OM}$. 
$\underline{\text { Zinc }}$

Zinc associations with the residual fraction generally increased with depth ranging from $15 \%$ to $65 \%$. The only exception was at core $\mathrm{S} 3$ at $75 \mathrm{~cm}$ depth where over $60 \%$ of the $\mathrm{Zn}$ was associated with $\mathrm{OM}$. Also, $\mathrm{Zn}$ associations with the organic fraction of the sediment generally increased with depth. At core S1, the fraction of $\mathrm{Zn}$ associated with the OM fraction decreased from $45 \%$ at $50 \mathrm{~cm}$ depth to approximately $35 \%$ at $75 \mathrm{~cm}$ depth. This was matched with almost a $20 \%$ increase in $\mathrm{Zn}$ associated with the residual fraction, thus there could be some competition between the formation of $\mathrm{Zn}$ sulfides and adsorption to $\mathrm{OM}$. $\mathrm{Zn}$ associations with the $\mathrm{Fe}$ and $\mathrm{Mn}$ oxide fraction of the sediment varied from $25 \%$ to less than $10 \%$. At Cores S1, S2, and S3, Zn associations with the oxide fraction at $25 \mathrm{~cm}$ depth averaged at $20 \%$ with associations decreasing noticeably with depth. At Cores S4 and S5, the Zn associated with the oxides fraction were considerably less, with maximum percentage of $\mathrm{Zn}$ associated with the oxides fraction at approximately $10 \% . \mathrm{Zn}$ associated with the carbonates fraction of the sediment ranged from less than $5 \%$ to $20 \%$. With the exception of Core $\mathrm{S} 1$, the $\mathrm{Zn}$ associations with carbonate minerals generally decreased with depth. At core $\mathrm{S} 1$, the $\mathrm{Zn}$ associations with carbonates increased slightly with depth however for all depths the percentage of associations with $\mathrm{Zn}$ remained below $10 \%$. Associations with the exchangeable fraction were only detected in cores $\mathrm{S} 2, \mathrm{~S} 3$. At cores $\mathrm{S} 2$, approximately $8 \%$ of $\mathrm{Zn}$ was associated with the exchangeable fraction only at the $25 \mathrm{~cm}$ depth. No $\mathrm{Zn}$ associations were found at the two deeper depths. At Core S3, Zn associations were noted at all three depths with 
$\mathrm{Zn}$ associations ranging from $8 \%$ at $25 \mathrm{~cm}$ depth, to approximately $12 \%$ at $50 \mathrm{~cm}$ depth, and dropping to less than $5 \%$ at $75 \mathrm{~cm}$ depth.

Based on the results from the sequential extractions, it appears that $\mathrm{Zn}$ was predominantly associated with the residual and OM fractions of the sediments and that there potentially could be competition between these two fractions, most likely under reducing conditions where $\mathrm{Zn}$ sulfides would be forming.

\section{Copper}

Copper associated with the residual fraction of the sediment ranged from less than $10 \%$ to $50 \%$. Copper associated with the OM fraction of the sediment ranged from $40 \%$ to $85 \%$. There appeared to be some competition between $\mathrm{Cu}$ associations with these fractions. Generally, the $\mathrm{Cu}$ association with $\mathrm{OM}$ increased or remained relatively constant with depth. This was not observed at cores $\mathrm{S} 1$ and $\mathrm{S} 4$ due to marked increases in $\mathrm{Cu}$ associations with the residual fraction. Copper associations with exchangeable and oxide fractions were all less than $10 \%$. The fraction of $\mathrm{Cu}$ associated with the carbonate fraction ranged from $20 \%$ to less than $5 \%$. Generally, $\mathrm{Cu}$ associated with the carbonate fraction decreased with depth.

Based on the results of the sequential extractions, it appears that $\mathrm{Cu}$ was predominantly adsorbed to OM and associated with the residual fraction. 
Nickel

Nickel associated with the residual fraction of the sediment ranged from less than $10 \%$ to $100 \%$. Associations with the residual fraction increased with depth at most locations. At core $\mathrm{S} 3$, there was a sharp increase in association with $\mathrm{OM}$ at $75 \mathrm{~cm}$ depth which reduced the amount of $\mathrm{Ni}$ associated with the residual fraction. Nickel associated with the OM fraction of the sediment was intermittent and ranged from less than $1 \%$ to $80 \%$. There appeared to be some competition between $\mathrm{Ni}$ associations with these fractions. Nickel associations with the exchangeable and oxide fractions were also intermittent and ranged from less than $1 \%$ to $20 \%$. The fraction of $\mathrm{Ni}$ associated with the carbonate fraction ranged from $23 \%$ to less than $1 \%$. Generally, higher percentages of Ni were associated with the carbonate fraction at shallower depths.

Based on the results of the sequential extractions, it appears that Ni was predominantly associated with the residual fraction of the sediment.

\section{$\underline{\text { Lead }}$}

Lead was strongly associated with the carbonate fraction of the sediment, with associations ranging from $35 \%$ to $65 \%$. No consistent trends were observed for $\mathrm{Pb}$ associated with the carbonates fraction. Associations of $\mathrm{Pb}$ with the residual fractions ranged from less than $1 \%$ to approximately $50 \%$. Associations of $\mathrm{Pb}$ with the $\mathrm{OM}$, oxide and exchangeable fractions were sporadic and ranged from less than $1 \%$ to $40 \%$. The 
oxides were associated with cores $\mathrm{S} 1, \mathrm{~S} 2$, and $\mathrm{S} 3$, however, none were found at $\mathrm{S} 4$ and S5.

Based on the results of the sequential extractions, it appears that $\mathrm{Pb}$ was predominantly associated with the carbonate and to a lesser extent, the residual fraction of the sediment.

\section{Antimony}

Antimony was predominantly associated with the residual fraction. The associations of Sb with the oxide fraction ranged from $42 \%$ to $62 \%$, however, these were only encountered at the $25 \mathrm{~cm}$ depths for cores $\mathrm{S} 1, \mathrm{~S} 2$, and $\mathrm{S} 3$. The associations of $\mathrm{Sb}$ with the exchangeable fraction ranged from $22 \%$ to $45 \%$. These associations were only noted for cores S1, S3, and S4 intermittently. There were no associations of Sb with the carbonate or OM fractions of the sediments.

\subsection{Acid Volatile Sulfides (AVS) and Chromium Reducible Sulfides (CRS) Extractions}

AVS and CRS extractions were conducted on the five cores collected in September 2004. The results for AVS and CRS for each core are provided in Figures 4-6a through 4-6e. In all cases, the concentrations for AVS remained lower than $5 \mathrm{ppm}$. The AVS fraction corresponds to reduced sulfur species $\left(\mathrm{H}_{2} \mathrm{~S}\right)$ and monosulfides in the sediment. These reduced sulfur species are both the product of dissimilatory sulfate reduction and the 
decomposition of organic sulfur, amorphous iron monosulfides, and crystalline iron sulfides (Praharaj, 2004). The CRS fraction corresponds to pyrite and elemental sulfur in the sediments.

The concentration of AVS in the sediments is a function of both the rate at which it is produced and the rate at which it is lost by oxidation and diffusion (Oehm et al., 1997). The concentrations of AVS can vary therefore with the supply of organic matter, the rate of sulfate reduction, and the redox status of the sediments (Praharaj and Fortin, 2004).

The CRS concentrations from Core $\mathrm{S} 1$ increased to $50 \mathrm{~cm}$ depth and then began to decrease. In core S2 the CRS concentrations showed a slight decreasing trend. CRS concentrations measured at S3 increased with depth. At Core S4, the CRS concentrations exhibited a decreasing trend to a depth of $75 \mathrm{~cm}$ followed by increasing concentrations. At core $\mathrm{S} 5$, the CRS concentrations showed sharp increases below a depth of $50 \mathrm{~cm}$. The reported elemental sulfur concentrations with depth are presented in Table 4-1. As shown, the elemental sulfur concentrations show a similar trend to the observed CRS concentration profiles with depth. Previous work conducted by the GSC (1997) reported that there were negligible amounts of pyrite or pyrrhotite in these tailings. Therefore it is possible that the sample size used for the analysis was not large enough to accurately quantify the AVS fraction in the sediment. Based on the results, it is not possible to determine if metal sulfides are being produced at these core locations. The porewater chemistry results (presented in Sections 4.5 and 4.6) and geochemical speciation modeling results (presented in Section 5.0) may provide some additional information. 

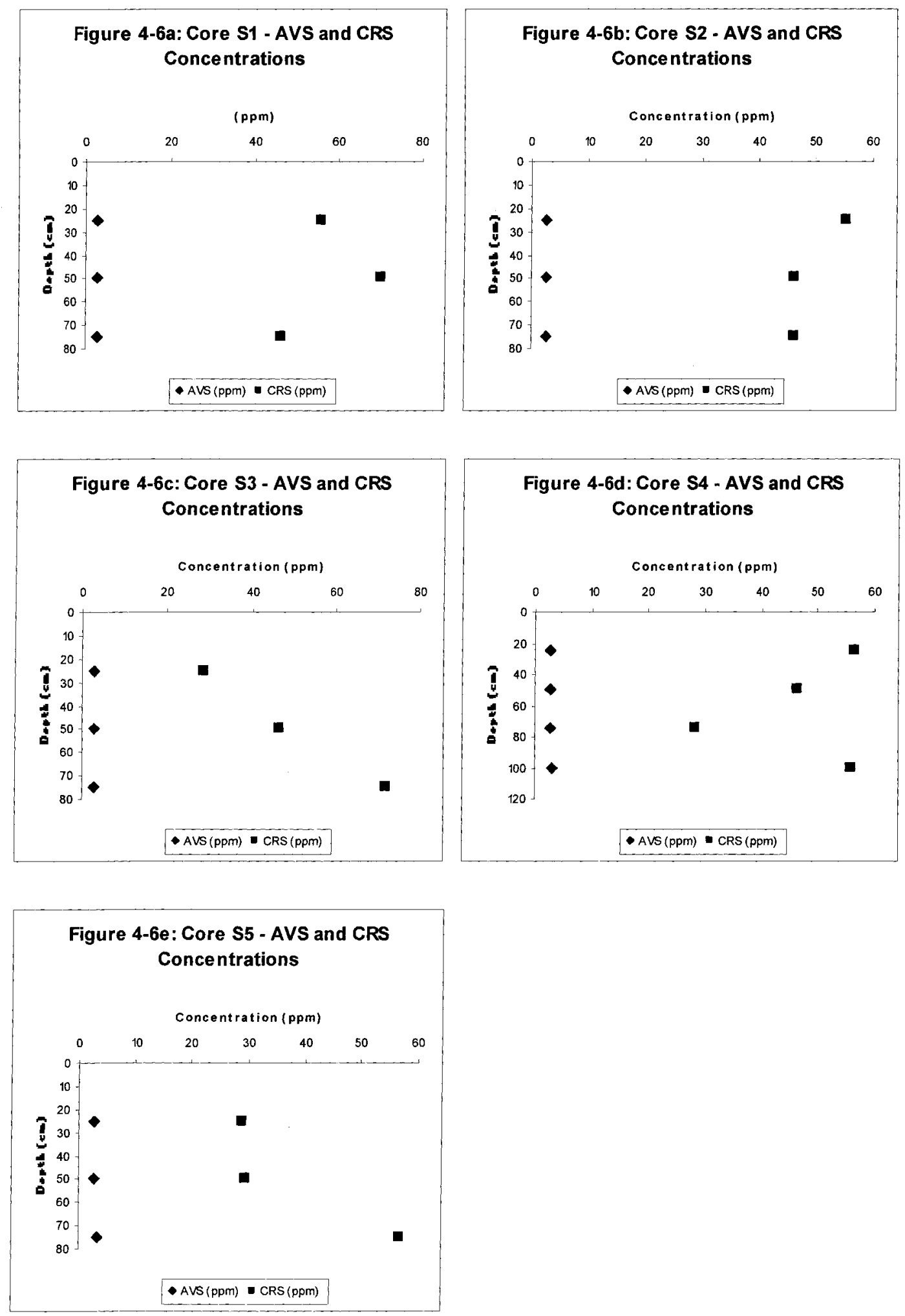


\subsection{Porewater Metal Concentrations}

Table 4-2 presents the dissolved metals concentrations extracted from the five cores collected in September 2004 and from the 7 groundwater monitoring wells installed at the site in June 2004, which were sampled in September 2004.

The porewater metals concentrations collected from MW5 appear slightly elevated for As, $\mathrm{Co}$ and $\mathrm{Zn}$ compared to the remaining porewater data from the other monitoring wells. MW5 was the only well installed away from the creeks or the waterlogged areas. The only vegetation near MW5 was grasses. It is possible that the lack or organic material and cattail vegetation could be influencing geochemical interactions at this location. Nickel concentrations for all locations were reported below the method detection limit of $0.06 \mathrm{mg} / \mathrm{l}$. Also, lead was reported below the method detection limit of $0.21 \mathrm{mg} / \mathrm{l}$ for all of the monitoring wells. Lead was only detected at $45 \mathrm{~cm}$ depth for core $\mathrm{S} 1,75 \mathrm{~cm}$ and $135 \mathrm{~cm}$ depth for core $\mathrm{S} 2,50 \mathrm{~cm}$ depth for core $\mathrm{S} 3,23.5 \mathrm{~cm}$ depth for core $\mathrm{S} 4$, and $50 \mathrm{~cm}$ depth for core $\mathrm{S} 5$. In all cases the reported lead concentrations were less than $0.6 \mathrm{mg} / \mathrm{l}$. Figures $4-7 \mathrm{a}$ through $4-7 \mathrm{o}$ present the concentration profiles with depth for selected heavy metals. For all these cores, concentrations of Fe and Al were strongly correlated, with correlation coefficients ranging from $98.2 \%$ to greater than $99.99 \%$, despite fluctuating concentrations with depth.

Zn concentrations demonstrated increasing concentrations with depth at cores S1 and S3. At core $\mathrm{S} 5, \mathrm{Zn}$ showed increasing concentrations to a depth of $50 \mathrm{~cm}$ followed by 


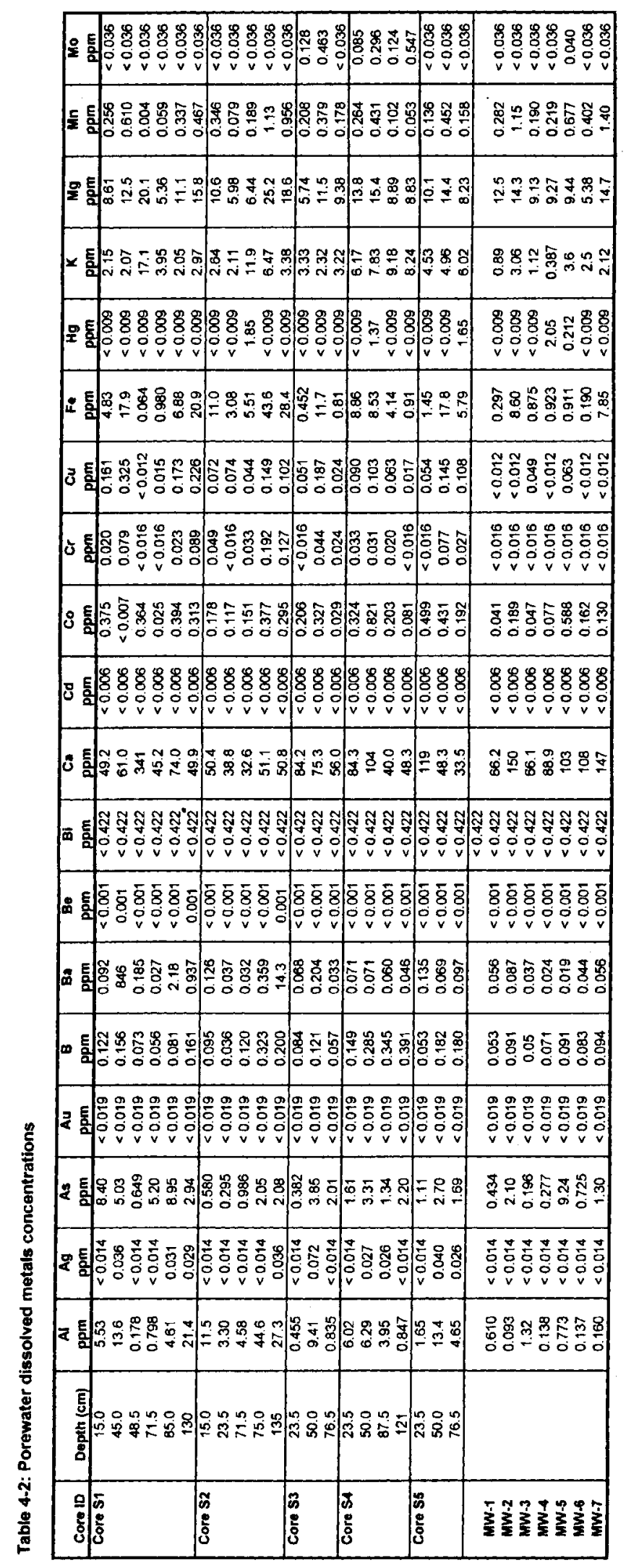




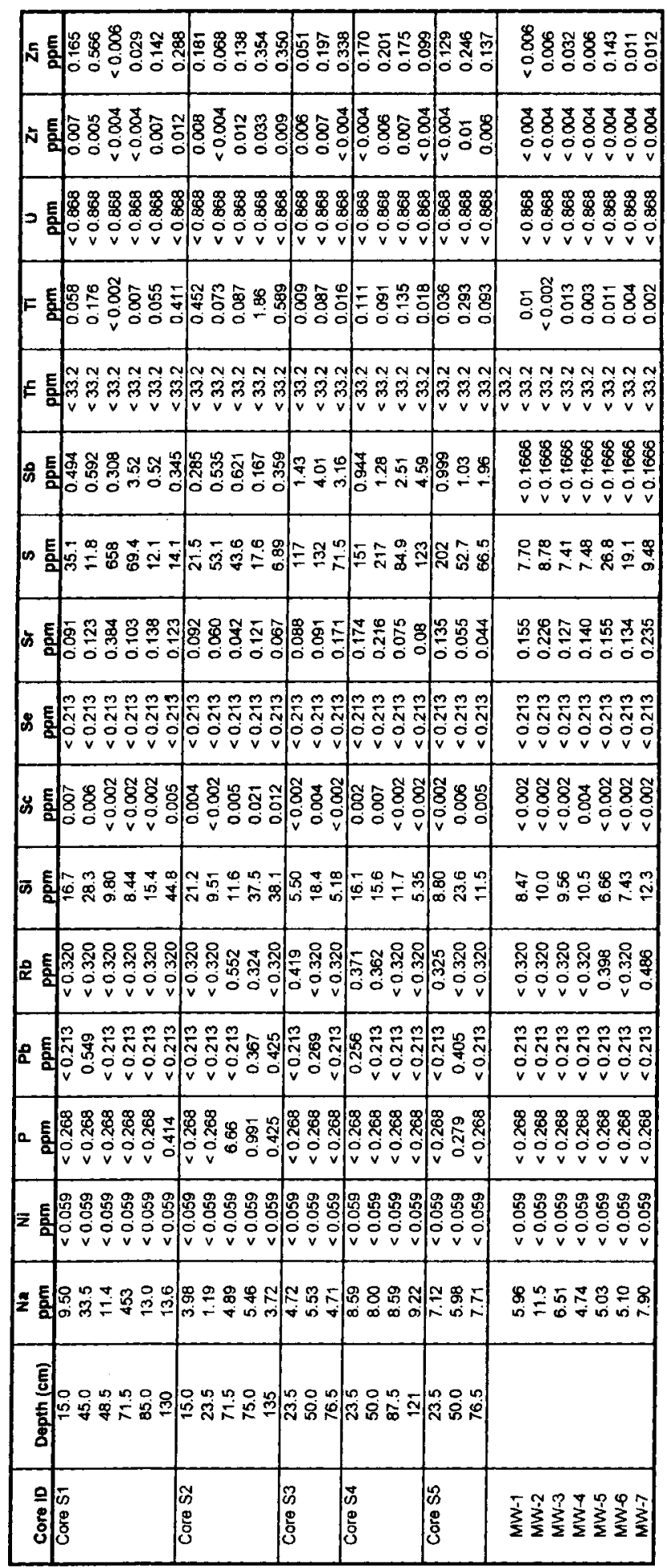



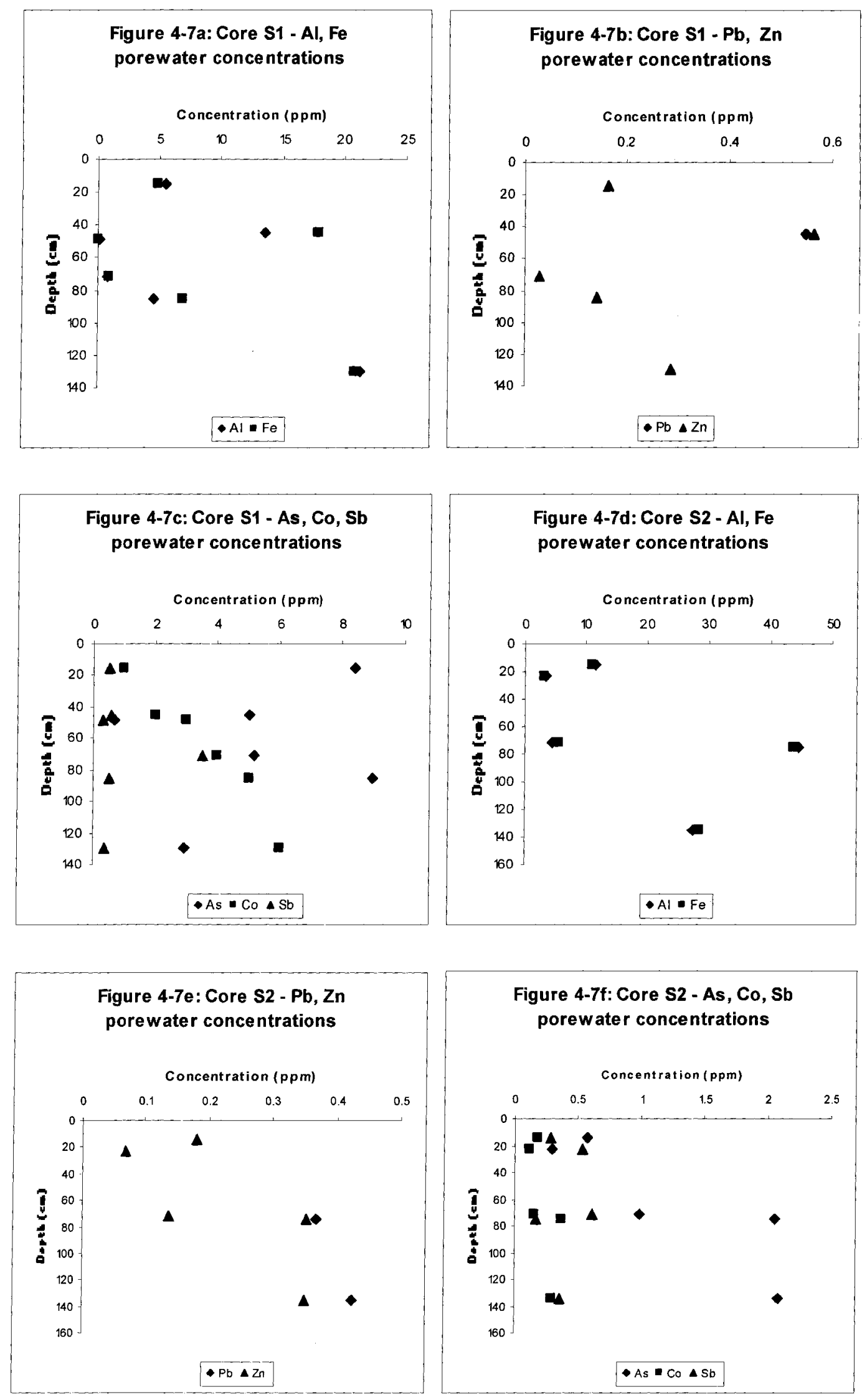

Reproduced with permission of the copyright owner. Further reproduction prohibited without permission. 

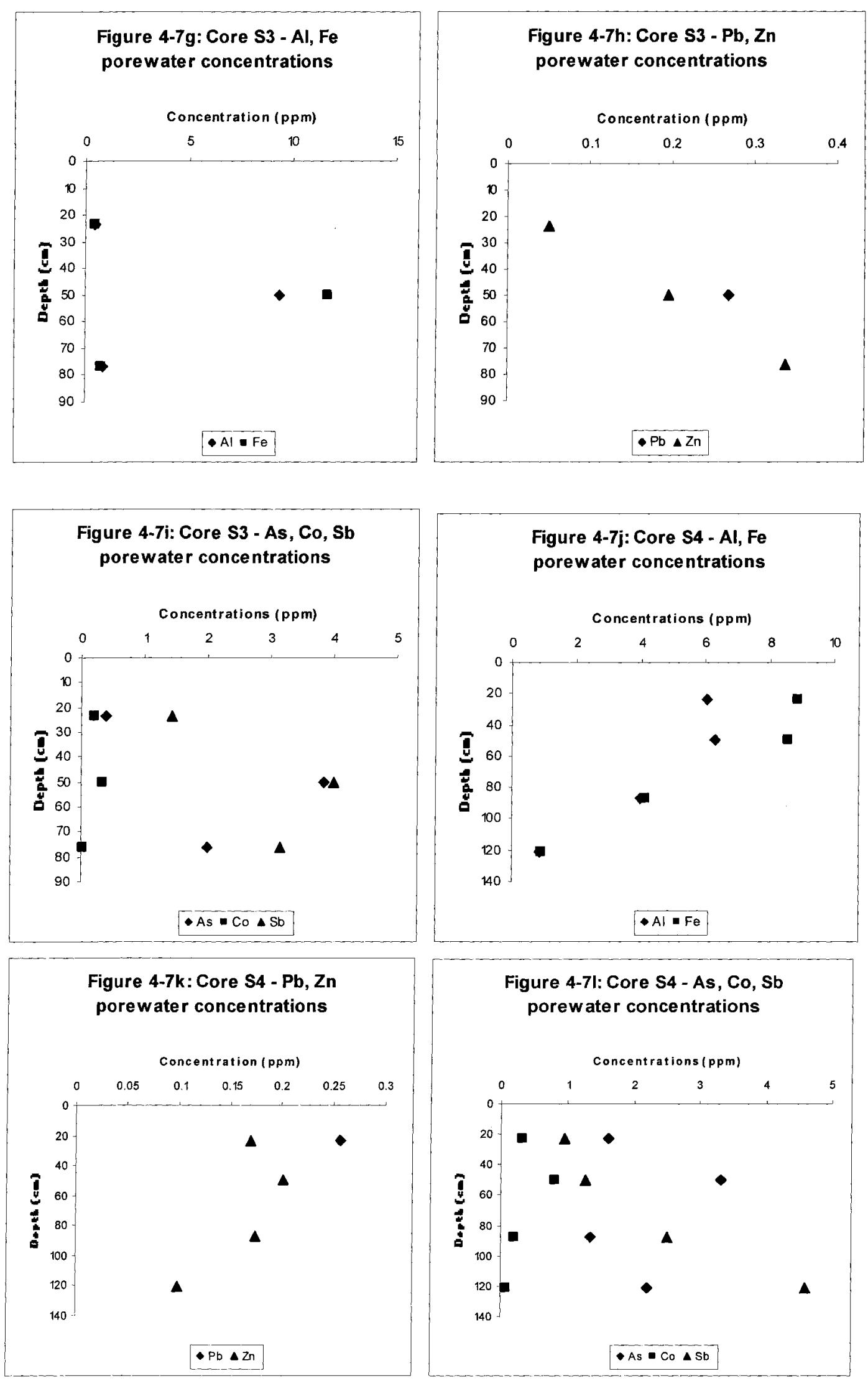

Reproduced with permission of the copyright owner. Further reproduction prohibited without permission. 

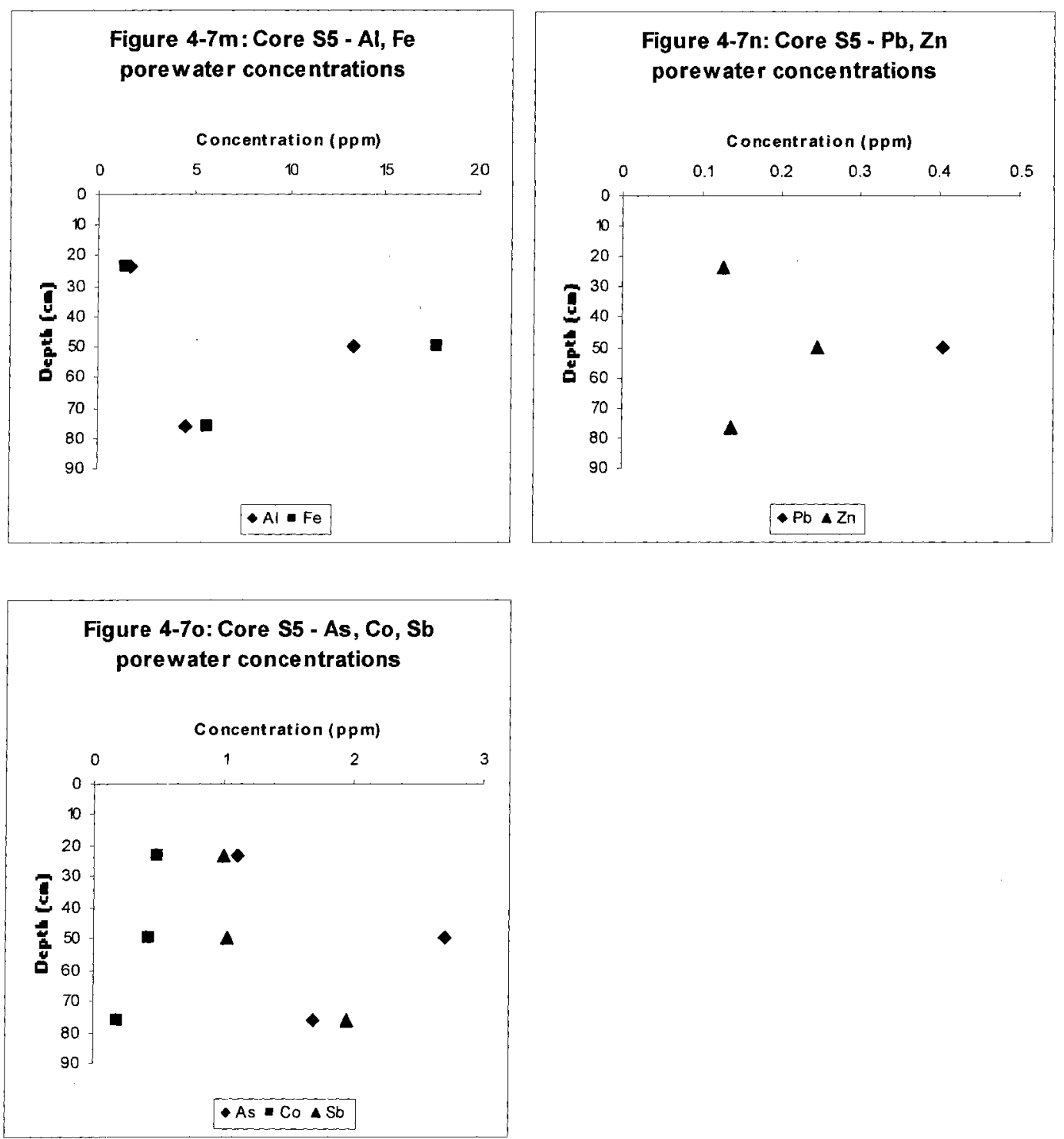
decreasing concentrations. At core S2, Zn showed no observable trend in the concentration profile and at core $\mathrm{S} 4 \mathrm{Zn}$ showed a decreasing concentration profile with depth.

At cores $\mathrm{S} 1, \mathrm{~S} 3, \mathrm{~S} 4$ and $\mathrm{S} 5$, there was only one data point where $\mathrm{Pb}$ was reported above the method detection limit and therefore no concentration profile trends were observed. At Core $\mathrm{S} 2, \mathrm{~Pb}$ concentrations demonstrated increasing concentrations with depth. Antimony demonstrated relatively constant concentrations with depth at S1 and S2. Cores S4 and S5 demonstrated increasing concentrations to a depth of 50cm followed by decreasing concentrations.

At cores $\mathrm{S} 3$ and S5, As and Co concentrations increased to a depth of $50 \mathrm{~cm}$ followed by decreasing concentrations. At cores $\mathrm{S} 1$ and $\mathrm{S} 4$ no trends were observed and at core $\mathrm{S} 2$ both As and Co concentrations increased with depth.

\subsection{Porewater Field Parameters Chemistry}

Table 4-3 presents the field chemistry results collected from the groundwater samples. Concentrations of ferric iron and $\mathrm{HS}^{-}$were low. The maximum ferric iron ( $\left.\mathrm{Fe}(\mathrm{II})\right)$ concentration was reported at $2.0 \mathrm{mg} / \mathrm{l}$ for MW4 and the maximum $\mathrm{HS}^{-}$concentration was reported at $0.4 \mathrm{mg} / \mathrm{l}$ for $\mathrm{MW} 1$. 
Table 4-3: Monitoring wells groundwater field chemistry

\begin{tabular}{|c|c|c|c|c|c|c|c|c|}
\hline Parameter & Units & MW1 & MW2 & MW3 & MW4 & MW5 & MW6 & MW7 \\
\hline HS & $\mathrm{mg} / \mathrm{l}$ & 0.40 & $\mathrm{nd}$ & 0.10 & 0.10 & $\mathrm{~nm}$ & 0.15 & 0.1 \\
$\mathrm{Fe}$ (II) & $\mathrm{mg} / \mathrm{l}$ & 1.0 & $\mathrm{nd}$ & 0.05 & 2.0 & 0.10 & $\mathrm{nd}$ & 0.80 \\
$\mathbf{S O 4}$ & $\mathrm{mg} / 1$ & 1800 & 100 & 130 & 50 & 220 & 150 & 50 \\
DO & $\mathrm{mg} / 1$ & 2.23 & 0.34 & 0.25 & 3.52 & 3.68 & 2.92 & 4.98 \\
cond & $\mathrm{uS} / \mathrm{cm}$ & 349 & 346 & 80.0 & 53.0 & 198 & 386 & 593 \\
$\mathbf{p H}$ & & 6.93 & 6.59 & 6.66 & 6.48 & 7.60 & 7.55 & 7.40 \\
temp & $\mathrm{C}$ & 11.3 & 13.5 & 19.5 & 16.9 & 20.5 & 16.2 & 16.3 \\
alk & $\mathrm{mg} / 1$ & 230 & 266 & 130 & 423 & $\mathrm{~nm}$ & 178 & $\mathrm{~nm}$ \\
$\mathrm{Cl}$ & $\mathrm{mg} / 1$ & $\mathrm{~nm}$ & 90 & 15 & 2.2 & 7.5 & 30 & $\mathrm{~nm}$ \\
\hline
\end{tabular}

$\underline{\text { Notes }}$

nm not measured
nd $\quad$ not detected

Sulfate concentrations ranged from 50 to $220 \mathrm{ppm}$ with the exception of MW1, which had an elevated concentration of $1800 \mathrm{mg} / \mathrm{l}$. It is not clear as to the reason for the dramatic difference. Conductivity values ranged from $593 \mu \mathrm{S} / \mathrm{cm}$ at $\mathrm{MW} 7$ to $53 \mu \mathrm{S} / \mathrm{cm}$ at MW4. The $\mathrm{pH}$ remained relatively similar for all monitoring wells, ranging from 6.57.60 .

Figures 4-8a through to 4-8o present the porewater concentration profiles for ferric iron, sulfate, sulfide, alkalinity, $\mathrm{pH}$, and dissolved oxygen with depth measured from the five 

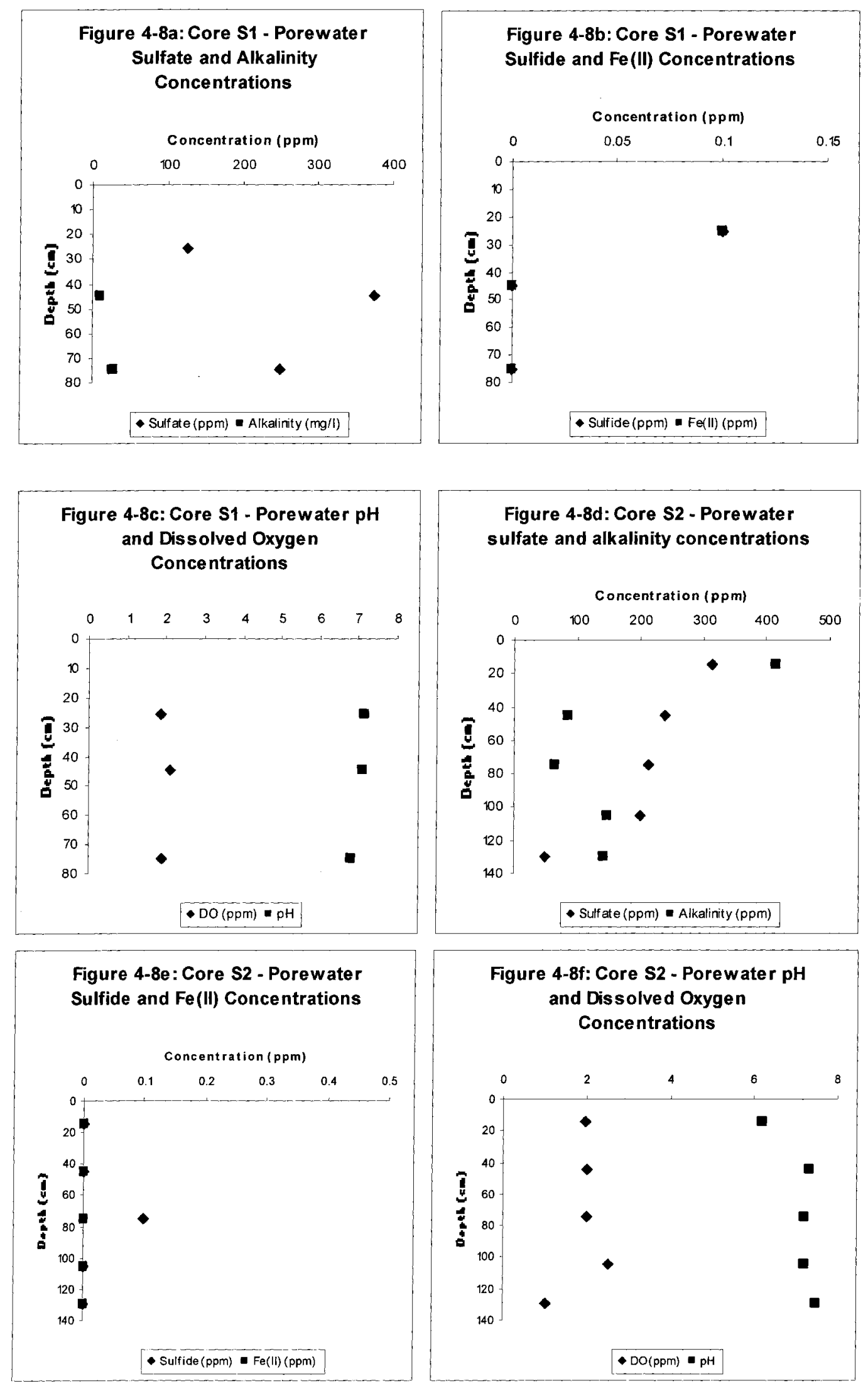

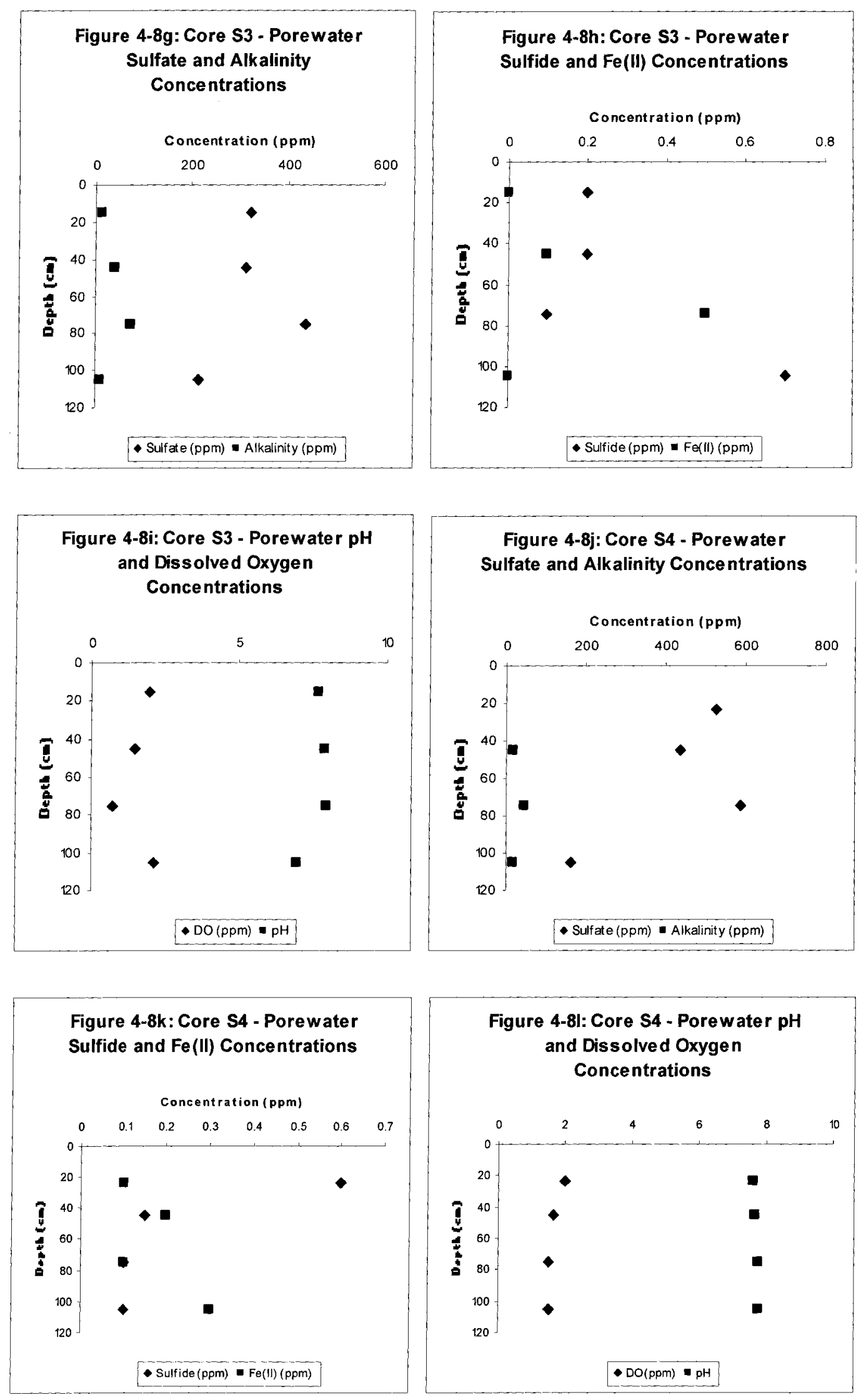

Reproduced with permission of the copyright owner. Further reproduction prohibited without permission. 

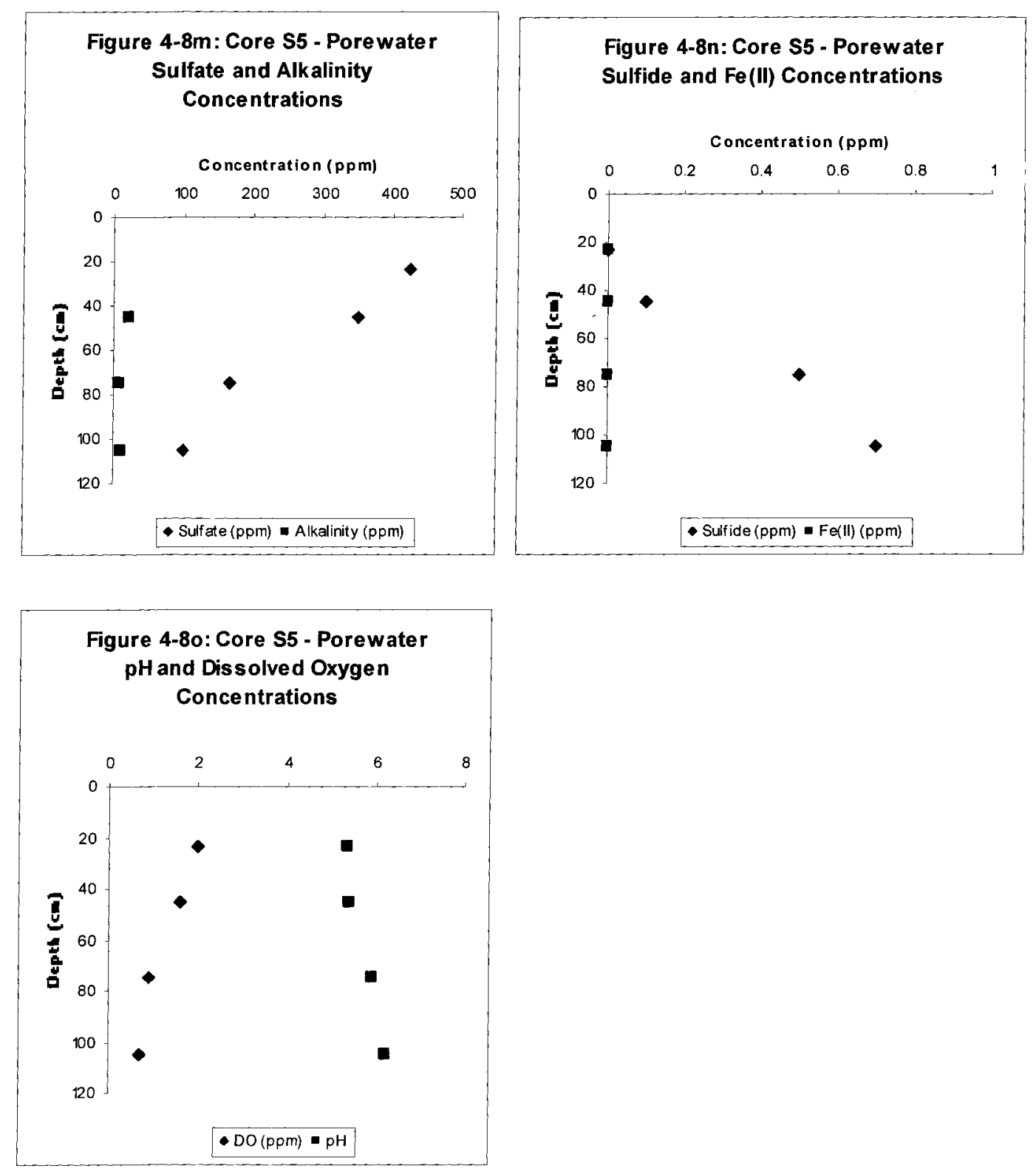
cores collected in September 2004. A reduction in sulfate concentration with depth was observed in all of the cores. Only cores S3, S4, and S5 showed increased or even measurable concentrations of $\mathrm{Fe}(\mathrm{II})$ and $\mathrm{HS}^{-}$with depth, a further indication of the development of reducing conditions with depth.

The alkalinity was highly variable ranging from $10 \mathrm{mg} \mathrm{HCO}_{3} / 1$ to $415 \mathrm{mg} \mathrm{HCO}_{3} / 1$. Alternatively, the $\mathrm{pH}$ values were relatively consistent throughout the entire porewater profile with the $\mathrm{pH}$ averaging 7.0 (std. dev 0.87 ).

Based on the above results, it appears that anoxic conditions have developed in cores $\mathrm{S} 1$, $\mathrm{S} 2, \mathrm{~S} 4$, and S5. At cores S1 and S2, the dissolved Fe concentrations increased with depth and the $\mathrm{Zn}$ and $\mathrm{Pb}$ concentrations decreased with depth. This may be indicative of the formation of metal sulfides. Also, there would most likely be some competition among $\mathrm{Zn}, \mathrm{Pb}$, and $\mathrm{Fe}$ for sulfide. This is further supported by the strong sulfate reduction observed for these cores and the lack of measurable $\mathrm{H}_{2} \mathrm{~S}$ concentrations at these core locations. Cores S4 and S5 showed decreased concentrations of Fe, $\mathrm{Zn}$, and $\mathrm{Pb}$ with depth and measurable $\mathrm{H}_{2} \mathrm{~S}$ with depth as well. There could be more reduced sulfides at this location, which would allow all metals to form metal sulfide precipitates at this location.

At Core S3, decreased concentrations of As, Co and Fe were observed with depth and increasing concentrations of $\mathrm{Zn}$ were observed with increasing depth. This core is located at the confluence of Mill Creek with Farr Creek and as such, localized zones of 
oxidation could be expected. This would suggest that Fe oxides exist and As and Co may adsorb to or coprecipitate with these Fe oxides. $\mathrm{H}_{2} \mathrm{~S}$ concentrations were measured at this location and sulfate reduction was clearly occurring as well. There could also be competition between $\mathrm{As}, \mathrm{Co}$, and $\mathrm{Zn}$ for sulfides and sorption sites onto OM.

\subsection{Surface Water Chemistry}

Table 4-4 presents the surface water chemistry analytical results for selected parameters. Generally the concentrations of most compounds were consistent throughout the entire wetland. The electrical conductivity measured throughout the wetland ranged from 69.4 to $308.6 \mu \mathrm{S} / \mathrm{cm}$, which is typical of most freshwaters. SW9, located in the hummocky area approximately 300 m northwest of SW8 (Figure 3-3), showed elevated concentrations relative to all of the remaining surface water samples. The dissolved oxygen at this location was much lower $(1.2 \mathrm{mg} / \mathrm{l})$ than at the remaining sampling locations. The surface water at this location was only a few $\mathrm{cm}$ deep and was not connected to the rest of Farr Creek and Mill Creek. Therefore, the surface water concentrations are most likely more representative of local geochemical transformations between the surface water, porewater and sediments than the bulk stream flow concentrations, as is the case for the rest of the surface water samples collected. 


\begin{tabular}{|c|c|}
\hline 已富总 & 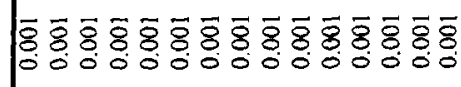 \\
\hline 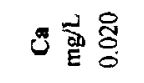 & 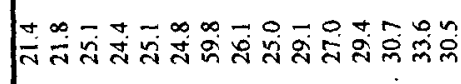 \\
\hline उ察旁 & 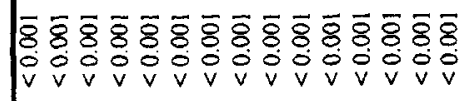 \\
\hline 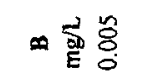 & 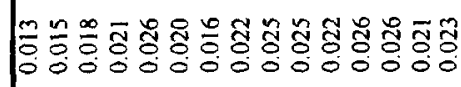 \\
\hline 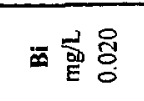 & 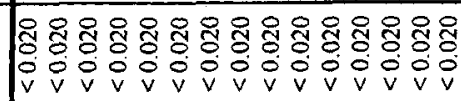 \\
\hline 䓟总 & 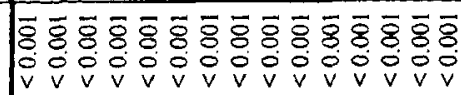 \\
\hline 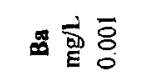 & 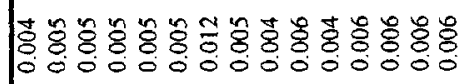 \\
\hline 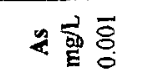 & 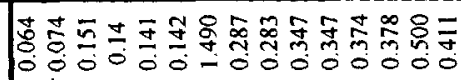 \\
\hline की 宫文 & 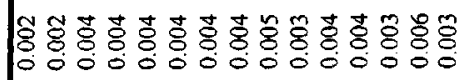 \\
\hline द昆哭 & 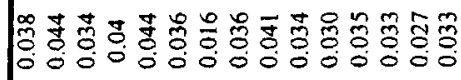 \\
\hline 总要量 & 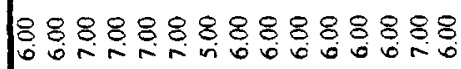 \\
\hline 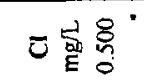 & 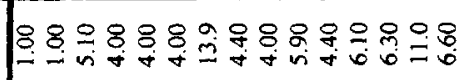 \\
\hline 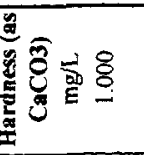 & 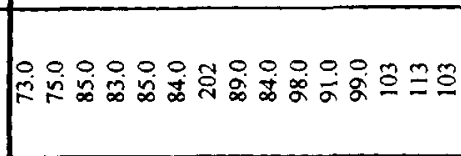 \\
\hline 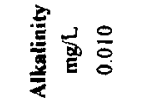 & 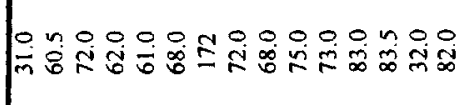 \\
\hline 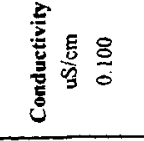 & 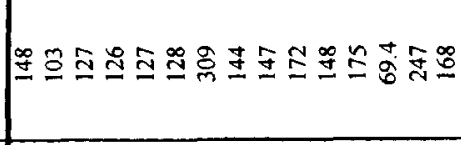 \\
\hline 言。号 & 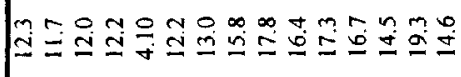 \\
\hline$\&$ 丽号 & 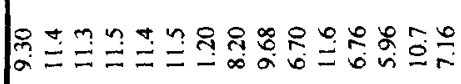 \\
\hline 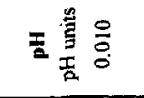 & 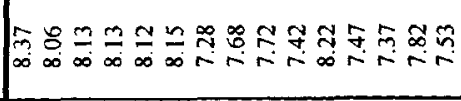 \\
\hline 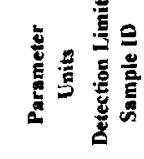 & 䇣旁 \\
\hline
\end{tabular}

\begin{tabular}{|c|c|}
\hline 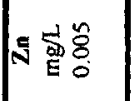 & $\begin{array}{l}0 \\
0 \\
0 \\
0 \\
0 \\
\\
\end{array}$ \\
\hline$p$ के & 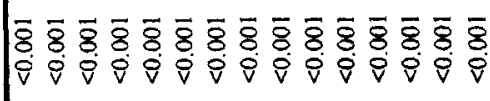 \\
\hline & 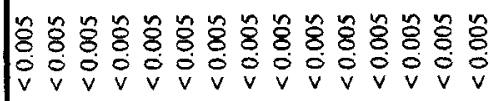 \\
\hline क家 & 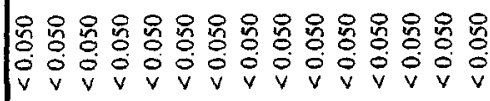 \\
\hline के & 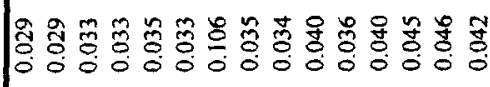 \\
\hline$\frac{\pi}{2} \underset{2}{\frac{D}{a}}$ & 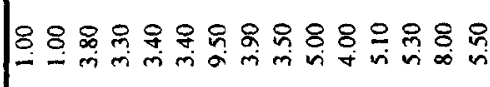 \\
\hline कृ 定 & 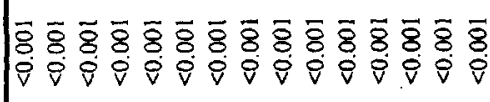 \\
\hline 䄱商要 & 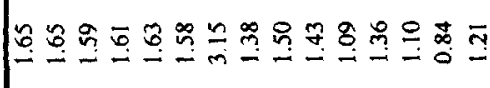 \\
\hline$\simeq \stackrel{\text { 首 }}{8}$ & 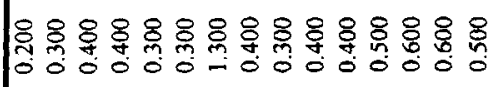 \\
\hline$\stackrel{2}{\overrightarrow{\mathrm{d}}}$ & 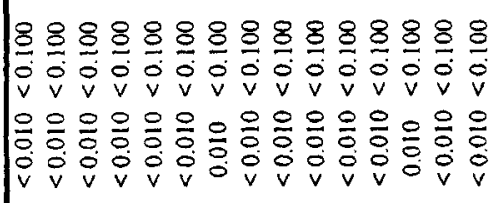 \\
\hline 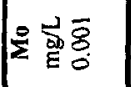 & 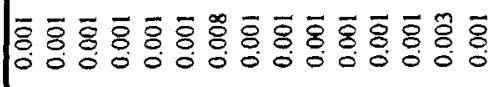 \\
\hline 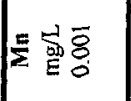 & 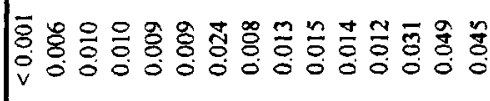 \\
\hline 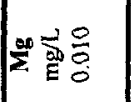 & 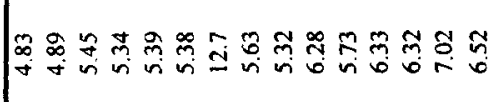 \\
\hline 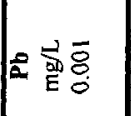 & 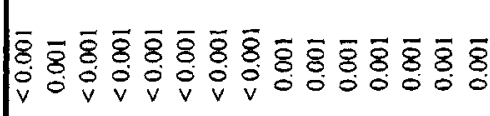 \\
\hline 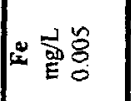 & 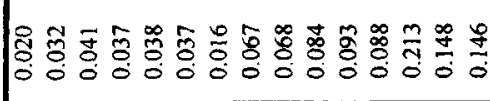 \\
\hline 兽客 & 容 \\
\hline 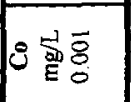 & 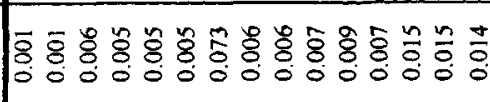 \\
\hline 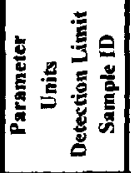 & 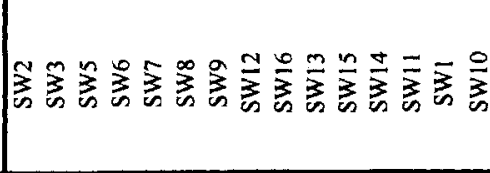 \\
\hline
\end{tabular}




\subsection{Vegetation}

Table 4-5 presents the results of selected metal extractions from the cattail (Typha latfolia) leaf samples collected (refer to Appndix B for the complete chemical analysis results). As can be seen from the table, significant concentrations of selected metals were taken up into the leaf samples. Much higher metal concentrations were extracted from the leaf samples collected near the wetland inlet and MW1. Higher metal concentrations are expected due to higher loadings at the wetland inlet. This observation is supported by other studies (O’Sullivan et al, 2004; Miller et al., 1983). Background conditions were not known for the Typha latfolia in the area, however, the vegetation was flourishing in the area and thus it was not expected that the presence of metals at these concentrations were having a negative effect on Typha latfolia. There was also considerable variability between sample locations. This could most likely be attributed to variations in metal loadings at each location.

\subsection{Microbiology}

Figures 4-9a through to $4-9 \mathrm{e}$ present the results from the bacterial enumerations. As can be seen from these figures, the bacterial populations were relatively constant with depth. Also, there appeared to be equally strong acid producing (oxidizing) bacteria as there were reducing bacteria. 
Table 4-5: Extracted metal concentrations from cattail samples

\begin{tabular}{|c|c|c|c|c|c|c|c|c|c|c|c|c|}
\hline Sample ID & $\begin{array}{c}\text { Element } \\
\text { Units } \\
\end{array}$ & $\begin{array}{c}\mathbf{A l} \\
\mathbf{p p m}\end{array}$ & $\begin{array}{c}\text { As } \\
\text { ppm } \\
\end{array}$ & $\begin{array}{c}\text { Co } \\
\text { ppm }\end{array}$ & $\begin{array}{c}\text { Cr } \\
\text { ppm }\end{array}$ & $\begin{array}{c}\mathrm{Cu} \\
\mathrm{ppm} \\
\end{array}$ & $\begin{array}{c}\mathbf{F e} \\
\mathrm{ppm}\end{array}$ & $\begin{array}{c}\mathrm{Hg} \\
\mathrm{ppm} \\
\end{array}$ & $\begin{array}{l}\text { Mn } \\
\text { ppm } \\
\end{array}$ & $\begin{array}{l}\mathrm{Na} \\
\mathrm{ppm}\end{array}$ & $\begin{array}{c}\mathrm{Si} \\
\mathrm{ppm}\end{array}$ & $\begin{array}{c}\mathbf{Z n} \\
\mathrm{ppm}\end{array}$ \\
\hline INLET(1) & $\mathrm{mg} / 1$ & 4280 & 182 & 171 & 22.5 & 19.7 & 3020 & & 663 & 1890 & 216 & 98.1 \\
\hline Core S1 & $\mathrm{mg} / \mathrm{l}$ & 95.0 & & & & $\begin{array}{l}-13.8 \\
\end{array}$ & 145 & 153 & 336 & 2390 & 217 & 52.2 \\
\hline Core S3 & $\mathrm{mg} / \mathrm{l}$ & 201 & 146 & 9.38 & 11.3 & 11.9 & 335 & & 678 & 1440 & 251 & 58.1 \\
\hline MW1 & $\mathrm{mg} / \mathrm{l}$ & 111 & & & 13.1 & 10.3 & 180 & 20.0 & 229 & 2230 & 311 & 66.6 \\
\hline MW3 & $\mathrm{mg} / \mathrm{l}$ & 138 & 184 & & 10.0 & 7.50 & 212 & 8.13 & 375 & 1740 & 192 & 50.3 \\
\hline MW6 & $\mathrm{mg} / \mathrm{l}$ & 872 & & 23.1 & 15.0 & 14.4 & 1050 & 21.9 & 438 & 848 & 286 & 65.3 \\
\hline MW7 & $\mathrm{mg} / \mathrm{l}$ & 302 & 80.0 & 13.4 & & 15.6 & 380 & 8.75 & 218 & 2980 & 278 & 75.0 \\
\hline
\end{tabular}



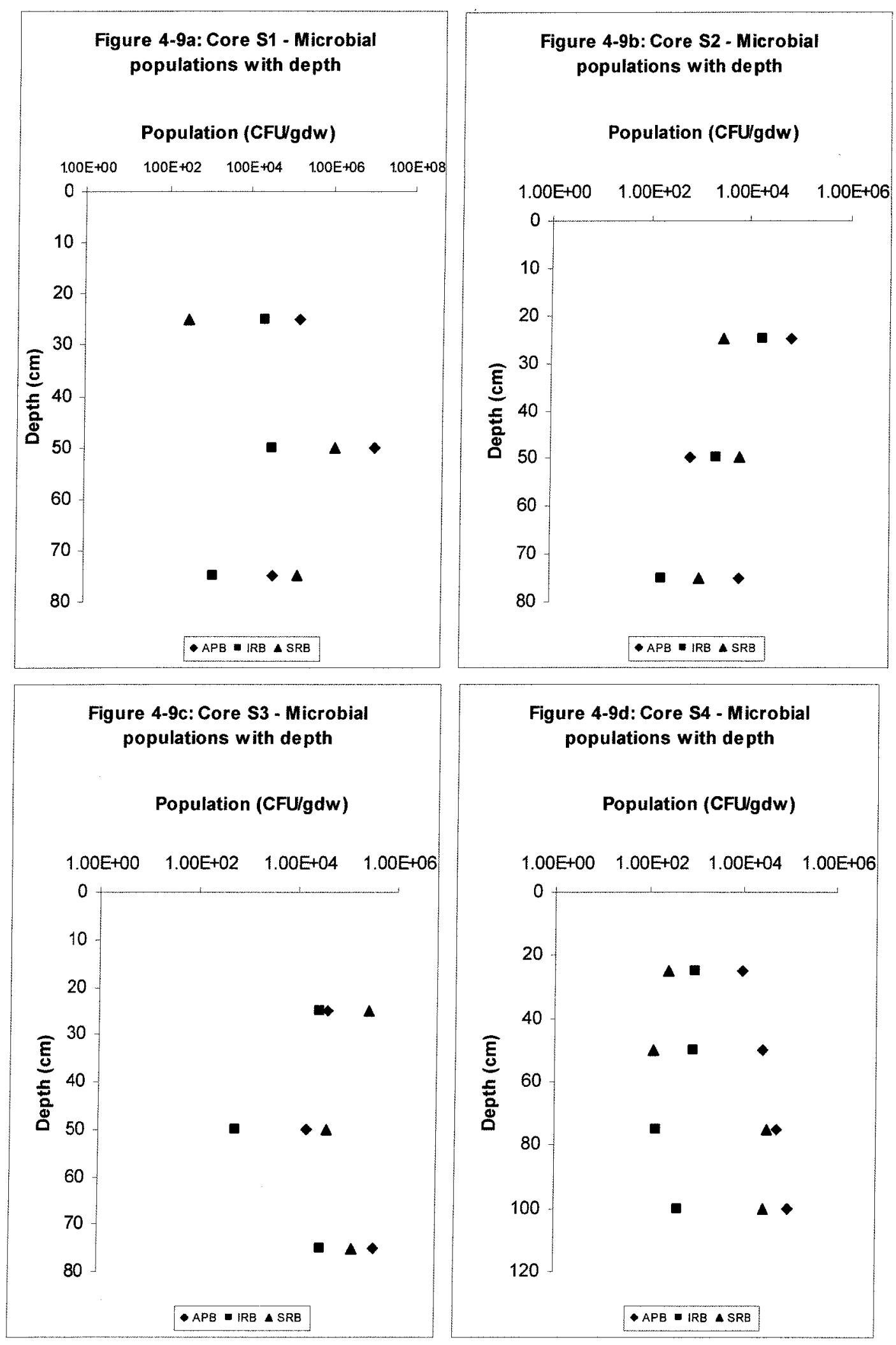


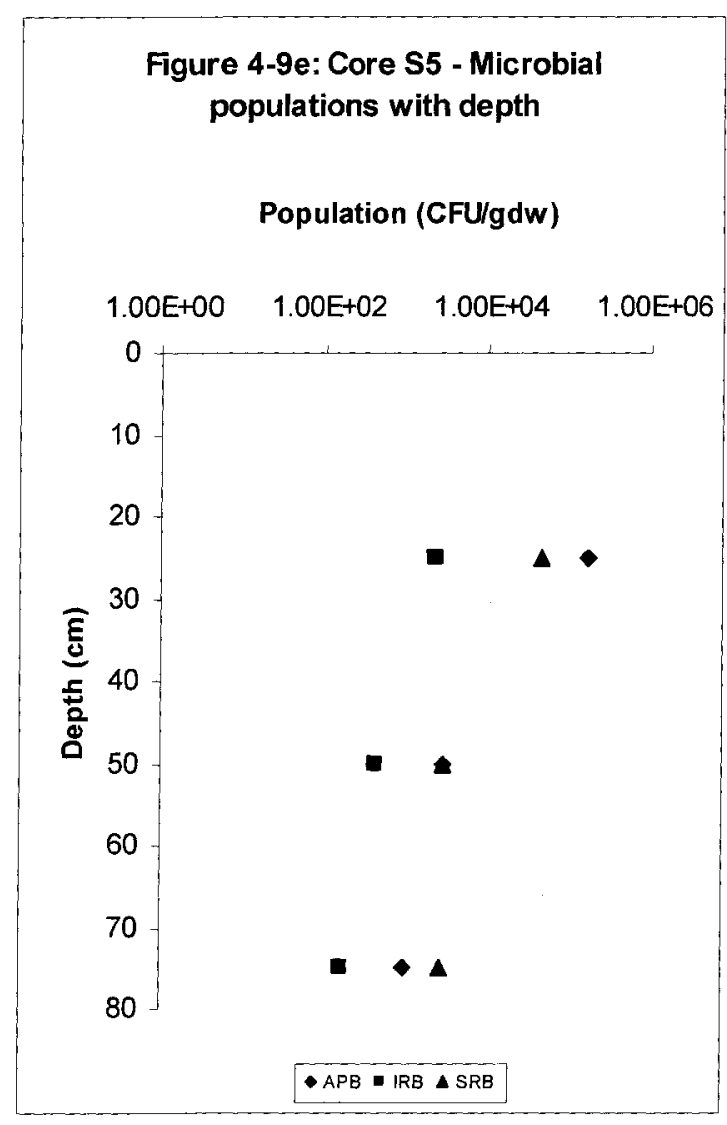


At core $\mathrm{S} 1$ all three types of bacteria were prevalent with population densities ranging from $100 \mathrm{MPN} /($ grams dry weight $(\mathrm{gdw}))$ to greater than $10^{7} \mathrm{MPN} / \mathrm{gdw}$. APBs showed the highest concentrations, however, they also exhibited a decreasing population trend with depth. SRB populations decreased significantly below a depth of $50 \mathrm{~cm}$, whereas the IRB population remained relatively constant throughout the depth of the core.

At core $\mathrm{S} 2$ all three types of microbial populations demonstrated similar populations averaging between $100-1000 \mathrm{MPN} / \mathrm{gdw}$. The IRBs appeared to decrease in population with depth and the SRB populations increased to a depth of approximately $50 \mathrm{~cm}$ and then began to decrease. The APB populations demonstrated a reversed trend to that of the SRBs.

At core S3 all three types of microbial populations had similar population numbers, ranging from 100 to $10,000 \mathrm{MPN} / \mathrm{gdw}$. The SRBs remained relatively constant with depth and the APB populations increased slightly with depth. The IRB populations decreased to a depth of $50 \mathrm{~cm}$ and then began to increase.

At core $\mathrm{S} 4$ all three microbial populations reported similar values ranging from 100 to 10,000 MPN/gdw. SRB populations exhibited a sharp increase below $45 \mathrm{~cm}$. The IRB populations remained fairly constant throughout the entire depth of the core and the APBs showed a slight increase with depth. 
As with the other cores, all three microbial populations exhibited similar population values at core S5. IRB and APB populations decreased slightly with depth. The SRB population decreased to a depth of $50 \mathrm{~cm}$ and then appeared to stabilize.

The presence of all three types of microorganisms throughout the entire wetland and at consistent concentrations with depth at each core location may suggest that both oxic and anoxic conditions exist throughout the wetland.

\subsection{Mass distribution of metals between phases}

Table 4-6 presents the mass distribution of $\mathrm{As}, \mathrm{Co}, \mathrm{Cu}, \mathrm{Sb}, \mathrm{Pb}$, and $\mathrm{Zn}$ through the sediments, porewater, surface water, and vegetation samples at each core location. For most metals, over $80 \%$ of the total mass was tied up in the sediments, either as primary or secondary minerals, precipitated sulfides, adsorbed onto organic, or on oxide fractions in the sediments. This is consistent with a previous study conducted by O'Sullivan et al.(2004). Less than $5 \%$ of the total mass of metals was associated with the porewater, which indicates that this wetland appeared to be successful in immobilizing metals, at least in the short term. Up to $20 \%$ of the metals have been taken up by Typha latfolia. Studies have shown that metal uptake by plant materials can be over $90 \%$ of the total mass distribution (Mays and Edwards, 2001; Zayed et al., 1998; Jackson et al., 1991). There was a large fluctuation (non-detect to 20\%) of metals being taken up by Typha latfolia at different core locations. This could be attributed to differential loading of 
metals in different locations of the wetlands or it could be associated with a mechanism from the plant itself preventing metals from being taken into their leaves.

\subsection{Discussion}

This natural wetland appears to be an overall sink for metals, with the majority of the metals being tied up in the sediments or being taken up into the leaves of Typha latfolia. A detailed mass balance would confirm this; however, insufficient data were collected for such a calculation in this project, but would be worthwhile in future studies. The results from the sequentially extracted metals (SEM) indicated that much of the metals were associated with the residual and OM fractions of the sediment.

Previous studies (Fuller et al., 1993; Lagmuir et al., 1999; Soprovich, 1995) have shown that As has a high affinity for Fe oxides and oxyhydroxides. The results from the SEMs indicated that much of the Fe was associated with the residual fraction of the sediment and not the oxide fraction (refer to Appendix B). As a result, much of the As was associated with the residual and OM fractions of the sediment. These results may indicate that As can be retained significantly under both reducing and oxidizing conditions given sufficient quantities of Fe oxides and OM. Also, Doyle and Otte (1999) reported that in the presence of Fe and Mn oxides and OM, metals will tend to be associated with these fractions. Under more reducing conditions, where sulfate is not limiting, metal sulfides are the predominant removal mechanism (Machemer et al., 1993; Yu et al., 2001). 
Previous studies have concluded that most of the extracted metals from treatment wetlands for mine drainage are associated with the residual fraction of the sediment (O’Sullivan et al., 2004; Sobolewski, 1996). Metals associated with the residual fraction are likely in the form of metal sulfides and are relatively unavailable for uptake by organisms (Allen et al., 1993).

Zinc and copper were predominantly associated with the OM and residual fractions of the sediments. Co and $\mathrm{Pb}$ were also predominantly associated with the residual fraction, however, they were also significantly associated with carbonates. Both $\mathrm{Pb}$ and $\mathrm{Co}$ have known affinities for carbonates (Brookins, 1988) and therefore competition for sorption sites between $\mathrm{OM}$ and carbonates are likely. Nickel and antimony were both almost soley associated with the residual fraction of the sediment indicating that they were likely still in the form of primary or secondary minerals from the tailings.

The porewater sulfate and sulfide concentrations profiles indicated that sulfate reduction was occurring throughout the wetland. The microbiology results identified the presence of APB populations in consistent numbers with the SRB and IRB populations. This may indicate that all these bacteria are active and the acid produced by these populations is immediately neutralized by the dissolution of carbonate minerals within the tailings. Above $\mathrm{pH}$ 6.3, which was the case throughout much of the study area, the dissolution of one mole of calcite consumes one mole of $\mathrm{H}^{+}$as shown in the following equation: 


$$
\mathrm{CaCO} 3+\mathrm{H}^{+} \rightarrow \mathrm{Ca}^{2+}{ }_{(\mathrm{aq})}+\mathrm{HCO}_{(\mathrm{aq})}^{-} \quad \text { [Equation 4-1; Blowes et al., 1998] }
$$

This would also account for the elevated dissolved concentrations of $\mathrm{Ca}^{2+}$ in the pore water. It is also possible that APB populations are supported at depth throughout the wetland in the vicinity of vegetation root zones. Oxygen is transported by wetland plants to the root zones generating localized zones of oxidation. This could allow for sustainable populations of APBs throughout the wetland. In regions located away from the root zones, conditions are likely anoxic which are favourable conditions for IRB and SRB populations.

It is also likely from the microbiology results that there is considerable competition between bacteria species for organic substrates. This was supported by changes in population trends at different locations within the study area where there were only small changes in sulfate and reduced Fe concentrations. Previous studies have shown the competitiveness between SRBs and IRBs, which appears to be dependent on electron donor availability and pore water chemistry (Rioux and Fortin, 2002). It should also be noted that Fe reduction can occur both biotically and abiotically, whereas sulfate reduction can only proceed with the aid of SRBs (Fortin, 2002).

The AVS and CRS data reported herein were inconclusive in determining whether biogenic metal sulfides were being produced within the wetland. Stable sulfur isotope fractionation can be used as indicators for microbial sulfate reduction because biogenic sulfides generally display a unique isotopic composition due to the fact that SRB 
preferentially utilize the lighter sulfur isotope ${ }^{32} \mathrm{~S}$, leaving pore fluids enriched in ${ }^{34} \mathrm{~S}$ (Praharaj and Fortin, 2004). In order to accurately quantify the amount of sulfate being reduced biogenically, stable sulfur isotope fractionation may be employed but was not attempted in this thesis. Quantification of sulfate reduction simply based on measurements of porewater sulfate and sulfide concentrations is inaccurate due to concurrent abiotic geochemical transformations such as the dissolution of gypsum $\left(\mathrm{CaSO}_{4}\right)$, or the precipitation of reduced sulfur in the form of iron sulfides (Anderson and Lovely, 2000). A wide range of factors may influence sulfur isotope fractionation. Such factors include heterogeneity, carbon source variations and limitations, microbial diversity, and geochemical reactions including changing redox conditions (Kleikemper et al., 2004). Generally, at sites where re-oxidation is not important, determining sulfate reduction rates using stable sulfur isotope fractionation may prove to be useful (Spence, 2001).

The results from the extraction of metals from Typha latfolia leaf samples indicated that up to $20 \%$ of the total mass of metals was taken up by the leaves. Previous studies have reported metal uptake in both the leaves and root zones of Typha latfolia and found much higher percentages of metals associated with the roots than the leaves (Deng et al., 2004; Jackson et al., 1993). This suggests that phytoremediation may be an even more powerful source of metal immobilization in this wetland. There has been conflicting research on the ability of wetland plants to immobilize metals in the long term. This is in part due to the fact that plants transport oxygen to their root zones generating a zone of radial oxygen loss. This can result in the generation of localized oxic conditions in the 
immediate vicinity of the roots which can further cause reduced sulfur and iron species to oxidize. Under these conditions metals such as As and Co may adsorb or coprecipitate with the Fe oxides, however, metals such as $\mathrm{Zn}$ would likely remain mobilized in the dissolved state (Jacob and Otte, 2004).

The wetland was covered with Typha latfolia and there did not appear to be any limitation on the growth of this plant species. It is possible, however, that the growth of other wetland plants was inhibited due to elevated metal loading to the wetland system. In addition, background metal concentrations in Typha latfolia and other vegetation species in the area were not known. This would aid in determining the degree of metal uptake by Typha latfolia as a direct result of the mine tailings deposits. 


\subsection{GEOCHEMICAL SPECIATION MODELLING}

The following section gives background information on MINTEQA2, a geochemical speciation modeling program developed by the USEPA (Section 5.1), summarizes the methodology employed for the modeled simulations (Section 5.2), provides the results of the modeled simulations (Section 5.3), and presents and discusses the results of the modeling and how it applies to each core location (Sections 5.4 and 5.5). Raw data produced from the modeling runs are provided in Appendix C.

\subsection{Background on MINTEQA2}

MINTEQA2 was developed by the USEPA to predict equilibrium behavior of various metal species in dilute solutions. Input data required for the model consist of the chemical data of the sample to be analyzed, such as dissolved concentrations of the components of interest, $\mathrm{pH}, \mathrm{pe}$, partial pressures of gases or minerals (Allison et al., 1991). Also included in the model is an extensive thermodynamic database for a wide range of components of interest to environmental systems, however, the user may add new components and their corresponding thermodynamic information to this database. The model solves equilibrium speciation problems by solving simultaneous solution of nonlinear mass action expressions and linear mass balance equations (Allison et al., 1991). The model uses initial estimates for the activity of each component to calculate the concentration of each species according to mass action expressions that are written in terms of its component activities (Allison et al., 1991). The total mass of each 
component is calculated, based on mass action expressions, and is then compared with the known input total mass for each component. Once the calculated total mass for each component is within the error tolerance limit for each component the corresponding solution is accepted. After equilibrating the aqueous phase, the model then computes the saturation indexes (SI) of all the possible solids with respect to the solution. The solid with the most positive SI is allowed to precipitate and the solution is then re-equilibrated after the mass has changed in the aqueous phase. This iteration is repeated until the change in SI indices for all species does not result in a species becoming precipitated or dissolved (Allison et al., 1991).

MINTEQA2 can also incorporate an adsorption routine into the model. MINTEQA2 has seven different adsorption models to choose from: activity Kd model, activity Langmuir model, activity Freudlich model, ion exchange model, constant capacitance model, triple layer model, and diffuse layer model.

An adsorption surface is created by the user with specific adsorption site information. Reactions are then defined by the user between components and the adsorption site(s). The solution is equilibrated with the surface species treated mathematically as aqueous species with constraints specified by the adsorption model. When the equilibrium composition is determined, the equilibrated mass distribution between dissolved, sorbed, and solid phases is computed and reported (Allison et al., 1991). 


\subsection{Model Runs}

27 model runs were performed, 9 of which included adsorption. Table 5-1 lists the locations and depths for each run.

Table 5-1: Location and depth for each modeled run

\begin{tabular}{|c|c|}
\hline Location & Depth (cm) \\
\hline MW1 & 49 \\
MW2 & 87 \\
MW3 & 81 \\
MW4 & 107 \\
MW5 & 34 \\
MW6 & 49 \\
MW7 & 105 \\
S1* & 45 \\
S1* & 75 \\
S2 & 15 \\
S2* & 45 \\
S2 & 130 \\
S3* & 45 \\
S3* & 75 \\
S4* & 23.5 \\
S4* & 45 \\
S5* & 23.5 \\
S5* & 75 \\
\hline
\end{tabular}

Notes:

* Additional modeled run including adsorption (activity $\mathrm{Kd}$ model)

The depths that were selected from the September cores to be included in the geochemical modeling were those that had adequate cation and anion input parameters for the model. The activity $\mathrm{Kd}$ adsorption model was used for the adsorption runs. No specific adsorption experiments were conducted. The results from the sequential 
extractions indicated significant heavy metal enrichments in the organic matter fractions of the sediment. It was also observed that significant metal adsorption occurred onto iron and manganese oxide surfaces and carbonate mineral surfaces. As such, the results from the sequential extractions were used to derive Kd sorption coefficients for use in the activity Kd adsorption model. The output files from all the modeling results are provided in Appendix C. The following assumptions were made for modeling purposes:

1) The pore water analytical chemistry was representative of equilibrium conditions

2) The Kd sorption coefficient was calculated from the sequential extraction data. It was assumed that heavy metals (specifically $\mathrm{As}, \mathrm{Co}, \mathrm{Cu}, \mathrm{Sb}$, and $\mathrm{Zn}$ ) associated with the carbonate, $\mathrm{Fe}$ and $\mathrm{Mn}$ oxide, and organic matter fractions of the sediment were involved in adsorption/coprecipitation reactions and that these concentrations were in equilibrium with the dissolved phase concentrations. The $\mathrm{Kd}$ values were calculated for each of the above mentioned metals at each location modeled, by summing up their solid phase concentration from the carbonates, oxides, and organic matter fractions and dividing this number by the corresponding dissolved phase porewater concentration, as shown in equation 5-1 below:

$$
K d=\frac{\sum\left(M_{s c}+M_{s o}+M_{s o m}\right)}{\sum M_{a q}} \quad \text { [Equation 5-1] }
$$

Where:

$\mathrm{M}_{\mathrm{sc}}=$ Concentration of metals associated with carbonate fraction $(\mathrm{mg} / \mathrm{kg})$ 
$\mathbf{M}_{\mathrm{so}}=$ Concentration of metals associated with $\mathrm{Fe}$ and $\mathrm{Mn}$ oxides fraction $(\mathrm{mg} / \mathrm{kg})$

$\mathrm{M}_{\mathrm{som}}=$ Concentration of metals associated with organic matter fraction $(\mathrm{mg} / \mathrm{kg})$

$\mathrm{M}_{\mathrm{aq}}=$ Concentration of metals in porewater (mg/l)

3) MINTEQA2 requires the user to input $\mathrm{As}$, $\mathrm{Fe}$ and $\mathrm{Sb}$ concentrations in either their more oxidized form or more reduced form. For As, it was assumed that As was predominantly in the form of $\mathrm{H}_{3} \mathrm{AsO}_{4}$ based on the eh-pH condition. $\mathrm{H}_{3} \mathrm{AsO}_{3}$ was also included as a component in the model in the form of a redox reaction with $\mathrm{H}_{3} \mathrm{AsO}_{4}$. It was assumed that most of the dissolved $\mathrm{Fe}$ was in its reduced form of

$\mathrm{Fe}^{2+}$, however, $\mathrm{Fe}^{3+}$ was also included as a component via its redox reaction. Similarly $\mathrm{Sb}$ was assumed to be primarily in the form of $\mathrm{Sb}(\mathrm{OH})_{3}$ based on the Eh-pH condition, however $\mathrm{Sb}(\mathrm{OH})_{6}^{-}$was also included as a component via its redox reaction with $\mathrm{Sb}(\mathrm{OH})_{3}$. These species were chosen based on the Eh and $\mathrm{pH}$ conditions of the porewater (Brookings, 1988).

4) Assumed value for sediment bulk density was $2 \mathrm{~kg} / \mathrm{L}$ based on literature (Brady and Weil, 1996).

\subsection{Results}

\subsubsection{Modeled Runs without Adsorption}

Generally, all 18 modeled runs without adsorption showed very little difference in all dissolved phase concentrations. The one exception with almost every run was the $\mathrm{pH}$. The modeled $\mathrm{pH}$ differed significantly from the initial field measured $\mathrm{pH}$. In 
MINTEQA2, the user can fix the $\mathrm{pH}$ such that it will not change throughout the modeling process. This was attempted; however, the model was unable to reach equilibrium conditions when this was specified. Table 5-2 summarizes the $\mathrm{pH}$ differences between initial field measured $\mathrm{pH}$ and modeled $\mathrm{pH}$ results.

The differences in $\mathrm{pH}$ change between measured and modeled values ranged from 0.09 to 3.99. There appeared to be a slightly better convergence in the core pore water samples than those obtained from the monitoring well data. It should also be noted that the modeled $\mathrm{pH}$ was lower than the initial $\mathrm{pH}$ for all the core samples with the exception of $\mathrm{S} 1$ at $75 \mathrm{~cm}$ depth, $\mathrm{S} 2$ at $15 \mathrm{~cm}$ depth and $\mathrm{S} 5$ at $23.5 \mathrm{~cm}$ depth. Conversely, the modeled $\mathrm{pH}$ was higher than the initial $\mathrm{pH}$ for all monitoring wells.

All of the modeled runs reported the formation of iron and manganese oxides and oxyhydroxides, aluminum oxides, antimony hydroxides, and carbonate minerals. Sulfide precipitates were only reported for core $\mathrm{S} 4$ at a depth of $23.5 \mathrm{~cm}$, core $\mathrm{S} 5$ at a depth of 75cm, MW1, MW3, MW4, MW6, and MW7. This may indicate that at these locations, strongly reducing conditions were maintained. 
Table 5-2: Percent Difference of $\mathrm{pH}$ values for modeled runs without adsorption

\begin{tabular}{|c|c|c|c|c|}
\hline Location & Depth (cm) & Initial pH & Modeled pH & Difference \\
\hline MW1 & 49 & 7.55 & 9.39 & 1.84 \\
MW2 & 87 & 6.6 & 10.13 & 3.53 \\
MW3 & 81 & 6.66 & 9.77 & 3.11 \\
MW4 & 107 & 6.48 & 10.47 & 3.99 \\
MW5 & 34 & 7.6 & 9.8 & 2.2 \\
MW6 & 49 & 7.55 & 10.34 & 2.79 \\
MW7 & 105 & 6.6 & 10.19 & 3.59 \\
S1 & 45 & 7.1 & 5.3 & -1.8 \\
S1 & 75 & 6.8 & 9.48 & 2.68 \\
S2 & 15 & 6.18 & 6.27 & 0.09 \\
S2 & 45 & 7.2 & 5.48 & -1.72 \\
S2 & 130 & 7.48 & 6.91 & -0.57 \\
S3 & 45 & 7.9 & 6.36 & -1.54 \\
S3 & 75 & 7.97 & 7.05 & -0.92 \\
S4 & 23.5 & 7.6 & 5.51 & -2.09 \\
S4 & 45 & 7.64 & 5.97 & -1.67 \\
S5 & 23.5 & 5.42 & 8.96 & 3.54 \\
S5 & 75 & 5.92 & 5.68 & -0.24 \\
\hline
\end{tabular}

5.3.2 Modeled runs with Adsorption

The dissolved phase concentrations for components involved in adsorption (As, $\mathrm{Co}, \mathrm{Cu}$, Zn) showed significant differences from the measured concentrations. In some instances, the dissolved phase concentrations of the modeled species were up to four orders of magnitude smaller than the actual measured concentrations. This was attributed to the very large Kd sorption coefficients calculated. The assumption that the solid phase concentrations are in equilibrium with the aqueous phase and the assumption that there are an infinite number of sorption sites was probably presumptuous. It is likely that 
adsorption sites are limited and best represented by a more detailed model than a linear adsorption isotherm model.

With respect to the precipitates formed, there were only minor changes. Generally there were less precipitates formed under the adsorption conditions. Only $\mathrm{Co}, \mathrm{Zn}$, and $\mathrm{Cu}$ precipitates were affected.

\subsection{Discussion of Modeling Results from Each Core Location}

\section{Core $\mathrm{S} 1$}

The geochemical speciation modeling results from Core $\mathrm{S} 1$ did not show the production of sulfide precipitates, however, the results from MW1, also located within $30 \mathrm{~m}$ of core $\mathrm{S} 1$ indicated the formation of metal sulfide precipitates, including orpiment, $\mathrm{CoS}$, and FeS at a depth of $49 \mathrm{~cm}$. At this location, there was over $30 \mathrm{~cm}$ of standing water which would enhance the establishment of reducing conditions.

\section{$\underline{\text { Core S2 }}$}

The geochemical modeling results for core S2 showed the formation of iron oxide minerals and carbonate precipitates, an indication that oxic conditions may have been present at greater depth. 


\section{Core $\mathrm{S} 3$}

The results from the geochemical modeling from this core location did not indicate the precipitation of metal sulfides. The detected pore water concentrations of sulfides and reduced Fe may suggest that there was insufficient concentrations of metals and sulfides to form precipitates. There may also be competition with metals adsorbing onto the organic matter as the organic matter content of the sediments at this location increased with depth. A significant number of oxide minerals were reported to be supersaturated from the modeling results. The geochemical modeling results for MW6 (49 cm depth) and MW 7 (105 cm depth), both located near core S3 did report the formation of metal sulfide precipitates.

\section{$\underline{\text { Core S4 }}$}

Geochemical speciation modeling analysis completed for this core location indicated the production of metal sulfides near the surface $(23.5 \mathrm{~cm})$; however, no sulfide precipitates were reported at $45 \mathrm{~cm}$ depth. It is suspected that sulfide precipitates were being formed at deeper depths in light of the sulfate and reduced iron pore water chemistry. Several iron oxides and carbonate minerals were also reported to be supersaturated with respect to their dissolved concentration, which could equally have provided metals with additional adsorption sites. 


\section{Core S5}

The geochemical modeling completed for this core reported the formation of metal sulfide precipitates at a depth of $75 \mathrm{~cm}$. The modeling results from MW3, also located near core $\mathrm{S} 5$, reported the formation of metal sulfide precipitates at a depth of $81 \mathrm{~cm}$. The organic matter profile for the core noted over $30 \%$ organic matter content near the surface, followed by a rapid decrease with depth. The presence of such high organic matter contents near the surface most likely enhanced the formation of reducing conditions with depth.

\subsection{Discussion}

The modeling results from some of the cores clearly indicated the formation of metal sulfides (cores S1, S4, and S5). At all core locations Fe, Mn and $\mathrm{Al}$ oxides and/or oxyhyroxide precipitates were reported. This would suggest that both oxic and anoxic conditions existed throughout the wetland. This statement is further supported by the results from the microbiological analysis where both oxidizing and reducing bacteria were present at similar population levels. The porewater chemistry also noted consistent sulfate reduction throughout the wetland and the formation of $\mathrm{H}_{2} \mathrm{~S}$.

Core S2 was collected just upstream of a make-shift washed out gravel dam. This dam separates Crosswise Lake from Farr Creek. It is possible that aerobic lake water seeps through the sediment generating intermittent oxic conditions in the vicinity of core S2. In 
addition, core S3 is located at the confluence of Mill Creek with Farr Creek and it is likely that some localized oxidation arises due to the mixing of these waters. Therefore, in the vicinity of these cores there may have been limited formation of permanent sulfide precipitates due to the existence of localized zones of oxidation. Any sulfides that may have formed likely diffused to areas of low sulfide concentrations and quickly became reoxidized to sulfate. Thus, metal movement and distribution under these conditions were likely regulated by other geochemical processes, such as adsorption to OM, carbonates, and/or oxides surfaces, and uptake by vegetation. 


\subsection{CONCLUSIONS}

The metals of concern for this wetland system were $\mathrm{As}, \mathrm{Co}, \mathrm{Cu}, \mathrm{Zn}, \mathrm{Pb}$, and $\mathrm{Sb}$. This wetland is clearly a sink for these metals, with over $75 \%$ of the metals tied up in the sediments. The results of the current study also indicated that several mechanisms have been responsible for the metal attenuation within this wetland system. Phytoremediation, specifically with cattails (Typha latfolia), appeared to attenuate significant quantities of selected metals. The results from the microbiological analysis indicated that both oxidizing and reducing bacteria were abundant throughout the wetland system and the reported populations of $\mathrm{APB}, \mathrm{SRB}$ and IRB were all within an order of magnitude of each other. This would suggest that both oxic and anoxic geochemical processes were prevalent throughout this system. It is likely that the presence of localized oxic zones in the vicinity of root zones of Typha latfolia, supported the APB populations observed. The modeling data further supported the occurrence of concurrent oxic and anoxic conditions throughout the study area as both $\mathrm{Fe}, \mathrm{Mn}$ and $\mathrm{Al}$ oxides and/or oxyhydroxides and metal sulfide precipitates were reported throughout the wetland system. The porewater chemistry also reported consistent sulfate reduction profiles.

The SEM results indicated that much of the metals retained in the sediments were associated with the residual and OM fractions. Arsenic was most strongly associated with the residual and OM fractions of the sediment. However, it has been well documented in the literature that As adsorbs to or coprecipitates with Fe and Mn oxides quite readily, thus given the presence of adequate Fe and Mn oxides under oxidizing 
conditions and adequate sulfides or OM under reducing conditions, As is likely to be well attenuated in this wetland. Lead and Co were mainly associated with the residual, OM, and carbonates fraction of the sediments. Both $\mathrm{Co}$ and $\mathrm{Pb}$ have known affinities for carbonates and as such there was likely competition between $\mathrm{OM}$ and carbonates for sorption sites.

The data collected suggests that this is a relatively stable system. Should the current state of the system change, such as the input of waste stream elevated in organic substrate, it is likely that a considerable amount of the metals retained within this system would become mobilized in the short term. Over time, the geochemical processes regulating metal mobilizations throughout the system would change resulting in different biogeochemical controls on the metals throughout this system.

Alkaline drainage systems are geochemically different than acidic drainage systems. Alkaline drainage systems can immobilize metals under both oxic conditions, such as adsorption onto OM or oxide precipitates and uptake by wetland vegetation, and under anoxic conditions via microbial transformations such as biogenic sulfate reduction generating reduced sulfides which can then form metal sulfide precipitates. Acidic drainage systems typically require the formation of strongly reducing conditions in order to immobilize metals.

These results have indicated that it is important to consider both the geochemical condition of the wetland or system being used to treat the mine drainage as well as have a 
detailed understanding of the metals of concern within the mining waste, because different metals will have different geochemical interactions based on redox condition, presence of sulfides, $\mathrm{Fe}$ and $\mathrm{Mn}$ oxides, and organic matter. 


\subsection{RECOMMENDATIONS}

The following study characterized the biogeochemistry of the wetland area in question, demonstrating that several biogeochemical processes are occurring within this system. Further research is required, however, to verify and provide more specific information on the interplay between the various attenuation pathways active at this site. Recommendations for future work are outlined below:

1. Conduct stable isotope fractionation studies to quantify sulfate reduction rates.

2. Collect vegetation samples from both the shoots and roots to fully characterize the ability of such vegetation to both uptake metals and/or immobilize them through their root zones.

3. Characterize the difference in metal sediment concentrations within the root zones of wetland plants and in the bulk sediments away from these areas to determine the influence of adsorption onto Fe and Mn oxides and/or oxyhydroxides and organic matter in this region.

4. Conduct a detailed mass balance on the system to verify that this wetland is a net sink for metals. The mass balance should include both summer and winter sampling to assess the effect seasonality may have on the wetland system.

5. Sample several different types of wetland vegetation in the area to determine if certain species of vegetation are more tolerant of metals than others. It is known that Typha latfolia is quite metal tolerant. 
6. Conduct more detailed adsorption studies to better quantify adsorption isotherms for metals of concern to OM, carbonate, and oxide fractions of the sediment. It would also be of interest to determine how significant competition for sorption sites among those three fractions is for metals of interest 


\title{
8.0 REFERENCES
}

Allen, HE, Fu, G, Deng, B., 1993. Analysis of acid volatile sulfide (AVS) and simultaneously extracted metals (SEM) for the estimation of potential toxicity in aquatic sediments. Environmental toxicology and chemistry, 12, 1441-1453.

\begin{abstract}
Allison, J.D., Brown, D.S., Novo-Gradac, K.L., 1990. MINTEQA2/PRODEFA2, a geochemical assessment model for environmental systems: User's Manual. Environmental Research Laboratory. Office of Research and Development, US EPA, Athens, GA.
\end{abstract}

Anderson, R.T., Lovely, D.R., 2000. Anaerobic bioremediation of benzene under sulfate reducing conditions in a petroleum-contaminated aquifer. Environmental Science and Technology, 34 (11) 2261-2266.

Agency for Toxic Substances and Disease Registry (ATSDR), 1992. Toxicological Profile for Antimony. US Department of Health and Human Services, Public Health Service, Atlanta, GA.

August, E.E., McKnight, D.M., Hrncir, D.C., Garhart, K.S., 2002. Seasonal variability of metals transport through a wetland impacted by mine drainage in the rocky mountains. Environmental Science and Technology, 36, 3779-3786.

Berghorn, G.H. and Hunzeker, G.R., 2001. Passive Treatment Alternatives for Remediating Abandoned-Mine Drainage. John Wiley and Sons, USA.

Boyle, R.W., Dass, A.S., 1971. The geochemistry of the supergene processes in the native silver veins of the Cobalt-South Lorrain area, Ontario. In Berry, L.G. (ed.), The silver-arsenide deposits of the Cobalt-Gowganda Region, Ontario. The Canadian Mineralogist, Vol. 11, Pt. 1, pp. 358-390.

Boyle, R.W., Dass, A.S., Church, D., Mihailov, G., Durham, C., Lynch, J., Dyck, W., 1967. Research in Geochemical Prospecting Methods for Silver Deposits, Cobalt Area, Ontario, 1966. Geological Survey of Canada, Paper 67-35, Ottawa.

Blowes, D.W., Jambor, J.L., Hanton-Fong, C.L., 1998. Geochemical, mineralogical and microbiological characterization of a sulfide-bearing carbonate-rich gold mine tailings impoundment, Joutel, Quebec. Applied Geochemistry13 (6), 687-705.

Brookings, Douglas G., 1988. Eh-pH Diagrams for Geochemistry. Springer-Verlag, USA.

Canadian Council of ministers of the Environment (CCME), 2003. Canadian Environmental Quality Guidelines. 
Chague-Goff, C., Rosen, M., 2001. Using sediment chemistry to determine the impact of treated wastewater discharge on a natural wetland in New Zealand. Environmental Geology, 40, 1411-1423.

Cochran, W.G., 1950. Estimation of bacterial densities by means of the most probable number. Biometrics, 6, 105-116.

Cook, R.B., Kelly, C.A., Schindler, D.W., Turner, M.A., 1986. Mechanisms of hydrogen ion neutralization in an experimentally acidified lake. Limnology and Oceanography, 31 , 134-148.

Doyle, M., and Otte, M., 1997. Organism-induced accumulation of iron, zinc and arsenic in wetland soils. Environmental Pollution, 96, 1-11.

Dumaresq, C.G., 1993. The occurrence of arsenic and heavy metal contamination from natural and anthropogenic sources in the Cobalt area of Ontario. M.Sc Thesis, Department of Earth Sciences, Carleton University, Ottawa.

Engler, R.M., and Patrick Jr., W.H., 1975. Stability of sulfides of manganese, iron, zinc, copper, and mercury in flooded and non-flooded soil. Soil Science, 119(3), 217-221.

Fortin, D. 2003. GEO5147 Geochemistry of natural waters Course notes.

Fortin, D., Davis, B., Beveridge, T.J., 1996. Role of Thiobacillus and sulfate-reducing bacteria on iron biocycling in oxic and acidic mine drainage, FEMS Microbiology Ecology, 21, 11-24.

Fuller et al., (1993). Surface Chemistry of Ferrihydrite: Part 2. Kinetics of Arsenate Adsorption and Coprecipitation, Geochimica et Cosmochimica Acta, Vol. 57, pp. 22712282.

Gambrell, R.P., 1994. Trace and toxic metals in wetlands - A review. Journal of Environmental Quality, 23, 883-891.

Gambrell, R.P., Wiesepape, J., Patrick Jr., W., Duff, M., 1991. The effects of pH, redox, and salinity on metal release from a contaminated sediment. Water, Air, and Soil Pollution, 57-58, 359-367.

Hunter, Kimberly S., Wang, Yifeng, Van Cappellen, Philippe, 1998. Kinetic modeling of microbially-driven redox chemistry of subsurface environments: coupling transport, microbial metabolism and geochemistry. Journal of Hydrology, 209, 53-80.

Jackson, L.J., Kalff, J., Rasmussen, J.B., 1993. Sediment $\mathrm{pH}$ and redox potential affect the bioavailability of $\mathrm{Al}, \mathrm{Cu}, \mathrm{Fe}, \mathrm{Mn}$ and $\mathrm{Zn}$ to rooted aquatic macrophytes. Can. J. Fish. Aquat. Sci., 50, 143-148. 
Jacob, D.L., Otte, M.L., 2004. Long-term effects of submergence and wetland vegetation on metals in a 90 year old abandoned $\mathrm{Pb}-\mathrm{Zn}$ mine tailings pond. Environmental Pollution, 130, 337-365.

Jacob, D.L., Otte, M.L., 2004. Influence of Typha latfolia and fertilization on metal mobility in two different $\mathrm{Pb}-\mathrm{Zn}$ mine tailings types. Science of the total environment, $333,9-24$.

Jacob, D.L., Otte, M.L., 2003. Conflicting processes in the wetland plant rhizosphere: metal retention or mobilization? Water, Air, and Soil Pollution Focus, 3, 91-104.

Jambor, J.L., 1971. General geology. In Berry, L.G. (ed.): The silver-arsenide deposits of the cCobalt-Gowganda Region, Ontario. The Candian Mineralogist, Vol. 11, Pt. 1, pp. $12-33$.

Kirby, C.S., Thomas, H.M., Southam, G., Donald, R., 1999. Relative contribution of abiotic and biotic biological factors in Fe(II) oxidation in mine drainage. Applied Geochemistry, 14, 511-530.

Kleikemper, J., Schroth, M.H., Bernasconi, S.M., Brunner, B., Zeyer, J., 2004. Sulfur isotope fractionation during growth of sulfate-reducing bacteria on various carbon sources. Gechimica et Cosmochimica Acta, 68 (23), 4891-4904.

Krupka, K.M., Serne, R.J., 2002. Geochemical Factors Affecting the Behavior of Antimony, Cobalt, Europium, Technetium, and Uranium in Vadose Sediments. Pacific Northwest National Laboratory, TN.

Lagmuir,D., Mahoney, J., MacDonald, A., and Rowson, J., (1999). Predicting Arsenic Concentrations in the Porewaters of Buried Uranium Mill Tailings, Geochimica et Cosmochimica Acta, Vol. 63, No. 19/20, pp. 3379-3394.

Machemer, S., Reynolds, J., Laudon, L., Wildeman, T., 1993. Balance of S in a constructed wetland built to treat acid mine drainage, Idaho Springs, Colorado, USA. Applied geochemistry, 8, 587-603.

Machemer, S. and Wildeman, T., 1992. Adsorption compared with sulfide precipitation as metal removal processes from acid mine drainage in a constructed wetland. Journal of Contaminant Hydrology, 9, 115-131.

Miller, W., McFee, W., Kelly, J., 1983. Mobility and retention of heavy metals in sandy soils. Journal of Environmental Quality, 12(4), 579-584.

Morel, F.M.M., Hering, J.G., 1993. Principles and applications of aquatic chemistry. John Wiley and Sons Inc., NY. 
Oehm, N.J., Luben, T.J., Ostrofsky, M.L., 1997. Spatial distribution of acid volatile sulfur in the sediments of Canadohta Lake, PA. Hydrobiologia, 345, 7-85.

O'Sullivan, A.D., Moran, B.M., Otte, M.L., 2004. Accumulation and fate of contaminants $(\mathrm{Zn}, \mathrm{Pb}, \mathrm{Fe}$ and $\mathrm{S})$ in substrates of wetlands constructed for treating mine wastewater. Water, Air, and Soil Pollution, 157, 345-364.

Praharaj, T., Fortin, D., 2004. Determination of acid volatile sulfides and chromium reducible sulfides in $\mathrm{Cu}-\mathrm{Zn}$ and $\mathrm{Au}$ mine tailings. Water, air, and soil pollution, 155, 3550 .

Praharaj, T., Fortin, D., 2004. Indicators of microbial sulfate reduction in acidic sulfiderich mine tailings. Geomicrobiology, 21, 457-467.

Petruk, W., 1971b. Geochemistry of the ores. In Berry, L.G. (ed.): The silver-arsenide deposits of the Cobalt-Gowganda Region, Ontario. The Canadian Mineralogist, Vol. 11, Pt. 1, pp.140-149.

Reimann, Clement., de Caritat, Patricia., 1998. Chemical Elements in the Environment. Springer, Germany.

Rioux, J.P., and Fortin, D., 2002. Microbial activity of iron-reducing bacteria and sulfate reducing bacteria isolated from mine tailings in the presence of various electron donors. Department of Earth Sciences, University of Ottawa, Ottawa.

Rudd, John W.M., Kelly, C.A., St. Louis, Vincent, Hesslein, R.H., Furutani, A., Holoka, M.H., 1986. Microbial consumption of nitric and sulfuric acids in an acidified north temperate lake. Limnology and Oceanography, 31, 1280-1986.

Schnoor, J., 1996. 'Modeling trace metals', in J. Schnoor and A. Zehnder (eds) Environmental Modeling: Fate and Transport of Pollutants in Water, Air. Soil, Wiley, New York, 381-451.

Sobolewski, A., 1996. Metal species indicate the potential of constructed wetlands for long-term treatment of metal mine drainage. Ecological Engineering, 6, 259-271.

Soprovich, E., (1995). Arsenic Release From Oxide Tailings Containing Scordite, Fe-Ca Arsenates, and As-Containing Goethites, Environmental Protection Branch - Yukon Division, Environment Canada, Whitehorse, Yukon.

Spence, M.J., Bottrell, S.H., Thornton, S.F., Lerner, D.N., 2001. Isotopic modeling of the significance of bacterial sulfate reduction for phenol attenuation in a contaminated aquifer. Journal of Contaminant Hydrology, 53 (3-4), 285-304.

Tessier, A., Fortin, D., Belzile, N., DeVitre, R, Leppard, G.G., 1996. Metal sorption to diagenic iron and manganese Oxyhydroxides and associated organic matter: narrowing 
the gap between field and laboratory measurements. Geochimica et Cosmochimica Acta, $60,387-404$.

Tipping, E., Thompson, D.W., Davidson, W., 1984. Oxidation products of Mn(II) in lake waters. Chemical Geology, 44, 359-383.

Trolldenier, G., 1988. Visualization of oxidizing power of rice roots and of possible participation of bacterial in iron deposition. Z. Pflanzenernaehr. Bodenkd, 151, 117-121.

Weiss, J.V., Backer, S., Megonigal, J.P., Emerson, D., 2001. 'Enumeration of Feoxidizing and Fe-reducing bacteria in the wetland plant rhizosphere: implications for a rhizosphere Fe cycle' in Proceedings of the Seventh International Symposium on Biogeochemistry of Wetlands, Duke University Wetland Center, Nicholas School of the Environment and Earth Sciences, Duke University, Durham, North Carolina, USA, 1720.

Yee, N., Fein, J.B., 2001. Cd adsorption onto bacterial surfaces: A universal adsorption edge. Geochimica et Cosmochimica Acta, 65, 2037-2042.

Yee, N., Fein, J.B., Daugney, C.J., 2000. Experimental study of the pH, ionic strength. and reversibility behavior of bacteria-mineral adsorption. Geochimica et Cosmochimica Acta, 64, 609-617.

Yu, K-C., Tsai, L.-J., Chen, S.-H., Ho, S-T., 2001. Chemical binding of heavy metals in anoxic river sediments. Water Research, 35(17), 4086-4094. 
APPENDIX A

BOREHOLE LOGS

147

Reproduced with permission of the copyright owner. Further reproduction prohibited without permission. 


\section{Borehole Logs}

Core J1

Location $\quad 47.405833 \mathrm{~N} ; \mathbf{7 9 . 6 5 3 9 3 3 ~ W}$

Depth (cm) Description

$0-60 \quad$ grey to brown sandy tailings

60-100 varved grey to brown silty clay

100-110 dark organic layer with woodchips

110-120 brown clay

End of hole

Core J2

Location $\quad 47.406200 \mathrm{~N} ; 79.653717 \mathrm{~W}$

Depth (cm) Description

$0-137$ very wet, grey to brown silty and sandy tailings

137-139 dark organic layer

139-208 Light brown clay with intermittent woodchips and roos

End of hole

\section{Core J3}

Location $\quad 47.407617 \mathrm{~N} ; 79.652717 \mathrm{~W}$

Depth (cm) Description

0-70 Grey silty, sandy tailings

70-71 coarse sand

End of hole

Core J4

Location $\quad 47.403317 \mathrm{~N} ; 79.655383 \mathrm{~W}$

Depth (cm) Description

\begin{tabular}{ll}
\hline $0-70$ & Brown silty, sandy tailings \\
$70-71$ & coarse sand \\
$71-97$ & varved grey clay \\
$97-100$ & dark organic layer \\
\hline
\end{tabular}

End of hole




\section{Core J5}

Location $\quad 47.402767 \mathrm{~N} ; 79.656267 \mathrm{~W}$

Depth (cm) Description

\begin{tabular}{ll}
\hline $0-105$ & grey to brown silty, sandy tailings \\
$105-112$ & dark organic layer \\
$112-142$ & varved grey clay \\
\hline
\end{tabular}

End of hole

Core J7

Location $\quad 47.406967 \mathrm{~N} ; 79.655300 \mathrm{~W}$

Depth (cm) Description

$0-65 \quad$ grey to brown silty, sandy tailings

End of hole

Core $\mathbf{J 8}$

Location $\quad 47.408367 \mathrm{~N} ; 79.654150 \mathrm{~W}$

Depth (cm) Description

\begin{tabular}{ll}
$0-100$ & grey to brown silty, sandy tailings, very wet \\
\hline End of hole
\end{tabular}

Core J9

Location $\quad 47.415933 \mathrm{~N} ; 79.646700 \mathrm{~W}$

Depth (cm) Description

0-20 water cover

20-67 grey to brown silty, sandy tailings, very wet

67-84 dark organic layer

$84-94 \quad$ grey clay

End of hole

Core J10

Location $\quad 47.414150 \mathrm{~N} ; 79.646883 \mathrm{~W}$

Depth (cm) Description

\begin{tabular}{ll}
\hline $0-22$ & water cover \\
$22-42$ & dark organic layer \\
$42-60$ & grey to brown silty, sandy tailings, very wet \\
$60-128$ & dark organic layer with woodchips \\
\hline
\end{tabular}


APPENDIX B

\section{SUMMARY OF FIELD AND LABORATORY CHEMICAL ANALYSIS \\ RESULTS}


Table B1: Sediment Water Contents and Organic Matter Contents from June and September Cores

\begin{tabular}{|c|c|c|c|}
\hline Location & Depth (cm) & Water Content (\%) & OC (\%) \\
\hline \multirow[t]{10}{*}{ Core J1 } & 15 & 54.7 & 15.0 \\
\hline & 7.5 & 40.8 & 4.8 \\
\hline & 22.5 & 32.9 & 2.3 \\
\hline & 37.5 & 31.2 & 2.9 \\
\hline & 52.5 & 26.4 & 2.1 \\
\hline & 67.5 & 27.7 & 2.3 \\
\hline & 82.5 & 24.9 & 2.1 \\
\hline & 100 & 27.0 & 3.6 \\
\hline & 115 & 50.8 & 15.5 \\
\hline & 125 & 40.4 & 6.9 \\
\hline \multirow[t]{15}{*}{ Core $\mathrm{J} 2$} & 7.5 & 33.1 & 3.4 \\
\hline & 22.5 & 34.5 & 3.5 \\
\hline & 37.5 & 26.5 & 1.7 \\
\hline & 52.5 & 25.3 & 1.7 \\
\hline & 67.5 & 27.0 & 1.8 \\
\hline & 82.5 & 24.4 & 1.7 \\
\hline & 97.5 & 25.1 & 1.7 \\
\hline & 112.5 & 28.4 & 1.9 \\
\hline & 127.5 & 31.7 & 2.3 \\
\hline & 138 & 65.3 & 24.5 \\
\hline & 147.5 & 28.3 & 2.3 \\
\hline & 162.5 & 39.2 & 7.7 \\
\hline & 177.5 & 42.5 & 13.8 \\
\hline & 192.5 & 60.8 & 22.3 \\
\hline & 204 & 47.0 & 11.5 \\
\hline \multirow[t]{5}{*}{ Core $\mathrm{J} 3$} & 7.5 & 35.7 & 3.6 \\
\hline & 22.5 & 33.6 & 3.0 \\
\hline & 37.5 & 25.3 & 1.5 \\
\hline & 52.5 & 22.7 & 1.6 \\
\hline & 67.5 & 20.5 & 1.6 \\
\hline \multirow[t]{11}{*}{ Core J4 } & 7.5 & 26.7 & 1.9 \\
\hline & 57.5 & 25.8 & 1.7 \\
\hline & 22.5 & 25.1 & 1.8 \\
\hline & 72.5 & 20.7 & 1.2 \\
\hline & 37.5 & 26.6 & 1.8 \\
\hline & 77.5 & 29.8 & 1.9 \\
\hline & 57.5 & 26.4 & 1.5 \\
\hline & 90 & 31.1 & 1.8 \\
\hline & 97.5 & 71.0 & 31.1 \\
\hline & 90 & 35.6 & 1.7 \\
\hline & 106 & 63.6 & 27.4 \\
\hline
\end{tabular}




\begin{tabular}{|c|c|c|c|}
\hline Location & Depth (cm) & Water Content (\%) & OC $(\%)$ \\
\hline \multirow[t]{10}{*}{ Core J5 } & 7.5 & 22.9 & 1.6 \\
\hline & 22.5 & 24.3 & 1.5 \\
\hline & 37.5 & 22.0 & 1.5 \\
\hline & 62.5 & 27.1 & 2.3 \\
\hline & 77.5 & 23.3 & 1.5 \\
\hline & 92.5 & 22.2 & 1.1 \\
\hline & 102.5 & 25.7 & 2.2 \\
\hline & 117.5 & 41.5 & 9.3 \\
\hline & 132.5 & 35.4 & 3.9 \\
\hline & 147.5 & 37.1 & 3.5 \\
\hline \multirow[t]{4}{*}{ Core $\mathrm{J} 7$} & 7.5 & 24.2 & 1.0 \\
\hline & 22.5 & 21.8 & 1.1 \\
\hline & 37.5 & 20.2 & 1.0 \\
\hline & 57.5 & 21.1 & 1.0 \\
\hline \multirow[t]{6}{*}{ Core $\mathrm{J} 8$} & 40 & 22.1 & 1.0 \\
\hline & 57.5 & 23.2 & 1.6 \\
\hline & 72.5 & 17.9 & 1.0 \\
\hline & 87.5 & 19.5 & 1.2 \\
\hline & 102.5 & 18.4 & 1.0 \\
\hline & 117.5 & 17.7 & 0.8 \\
\hline \multirow[t]{5}{*}{ Core $\mathrm{J} 9$} & 27.5 & 44.5 & 6.7 \\
\hline & 42.5 & 32.0 & 4.5 \\
\hline & 57.5 & 41.7 & 12.2 \\
\hline & 75.5 & 52.9 & 15.1 \\
\hline & 89 & 31.3 & 3.1 \\
\hline \multirow[t]{6}{*}{ Core J10 } & 36 & 41.0 & 4.4 \\
\hline & 55 & 59.7 & 13.2 \\
\hline & 67.5 & 86.3 & 75.2 \\
\hline & 82.5 & 82.2 & 66.9 \\
\hline & 97.5 & 88.5 & 32.8 \\
\hline & 112.5 & 58.3 & 22.8 \\
\hline \multirow[t]{3}{*}{ Core S1 } & 25 & 29.5 & 2.5 \\
\hline & 50 & 39.3 & 2.8 \\
\hline & 75 & 21.9 & 0.8 \\
\hline \multirow[t]{3}{*}{ Core $\mathrm{S} 2$} & 25 & 22.1 & 0.8 \\
\hline & 50 & 21.0 & 3.3 \\
\hline & 71.5 & 22.8 & 3.2 \\
\hline \multirow[t]{3}{*}{ Core S3 } & 25 & 15.9 & 3.7 \\
\hline & 50 & 24.3 & 6.6 \\
\hline & 75 & 65.2 & 13.0 \\
\hline \multirow[t]{5}{*}{ Core $\mathrm{S} 4$} & 25 & 14.6 & 0.8 \\
\hline & 50 & 10.0 & 0.8 \\
\hline & 75 & 11.5 & 0.2 \\
\hline & 87.5 & 7.6 & 0.6 \\
\hline & 125 & 17.1 & 0.8 \\
\hline \multirow[t]{3}{*}{ Core S5 } & 25 & 23.9 & 0.8 \\
\hline & 50 & 22.5 & 1.0 \\
\hline & 75 & 19.8 & 1.1 \\
\hline
\end{tabular}




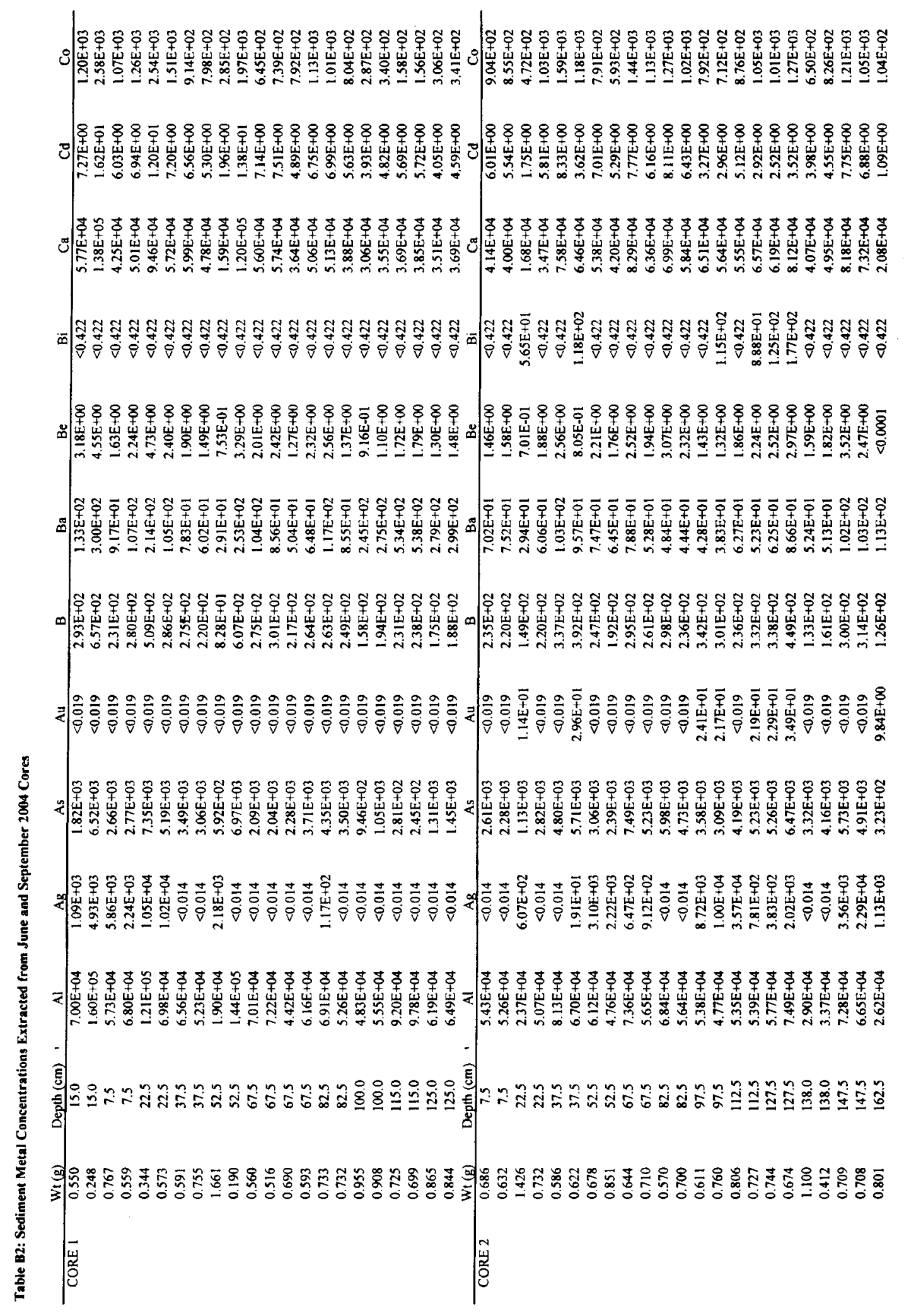




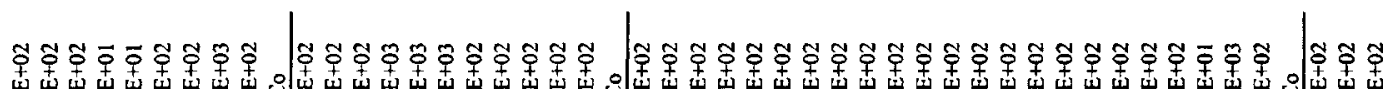

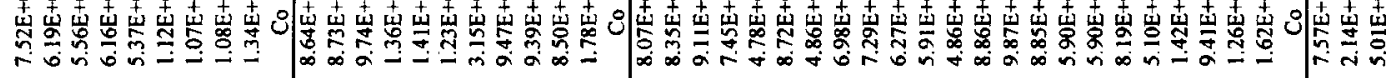

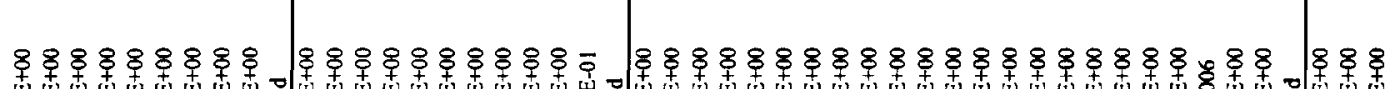

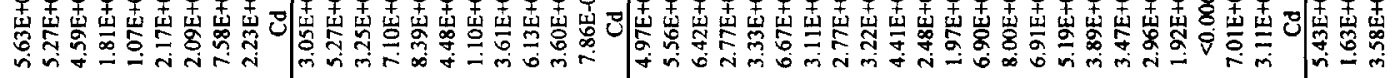

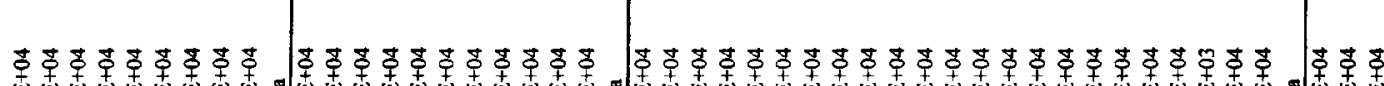

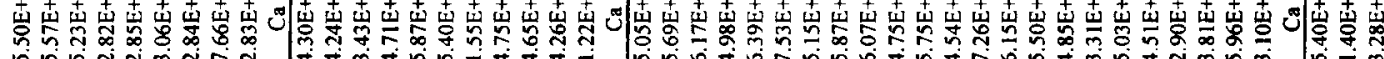

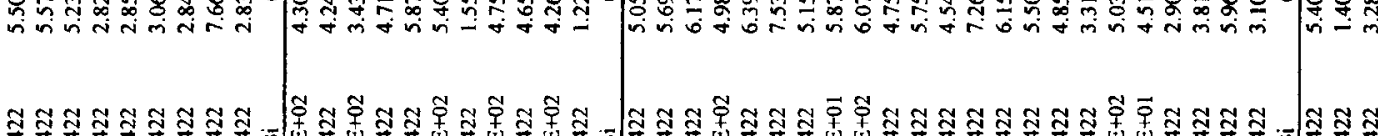

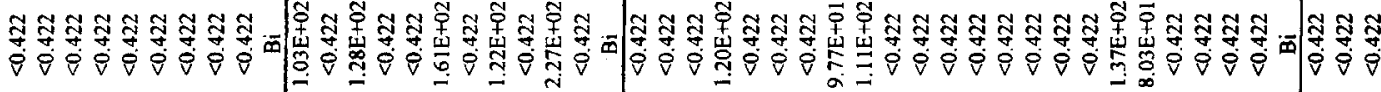

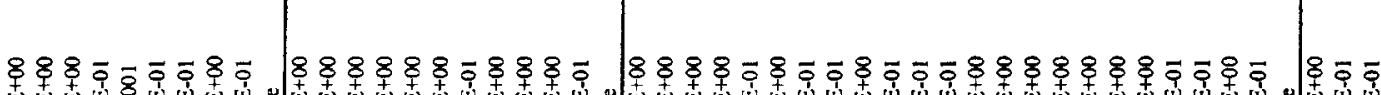

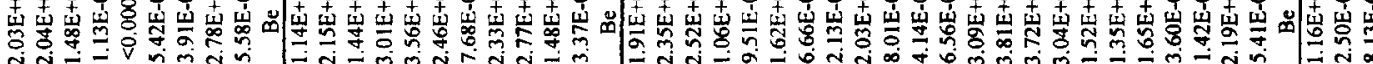

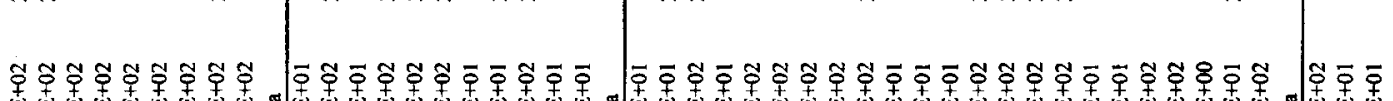

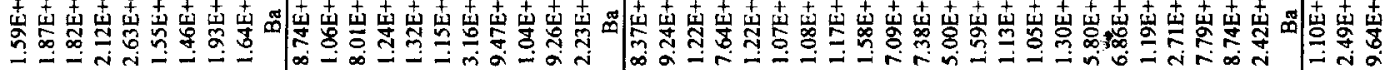

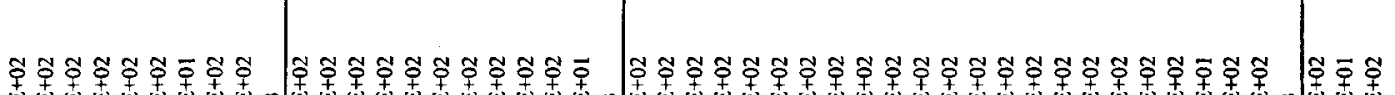

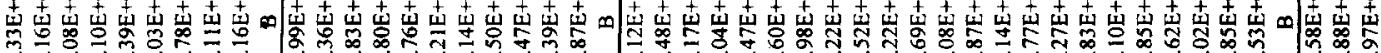

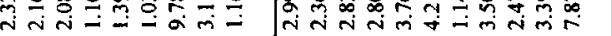

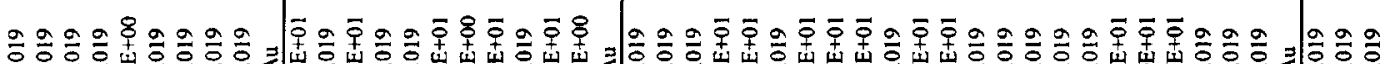

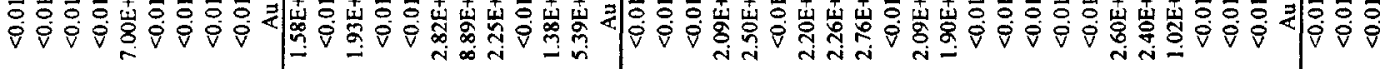

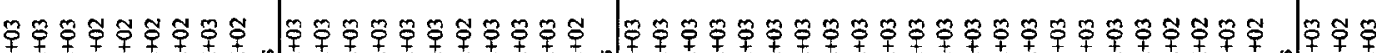

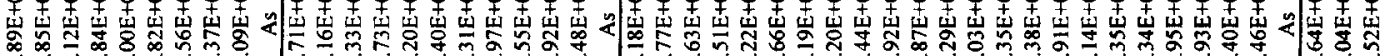

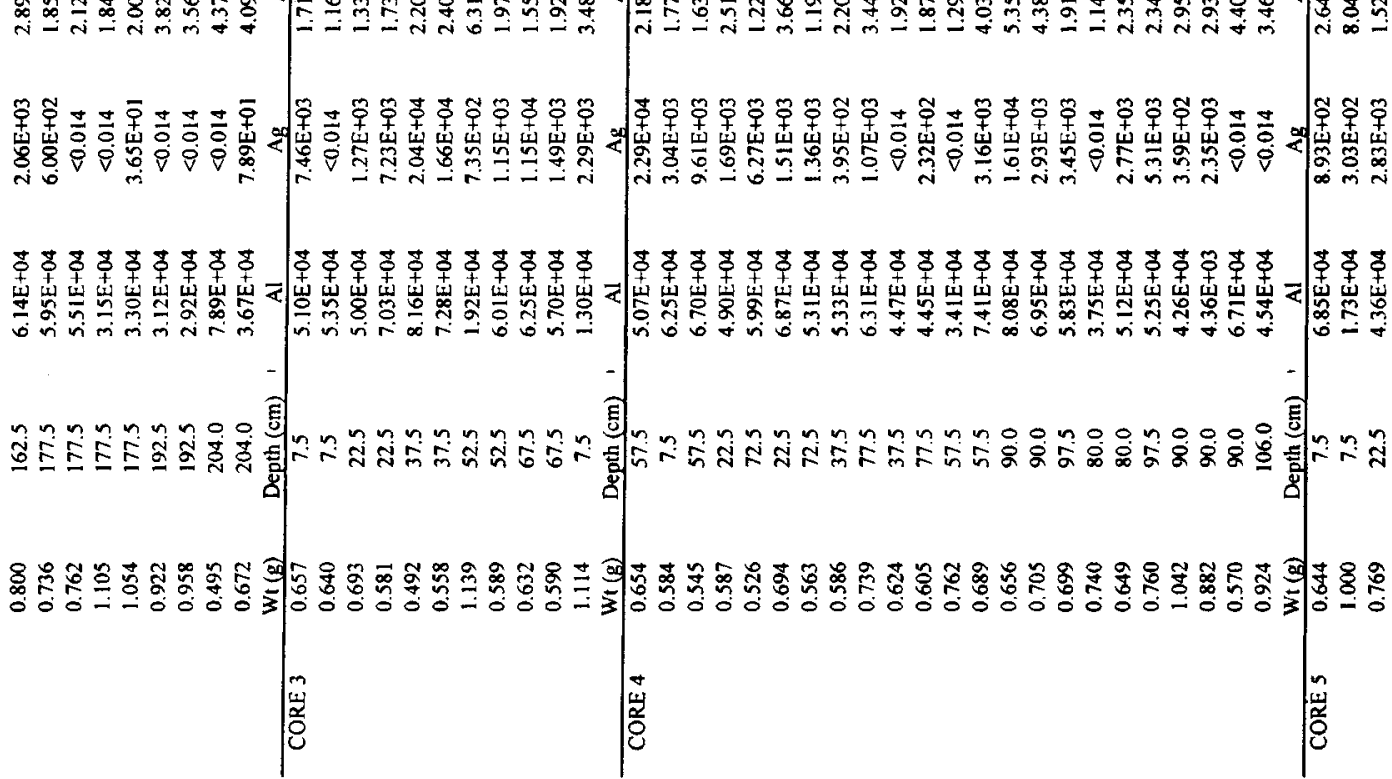




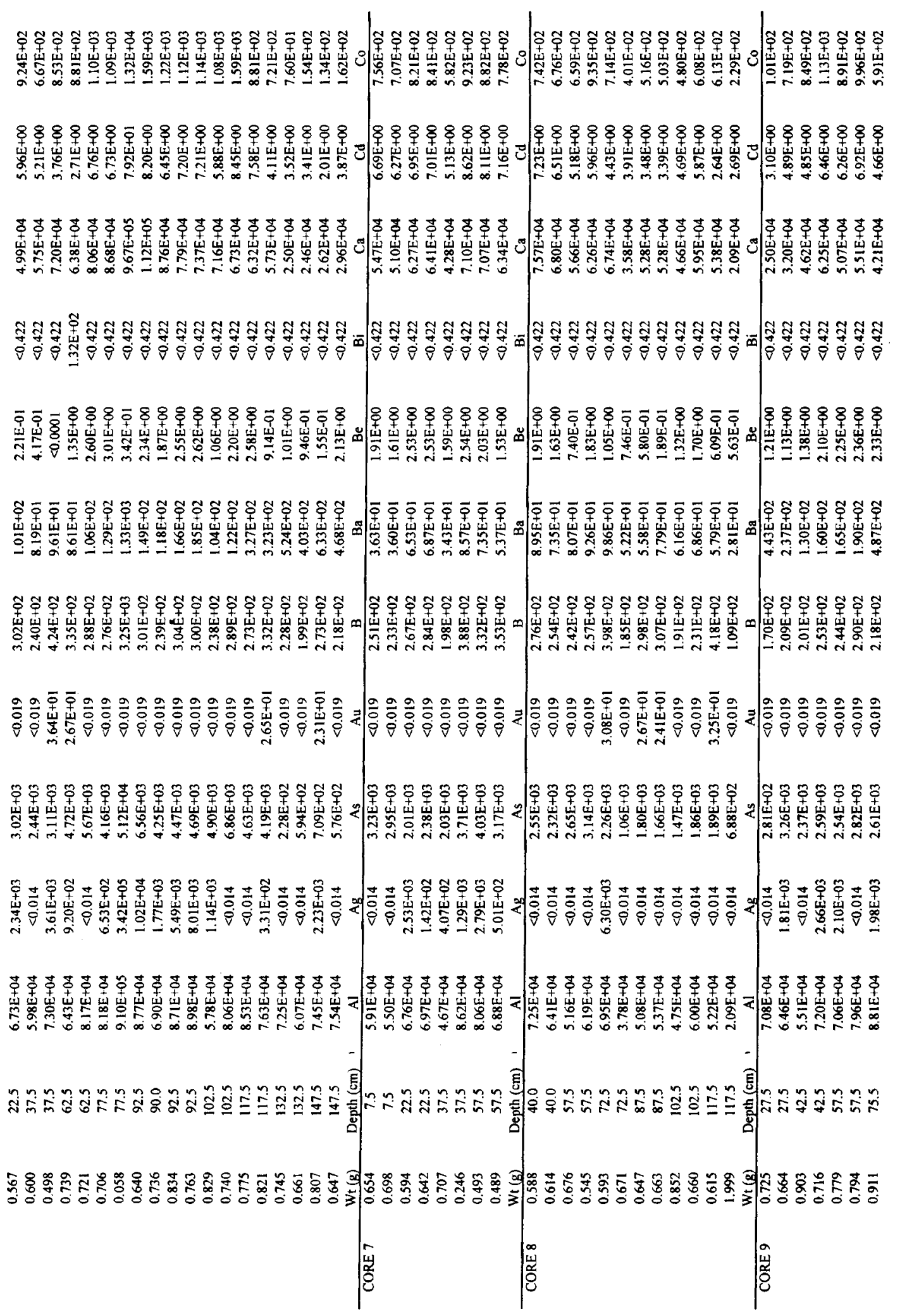




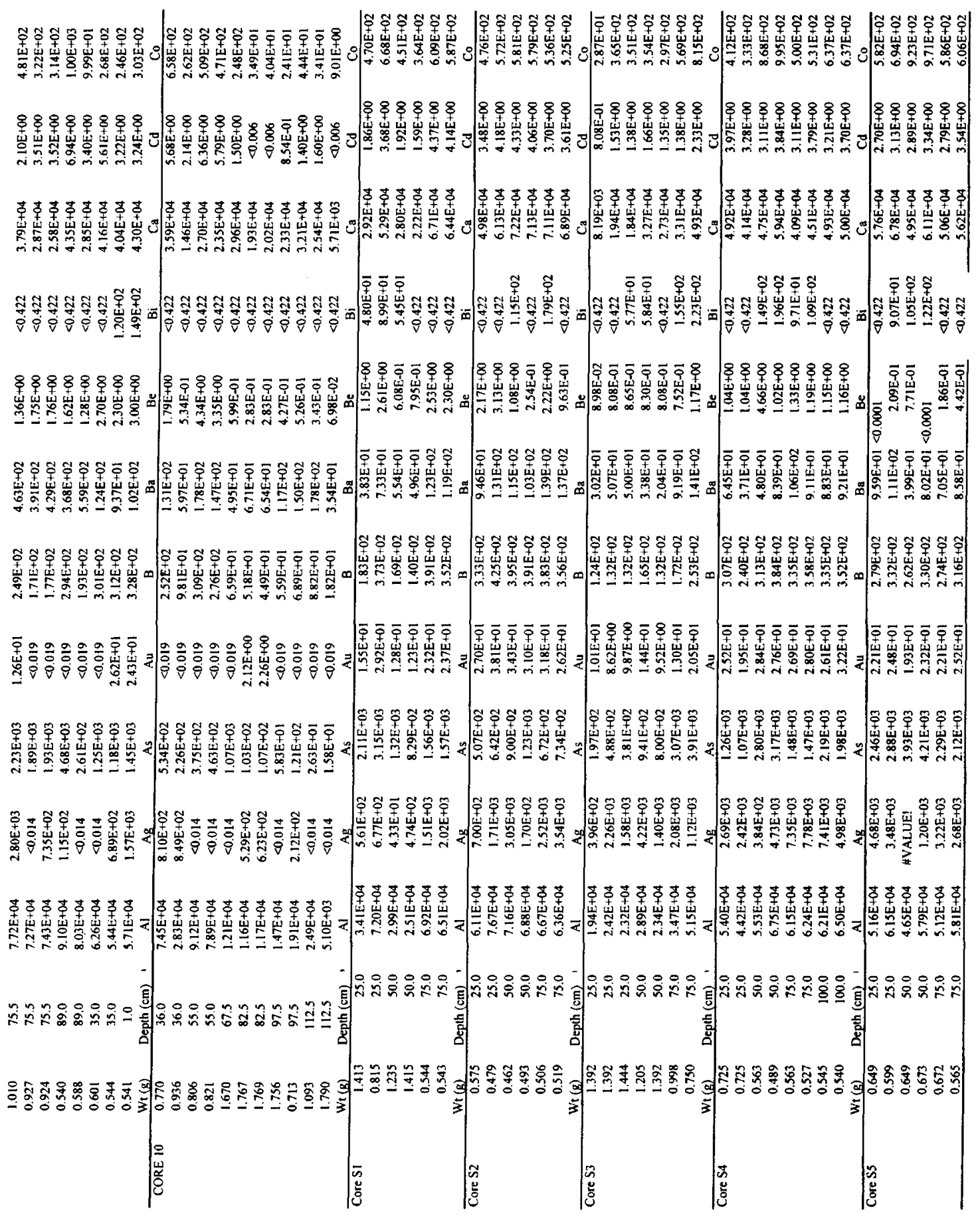




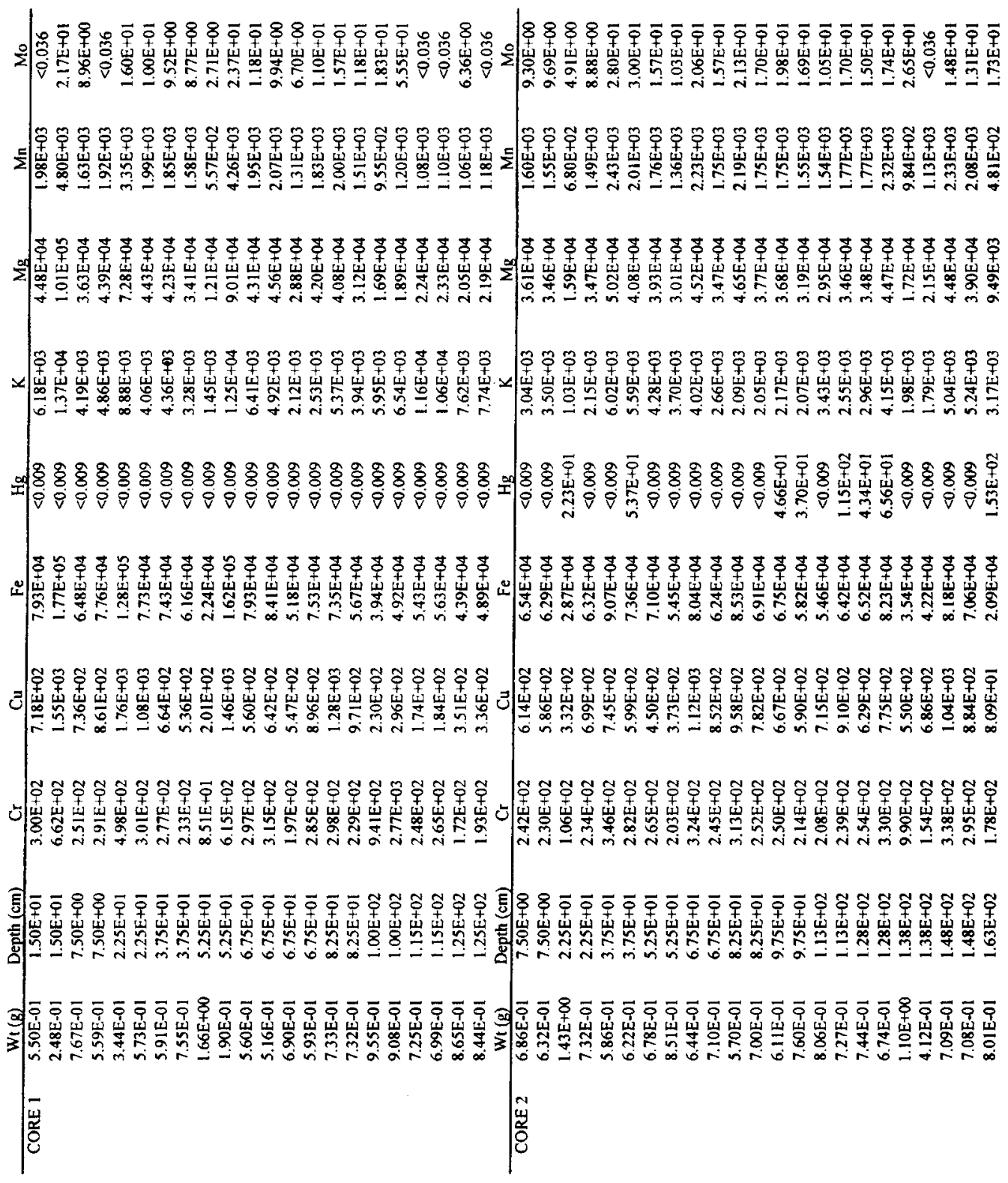




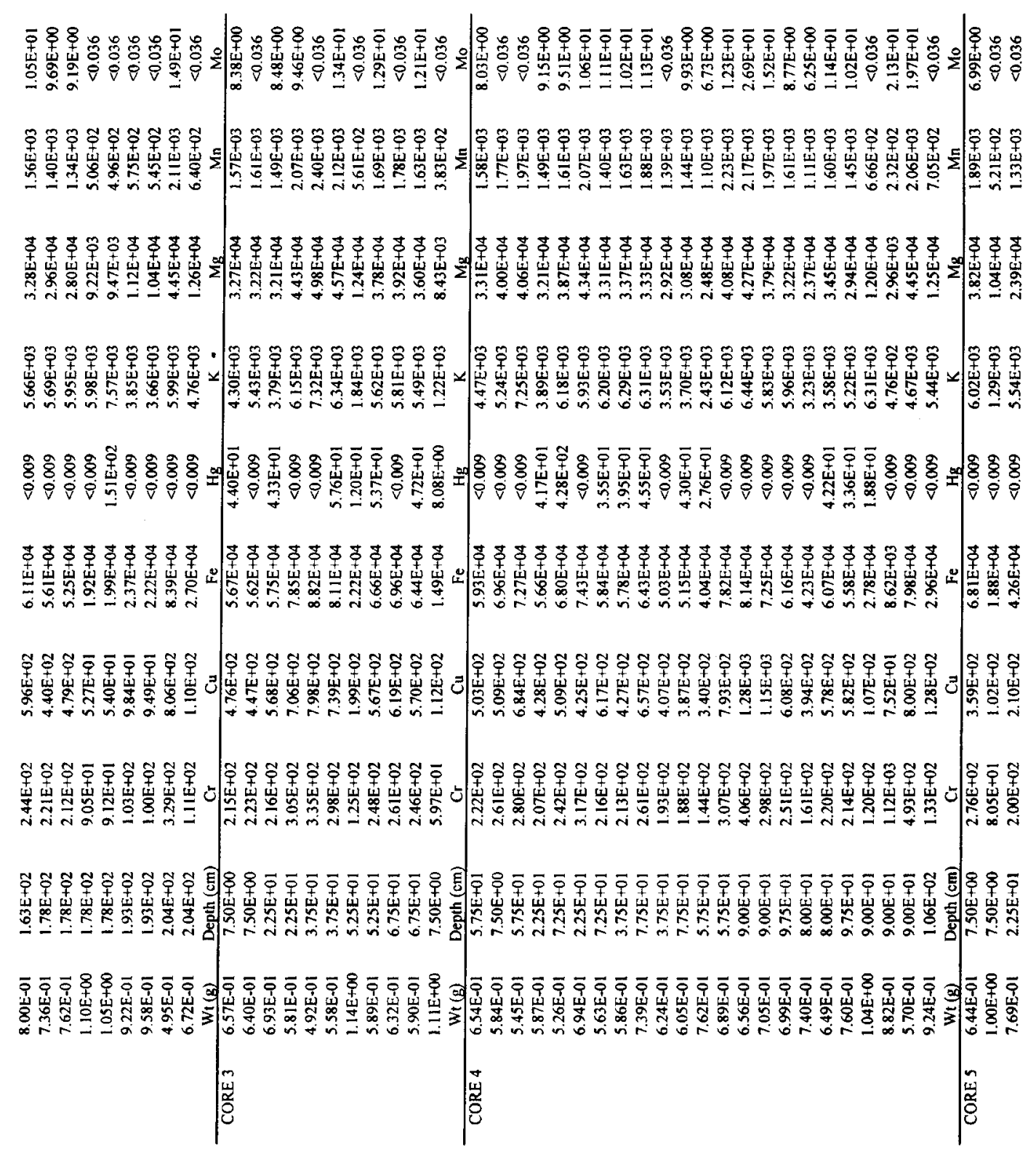




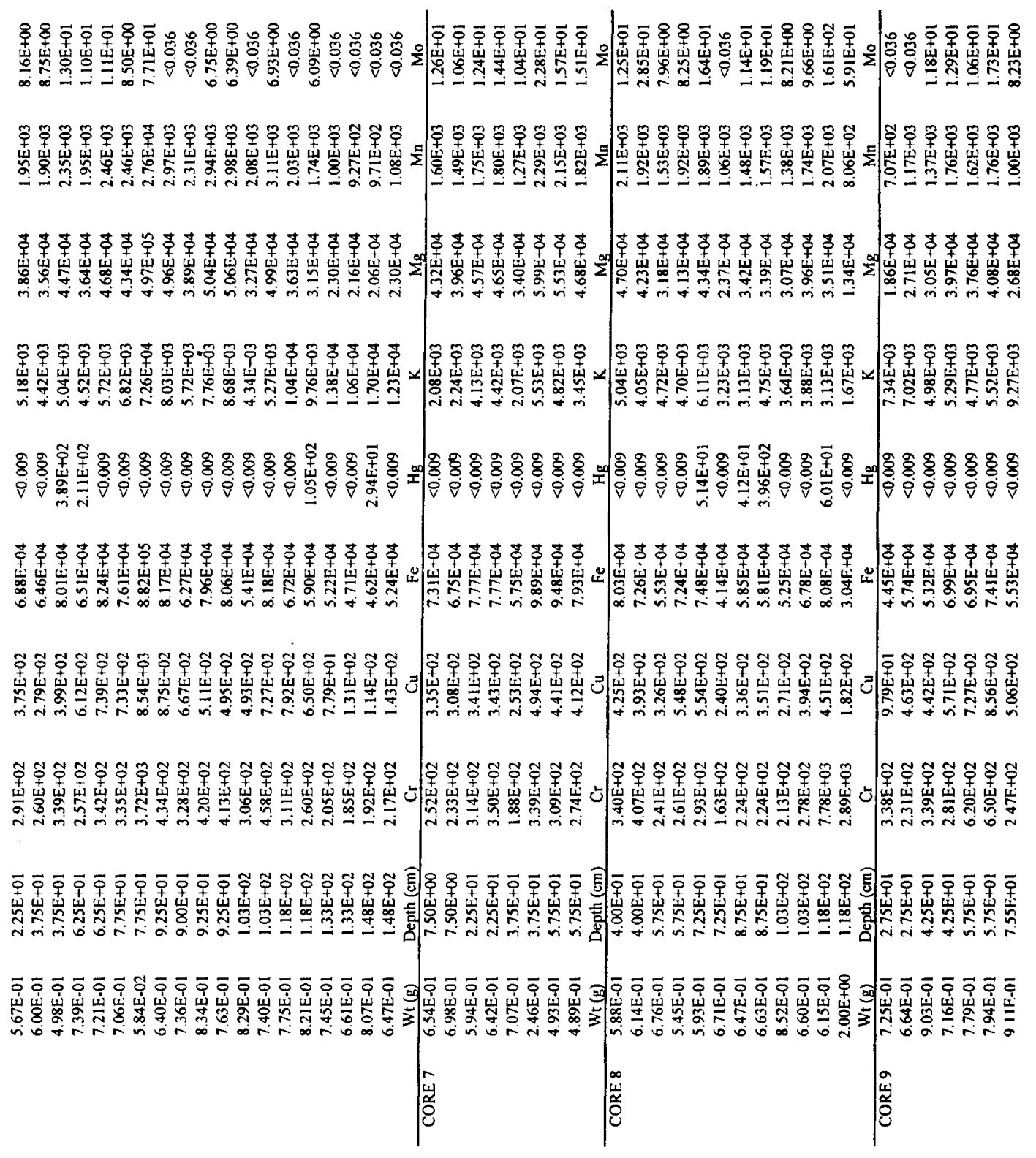




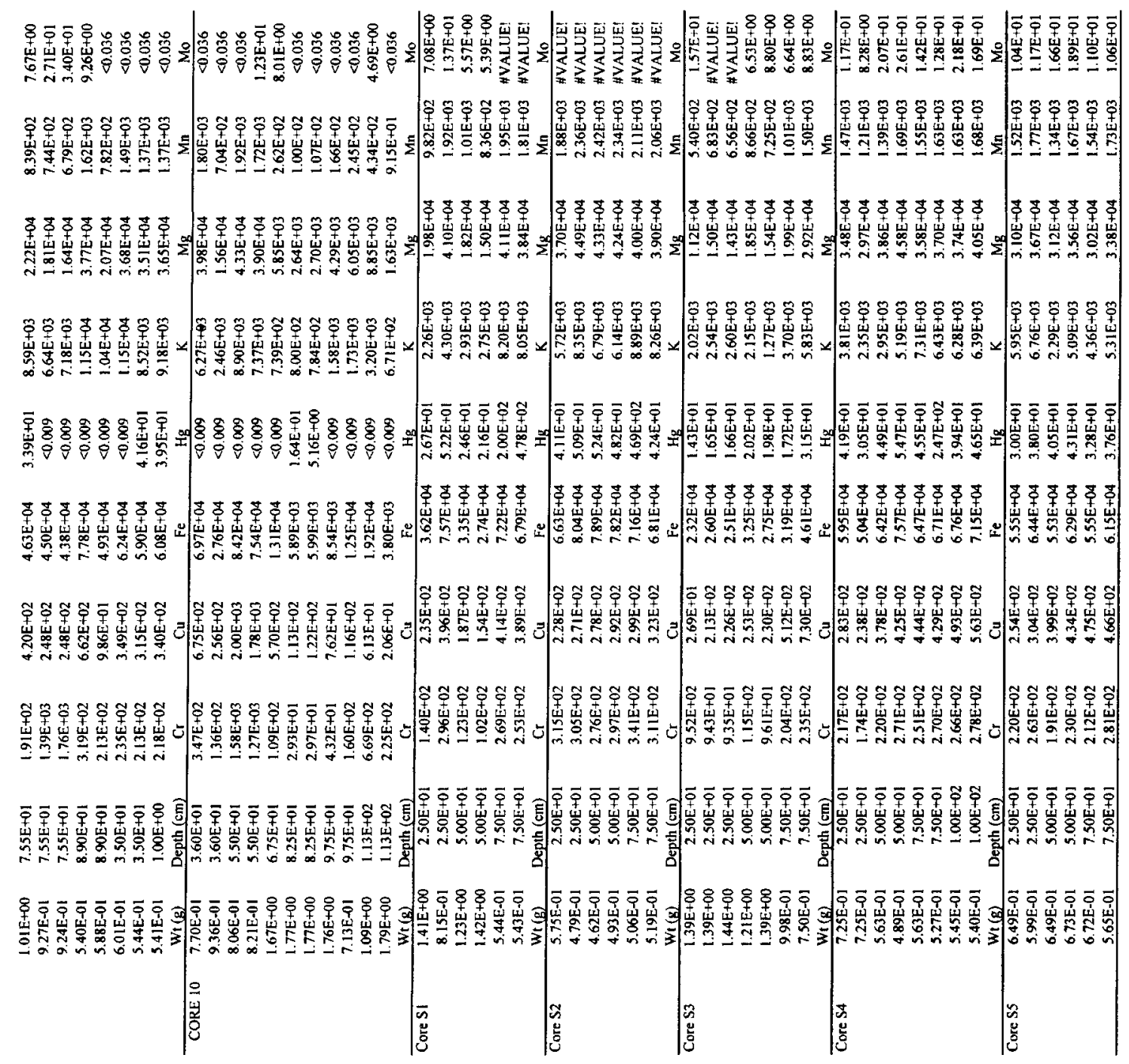




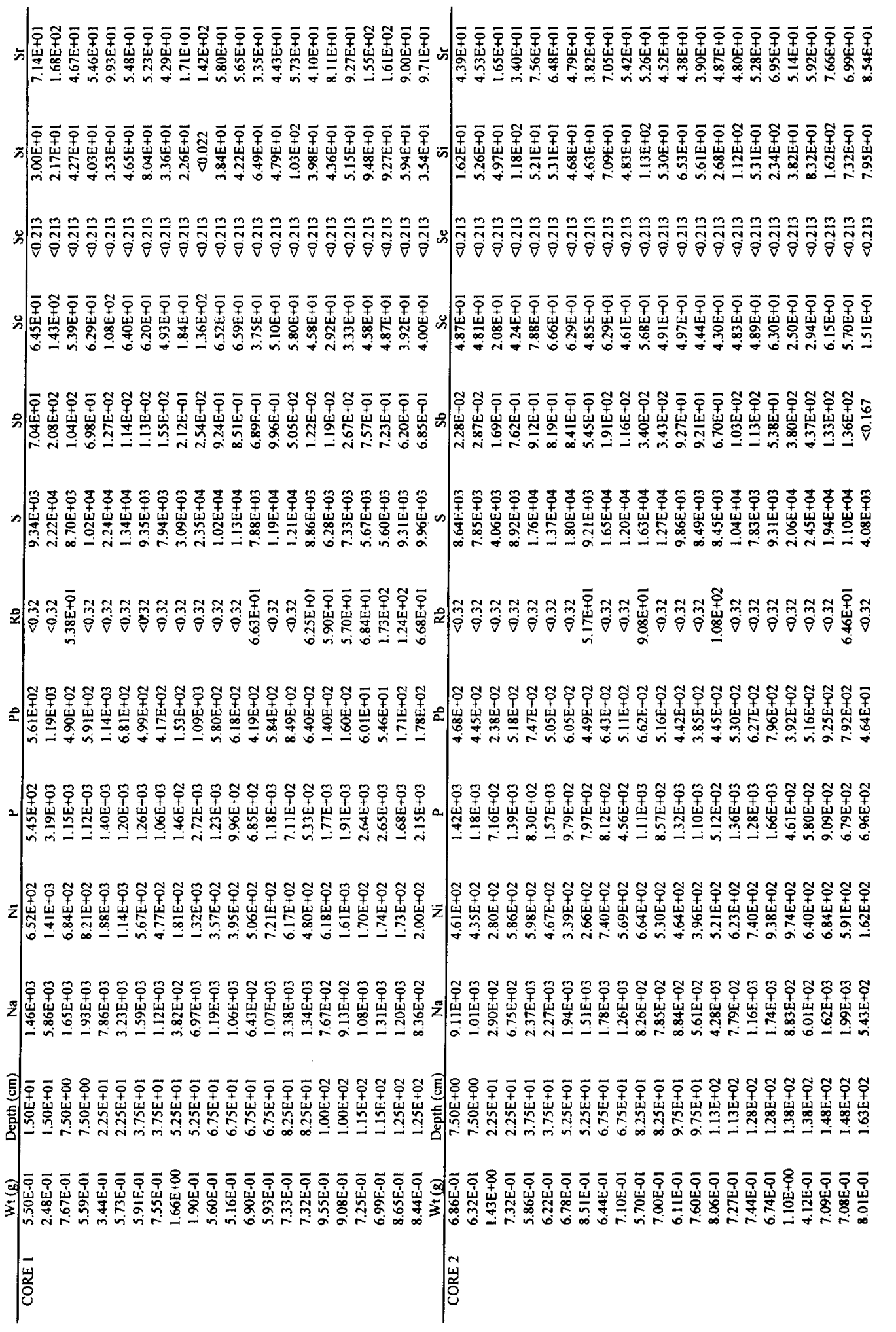




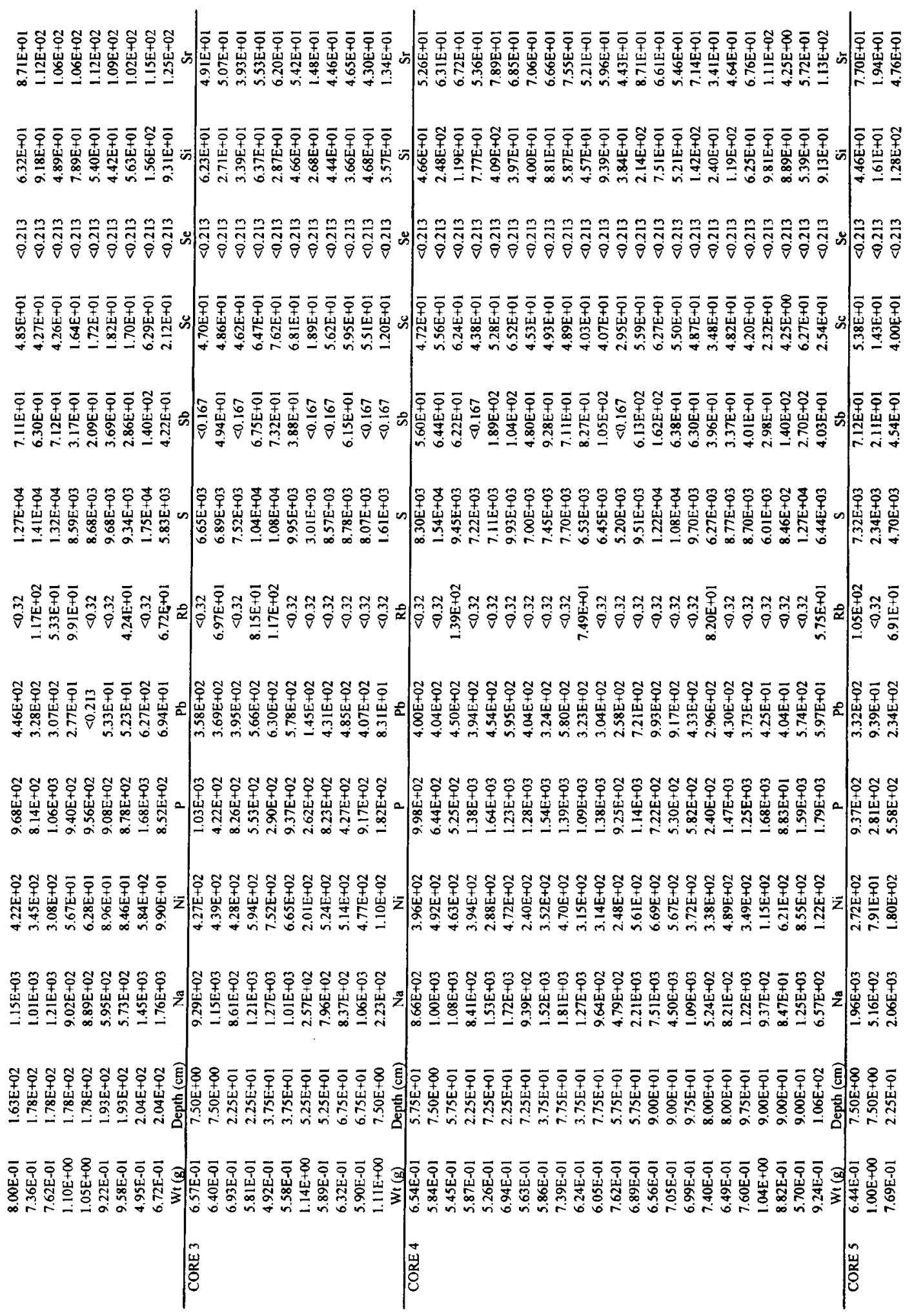




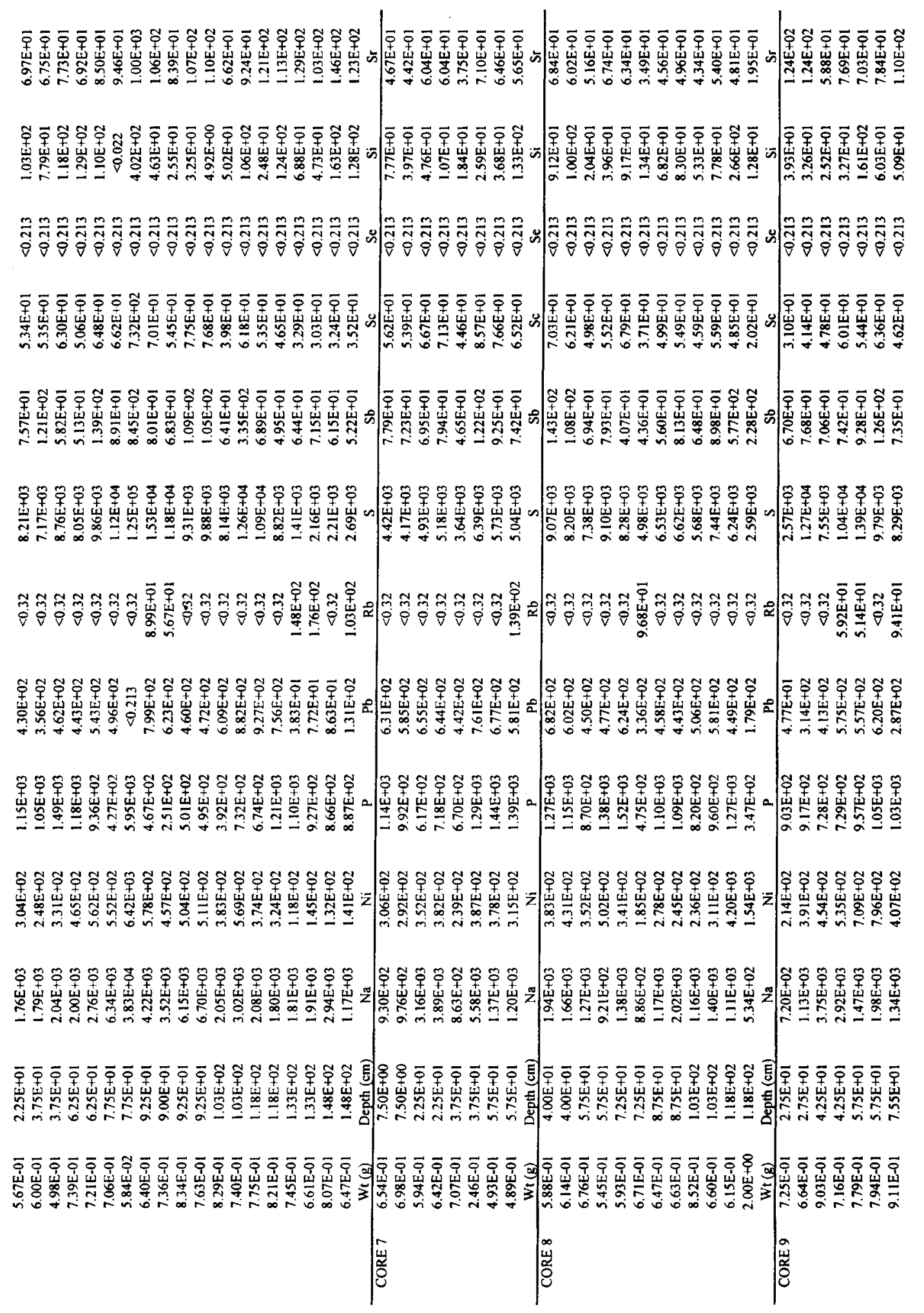

163 


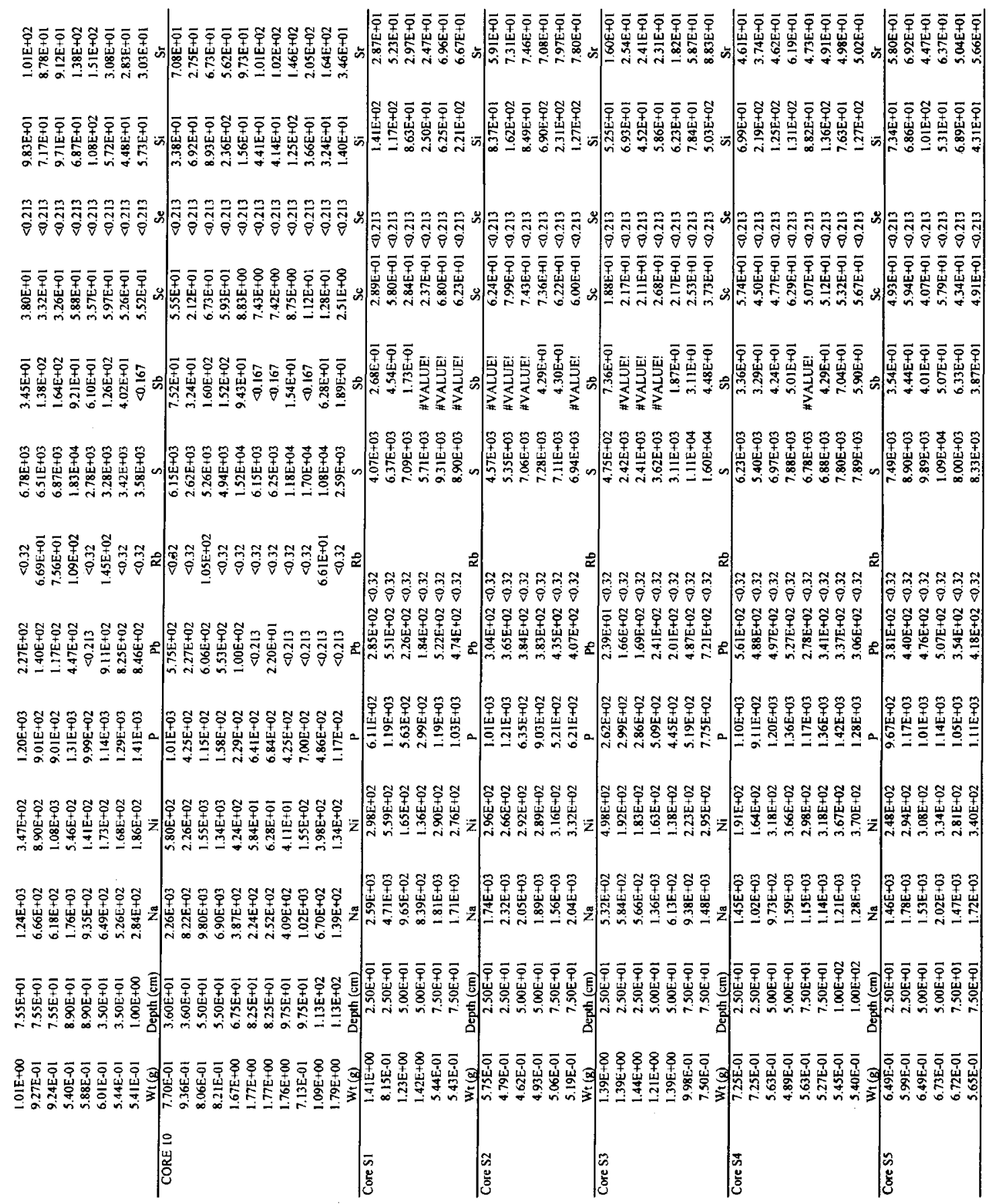




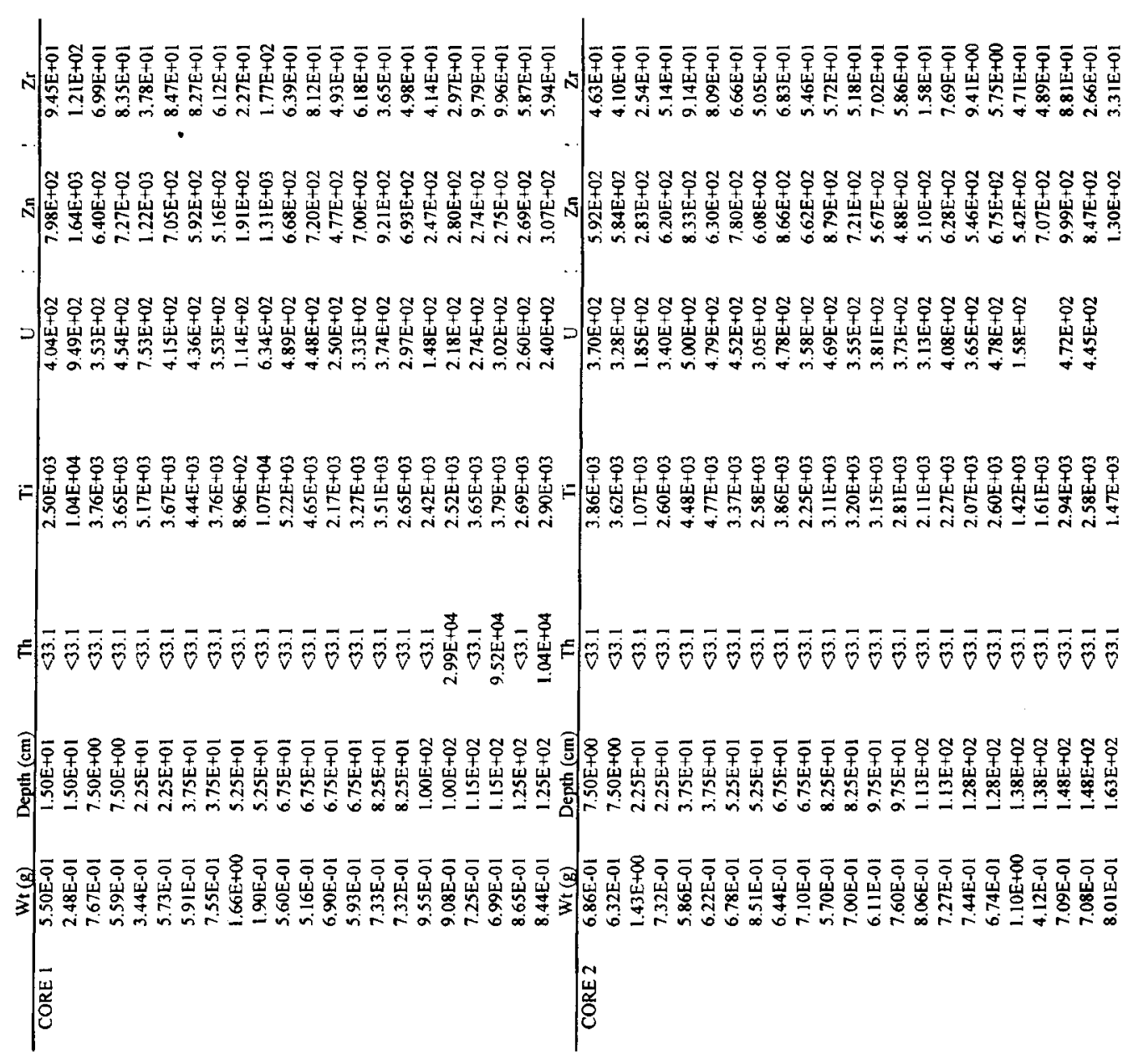




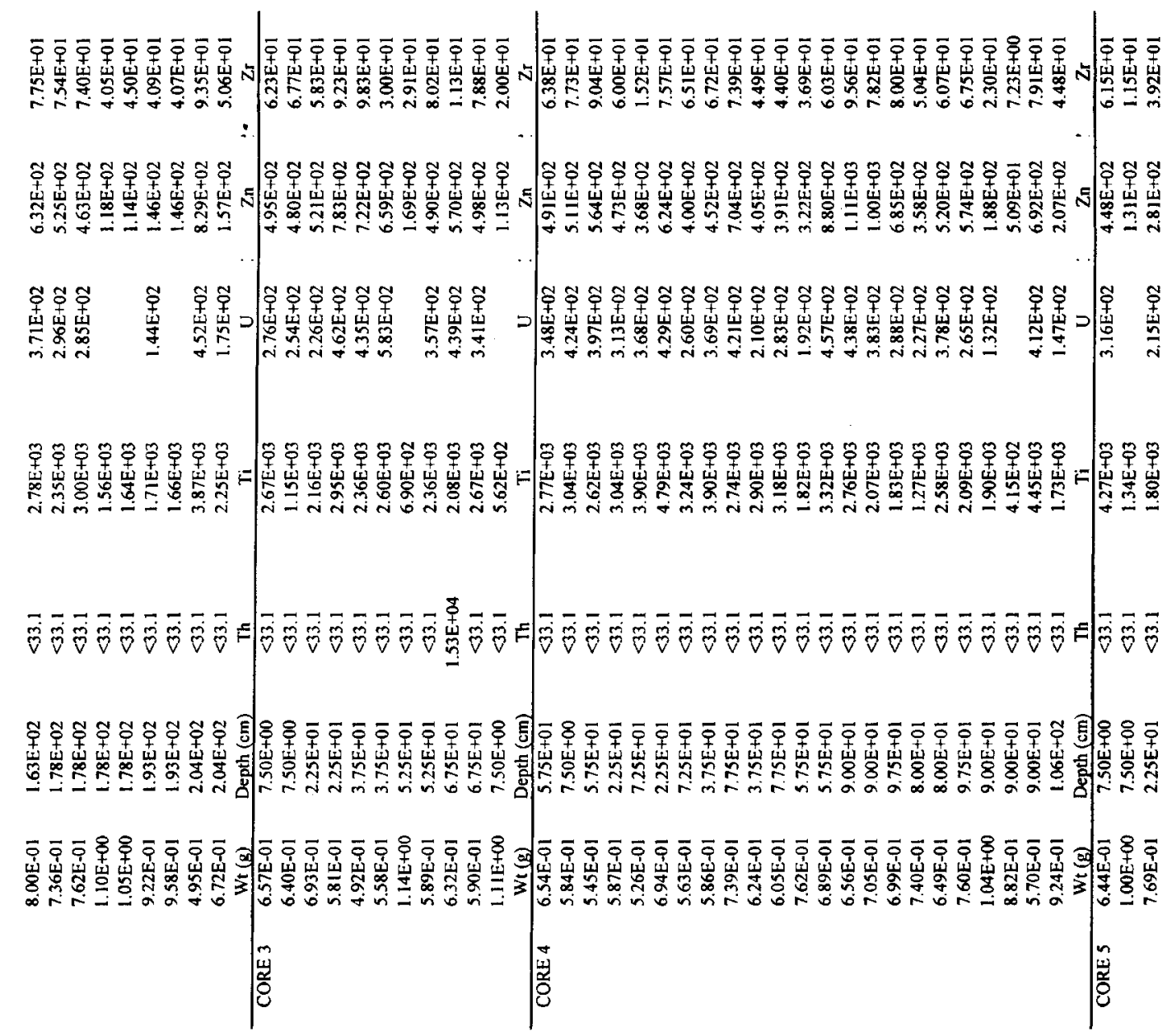




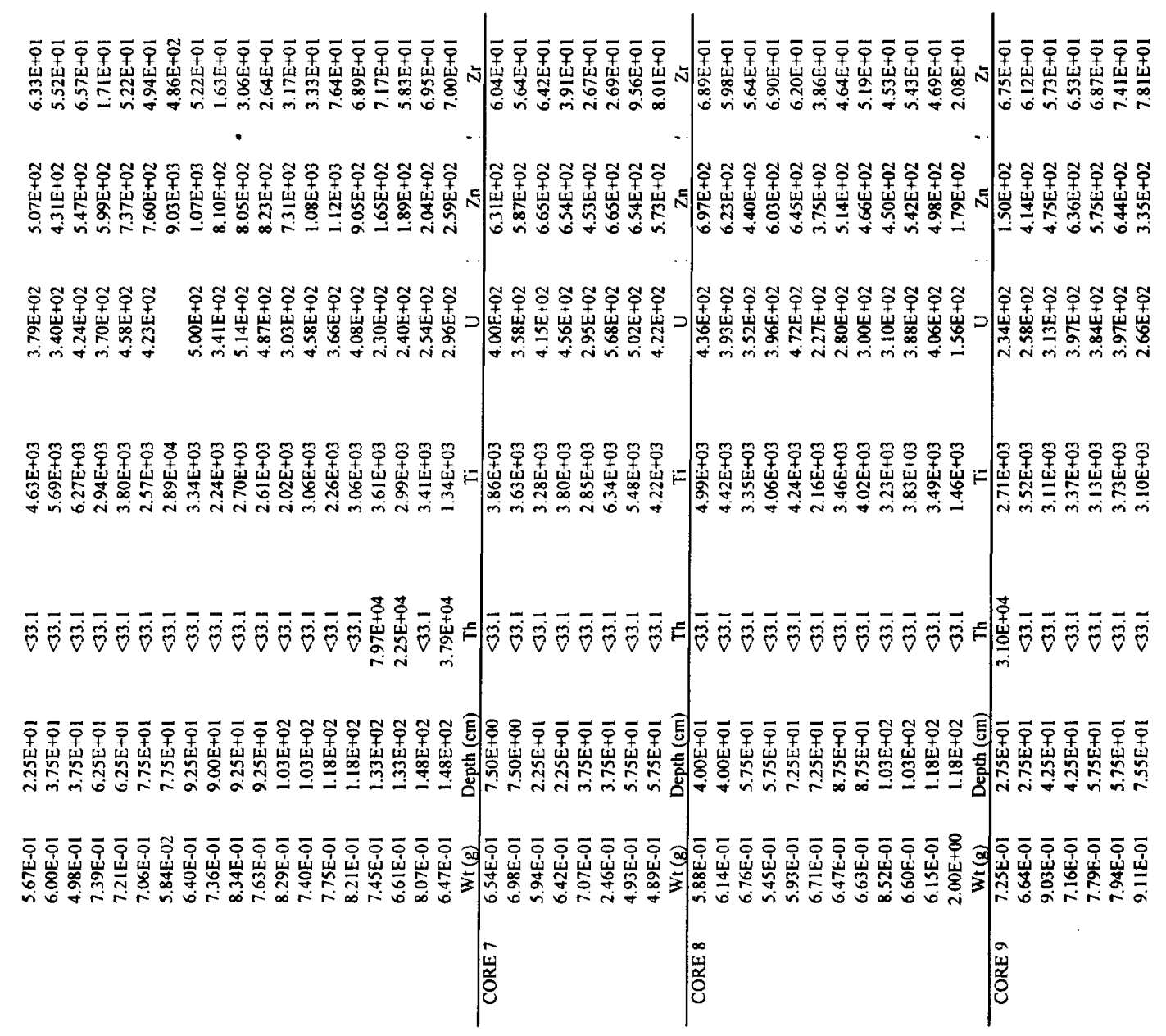




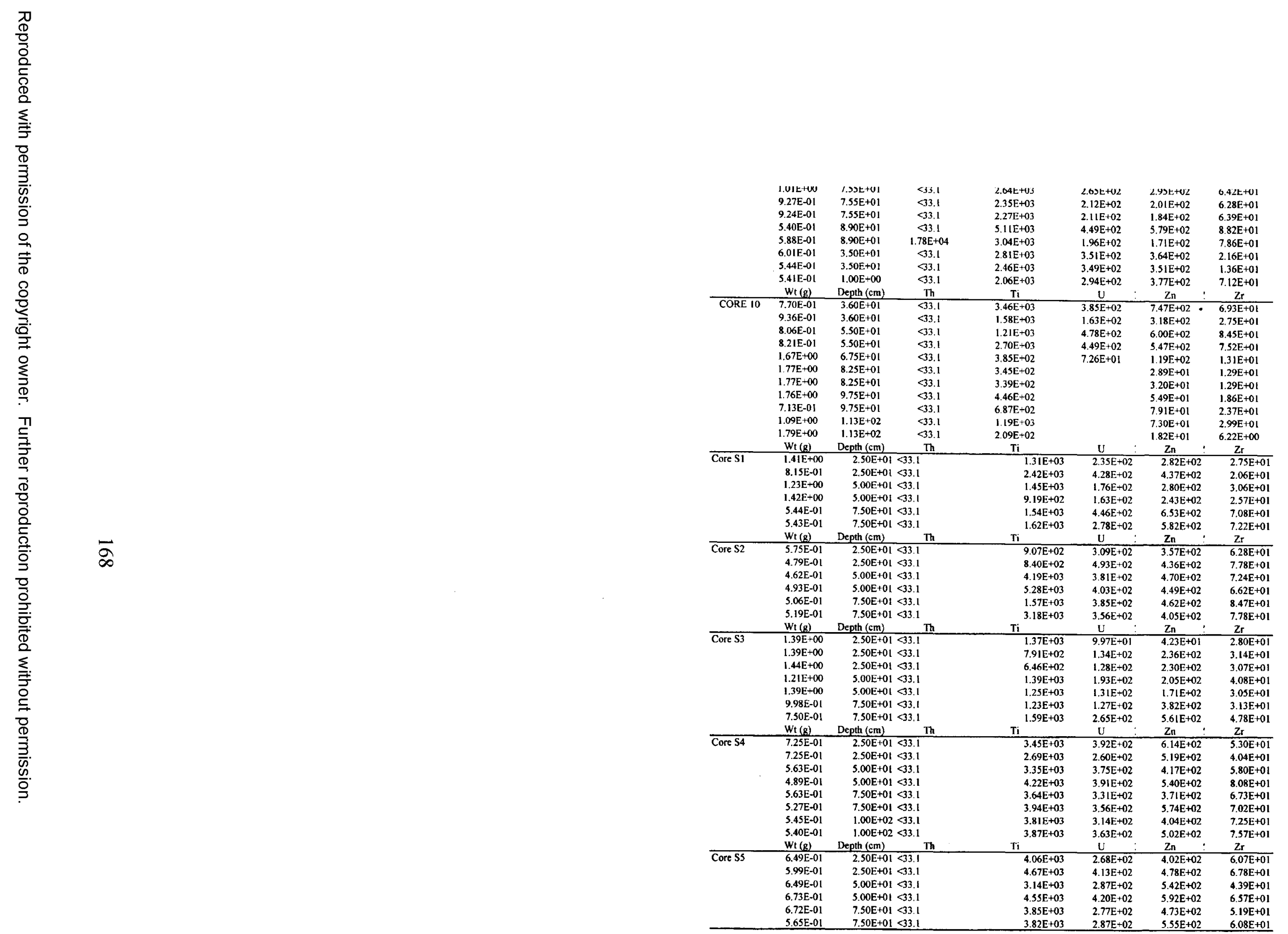


Table B3: Metal Sequential Extraction Results from September 2004 Cores

\begin{tabular}{|c|c|c|c|c|c|c|c|c|c|}
\hline Core ID & Extraction & Wt (g) & Depth (cm) & A! & $\mathbf{A g}$ & As & Au & B & Ba \\
\hline \multirow[t]{34}{*}{ Core S1 } & Exchangeable & $1.41 \mathrm{E}+00$ & $2.50 \mathrm{E}+01$ & $3.12 \mathrm{E}+01$ & $2.62 E+02$ & $1.03 \mathrm{E}+02$ & $1<0.019$ & $5.57 E+00$ & $5.04 E+\infty 0$ \\
\hline & Carbonate & $1.41 \mathrm{E}+00$ & $2.50 \mathrm{E}+01$ & 1.23E+02 & $<0.014$ & $1.93 E+02$ & $2.04 \mathrm{E}+00$ & $2.92 \mathrm{E}+00$ & $6.46 \mathrm{E}+00$ \\
\hline & Fe, Mn Oxides & $1.41 \mathrm{E}+00$ & $2.50 \mathrm{E}+01$ & 1. $15 E+03$ & $6.06 \mathrm{E}+01$ & $5.60 \mathrm{E}+02$ & $1<0.019$ & $1.57 \mathrm{E}+01$ & $2.04 \mathrm{E}+00$ \\
\hline & Organic Matter & $1.41 \mathrm{E}+00$ & $2.50 \mathrm{E}+01$ & $6.30 \mathrm{E}+02$ & $1.42 \mathrm{E}+02$ & $2.42 \mathrm{E}+02$ & $1<0.019$ & 4.87E+00 & $1.33 \mathrm{E}+00$ \\
\hline & Residual & $1.41 \mathrm{E}+00$ & $2.50 \mathrm{E}+01$ & $3.56 \mathrm{E}+04$ & $1.20 \mathrm{E}+03$ & $1.56 \mathrm{E}+03$ & $1.5|E+0|$ & $1.87 E+02$ & $3.92 \mathrm{E}+01$ \\
\hline & Exchangeable & 8.15E-01 & $2.50 \mathrm{E}+01$ & $5.17 \mathrm{E}+01$ & $1.36 \mathrm{E}+03$ & $1.23 \mathrm{E}+02$ & $1<0.019$ & $3.20 E+01$ & $5.75 E+00$ \\
\hline & Carbonate & $8.15 E-01$ & $2.50 \mathrm{E}+01$ & $2.32 \mathrm{E}+02$ & $<0.014$ & $1.87 E+02$ & $1<0.019$ & $2.17 \mathrm{E}+01$ & $6.28 \mathrm{E}+00$ \\
\hline & Fe. Mn Oxides & $8.15 E-01$ & $2.50 \mathrm{E}+01$ & $1.86 \mathrm{E}+03$ & $1.20 \mathrm{E}+02$ & $5.07 \mathrm{E}+02$ & $1<0.019$ & $1.52 \mathrm{E}+01$ & $2.12 \mathrm{E}+00$ \\
\hline & Organic Matter & $8.15 E-01$ & $2.50 \mathrm{E}+01$ & $9.71 E+02$ & $8.02 \mathrm{E}+01$ & 2. $14 \mathrm{E}+02$ & $1<0.019$ & $<0.012$ & $7.96 \mathrm{E}-01$ \\
\hline & Residual & $8.15 E-01$ & $2.50 \mathrm{E}+01$ & $6.61 E+04$ & $3.00 \mathrm{E}+03$ & $1.47 E+03$ & $1.45 \mathrm{E}+01$ & $1.78 \mathrm{E}+02$ & $4.71 E+01$ \\
\hline & Exchangeable & $7.69 \mathrm{E}-01$ & $5.00 \mathrm{E}+01$ & $4.00 \mathrm{E}+01$ & $1.27 \mathrm{E}+01$ & $1.17 \mathrm{E}+01$ & $1<0.019$ & $3.98 \mathrm{E}+00$ & $5.75 E+\infty 0$ \\
\hline & Exchangeable & $7.69 \mathrm{E}-01$ & $5.00 \mathrm{E}+01$ & $1.32 \mathrm{E}+01$ & $4.66 \mathrm{E}+01$ & $<0,124$ & $1<0.019$ & $2.48 \mathrm{E}+00$ & $2.74 E+\infty 0$ \\
\hline & Carbonate & $7.69 \mathrm{E}-01$ & $5.00 \mathrm{E}+01$ & $1,08 \mathrm{E}+02$ & $<0.014$ & $3.47 \mathrm{E}+01$ & i $<0.019$ & $6.99 \mathrm{E}+00$ & $4.42 \mathrm{E}+00$ \\
\hline & Carbonate & $7.69 \mathrm{E}-01$ & $5.00 E+01$ & $1.47 E+02$ & $<0.014$ & $6.09 \mathrm{E}+01$ & $: \quad<0.019$ & $4.78 \mathrm{E}+00$ & $2.21 E+00$ \\
\hline & $\mathrm{Fe}, \mathrm{Mn}$ Oxides & $7.69 \mathrm{E}-01$ & $5.00 \mathrm{E}+01$ & $4.68 E+02$ & $<0.014$ & $2.39 \mathrm{E}+02$ & $1<0,019$ & $1.22 \mathrm{E}+01$ & J.15E+00 \\
\hline & $\mathrm{Fe}, \mathrm{Mn}$ Oxides & $7.69 \mathrm{E}-01$ & $5.00 \mathrm{E}+01$ & $1.72 \mathrm{E}+02$ & $<0.014$ & $3.97 \mathrm{E}+01$ & $1<0.019$ & $3.89 \mathrm{E}+00$ & $7.08 \mathrm{E}-01$ \\
\hline & Organic Matter & $7.69 \mathrm{E}-01$ & $5.00 \mathrm{E}+01$ & $1.08 \mathrm{E}+03$ & $1.09 E+02$ & $3.84 \mathrm{E}+02$ & $1<0.019$ & $4.16 \mathrm{E}+00$ & $6.19 \mathrm{E}-01$ \\
\hline & Organic Matter & $7.69 \mathrm{E}-01$ & $5.00 \mathrm{E}+01$ & $4.21 E+02$ & $2.16 E+02$ & $1.42 E+02$ & $1<0.019$ & $5.22 \mathrm{E}+00$ & $3.54 \mathrm{E}-01$ \\
\hline & Residual & $8.15 E-01$ & $5.00 \mathrm{E}+01$ & $3.70 \mathrm{E}+04$ & $8.08 E+02$ & $4.91 \mathrm{E}+02$ & $7.43 E+00$ & $1.21 \mathrm{E}+02$ & $2.51 \mathrm{E}+01$ \\
\hline & Exchangeable & $5.86 \mathrm{E}-01$ & $5.00 E+01$ & $3.52 \mathrm{E}+01$ & $9.38 E+00$ & $1.90 \mathrm{E}+01$ & $1<0.019$ & $9.82 \mathrm{E}+00$ & $1.24 \mathrm{E}+00$ \\
\hline & Carbonate & $5.86 \mathrm{E}-01$ & $5.00 \mathrm{E}+01$ & $9.83 \mathrm{E}+01$ & $1.11 \mathrm{E}+02$ & $1.11 E+02$ & $1<0.019$ & $6.55 \mathrm{E}+00$ & $7.70 \mathrm{E}+00$ \\
\hline & $\mathrm{Fe}$, Mn Oxides & $5.86 \mathrm{E}-01$ & $5.00 \mathrm{E}+01$ & $5.63 \mathrm{E}+02$ & $<0.014$ & $3.34 \mathrm{E}+02$ & $1<0.019$ & $1.03 \mathrm{E}+01$ & $2.39 \mathrm{E}+00$ \\
\hline & Organic Matter & $5.86 \mathrm{E}-01$ & $5.00 \mathrm{E}+01$ & $4.92 \mathrm{E}+02$ & $7.97 \mathrm{E}+01$ & $2.41 \mathrm{E}+02$ & $1<0.019$ & $3.54 \mathrm{E}+00$ & $6.19 \mathrm{E}-01$ \\
\hline & Residual & $5.86 \mathrm{E}-01$ & $5.00 \mathrm{E}+01$ & $5.16 E+04$ & $9.91 E+02$ & $5.33 \mathrm{E}+02$ & $9.64 \mathrm{E}+00$ & $1.22 \mathrm{E}+02$ & 3. $10 \mathrm{E}+01$ \\
\hline & Exchangeable & $5.44 \mathrm{E}-01$ & $7.50 \mathrm{E}+01$ & $2.87 \mathrm{E}+02$ & $1.04 \mathrm{E}+02$ & $1.56 \mathrm{E}+01$ & $1<0.019$ & $4.25 \mathrm{E}+00$ & $3.63 E+\infty 0$ \\
\hline & Carbonate & $5.44 E-01$ & $7.50 \mathrm{E}+01$ & $5.01 E+02$ & $6.42 \mathrm{E}+01$ & $2.85 \mathrm{E}+01$ & $1<0.019$ & $6.46 \mathrm{E}+00$ & $3.54 \mathrm{E}+00$ \\
\hline & Fe, Mn Oxides & $5.44 \mathrm{E}-01$ & $7.50 \mathrm{E}+01$ & $5.77 E+02$ & $7.83 \mathrm{E}+01$ & $4.45 \mathrm{E}+01$ & $: \quad<0.019$ & $2.74 E+00$ & $1.06 \mathrm{E}+00$ \\
\hline & Organic Matter & $5.44 \mathrm{E}-01$ & $7.50 \mathrm{E}+01$ & $6.59 \mathrm{E}+02$ & $1.93 \mathrm{E}+02$ & $1.73 E+02$ & $: \quad<0.019$ & $<0.012$ & $9.73 \mathrm{E}-0 \mathrm{I}$ \\
\hline & Residual & $5.44 \mathrm{E}-01$ & $7.50 \mathrm{E}+01$ & $6.11 E+04$ & $8.77 \mathrm{E}+02$ & $2.65 \mathrm{E}+02$ & $7.79 \mathrm{E}+\infty 0$ & $133 E+02$ & $3.67 \mathrm{E}+01$ \\
\hline & Exchangeable & $5.43 \mathrm{E}-01$ & $7.50 \mathrm{E}+01$ & $3.20 \mathrm{E}+02$ & $1.32 E+02$ & $1.24 \mathrm{E}+01$ & $1<0.019$ & $5.31 E+00$ & $3.45 \mathrm{E}+00$ \\
\hline & Carbonate & $5.43 E-01$ & $7.50 \mathrm{E}+01$ & $4.49 \mathrm{E}+02$ & $5.34 \mathrm{E}+01$ & $3.12 \mathrm{E}+01$ & $1<0.019$ & $2.65 \mathrm{E}+00$ & $3.45 \mathrm{E}+00$ \\
\hline & Fe, Mn Oxides & $5.43 \mathrm{E}-0$ & $7.50 \mathrm{E}+01$ & $5.36 \mathrm{E}+02$ & $4.29 E+01$ & $5.60 \mathrm{E}+01$ & $1<0.019$ & $6.72 \mathrm{E}+00$ & $1.24 E+00$ \\
\hline & Organic Matter & $5.43 \mathrm{E}-01$ & $7.50 \mathrm{E}+01$ & $4.44 \mathrm{E}+02$ & $1.17 \mathrm{E}+02$ & $1.44 E+02$ & $1<0.019$ & $2.48 \mathrm{E}+00$ & $5.31 \mathrm{E}-01$ \\
\hline & Residual & $5.43 \mathrm{E}-01$ & $7.50 \mathrm{E}+01$ & $6.07 E+04$ & $2,26 \mathrm{E}+03$ & $4.34 E+02$ & $7.34 E+00$ & $1.27 \mathrm{E}+02$ & $4.15 \mathrm{E}+01$ \\
\hline Core ID & Extraction & Wt $(g)$ & Depth (cm) & Al & $\mathbf{A g}$ & As & - Au & B & Ba \\
\hline \multirow[t]{30}{*}{ Core S2 } & Exchangeable & $5.75 \mathrm{E}-01$ & $2.50 \mathrm{E}+01$ & $2.61 \mathrm{E}+02$ & $6.16 \mathrm{E}+01$ & $<0.124$ & $<0.019$ & $1.68 \mathrm{E}+01$ & 4. $16 \mathrm{E}+00$ \\
\hline & Carbonate & $5.75 \mathrm{E}-01$ & $2.50 \mathrm{E}+01$ & $3.70 \mathrm{E}+02$ & $7.28 \mathrm{E}+01$ & $1.83 \mathrm{E}+01$ & $1<0.019$ & $3.63 E+00$ & $1.68 \mathrm{E}+00$ \\
\hline & $\mathrm{Fe}, \mathrm{Mn}$ Oxides & $5.75 \mathrm{E}-01$ & $2.50 \mathrm{E}+01$ & $4.26 E+02$ & $3.71 E+01$ & $4.26 \mathrm{E}+01$ & $1<0.019$ & $4.87 \mathrm{E}+00$ & 8.85E-01 \\
\hline & Organic Matter & $5.75 \mathrm{E}-01$ & $2.50 \mathrm{E}+01$ & $5.50 \mathrm{E}+02$ & $8.67 \mathrm{E}+01$ & $6.90 E+01$ & $1<0.019$ & $6.28 \mathrm{E}+00$ & $7,08 \mathrm{E}-01$ \\
\hline & Residual & $5.75 \mathrm{E}-01$ & $2.50 \mathrm{E}+01$ & $5.89 \mathrm{E}+04$ & $7.49 \mathrm{E}+02$ & $1.43 \mathrm{E}+02$ & $1.24 \mathrm{E}+01$ & $1.36 \mathrm{E}+02$ & $3.93 \mathrm{E}+01$ \\
\hline & Exchangeable & $4.79 \mathrm{E}-01$ & $2.50 \mathrm{E}+01$ & $2.37 E+02$ & $2.92 \mathrm{E}+01$ & $<0.124$ & $i<0.019$ & $2.92 \mathrm{E}+00$ & $4.34 E+00$ \\
\hline & Carbonate & 4.79E-01 & $2.50 \mathrm{E}+01$ & $4.20 E+02$ & $3.22 \mathrm{E}+01$ & $1.75 E+01$ & $i<0.019$ & $2.04 \mathrm{E}+00$ & $1.24 \mathrm{E}+00$ \\
\hline & $\mathrm{Fe}, \mathrm{Mn}$ Oxides & $4.79 E-01$ & $2.50 \mathrm{E}+01$ & $6.19 E+02$ & $7.26 \mathrm{E}+02$ & $5.03 E+01$ & $: \quad<0.019$ & $4.96 \mathrm{E}+00$ & $9.73 \mathrm{E}-01$ \\
\hline & Organic Matfer & $4.79 \mathrm{E}-01$ & $2.50 E+01$ & $8.33 \mathrm{E}+02$ & $1.48 \mathrm{E}+02$ & $7.40 \mathrm{E}+01$ & $1<0.019$ & $4.34 \mathrm{E}+00$ & $1.06 \mathrm{E}+00$ \\
\hline & Residual & $4.79 \mathrm{E}-01$ & $2.50 \mathrm{E}+01$ & $6.86 \mathrm{E}+04$ & $3.85 \mathrm{E}+02$ & $9.91 \mathrm{E}+01$ & $1.25 \mathrm{E}+01$ & $1.40 \mathrm{E}+02$ & $3.87 \mathrm{E}+01$ \\
\hline & Exchangeable & $4.62 \mathrm{E}-01$ & $5.00 \mathrm{E}+01$ & $4.87 \mathrm{E}+02$ & $1.15 E+02$ & $3.58 \mathrm{E}+01$ & $1<0.019$ & $3.19 \mathrm{E}+00$ & $3.27 \mathrm{E}+00$ \\
\hline & Carbonate & $4.62 \mathrm{E}-01$ & $5.00 \mathrm{E}+01$ & $6.33 E+02$ & $7.11 \mathrm{E}+01$ & $5.33 E+01$ & $1<0.019$ & $2.74 \mathrm{E}+00$ & $3.10 \mathrm{E}+00$ \\
\hline & $\mathrm{Fe}, \mathrm{Mn}$ Oxides & $4.62 \mathrm{E}-01$ & $5.00 \mathrm{E}+01$ & $8.27 \mathrm{E}+02$ & $2.71 E+01$ & $6.80 \mathrm{E}+01$ & $1<0.019$ & $7.17 \mathrm{E}+00$ & $1.50 \mathrm{E}+\infty 0$ \\
\hline & Organic Matter & $4.62 \mathrm{E}-01$ & $5.00 \mathrm{E}+01$ & $7.33 \mathrm{E}+02$ & $1.15 \mathrm{E}+02$ & $1.49 E+02$ & $1<0.019$ & $<0.012$ & $9.73 \mathrm{E}-01$ \\
\hline & Residual & $4.62 \mathrm{E}-01$ & $5.00 \mathrm{E}+01$ & $6.89 \mathrm{E}+04$ & $<0.014$ & $2.63 \mathrm{E}+02$ & $1.14 \mathrm{E}+01$ & $1.31 \mathrm{E}+02$ & $3.09 \mathrm{E}+01$ \\
\hline & Exchangeable & $4.93 \mathrm{E}-01$ & $5.00 \mathrm{E}+01$ & $4.80 \mathrm{E}+02$ & $1.21 \mathrm{E}+02$ & $3.82 E+01$ & I $<0.019$ & $7.17 \mathrm{E}+00$ & $2.83 \mathrm{E}+00$ \\
\hline & Carbonate & $4.93 \mathrm{E}-01$ & $5.00 \mathrm{E}+01$ & $5.05 \mathrm{E}+02$ & $7.33 \mathrm{E}+01$ & $4.80 \mathrm{E}+01$ & $1<0.019$ & $2.83 E+00$ & $2.83 \mathrm{E}+00$ \\
\hline & Fe. Mn Oxides & $4.93 \mathrm{E}-01$ & $5.00 \mathrm{E}+01$ & $6.34 E+02$ & $1.10 \mathrm{E}+02$ & $1.18 \mathrm{E}+02$ & $1<0.019$ & $<0.012$ & $7.08 \mathrm{E}-01$ \\
\hline & Organic Matter & $4.93 \mathrm{E}-01$ & $5.00 \mathrm{E}+01$ & $6.90 \mathrm{E}+02$ & $3.46 \mathrm{E}+01$ & $6.82 E+01$ & $1<0.019$ & $6.02 \mathrm{E}+00$ & $1.59 \mathrm{E}+00$ \\
\hline & Residual & $4.93 \mathrm{E}-01$ & $5.00 \mathrm{E}+01$ & $5.91 \mathrm{E}+04$ & $2.80 \mathrm{E}+02$ & $2.69 E+02$ & $1.08 \mathrm{E}+01$ & $1.23 \mathrm{E}+02$ & $3.75 \mathrm{E}+01$ \\
\hline & Exchangeable & $5.06 \mathrm{E}-01$ & $7.50 \mathrm{E}+01$ & $2.33 \mathrm{E}+02$ & $3.15 E+01$ & $2.18 E+01$ & $: \quad<0.019$ & $2.57 \mathrm{E}+00$ & $5.13 E+00$ \\
\hline & Carbonate & $5.06 \mathrm{E}-01$ & $7.50 \mathrm{E}+01$ & $3.43 E+02$ & $2.52 \mathrm{E}+01$ & $7.13 E+01$ & $1<0.019$ & $5.57 \mathrm{E}+00$ & $1.15 \mathrm{E}+00$ \\
\hline & Fe, Mn Oxides & 5.06E-0I & $7.50 \mathrm{E}+01$ & $7.63 \mathrm{E}+02$ & $1.95 \mathrm{E}+01$ & $7.05 \mathrm{E}+01$ & $: \quad<0.019$ & $7.43 E+00$ & $1.33 \mathrm{E}+\infty 0$ \\
\hline & Organic Matter & $5.06 \mathrm{E}-01$ & $7.50 \mathrm{E}+01$ & $6.42 E+02$ & $1.43 \mathrm{E}+02$ & $1.88 \mathrm{E}+02$ & $1<0.019$ & $<0.012$ & $8.85 \mathrm{E}-01$ \\
\hline & Residual & $5.06 \mathrm{E}-01$ & $7.50 \mathrm{E}+01$ & $5.63 E+04$ & $8.09 \mathrm{E}+02$ & $3.47 \mathrm{E}+02$ & $9.82 \mathrm{E}+00$ & 1.19E+02 & $3.96 \mathrm{E}+01$ \\
\hline & Exchangeable & $5.19 \mathrm{E}-01$ & $7.50 \mathrm{E}+01$ & $3.23 \mathrm{E}+02$ & 3.06E+01 & $1.77 \mathrm{E}+01$ & $<<0.019$ & $4.87 \mathrm{E}+00$ & $5.22 \mathrm{E}+00$ \\
\hline & Carbonate & $5.19 \mathrm{E}-01$ & $7.50 \mathrm{E}+01$ & $3.23 \mathrm{E}+02$ & $2.57 \mathrm{E}+01$ & 4. $22 \mathrm{E}+01$ & $1<0.019$ & $2.83 \mathrm{E}+00$ & $3.19 \mathrm{E}+00$ \\
\hline & $\mathrm{Fe}$, Mn Oxides & $5.19 \mathrm{E}-01$ & $7.50 \mathrm{E}+01$ & $7.34 E+02$ & $1.73 \mathrm{E}+02$ & $6.18 \mathrm{E}+01$ & $1<0.019$ & $6.55 \mathrm{E}+00$ & $1.24 E+00$ \\
\hline & Organic Matter & $5.19 \mathrm{E}-01$ & $7.50 \mathrm{E}+01$ & $6.67 \mathrm{E}+02$ & $8.45 \mathrm{E}+01$ & $1.70 \mathrm{E}+02$ & $1<0.019$ & $3.01 \mathrm{E}+00$ & $7.96 \mathrm{E}-01$ \\
\hline & Residual & $5.19 \mathrm{E}-0]$ & $7.50 \mathrm{E}+01$ & $6.53 E+04$ & $2.31 \mathrm{E}+02$ & $3.53 \mathbf{E}+02$ & $1.04 \mathrm{E}+01$ & $1.32 \mathrm{E}+02$ & $5.34 E+01$ \\
\hline Core ID & Extraction & Wt (g) & Depth $(\mathrm{cm})$ & Al & $\mathbf{A g}$ & As & $\mathrm{Au}$ & B & $\mathbf{B a}$ \\
\hline Core $\mathbf{S 3}$ & Exchangeable & $6.10 \mathrm{E}-01$ & $2.50 \mathrm{E}+01$ & $4.33 \mathrm{E}+02$ & $7.72 \mathrm{E}+02$ & $1.39 \mathrm{E}+01$ & $<<0.019$ & $6.46 \mathrm{E}+00$ & $8.94 E+00$ \\
\hline & Exchangeable & $6.10 \mathrm{E}-01$ & $2.50 \mathrm{E}+01$ & $3.44 \mathrm{E}+02$ & $6.21 \mathrm{E}+02$ & $<0.124$ & $1<0.019$ & $2.83 \mathrm{E}+00$ & $3.89 \mathrm{E}+00$ \\
\hline & Carbonate & 6. $10 \mathrm{E}-01$ & $2.50 \mathrm{E}+01$ & $2.21 \mathrm{E}+02$ & $6.94 \mathrm{E}+01$ & $2.93 \mathrm{E}+01$ & $: \quad<0.019$ & $4.69 \mathrm{E}+00$ & $2.21 \mathrm{E}+\infty 0$ \\
\hline & Carbonate & 6. $10 \mathrm{E}-01$ & $2.50 \mathrm{E}+01$ & $2.89 E+02$ & $<0.014$ & 4. $12 \mathrm{E}+01$ & $1<0.019$ & $4.34 \mathrm{E}+00$ & $9.73 \mathrm{E}-01$ \\
\hline & $\mathrm{Fe}, \mathrm{Mn}$ Oxides & 6.10E-01 & $2.50 \mathrm{E}+01$ & $7.05 \mathrm{E}+02$ & $2.06 \mathrm{E}+01$ & $1.54 \mathrm{E}+02$ & $: \quad<0.019$ & $7.70 \mathrm{E}+\infty 0$ & $1.06 E+\infty 0$ \\
\hline & Fe, Mn Oxides & $6.10 \mathrm{E}-01$ & $2.50 \mathrm{E}+01$ & $3.44 E+02$ & $1.65 \mathrm{E}+01$ & $3.34 \mathrm{E}+01$ & $1<0.019$ & $5.13 E+00$ & 8.8SE-01 \\
\hline & Organic Matter & 6. $10 \mathrm{E}-01$ & $2.50 \mathrm{E}+01$ & $1.64 \mathrm{E}+03$ & $1.70 \mathrm{E}+02$ & $3.25 E+02$ & $<\quad<0.019$ & $5.66 \mathrm{E}+00$ & $1.24 \mathrm{E}+00$ \\
\hline & Organic Matter & $6.10 \mathrm{E}-01$ & $2.50 \mathrm{E}+01$ & $6.01 E+02$ & $2.79 \mathrm{E}+02$ & $7.59 \mathrm{E}+01$ & $1<0.019$ & $2.30 \mathrm{E}+00$ & $7.08 \mathrm{E}-01$ \\
\hline & Exchangeable & $5.58 \mathrm{E}-01$ & $2.50 \mathrm{E}+01$ & $3.61 \mathrm{E}+01$ & $<0.014$ & $<0.124$ & $1<0.019$ & $4.34 \mathrm{E}+00$ & $9.03 \mathrm{E}+00$ \\
\hline & Carbonate & $5.58 \mathrm{E}-01$ & $2.50 \mathrm{E}+01$ & $1.37 E+02$ & $1.58 \mathrm{E}+01$ & $5.37 \mathrm{E}+01$ & $1<0.019$ & $2.21 \mathrm{E}+00$ & $4.69 \mathrm{E}+00$ \\
\hline & Fe, Mn Oxides & $5.58 \mathrm{E}-01$ & $2.50 \mathrm{E}+01$ & $1.18 E+03$ & $5.21 \mathrm{IE}+01$ & $3.01 \mathrm{E}+02$ & $1 \quad<0.019$ & $9.56 \mathrm{E}+00$ & $2.65 \mathrm{E}+00$ \\
\hline & Organic Matter & $5.58 \mathrm{E}-01$ & $2.50 \mathrm{E}+01$ & $7.04 \mathrm{E}+02$ & $1.32 \mathrm{E}+02$ & $1.54 E+02$ & $1<0.019$ & $<0.012$ & $9.73 \mathrm{E}-01$ \\
\hline & Residual & $5.58 \mathrm{E}-01$ & $2.50 \mathrm{E}+01$ & 4. $57 \mathrm{E}+04$ & $1.05 E+03$ & $2.26 \mathrm{E}+02$ & $5.75 E+00$ & $1.04 \mathrm{E}+02$ & $3.80 \mathrm{E}+01$ \\
\hline & Exchangeable & $6.55 \mathrm{E}-01$ & $5.00 \mathrm{E}+01$ & $1.67 \mathrm{E}+02$ & $5.04 \mathrm{E}+01$ & $1.37 \mathrm{E}+01$ & $1<0.019$ & $7.34 \mathrm{E}+00$ & $4.07 \mathrm{E}+00$ \\
\hline & Carbonate & $6.55 \mathrm{E}-01$ & $5.00 \mathrm{E}+01$ & $3.76 E+02$ & $<0.014$ & $7.15 \mathrm{E}+01$ & $1<0.019$ & $2.57 \mathrm{E}+\infty 0$ & $1.06 E+00$ \\
\hline & Fe, Mn Oxides & $6.55 \mathrm{E}-01$ & $5.00 \mathrm{E}+01$ & $6.94 \mathrm{E}+02$ & $1.37 \mathrm{E}+02$ & $9.03 E+01$ & $1<0.019$ & $5.66 \mathrm{E}+00$ & $1.15 E+00$ \\
\hline & Organic Matter & $6.55 \mathrm{E}-01$ & $5.00 \mathrm{E}+01$ & $6.09 E+02$ & $1.19 \mathrm{E}+02$ & $2.04 \mathrm{E}+02$ & $1<0.019$ & $3.36 \mathrm{E}+00$ & $8.85 \mathrm{E}-01$ \\
\hline
\end{tabular}




\begin{tabular}{|c|c|c|c|c|c|c|c|c|c|}
\hline & Residual & 6.55E-01 & $5.00 \mathrm{E}+01$ & $4.22 \mathrm{E}+04$ & $1.83 \mathrm{E}+02$ & 4. $52 \mathrm{E}+02$ & $5.75 E+00$ & $1.20 \mathrm{E}+02$ & $1.50 \mathrm{E}+01$ \\
\hline & Exchangeable & $7.98 \mathrm{E}-01$ & $5.00 \mathrm{E}+01$ & $2.04 \mathrm{E}+02$ & $7.62 \mathrm{E}+01$ & $<0.124$ & $1<0.019$ & $3.72 \mathrm{E}+00$ & $3.54 \mathrm{E}+\infty 0$ \\
\hline & Exchangeable & $7.98 \mathrm{E}-01$ & $5.00 \mathrm{E}+01$ & $2.38 \mathrm{E}+02$ & $1.42 \mathrm{E}+02$ & $1.22 \mathrm{E}+01$ & $1<0.019$ & $3.27 \mathrm{E}+00$ & $1.15 E+00$ \\
\hline & Carbonate & 7.98E-01 & $5.00 E+01$ & $2.71 \mathrm{E}+02$ & $2.04 E+0 I$ & $3.50 \mathrm{E}+01$ & $1<0.019$ & $4.51 E+00$ & $7.08 \mathrm{E}-01$ \\
\hline & Carbonate & $7.98 \mathrm{E}-01$ & $5.00 \mathrm{E}+01$ & $3.40 \mathrm{E}+02$ & $4.73 \mathrm{E}+01$ & $8.27 E+01$ & $1<0.019$ & $4.96 E+00$ & $5.31 \mathrm{E}-01$ \\
\hline & Fe, Mn Oxides & $7.98 \mathrm{E}-01$ & $5.00 E+01$ & $4.32 \mathrm{E}+02$ & $6.33 \mathrm{E}+01$ & $4.21 \mathrm{E}+01$ & $1<0.019$ & $5.13 \mathrm{E}+00$ & $5.31 \mathrm{E}-01$ \\
\hline & Fe, Mn Oxides & 7.98E-01 & $5.00 E+01$ & $3.26 \mathrm{E}+02$ & $6.82 \mathrm{E}+01$ & $<0.124$ & : $\quad<0.019$ & $5.22 \mathrm{E}+\infty 0$ & $6.19 \mathrm{E}-01$ \\
\hline & Organic Matter & $7.98 \mathrm{E}-01$ & $5.00 \mathrm{E}+01$ & $9.46 \mathrm{E}+02$ & $2.25 E+02$ & $5.15 \mathrm{E}+02$ & $1<0.019$ & $4.78 \mathrm{E}+\infty 0$ & $5.31 \mathrm{E}-01$ \\
\hline & Organic Matter & $7.98 \mathrm{E}-01$ & $5.00 \mathrm{E}+01$ & $3.45 E+02$ & $2.92 E+02$ & $4.81 E+01$ & $1<0.019$ & $2.48 \mathrm{E}+\infty 0$ & $1.77 \mathrm{E}-01$ \\
\hline & Residual & $7.98 \mathrm{E}-01$ & $5.00 \mathrm{E}+01$ & $2.76 \mathrm{E}+04$ & $2.08 \mathrm{E}+02$ & $5.06 E+01$ & $6.19 \mathrm{E}+00$ & $1.03 E+02$ & $1.34 \mathrm{E}+01$ \\
\hline & Exchangeable & $1.25 E+00$ & $7.50 \mathrm{E}+01$ & $1.92 E+01$ & $<0.014$ & $1.38 \mathrm{E}+02$ & $i<0.019$ & $7.26 \mathrm{E}+\infty 0$ & $2.42 E+01$ \\
\hline & Carbonate & $1.25 E+00$ & $7.50 \mathrm{E}+01$ & 4.01E+01 & $<0.014$ & $4.11 E+02$ & $1<0.019$ & $5.40 E+00$ & $1.46 \mathrm{E}+01$ \\
\hline & Fe, Mn Oxides & $1.25 E+00$ & $7.50 \mathrm{E}+01$ & $2.03 E+03$ & $5.04 E+00$ & $2.70 \mathrm{E}+02$ & $1<0.019$ & $5.75 E+00$ & $1.08 E+01$ \\
\hline & Organic Matter & $1.25 \mathrm{E}+00$ & $7.50 \mathrm{E}+01$ & $2.45 E+03$ & $2.77 E+01$ & $9.20 \mathrm{E}+02$ & $1<0.019$ & $7.70 \mathrm{E}+00$ & $5.22 E+00$ \\
\hline & Residual & $1.25 E+00$ & $7.50 \mathrm{E}+01$ & $1.84 E+04$ & $2.19 E+03$ & 8.05E+02 & $8.23 E+00$ & $8.37 E+01$ & $4.61 \mathrm{E}+01$ \\
\hline & Exchangeable & $1.01 \mathrm{E}+00$ & $7.50 \mathrm{E}+01$ & $2.14 \mathrm{E}+01$ & $4.80 \mathrm{E}+01$ & $2.09 E+01$ & $1<0.019$ & $3.36 \mathrm{E}+00$ & $1.73 \mathrm{E}+01$ \\
\hline & Exchangeable & $1.01 \mathrm{E}+00$ & $7.50 \mathrm{E}+01$ & $1.48 \mathrm{E}+0 \mathrm{I}$ & $5.12 \mathrm{E}+01$ & $2.79 \mathrm{E}+01$ & $1<0.019$ & $2.83 \mathrm{E}+00$ & $7.34 \mathrm{E}+00$ \\
\hline & Carbonate & $1.01 E+\infty$ & $7.50 \mathrm{E}+01$ & $1.54 E+02$ & $<0.014$ & $9.11 \mathrm{E}+01$ & $1<0.019$ & $3.27 \mathrm{E}+00$ & $6.81 E+00$ \\
\hline & Carbonate & $1.01 E+00$ & $7.50 \mathrm{E}+01$ & $2.77 \mathrm{E}+02$ & $<0.014$ & $2.76 \mathrm{E}+02$ & $1<0.019$ & $6.72 \mathrm{E}+00$ & $2.12 E+00$ \\
\hline & $\mathrm{Fe}, \mathrm{Mn}$ Oxides & $1.01 E+00$ & $7.50 \mathrm{E}+01$ & $1.59 \mathrm{E}+03$ & $<0.014$ & $4.74 E+02$ & $1<0.019$ & $1.17 \mathrm{E}+01$ & $2.39 \mathrm{E}+00$ \\
\hline & $\mathrm{Fe}, \mathrm{Mn}$ Oxides & $1.01 \mathrm{E}+00$ & $7.50 \mathrm{E}+01$ & $4.47 \mathrm{E}+02$ & $1.07 E+01$ & $9.56 \mathrm{E}+01$ & $1<0.019$ & $8.32 E+00$ & $9.73 \mathrm{E}-01$ \\
\hline & Organic Matter & $1.01 \mathrm{E}+\infty 0$ & $7.50 \mathrm{E}+01$ & $1.79 \mathrm{E}+03$ & $1.05 \mathrm{E}+02$ & $7.57 \mathrm{E}+02$ & $1<0.019$ & $4.51 \mathrm{E}+00$ & $1.68 E+00$ \\
\hline & Organic Matter & $1.01 E+00$ & $7.50 \mathrm{E}+01$ & $6.35 \mathrm{E}+02$ & $288 \mathrm{E}+02$ & $2.27 \mathrm{E}+02$ & $1<0.019$ & $5.22 \mathrm{E}+00$ & 7.96E-01 \\
\hline & Residual & $1.01 E+\infty 0$ & $7.50 E+01$ & $3.37 \mathrm{E}+04$ & $3.00 \mathrm{E}+03$ & $2.67 \mathrm{E}+03$ & $1.06 \mathrm{E}+01$ & $1.50 \mathrm{E}+02$ & $4.79 \mathrm{E}+01$ \\
\hline Core ID & Extraction & $W_{t}(g)$ & Depth $(\mathrm{cm})$ & $\mathbf{A} \mathbf{I}$ & $\mathbf{A g}_{\mathbf{g}}$ & $A_{3}$ & 1. $\quad \mathbf{A u}_{\mathbf{u}}$ & B & Ba \\
\hline \multirow[t]{40}{*}{ Core S4 } & Exchangeable & $7.25 \mathrm{E}-01$ & $2.50 \mathrm{E}+01$ & $1.97 \mathrm{E}+02$ & $2.01 \mathrm{E}+02$ & $<0.124$ & $1<0.019$ & $8.76 E+00$ & $3.36 \mathrm{E}+00$ \\
\hline & Carbonate & 7.25E-01 & $2.50 \mathrm{E}+01$ & $3.74 E+02$ & $3.73 \mathrm{E}+01$ & $7.32 \mathrm{E}+01$ & $1<0.019$ & $9.03 \mathbf{E}+00$ & $2.83 E+00$ \\
\hline & Fe, Mn Oxides & 7.25E-01 & $2.50 \mathrm{E}+01$ & 4. $14 \mathrm{E}+02$ & $2.89 \mathrm{E}+01$ & $4.16 \mathrm{E}+0 !$ & $1<0.019$ & $6.37 \mathrm{E}+00$ & 8.85E-01 \\
\hline & Organic Matter & 7.25E-01 & 2.50E+01 & $2.78 E+02$ & $5.59 \mathrm{E}+01$ & $1.23 E+02$ & $1<0.019$ & $2.83 E+00$ & $3.54 \mathrm{E}-01$ \\
\hline & Residual & 7.25E.01 & $2.50 \mathrm{E}+01$ & $3.93 \mathrm{E}+04$ & $1.85 E+02$ & $2.50 \mathrm{E}+02$ & $7.96 \mathrm{E}+00$ & $1.26 \mathrm{E}+02$ & $1.31 \mathrm{E}+01$ \\
\hline & Exchangeable & $4.99 \mathrm{E} \cdot 01$ & $2.50 \mathrm{E}+01$ & $2.93 E+02$ & $3.22 \mathrm{E}+02$ & $<0.124$ & $<0.019$ & $7.26 \mathrm{E}+00$ & $3.36 \mathrm{E}+00$ \\
\hline & Carbonate & $4.99 \mathrm{E}-01$ & $2.50 \mathrm{E}+01$ & $6.01 E+02$ & $3.86 E+01$ & $8.01 E+01$ & $<0.019$ & $6.19 \mathrm{E}+00$ & $2.92 \mathrm{E}+00$ \\
\hline & Fe, Mn Oxides & 4.99E-01 & $2.50 \mathrm{E}+01$ & $6.74 E+02$ & $3.69 E+01$ & $4.02 E+01$ & $1<0.019$ & $2.92 \mathrm{E}+00$ & $7.96 \mathrm{E}-01$ \\
\hline & Organic Matter & $4.99 \mathrm{E}-01$ & $2.50 \mathrm{E}+01$ & $6.42 E+02$ & $7.81 E+01$ & $1.01 E+02$ & $1<0.019$ & $2.83 \mathrm{E}+00$ & $3.54 \mathrm{E}-01$ \\
\hline & Residual & $4.99 \mathrm{E}-01$ & $2.50 \mathrm{E}+01$ & $6.64 E+04$ & $3.48 \mathrm{E}+01$ & $3.08 \mathrm{E}+02$ & $9.56 \mathrm{E}+00$ & $1.39 \mathrm{E}+02$ & $1.77 E+01$ \\
\hline & Exchangeable & $5.63 \mathrm{E}-01$ & $5.00 \mathrm{E}+01$ & $1.81 E+02$ & $1.10 \mathrm{E}+02$ & $1.92 E+01$ & $1<0.019$ & $1.27 \mathrm{E}+01$ & $2.57 \mathrm{E}+00$ \\
\hline & Carbonate & $5.63 \mathrm{E}-01$ & $5.00 \mathrm{E}+01$ & $6.57 E+02$ & $1.50 \mathrm{E}+02$ & $6.28 \mathrm{E}+01$ & $:<0.019$ & $3.89 \mathrm{E}+00$ & $2.39 \mathrm{E}+00$ \\
\hline & Fe, Mn Oxides & 5. 63E-01 & $5.00 \mathrm{E}+01$ & $6.17 \mathrm{E}+02$ & $8.94 \mathrm{E}+01$ & $3.77 \mathrm{E}+01$ & $:<0.019$ & $2.74 \mathrm{E}+00$ & $1.15 \mathrm{E}+00$ \\
\hline & Organic Matter & $5.63 \mathrm{E}-01$ & $5.00 E+01$ & $6.42 E+02$ & $1.39 E+02$ & $2.04 \mathrm{E}+02$ & $1<0.019$ & $1.86 \mathrm{E}+00$ & $4.42 \mathrm{E}-01$ \\
\hline & Residual & $5.63 \mathrm{E}-01$ & $5.00 E+01$ & $5.11 \mathrm{E}+04$ & $5.24 E+02$ & $3.10 \mathrm{E}+02$ & $1.00 E+01$ & $1.24 E+02$ & $1.58 \mathrm{E}+01$ \\
\hline & Exchangeable & $4.89 \mathrm{E}-01$ & $5.00 \mathrm{E}+01$ & $4.58 \mathrm{E}+02$ & $1.89 E+02$ & $3.13 E+01$ & $1<0.019$ & $8.14 E+00$ & $2.74 E+00$ \\
\hline & Carbonate & $4.89 \mathrm{E}-01$ & $5.00 \mathrm{E}+01$ & $5.58 \mathrm{E}+02$ & $8.39 E+01$ & $5.94 \mathrm{E}+01$ & $1<0.019$ & 4. $.07 \mathrm{E}+00$ & $1.95 \mathrm{E}+00$ \\
\hline & Fe, Mn Oxides & $4.89 \mathrm{E}-01$ & $5.00 \mathrm{E}+01$ & $7.01 \mathrm{E}+02$ & $8.30 \mathrm{E}+01$ & $2.97 \mathrm{E}+01$ & $1<0.019$ & $5.13 E+00$ & $9.73 \mathrm{E}-01$ \\
\hline & Organic Matter & $4.89 \mathrm{E}-01$ & $5.00 E+01$ & $5.30 \mathrm{E}+02$ & $9.38 \mathrm{E}+01$ & $2.25 \mathrm{E}+02$ & $1<0.019$ & $2.39 \mathrm{E}+00$ & $4.42 \mathrm{E}-01$ \\
\hline & Residual & $4.89 \mathrm{E}-01$ & $5.00 \mathrm{E}+01$ & $5.86 \mathrm{E}+04$ & $<0.014$ & $5.75 \mathrm{E}+02$ & $7.61 \mathrm{E}+00$ & $1.18 \mathrm{E}+02$ & $1.97 \mathrm{E}+01$ \\
\hline & Exchangeable & $5.63 \mathrm{E}-01$ & $7.50 \mathrm{E}+01$ & $1.96 \mathrm{E}+02$ & $3.71 E+02$ & $1.22 \mathrm{E}+01$ & $1<0.019$ & $4.25 \mathrm{E}+00$ & $4.42 \mathrm{E}+\infty 0$ \\
\hline & Carbonate & $5.63 \mathrm{E}-01$ & $7.50 \mathrm{E}+01$ & $6.04 E+02$ & $2.23 \mathrm{E}+02$ & 5. $19 E+01$ & $1<0.019$ & $3.10 \mathrm{E}+00$ & $1.95 \mathrm{E}+00$ \\
\hline & Fe, Mn Oxides & $5.63 \mathrm{E}-01$ & $7.50 \mathrm{E}+01$ & $5.84 E+02$ & $1.25 E+02$ & $2.60 \mathrm{E}+01$ & $1<0.019$ & $9.20 \mathrm{E}+00$ & $1.15 E+00$ \\
\hline & Organic Matter & $5.63 \mathrm{E}-01$ & $7.50 \mathrm{E}+01$ & $5.55 \mathrm{E}+02$ & $2.35 E+02$ & $1.35 \mathrm{E}+02$ & $1<0.019$ & $2.57 \mathrm{E}+00$ & $4.51 E+00$ \\
\hline & Residual & $5.63 E_{-01}$ & $7.50 \mathrm{E}+01$ & $4.67 E+04$ & $<0.014$ & $2.27 E+02$ & $1.04 \mathrm{E}+01$ & $1.42 E+02$ & $2.48 \mathrm{E}+01$ \\
\hline & Exchangeable & 5.27E-01 & $7.50 \mathrm{E}+01$ & $1.01 \mathrm{E}+02$ & $3.19 \mathrm{E}+02$ & $<0.124$ & $1<0.019$ & $4.42 \mathrm{E}+00$ & $4.25 \mathrm{E}+\infty 0$ \\
\hline & Carbonate & $5.27 \mathrm{E}-01$ & $7.50 \mathrm{E}+01$ & $4.77 E+02$ & $1.04 E+02$ & $4.73 \mathrm{E}+01$ & $1<0.019$ & $3.10 \mathrm{E}+00$ & $1.68 \mathrm{E}+\infty$ \\
\hline & Fe, Mn Oxides & $5.27 \mathrm{E}-01$ & $7.50 \mathrm{E}+01$ & $6.71 E+02$ & $9.82 \mathrm{E}+01$ & $2.34 E+01$ & $1<0.019$ & $1.00 \mathrm{E}+01$ & $1.33 \mathrm{E}+00$ \\
\hline & Organic Matter & $5.27 \mathrm{E}-01$ & $7.50 \mathrm{E}+01$ & $3.01 \mathrm{E}+02$ & $2.49 \mathrm{E}+02$ & $9.38 \mathrm{E}+01$ & $1<0.019$ & $5.75 E+\infty 0$ & 5.31E-01 \\
\hline & Residual & $5.27 \mathrm{E}-01$ & $7.50 \mathrm{E}+01$ & $5.88 \mathrm{E}+04$ & $2.12 \mathrm{E}+03$ & $3.80 \mathrm{E}+02$ & $9.38 \mathrm{E}+00$ & $1.27 \mathrm{E}+02$ & $2.58 \mathrm{E}+01$ \\
\hline & Exchangeable & $5.45 \mathrm{E}-01$ & $1.00 \mathrm{E}+02$ & $2.45 E+02$ & $2.56 \mathrm{E}+02$ & $3.72 \mathrm{E}+01$ & $1<0.019$ & $1.36 \mathrm{E}+01$ & $2.04 \mathrm{E}+00$ \\
\hline & Carbonate & $5.45 \mathrm{E}-01$ & $1.00 \mathrm{E}+02$ & $7.15 E+02$ & $1.92 \mathrm{E}+02$ & $1.01 E+02$ & $1<0.019$ & $<0.012$ & $2.04 E+00$ \\
\hline & Fe. Mn Oxides & $5.45 \mathrm{E}-01$ & $1.00 \mathrm{E}+02$ & $7.08 \mathrm{E}+02$ & $1.96 \mathrm{E}+02$ & $4.41 E+01$ & $1<0.019$ & $6.02 \mathrm{E}+00$ & $1.15 \mathrm{E}+00$ \\
\hline & Organic Matter & $5.45 \mathrm{E}-01$ & $1.00 \mathrm{E}+02$ & $1.95 \mathrm{E}+02$ & $9.91 E+02$ & 2.12E+02 & $1<0.019$ & $2.48 \mathrm{E}+00$ & $2.65 \mathrm{E}-01$ \\
\hline & Residual & 5.45E-01 & $1.00 \mathrm{E}+02$ & $4.95 \mathrm{E}+04$ & $<0.014$ & $5.06 E+02$ & $1.07 E+01$ & $1.38 \mathrm{E}+02$ & $3.42 \mathrm{E}+01$ \\
\hline & Exchangeable & $5.40 \mathrm{E}-01$ & $1.00 \mathrm{E}+02$ & $2.62 \mathrm{E}+02$ & $2.18 \mathrm{E}+02$ & $3.32 \mathrm{E}+01$ & $1<0.019$ & $5.49 \mathrm{E}+00$ & $2.04 E+00$ \\
\hline & Carbonate & $5.40 \mathrm{E}-01$ & $1.00 \mathrm{E}+02$ & $5.14 \mathrm{E}+02$ & $1.08 \mathrm{E}+02$ & $7.59 \mathrm{E}+01$ & $1<0.019$ & $4.16 \mathrm{E}+00$ & $1.68 \mathrm{E}+00$ \\
\hline & Fe, Mn Oxides & $5.40 \mathrm{E}-01$ & $1.00 \mathrm{E}+02$ & $6.88 \mathrm{E}+02$ & $5.65 \mathrm{E}+01$ & $3.48 \mathrm{E}+01$ & $1<0.019$ & $9.82 \mathrm{E}+00$ & $1.15 \mathrm{E}+\infty$ \\
\hline & Organic Matter & $5.40 E-0 !$ & $1.00 \mathrm{E}+02$ & $4.95 \mathrm{E}+02$ & $1.02 \mathrm{E}+02$ & $1.30 \mathrm{E}+02$ & $1<0.019$ & $<0.012$ & $3.54 \mathrm{E}-01$ \\
\hline & Residual & $5.40 \mathrm{E}-01$ & $1.00 \mathrm{E}+02$ & $5.95 E+04$ & $3.95 E+01$ & $3.46 E+02$ & $8.94 \mathrm{E}+00$ & $1.31 \mathrm{E}+02$ & $3.40 \mathrm{E}+01$ \\
\hline Core ID & Extraction & $w_{t}(\mathrm{~g})$ & Depth $(\mathrm{cm})$ & A! & $\mathbf{A}_{\mathbf{R}}$ & As & An & B & Ba \\
\hline \multirow[t]{19}{*}{ Core S5 } & Exchangeable & 6.49E-01 & $2.50 \mathrm{E}+01$ & $2.08 E+02$ & $1.73 \mathrm{E}+02$ & $2.42 \mathrm{E}+01$ & $1<0.019$ & $6.28 \mathrm{E}+00$ & $4.34 E+00$ \\
\hline & Carbonate & $6.49 \mathrm{E}-01$ & $2.50 \mathrm{E}+01$ & $2.89 \mathrm{E}+02$ & $1.68 \mathrm{E}+00$ & $9.03 \mathbf{E}+01$ & $1<0.019$ & $5.84 \mathrm{E}+00$ & $3.27 \mathrm{E}+00$ \\
\hline & Fe, Mn Oxides & $6.49 \mathrm{E}-01$ & $2.50 \mathrm{E}+0 \mathrm{I}$ & $4.24 \mathrm{E}+02$ & $3.32 E+01$ & $5.23 \mathrm{E}+01$ & $: \quad<0.019$ & $2.74 E+00$ & $1.42 \mathrm{E}+00$ \\
\hline & Organic Matter & $6.49 \mathrm{E}-01$ & $2.50 \mathrm{E}+01$ & $8.01 E+02$ & $1.80 \mathrm{E}+02$ & $2.47 \mathrm{E}+02$ & $1<0.019$ & $1.06 \mathrm{E}+00$ & $6.19 \mathrm{E}-01$ \\
\hline & Residual & $6.49 \mathrm{E}-01$ & $2.50 \mathrm{E}+01$ & $4.78 \mathrm{E}+04$ & $4.57 E+02$ & $5.99 \mathrm{E}+02$ & $8.05 E+00$ & $1.27 \mathrm{E}+02$ & $257 \mathrm{E}+01$ \\
\hline & Exchangeable & $5.99 \mathrm{E}-01$ & $2.50 \mathrm{E}+0 \mathrm{I}$ & $1.98 \mathrm{E}+02$ & $1.48 \mathrm{E}+02$ & $3.50 \mathrm{E}+01$ & $1 \quad<0.019$ & $9,56 \mathrm{E}+00$ & $4.78 \mathrm{E}+00$ \\
\hline & Carbonate & $5.99 \mathrm{E}-01$ & $2.50 \mathrm{E}+01$ & $2.77 \mathrm{E}+02$ & $3.36 \mathrm{E}+00$ & $8.20 \mathrm{E}+01$ & $1<0.019$ & $6.02 \mathbf{E}+00$ & $2.83 \mathrm{E}+00$ \\
\hline & Fe, Mn Oxides & $5.99 E-01$ & $2.50 \mathrm{E}+01$ & $4.46 \mathrm{E}+02$ & $1.23 E+01$ & $6.08 \mathrm{E}+01$ & $: \quad<0.019$ & $6.19 \mathrm{E}+00$ & $1.59 \mathrm{E}+00$ \\
\hline & Organic Matter & $5,99 \mathrm{E}-01$ & $2.50 \mathrm{E}+01$ & $6.19 E+02$ & $1.24 E+02$ & $2.96 \mathrm{E}+02$ & $<0.019$ & 40.012 & $1.06 \mathrm{E}+00$ \\
\hline & Residual & $5.99 \mathrm{E}-01$ & $2.50 \mathrm{E}+01$ & $5.26 \mathrm{E}+04$ & $<0.014$ & $6.63 E+02$ & $1.02 E+01$ & $1.38 \mathrm{E}+02$ & $2.93 E+01$ \\
\hline & Exchangeable & $6.49 \mathrm{E}-01$ & $5.00 E+01$ & $2.22 \mathrm{E}+02$ & $1.16 \mathrm{E}+02$ & $2.80 \mathrm{E}+01$ & $1<0.019$ & $3.10 \mathrm{E}+00$ & $2.74 \mathrm{E}+00$ \\
\hline & Carbonate & $6.49 \mathrm{E}-01$ & $5.00 \mathrm{E}+01$ & $3.78 \mathrm{E}+02$ & $6.49 \mathrm{E}+01$ & $9.56 \mathrm{E}+01$ & $<0.019$ & $3.89 \mathrm{E}+00$ & $2.48 \mathrm{E}+00$ \\
\hline & Fe, Mn Oxides & $6.49 \mathrm{E}-01$ & $5.00 \mathrm{E}+01$ & $4.74 E+02$ & $6.29 \mathrm{E}+01$ & $4.19 E+01$ & $<0.019$ & $4.07 \mathrm{E}+00$ & $8.85 \mathrm{E}-01$ \\
\hline & Organic Matter & $6.49 \mathrm{E}-01$ & $5.00 \mathrm{E}+01$ & $5.40 \mathrm{E}+02$ & $1.37 \mathrm{E}+02$ & $4.51 E+02$ & $<0.019$ & $<0.012$ & $4.42 \mathrm{E}-01$ \\
\hline & Exchangeable & $6.73 E-01$ & $5.00 \mathrm{E}+01$ & $1.74 \mathrm{E}+02$ & $9.56 \mathrm{E}+01$ & $2.61 \mathrm{E}+01$ & $<0.019$ & $3.80 \mathrm{E}+00$ & $3.10 \mathrm{E}+00$ \\
\hline & Carbonate & $6.73 \mathrm{E}-01$ & $5.00 \mathrm{E}+01$ & $3.25 \mathrm{E}+02$ & $6.23 \mathrm{E}+01$ & $1.02 \mathrm{E}+02$ & $<0.019$ & $2.83 \mathrm{E}+00$ & $2.21 \mathrm{E}+00$ \\
\hline & $\mathrm{Fe}, \mathrm{Mn}$ Oxides & $6.73 \mathrm{E}-01$ & $5.00 \mathrm{E}+01$ & $5.16 \mathrm{E}+02$ & $4.95 \mathrm{E}+01$ & $3.92 \mathrm{E}+01$ & $<0.019$ & $5.75 \mathrm{E}+00$ & $8.85 \mathrm{E}-01$ \\
\hline & Organic Matter & $6.73 \mathrm{E}-01$ & $5.00 \mathrm{E}+01$ & $3.77 \mathrm{E}+02$ & $4.28 \mathrm{E}+01$ & $3.73 E+02$ & $<0.019$ & $5.84 E+00$ & 3.54E-01 \\
\hline & Residual & $6.73 \mathrm{E}-01$ & $5.00 \mathrm{E}+01$ & $4.25 \mathrm{E}+04$ & $<0.014$ & $1.11 \mathrm{E}+03$ & $1.03 E+01$ & $1.48 \mathrm{E}+02$ & $1.52 \mathrm{E}+01$ \\
\hline
\end{tabular}




\begin{tabular}{|c|c|c|c|c|c|c|c|c|c|}
\hline & Exchangeable & $6.72 \mathrm{E}-01$ & $7.50 E+01$ & $1.63 \mathrm{E}+02$ & $5.22 \mathrm{E}+02$ & $<0.124$ & $<0.019$ & $9.03 \mathrm{E}+00$ & $3.19 E+00$ \\
\hline & Carbonate & $6.72 \mathrm{E}-01$ & $7.50 \mathrm{E}+01$ & $3.15 \mathrm{E}+02$ & $5.43 E+01$ & $4.83 \mathrm{E}+01$ & $1<0.019$ & $3.01 E+00$ & $2.04 E+00$ \\
\hline & Fe, Mn Oxides & $6.72 \mathrm{E}-01$ & $7.50 \mathrm{E}+01$ & $3.76 \mathrm{E}+02$ & $5.26 \mathrm{E}+01$ & $2.59 \mathrm{E}+01$ & $<0.019$ & $5.57 \mathrm{E}+00$ & $7.96 \mathrm{E}-01$ \\
\hline & Organic Matter & $6.72 \mathrm{E}-01$ & $7.50 \mathrm{E}+01$ & $4.36 \mathrm{E}+02$ & $128 \mathrm{E}+02$ & $1.83 E+02$ & $<0.019$ & $3.89 \mathrm{E}+00$ & $5.31 \mathrm{E}-01$ \\
\hline & Residual & $6.72 \mathrm{E}-01$ & $7.50 \mathrm{E}+01$ & $3.83 E+04$ & $2.96 \mathrm{E}+02$ & $3.82 \mathrm{E}+02$ & $6.90 \mathrm{E}+00$ & $1.01 E+02$ & $2.24 \mathrm{E}+01$ \\
\hline & Exchangeable & $5.65 \mathrm{E}-01$ & $7.50 \mathrm{E}+01$ & $2.45 \mathrm{E}+02$ & $5.34 \mathrm{E}+02$ & $<0.124$ & $<0.019$ & $1.02 \mathrm{E}+01$ & $3.01 \mathrm{E}+00$ \\
\hline & Carbonate & 5.65E-01 & $7.50 \mathrm{E}+01$ & $5.35 E+02$ & $1.02 E+02$ & $5.19 \mathrm{E}+01$ & $<0.019$ & $3.80 \mathrm{E}+00$ & $2.30 E+00$ \\
\hline & $\mathrm{Fe}, \mathrm{Mn}$ Oxides & $5.65 \mathrm{E}-01$ & $7.50 \mathrm{E}+01$ & $4.60 \mathrm{E}+02$ & $4.84 \mathrm{E}+01$ & $2.83 E+01$ & $<0.019$ & $6.81 E+00$ & $8.85 \mathrm{E}-01$ \\
\hline & Organic Matter & $5.65 \mathrm{E}-01$ & $7.50 \mathrm{E}+01$ & $5.44 \mathrm{E}+02$ & $1.36 \mathrm{E}+02$ & $2.22 \mathrm{E}+02$ & $<<0.019$ & $<0.012$ & $4.42 \mathrm{E}-01$ \\
\hline & Residual & $5.65 \mathrm{E}-01$ & $7.50 \mathrm{E}+01$ & $5.13 E+04$ & $3.50 \mathrm{E}+01$ & $5.76 \mathrm{E}+02$ & $9.11 \mathrm{E}+00$ & $1.19 \mathrm{E}+02$ & $1.50 \mathrm{E}+01$ \\
\hline \multicolumn{10}{|c|}{ Total Digestions } \\
\hline$\frac{\text { Core ID }}{\text { Core SI }}$ & Extraction & Wt $(\mathrm{g})$ & $\frac{\text { Depth }(\mathrm{cm})}{2.50 \mathrm{E}+0 \mathrm{l}}$ & Al & $\mathbf{A}_{\mathbf{g}}$ & As & Au & B & B. \\
\hline \multirow[t]{6}{*}{ Core SI } & & $1.41 \mathrm{E}+00$ & $2.50 \mathrm{E}+0 \mathrm{I}$ & $3,41 E+04$ & $5.61 E+02$ & $2.11 \mathrm{E}+03$ & $1.55 \mathrm{E}+01$ & $1.83 \mathrm{E}+02$ & $3.83 \mathrm{E}+01$ \\
\hline & & 8.15E-01 & $2.50 \mathrm{E}+01$ & $7.20 \mathrm{E}+04$ & $6.77 \mathrm{E}+02$ & $3.15 \mathrm{E}+03$ & $2.92 \mathrm{E}+01$ & $3.73 E+02$ & $7.33 \mathrm{E}+01$ \\
\hline & & $1.23 E+00$ & $5.00 \mathrm{E}+01$ & $2.99 E+04$ & $4.33 \mathrm{E}+01$ & $1.32 E+03$ & $1.28 \mathrm{E}+01$ & $1.69 \mathrm{E}+02$ & $5.54 E+01$ \\
\hline & & $1.42 E+00$ & $5.00 \mathrm{E}+01$ & $2.51 E+04$ & $4.74 \mathrm{E}+02$ & $8.29 E+02$ & $1.23 \mathrm{E}+01$ & $1.40 \mathrm{E}+02$ & $4.96 E+01$ \\
\hline & & $5.44 \mathrm{E}-01$ & $7.50 \mathrm{E}+01$ & $6.92 E+04$ & $1.51 E+03$ & $1.56 \mathrm{E}+03$ & $2.32 \mathrm{E}+01$ & $3.91 E+02$ & $1.23 E+02$ \\
\hline & & $5.43 \mathrm{E} \cdot 01$ & $7.50 \mathrm{E}+01$ & $6.51 \mathrm{E}+04$ & $2.02 \mathrm{E}+03$ & $1.57 \mathrm{E}+03$ & $2.37 \mathrm{E}+01$ & $3.52 \mathrm{E}+02$ & $1.19 E+02$ \\
\hline \multirow[t]{6}{*}{ Core \$2 } & & $5.75 \mathrm{E}-01$ & $2.50 \mathrm{E}+01$ & $6.11 \mathrm{E}+04$ & $7.00 \mathrm{E}+02$ & $5.07 \mathrm{E}+02$ & $2.70 \mathrm{E}+01$ & $3.33 \mathrm{E}+02$ & $9.46 \mathrm{E}+01$ \\
\hline & & $4.79 \mathrm{E}-01$ & $2.50 \mathrm{E}+01$ & $7.67 \mathrm{E}+04$ & $1.71 E+03$ & $6.42 E+02$ & $3.81 E+01$ & $4.25 \mathrm{E}+02$ & $1.31 E+02$ \\
\hline & & 4.62E-01 & $5.00 \mathrm{E}+01$ & $7.16 \mathrm{E}+04$ & $3.05 E+03$ & $9.00 \mathrm{E}+02$ & $3.43 \mathrm{E}+01$ & $3.95 \mathrm{E}+02$ & 1. $15 \mathrm{E}+02$ \\
\hline & & $493 \mathrm{E}-01$ & $5.00 \mathrm{E}+01$ & $6.88 \mathrm{E}+04$ & $1.70 \mathrm{E}+02$ & $1.23 \mathrm{E}+03$ & $3.10 \mathrm{E}+01$ & $3.91 E+02$ & $1.03 E+02$ \\
\hline & & $5.06 \mathrm{E}-01$ & $7.50 \mathrm{E}+01$ & $6.67 \mathrm{E}+04$ & $2.52 E+03$ & $6.72 \mathrm{E}+02$ & 3. $18 \mathrm{E}+01$ & $3.83 E+02$ & $1.39 \mathrm{E}+02$ \\
\hline & & $5.19 \mathrm{E}-01$ & $7.50 \mathrm{E}+01$ & $6.36 \mathrm{E}+04$ & $3.54 \mathrm{E}+03$ & $7.34 \mathrm{E}+02$ & $2.62 \mathrm{E}+01$ & $3.56 \mathrm{E}+02$ & $1.37 \mathrm{E}+02$ \\
\hline \multirow[t]{7}{*}{ Core $\mathbf{S 3}$} & & $1.39 \mathrm{E}+00$ & $2.50 \mathrm{E}+01$ & $1.94 \mathrm{E}+04$ & $3.96 \mathrm{E}+02$ & $1.97 \mathrm{E}+02$ & $1.01 \mathrm{E}+01$ & $1.24 \mathrm{E}+02$ & $3.02 \bar{E}+01$ \\
\hline & & $1.39 \mathrm{E}+00$ & $2.50 \mathrm{E}+01$ & $2.42 \mathrm{E}+04$ & $2.26 \mathrm{E}+03$ & $4.88 \mathrm{E}+02$ & $8.62 E+00$ & $1.32 E+02$ & $5.07 E+01$ \\
\hline & & $1.44 \mathrm{E}+00$ & $2.50 \mathrm{E}+01$ & $2.32 \mathrm{E}+04$ & $1.58 \mathrm{E}+03$ & $3.81 \mathrm{E}+02$ & $9.87 \mathrm{E}+00$ & $1.32 \mathrm{E}+02$ & $5.00 \mathrm{E}+01$ \\
\hline & & $1.21 \mathrm{E}+\infty 0$ & $5.00 E+01$ & $2.89 \mathrm{E}+04$ & $4.22 \mathrm{E}+03$ & $9.41 E+02$ & $1.44 E+01$ & $1.65 E+02$ & $3.38 \mathrm{E}+01$ \\
\hline & & $1.39 E+\infty 0$ & $5.00 E+01$ & $2.34 E+04$ & $1.40 E+03$ & $8.00 \mathrm{E}+02$ & $9.52 E+00$ & $1.32 E+02$ & $2.04 \mathrm{E}+01$ \\
\hline & & $9.98 \mathrm{E}-01$ & $7.50 \mathrm{E}+01$ & $3.47 E+04$ & $2.08 \mathrm{E}+03$ & $3.07 \mathrm{E}+03$ & $1.30 E+01$ & $1.72 E+02$ & $9.19 \mathrm{E}+01$ \\
\hline & & $7.50 \mathrm{E}-01$ & $7.50 \mathrm{E}+01$ & $5.15 \mathrm{E}+04$ & $1.12 E+03$ & $3.91 \mathrm{E}+03$ & $2.05 E+01$ & $2.53 \mathrm{E}+02$ & $1.41 \mathrm{E}+02$ \\
\hline \multirow[t]{8}{*}{ Core S4 } & & $7.25 \mathrm{E}-01$ & $2.50 \mathrm{E}+01$ & $5.40 \mathrm{E}+04$ & $2.69 \mathrm{E}+03$ & $1.26 \mathrm{E}+03$ & $2.52 \mathrm{E}+01$ & $3.07 \mathrm{E}+02$ & $6.45 \mathrm{E}+01$ \\
\hline & & $7.25 \mathrm{E}-01$ & $2.50 \mathrm{E}+01$ & $4.42 \mathrm{E}+04$ & $2.42 \mathrm{E}+03$ & $1.07 \mathrm{E}+03$ & $1.95 E+01$ & $2.40 \mathrm{E}+02$ & $3.71 \mathrm{E}+01$ \\
\hline & & $5.63 \mathrm{E}-01$ & $5.00 \mathrm{E}+01$ & $5.53 \mathrm{E}+04$ & $3.84 \mathrm{E}+02$ & $2.80 E+03$ & $2.84 \mathrm{E}+01$ & $3.13 E+02$ & $4.80 \mathrm{E}+01$ \\
\hline & & $4.89 \mathrm{E}-01$ & $5.00 \mathrm{E}+01$ & $6.75 E+04$ & $4.73 \mathrm{E}+03$ & $3.17 \mathbf{E}+03$ & $2.76 \mathrm{E}+01$ & $3.84 \mathrm{E}+02$ & $8.39 \mathrm{E}+01$ \\
\hline & & $5.63 \mathrm{E}-01$ & $7.50 \mathrm{E}+01$ & $6.15 E+04$ & $7.35 \mathrm{E}+03$ & $1.48 E+03$ & $2.69 \mathrm{E}+01$ & $3.35 \mathrm{E}+02$ & $1.06 \mathrm{E}+02$ \\
\hline & & $5.27 \mathrm{E}-01$ & $7.50 \mathrm{E}+01$ & $6.24 \mathrm{E}+04$ & $7.78 E+03$ & $1.47 E+03$ & $2.80 \mathrm{E}+01$ & $3.58 \mathrm{E}+02$ & $9.11 \mathrm{E}+01$ \\
\hline & & 5.45E-01 & $1.00 E+02$ & $6.21 \mathrm{E}+04$ & $7.41 E+03$ & $2.19 \mathrm{E}+03$ & $2.61 E+01$ & $3.35 \mathrm{E}+02$ & $8.83 E+01$ \\
\hline & & $5.40 \mathrm{E}-01$ & $1.00 \mathrm{E}+02$ & $6.50 \mathrm{E}+04$ & $4.98 E+03$ & $1.98 \mathrm{E}+03$ & $3.22 \mathrm{E}+01$ & $3.52 \mathrm{E}+02$ & $9.21 \mathrm{E}+01$ \\
\hline \multirow[t]{6}{*}{ Core S5 } & & 6.49E-01 & $2.50 \mathrm{E}+01$ & $5.16 \mathrm{E}+04$ & $4.68 \mathrm{E}+03$ & $2.46 E+03$ & $2.21 \mathrm{E}+01$ & $2.79 \mathrm{E}+02$ & $9.59 \mathrm{E}+01$ \\
\hline & & $5.99 \mathrm{E}-01$ & $2.50 \mathrm{E}+01$ & $6.15 E+04$ & $3.48 E+03$ & $2.88 \mathrm{E}+03$ & $2.48 \mathrm{E}+01$ & $3.32 \mathrm{E}+02$ & $1.11 E+02$ \\
\hline & & $6.49 \mathrm{E}-01$ & $5.00 \mathrm{E}+01$ & $4.65 \mathrm{E}+04$ & $<0.014$ & $3.93 E+03$ & $1.93 E+01$ & $2.62 \mathrm{E}+02$ & $3.99 E+01$ \\
\hline & & $6.73 \mathrm{E}-01$ & $5.00 \mathrm{E}+01$ & $5.79 E+04$ & $1.20 \mathrm{E}+03$ & $4.21 \mathrm{E}+03$ & $2.32 E+01$ & $3.30 \mathrm{E}+02$ & $8.02 E+01$ \\
\hline & & $6.72 \mathrm{E}-01$ & $7.50 \mathrm{E}+01$ & $5.12 \mathrm{E}+04$ & $3.22 E+03$ & $2.29 \mathrm{E}+03$ & $2.21 \mathrm{E}+01$ & $2.74 \mathrm{E}+02$ & $7.05 E+01$ \\
\hline & & $5.65 \mathrm{E}-0]$ & $7.50 \mathrm{E}+01$ & $5.81 \mathrm{E}+04$ & $2.68 \mathrm{E}+03$ & $2.12 \mathrm{E}+03$ & $2.52 \mathrm{E}+01$ & $3.16 \mathrm{E}+02$ & $8.58 \mathrm{E}+01$ \\
\hline
\end{tabular}




\begin{tabular}{|c|c|c|c|c|c|c|c|c|c|}
\hline Core ID & Extraction & $\mathrm{Be}$ & Bi & $\mathrm{Ca}$ & $\mathrm{Cd}$ & Co & $\mathrm{Cr}$ & $\mathrm{Cu}$ & $\mathrm{Fe}$ \\
\hline \multirow[t]{34}{*}{ Core SI } & Exchangeable & $<0.0001$ & $1.50 E+02$ & $3.00 \mathrm{E}+03$ & $<0.006$ & $4.69 E+00$ & $5.84 E+00$ & $3.36 \mathrm{E}+00$ & $2.77 \mathrm{E}+01$ \\
\hline & Carbonate & $1.77 \mathrm{E}-01$ & $8.41 E+01$ & $3.02 \mathrm{E}+04$ & $<0.006$ & $5.79 \mathrm{E}+01$ & $1.42 E+00$ & $3.63 \mathrm{E}+00$ & $2.31 \mathrm{E}+02$ \\
\hline & Fe, Mn Oxides & $1.77 \mathrm{E}-01$ & $<0.422$ & $7.90 \mathrm{E}+02$ & $<0.006$ & $8.54 E+01$ & $4.87 \mathrm{E}+00$ & $<0.012$ & $1.94 E+03$ \\
\hline & Organic Matter & 8.85E-02 & $<0.422$ & $9.11 E+02$ & $<0.006$ & $2.42 \mathrm{E}+02$ & $2.30 \mathrm{E}+00$ & $1.29 \mathrm{E}+02$ & $4.20 \mathrm{E}+02$ \\
\hline & Residual & $6.19 \mathrm{E}-01$ & $<0.422$ & $7.28 \mathrm{E}+03$ & $1.33 \mathrm{E}+00$ & $4.00 \mathrm{E}+01$ & $1.42 \mathrm{E}+02$ & $2.18 \mathrm{E}+01$ & $3.65 \mathrm{E}+04$ \\
\hline & Exchangeable & $<0.0001$ & $9.91 \mathrm{E}+01$ & $3.36 \mathrm{E}+03$ & $<0.006$ & $4.42 \mathrm{E}+00$ & $5.49 \mathrm{E}+\infty$ & $1.95 E+00$ & $3.62 \mathrm{E}+01$ \\
\hline & Carbonate & 8.85E-02 & $6.50 \mathrm{E}+01$ & $2.80 \mathrm{E}+04$ & $<0.006$ & $5.65 \mathrm{E}+01$ & $<0,016$ & $3.36 \mathrm{E}+00$ & $2.37 \mathrm{E}+02$ \\
\hline & Fe, Mn Oxides & 1.77E-01 & $<0.422$ & $8.49 \mathrm{E}+02$ & $<0.006$ & $7.75 E+01$ & $4.51 \mathrm{E}+00$ & $1.33 \mathrm{E}+00$ & $1.77 \mathrm{E}+03$ \\
\hline & Organic Matter & 8.85E-02 & $<0.422$ & $6.17 \mathrm{E}+02$ & $<0.006$ & $2.34 E+02$ & $1.86 \mathrm{E}+00$ & $1.21 \mathrm{E}+02$ & $2.84 E+02$ \\
\hline & Residual & $6.19 \mathrm{E}-01$ & $<0.422$ & $6.69 E+03$ & $1.24 \mathrm{E}+00$ & $3.86 \mathrm{E}+01$ & $1.31 E+02$ & $2.06 \mathrm{E}+01$ & $3.34 E+04$ \\
\hline & Exchangeable & $<0.0001$ & $1.04 E+02$ & $3.88 E+03$ & $<0.006$ & $1.97 \mathrm{E}+01$ & $4.51 \mathrm{E}+00$ & $<0.012$ & $2.99 E+01$ \\
\hline & Exchangeable & $<0.0001$ & $1.09 E+02$ & I. I JE+03 & $<0.006$ & $1.07 \mathrm{E}+0 \mathrm{I}$ & $4.51 \mathrm{E}+00$ & 1.15E $+\infty 0$ & $1.79 E+01$ \\
\hline & Carbonate & $<0.0001$ & $4.23 \mathrm{E}+0 \mathrm{I}$ & $5.78 E+03$ & $<0.006$ & $9.47 E+01$ & $<0.016$ & $4.34 E+\infty 0$ & $1.73 E+02$ \\
\hline & Carbonate & $<0,0001$ & $<0.422$ & $2.29 \mathrm{E}+03$ & $<0,006$ & 4.27E+01 & $<0.016$ & $3.36 \mathrm{E}+00$ & $2.73 E+02$ \\
\hline & $\mathrm{Fe}, \mathrm{M}$ ก Oxides & $<0.0001$ & $<0.422$ & $2.72 \mathrm{E}+02$ & $<0.006$ & $2.73 E+01$ & $1.68 \mathrm{E}+00$ & $<0.012$ & $1.52 \mathrm{E}+03$ \\
\hline & $\mathrm{Fe}, \mathrm{Mn}$ Oxides & $<0.0001$ & $<0.422$ & $1.27 \mathrm{E}+02$ & $<0.006$ & $7.43 \mathrm{E}+00$ & $<0.016$ & $<0.012$ & $3.07 E+02$ \\
\hline & Organic Matter & 8.85E-02 & $<0.422$ & $5.61 \mathrm{E}+02$ & $<0.006$ & $1.88 \mathrm{E}+02$ & $2.74 \mathrm{E}+00$ & $1.44 E+02$ & 8. $14 E+02$ \\
\hline & Organic Matter & $<0.0001$ & $<0.422$ & $6.90 \mathrm{E}+02$ & $<0.006$ & $2.12 \mathrm{E}+01$ & $<0.016$ & $1.03 E+01$ & $2.34 E+02$ \\
\hline & Residual & $<0.0001$ & $<0.422$ & $1.01 E+04$ & $8.85 \mathrm{E}-01$ & $2.37 \mathrm{E}+01$ & $9.82 E+01$ & $1.02 E+01$ & $2.32 E+04$ \\
\hline & Exchangeable & $<0.0001$ & $8.49 \mathrm{E}+01$ & $1.32 \mathrm{E}+03$ & $<0.006$ & $9.03 \mathrm{E}+00$ & $1.68 \mathrm{E}+00$ & $<0.012$ & $1.64 \mathrm{E}+01$ \\
\hline & Carbonate & $<0.0001$ & $8.58 \mathrm{E}+01$ & $9.38 \mathrm{E}+03$ & $<0.006$ & $9.91 E+01$ & $2.21 \mathrm{E}+00$ & $4.69 \mathrm{E}+00$ & $1.40 \mathrm{E}+02$ \\
\hline & Fe, Mn Oxides & $<0.0001$ & $<0.422$ & $6.61 E+02$ & $<0.006$ & $4.88 \mathrm{E}+01$ & $1.86 E+00$ & $1.06 E+00$ & $1.69 \mathrm{E}+03$ \\
\hline & Organic Matter & $<0.0001$ & $<0.422$ & $1.33 \mathrm{E}+03$ & $<0.006$ & $1.06 \mathrm{E}+02$ & $<0.016$ & $7.37 \mathrm{E}+01$ & $2.91 \mathrm{E}+02$ \\
\hline & Residual & $<0,0001$ & $<0.422$ & $1,00 \mathrm{E}+04$ & $9.73 \mathrm{E}-01$ & $4.77 \mathrm{E}+01$ & $8.63 \mathrm{E}+01$ & $2.20 \mathrm{E}+01$ & $2.32 \mathrm{E}+04$ \\
\hline & Exchangeable & $<0.0001$ & $1.20 \mathrm{E}+02$ & $1.69 \mathrm{E}+03$ & $<0.006$ & $5.75 \mathrm{E}+00$ & 5. $13 \mathrm{E}+\infty$ & $<0.012$ & $1.28 \mathrm{E}+02$ \\
\hline & Carbonate & $<0.0001$ & $7.48 \mathrm{E}+01$ & $1.32 E+04$ & $<0.006$ & $3.02 E+01$ & $1.68 \mathrm{E}+00$ & $4.07 \mathrm{E}+00$ & $3.44 E+02$ \\
\hline & Fe, Mn Oxides & $<0.0001$ & $<0.422$ & $5.52 \mathrm{E}+02$ & $<0.006$ & $2.31 \mathrm{E}+01$ & $1.42 \mathrm{E}+00$ & $1.50 E+00$ & $4.26 \mathrm{E}+02$ \\
\hline & Organic Matter & $8.85 \mathrm{E}-02$ & $<0.422$ & $1.64 \mathrm{E}+03$ & $<0,006$ & $8.14 E+01$ & $1.50 \mathrm{E}+00$ & $7.95 \mathrm{E}+01$ & $3.57 \mathrm{E}+02$ \\
\hline & Residual & $1.77 \mathrm{E}-0$ & $<0.422$ & $1.06 E+04$ & $1.15 E+\infty$ & $6.33 \mathrm{E}+01$ & $9.29 \mathrm{E}+01$ & $3.42 \mathrm{E}+01$ & 2.50E+04 \\
\hline & Exchangeable & $<0,0001$ & $1.08 \mathrm{E}+02$ & $1.62 \mathrm{E}+03$ & $<0.006$ & $5.31 \mathrm{E}+00$ & $5.04 E+00$ & $1.06 \mathrm{E}+00$ & $1.40 E+02$ \\
\hline & Carbonate & $8.85 \mathrm{E}-02$ & $9.20 \mathrm{E}+01$ & $1.45 \mathrm{E}+04$ & $<0.006$ & $3.27 \mathrm{E}+01$ & $1.68 \mathrm{E}+00$ & $5.84 \mathrm{E}+00$ & $3,38 \mathrm{E}+02$ \\
\hline & Fe. Mn Oxides & $<0.0001$ & $<0.422$ & $6.12 E+02$ & $<0.006$ & $2.89 \mathrm{E}+01$ & $1.50 \mathrm{E}+00$ & $1.68 E+\infty 0$ & $4.66 E+02$ \\
\hline & Organic Matter & $<0.0001$ & $<0.422$ & $1.35 \mathrm{E}+03$ & $<0.006$ & $7.97 \mathrm{E}+01$ & $<0.016$ & $7.26 \mathrm{E}+01$ & $2.13 E+02$ \\
\hline & Residual & $<0.0001$ & $<0.422$ & $1.06 \mathrm{E}+04$ & $1.06 \mathrm{E}+00$ & $6.35 E+01$ & $9.20 \mathrm{E}+01$ & $2.86 \mathrm{E}+01$ & $2.42 E+04$ \\
\hline Core ID & Extraction & Be & Bi & $C_{n}$ & Cd & Co & $\mathrm{Cr}$ & $\mathrm{Cu}$ & $\mathbf{F e}$ \\
\hline \multirow[t]{30}{*}{ Core 52} & Exchangeable & $<0.0001$ & $<0.422$ & $6.24 E+03$ & $<0.006$ & $1.40 E+01$ & $<0.016$ & $1.85 \mathrm{E}+01$ & $1.28 \mathrm{E}+02$ \\
\hline & Carbonate & $<0.0001$ & $<0.422$ & $4.64 E+03$ & $<0.006$ & $4.00 \mathrm{E}+01$ & $<0.016$ & $2.05 \mathrm{E}+01$ & $2.18 \mathrm{E}+02$ \\
\hline & $\mathrm{Fe}, \mathrm{Mn}$ Oxides & $<0.0001$ & $<0.422$ & $4.11 E+02$ & $<0.006$ & $5.95 \mathrm{E}+01$ & $1.59 \mathrm{E}+00$ & $3.54 \mathrm{E}+\infty 0$ & $4.06 \mathrm{E}+02$ \\
\hline & Organic Matter & $8.85 \mathrm{E}-02$ & $<0.422$ & $1.4 ! E+03$ & $<0.006$ & 4. $12 \mathrm{E}+01$ & $<0.016$ & $3.60 \mathrm{E}+01$ & $2.33 \mathrm{E}+02$ \\
\hline & Residual & $<0.0001$ & $<0.422$ & $1.26 \mathrm{E}+04$ & $1.15 E+00$ & $5.35 \mathrm{E}+01$ & $9.91 \mathbf{E}+01$ & $1.74 \mathrm{E}+01$ & $2.62 E+04$ \\
\hline & Exchangeable & $<0.0001$ & $<0.422$ & $5.93 \mathrm{E}+03$ & $<0.006$ & $1.24 \mathrm{E}+01$ & $<0.016$ & $1.69 \mathrm{E}+01$ & $1.02 \mathrm{E}+02$ \\
\hline & Carbonate & $<0.0001$ & $<0.422$ & $3.98 E+03$ & $<0.006$ & $3.92 \mathrm{E}+01$ & $<0.016$ & $1.86 \mathrm{E}+01$ & $2.18 \mathrm{E}+02$ \\
\hline & $\mathrm{Fe}, \mathrm{Mn}$ Oxides & $<0.0001$ & $<0.422$ & $4.96 \mathrm{E}+02$ & $<0.006$ & $6.88 \mathrm{E}+01$ & $1.77 \mathrm{E}+00$ & $3.80 \mathrm{E}+00$ & $4.67 \mathrm{E}+02$ \\
\hline & Organic Matter & 8.85E-02 & $<0.422$ & $1.31 \mathrm{E}+03$ & $<0,006$ & $4.51 E+01$ & $1.42 \mathrm{E}+00$ & $3.99 \mathrm{E}+01$ & $2.96 \mathrm{E}+02$ \\
\hline & Residuar" & $<0.0001$ & $<0.422$ & $1.23 \mathrm{E}+04$ & $1.15 \mathrm{E}+\infty$ & $4.86 \mathrm{E}+01$ & $9.38 \mathrm{E}+01$ & $1.50 \mathrm{E}+01$ & $2.54 E+04$ \\
\hline & Exchangeable & $<0.0001$ & $1.21 \mathrm{E}+02$ & $1.79 \mathrm{E}+03$ & $<0.006$ & $8.23 E+\infty 0$ & $5.75 \mathrm{E}+00$ & $<0.012$ & $2.06 \mathrm{E}+02$ \\
\hline & Carbonate & 8.85E-02 & $9.38 E+01$ & $1.36 \mathbf{E}+04$ & $<0.006$ & $4.42 \mathrm{E}+01$ & $2.48 \mathrm{E}+00$ & $5.57 \mathrm{E}+00$ & $3.44 \mathrm{E}+02$ \\
\hline & Fe, Mn Oxides & $<0.0001$ & $<0.422$ & $5.60 \mathrm{E}+02$ & $<0.006$ & $4.20 \mathrm{E}+01$ & $2.39 \mathrm{E}+00$ & $1.86 \mathrm{E}+00$ & $5.02 E+02$ \\
\hline & Organic Matter & 8.85E-02 & $<0.422$ & $1.28 \mathrm{E}+03$ & $<0.006$ & $6.34 \mathrm{E}+01$ & $<0.016$ & $4.72 E+01$ & $2.48 \mathrm{E}+02$ \\
\hline & Residual & $<0.0001$ & $<0.422$ & $1.11 E+04$ & $1.06 \mathrm{E}+00$ & $4.58 \mathrm{E}+01$ & $9.38 \mathrm{E}+01$ & $3.12 \mathrm{E}+01$ & $2.51 E+04$ \\
\hline & Exchangeable & $<0.0001$ & $1.20 \mathrm{E}+02$ & $1.78 E+03$ & $<0.006$ & $8.58 \mathrm{E}+00$ & $5.57 \mathrm{E}+00$ & $1.33 \mathrm{E}+\infty 0$ & $1.76 \mathrm{E}+02$ \\
\hline & Carbonate & $<0.0001$ & $1.09 \mathrm{E}+02$ & $1.32 \mathrm{E}+04$ & $<0.006$ & $4.09 \mathrm{E}+01$ & $2.57 \mathrm{E}+00$ & $5.31 E+\infty 0$ & $3.09 \mathrm{E}+02$ \\
\hline & Fe, Mn Oxides & $8.85 \mathrm{E}-02$ & $<0.422$ & $1.14 \mathrm{E}+03$ & $<0.006$ & $5.81 \mathrm{E}+0 \mathrm{t}$ & $<0.016$ & $4.75 E+01$ & $2.44 E+02$ \\
\hline & Organic Matter & $<0.0001$ & $<0.422$ & $6.61 E+02$ & $<0.006$ & $4.34 \mathrm{E}+01$ & $2.12 \mathrm{E}+00$ & $<0.012$ & $4.62 \mathrm{E}+02$ \\
\hline & Residual & $<0.0001$ & $<0.422$ & $1.06 \mathrm{E}+04$ & $9.73 \mathrm{E}-01$ & $3.67 \mathrm{E}+01$ & $8.66 \mathrm{E}+01$ & $1.82 E+01$ & $2.27 \mathrm{E}+04$ \\
\hline & Exchangeable & $<0.0001$ & $<0.422$ & $6.44 \mathrm{E}+03$ & $<0.006$ & $8.94 \mathrm{E}+00$ & $<0.016$ & $7.17 E+00$ & $1.04 E+02$ \\
\hline & Carbonate & $<0.0001$ & $<0.422$ & 1. $29 \mathrm{E}+04$ & $<0.006$ & $2.78 \mathrm{E}+01$ & $<0.016$ & $3.80 \mathrm{E}+00$ & $2.25 E+02$ \\
\hline & Fe, Mn Oxides & $<0.0001$ & $<0.422$ & $4.89 \mathrm{E}+02$ & $<0.006$ & $2.89 E+01$ & $2.92 \mathrm{E}+\infty 0$ & $<0.012$ & $5.08 E+02$ \\
\hline & Organic Matter & $8.85 \mathrm{E}-02$ & $<0.422$ & $1.25 E+03$ & $<0.006$ & $6.65 \mathrm{E}+01$ & $1.59 \mathrm{E}+\infty$ & $4.37 \mathrm{E}+01$ & $2.29 \mathrm{E}+02$ \\
\hline & Residual & $<0.0001$ & $<0.422$ & $9.82 E+03$ & $9.73 \mathrm{E}-01$ & $4.65 \mathrm{E}+01$ & $1.08 \mathrm{E}+02$ & $3.65 \mathrm{E}+01$ & $2.28 \mathrm{E}+04$ \\
\hline & Exchangeable & $<0.0001$ & $1.04 E+02$ & $2.04 E+03$ & $<0.006$ & $4.96 \mathrm{E}+00$ & $5.57 \mathrm{E}+00$ & $<0.012$ & $1.29 E+02$ \\
\hline & Carbonate & $<0.0001$ & $1.03 \mathrm{E}+02$ & $1.42 \mathrm{E}+04$ & $<0.006$ & $2.80 \mathrm{E}+01$ & $2.30 \mathrm{E}+00$ & $3.72 \mathrm{E}+00$ & $2.25 \mathrm{E}+02$ \\
\hline & Fe. Mn Oxides & $<0.0001$ & $<0.422$ & $4.85 \mathrm{E}+02$ & $<0.006$ & $3.02 \mathrm{E}+01$ & $3.01 \mathrm{E}+00$ & $1.86 \mathrm{E}+00$ & $4.65 \mathrm{E}+02$ \\
\hline & Organic Matter & $<0.0001$ & $<0.422$ & $1.03 E+03$ & $<0.006$ & $6.48 \mathrm{E}+01$ & $1.42 \mathrm{E}+00$ & $5.26 \mathrm{E}+01$ & $2.79 E+02$ \\
\hline & $\begin{array}{c}\text { Residual } \\
\text { Extraction }\end{array}$ & $\begin{array}{c}<0.0001 \\
\mathrm{Be}\end{array}$ & $\begin{array}{c}<0.422 \\
\quad \text { Bi } \\
\end{array}$ & $\begin{array}{c}1.16 \mathrm{E}+04 \\
\mathrm{Ca}\end{array}$ & $\begin{array}{c}1.15 E+00 \\
C d\end{array}$ & $\begin{array}{c}5.40 \mathrm{E}+01 \\
\mathrm{Co}\end{array}$ & $\begin{array}{c}1.19 \mathrm{E}+02 \\
\mathrm{Cr}\end{array}$ & $\begin{array}{c}5.71 \mathrm{E}+01 \\
\mathrm{ClI}^{\prime \prime}\end{array}$ & $\begin{array}{c}2.58 \mathrm{E}+04 \\
\mathrm{Fe}\end{array}$ \\
\hline \multirow[t]{17}{*}{ Core 53} & Exchangeable & $<0.0001$ & $1.11 E+02$ & $2.81 E+03$ & $<0.006$ & $2.88 \mathrm{E}+01$ & $5.04 \mathrm{E}+00$ & $7.96 \mathrm{E}+00$ & $2.10 \mathrm{E}+02$ \\
\hline & Exchangeable & $<0.0001$ & $9.38 \mathrm{E}+01$ & $1.04 \mathrm{E}+03$ & $<0.006$ & $1.39 E+01$ & $5.31 \mathrm{E}+00$ & $3.63 \mathrm{E}+00$ & $1.63 E+02$ \\
\hline & Carbonate & $<0.0001$ & $5.30 \mathrm{E}+01$ & $4.02 E+03$ & $<0.006$ & $5.97 \mathrm{E}+01$ & $1.77 \mathrm{E}+00$ & $2.00 \mathrm{E}+01$ & $1.65 \mathrm{E}+02$ \\
\hline & Carbonate & $<0.0001$ & $<0.422$ & $2.66 \mathrm{E}+03$ & $<0.006$ & $4.51 E+01$ & $<0.016$ & $1.13 \mathrm{E}+01$ & $2.37 \mathrm{E}+02$ \\
\hline & Fe, Mn Oxides & $<0.0001$ & $<0.422$ & $3.25 \mathrm{E}+02$ & $<0.006$ & $5.80 \mathrm{E}+01$ & $1.50 \mathrm{E}+00$ & $2.48 \mathrm{E}+00$ & $8.85 E+02$ \\
\hline & $\mathrm{Fe}, \mathrm{Mn}$ Oxides & $<0.0001$ & $<0.422$ & $1.90 \mathrm{E}+02$ & $<0.006$ & $1.86 \mathrm{E}+01$ & $<0.016$ & $1.59 \mathrm{E}+00$ & $2.96 \mathrm{E}+02$ \\
\hline & Organic Matter & 8.85E-02 & $<0.422$ & $7.20 \mathrm{E}+02$ & $<0.006$ & $1.23 \mathrm{E}+02$ & $3.10 \mathrm{E}+\infty 0$ & $1.70 \mathrm{E}+02$ & $9.38 \mathrm{E}+02$ \\
\hline & Organic Matter & $<0.0001$ & $<0.422$ & $7.42 \mathrm{E}+02$ & $<0.006$ & $1.39 \mathrm{E}+01$ & $<0.016$ & $1.53 \mathrm{E}+01$ & $2.47 E+02$ \\
\hline & Exchangeable & $<0.0001$ & $<0.422$ & $5.31 E+03$ & $<0.006$ & $2.40 \mathrm{E}+01$ & $<0.016$ & $1.14 \mathrm{E}+01$ & 1. $72 \mathrm{E}+01$ \\
\hline & Carbonate & $8.85 \mathrm{E}-02$ & $<0.422$ & $5.00 E+03$ & $<0.006$ & $9.20 \mathrm{E}+01$ & $<0.016$ & $320 \mathrm{E}+01$ & $1.25 \mathrm{E}+02$ \\
\hline & $\mathrm{Fe}, \mathrm{Mn}$ Oxides & $8.85 \mathrm{E}-02$ & $<0.422$ & $1.04 \mathrm{E}+03$ & $<0.006$ & $1,38 \mathrm{E}+02$ & $2.21 \mathrm{E}+\infty$ & $8.85 \mathrm{E}+00$ & $1.58 \mathrm{E}+03$ \\
\hline & Organic Matter & $8.85 E-02$ & $<0.422$ & $2.03 E+03$ & $<0.006$ & $7.74 E+01$ & $<0.016$ & $9.56 \mathrm{E}+0 ?$ & $2.55 E+02$ \\
\hline & Residual & $1.77 \mathrm{E}-01$ & $<0.422$ & $7.21 E+03$ & $7.96 \mathrm{E}-01$ & $5.01 E+01$ & $7.21 \mathrm{E}+01$ & $3.53 \mathrm{E}+01$ & $1.86 E+04$ \\
\hline & Exchangeable & $<0.0001$ & $<0.422$ & $6.16 \mathrm{E}+03$ & $<0.006$ & $9.64 \mathrm{E}+00$ & $<0.016$ & 1.17E+01 & 8.21E+01 \\
\hline & Carbonate & 8.85E-02 & $<0.422$ & $1.98 E+04$ & $<0.006$ & $2.56 \mathrm{E}+01$ & $<0.016$ & $6.28 \mathrm{E}+00$ & $2.44 E+02$ \\
\hline & $\mathrm{Fe}, \mathrm{Mn}$ Oxides & $8.85 E-02$ & $<0.422$ & $7.06 \mathrm{E}+02$ & $<0.006$ & $2.03 \mathrm{E}+01$ & $1.42 \mathrm{E}+00$ & $<0.012$ & $5.23 \mathrm{E}+02$ \\
\hline & Organic Matter & 8.85E-02 & $<0.422$ & $1.59 \mathrm{E}+03$ & $<0.006$ & $1.46 \mathrm{E}+02$ & $<0.016$ & $1.19 \mathrm{E}+02$ & $2.98 \mathrm{E}+02$ \\
\hline
\end{tabular}




\begin{tabular}{|c|c|c|c|c|c|c|c|c|c|}
\hline & Residual & $2.65 \mathrm{E}-01$ & $<0.422$ & $4.39 E+03$ & $1.06 E+00$ & $6.16 E+0 I$ & $9.20 \mathrm{E}+01$ & 4.15E+01 & $2.40 \mathrm{E}+04$ \\
\hline & Exchangeable & $<0.0001$ & $7.79 \mathrm{E}+01$ & $1.64 \mathrm{E}+03$ & $<0.006$ & $4.25 E+00$ & $4,96 E+00$ & $<0.012$ & $1.27 E+02$ \\
\hline & Exchangeable & $<0.0001$ & $1.03 \mathrm{E}+02$ & $1.32 \mathrm{E}+03$ & $<0.006$ & $3.89 \mathrm{E}+00$ & $5,40 E+00$ & $<0.012$ & I. $46 \mathrm{E}+02$ \\
\hline & Carbonate & $8.85 \mathrm{E}-02$ & $3.84 E+01$ & $1.64 \mathrm{E}+04$ & $<0.006$ & $1.74 E+01$ & $2.12 \mathrm{E}+\infty 0$ & $2.74 E+00$ & $2.20 \mathrm{E}+02$ \\
\hline & Carbonate & $<0.0001$ & $<0.422$ & $2.88 \mathrm{E}+03$ & $<0.006$ & $2.08 \mathrm{E}+01$ & $<0.016$ & $4.51 E+00$ & $2.85 \mathrm{E}+02$ \\
\hline & Fe, Mn Oxides & $<0.0001$ & $<0.422$ & $1.47 \mathrm{E}+02$ & $<0.006$ & $7.34 E+00$ & $<0.016$ & $1.77 \mathrm{E}+\infty 0$ & $3.51 \mathrm{E}+02$ \\
\hline & $\mathrm{Fe}, \mathrm{Mn}$ Oxides & $<0.0001$ & $<0.422$ & $1.00 E+02$ & $<0.006$ & $2.39 \mathrm{E}+00$ & $1.59 \mathrm{E}+00$ & $<0.012$ & $2.39 E+02$ \\
\hline & Organic Matter & 8.85E-02 & $<0.422$ & $3.60 \mathrm{E}+02$ & $<0.006$ & $2.07 E+02$ & $2.04 \mathrm{E}+00$ & $1.65 \mathrm{E}+02$ & $8.15 \mathrm{E}+02$ \\
\hline & Organic Matter & $<0.0001$ & $<0.422$ & $5.63 E+02$ & $<0.006$ & $1.93 \mathrm{E}+01$ & $<0.016$ & $1.04 E+01$ & $2.04 \mathrm{E}+02$ \\
\hline & Residual & $2.65 \mathrm{E}-01$ & $<0.422$ & $3.80 E+03$ & $7.96 \mathrm{E}-0 \mathrm{I}$ & $1.03 E+01$ & $7.01 \mathrm{E}+01$ & $2.65 \mathrm{E}+00$ & $1.90 \mathrm{E}+04$ \\
\hline & Exchangeable & $<0.0001$ & $<0.422$ & $1.41 E+04$ & $<0.006$ & $1.68 \mathrm{E}+00$ & $<0.016$ & $<0.012$ & $1.79 E+01$ \\
\hline & Carbonate & $<0.0001$ & $<0.422$ & $1.26 E+04$ & $<0.006$ & $4.79 E+01$ & $<0.016$ & $<0.012$ & $1.09 \mathrm{E}+01$ \\
\hline & Fe, Mn Oxides & $1.77 \mathrm{E}-01$ & $<0.422$ & $3.79 \mathrm{E}+03$ & $<0.006$ & $5.57 \mathrm{E}+00$ & $5.04 E+00$ & $1.24 \mathrm{E}+00$ & $1.34 \mathrm{E}+03$ \\
\hline & Organic Matter & $1.77 \mathrm{E}-01$ & $<0.422$ & $8.84 \mathrm{E}+02$ & $6.19 \mathrm{E}-01$ & $3.54 \mathrm{E}+02$ & $9.56 \mathrm{E}+\infty 0$ & $3.36 E+02$ & $2.27 \mathrm{E}+03$ \\
\hline & Residual & $1.77 \mathrm{E}-01$ & $5.34 \mathrm{E}+01$ & $7.35 E+03$ & $<0.006$ & $2.61 E+01$ & $7.54 \mathrm{E}+01$ & $3.33 \mathrm{E}+01$ & $1.49 \mathrm{E}+04$ \\
\hline & Exchangeable & $<0.0001$ & $9.56 E+01$ & $4.66 \mathrm{E}+03$ & $<0.006$ & $2.92 \mathrm{E}+00$ & 4.51E+00 & $<0.012$ & $2.61 \mathrm{IE}+01$ \\
\hline & Exchangeable & $<0.0001$ & $9.82 \mathrm{E}+01$ & $2.43 E+03$ & $<0.006$ & $2.39 E+\infty 0$ & $4.78 \mathrm{E}+00$ & $<0.012$ & $1.05 E+01$ \\
\hline & Carbonate & $8.85 \mathrm{E}-02$ & $5.16 E+01$ & $2.72 \mathrm{E}+04$ & $<0.006$ & $5.34 E+01$ & $1.50 \mathrm{E}+00$ & $2.30 \mathrm{E}+00$ & $1.58 \mathrm{E}+02$ \\
\hline & Carbonate & 8.85E-02 & $<0.422$ & $4.80 \mathrm{E}+03$ & $<0.006$ & $7.03 E+01$ & $<0.016$ & $2.48 \mathrm{E}+00$ & $3.30 \mathrm{E}+02$ \\
\hline & Fe, Mn Oxides & $1.77 \mathrm{E}-01$ & $<0.422$ & $5.68 \mathrm{E}+02$ & $<0.006$ & $2.34 \mathrm{E}+01$ & $3.72 \mathrm{E}+00$ & $<0.012$ & $2.09 \mathrm{E}+03$ \\
\hline & Fe, Mn Oxides & $<0.0001$ & $<0.422$ & $1.94 \mathrm{E}+02$ & $<0.006$ & $7.96 \mathrm{E}+\infty 0$ & $<0.016$ & $<0.012$ & $4.42 \mathrm{E}+02$ \\
\hline & Organic Matter & $1.77 \mathrm{E}-01$ & $<0.422$ & $3.27 \mathrm{E}+02$ & $6.19 \mathrm{E}-01$ & $7.41 E+02$ & $4.42 E+00$ & $4.36 E+02$ & $4.34 \mathrm{E}+02$ \\
\hline & Organic Matter & $8.85 \mathrm{E}-02$ & $<0.422$ & $3.48 \mathrm{E}+02$ & $<0.006$ & $7.88 \mathrm{E}+01$ & $1.68 \mathrm{E}+00$ & 4. $05 E+01$ & $2.24 \mathrm{E}+02$ \\
\hline Core ID & $\begin{array}{l}\text { Residual } \\
\text { Extraction }\end{array}$ & $\begin{array}{c}\text { 7.08E-01 } \\
\mathrm{Be}\end{array}$ & $<0.422$ & $7.82 \mathrm{E}+03$ & $5.31 \mathrm{E}-01$ & $4.88 \mathrm{E}+01$ & $2.02 \mathrm{E}+02$ & $2.86 \mathrm{E}+01$ & $2.59 E+04$ \\
\hline \multirow[t]{40}{*}{ Core S4 } & $\begin{array}{l}\text { Extraction } \\
\text { Exchangeable }\end{array}$ & $<0.0001$ & $\frac{B i}{9.91 E+01}$ & $\frac{C=}{1.53 \mathrm{E}+03}$ & $\frac{\text { Cd }}{<0.006}$ & $\frac{\mathrm{Co}_{0}}{6.37 \mathrm{E}+00}$ & $\frac{\mathrm{Cr}}{5.66 \mathrm{E}+00}$ & $\frac{\mathrm{Cu}}{1.42 \mathrm{E}+00}$ & $\frac{\mathbf{F e}}{1.49 \mathrm{E}+02}$ \\
\hline & Carbonate & 8.85E-02 & $3.86 \mathrm{E}+01$ & $1.33 \mathrm{E}+04$ & $<0,006$ & 3.39E+01 & $1.50 E+00$ & $8.32 E+\infty 0$ & $9.03 E+02$ \\
\hline & $\mathrm{Fe}, \mathrm{Mn}$ Oxides & $<0.0001$ & $<0.422$ & $7.57 \mathbf{E}+02$ & $<0.006$ & $2.11 \mathrm{E}+01$ & $1.50 \mathrm{E}+00$ & $1.15 E+00$ & $4.89 \mathrm{E}+02$ \\
\hline & Organic Matter & $<0.0001$ & $<0.422$ & $1,49 E+03$ & $<0.006$ & $6.57 E+01$ & $<0.016$ & $5.57 \mathrm{E}+01$ & $1.25 \mathrm{E}+02$ \\
\hline & Residual & $1.77 \mathrm{E}-01$ & $<0.422$ & $6.65 \mathrm{E}+03$ & $9.73 \mathrm{E}-01$ & $3.21 \mathrm{E}+01$ & $3.94 \mathrm{E}+02$ & $2.75 E+01$ & $2.42 \mathrm{E}+04$ \\
\hline & Exchangeable & $<0.0001$ & $1.17 E+02$ & $1.40 \mathrm{E}+03$ & $<0.006$ & $5.93 \mathrm{E}+00$ & $5.84 E+00$ & $1.33 \mathrm{E}+00$ & $1.25 \mathrm{E}+02$ \\
\hline & Carbonate & 8.85E-02 & $4.48 E+01$ & $1.54 \mathrm{E}+04$ & $<0.006$ & $3.71 \mathrm{E}+01$ & $1.77 E+00$ & $9.56 \mathrm{E}+00$ & $9.82 \mathrm{E}+02$ \\
\hline & Fe, Mn Oxides & $<0.0001$ & $<0.422$ & $7.38 \mathrm{E}+02$ & $<0.006$ & $1.96 E+01$ & $1.77 \mathrm{E}+\infty 0$ & $1.59 E+00$ & $4.95 \mathrm{E}+02$ \\
\hline & Organic Matter & 8.85E-02 & $<0.422$ & $1.50 \mathrm{E}+03$ & $<0.006$ & $6.52 \mathrm{E}+01$ & $<0.016$ & $6.14 \mathrm{E}+01$ & $2.11 E+02$ \\
\hline & Residual & $1.77 \mathrm{E}-01$ & $<0.422$ & $8.65 E+03$ & $1.33 \mathrm{E}+\infty$ & $3.81 E+01$ & $1.00 E+02$ & $2.14 \mathrm{E}+01$ & $2.69 \mathrm{E}+04$ \\
\hline & Exchangeable & $<0.0001$ & $1.10 \mathrm{E}+02$ & $1.28 \mathrm{E}+03$ & $<0.006$ & $5.13 \mathrm{E}+00$ & $5.22 \mathrm{E}+00$ & $<0.012$ & $7.71 \mathrm{E}+01$ \\
\hline & Carbonate & $8.85 \mathrm{E}-02$ & $4.68 \mathrm{E}+01$ & $1.04 E+04$ & $<0.006$ & $2.99 \mathrm{E}+01$ & $1.42 \mathrm{E}+00$ & $5.31 E+00$ & $4.34 \mathrm{E}+02$ \\
\hline & Fe, Mn Oxides & $<0.0001$ & $<0.422$ & $6.43 \mathrm{E}+02$ & $<0.006$ & $1.50 \mathrm{E}+01$ & $<0.016$ & $1.59 \mathrm{E}+00$ & $3.67 \mathrm{E}+02$ \\
\hline & Organic Matter & $8.85 \mathrm{E}-02$ & $<0.422$ & $1.19 \mathrm{E}+03$ & $<0.006$ & $1.21 E+02$ & $<0.016$ & $7.60 \mathrm{E}+01$ & $2.27 \mathrm{E}+02$ \\
\hline & Residual & $8.85 \mathrm{E}-02$ & $<0.422$ & $6.41 E+03$ & $1.06 \mathrm{E}+00$ & $5.49 \mathrm{E}+01$ & $8.94 \mathrm{E}+01$ & $4.51 \mathrm{E}+01$ & $2.34 \mathrm{E}+04$ \\
\hline & Exchangeable & $<0.0001$ & $1.06 \mathrm{E}+02$ & $1.21 E+03$ & $<0.006$ & $8.05 E+00$ & $5.49 \mathrm{E}+00$ & $1.33 \mathrm{E}+00$ & $1.73 \mathrm{E}+02$ \\
\hline & Cartonate & $8.85 \mathrm{E}-02$ & $5.95 E+01$ & $1.00 E+04$ & $<0.006$ & $2.67 \mathrm{E}+01$ & $<0.016$ & 4. $51 E+00$ & $3.49 \mathrm{E}+02$ \\
\hline & $\mathrm{Fe}, \mathrm{Mn}$ Oxides & $<0.0001$ & $<0.422$ & $6.51 \mathrm{H}+02$ & $<0.006$ & $1.33 \mathrm{E}+01$ & $<0.016$ & $<0.012$ & $3.73 E+02$ \\
\hline & Organic Matter & $8.85 \mathrm{E}-02$ & $<0.422$ & $1.19 \mathrm{E}+03$ & $<0.006$ & $1.31 E+02$ & $<0.016$ & $6.00 \mathrm{E}+01$ & $1.42 E+02$ \\
\hline & Residual & $<0.0001$ & $<0.422$ & $7.22 E+03$ & $9.73 \mathrm{E}-01$ & $4.75 E+01$ & $8.25 E+01$ & $3.54 \mathrm{E}+01$ & $2.30 E+04$ \\
\hline & Exchangeable & $<0.0001$ & $1.15 E+02$ & $1.09 \mathrm{E}+03$ & $<0.006$ & $8.85 E+00$ & 5.57E +00 & $1.15 E+00$ & $7.66 \mathrm{E}+01$ \\
\hline & Carbonate & $8.85 \mathrm{E}-02$ & $3.96 \mathrm{E}+01$ & $8.85 E+03$ & $<0.006$ & $2.80 \mathrm{E}+0 \mathrm{I}$ & $<0.016$ & $8.85 E+00$ & $3.43 E+02$ \\
\hline & Fe, Mn Oxides & $<0.0001$ & $<0.422$ & $5.57 \mathrm{E}+02$ & $<0.006$ & $1.12 \mathrm{E}+01$ & $<0.016$ & $<0.012$ & $3.09 \mathrm{E}+02$ \\
\hline & Organic Matter & $8.85 \mathrm{E}-02$ & $<0.422$ & $1.04 \mathrm{E}+03$ & $<0.006$ & $7.06 \mathrm{E}+01$ & $<0.016$ & $8.11 E+01$ & $2.31 \mathrm{E}+02$ \\
\hline & Residual & 2.65E-01 & $<0.422$ & $6.47 \mathbf{E}+03$ & $6.19 \mathrm{E}-01$ & $6.84 E+01$ & $2.80 \mathrm{E}+03$ & $1.07 E+02$ & 2.75E+04 \\
\hline & Exchangeable & $<0.0001$ & $1.22 \mathrm{E}+02$ & $9.38 E+02$ & $<0.006$ & $7.52 \mathrm{E}+00$ & $5.04 E+00$ & $<0.012$ & $3.66 \mathrm{E}+01$ \\
\hline & Carbonate & $8.85 \mathrm{E}-02$ & $<0.422$ & $8.74 E+03$ & $<0.006$ & $2.51 E+01$ & $<0.016$ & $8.05 E+00$ & $2.67 \mathrm{E}+02$ \\
\hline & $\mathrm{Fe}, \mathrm{Mn}$ Oxides & $<0.0001$ & $<0.422$ & $6.34 \mathrm{E}+02$ & $<0.006$ & $1.17 E+01$ & $<0.016$ & $1.24 \mathrm{E}+00$ & $3.16 \mathrm{E}+02$ \\
\hline & Organic Matter & $<0.0001$ & $<0.422$ & $9.11 E+02$ & $<0.006$ & $3.91 \mathrm{E}+0 \mathrm{I}$ & $<0.016$ & $3.74 E+01$ & $1.43 E+02$ \\
\hline & Residual & $1.77 \mathrm{E}-01$ & $<0.422$ & $7.53 E+03$ & $9.73 \mathrm{E}-01$ & $6.86 E+01$ & $1.12 \mathrm{E}+02$ & $4.72 \mathrm{E}+01$ & $2.46 \mathrm{E}+04$ \\
\hline & Exchangeable & $<0,0001$ & $1.20 \mathrm{E}+02$ & $1.26 \mathrm{E}+03$ & $<0.006$ & $8.67 E+00$ & $5.49 \mathrm{E}+00$ & $1.42 \mathrm{E}+00$ & $9.64 \mathrm{E}+01$ \\
\hline & Carbonate & $8.85 \mathrm{E}-02$ & $<0.422$ & $1.19 \mathrm{E}+04$ & $<0.006$ & $3.81 \mathrm{E}+01$ & $1.50 \mathrm{E}+\infty 0$ & $9.38 \mathrm{E}+\infty 0$ & $3.92 \mathrm{E}+02$ \\
\hline & Fe, Mn Oxides & $<0.0001$ & $<0.422$ & $7.52 E+02$ & $<0.006$ & $1.62 \mathrm{E}+01$ & $<0.016$ & $1.06 \mathrm{E}+\infty$ & $3.63 \mathrm{E}+02$ \\
\hline & Organic Matter & $<0.000 t$ & $<0.422$ & $1.25 E+03$ & $<0.006$ & $6.85 E+01$ & $<0.016$ & $6.06 \mathrm{E}+01$ & $9.38 \mathrm{E}+01$ \\
\hline & Residual & 1.77E-01 & $<0.422$ & $8.46 E+03$ & $6.19 \mathrm{E}-01$ & $8.46 E+01$ & $1.88 \mathrm{E}+03$ & $6.55 \mathrm{E}+01$ & $2.52 \mathrm{E}+04$ \\
\hline & Exchangeable & $<0.0001$ & $1.04 E+02$ & $1.34 \mathrm{E}+03$ & $<0.006$ & $8.23 \mathrm{E}+00$ & $5.49 \mathrm{E}+00$ & $1.33 \mathrm{E}+00$ & $1.05 E+02$ \\
\hline & Carbonate & $8.85 \mathrm{E}-02$ & $<0.422$ & $1.02 \mathrm{E}+04$ & $<0.006$ & $3.33 E+01$ & $<0.016$ & $7.79 \mathrm{E}+00$ & $3.10 \mathrm{E}+02$ \\
\hline & Fe, Mn Oxides & $<0.0001$ & $<0.422$ & $6.91 \mathrm{E}+02$ & $<0.006$ & $1.60 E+01$ & $<0.016$ & $<0.012$ & $3.56 \mathrm{E}+02$ \\
\hline & Organic Matter & $8.85 \mathrm{E}-02$ & $<0.422$ & $1.06 \mathrm{E}+03$ & $<0.006$ & $7.55 \mathrm{E}+01$ & $<0.016$ & $8.17 E+01$ & $1.42 E+02$ \\
\hline & Residual & $1.77 \mathrm{E}-01$ & $<0.422$ & $8.66 \mathrm{E}+03$ & $1.06 \mathrm{E}+00$ & $5.71 \mathrm{E}+01$ & $1.00 \mathrm{E}+02$ & $6.68 \mathrm{E}+01$ & $2.43 \mathrm{E}+04$ \\
\hline Core ID & Extraction & Be & $\mathbf{B i}$ & $\mathrm{Ca}$ & $\mathrm{Cd}$ & Co & $\mathrm{Cr}$ & $\mathrm{Cu}$ & $\mathbf{F e}$ \\
\hline \multirow[t]{19}{*}{ Core S5 } & Exchangeable & $<0.0001$ & $1.43 \mathrm{E}+02$ & $1.62 \mathrm{E}+03$ & $<0.006$ & $7.26 \mathrm{E}+\infty 0$ & $6.28 \mathrm{E}+00$ & $3.19 \mathrm{E}+00$ & $1.05 \mathrm{E}+02$ \\
\hline & Carbonate & $8.85 \mathrm{E}-02$ & $5.72 \mathrm{E}+01$ & $1.30 \mathrm{E}+04$ & $<0.006$ & $3.67 \mathrm{E}+01$ & $1.50 \mathrm{E}+00$ & $5.84 E+\infty$ & $3.25 \mathrm{E}+02$ \\
\hline & $\mathrm{Fe}, \mathrm{Mn}$ Oxides & $<0.0001$ & $<0.422$ & $8.41 E+02$ & $<0.006$ & $2.22 E+01$ & $1.59 \mathrm{E}+\infty 0$ & $1.33 \mathrm{E}+\infty$ & $3.77 E+02$ \\
\hline & Organic Matter & $8.85 \mathrm{E}-02$ & $<0.422$ & $1.62 \mathrm{E}+03$ & $<0.006$ & $1.19 \mathrm{E}+02$ & $2.12 \mathrm{E}+00$ & $6.44 E+01$ & $3.26 \mathrm{E}+02$ \\
\hline & Residual & $<0.0001$ & $<0.422$ & $1.01 \mathrm{E}+04$ & $9.73 \mathrm{E}-01$ & 3.77E+01 & $9.38 \mathrm{E}+01$ & $1.50 \mathrm{E}+01$ & $2.43 E+04$ \\
\hline & Exchangeable & $<0.0001$ & $1.09 \mathrm{E}+02$ & $1.71 E+03$ & $<0.006$ & $6.46 \mathrm{E}+00$ & $5.04 E+\infty 0$ & $1.15 E+00$ & $9.11 E+01$ \\
\hline & Carbonate & $8.85 \mathrm{E}-02$ & $5.51 E+01$ & $1.21 E+04$ & $<0.006$ & $3.45 \mathrm{E}+01$ & $<0.016$ & $5.84 \mathrm{E}+00$ & $2.96 \mathrm{E}+02$ \\
\hline & Fe, Mn Oxides & $<0.0001$ & $<0.422$ & 1. $14 \mathbf{E}+03$ & $<0.006$ & $2.71 E+01$ & $1.68 \mathrm{E}+00$ & $<0.012$ & $4.26 \mathrm{E}+02$ \\
\hline & Organic Matter & $8.85 \mathrm{E}-02$ & $<0.422$ & $1.87 \mathrm{E}+03$ & $<0.006$ & $1.30 \mathrm{E}+02$ & $1.77 \mathrm{E}+00$ & $6.58 \mathrm{E}+01$ & $1.74 E+02$ \\
\hline & Residual & $<0.0001$ & $<0.422$ & $9.91 E+03$ & $9.73 \mathrm{E}-01$ & 4.13E+01 & $5.61 \mathrm{E}+02$ & $2.36 \mathrm{E}+01$ & $2.57 E+04$ \\
\hline & Exchangeable & $<0.0001$ & $1.49 \mathrm{E}+02$ & $1.56 \mathrm{E}+03$ & $<0.006$ & $7.08 \mathrm{E}+00$ & $6.81 E+\infty 0$ & $3.10 \mathrm{E}+00$ & $1.19 \mathrm{E}+02$ \\
\hline & Carbonate & $8.85 \mathrm{E}-02$ & $6.25 \mathrm{E}+01$ & $1.46 \mathrm{E}+04$ & $<0.006$ & $3.34 \mathrm{E}+01$ & $<0.016$ & $3.72 E+00$ & $3.43 \mathrm{E}+02$ \\
\hline & Fe, Mn Oxides & $<0.0001$ & $<0.422$ & $1.00 \mathrm{E}+03$ & $<0.006$ & $1.73 \mathrm{E}+01$ & $<0.016$ & $<0.012$ & $3.84 \mathrm{E}+02$ \\
\hline & Organic Matter & $8.85 \mathrm{E}-02$ & $<0.422$ & $1.34 E+03$ & $<0.006$ & $2.27 E+02$ & $1.42 \mathrm{E}+00$ & $9.64 \mathrm{E}+01$ & $2.85 \mathrm{E}+02$ \\
\hline & Exchangeable & $<0.0001$ & $1.49 E+02$ & $1.57 \mathrm{E}+03$ & $<0.006$ & $7.17 \mathrm{E}+00$ & $6.46 \mathrm{E}+00$ & $2.92 \mathrm{E}+\infty 0$ & $1.03 \mathrm{E}+02$ \\
\hline & Carbonate & $8.85 \mathrm{E}-02$ & $6.33 E+01$ & $1.48 \mathrm{E}+04$ & $<0.006$ & $3.44 \mathrm{E}+01$ & $<0.016$ & $3.36 \mathrm{E}+\infty 0$ & $3.19 E+02$ \\
\hline & Fe, Mn Oxides & $<0.0001$ & $<0.422$ & $6.72 \mathrm{E}+02$ & $<0.006$ & $1.68 \mathrm{E}+01$ & $1.50 E+\infty$ & $<0.012$ & $4.26 \mathrm{E}+02$ \\
\hline & Organic Matter & $8.85 \mathrm{E}-02$ & $<0.422$ & $1.25 E+03$ & $<0.006$ & $2.28 \mathrm{E}+02$ & $<0.016$ & $9.64 \mathrm{E}+01$ & $1.38 E+02$ \\
\hline & Residual & $<0.0001$ & $<0.422$ & 8.29E+03 & $7.08 \mathrm{E}-01$ & $8.66 \mathrm{E}+01$ & $1.90 E+03$ & $5.45 E+01$ & $2.88 \mathrm{E}+04$ \\
\hline
\end{tabular}




\begin{tabular}{|c|c|c|c|c|c|c|c|c|c|}
\hline & Exchangeable & $<0.0001$ & $1.04 \mathrm{E}+02$ & $1.52 \mathrm{E}+03$ & $<0.006$ & $7.87 \mathrm{E}+00$ & $5.84 \mathrm{E}+\infty 0$ & $1.68 \mathrm{E}+00$ & $9.73 E+01$ \\
\hline & Carbonate & 8.85E-02 & $4.88 \mathrm{E}+01$ & $1.21 E+04$ & $<0.006$ & $3.75 \mathrm{E}+01$ & $<0.016$ & $7.70 \mathrm{E}+00$ & $3.01 E+02$ \\
\hline & $\mathrm{Fe}, \mathrm{Mn}$ Oxides & $<0.0001$ & $<0.422$ & $5.80 \mathrm{E}+02$ & $<0.006$ & $2.00 \mathrm{E}+01$ & $<0.016$ & $<0.012$ & $3.25 \mathrm{E}+02$ \\
\hline & Organic Matter & $8.85 \mathrm{E}-02$ & $<0.422$ & $1.19 \mathrm{E}+03$ & $<0.006$ & $1.04 \mathrm{E}+02$ & $1.42 \mathrm{E}+00$ & $9.56 \mathrm{E}+01$ & $1.82 \mathrm{E}+02$ \\
\hline & Residual & $<0.0001$ & $<0.422$ & $7.97 E+03$ & $7.96 \mathrm{E}-01$ & 4. $19 \mathrm{E}+01$ & $7.95 \mathrm{E}+01$ & $2.42 \mathrm{E}+01$ & $1.97 \mathrm{E}+04$ \\
\hline & Exchangeable & $<0.0001$ & $1.22 \mathrm{E}+02$ & $1.50 \mathrm{E}+03$ & $<0.006$ & $7.96 \mathrm{E}+00$ & $5.40 \mathrm{E}+00$ & $1.95 E+00$ & $1.13 E+02$ \\
\hline & Carbonate & $<0.0001$ & $4.67 \mathrm{E}+01$ & $1.24 \mathrm{E}+04$ & $<0.006$ & $4.06 \mathrm{E}+01$ & $<0.016$ & $8.58 \mathrm{E}+00$ & $3.80 \mathrm{E}+02$ \\
\hline & Fe, Mn Oxides & $<0.0001$ & $<0.422$ & $5.61 \mathrm{E}+02$ & $<0,006$ & $2.18 \mathrm{E}+01$ & $<0.016$ & $<0.012$ & $3.27 \mathrm{E}+02$ \\
\hline & Organic Matter & 8.85E-02 & $<0.422$ & $1.27 E+03$ & $<0.006$ & $1.16 \mathrm{E}+02$ & $<0.016$ & $1.19 \mathrm{E}+02$ & $2.00 E+02$ \\
\hline & Residual & $1.77 \mathrm{E}-01$ & $<0.422$ & $6.98 \mathrm{E}+03$ & $9.73 \mathrm{E}-01$ & $5.64 \mathrm{E}+01$ & $1.40 E+02$ & $3.33 E+01$ & $2.34 E+04$ \\
\hline \multicolumn{9}{|l|}{$\begin{array}{l}\text { Total Dizestions } \\
\text { Core ID }\end{array}$} & $\mathrm{Fe}$ \\
\hline \multirow[t]{6}{*}{ Core SI } & & $1.15 \mathrm{E}+\infty$ & $4.80 \mathrm{E}+01$ & $2.92 \mathrm{E}+04$ & $1.86 \mathrm{E}+00$ & $4.70 \mathrm{E}+02$ & $1.40 \mathrm{E}+02$ & $2.35 \mathrm{E}+02$ & $3.62 \mathrm{E}+04$ \\
\hline & & $2.61 E+00$ & $8.99 \mathrm{E}+01$ & $5.29 \mathrm{E}+04$ & $3.68 \mathrm{E}+00$ & $6.68 \mathrm{E}+02$ & $2.96 \mathrm{E}+02$ & $3.96 \mathrm{E}+02$ & $7.57 \mathrm{E}+04$ \\
\hline & & $6.08 \mathrm{E}-01$ & $5.45 E+01$ & $2.80 E+04$ & $1.92 \mathrm{E}+\infty 0$ & $4.51 E+02$ & $1.23 E+02$ & $1.87 E+02$ & $3.35 E+04$ \\
\hline & & $7.95 \mathrm{E}-01$ & $<0.422$ & $2.22 \mathrm{E}+04$ & $1.59 \mathrm{E}+00$ & $3.64 \mathrm{E}+02$ & $1.02 \mathrm{E}+02$ & $1.54 \mathrm{E}+02$ & $2.74 E+04$ \\
\hline & & $2.53 E+00$ & $<0.422$ & $6.71 E+04$ & $4.37 E+00$ & $6.09 \mathrm{E}+02$ & $2.69 E+02$ & 4.14E+02 & $7.22 \mathrm{E}+04$ \\
\hline & & $2.30 \mathrm{E}+00$ & $<0.422$ & $6.44 E+04$ & $4.34 \mathrm{E}+00$ & $5.87 \mathrm{E}+02$ & $2.53 \mathrm{E}+02$ & $3.89 \mathrm{E}+02$ & $6.79 E+04$ \\
\hline \multirow[t]{6}{*}{ Core $\$ 2$} & & $2.17 \mathrm{E}+00$ & $<0.422$ & $4.98 \mathrm{E}+04$ & $3.48 \mathrm{E}+\infty 0$ & $4.76 \mathrm{E}+02$ & $3.15 \mathrm{E}+02$ & $2.28 \mathrm{E}+02$ & $6.63 \mathrm{E}+04$ \\
\hline & & $3.13 \mathrm{E}+00$ & $<0.422$ & $6.13 E+04$ & 4. $18 \mathrm{E}+00$ & $5.72 \mathrm{E}+02$ & $3.05 E+02$ & $2.71 \mathrm{E}+02$ & $8.04 \mathrm{E}+04$ \\
\hline & & $1.08 \mathrm{E}+00$ & $1.15 \mathrm{E}+02$ & $7.22 E+04$ & $4.33 \mathrm{E}+00$ & $5.81 E+02$ & $2.76 \mathrm{E}+02$ & $2.78 \mathrm{E}+02$ & $7.89 \mathrm{E}+04$ \\
\hline & & $2.54 \mathrm{E}-01$ & $<0.422$ & $7.13 \mathrm{E}+04$ & $4.06 E+00$ & $5.79 \mathrm{E}+02$ & $2.97 \mathrm{E}+02$ & $2.92 \mathrm{E}+02$ & $7.82 \mathrm{E}+04$ \\
\hline & & $2.22 \mathrm{E}+00$ & $1.79 \mathrm{E}+02$ & $7.11 E+04$ & $3.70 E+00$ & $5.36 \mathrm{E}+02$ & $3.41 E+02$ & $2.99 \mathrm{E}+02$ & $7.16 E+04$ \\
\hline & & $9.63 \mathrm{E}-01$ & $<0.422$ & $6.89 E+04$ & $3.61 E+00$ & $5.25 E+02$ & $3.11 \mathrm{E}+02$ & $3.23 \mathrm{E}+02$ & $6.81 \mathrm{E}+04$ \\
\hline \multirow[t]{7}{*}{ Core S3 } & & $8.98 \mathrm{E}-02$ & $<0.422$ & $8.19 E+03$ & $8.08 \mathrm{E}-01$ & $2.87 \mathrm{E}+01$ & $9.52 \mathrm{E}+02$ & $2.69 \mathrm{E}+01$ & $2.32 \mathrm{E}+04$ \\
\hline & & $8.08 \mathrm{E}-01$ & $<0.422$ & $1.94 E+04$ & $1.53 \mathrm{E}+00$ & $3.65 \mathrm{E}+02$ & $9.43 \mathrm{E}+01$ & $2.13 E+02$ & $2.60 E+04$ \\
\hline & & $8.65 \mathrm{E}-01$ & $5.77 E+01$ & $1.84 \mathrm{E}+04$ & $1.38 E+\infty 0$ & $3.51 \mathrm{E}+02$ & $9.35 E+01$ & $2.26 \mathrm{E}+02$ & $2.51 E+04$ \\
\hline & & $8.30 \mathrm{E}-01$ & $5.84 \mathrm{E}+01$ & $3.27 \mathrm{E}+04$ & $1.66 \mathrm{E}+00$ & $3.54 \mathrm{E}+02$ & $1.15 E+02$ & $2.53 \mathrm{E}+02$ & $3.25 E+04$ \\
\hline & & $8.08 E_{-01}$ & $<0.422$ & $2.73 E+04$ & $1.35 E+00$ & $2.97 \mathrm{E}+02$ & $9.61 \mathrm{E}+01$ & $2.30 \mathrm{E}+02$ & $2.75 \mathrm{E}+04$ \\
\hline & & $7.52 \mathrm{E}-01$ & $1.55 \mathrm{E}+02$ & $3.31 E+04$ & $1.38 \mathrm{E}+00$ & $5.69 \mathrm{E}+02$ & $2.04 \mathrm{E}+02$ & $5.12 E+02$ & $3.19 E+04$ \\
\hline & & $1.17 \mathrm{E}+00$ & $2.23 \mathrm{E}+02$ & $4.93 \mathrm{E}+04$ & $2.33 E+00$ & $8.15 \mathrm{E}+02$ & $2.35 E+02$ & $7.30 \mathrm{E}+02$ & 4.61E+04 \\
\hline \multirow[t]{8}{*}{ Core S4 } & & $1.04 \mathrm{E}+00$ & $<0.422$ & $4.92 \mathrm{E}+04$ & $3.97 \mathrm{E}+00$ & $4.12 \mathrm{E}+02$ & $2.17 \mathrm{E}+02$ & $2.83 \mathrm{E}+02$ & $5.95 \mathrm{E}+04$ \\
\hline & & $1.04 E+00$ & $<0.422$ & $4.14 E+04$ & $3.28 \mathrm{E}+00$ & $3.33 \mathrm{E}+02$ & $1.74 \mathrm{E}+02$ & $2.38 \mathrm{E}+02$ & $5.04 \mathrm{E}+04$ \\
\hline & & $4.66 \mathrm{E}+00$ & $1.49 \mathrm{E}+02$ & $4.75 E+04$ & $3.11 \mathrm{E}+00$ & $8.68 \mathrm{E}+02$ & $2.20 \mathrm{E}+02$ & $3.78 \mathrm{E}+02$ & $6.42 E+04$ \\
\hline & & $1.02 E-00$ & $1.96 \mathrm{E}+02$ & $5.94 \mathrm{E}+04$ & $3.84 E+00$ & $9.95 \mathrm{E}+02$ & $2.71 \mathrm{E}+02$ & $4.25 \mathrm{E}+02$ & $7.57 E+04$ \\
\hline & & $1.33 \mathrm{E}+00$ & $9.7 \mid E+01$ & $4.09 \mathrm{E}+04$ & $3.11 \mathrm{E}+00$ & $5.00 \mathrm{E}+02$ & $2.51 \mathrm{E}+02$ & $4.44 \mathrm{E}+02$ & $6.47 E+04$ \\
\hline & & $1.19 \mathrm{E}+00$ & $1.09 \mathrm{E}+02$ & $4.51 \mathrm{E}+04$ & $3.79 \mathrm{E}+00$ & $5.31 \mathrm{E}+02$ & $2.70 \mathrm{E}+02$ & 4.29E+02 & $6.71 E+04$ \\
\hline & & $1.15 E+00$ & $<0.422$ & $4.93 E+04$ & $3.21 E+00$ & $6.37 \mathrm{E}+02$ & $2.66 \mathrm{E}+02$ & $4.93 \mathrm{E}+02$ & $6.76 \mathrm{E}+04$ \\
\hline & & $1.16 \mathrm{E}+00$ & $<0.422$ & $5.00 \mathrm{E}+04$ & $3.70 \mathrm{E}+00$ & $6.37 \mathrm{E}+02$ & $2.78 E+02$ & $5.63 \mathrm{E}+02$ & $7.15 E+04$ \\
\hline \multirow[t]{6}{*}{ Core S5 } & & $<0.0001$ & $<0.422$ & $5.76 E+04$ & $2.70 \mathrm{E}+00$ & $5.82 \mathrm{E}+02$ & $2.20 \mathrm{E}+02$ & $2.54 \mathrm{E}+02$ & $5.55 \mathrm{E}+04$ \\
\hline & & $2.09 \mathrm{E}-01$ & $9.07 \mathrm{E}+01$ & $6.78 \mathrm{E}+04$ & $3.13 E+00$ & $6.94 \mathrm{E}+02$ & $2.63 \mathrm{E}+02$ & $3.04 E+02$ & $6.44 E+04$ \\
\hline & & $7.71 \mathrm{E}-01$ & $1.05 E+02$ & $4.95 \mathrm{E}+04$ & $2.89 E+00$ & $9.23 E+02$ & $1.91 \mathrm{E}+02$ & $3.99 \mathrm{E}+02$ & $5.53 E+04$ \\
\hline & & $<0.0001$ & $1.22 E+02$ & $6.11 E+04$ & $3.34 E+00$ & $9.71 \mathrm{E}+02$ & $2.30 \mathrm{E}+02$ & $4.34 \mathrm{E}+02$ & $6.29 \mathrm{E}+04$ \\
\hline & & $1.86 \mathrm{E}-01$ & $<0.422$ & $5.06 \mathrm{E}+04$ & $2.79 \mathrm{E}+00$ & $5.86 \mathrm{E}+02$ & 2. $12 \mathrm{E}+02$ & $4.75 E+02$ & $5.55 \mathrm{E}+04$ \\
\hline & & 4.42E-01 & $<0.422$ & $5.62 \mathrm{E}+04$ & $3.54 \mathrm{E}+00$ & $6.06 \mathrm{E}+02$ & $2.81 \mathrm{E}+02$ & $4.66 \mathrm{E}+02$ & $6.15 \mathrm{E}+04$ \\
\hline
\end{tabular}




\begin{tabular}{|c|c|c|c|c|c|c|c|}
\hline Core ID & Extraction & $\mathrm{Hg}_{\mathrm{g}}$ & $\mathbf{K}$ & $\mathbf{M g}$ & $\mathbf{M n}$ & Mo & $\mathrm{Na}$ \\
\hline \multirow[t]{34}{*}{ Core S1 } & Exchangeable & $<0.009$ & $1.34 \bar{E}+02$ & $1.25 E+05$ & $2.15 \mathrm{E}+01$ & $8.05 E+00$ & $1.41 \mathrm{E}+04$ \\
\hline & Carbonate & $<0.009$ & $1.85 E+02$ & $2.34 \mathrm{E}+04$ & $2.78 \mathrm{E}+02$ & $<0.036$ & $<0.1$ \\
\hline & $\mathrm{Fe}, \mathrm{Mn}$ Oxides & $<0.009$ & $4.50 E+01$ & $8.94 E+02$ & $5.13 \mathrm{E}+01$ & $<0.036$ & $<0.1$ \\
\hline & Organic Matter & $2.65 \mathrm{E}+00$ & $4.18 \mathrm{E}+01$ & $7.57 \mathrm{E}+02$ & $2.13 \mathrm{E}+0 \mathrm{I}$ & $<0.036$ & $1.89 \mathrm{E}+03$ \\
\hline & Residual & $2.24 \mathrm{E}+01$ & $2.45 E+03$ & $1.91 E+04$ & $7.87 \mathrm{E}+02$ & $5.31 E+00$ & $3.62 E+03$ \\
\hline & Exchangeable & $2.79 \mathrm{E}+01$ & $1.52 \mathrm{E}+02$ & $1.33 E+05$ & $2.50 E+01$ & $6.99 \mathrm{E}+00$ & $1.68 E+04$ \\
\hline & Carbonate & $9.03 E+00$ & $1.70 \mathrm{E}+02$ & $2.41 E+04$ & $2.72 E+02$ & $<0.036$ & $<0.1$ \\
\hline & $\mathrm{Fe}, \mathrm{Mn}$ Oxides & $<0.009$ & $5.21 \mathrm{E}+01$ & $9.38 E+02$ & $4.88 \mathrm{E}+01$ & $<0.036$ & $<0.1$ \\
\hline & Organic Matter & $<0.009$ & $3.90 \mathrm{E}+01$ & $4.03 E+02$ & $1.72 E+01$ & $<0.036$ & $1.25 E+03$ \\
\hline & Residual & $1.89 E+01$ & $2.84 E+03$ & $1.74 E+04$ & $7.10 E+02$ & $4.34 \mathrm{E}+00$ & $6.45 E+03$ \\
\hline & Exchangeable & $2.27 \mathrm{E}+01$ & $9.20 E+01$ & $1.15 E+05$ & $1.84 \mathrm{E}+0 \mathrm{I}$ & $6.19 \mathrm{E}+00$ & $2.04 E+04$ \\
\hline & Exchangeable & $2.36 \mathrm{E}+01$ & $5.33 \mathrm{E}+01$ & I. $18 \mathrm{E}+05$ & $1.34 \mathrm{E}+0 \mathrm{I}$ & $6.19 \mathrm{E}+\infty 0$ & $2.01 \mathrm{E}+04$ \\
\hline & Carbonate & $1.36 \mathrm{E}+01$ & $8.28 \mathrm{E}-01$ & $1.68 \mathrm{E}+04$ & $1.81 \mathrm{E}+02$ & $<0.036$ & $<0.1$ \\
\hline & Carbonate & $<0.009$ & $8.36 \mathrm{E}+01$ & $2.96 \mathrm{E}+03$ & $5.46 E+0 t$ & $<0.036$ & $<0.1$ \\
\hline & Fe, Mn Oxides & $<0.009$ & $2.37 \mathrm{E}+01$ & $2.59 \mathrm{E}+02$ & $1.11 \mathrm{E}+01$ & $<0.036$ & $<0.1$ \\
\hline & Fe, Mn Oxides & $<0.009$ & $2.29 \mathrm{E}+01$ & $8.78 E+01$ & $3.72 \mathrm{E}+00$ & $<0.036$ & $<0.1$ \\
\hline & Organic Matter & $<0.009$ & $3.24 E+01$ & $5.13 E+02$ & $1,85 \mathrm{E}+01$ & $4.25 \mathrm{E}+00$ & $2.52 \mathrm{E}+03$ \\
\hline & Organic Matter & $7.02 \mathrm{E}+01$ & $1.78 \mathrm{E}+01$ & $1.68 \mathrm{E}+02$ & $6.46 \mathrm{E}+\infty 0$ & $<0.036$ & $1.52 \mathrm{E}+02$ \\
\hline & Residual & $1.28 \mathrm{E}+01$ & $1.74 E+03$ & $1.27 \mathrm{E}+04$ & $5.25 \mathrm{E}+02$ & $<0.036$ & $6.20 \mathrm{E}+02$ \\
\hline & Exchangeable & $1.70 E+01$ & $2.79 E+01$ & $5.57 \mathrm{E}+04$ & $1.14 \mathrm{E}+01$ & $3.54 \mathrm{E}+00$ & $4.87 \mathrm{E}+03$ \\
\hline & Carbonate & $1.75 \mathrm{E}+01$ & 1. $20 \mathrm{E}+02$ & $5.41 \mathrm{E}+04$ & $1.90 \mathrm{E}+02$ & $<0.036$ & $<0.1$ \\
\hline & Fe, Mn Oxides & $<0.009$ & $3.62 \mathrm{E}+01$ & $1.69 E+03$ & $2.94 \mathrm{E}+01$ & $<0.036$ & $<0.1$ \\
\hline & Organic Matter & $<0.009$ & $9.11 \mathrm{E}+00$ & $4.26 \mathrm{E}+02$ & $1.58 \mathrm{E}+01$ & $<0.036$ & $8.80 E+02$ \\
\hline & Residual & $1.15 \mathrm{E}+02$ & $2.07 E+03$ & $1.26 \mathrm{E}+04$ & $5.58 \mathrm{E}+02$ & $3.63 \mathrm{E}+00$ & $6.95 \mathrm{E}+02$ \\
\hline & Exchangeable & 2. IIE+01 & $8.94 E+01$ & $1.24 E+05$ & $2.04 \mathrm{E}+01$ & $6.64 E+\infty 0$ & $1.47 \mathrm{E}+04$ \\
\hline & Carbonate & $9.11 E+\infty$ & $1.61 E+02$ & $2.62 \mathrm{E}+04$ & $1.19 E+02$ & $<0.036$ & $<0.1$ \\
\hline & $\mathrm{Fe}, \mathrm{Mn}$ Oxides & $<0.009$ & $3.97 E+01$ & $5.91 E+02$ & $1.09 \mathrm{E}+01$ & $<0.036$ & $<0.1$ \\
\hline & Organic Matter & $<0.009$ & $2.71 E+01$ & $4.88 \mathrm{E}+02$ & $1.72 \mathrm{E}+01$ & $<0.036$ & 1. $19 \mathrm{E}+03$ \\
\hline & Residual & $1.50 E+02$ & $2.50 \mathrm{E}+03$ & $1.35 E+04$ & $6.11 \mathrm{E}+02$ & $<0.036$ & $8.08 E+02$ \\
\hline & Exchangeable & $2.22 \mathrm{E}+01$ & $7.59 \mathrm{E}+01$ & $1.18 \mathrm{E}+05$ & $1.96 \mathrm{E}+01$ & $5.93 E+00$ & $1.41 E+04$ \\
\hline & Carbonate & $<0.009$ & $1.66 \mathrm{E}+02$ & $2.12 \mathrm{E}+04$ & $1.25 \mathrm{E}+02$ & $<0.036$ & $<0.1$ \\
\hline & $\mathrm{Fe}, \mathrm{Mn}$ Oxides & $<0.009$ & $3.75 E+01$ & $5.31 \mathrm{E}+02$ & $1.22 E+01$ & $<0.036$ & $<0.1$ \\
\hline & Organic Matter & $<0.009$ & $1.63 E+01$ & $3.75 \mathrm{E}+02$ & $1.36 E+01$ & $<0.036$ & 1. $12 \mathrm{E}+03$ \\
\hline & Residual & 1. $22 \mathrm{E}+01$ & $2.80 \mathrm{E}+03$ & $1.30 \mathrm{E}+04$ & $5.83 E+02$ & $4.78 \mathrm{E}+00$ & 1. $13 E+03$ \\
\hline Core ID & Extraction & $\mathrm{Hg}_{\mathrm{g}}$ & $\mathbf{K}$ & $\mathbf{M g}$ & $\mathbf{M n}$ & Mo & $\mathrm{Na}$ \\
\hline \multirow[t]{30}{*}{ Core S2 } & Exchangeable & $4.69 \mathrm{E}+00$ & $6.95 \mathrm{E}+01$ & $9.38 \mathrm{E}+03$ & $4.6 \mathrm{IE}+0 \mathrm{I}$ & $<0.036$ & $<0.1$ \\
\hline & Carbonate & $<0.009$ & $6.72 \mathrm{E}+01$ & $2.83 \mathrm{E}+03$ & $4.58 \mathrm{E}+01$ & $<0.036$ & $<0.1$ \\
\hline & Fe, Mn Oxides & $<0.009$ & $2.12 \mathrm{E}+01$ & $2.00 \mathrm{E}+02$ & $9.47 \mathrm{E}+00$ & $<0.036$ & $<0.1$ \\
\hline & Organic Matter & $4.81 \mathrm{E}+01$ & $2.28 \mathrm{E}+01$ & $3.50 \mathrm{E}+02$ & $1.37 \mathrm{E}+01$ & $<0.036$ & $7.03 \mathrm{E}+02$ \\
\hline & Residual & $165 \mathrm{E}+01$ & $2.50 \mathrm{E}+03$ & $140 E+04$ & $7.51 E+02$ & $<0.036$ & $1.02 E+03$ \\
\hline & Exchangeable & $5,31 E+00$ & $6.48 E+01$ & $8.73 \mathrm{E}+03$ & $4.30 \mathrm{E}+01$ & $<0.036$ & $<0.1$ \\
\hline & Carbonate & $<0.009$ & $5.93 E+01$ & $2.05 E+03$ & $4.18 E+01$ & $<0.036$ & $<0.1$ \\
\hline & Fe, Mn Oxides & $<0.009$ & $1.65 \mathrm{E}+01$ & $2.36 \mathrm{E}+02$ & $1.16 \mathrm{E}+01$ & $<0.036$ & $<0.1$ \\
\hline & Organic Matter & $<0.009$ & $2.34 \mathrm{E}+01$ & $3.85 E+02$ & $1.55 \mathrm{E}+01$ & $<0.036$ & $9.73 E+02$ \\
\hline & Residual & $1.70 \mathrm{E}+01$ & $2.34 E+03$ & $1.37 \mathrm{E}+04$ & $7.35 \mathrm{E}+02$ & $<0.036$ & $1.04 \mathrm{E}+03$ \\
\hline & Exchangeable & $2.13 \mathrm{E}+01$ & $6.95 E+01$ & $1.26 \mathrm{E}+05$ & $2.03 E+01$ & $6.72 \mathrm{E}+00$ & $1.50 \mathrm{E}+04$ \\
\hline & Carbonate & $<0.009$ & $1.53 \mathrm{E}+02$ & $3.26 \mathrm{E}+04$ & $1.09 \mathrm{E}+02$ & $<0.036$ & $<0.1$ \\
\hline & $\mathrm{Fe}, \mathrm{Mn}$ Oxides & $<0.009$ & $3.08 \mathrm{E}+01$ & $8.19 E+02$ & $1.36 \mathrm{E}+01$ & $<0.036$ & $<0.1$ \\
\hline & Organic Matter & $<0.009$ & $3.18 \mathrm{E}+01$ & $3.34 \mathrm{E}+02$ & $1.31 \mathrm{E}+01$ & $<0.036$ & $9.9[E+02$ \\
\hline & Residual & $1.34 E+01$ & $2.03 \mathrm{E}+03$ & $1.31 \mathrm{E}+04$ & $7.36 \mathrm{E}+02$ & $<0.036$ & $7.09 \mathrm{E}+02$ \\
\hline & Exchangeable & $2.96 \mathrm{E}+01$ & $6.03 E+01$ & $1.25 \mathrm{E}+05$ & $2.01 \mathrm{E}+0 \mathrm{I}$ & $6.28 \mathrm{E}+00$ & $1.53 \mathrm{E}+04$ \\
\hline & Carbonate & $<0.009$ & $1.47 \mathrm{E}+02$ & $3.50 E+04$ & $1.04 \mathrm{E}+02$ & $<0.036$ & $<0.1$ \\
\hline & Fe, Mn Oxides & $<0.009$ & $3.20 \mathrm{E}+01$ & $3.13 \mathrm{E}+02$ & $1.14 \mathrm{E}+01$ & $<0.036$ & $1.19 \mathrm{E}+03$ \\
\hline & Organic Matter & $<0.009$ & $3.92 \mathrm{E}+01$ & $1.14 E+03$ & $1.33 \mathrm{E}+01$ & $<0.036$ & $<0.1$ \\
\hline & Residual & $1.39 \mathrm{E}+01$ & $2.36 \mathrm{E}+03$ & $1.19 \mathrm{E}+04$ & $6.71 \mathrm{E}+02$ & $<0.036$ & $7.53 E+02$ \\
\hline & Exchangeable & $5.13 E+00$ & $8.18 \mathrm{E}+0 \mathrm{I}$ & $8.48 E+03$ & $4.12 \mathrm{E}+01$ & $<0.036$ & $<0.1$ \\
\hline & Carbonate & $1.57 \mathrm{E}+01$ & $5.90 \mathrm{E}+01$ & $1.47 \mathrm{E}+03$ & $9.56 \mathrm{E}+01$ & $<0.036$ & $<0.1$ \\
\hline & $\mathrm{Fe}, \mathrm{Mn}$ Oxides & $<0.009$ & $3.45 E+01$ & $2.11 E+02$ & 1.19E+01 & $<0.036$ & $<0.1$ \\
\hline & Organic Matter & $<0.009$ & $5.07 \mathrm{E}+01$ & $2.99 \mathrm{E}+02$ & $1.10 \mathrm{E}+01$ & $<0.036$ & $7.00 \mathrm{E}+02$ \\
\hline & Residual & $1.40 \mathrm{E}+01$ & $2.22 E+03$ & $1.21 E+04$ & $6.27 \mathrm{E}+02$ & $<0.036$ & $6.86 \mathrm{E}+02$ \\
\hline & Exchangeable & $2.25 E+01$ & $1.19 E+02$ & $1.23 \mathrm{E}+05$ & $1.70 E+01$ & $6.28 \mathrm{E}+00$ & $1.45 E+04$ \\
\hline & Carbonate & $<0.009$ & $1.55 \mathrm{E}+02$ & $3.56 \mathrm{E}+04$ & $1.02 E+02$ & $3.19 \mathrm{E}+00$ & $<0.1$ \\
\hline & Fe, Mn Oxides & $1.06 \mathrm{E}+00$ & $4.07 \mathrm{E}+01$ & $5.70 \mathrm{E}+02$ & $1.11 E+01$ & $<0.036$ & $<0.1$ \\
\hline & Organic Matter & $<0.009$ & $1.57 \mathrm{E}+01$ & $2.78 \mathrm{E}+02$ & $1.10 E+01$ & $<0.036$ & $6.82 E+02$ \\
\hline & Residual & $1.33 E+01$ & $3.19 \mathrm{E}+03$ & $1.40 E+04$ & 7. $19 \mathrm{E}+02$ & $<0.036$ & $9.91 \mathbf{E}+02$ \\
\hline Core ID & Extraction & $\mathrm{Hg}$ & $\mathbf{K}$ & $\mathbf{M g}$ & $\mathbf{M n}$ & Mo & $\mathbf{N a}$ \\
\hline \multirow[t]{17}{*}{ Core $\mathbf{S 3}$} & Exchangeable & $4.61 E+01$ & $7.80 \mathrm{E}+01$ & $1.14 \mathrm{E}+05$ & $5.77 E+01$ & $5.93 \mathrm{E}+00$ & $1.96 E+04$ \\
\hline & Exchangeable & $2.19 \mathrm{E}+01$ & $3.37 \mathrm{E}+01$ & $1.23 E+05$ & $2.04 \mathrm{E}+01$ & $6.64 \mathrm{E}+00$ & $2.19 \mathrm{E}+04$ \\
\hline & Carbonate & $9.29 \mathrm{E}+00$ & $4.03 \mathrm{E}+01$ & $1.91 \mathbf{E}+04$ & $6.18 \mathrm{E}+01$ & $<0.036$ & $<0.1$ \\
\hline & Carbonate & $<0.009$ & $5.22 \mathrm{E}+01$ & $2.21 \mathrm{E}+03$ & $2.79 \mathrm{E}+01$ & $<0.036$ & $<0.1$ \\
\hline & Fe, Mn Oxides & $<0.009$ & $3.03 \mathrm{E}+01$ & $2.01 E+02$ & $1.05 \mathrm{E}+01$ & $<0.036$ & $<0.1$ \\
\hline & Fe, Mn Oxides & $<0.009$ & $2.83 \mathrm{E}+01$ & $1.02 \mathrm{E}+02$ & $4.60 \mathrm{E}+00$ & $<0.036$ & $<0.1$ \\
\hline & Organic Matter & $<0.009$ & $3.73 E+01$ & $5.94 E+02$ & $2.05 E+01$ & 3.19E+00 & $2.62 E+03$ \\
\hline & Organic Matter & $<0.009$ & $182 E+01$ & $1.65 \mathrm{E}+02$ & $6.55 \mathrm{E}+00$ & $<0.036$ & $2.05 E+02$ \\
\hline & Exchangeable & $6.90 \mathrm{E}+00$ & $6.46 \mathrm{E}+01$ & $6.52 \mathrm{E}+03$ & 8.53E+01 & $<0.036$ & $<0.1$ \\
\hline & Carbonate & $<0.009$ & $5.92 \mathrm{E}+01$ & $2.11 E+03$ & $8.49 \mathrm{E}+01$ & $<0.036$ & $<0.1$ \\
\hline & Fe, Mn Oxides & $<0.009$ & $3.13 E+01$ & $3.91 \mathrm{E}+02$ & $2.90 \mathrm{E}+01$ & $<0.036$ & $<0.1$ \\
\hline & Organic Matter & $<0.009$ & $2.47 \mathrm{E}+01$ & $6.48 \mathrm{E}+02$ & $1.81 \mathrm{E}+01$ & $<0.036$ & $1.07 E+03$ \\
\hline & Residual & $2.43 E+01$ & $2.33 E+03$ & $9.56 \mathrm{E}+03$ & 4.35E+02 & $<0.036$ & $7.96 \mathrm{E}+02$ \\
\hline & Exchangeable & $3.89 \mathrm{E}+00$ & $6.18 E+01$ & $6.90 \mathrm{E}+03$ & 4.57E+01 & $<0.036$ & $<0.1$ \\
\hline & Carbonate & $<0.009$ & 4.56E+01 & $1.70 \mathrm{E}+03$ & $1.83 \mathrm{E}+02$ & $<0.036$ & $<0.1$ \\
\hline & Fe, Mn Oxides & $<0.009$ & $1.74 E+01$ & $2.47 E+02$ & $1.59 \mathrm{E}+01$ & $<0.036$ & $<0.1$ \\
\hline & Organic Matter & $<0.009$ & $9.56 \mathrm{E}+00$ & $4.77 \mathrm{E}+02$ & $2.23 \mathrm{E}+01$ & $<0.036$ & $7.32 \mathrm{E}+02$ \\
\hline
\end{tabular}




\begin{tabular}{|c|c|c|c|c|c|c|c|}
\hline & Residual & $1.42 \mathrm{E}+01$ & $1.02 \mathrm{E}+03$ & $1.26 \mathrm{E}+04$ & $4.78 \mathrm{E}+02$ & $5.84 \mathbf{E}+00$ & $4.80 E+02$ \\
\hline & Exchangeable & $2.23 \mathrm{E}+01$ & $3.57 \mathrm{E}+01$ & $1.17 \mathrm{E}+05$ & $1.31 \mathrm{E}+01$ & $6.72 E+00$ & $2.07 E+04$ \\
\hline & Exchangeable & $2.14 \mathrm{E}+01$ & $2.29 \mathrm{E}+01$ & $1.24 \mathrm{E}+05$ & $1.19 \mathrm{E}+01$ & $6.37 \mathrm{E}+00$ & $2.15 \mathrm{E}+04$ \\
\hline & Carbonate & $3,45 E+00$ & $4.42 \mathrm{E}+01$ & $8.94 \mathrm{E}+03$ & $1.41 \mathrm{E}+02$ & $<0.036$ & $<0.1$ \\
\hline & Carbonate & $<0.009$ & $5.34 \mathrm{E}+01$ & $1.31 \mathrm{E}+03$ & $4.05 E+01$ & $<0.036$ & $<0.1$ \\
\hline & Fe, Mn Oxides & $<0.009$ & $2.65 E+01$ & $1.43 \mathrm{E}+02$ & $5.84 E+00$ & $<0.036$ & $<0.1$ \\
\hline & Fe, Mn Oxides & $<0.009$ & $2.29 \mathrm{E}+01$ & $1.19 \mathrm{E}+02$ & $4.51 E+00$ & $<0.036$ & $<0.1$ \\
\hline & Organic Matter & $<0.009$ & $2.24 E+01$ & 5. $59 \mathrm{E}+02$ & $1.42 \mathrm{E}+01$ & $6.28 E+00$ & $4.24 \mathrm{E}+03$ \\
\hline & Organic Matter & $<0.009$ & $1.24 E+01$ & $1.43 E+02$ & $5.57 \mathrm{E}+00$ & $<0.036$ & $5.15 E+02$ \\
\hline & Residual & $8.75 E+01$ & $9.47 \mathrm{E}+02$ & $1.00 E+04$ & $3.85 \mathrm{E}+02$ & $<0.036$ & $3.19 E+02$ \\
\hline & Exchangeable & $6.64 E+00$ & $1.47 \mathrm{E}+02$ & $7.20 \mathrm{E}+03$ & $5.22 \mathrm{E}+01$ & $<0.036$ & $<0.1$ \\
\hline & Carbonate & $9.73 \mathrm{E}-01$ & $8.09 E+01$ & $2.96 \mathrm{E}+03$ & $1.25 \mathrm{E}+02$ & $<0.036$ & $<0.1$ \\
\hline & Fe, Mn Oxides & $<0.009$ & $4.82 \mathrm{E}+01$ & $7,44 \mathrm{E}+02$ & $5.76 \mathrm{E}+01$ & $<0.036$ & $<0.1$ \\
\hline & Organic Matter & $<0.009$ & $6.10 \mathrm{E}+01$ & $1.25 E+03$ & $5.66 \mathrm{E}+01$ & $<0.036$ & $2.40 \mathrm{E}+03$ \\
\hline & Residual & $9.47 E+00$ & $2.24 \mathrm{E}+03$ & $8.76 E+03$ & $4.36 E+02$ & $<0.036$ & $8.57 \mathrm{E}+02$ \\
\hline & Exchangeable & $2.44 \mathrm{E}+01$ & $1.01 E+02$ & $1.16 \mathrm{E}+05$ & $3.75 \mathrm{E}+01$ & $6.19 \mathrm{E}+\infty 0$ & $2.04 E+04$ \\
\hline & Exchangeable & $2.37 \mathrm{E}+01$ & $5.05 \mathrm{E}+01$ & $1.25 E+05$ & $2.05 \mathrm{E}+01$ & $6.55 \mathrm{E}+00$ & $2.21 E+04$ \\
\hline & Carbonate & $<0.009$ & $1.39 E+02$ & $1.91 \mathrm{E}+04$ & $1.89 \mathrm{E}+02$ & $<0.036$ & $<0.1$ \\
\hline & Carbonate & $7.70 \mathrm{E}+00$ & $6.39 \mathrm{E}+01$ & $2.57 \mathrm{E}+03$ & $4.42 \mathrm{E}+01$ & $<0,036$ & $<0.1$ \\
\hline & Fe, Mn Oxides & $<0.009$ & $4.69 \mathrm{E}+01$ & $4.41 \mathrm{E}+02$ & $3.04 \mathrm{E}+01$ & $<0.036$ & $<0.1$ \\
\hline & Fe, Mn Oxides & $3.36 \mathrm{E}+00$ & $2.96 \mathrm{E}+01$ & $1.55 \mathrm{E}+02$ & $7.96 \mathrm{E}+\infty$ & $<0.036$ & $<0.1$ \\
\hline & Organic Matter & $1.73 \mathrm{E}+02$ & $4.88 \mathrm{E}+01$ & $6.58 \mathrm{E}+02$ & $2.96 \mathrm{E}+01$ & $4.96 \mathrm{E}+00$ & $1.60 \mathrm{E}+03$ \\
\hline & Organic Matter & $<0.009$ & $2.11 E+01$ & $2.66 \mathrm{E}+02$ & $1.06 \mathrm{E}+01$ & $<0.036$ & $5.25 E+02$ \\
\hline & Residual & $2.90 \mathrm{E}+01$ & $2.88 \mathrm{E}+03$ & $1.22 E+04$ & $5.33 E+02$ & $<0.036$ & $7.80 \mathrm{E}+02$ \\
\hline Core ID & Extraction & Hg & $\mathbf{K}$ & $\mathbf{M g}$ & Mn & Mo & $\mathrm{Na}_{\mathbf{n}}$ \\
\hline \multirow[t]{40}{*}{ Core S4 } & Exchangeable & $2.73 \mathrm{E}+01$ & $7.49 \mathrm{E}+01$ & $1.30 \mathrm{E}+05$ & $1.38 \mathrm{E}+01$ & $6.90 E+00$ & $2.06 \mathrm{E}+04$ \\
\hline & Carbonate & $3.86 \mathrm{E}+01$ & $1.72 E+02$ & $4.52 \mathrm{E}+03$ & $1.34 E+02$ & $<0.036$ & $<0.1$ \\
\hline & Fe, Mn Oxides & $<0.009$ & $2.88 E+01$ & $3.31 \mathrm{E}+02$ & $1.49 \mathrm{E}+01$ & $<0.036$ & $<0.1$ \\
\hline & Organic Matter & $<0.009$ & $1.08 E+01$ & $4.41 E+02$ & $1.65 \mathrm{E}+01$ & $<0.036$ & $8.68 \mathrm{E}+02$ \\
\hline & Residual & $1.05 E+02$ & $8.94 \mathrm{E}+02$ & $1.29 E+04$ & $4.86 \mathrm{E}+02$ & $7.79 \mathrm{E}+00$ & $4.98 \mathrm{E}+02$ \\
\hline & Exchangeable & $2.19 \mathrm{E}+01$ & $7.64 \mathrm{E}+01$ & $1.32 \mathrm{E}+05$ & $1.24 \mathrm{E}+01$ & $6.90 \mathrm{E}+00$ & $2.12 E+04$ \\
\hline & Carbonate & $<0.009$ & $2.00 E+02$ & $5.70 \mathrm{E}+03$ & $1.51 \mathbf{E}+02$ & $<0.036$ & $<0.1$ \\
\hline & Fe, Mn Oxides & $<0.009$ & $4.42 E+01$ & $3.47 \mathrm{E}+02$ & $1.36 \mathbf{E}+01$ & $<0.036$ & $<0.1$ \\
\hline & Organic Matter & $<0.009$ & $1.65 \mathrm{E}+01$ & $5.11 \mathrm{E}+02$ & $1.84 E+01$ & $<0.036$ & $1.48 \mathrm{E}+03$ \\
\hline & Residual & $1.81 \mathrm{E}+01$ & $1.27 \mathrm{E}+03$ & $1.50 \mathrm{E}+04$ & $5.49 \mathrm{E}+02$ & $<0.036$ & 8. $25 \mathrm{E}+02$ \\
\hline & Exchangeable & $2.68 \mathrm{E}+01$ & $7.41 \mathrm{E}+01$ & $1.26 \mathrm{E}+0.5$ & $9.73 E+00$ & $6.81 E+\infty 0$ & $1.96 \mathrm{E}+04$ \\
\hline & Carbonate & $<0.009$ & $1.31 \mathrm{E}+02$ & $3.00 \mathrm{E}+03$ & $9.38 \mathrm{E}+01$ & $<0.036$ & $<0.1$ \\
\hline & $\mathrm{Fe}$, Mn Oxides & $<0.009$ & $3.45 \mathrm{E}+01$ & $2.96 \mathrm{E}+02$ & $1.09 \mathrm{E}+01$ & $<0.036$ & $<0.1$ \\
\hline & Organic Matter & $<0.009$ & $1.96 \mathrm{E}+01$ & $4.38 \mathrm{E}+02$ & $1.46 \mathrm{E}+01$ & $3.89 \mathrm{E}+\infty 0$ & 1. $40 \mathrm{E}+03$ \\
\hline & Residual & $1.57 \mathbf{E}+01$ & $1.07 E+03$ & $1.33 \mathrm{E}+04$ & $4.39 \mathrm{E}+02$ & $<0.036$ & $6.55 \mathrm{E}+02$ \\
\hline & Exchangeable & $2.83 \mathrm{E}+01$ & $7.13 E+01$ & $1.23 \mathrm{E}+05$ & $1.06 \mathrm{E}+01$ & $6.55 E+\infty$ & $1.88 \mathrm{E}+04$ \\
\hline & Carbonate & $<0.009$ & 1. $19 \mathrm{E}+02$ & $4.32 \mathrm{E}+03$ & $8.65 E+01$ & $<0.036$ & $<0.1$ \\
\hline & Fe, Mn Oxides & $<0.009$ & $3.57 \mathrm{E}+01$ & $3.54 \mathrm{E}+02$ & $1.16 \mathrm{E}+01$ & $<0.036$ & $<0.1$ \\
\hline & Organic Matter & $1.15 \mathrm{E}+\infty 0$ & $1.67 \mathrm{E}+01$ & $4.09 \mathrm{E}+02$ & $1.34 \mathrm{E}+01$ & $3.89 \mathrm{E}+00$ & $9.91 \mathrm{E}+02$ \\
\hline & Residual & $1.42 \mathrm{E}+01$ & $1.35 \mathrm{E}+03$ & $1.30 \mathrm{E}+04$ & $4.65 \mathrm{E}+02$ & $<0,036$ & $6.45 \mathrm{E}+02$ \\
\hline & Exchangeable & $2.38 \mathrm{E}+01$ & $7.75 \mathrm{E}+01$ & $1.30 \mathrm{E}+05$ & $8.58 \mathrm{E}+00$ & $6.99 E+00$ & $2.07 E+04$ \\
\hline & Carbonate & $<0.009$ & $1.37 E+02$ & $4.80 \mathrm{E}+03$ & $7.67 \mathrm{E}+01$ & $<0.036$ & $<0.1$ \\
\hline & $\mathrm{Fe}$, Mn Oxides & $3.10 \mathrm{E}+00$ & $3.76 \mathrm{E}+01$ & $2.57 \mathrm{E}+02$ & $1.04 \mathrm{E}+01$ & $<0.036$ & $<0.1$ \\
\hline & Organic Matter & 7.96E-01 & $1.06 \mathrm{E}+01$ & $3.73 E+02$ & $1.39 E+01$ & $<0.036$ & $8.70 \mathrm{E}+02$ \\
\hline & Residual & $1.86 \mathrm{E}+01$ & $1.82 \mathrm{E}+03$ & $1.08 \mathrm{E}+04$ & $6.31 E+02$ & $5.58 \mathrm{E}+01$ & $3.62 \mathrm{E}+02$ \\
\hline & Exchangeable & $2.17 \mathrm{E}+01$ & $6.49 \mathrm{E}+01$ & $1.25 \mathrm{E}+05$ & $7.17 E+00$ & $6.64 \mathbf{E}+00$ & $1.92 \mathrm{E}+04$ \\
\hline & Carbonate & $<0.009$ & $1.39 E+02$ & $5.52 \mathbf{E}+03$ & $7.50 \mathrm{E}+01$ & $<0.036$ & $<0.1$ \\
\hline & Fe, Mn Oxides & $4.22 E+01$ & 4.55E+01 & $2.94 \mathrm{E}+02$ & $1.09 E+01$ & $<0.036$ & $<0.1$ \\
\hline & Organic Matter & $8.14 E+00$ & $4.78 \mathrm{E}+00$ & $2.42 E+02$ & $6.81 E+\infty 0$ & $<0.036$ & $4.92 \mathrm{E}+02$ \\
\hline & Residual & $1.57 \mathrm{E}+01$ & $1.90 \mathrm{E}+03$ & $1.30 E+04$ & $5.04 E+02$ & $<0.036$ & $3.73 \mathrm{E}+02$ \\
\hline & Exchangeable & $2.27 \mathrm{E}+01$ & $7.28 \mathrm{E}+01$ & $127 \mathrm{E}+05$ & $1.04 \mathrm{E}+01$ & $6.72 \mathrm{E}+00$ & $1.97 E+04$ \\
\hline & Carbonate & $<0.009$ & $1.44 E+02$ & $3.65 \mathrm{E}+03$ & $1.04 E+02$ & $<0.036$ & $<0.1$ \\
\hline & Fe, Mn Oxides & $<0.009$ & 4.98E+01 & $3.01 \mathrm{E}+02$ & $1.34 \mathrm{E}+01$ & $<0.036$ & $<0.1$ \\
\hline & Organic Matter & $9.73 \mathrm{E}-01$ & $1.42 \mathrm{E}+01$ & $3.22 \mathrm{E}+02$ & $1.12 \mathrm{E}+01$ & $<0.036$ & $1.27 \mathrm{E}+02$ \\
\hline & Residual & $1.73 E+01$ & $2.50 \mathrm{E}+03$ & $1.10 E+04$ & $5.85 \mathrm{E}+02$ & $3.62 \mathrm{E}+01$ & $5.97 E+02$ \\
\hline & Exchangeable & $2.29 \mathrm{E}+01$ & $7.84 \mathrm{E}+01$ & $1.28 E+05$ & $1.09 \mathrm{E}+01$ & $6.99 \mathrm{E}+00$ & $2.06 \mathrm{E}+04$ \\
\hline & Carbonate & $<0.009$ & $1.32 E+02$ & $3.92 \mathrm{E}+03$ & $9.11 \mathrm{E}+01$ & $<0.036$ & $<0.1$ \\
\hline & $\mathrm{Fe}, \mathrm{Mn}$ Oxides & $1.27 \mathrm{E}+01$ & $4.32 E+01$ & $3.00 \mathrm{E}+02$ & $1.24 \mathrm{E}+01$ & $<0.036$ & $<0.1$ \\
\hline & Organic Matter & $<0.009$ & $2.22 \mathrm{E}+01$ & $3.24 \mathrm{E}+02$ & $1.20 \mathrm{E}+01$ & $<0.036$ & $1.17 \mathrm{E}+03$ \\
\hline & $\begin{array}{c}\text { Residual } \\
\text { Extraction } \\
\end{array}$ & $\begin{array}{c}1.73 E+01 \\
\mathrm{Hg}\end{array}$ & $\begin{array}{c}2.48 \mathrm{E}+03 \\
\mathrm{~K}\end{array}$ & $\begin{array}{c}1.28 \mathrm{E}+04 \\
\mathrm{Mg}\end{array}$ & $\begin{array}{c}5.44 \mathrm{E}+02 \\
\mathrm{Mn}\end{array}$ & $\begin{array}{c}<0.036 \\
\text { Mo }\end{array}$ & $\begin{array}{c}6.34 \mathrm{E}+02 \\
\mathrm{Na}\end{array}$ \\
\hline \multirow[t]{19}{*}{ Core S5 } & Exchangeable & $4.88 \mathrm{E}+01$ & $8.03 E+01$ & $1.24 \mathrm{E}+05$ & $1.13 E+01$ & $7.52 \mathrm{E}+00$ & $1.88 \mathrm{E}+04$ \\
\hline & Carbonate & $118 E+02$ & $1.42 \mathrm{E}+02$ & $1.03 E+04$ & $1.14 E+02$ & $<0.036$ & $<0.1$ \\
\hline & Fe, Mn Oxides & $<0.009$ & $2.81 \mathrm{E}+01$ & $5.34 \mathrm{E}+02$ & $1.19 E+01$ & $<0.036$ & $<0.1$ \\
\hline & Organic Matter & $<0.009$ & $3.21 \mathrm{E}+01$ & $6.05 E+02$ & $1.81 \mathrm{E}+01$ & $<0.036$ & $2.20 \mathrm{E}+03$ \\
\hline & Residual & $1.45 E+01$ & $1.77 E+03$ & $1.28 E+04$ & $5.49 \mathrm{E}+02$ & $<0.036$ & $7.87 \mathrm{E}+02$ \\
\hline & Exchangeable & $2.89 \mathrm{E}+01$ & $7.17 \mathrm{E}+01$ & $1.25 \mathrm{E}+05$ & $1.17 \mathrm{E}+01$ & $6.19 \mathrm{E}+\infty 0$ & $1.95 E+04$ \\
\hline & Carbonate & $3.03 E+01$ & $1.32 E+02$ & $8.48 E+03$ & $1.03 E+02$ & $<0.036$ & $<0.1$ \\
\hline & Fe, Mn Oxides & $<0.009$ & $3,05 E+01$ & $7.11 E+02$ & $1.51 \mathrm{E}+01$ & $<0.036$ & $<0.1$ \\
\hline & Organic Matter & $<0.009$ & $2.85 E+01$ & $5.58 \mathrm{E}+02$ & $1.67 \mathrm{E}+01$ & $<0.036$ & $1.65 E+03$ \\
\hline & Residual & $1.50 \mathrm{E}+01$ & $1.97 \mathrm{E}+03$ & $1.27 \mathrm{E}+04$ & $5.82 \mathrm{E}+02$ & $1.06 \mathrm{E}+01$ & $8.16 E+02$ \\
\hline & Exchangeable & $<0.009$ & $9.38 \mathrm{E}+01$ & $1.33 \mathrm{E}+05$ & $1.17 E+01$ & $8.05 E+\infty 0$ & $2.04 E+04$ \\
\hline & Carbonate & $<0.009$ & $1.66 \mathrm{E}+02$ & $5.83 \mathrm{E}+03$ & $1.22 \mathrm{E}+02$ & $<0.036$ & $<0.1$ \\
\hline & Fe, Mn Oxides & $<0.009$ & $3.64 E+01$ & $4.72 E+02$ & $1.40 E+0]$ & $<0,036$ & $<0.1$ \\
\hline & Organic Matter & $<0.009$ & $2.63 \mathrm{E}+01$ & $4.72 \mathrm{E}+02$ & $1.56 \mathrm{E}+01$ & $3.63 \mathrm{E}+\infty 0$ & $1.43 \mathrm{E}+03$ \\
\hline & Exchangeable & $<0.009$ & $1.40 \mathrm{E}+02$ & $1.26 \mathrm{E}+05$ & $1.17 \mathrm{E}+01$ & $7.87 \mathrm{E}+00$ & $<0.1$ \\
\hline & Carbonate & $<0.009$ & $1.59 \mathrm{E}+02$ & $5.10 E+03$ & $1.20 \mathrm{E}+02$ & $<0.036$ & $<0.1$ \\
\hline & Fe, Mn Oxides & $<0,009$ & $3.11 \mathrm{E}+01$ & $3.42 E+02$ & $1.24 \mathrm{E}+01$ & $<0.036$ & $<0.1$ \\
\hline & Organic Matter & $7.61 \mathrm{E}+00$ & $1.14 \mathrm{E}+01$ & $4.02 E+02$ & $1.42 \mathrm{E}+01$ & $3.45 E+00$ & $1.06 \mathrm{E}+03$ \\
\hline & Residual & $1.72 \mathrm{E}+01$ & $9.56 \mathrm{E}+02$ & $1.27 \mathrm{E}+04$ & $6.10 E+02$ & $3.80 E+01$ & $5.20 \mathrm{E}+02$ \\
\hline
\end{tabular}




\begin{tabular}{|c|c|c|c|c|c|c|c|}
\hline & Exchangeable & $2.29 \mathrm{E}+01$ & $1.30 \mathrm{E}+02$ & $1.29 \mathrm{E}+05$ & $1.22 \mathrm{E}+01$ & $7.43 \mathrm{E}+00$ & $<0.1$ \\
\hline & Carbonate & $<0.009$ & $1.46 \mathrm{E}+02$ & $5.49 \mathrm{E}+03$ & $1.08 \mathrm{E}+02$ & $<0.036$ & $<0.1$ \\
\hline & $\mathrm{Fe}$, Mn Oxides & $<0.009$ & $3.06 \mathrm{E}+01$ & $2.85 E+02$ & $1.07 \mathrm{E}+01$ & $<0.036$ & $<0.1$ \\
\hline & Organic Matter & $<0.009$ & $1.98 \mathrm{E}+01$ & $3.85 E+02$ & $1.48 \mathrm{E}+01$ & $<0.036$ & $1.17 \mathrm{E}+03$ \\
\hline & Residual & $1,21 E+01$ & $1.50 \mathrm{E}+03$ & $1.03 E+04$ & $4.65 \mathrm{E}+02$ & $<0.036$ & $4.79 \mathrm{E}+02$ \\
\hline & Exchangeable & $2.41 E+01$ & $1.31 E+02$ & $1.25 \mathrm{E}+05$ & $1.23 \mathrm{E}+01$ & $7.26 \mathrm{E}+00$ & $<0.1$ \\
\hline & Carbonate & $<0.009$ & $1.42 E+02$ & $6.22 \mathrm{E}+03$ & $1.15 \mathrm{E}+02$ & $<0.036$ & $<0.1$ \\
\hline & Fe, Mn Oxides & $<0.009$ & $1.94 \mathrm{E}+01$ & $2.80 \mathrm{E}+02$ & $1.07 \mathrm{E}+01$ & $<0.036$ & $<0.1$ \\
\hline & Organic Matter & $<0,009$ & $3.00 \mathrm{E}+01$ & $3.93 \mathrm{E}+02$ & $1.49 \mathrm{E}+01$ & $<0.036$ & $1.28 \mathrm{E}+03$ \\
\hline & Residual & $1.58 E+01$ & $8.62 E+02$ & $1.24 \mathrm{E}+04$ & $5.25 \mathrm{E}+02$ & $<0,036$ & $4.97 \mathrm{E}+02$ \\
\hline \multicolumn{5}{|l|}{$\begin{array}{l}\text { Total Digestions } \\
\text { Core ID }\end{array}$} & & & $N_{\mathbf{m}}$ \\
\hline \multirow[t]{6}{*}{ Core SI } & & $2.67 \mathrm{E}+01$ & $2.26 \mathrm{E}+03$ & $1.98 \mathrm{E}+04$ & $9.82 \mathrm{E}+02$ & $7.08 \mathrm{E}+00$ & $2.59 \mathrm{E}+03$ \\
\hline & & $5.22 \mathbf{E}+01$ & $4.30 \mathrm{E}+03$ & 4. $10 \mathrm{E}+04$ & $1.92 \mathrm{E}+03$ & $1.37 \mathrm{E}+01$ & 4.71E+03 \\
\hline & & $2.46 \mathrm{E}+01$ & $2.93 E+03$ & $1.82 E+04$ & $1.01 E+03$ & $5.57 \mathrm{E}+00$ & $9.65 \mathrm{E}+02$ \\
\hline & & $2.16 E+01$ & $2.75 E+03$ & $1.50 E+04$ & $8.36 \mathrm{E}+02$ & $5.39 \mathrm{E}+00$ & $8.39 \mathrm{E}+02$ \\
\hline & & $2.00 \mathrm{E}+02$ & $8.20 \mathrm{E}+03$ & 4. $11 \mathrm{E}+04$ & $1.95 E+03$ & $<0.036$ & $1.81 \mathrm{E}+03$ \\
\hline & & $4.78 \mathrm{E}+02$ & $8.05 \mathrm{E}+03$ & $3.84 E+04$ & $1.81 \mathrm{E}+03$ & $<0.036$ & $1.71 \mathrm{E}+03$ \\
\hline \multirow[t]{6}{*}{ Core S2 } & & $4.11 \mathrm{E}+01$ & $5.72 E+03$ & $3.70 \mathrm{E}+04$ & $1.88 \mathrm{E}+03$ & $<0.036$ & $1.74 E+03$ \\
\hline & & $5.09 \mathrm{E}+01$ & 8.35E+03 & $4.49 E+04$ & $2.36 \mathrm{E}+03$ & $<0.036$ & $2.32 E+03$ \\
\hline & & $5.24 \mathrm{E}+01$ & $6.79 \mathrm{E}+03$ & 4.33E+04 & $2.42 \mathrm{E}+03$ & $<0.036$ & $2.05 E+03$ \\
\hline & & $4.82 \mathrm{E}+01$ & 6. $14 E+03$ & 4. $24 \mathrm{E}+04$ & $2.34 E+03$ & $<0.036$ & $1.89 \mathrm{E}+03$ \\
\hline & & $4.69 \mathrm{E}+02$ & $8.89 E+03$ & $4.00 \mathrm{E}+04$ & $2.11 \mathrm{E}+03$ & $<0.036$ & $1.56 \mathrm{E}+03$ \\
\hline & & $4.24 \mathrm{E}+01$ & $8.26 \mathrm{E}+03$ & $3.90 \mathrm{E}+04$ & $2.06 \mathrm{E}+03$ & $<0.036$ & $2.04 E+03$ \\
\hline \multirow[t]{7}{*}{ Core $\mathbf{S 3}$} & & $1.43 \mathrm{E}+01$ & $2.02 \mathrm{E}+03$ & $1.12 \mathrm{E}+04$ & $5.40 \mathrm{E}+02$ & $1.57 \mathrm{E}+01$ & $5.32 \mathrm{E}+02$ \\
\hline & & $1.65 E+01$ & $2.54 \mathrm{E}+03$ & $1.50 \mathrm{E}+04$ & $6.83 \mathrm{E}+02$ & $<0.036$ & $5.84 E+02$ \\
\hline & & $1.66 \mathrm{E}+01$ & $2.60 \mathrm{E}+03$ & $1.43 E+04$ & $6.56 \mathrm{E}+02$ & $<0.036$ & $5.66 \mathrm{E}+02$ \\
\hline & & $2.02 E+01$ & $2.15 \mathrm{E}+03$ & $1.85 E+04$ & $8.66 \mathrm{E}+02$ & $6.53 E+\infty 0$ & $1.36 \mathrm{E}+03$ \\
\hline & & $1.98 \mathrm{E}+01$ & $1.27 E+03$ & $1.54 \mathrm{E}+04$ & $7.25 \mathrm{E}+02$ & $8.80 E+00$ & $6.13 E+02$ \\
\hline & & $1.72 E+01$ & $3.70 \mathrm{E}+03$ & $1.99 \mathrm{E}+04$ & $1.01 \mathrm{E}+03$ & $6.64 \mathrm{E}+00$ & $9.38 E+02$ \\
\hline & & $3.15 E+01$ & $5.83 \mathrm{E}+03$ & $2.92 \mathrm{E}+04$ & $1.50 E+03$ & $8.83 \mathrm{E}+00$ & $1.48 \mathrm{E}+03$ \\
\hline \multirow{8}{*}{ Core 54} & & $4.19 \mathrm{E}+01$ & $3.81 \mathrm{E}+03$ & $3.48 \mathrm{E}+04$ & $1.47 \mathbf{E}+03$ & $1.17 \mathrm{E}+01$ & $1.45 E+03$ \\
\hline & & $3.05 E+01$ & $2.35 E+03$ & $2.97 E+04$ & $1.21 E+03$ & $8.28 \mathrm{E}+00$ & $1.02 \mathrm{E}+03$ \\
\hline & & $4.49 E+01$ & $2.95 E+03$ & $3.86 E+04$ & $1.39 \mathrm{E}+03$ & $2.07 \mathrm{E}+01$ & $9.73 E+02$ \\
\hline & & $5.47 \mathrm{E}+01$ & $5.19 E+03$ & $4.58 \mathrm{E}+04$ & $1.69 \mathrm{E}+03$ & $2.61 \mathrm{E}+01$ & $1.59 E+03$ \\
\hline & & $4.55 \mathrm{E}+01$ & $7.31 \mathrm{E}+03$ & $3.58 \mathrm{E}+04$ & $1.55 \mathrm{E}+03$ & $1.42 E+01$ & $1.15 E+03$ \\
\hline & & $2.47 \mathrm{E}+02$ & $6.43 E+03$ & $3.70 \mathrm{E}+04$ & $1.63 E+03$ & $1.28 \mathrm{E}+01$ & 1. $14 \mathrm{E}+03$ \\
\hline & & $3.94 \mathrm{E}+01$ & $6.28 \mathrm{E}+03$ & $3.74 E+04$ & $1.63 \mathrm{E}+03$ & $2.18 \mathrm{E}+01$ & $1.21 E+03$ \\
\hline & & $4.65 \mathrm{E}+01$ & $6.39 \mathrm{E}+03$ & $4.05 E+04$ & $1.68 \mathrm{BE}+03$ & $1.69 \mathrm{E}+01$ & $1.28 \mathrm{E}+03$ \\
\hline \multirow[t]{6}{*}{ Core S5 } & & $3.00 \mathrm{E}+01$ & $5.95 E+03$ & $3.10 \mathrm{E}+04$ & $1.52 \mathrm{E}+03$ & $1.04 E+01$ & $1.46 \mathrm{E}+03$ \\
\hline & & $3.80 \mathbf{E}+01$ & $6.76 \mathrm{E}+03$ & $3.67 E+04$ & $1.77 \mathrm{E}+03$ & $1.17 E+01$ & $1.78 E+03$ \\
\hline & & $4.05 E+01$ & $2.29 \mathrm{E}+03$ & $3.12 E+04$ & $1.34 E+03$ & $1.66 \mathrm{E}+01$ & $1.53 \mathrm{E}+03$ \\
\hline & & $4.31 \mathrm{E}+01$ & $5.09 \mathrm{E}+03$ & $3.56 \mathrm{E}+04$ & $1.67 \mathrm{E}+03$ & $1.89 \mathrm{E}+01$ & $2.02 \mathrm{E}+03$ \\
\hline & & $3.28 \mathrm{E}+01$ & $4.36 \mathrm{E}+03$ & $3.02 \mathrm{E}+04$ & $1.54 \mathrm{E}+03$ & $1.10 \mathrm{E}+01$ & $1.47 \mathrm{E}+03$ \\
\hline & & $3.76 \mathrm{E}+01$ & $5.31 E+03$ & $3.38 \mathrm{E}+04$ & $1.73 \mathrm{E}+03$ & $1.06 \mathrm{E}+01$ & $1.72 \mathrm{E}+03$ \\
\hline
\end{tabular}




\begin{tabular}{|c|c|c|c|c|c|c|c|c|c|c|}
\hline Core ID & Extraction & $\mathbf{N i}$ & $\mathbf{P}$ & $\mathbf{P b}$ & $\mathbf{R b}$ & $\mathbf{s}$ & Sb & Sc & Se & $\mathbf{s i}$ \\
\hline \multirow{33}{*}{ Core S1 } & Exchangeable & $1.01 E+01$ & $<0.268$ & $<0.213$ & $<0.32$ & $3.24 \mathrm{E}+02$ & $3.04 \mathrm{E}+01$ & $3.54 \mathrm{E}-01$ & $2.09 \mathrm{E}+01$ & $1.19 E+02$ \\
\hline & Carbonate & $6.95 \mathrm{E}+01$ & $<0.268$ & $1.91 \mathrm{E}+02$ & $<0.32$ & $9.56 \mathrm{E}+02$ & $2.24 \mathrm{E}+01$ & $1.42 E+00$ & $<0.213$ & $1.93 E+02$ \\
\hline & Fe, Mn Oxides & $5.60 \mathrm{E}+01$ & $3.38 \mathrm{E}+01$ & $1.07 \mathrm{E}+02$ & $3.80 \mathrm{E}+01$ & $8.36 E+01$ & $6.97 \mathrm{E}+01$ & $2.30 \mathrm{E}+00$ & $<0.213$ & $1.17 \mathrm{E}+03$ \\
\hline & Organic Matter & $7.43 \mathrm{E}+01$ & $5.72 E+01$ & $4.23 \mathrm{E}+01$ & $<0.32$ & $1.62 \mathrm{E}+03$ & $<0.167$ & $1.15 E+00$ & $<0.213$ & $5.11 E+02$ \\
\hline & Residual & $7.70 \mathrm{E}+01$ & $6.28 \mathrm{E}+02$ & $3.85 \mathrm{E}+01$ & $<0.32$ & $5.01 E+02$ & $2.11 E+01$ & $2.80 \mathrm{E}+01$ & $<0.213$ & $1.83 E+01$ \\
\hline & Exchangeable & $<0.059$ & $<0.268$ & $<0.213$ & $<0.32$ & $3.79 \mathrm{E}+02$ & $4.35 \mathrm{E}+01$ & $7.08 \mathrm{E}-01$ & $2.63 \mathrm{E}+01$ & $1.14 \mathrm{E}+02$ \\
\hline & Carbonate & $5.61 \mathrm{E}+0 \mathrm{I}$ & $<0.268$ & $1.88 \mathrm{E}+02$ & $<0.32$ & $9.64 E+02$ & $2.52 \mathrm{E}+01$ & $1.42 \mathrm{E}+00$ & $<0.213$ & $1.74 E+02$ \\
\hline & Fe. Mn Oxides & $5.00 \mathrm{E}+01$ & $3.37 E+01$ & $1.02 \mathrm{E}+02$ & $<0.32$ & $7.49 \mathrm{E}+01$ & $6.21 \mathrm{E}+01$ & $1.95 \mathrm{E}+00$ & $<0.213$ & $1.13 E+03$ \\
\hline & Organic Matter & $3.91 E+01$ & $<0.268$ & $3.44 \mathrm{E}+01$ & $<0.32$ & $1.59 \mathrm{E}+03$ & $<0.167$ & $3.54 \mathrm{E}-01$ & $<0.213$ & $4.76 E+02$ \\
\hline & Residual & $7.16 E+01$ & $5.66 \mathrm{E}+02$ & $3.31 \mathrm{E}+01$ & $<0.32$ & $4.58 \mathrm{E}+02$ & $1.99 \mathrm{E}+01$ & $2.62 E+01$ & $<0.213$ & $2.65 E+01$ \\
\hline & Exchangeable & $<0.059$ & $<0.268$ & $<0.213$ & $<0.32$ & $2.25 \mathrm{E}+03$ & $<0.167$ & $<0.002$ & $2.28 E+01$ & $9.64 E+01$ \\
\hline & Exchangeable & $<0.059$ & $<0.268$ & $<0.213$ & $<0.32$ & $2.97 \mathrm{E}+02$ & $<0.167$ & $<0.002$ & $2.65 E+01$ & $5.68 \mathrm{E}+01$ \\
\hline & Carbonate & $1.69 \mathrm{E}+01$ & $<0.268$ & $4.49 \mathrm{E}+01$ & $<0.32$ & $2.50 E+02$ & $<0.167$ & $6.19 \mathrm{E}-01$ & $<0.213$ & $1.70 \mathrm{E}+02$ \\
\hline & Carbonate & $6.37 \mathrm{E}+00$ & $<0.268$ & $3.34 \mathrm{E}+01$ & $4.06 E+01$ & $1.34 E+02$ & $<0.167$ & $1.77 \mathrm{E}-01$ & $<0.213$ & $1.34 \mathrm{E}+02$ \\
\hline & $\mathrm{Fe}, \mathrm{Mn}$ Oxides & $<0.059$ & $1.68 \mathrm{E}+02$ & $3.56 \mathrm{E}+01$ & $<0.32$ & $1.43 E+02$ & $<0.167$ & $9.73 \mathrm{E}-01$ & $<0.213$ & 4.06E+02 \\
\hline & Fe, Mn Oxides & $<0.059$ & $3.25 \mathrm{E}+01$ & $<0.213$ & $<0.32$ & $5.21 \mathrm{E}+01$ & $<0.167$ & $1<0.002$ & $<0.213$ & $2.18 \mathrm{E}+02$ \\
\hline & Organic Matter & $5.84 E+\infty 0$ & $<0.268$ & 4.13E+01 & $<0.32$ & $2.72 E+03$ & $<0.167$ & 4.42E-01 & $<0.213$ & $5.94 \mathrm{E}+02$ \\
\hline & Organic Matter & $9.56 \mathrm{E}+00$ & $1.55 \mathrm{E}+02$ & $<0.213$ & $<0.32$ & $3.72 E+02$ & $<0.167$ & $4.42 \mathrm{E}-01$ & $<0.213$ & $3.97 E+02$ \\
\hline & Residual & $4.30 \mathrm{E}+01$ & $3.35 \mathrm{E}+02$ & $3.46 \mathrm{E}+01$ & $<0.32$ & $6.11 E+02$ & $<0.167$ & $2.04 \mathrm{E}+01$ & $<0.213$ & $3.07 \mathrm{E}+01$ \\
\hline & Exchangeable & $<0.059$ & $<0.268$ & $<0.213$ & $<0.32$ & $7.59 \mathrm{E}+02$ & $<0.167$ & $1<0,002$ & $<0.213$ & $6.72 \mathrm{E}+0 \mathrm{I}$ \\
\hline & Carbonate & $1.99 \mathrm{E}+01$ & $<0.268$ & $4.38 \mathrm{E}+01$ & $<0.32$ & $1.09 \mathrm{E}+03$ & $<0.167$ & $1.77 \mathrm{E}-01$ & $1.96 \mathrm{E}+01$ & $1.19 \mathrm{E}+02$ \\
\hline & Fe. Mn Oxides & $<0.059$ & $1.98 \mathrm{E}+02$ & $5.42 \mathrm{E}+01$ & $<0.32$ & $2.04 \mathrm{E}+02$ & $1.92 E+01$ & $6.19 \mathrm{E}-01$ & $<0.213$ & $4.24 E+02$ \\
\hline & Organic Matter & $1.31 \mathrm{E}+01$ & $6.12 E+01$ & $3.11 \mathrm{E}+01$ & $<0.32$ & $1.61 E+03$ & $<0.167$ & $1.77 \mathrm{E}-01$ & $<0.213$ & $2.10 \mathrm{E}+02$ \\
\hline & Residual & $4.20 \mathrm{E}+01$ & $2.83 \mathrm{E}+02$ & $4.47 \mathrm{E}+01$ & $<0.32$ & $7.69 \mathrm{E}+02$ & $<0.167$ & $2.08 E+01$ & $<0.213$ & $2.49 E+01$ \\
\hline & Exchangeable & $<0.059$ & $<0.268$ & $<0.213$ & $3.08 \mathrm{E}+01$ & $2.75 \mathrm{E}+02$ & $<0.167$ & $1<0.002$ & $2.67 \mathrm{E}+01$ & $2.32 \mathrm{E}+02$ \\
\hline & Carbonate & $<0.059$ & $<0.268$ & $7.25 \mathrm{E}+01$ & $<0.32$ & $4.72 E+02$ & $<0.167$ & $7.08 \mathrm{E}-01$ & $<0.213$ & $2.68 \mathrm{E}+02$ \\
\hline & Fe, Mn Oxides & $<0.059$ & $<0.268$ & $1.90 \mathrm{E}+01$ & $<0.32$ & $<0.568$ & $<0.167$ & 4.42E-01 & $<0.213$ & $3.47 \mathrm{E}+02$ \\
\hline & Organic Matter & $<0.059$ & $1.31 E+02$ & $4.52 \mathrm{E}+01$ & $<0.32$ & $1.30 \mathrm{E}+03$ & $<0.167$ & $2.65 \mathrm{E}-01$ & $<0.213$ & $2.76 \mathrm{E}+02$ \\
\hline & Residual & $4.67 \mathrm{E}+01$ & $1.96 \mathrm{E}+02$ & $4.43 \mathrm{E}+01$ & $<0.32$ & $8.57 \mathrm{E}+02$ & $<0.167$ & $2.32 \mathrm{E}+01$ & $<0.213$ & $1.75 \mathrm{E}+01$ \\
\hline & Exchangeable & $<0.059$ & $<0.268$ & $<0.213$ & $<0.32$ & $2.58 \mathrm{E}+02$ & $<0.167$ & $1.77 \mathrm{E}-01$ & $2.22 \mathrm{E}+01$ & $2.45 E+02$ \\
\hline & Carbonate & $2.19 \mathrm{E}+01$ & $<0.268$ & $8.34 \mathrm{E}+01$ & $<0.32$ & $4.94 E+02$ & $<0.167$ & $7.08 \mathrm{E}-01$ & $<0,213$ & $2.32 \mathrm{E}+02$ \\
\hline & Fe, Mn Oxides & $<0.059$ & $<0.268$ & $2.40 \mathrm{E}+01$ & $3.80 \mathrm{E}+01$ & $7.54 \mathrm{E}+01$ & $<0.167$ & $5.31 \mathrm{E} \cdot 01$ & $<0.213$ & $3.56 \mathrm{E}+02$ \\
\hline & Organic Matter & $1.17 \mathrm{E}+01$ & $6.77 \mathrm{E}+01$ & $3.90 E+01$ & $3.39 \mathrm{E}+01$ & $1.22 E+03$ & $<0.167$ & $1.77 \mathrm{E}-01$ & $<0.213$ & $1.74 \mathrm{E}+02$ \\
\hline Core ID & $\begin{array}{c}\text { Residual } \\
\text { Extraction }\end{array}$ & $\begin{array}{c}4.54 \mathrm{E}+01 \\
\mathrm{Ni}\end{array}$ & $\begin{array}{c}2.85 E+02 \\
P\end{array}$ & $\begin{array}{c}\text { 4.93E+01 } \\
\mathbf{P b}\end{array}$ & $\begin{array}{c}<0.32 \\
\mathbf{R b}\end{array}$ & $\begin{array}{c}9.64 \mathrm{E}+02 \\
\mathrm{~s}\end{array}$ & $\begin{array}{c}1.48 \mathrm{E}+01 \\
\mathrm{Sb}\end{array}$ & $i \begin{array}{c}2.19 \mathrm{E}+01 \\
\mathrm{Se}\end{array}$ & $\begin{array}{c}<0.213 \\
\mathrm{Se}\end{array}$ & $\begin{array}{c}1.68 \mathrm{E}+01 \\
\mathrm{Si}\end{array}$ \\
\hline \multirow[t]{30}{*}{ Core S2 } & Exchangeable & $<0.059$ & $<0.268$ & $2.74 \mathrm{E}+01$ & $<0.32$ & $5.76 \mathrm{E}+02$ & $<0.167$ & $2.65 \mathrm{E}-01$ & $<0.213$ & $1.81 E+02$ \\
\hline & Carbonate & $1.44 \mathrm{E}+01$ & $<0.268$ & $9.29 \mathrm{E}+01$ & $<0.32$ & $2.67 \mathrm{E}+02$ & $<0.167$ & $5.31 \mathrm{E}-01$ & $<0.213$ & $2.11 E+02$ \\
\hline & $\mathrm{Fe}, \mathrm{Mn}$ Oxides & $6.02 E+00$ & $<0.268$ & $2.43 \mathrm{E}+01$ & $4.36 \mathrm{E}+01$ & $5.19 E+01$ & $<0.167$ & $4.42 \mathrm{E}-01$ & $<0.213$ & $2.71 E+02$ \\
\hline & Organic Matter & $1.45 E+01$ & $2.33 \mathrm{E}+02$ & $<0.213$ & $<0.32$ & $5.15 E+02$ & $<0.167$ & $7.08 \mathrm{E}-01$ & $<0.213$ & $2.45 E+02$ \\
\hline & Residual & $4.65 \mathrm{E}+01$ & $1.90 \mathrm{E}+02$ & $2.51 \mathrm{E}+01$ & $<0.32$ & $6.14 E+02$ & $1.66 \mathrm{E}+0 \mathrm{I}$ & $2.60 \mathrm{E}+01$ & $<0.213$ & $1.59 \mathrm{E}+01$ \\
\hline & Exchangeable & $<0.059$ & $<0.268$ & $2.32 \mathrm{E}+01$ & $<0.32$ & $5.54 \mathrm{E}+02$ & $<0.167$ & $1<0.002$ & $<0.213$ & $1.35 E+02$ \\
\hline & Carbonate & $1.36 \mathrm{E}+01$ & $<0.268$ & $9.03 E+01$ & $<0.32$ & $2.31 \mathrm{E}+02$ & $<0.167$ & $4.42 \mathrm{E}-01$ & $<0.213$ & $1.84 E+02$ \\
\hline & $\mathrm{Fe}, \mathrm{Mn}$ Oxides & 8. $94 E+\infty 0$ & $<0.268$ & $2.66 \mathrm{E}+01$ & $3.05 \mathrm{E}+01$ & $7.16 \mathrm{E}+01$ & $<0.167$ & $5.31 \mathrm{E}-01$ & $<0.213$ & $2.72 E+02$ \\
\hline & Organic Matter & $<0.059$ & $1.73 \mathrm{E}+02$ & $<0.213$ & $<0.32$ & $5.79 \mathrm{E}+02$ & $<0.167$ & $3.54 \mathrm{E}-0 \mathrm{I}$ & $<0.213$ & $2.93 E+02$ \\
\hline & Resicual" & $4.67 \mathrm{E}+01$ & $1.94 \mathrm{E}+02$ & $2.23 \mathrm{E}+01$ & $<0.32$ & $6.08 E+02$ & $<0.167$ & $2.52 \mathrm{E}+01$ & $<0.213$ & $1.78 \mathrm{E}+01$ \\
\hline & Exchangeable & $<0.059$ & $<0.268$ & $<0.213$ & $<0.32$ & $2.73 E+02$ & $<0.167$ & $1<0.002$ & $2.26 \mathrm{E}+01$ & $3.18 \mathrm{E}+02$ \\
\hline & Carbonate & $1.86 \mathrm{E}+01$ & $<0.268$ & $6.92 \mathrm{E}+01$ & $<0.32$ & $4.70 \mathrm{E}+02$ & $<0.167$ & $6.19 \mathrm{E}-01$ & $<0.213$ & $2.96 \mathrm{E}+02$ \\
\hline & Fe, Mn Oxides & $<0.059$ & $<0.268$ & $<0.213$ & $<0.32$ & $6.93 \mathrm{E}+01$ & $<0.167$ & $4.42 \mathrm{E}-01$ & $<0.213$ & $4.26 \mathrm{E}+02$ \\
\hline & Organic Matter & $<0.059$ & $1.73 \mathrm{E}+02$ & $<0.213$ & $<0.32$ & $7.87 \mathrm{E}+02$ & $<0.167$ & $2.65 \mathrm{E}-01$ & $<0.213$ & $2.32 \mathrm{E}+02$ \\
\hline & Residual & $4.41 \mathrm{E}+01$ & $2.04 \mathrm{E}+02$ & $3.83 \mathrm{E}+01$ & $<0.32$ & $7.02 E+02$ & $1.61 \mathrm{E}+01$ & $2.36 E+01$ & $<0.213$ & $2.17 \mathrm{E}+01$ \\
\hline & Exchangeable & $<0.059$ & $<0.268$ & $<0.213$ & $<0.32$ & $2.38 \mathrm{E}+02$ & $<0,167$ & $6.19 \mathrm{E}-01$ & $2.52 E+01$ & $3.53 E+02$ \\
\hline & Carbonate & $1.63 \mathrm{E}+01$ & $<0.268$ & $6.76 \mathrm{E}+01$ & $<0,32$ & $4.65 E+02$ & $<0.167$ & $6.19 \mathrm{E}-01$ & $<0.213$ & $2.21 E+02$ \\
\hline & Fe, Mn Oxides & $<0.059$ & $1.36 \mathrm{E}+02$ & $<0.213$ & $<0.32$ & $7.49 \mathrm{E}+02$ & $<0.167$ & 2.65E-01 & $<0.213$ & $2.27 \mathrm{E}+02$ \\
\hline & Organic Matter & $<0.059$ & $<0.268$ & $1.88 \mathrm{E}+01$ & $3.85 \mathrm{E}+01$ & $6.81 E+01$ & $<0.167$ & 4.42E-01 & $<0.213$ & $3.85 E+02$ \\
\hline & Residual & $3.90 \mathrm{E}+01$ & $2.04 E+02$ & $2.93 E+01$ & $<0.32$ & $5.95 \mathrm{E}+02$ & $<0.167$ & $2.27 E+01$ & $<0.213$ & $2.31 E+01$ \\
\hline & Exchangeable & $<0.059$ & $<0.268$ & $<0.213$ & $<0.32$ & $4.19 \mathrm{E}+02$ & $<0.167$ & $<0.002$ & $<0.213$ & $1.27 \mathrm{E}+02$ \\
\hline & Carbonate & $1.81 E+01$ & $<0.268$ & $5.48 \mathrm{E}+01$ & $<0.32$ & $4.62 E+02$ & $<0.167$ & 8.85E-01 & $<0.213$ & $1.34 E+02$ \\
\hline & Fe, Mn Oxides & $<0.059$ & $<0.268$ & $<0.213$ & $<0.32$ & $5.12 \mathrm{E}+01$ & $<0.167$ & $4.42 \mathrm{E}-01$ & $<0.213$ & $4,30 \mathrm{E}+02$ \\
\hline & Organic Matter & $<0.059$ & $1.77 E+02$ & $3.23 \mathrm{E}+01$ & $<0.32$ & $9.29 \mathrm{E}+02$ & $<0.167$ & $1.77 \mathrm{E}-01$ & $<0.213$ & 2. $18 \mathrm{E}+02$ \\
\hline & Residual & $4.80 \mathrm{E}+01$ & $2.60 \mathrm{E}+02$ & $5.23 \mathrm{E}+01$ & $<0.32$ & $7.87 \mathrm{E}+02$ & $<0.167$ & $1.89 E+01$ & $<0.213$ & $1.98 \mathrm{E}+01$ \\
\hline & Exchangeable & $<0.059$ & $<0.268$ & $<0.213$ & $<0.32$ & $2.35 \mathrm{E}+02$ & $<0.167$ & $1.77 \mathrm{E}-01$ & $2.55 \mathrm{E}+01$ & $2.59 \mathrm{E}+02$ \\
\hline & Carbonate & $1.98 \mathrm{E}+01$ & $<0.268$ & 4. $58 \mathrm{E}+01$ & $<0.32$ & $4.98 \mathrm{E}+02$ & $<0.167$ & $5.31 E-01$ & $<0.213$ & $1.18 \mathrm{E}+02$ \\
\hline & $\mathrm{Fe}, \mathrm{Mn}$ Oxides & $<0.059$ & $<0.268$ & $<0.213$ & $<0.32$ & $<0.568$ & $<0.167$ & $1.06 \mathrm{E}+00$ & $<0.213$ & $3.64 \mathrm{E}+02$ \\
\hline & Organic Matter & $<0.059$ & $1.30 \mathrm{E}+02$ & 4.18E+01 & $<0.32$ & $8.69 \mathrm{E}+02$ & $<0.167$ & $1,77 \mathrm{E}_{-0} 01$ & $<0.213$ & $2.26 \mathrm{E}+02$ \\
\hline & Residual & $5.47 E+01$ & $2.98 \mathrm{E}+02$ & $5.26 \mathrm{E}+01$ & $<0.32$ & $1.11 \mathrm{E}+03$ & $1.58 \mathrm{E}+01$ & $2.25 E+01$ & $<0.213$ & $3.58 \mathrm{E}+01$ \\
\hline Core ID & Extraction & $\mathbf{N i}$ & $\mathbf{P}$ & $\mathbf{P b}$ & $\mathbf{R b}$ & $\mathbf{s}$ & St & Se & Se & $\mathbf{S i}$ \\
\hline Core S3 & Exchangeable & $<0.059$ & $<0.268$ & $<0.213$ & $<0.32$ & $3.79 \mathrm{E}+02$ & $1.72 \mathrm{E}+01$ & $4.42 \mathrm{E}-01$ & $2.45 \mathrm{E}+01$ & $3.03 \mathrm{E}+02$ \\
\hline & Exchangeable & $<0.059$ & $<0.268$ & $<0.213$ & $<0.32$ & $8.26 E+01$ & $<0.167$ & $1<0.002$ & $2.59 \mathrm{E}+01$ & $2.75 E+02$ \\
\hline & Carbonate & $2.04 \mathrm{E}+01$ & $<0.268$ & $5.72 \mathrm{E}+01$ & $<0.32$ & $1.65 \mathrm{E}+02$ & $<0.167$ & $1.77 \mathrm{E}-01$ & $<0.213$ & $1.50 \mathrm{E}+02$ \\
\hline & Carbonate & $1.03 \mathrm{E}+01$ & $<0.268$ & $2.34 \mathrm{E}+01$ & $3.99 \mathrm{E}+01$ & $1.18 \mathrm{E}+02$ & $<0.167$ & $1.77 \mathrm{E}-01$ & $<0.213$ & $1.41 \mathrm{E}+02$ \\
\hline & Fe, Mn Oxides & $136 \mathrm{E}+01$ & $7.73 \mathrm{E}+01$ & $2.80 \mathrm{E}+01$ & $3.99 \mathrm{E}+01$ & $7.53 \mathrm{E}+01$ & $<0.167$ & $5.31 \mathrm{E}-01$ & $<0.213$ & $3.73 E+02$ \\
\hline & Fe, Mn Oxides & $<0.059$ & $2.77 \mathrm{E}+01$ & $<0.213$ & $<0.32$ & $6.87 E+01$ & $<0.167$ & $1.77 \mathrm{E}-01$ & $<0.213$ & $2.78 \mathrm{E}+02$ \\
\hline & Organic Matter & $<0.059$ & $<0.268$ & $<0.213$ & $<0.32$ & $1.57 \mathrm{E}+03$ & $<0.167$ & $5.3\lfloor\mathrm{tE}-01$ & $<0.213$ & $6.50 \mathrm{E}+02$ \\
\hline & Organic Matter & $<0.059$ & $1.83 \mathrm{E}+02$ & $<0.213$ & $3.84 \mathrm{E}+01$ & $2.20 \mathrm{E}+02$ & $<0.167$ & $<0.002$ & $<0.213$ & $3.85 E+02$ \\
\hline & Exchangeable & $8.76 E+00$ & $<0.268$ & $<0.213$ & $<0.32$ & $3.81 \mathrm{E}+02$ & $<0.167$ & $1<0.002$ & $<0.213$ & $9.56 \mathrm{E}+01$ \\
\hline & Carbonate & $4.23 \mathrm{E}+01$ & $<0.268$ & $9.03 E+01$ & $<0.32$ & $2.29 \mathrm{E}+02$ & $<0.167$ & $1.77 E-0 I$ & $<0.213$ & $1.07 E+02$ \\
\hline & $\mathrm{Fe}, \mathrm{Mn}$ Oxides & $5.26 \mathrm{E}+01$ & $1.48 \mathrm{E}+02$ & $8.57 \mathrm{E}+01$ & $<0.32$ & $1.25 E+02$ & $1.99 \mathrm{E}+01$ & $6.19 \mathrm{E}-01$ & $<0.213$ & $4.61 E+02$ \\
\hline & Organic Matter & $8.32 \mathrm{E}+00$ & $4.54 \mathrm{E}+01$ & $<0.213$ & $3.03 \mathrm{E}+01$ & $1.05 E+03$ & $<0.167$ & $1.77 \mathrm{E}-01$ & $<0.213$ & $2.65 E+02$ \\
\hline & Residual & $4.82 \mathrm{E}+01$ & $2.31 \mathrm{E}+02$ & $2.61 \mathrm{E}+01$ & $<0.32$ & $6.49 E+02$ & $<0,167$ & $1.73 \mathrm{E}+01$ & $<0.213$ & $2.97 \mathrm{E}+01$ \\
\hline & Exchangeable & $5.84 E+00$ & $<0.268$ & $3.23 \mathrm{E}+01$ & $<0.32$ & $5.22 E+02$ & $<0,167$ & $1<0.002$ & $<0.213$ & $1.25 E+02$ \\
\hline & Carbonate & $<0.059$ & $<0.268$ & $1.31 \mathrm{E}+02$ & $<0.32$ & $7.34 \mathrm{E}+02$ & $<0.167$ & $1.06 \mathrm{E}+00$ & $<0.213$ & $1.87 \mathrm{E}+02$ \\
\hline & Fe, Mn Oxides & $<0.059$ & $<0.268$ & $3.49 \mathrm{E}+01$ & $3.69 \mathrm{E}+01$ & $7.03 \mathrm{E}+01$ & $<0.167$ & $6.19 \mathrm{E}-01$ & $<0.213$ & $3.94 E+02$ \\
\hline & Organic Matter & $2.19 \mathrm{E}+01$ & $9.91 \mathrm{E}+01$ & $2.46 \mathrm{E}+01$ & $<0.32$ & $1.13 E+03$ & $<0.167$ & $1.77 \mathrm{E}-01$ & $<0.213$ & $2.90 \mathrm{E}+02$ \\
\hline
\end{tabular}




\begin{tabular}{|c|c|c|c|c|c|c|c|c|c|c|}
\hline & Kesidual & $3.49 \mathrm{E}+01$ & $2.11 t+02$ & $2.85 E+01$ & $<0.52$ & $4.93 \mathrm{E}+02$ & $\langle 0,16\rangle$ & $1.81 \mathbf{t}+01$ & 40.213 & $3.45 \mathrm{E}+01$ \\
\hline & Exchangeable & $<0.059$ & $<0.268$ & $<0.213$ & $<0.32$ & $2.63 \mathrm{E}+02$ & $<0.167$ & $1.77 \mathrm{E}-01$ & $2.19 \mathrm{E}+01$ & $2.11 E+02$ \\
\hline & Exchangeable & $<0.059$ & $<0.268$ & $<0.213$ & $<0.32$ & $9.29 E+01$ & $<0.167$ & $1<0.002$ & $2.22 \mathbf{E}+01$ & $2.58 \mathrm{E}+02$ \\
\hline & Carbonate & $6.19 E+00$ & $<0.268$ & $8.34 \mathrm{E}+01$ & $3.24 E+01$ & $5.48 \mathrm{E}+02$ & $<0.167$ & $7.96 \mathrm{E}-01$ & $<0.213$ & $1.43 \mathrm{E}+02$ \\
\hline & Carbonate & $<0.059$ & $<0.268$ & $2.94 E+01$ & $3.84 E+01$ & $1.47 E+02$ & $<0.167$ & 4.42E-01 & $<0.213$ & $2.44 \mathrm{E}+02$ \\
\hline & $\mathrm{Fe}, \mathrm{Mn}$ Oxides & $<0.059$ & $<0.268$ & $<0.213$ & $<0.32$ & $<0.568$ & $<0.167$ & $2.65 \mathrm{E}-01$ & $<0.213$ & $3.23 E+02$ \\
\hline & Fe, Mn Oxides & $<0.059$ & $<0.268$ & $<0.213$ & $3.31 \mathrm{E}+01$ & $<0.568$ & $<0.167$ & $1.77 \mathrm{E}-01$ & $<0.213$ & $2.91 E+02$ \\
\hline & Organic Matter & $1.59 \mathrm{E}+01$ & $<0.268$ & $3.37 \mathbf{E}+01$ & $3.54 \mathrm{E}+01$ & $1.28 \mathrm{E}+03$ & $<0.167$ & $5.31 E-01$ & $<0.213$ & $5.55 E+02$ \\
\hline & Organic Matter & $<0.059$ & $1.75 \mathrm{E}+02$ & $<0.213$ & $4.19 \mathrm{E}+01$ & $1.81 E+02$ & $<0.167$ & $1<0.002$ & $<0.213$ & $2.80 E+02$ \\
\hline & Residual & $3.15 E+01$ & $1.50 \mathrm{E}+02$ & $<0.213$ & $<0.32$ & $2.19 \mathrm{E}+02$ & $<0.167$ & $150 E+01$ & $<0.213$ & $3.11 \mathrm{E}+01$ \\
\hline & Exchangeable & $<0,059$ & $<0.268$ & $<0.213$ & $<0.32$ & $1.14 E+03$ & $3.37 \mathrm{E}+01$ & 1 $<0.002$ & $<0.213$ & $4.47 E+01$ \\
\hline & Carbonate & $1.49 \mathrm{E}+01$ & $<0.268$ & $1.29 \mathrm{E}+02$ & $<0.32$ & $6.16 \mathrm{E}+02$ & $<0.167$ & $1.77 \mathrm{E}-01$ & $<0.213$ & 2. $19 \mathrm{E}+02$ \\
\hline & Fe, Mn Oxides & $<0.059$ & $6.55 E+01$ & $1.57 \mathrm{E}+02$ & $<0.32$ & $4.84 \mathrm{E}+02$ & $3.23 E+01$ & $2.21 \mathrm{E}+00$ & $<0.213$ & $9.20 \mathrm{E}+02$ \\
\hline & Organic Matter & $<0.059$ & $<0.268$ & $1.50 \mathrm{E}+02$ & $3.51 \mathrm{E}+01$ & $6.61 \mathrm{E}+03$ & $<0.167$ & $1.24 \mathrm{E}+00$ & $<0.213$ & $1.29 \mathrm{E}+03$ \\
\hline & Resiđual & $3.58 \mathrm{E}+01$ & $2.73 E+02$ & 4.57E+01 & $<0.32$ & $6.44 E+02$ & $<0.167$ & $1.24 \mathrm{E}+01$ & $<0.213$ & $1.50 E+01$ \\
\hline & Exchangeable & $<0.059$ & $<0.268$ & $<0.213$ & $<0.32$ & $1.01 E+03$ & $3.33 \mathrm{E}+01$ & $1<0.002$ & $2.65 \mathrm{E}+01$ & $6.12 \mathrm{E}+01$ \\
\hline & Exchangeable & $<0.059$ & $<0.268$ & $<0.213$ & $<0.32$ & $2.51 E+02$ & $1.94 E+01$ & ( $<0.002$ & $2.37 \mathrm{E}+01$ & $6.26 \mathrm{E}+01$ \\
\hline & Carbonate & $4.75 \mathrm{E}+01$ & $<0.268$ & $1.43 \mathrm{E}+02$ & $<0.32$ & $8.83 E+02$ & $<0.167$ & $4.42 \mathrm{E}-01$ & $<0.213$ & $2.07 \mathrm{E}+02$ \\
\hline & Carbonate & $2.54 \mathrm{E}+01$ & $<0.268$ & $6.49 E+01$ & $4.89 \mathrm{E}+01$ & $2.12 \mathrm{E}+02$ & $<0.167$ & $7.08 \mathrm{E}-01$ & $<0.213$ & $2.07 \mathrm{E}+02$ \\
\hline & Fe, Mn Oxides & $<0.059$ & $6.90 E+01$ & $7.30 \mathrm{E}+01$ & $<0.32$ & $1.32 \mathrm{E}+02$ & $5.85 \mathrm{E}+01$ & $2.04 \mathrm{E}+00$ & $<0.213$ & $9.03 E+02$ \\
\hline & Fe, Mn Oxides & $<0.059$ & $5.04 E+01$ & $2.14 \mathrm{E}+01$ & $3.54 \mathrm{E}+01$ & $6.66 \mathrm{E}+01$ & $<0.167$ & $8.85 \mathrm{E}-01$ & $<0.213$ & $5.03 \mathrm{E}+02$ \\
\hline & Organic Matter & $1.85 \mathrm{E}+02$ & $<0.268$ & $6.14 \mathrm{E}+01$ & $<0.32$ & $4.34 \mathrm{E}+03$ & $<0.167$ & $7.96 \mathrm{E}-01$ & $<0.213$ & $9.64 \mathrm{E}+02$ \\
\hline & Organic Matter & $<0.059$ & $<0.268$ & $3.19 \mathrm{E}+01$ & $<0.32$ & $8.64 \mathrm{E}+02$ & $<0.167$ & 2.65E-01 & $<0.213$ & $4.96 \mathrm{E}+02$ \\
\hline & Residual & $1.18 E+02$ & $5.13 \mathrm{E}+02$ & $8.09 \mathrm{E}+01$ & $<0.32$ & $8.50 \mathrm{E}+02$ & $1.93 \mathrm{E}+01$ & $1.88 \mathrm{E}+01$ & $<0.213$ & $3.41 E+01$ \\
\hline Core ID & Extraction & $\mathrm{Ni}$ & $\mathbf{P}$ & $\mathbf{P b}$ & $\mathbf{R b}$ & $\mathbf{s}$ & Sb & Sc & Se & $\mathbf{S i}$ \\
\hline \multirow[t]{40}{*}{ Core S4 } & Exchangeable & $<0.059$ & $<0.268$ & $2.26 \mathrm{E}+01$ & $<0.32$ & $3.42 \mathrm{E}+02$ & $<0.167$ & $7.96 \mathrm{E}-01$ & $2.54 \mathrm{E}+01$ & $2.08 \mathrm{E}+02$ \\
\hline & Carbonate & $1.81 \mathrm{E}+01$ & $<0.268$ & $1.91 \mathrm{E}+02$ & $<0.32$ & $4.59 \mathrm{E}+02$ & $<0.167$ & $1.24 \mathrm{E}+00$ & $<0.213$ & $2.61 E+02$ \\
\hline & Fe, Mn Oxides & $<0.059$ & $<0.268$ & $2.72 \mathrm{E}+01$ & $<0.32$ & $5.56 \mathrm{E}+01$ & $<0.167$ & 3.54E-01 & $<0.213$ & $3.50 \mathrm{E}+02$ \\
\hline & Organic Matter & $7.26 \mathrm{E}+00$ & $2.32 \mathrm{E}+02$ & $2.72 \mathrm{E}+01$ & $<0.32$ & $9.82 \mathrm{E}+02$ & $<0.167$ & $1<0.002$ & $<0.213$ & $1.56 \mathrm{E}+02$ \\
\hline & Residual & $1.97 E+02$ & $4.62 \mathrm{E}+02$ & $6.26 \mathrm{E}+01$ & $<0.32$ & $5.78 E+02$ & $3.36 \mathrm{E}+01$ & $2.09 \mathrm{E}+01$ & $<0.213$ & 4. $16 \mathrm{E}+01$ \\
\hline & Exchangeable & $<0.059$ & $<0.268$ & $2.04 \mathrm{E}+01$ & $<0.32$ & $3.49 \mathrm{E}+02$ & $<0.167$ & $1<0.002$ & $2.48 \mathrm{E}+01$ & $1.28 \mathrm{E}+02$ \\
\hline & Carbonate & $2.05 \mathrm{E}+01$ & $<0.268$ & $2.06 \mathrm{E}+02$ & $<0.32$ & $5.26 \mathrm{E}+02$ & $<0.167$ & $9.73 \mathrm{E}-01$ & $<0.213$ & $3.06 \mathrm{E}+02$ \\
\hline & $\mathrm{Fe}, \mathrm{Mn}$ Oxides & $<0.059$ & $<0.268$ & $2.27 \mathrm{E}+01$ & $<0.32$ & $<0.568$ & $<0.167$ & $4.42 \mathrm{E}-01$ & $<0.213$ & $3.80 E+02$ \\
\hline & Organic Matter & $<0.059$ & $1.88 E+02$ & $3.20 \mathrm{E}+01$ & $<0.32$ & $9.91 \mathrm{E}+02$ & $<0.167$ & $1<0.002$ & $<0.213$ & $2.23 \mathrm{E}+02$ \\
\hline & Residual & $4.31 E+01$ & $6.09 E+02$ & $5.80 \mathrm{E}+01$ & $<0.32$ & $7.44 \mathrm{E}+02$ & $<0.167$ & $2.49 \mathrm{E}+01$ & $<0.213$ & $2.33 \mathrm{E}+01$ \\
\hline & Exchangeable & $<0.059$ & $<0.268$ & $<0.213$ & $<0.32$ & $1.71 E+02$ & $<0.167$ & $5.31 \mathrm{E}-01$ & $2.65 E+01$ & $1.72 \mathrm{E}+02$ \\
\hline & Carbonate & $2.34 \mathrm{E}+01$ & $<0.268$ & $6.80 \mathrm{E}+01$ & $<0.32$ & $3.67 \mathrm{E}+02$ & $<0.167$ & $7.96 \mathrm{E}-01$ & $<0.213$ & $3.57 \mathrm{E}+02$ \\
\hline & $\mathrm{Fe}, \mathrm{Mn}$ Oxides & $<0.059$ & $<0.268$ & $<0.213$ & $<0.32$ & $<0.568$ & $<0.167$ & $3.54 \mathrm{E}-0 \mathrm{l}$ & $<0.213$ & $3.69 \mathrm{E}+02$ \\
\hline & Organic Matter & $9.56 \mathrm{E}+00$ & $2.11 \mathrm{E}+02$ & $2.80 E+01$ & $<0.32$ & $7.95 E+02$ & $<0.167$ & $2.65 \mathrm{E}-0]$ & $<0.213$ & $2.97 \mathrm{E}+02$ \\
\hline & Residual & $5.21 \mathrm{E}+01$ & $4.85 \mathrm{E}+02$ & $6.44 E+01$ & $<0.32$ & $8.01 E+02$ & $1.57 \mathrm{E}+01$ & $1.73 \mathrm{E}+01$ & $<0.213$ & $6.21 \mathrm{E}+01$ \\
\hline & Exchangeable & $<0.059$ & $<0.268$ & $<0.213$ & $<0.32$ & $1.71 \mathrm{E}+02$ & $<0.167$ & $6.19 \mathrm{E}-01$ & $2.52 \mathrm{E}+01$ & $2.89 \mathrm{E}+02$ \\
\hline & Carbonate & $2.01 \mathrm{E}+01$ & $<0.268$ & $6.15 \mathrm{E}+01$ & $<0.32$ & $3.53 \mathrm{E}+02$ & $<0.167$ & $1.15 E+\infty$ & $<0.213$ & $2.61 \mathrm{E}+02$ \\
\hline & $\mathrm{Fe}, \mathrm{Mn}$ Oxides & $<0.059$ & $<0.268$ & $<0.213$ & $3.01 \mathrm{E}+01$ & $<0.568$ & $<0.167$ & $3.54 \mathrm{E}-01$ & $<0.213$ & $3.72 \mathrm{E}+02$ \\
\hline & Organic Matter & $3.14 \mathrm{E}+01$ & $2.70 \mathrm{E}+02$ & $2.83 \mathrm{E}+01$ & $<0.32$ & $7.54 \mathrm{E}+02$ & $<0.167$ & $1<0.002$ & $<0.213$ & $1.92 E+02$ \\
\hline & Residual & $4.44 \mathrm{E}+01$ & $5.13 E+02$ & $6.24 \mathrm{E}+01$ & $<0.32$ & $7.17 \mathrm{E} \div 02$ & $1.59 \mathrm{E}+01$ & $1.83 E+01$ & $<0.213$ & $2.88 E+01$ \\
\hline & Exchangeable & $<0.059$ & $<0.268$ & $<0.213$ & $<0.32$ & $2.46 \mathrm{E}+02$ & $<0.167$ & $t<0.002$ & $2.46 \mathrm{E}+01$ & $1.60 E+02$ \\
\hline & Carbonate & $2.34 E+01$ & $<0.268$ & $5.60 \mathrm{E}+01$ & $<0.32$ & $3.20 \mathrm{E}+02$ & $<0.167$ & $6.19 \mathrm{E}-01$ & $<0.213$ & $3.61 \mathrm{E}+02$ \\
\hline & $\mathrm{Fe}, \mathrm{Mn}$ Oxides & $<0.059$ & $<0.268$ & $<0.213$ & $<0.32$ & $<0.568$ & $<0.167$ & $7.96 \mathrm{E}-01$ & $<0.213$ & $3.86 \mathrm{E}+02$ \\
\hline & Organic Matter & $2.52 \mathrm{E}+01$ & $2.73 E+02$ & $<0.213$ & $<0.32$ & $6.80 \mathrm{E}+02$ & $<0.167$ & $1.77 \mathrm{E}-01$ & $<0.213$ & $2.82 \mathrm{E}+02$ \\
\hline & Residual & $1.48 E+03$ & $4.31 E+02$ & $5.73 \mathrm{E}+01$ & $<0.32$ & $9.11 \mathrm{E}+02$ & $2.01 E+02$ & $1.51 \mathrm{E}+01$ & $<0.213$ & $1.98 \mathrm{E}+01$ \\
\hline & Exchangeable & $<0.059$ & $<0.268$ & $<0.213$ & $<0.32$ & $2.11 \mathrm{E}+02$ & $<0.167$ & $1<0.002$ & $2.44 \mathrm{E}+01$ & $9.56 \mathrm{E}+01$ \\
\hline & Carbonate & $1.98 \mathrm{E}+01$ & $<0.268$ & $4.91 \mathrm{E}+01$ & $<0.32$ & $3.07 \mathrm{E}+02$ & $<0.167$ & $6.19 \mathrm{E}-01$ & $<0.213$ & $2.29 \mathrm{E}+02$ \\
\hline & $\mathrm{Fe}, \mathrm{Mn}$ Oxides & $<0.059$ & $<0.268$ & $<0.213$ & $<0.32$ & $6.12 \mathrm{E}+01$ & $<0.167$ & $1.06 E+\infty 0$ & $<0.213$ & $4.20 \mathrm{E}+02$ \\
\hline & Organic Matter & $<0.059$ & $2.37 \mathrm{E}+02$ & $<0.213$ & $<0.32$ & $3.65 E+02$ & $<0.167$ & 8.85E-01 & $<0.213$ & $1.23 \mathrm{E}+02$ \\
\hline & Residual & $6.77 \mathrm{E}+01$ & $4.49 \mathrm{E}+02$ & $5.5 \nmid E+01$ & $<0.32$ & $9.20 \mathrm{E}+02$ & $1.68 \mathrm{E}+01$ & $180 E+01$ & $<0.213$ & $2.95 \mathrm{E}+01$ \\
\hline & Exchangeable & $<0.059$ & $<0.268$ & $<0.213$ & $<0.32$ & $3.09 \mathrm{E}+02$ & $2: 04 \mathrm{E}+01$ & $1.77 \mathrm{E}-01$ & $2.31 \mathrm{E}+01$ & $1.95 \mathrm{E}+02$ \\
\hline & Carbonate & $1.16 \mathrm{E}+01$ & $<0.268$ & $6.5[E+0]$ & $<0.32$ & $3.98 \mathrm{E}+02$ & $1.53 \mathrm{E}+01$ & $7.96 \mathrm{E}-01$ & $<0.213$ & $3.32 \mathrm{E}+02$ \\
\hline & $\mathrm{Fe}, \mathrm{Mn}$ Oxides & $<0.059$ & $<0.268$ & $<0.213$ & $4.85 E+01$ & $6.58 \mathrm{E}+01$ & $<0.167$ & $3.54 \mathrm{E}-01$ & $<0.213$ & $4.33 E+02$ \\
\hline & Organic Matter & $1.83 \mathrm{E}+01$ & $3.92 \mathrm{E}+02$ & $<0.213$ & $<0.32$ & $5.27 \mathrm{E}+02$ & $<0.167$ & $1<0.002$ & $<0.213$ & $1.04 \mathrm{E}+02$ \\
\hline & Residual & $9.64 \mathrm{E}+02$ & $3.61 \mathrm{E}+02$ & $4.57 E+01$ & $<0.32$ & $8.08 E+02$ & $1.51 \mathrm{E}+02$ & $1.76 E+01$ & $<0.213$ & $7.74 E+01$ \\
\hline & Exchangeable & $<0.059$ & $<0.268$ & $<0.213$ & $<0.32$ & $3.11 E+02$ & $2.11 E+01$ & $:<0.002$ & $2.32 \mathrm{E}+01$ & $1.95 E+02$ \\
\hline & Carbonate & $1.52 E+01$ & $<0.268$ & $5.77 \mathrm{E}+01$ & $<0.32$ & $3.88 E+02$ & $<0.167$ & $7.08 \mathrm{E}-01$ & $<0.213$ & $2.36 \mathrm{E}+02$ \\
\hline & Fe, Mn Oxides & $<0.059$ & $<0.268$ & $<0.213$ & $<0.32$ & $<0.568$ & $<0.167$ & $9.73 \mathrm{E}-01$ & $<0.213$ & $4.21 E+02$ \\
\hline & Organic Matter & $1.23 \mathrm{E}+01$ & $1.74 E+02$ & $<0.213$ & $3.43 \mathrm{E}+01$ & $1.08 \mathrm{E}+03$ & $<0.167$ & $1<0.002$ & $<0.213$ & $1.88 \mathrm{E}+02$ \\
\hline & Residual & $5.72 \mathrm{E}+01$ & $6.43 E+02$ & $5.52 \mathrm{E}+01$ & $<0.32$ & $1.09 E+03$ & $2.30 \mathrm{E}+01$ & $1.99 \mathrm{E}+01$ & $<0.213$ & $3.06 \mathrm{E}+01$ \\
\hline Core ID & Extraction & $\mathrm{Ni}$ & $\mathbf{P}$ & $\mathbf{P b}$ & $\mathbf{R b}$ & $\mathbf{s}$ & $\mathbf{S b}$ & Sc & Se & $\mathbf{S i}$ \\
\hline Core S5 & Exchangeable & $8.41 E+\infty 0$ & $<0.268$ & $<0.213$ & $<0.32$ & $3.54 \mathrm{E}+02$ & $<0.167$ & $4.42 \mathrm{E}-01$ & $2.12 \mathrm{E}+01$ & $2.88 \mathrm{E}+02$ \\
\hline & Carbonate & $1.04 E+01$ & $<0.268$ & $9.11 E+01$ & $<0.32$ & $4.88 \mathrm{E}+02$ & $<0.167$ & $1.24 E+00$ & $<0.213$ & $1.76 E+02$ \\
\hline & $\mathrm{Fe}, \mathrm{Mn}$ Oxides & $<0.059$ & $<0.268$ & $<0.213$ & $<0.32$ & $<0.568$ & $<0.167$ & $3.54 \mathrm{E}-01$ & $<0.213$ & $3.12 \mathrm{E}+02$ \\
\hline & Organic Matter & $<0.059$ & $2.04 \mathrm{E}+02$ & $3.01 \mathrm{E}+01$ & $<0.32$ & $1.30 E+03$ & $<0.167$ & $1.77 \mathrm{E}-01$ & $<0.213$ & $4.01 E+02$ \\
\hline & Residual & $4.27 E+01$ & $5.44 \mathrm{E}+02$ & $3.86 \mathrm{E}+01$ & $<0.32$ & $7.57 \mathrm{E}+02$ & $<0.167$ & $1.96 \mathrm{E}+01$ & $<0.213$ & $2.81 E+01$ \\
\hline & Exchangeable & $<0.059$ & $<0.268$ & $<0.213$ & $<0.32$ & $3.64 \mathrm{E}+02$ & $<0.167$ & $5.31 \mathrm{E}-01$ & $2.44 \mathrm{E}+01$ & $2.09 E+02$ \\
\hline & Carbonate & $2.04 \mathrm{E}+01$ & $<0.268$ & $8.66 \mathrm{E}+01$ & $<0.32$ & 4. $15 \mathrm{E}+02$ & $<0.167$ & $9.73 \mathrm{E}-01$ & $<0.213$ & $1.60 \mathrm{E}+02$ \\
\hline & $\mathrm{Fe}, \mathrm{Mn}$ Oxides & $<0.059$ & $<0.268$ & $2.08 \mathrm{E}+01$ & $3.39 \mathrm{E}+01$ & $7.56 \mathrm{E}+01$ & $<0.167$ & $3.54 \mathrm{E}-01$ & $<0.213$ & $3.09 \mathrm{E}+02$ \\
\hline & Organic Matter & $1.31 \mathrm{E}+01$ & $2.92 \mathrm{E}+02$ & $2.53 \mathrm{E}+01$ & $<0.32$ & $1.51 \mathrm{E}+03$ & $<0.167 \quad$ & $1<0.002$ & $<0.213$ & $2.53 \mathrm{E}+02$ \\
\hline & Residual & $2.83 \mathrm{E}+02$ & $6.19 \mathrm{E}+02$ & $488 \mathrm{E}+01$ & $<0.32$ & 8.73E+02 & $4.36 \mathrm{E}+01$ & $2.02 \mathrm{E}+01$ & $<0.213$ & $7.50 \mathrm{E}+01$ \\
\hline & Exchangeable & $8.32 E+00$ & $<0.268$ & $<0.213$ & $<0.32$ & $2.60 \mathrm{E}+02$ & $<0.167$ & $1.77 \mathrm{E}-01$ & $<0.213$ & $2.21 \mathrm{E}+02$ \\
\hline & Carbonate & $2.62 \mathrm{E}+01$ & $<0.268$ & $8.08 \mathrm{E}+01$ & $<0.32$ & $4.95 \mathrm{E}+02$ & $<0.167$ & $8.85 \mathrm{E}-01$ & $<0.213$ & $2.39 \mathrm{E}+02$ \\
\hline & $\mathrm{Fe}, \mathrm{Mn}$ Oxides & $<0.059$ & $<0.268$ & $<0.213$ & $<0.32$ & $<0.568$ & $<0.167$ & 4.42E-01 & $<0.213$ & $3.57 \mathrm{E}+02$ \\
\hline & Organic Matter & $3.05 E+01$ & $1.39 E+02$ & $5.10 \mathrm{E}+01$ & $<0.32$ & $1.94 E+03$ & $<0.167$ & $1.77 \mathrm{E}-01$ & $<0.213$ & $2.71 E+02$ \\
\hline & Exchangeable & $7.79 E+00$ & $<0.268$ & $<0.213$ & $<0.32$ & $2.66 \mathrm{E}+02$ & $<0.167$ & 2.65E-01 & $1.96 \mathrm{E}+01$ & $2.03 E+02$ \\
\hline & Carbonate & $2.74 \mathrm{E}+01$ & $<0.268$ & $8.17 \mathrm{E}+01$ & $<0.32$ & $4.99 E+02$ & $<0.167$ & $7.96 \mathrm{E}-01$ & $<0.213$ & $2.00 \mathrm{E}+02$ \\
\hline & Fe, Mn Oxides & $<0.059$ & $<0.268$ & $<0.213$ & $<0.32$ & $5.15 \mathrm{E}+01$ & $<0.167$ & $3.54 \mathrm{E}-01$ & $<0.213$ & $4.00 E+02$ \\
\hline & Organic Matter & $3.78 \mathrm{E}+01$ & $1.12 \mathrm{E}+02$ & $4.57 \mathrm{E}+01$ & $<0.32$ & $2.02 \mathrm{E}+03$ & $<0.167$ & $7.96 \mathrm{E}-01$ & $<0.213$ & $1.78 \mathrm{E}+02$ \\
\hline & Residual & $9.82 \mathrm{E}+02$ & $6.09 \mathbf{E}+02$ & $7.92 \mathrm{E}+01$ & $<0.32$ & $1.10 \mathrm{E}+03$ & $1.39 E+02$ & $1.79 E+01$ & $<0.213$ & $4.90 E+01$ \\
\hline
\end{tabular}




\begin{tabular}{|c|c|c|c|c|c|c|c|c|c|c|}
\hline & Exchangeable & $<0.059$ & $<0.268$ & $2.49 E+01$ & $<0.32$ & $2.37 \mathrm{E}+02$ & $<0.167$ & $1.77 \mathrm{E}-01$ & $2.24 E+01$ & $1.66 \mathrm{E}+02$ \\
\hline & Carbonate & $2.78 \mathrm{E}+01$ & $<0.268$ & $6.15 \mathrm{E}+01$ & $<0.32$ & $4.26 \mathrm{E}+02$ & $<0.167$ & $7.08 \mathrm{E}-01$ & $<0.213$ & $1.98 \mathrm{E}+02$ \\
\hline & $\mathrm{Fe}, \mathrm{Mn}$ Oxides & $<0.059$ & $<0.268$ & $<0.213$ & $<0.32$ & $<0.568$ & $<0.167$ & $2.65 \mathrm{E}-01$ & $<0.213$ & $3.03 \mathrm{E}+02$ \\
\hline & Organic Matter & $1.87 E+01$ & $1.66 E+02$ & $2.85 E+01$ & $3.61 E+01$ & $1.24 E+03$ & $<0.167$ & $1.77 \mathrm{E}-01$ & $<0.213$ & $2.28 \mathrm{E}+02$ \\
\hline & Residual & $4.30 \mathrm{E}+01$ & 4.39E+02 & $4.50 \mathrm{E}+01$ & $<0.32$ & $8.29 \mathrm{E}+02$ & $<0.167$ & $1.50 \mathrm{E}+01$ & $<0.213$ & $2.68 \mathrm{E}+01$ \\
\hline & Exchangeable & $<0.059$ & $<0.268$ & $2.45 \mathrm{E}+01$ & $<0.32$ & $2.24 \mathrm{E}+02$ & $<0.167$ & $1.77 E-01$ & $2.40 \mathrm{E}+01$ & 2. $18 \mathrm{E}+02$ \\
\hline & Carbonate & $1.12 E+01$ & $<0.268$ & $6.61 \mathrm{E}+01$ & $<0.32$ & $4.50 \mathrm{E}+02$ & $<0.167$ & $7.08 E-01$ & $<0.213$ & $2.94 \mathrm{E}+02$ \\
\hline & Fe, Mn Oxides & $<0.059$ & $<0.268$ & $<0.213$ & $<0.32$ & $<0.568$ & $<0.167$ & $2.65 \mathrm{E}-01$ & $<0.213$ & $3.03 \mathrm{E}+02$ \\
\hline & Organic Matter & $1.79 E+01$ & $1.49 \mathrm{E}+02$ & $2.73 \mathrm{E}+01$ & $<0.32$ & $1.48 \mathrm{E}+03$ & $<0.167$ & $1<0.002$ & $<0.213$ & 2. $19 \mathrm{E}+02$ \\
\hline & Residual & $7.85 E+01$ & $5.01 E+02$ & $6.18 \mathrm{E}+01$ & $<0.32$ & $9.91 \mathrm{E}+02$ & $<0.167$ & $1.44 E+01$ & $<0.213$ & $5.72 E+01$ \\
\hline \multicolumn{11}{|c|}{ Total Digestions } \\
\hline Core ID & Extraction & $\mathrm{Ni}$ & $\mathbf{P}$ & $\mathbf{P b}$ & Rb & $\mathbf{S}$ & Sb & Sc & Se & $\mathbf{S i}$ \\
\hline \multirow[t]{6}{*}{ Core \$1 } & & $2.98 \mathrm{E}+02$ & $6.11 E+02$ & $2.85 E+02$ & $<0.32$ & $4.07 E+03$ & $2.68 \mathrm{E}+01$ & $2.89 \mathrm{E}+01$ & $<0.213$ & $1.41 \mathrm{E}+02$ \\
\hline & & $5.59 \mathrm{E}+02$ & 1.19E+03 & $5.51 \mathrm{E}+02$ & $<0.32$ & $6.37 \mathrm{E}+03$ & $4.54 \mathrm{E}+01$ & $5.80 E+01$ & $<0.213$ & $1.17 \mathrm{E}+02$ \\
\hline & & $1.65 \mathrm{E}+02$ & $5.63 \mathrm{E}+02$ & $2.26 \mathrm{E}+02$ & $<0.32$ & $7.09 \mathrm{E}+03$ & $1.73 \mathrm{E}+01$ & $2.84 \mathrm{E}+01$ & $<0.213$ & $8.63 E+01$ \\
\hline & & $1.36 E+02$ & $2.99 \mathrm{E}+02$ & $1.84 E+02$ & $<0.32$ & $5.71 E+03$ & $<0.167$ & $2.37 E+01$ & $<0.213$ & $2.50 \mathrm{E}+01$ \\
\hline & & $2.90 E+02$ & $1.19 \mathrm{E}+03$ & $5.22 \mathrm{E}+02$ & $<0.32$ & $9.31 E+03$ & $<0.167$ & $6.80 \mathrm{E}+01$ & $<0.213$ & $6.25 E+01$ \\
\hline & & $2.76 \mathrm{E}+02$ & $1.03 \mathrm{E}+03$ & $4.74 \mathrm{E}+02$ & $<0.32$ & 8. $90 \mathrm{E}+03$ & $<0.167$ & $6.23 \mathrm{E}+01$ & $<0.213$ & $2.21 \mathrm{E}+02$ \\
\hline \multirow[t]{6}{*}{ Core S2 } & & $2.96 \mathrm{E}+02$ & $1.01 E+03$ & $3.04 E+02$ & $<0.32$ & $4.57 \mathrm{E}+03$ & $<0.167$ & $6.24 E+01$ & $<0.213$ & $8.37 \mathrm{E}+01$ \\
\hline & & $2.66 \mathrm{E}+02$ & $1.21 E+03$ & $3.65 E+02$ & $<0.32$ & $5.35 \mathrm{E}+03$ & $<0.167$ & $7.99 \mathrm{E}+01$ & $<0.213$ & $1.62 \mathrm{E}+02$ \\
\hline & & $2.92 \mathrm{E}+02$ & $6.35 \mathrm{E}+02$ & $3.84 E+02$ & $<0.32$ & $7.06 \mathrm{E}+03$ & $<0.167$ & $7.43 \mathrm{E}+01$ & $<0.213$ & $8.49 \mathrm{E}+01$ \\
\hline & & $2.89 \mathrm{E}+02$ & $9.03 \mathrm{E}+02$ & $3.83 E+02$ & $<0.32$ & $7.28 \mathrm{E}+03$ & $4.29 \mathrm{E}+01$ & $7.36 \mathrm{E}+01$ & $<0.213$ & $6.90 \mathrm{E}+02$ \\
\hline & & $3.16 \mathrm{E}+02$ & $5.21 \mathrm{E}+02$ & $4.35 E+02$ & $<0.32$ & $7.11 E+03$ & $4.30 E+01$ & $6.22 \mathrm{E}+01$ & $<0.213$ & $2.31 E+02$ \\
\hline & & $3.32 E+02$ & $6.21 \mathrm{E}+02$ & $4.07 \mathrm{E}+02$ & $<0.32$ & $6.94 \mathrm{E}+03$ & $<0.167$ & $6.00 \mathrm{E}+01$ & $<0.213$ & $1.27 \mathrm{E}+02$ \\
\hline \multirow[t]{7}{*}{ Core $\mathbf{3} 3$} & & $4.98 \mathrm{E}+02$ & $2.62 E+02$ & $2.39 \mathrm{E}+01$ & $<0.32$ & $4.75 E+02$ & $7.36 \mathrm{E}+01$ & $1.88 \mathrm{E}+01$ & $<0.213$ & $5.25 E+01$ \\
\hline & & $1.92 \mathrm{E}+02$ & $2.99 \mathrm{E}+02$ & $1.66 \mathrm{E}+02$ & $<0.32$ & $2.42 \mathrm{E}+03$ & $<0.167$ & $2.17 \mathrm{E}+01$ & $<0.213$ & $6.93 \mathrm{E}+01$ \\
\hline & & $1.83 E+02$ & $2.86 \mathrm{E}+02$ & $1.69 \mathrm{E}+02$ & $<0.32$ & $2,41 E+03$ & $<0.167$ & $2.11 \mathrm{E}+01$ & $<0.213$ & $4.52 \mathrm{E}+01$ \\
\hline & & $1.63 \mathrm{E}+02$ & $5.09 \mathrm{E}+02$ & $2.41 \mathrm{E}+02$ & $<0.32$ & $3.62 \mathrm{E}+03$ & $<0.167$ & $2.68 E+01$ & $<0.213$ & $5.86 \mathrm{E}+01$ \\
\hline & & $1.38 \mathrm{E}+02$ & $4.45 \mathrm{E}+02$ & $2.01 \mathrm{E}+02$ & $<0.32$ & $3.11 \mathrm{E}+03$ & $1.87 \mathrm{E}+01$ & 2.17E+01 & $<0.213$ & $6.23 \mathrm{E}+01$ \\
\hline & & $2.23 E+02$ & $5.19 E+02$ & $4.87 \mathrm{E}+02$ & $<0.32$ & $1.11 \mathrm{E}+04$ & $3.11 E+01$ & $2.53 \mathrm{E}+01$ & $<0.213$ & $7.84 \mathrm{E}+01$ \\
\hline & & $2.95 \mathrm{E}+02$ & $7.75 \mathrm{E}+02$ & $7.21 E+02$ & $<0.32$ & $1.60 \mathrm{E}+04$ & $4.48 \mathrm{E}+01$ & $3.73 \mathrm{E}+01$ & $<0.213$ & $5.03 \mathrm{E}+02$ \\
\hline \multirow[t]{8}{*}{ Core $\mathrm{S4}$} & & $1.91 E+02$ & $1 . \overline{10 E}+03$ & $5.61 \mathrm{IE}+02$ & $<0.32$ & $6.23 E+03$ & $3.36 \mathrm{E}+01$ & $5.74 E+01$ & $<0.213$ & $6.99 \mathrm{E}+01$ \\
\hline & & $1.64 \mathrm{E}+02$ & $9.11 \mathrm{E}+02$ & $4.88 \mathrm{E}+02$ & $<0.32$ & $5.40 \mathrm{E}+03$ & $3.29 \mathrm{E}+01$ & $4.50 \mathrm{E}+01$ & $<0.213$ & 2. $19 \mathrm{E}+02$ \\
\hline & & $3.18 \mathrm{E}+02$ & 1. $20 \mathrm{E}+03$ & $4.97 E+02$ & $<0.32$ & $6.97 \mathrm{E}+03$ & $4.24 \mathrm{E}+01$ & $4.77 \mathrm{E}+01$ & $<0.213$ & $1.25 \mathrm{E}+02$ \\
\hline & & $3.66 \mathrm{E}+02$ & $1.36 E+03$ & $5.27 \mathrm{E}+02$ & $<0.32$ & $7.88 \mathrm{E}+03$ & $5.01 \mathbf{E}+01$ & $6.29 \mathrm{E}+01$ & $<0.213$ & $1.31 E+02$ \\
\hline & & $2.98 \mathrm{E}+02$ & $1.17 \mathrm{E}+03$ & $2.78 \mathrm{E}+02$ & $<0.32$ & $6.78 \mathrm{E}+03$ & $<0.167$ & $5.07 \mathrm{E}+01$ & $<0.213$ & 8.82E+01 \\
\hline & & $3.18 \mathrm{E}+02$ & $1.36 \mathrm{E}+03$ & $3.41 \mathrm{E}+02$ & $<0.32$ & $6.88 \mathrm{E}+03$ & $4.29 E+01$ & $5.12 \mathrm{E}+01$ & $<0.213$ & $1.36 \mathrm{E}+02$ \\
\hline & & $3.67 \mathrm{E}+02$ & $1.42 E+03$ & $3.37 \mathrm{E}+02$ & $<0.32$ & $7.80 \mathrm{E}+03$ & $7.04 E+01$ & $5.32 \mathrm{E}+01$ & $<0.213$ & $7.63 E+01$ \\
\hline & & $3.70 \mathrm{E}+02$ & $1.28 \mathrm{E}+03$ & $3.06 \mathrm{E}+02$ & $<0.32$ & $7.89 \mathrm{E}+03$ & $5.90 \mathrm{E}+01$ & $5.67 \mathrm{E}+01$ & $<0.213$ & $1.27 \mathrm{E}+02$ \\
\hline \multirow[t]{6}{*}{ Core Ss } & & $2.48 \mathrm{E}+02$ & $9.67 \mathrm{E}+02$ & $3.81 E+02$ & $<0.32$ & $7.49 \mathrm{E}+03$ & $3.54 \mathrm{E}+01$ & $4.93 E+01$ & $<0.213$ & $7.34 E+01$ \\
\hline & & $2.94 \mathrm{E}+02$ & $1.17 \mathrm{E}+03$ & $4.40 \mathrm{E}+02$ & $<0.32$ & $8.90 \mathrm{E}+03$ & $4.44 \mathrm{E}+01$ & $5.94 E+01$ & $<0.213$ & $6.86 \mathrm{E}+01$ \\
\hline & & $3.08 \mathrm{E}+02$ & $1.01 \mathrm{E}+03$ & $4.76 \mathrm{E}+02$ & $<0.32$ & $9.89 \mathrm{E}+03$ & $4.01 \mathrm{E}+01$ & $4.07 \mathrm{E}+01$ & $<0.213$ & $1.01 E+02$ \\
\hline & & $3.34 \mathrm{E}+02$ & $1.14 \mathrm{E}+03$ & $5.07 \mathrm{E}+02$ & $<0.32$ & $1.09 E+04$ & $5.07 E+01$ & $5.79 E+01$ & $<0.213$ & $5.31 \mathrm{E}+01$ \\
\hline & & $2.81 \mathrm{E}+02$ & $1.05 \mathrm{E}+03$ & $3.54 E+02$ & $<0.32$ & $8.00 \mathrm{E}+03$ & $6.33 \mathrm{E}+01$ & $4.34 \mathrm{E}+01$ & $<0.213$ & $6.89 \mathrm{E}+01$ \\
\hline & & $3.40 \mathrm{E}+02$ & 1.11E+03 & $4.18 \mathrm{E}+02$ & $\leq 0.32$ & $8.33 \mathrm{E}+03$ & $3.87 \mathrm{E}+01$ & $4.91 \mathrm{E}+01$ & $\leq 0.213$ & $4.3[\mathrm{E}+01$ \\
\hline
\end{tabular}




\begin{tabular}{|c|c|c|c|c|c|c|c|}
\hline Core 1D & Extraction & $\mathbf{S r}$ & Th & $\mathbf{T i}$ & $\mathbf{U}$ & $\mathbf{Z n}$ & $\mathbf{Z r}$ \\
\hline \multirow[t]{34}{*}{ Core S1 } & Exchangeable & $5.22 \mathrm{E}+00$ & $<33.2$ & $7.96 \mathrm{E}-01$ & $<0.868$ & $<0.006$ & $6.19 \mathrm{E}-01$ \\
\hline & Carbonate & $1.73 \mathrm{E}+01$ & $<33.2$ & $1.77 \mathrm{E}-01$ & $<0.868$ & $1.55 \mathrm{E}+01$ & $<0.004$ \\
\hline & Fe, Mn Oxides & $9.73 \mathrm{E}-01$ & $<33.2$ & $1.49 \mathrm{E}+01$ & $<0.868$ & $5.37 \mathrm{E}+01$ & $2.57 \mathrm{E}+00$ \\
\hline & Organic Matter & $1.59 \mathrm{E}+00$ & $<33.2$ & $3.10 \mathrm{E}+00$ & $<0.868$ & $1.10 E+02$ & $7.08 \mathrm{E}-01$ \\
\hline & Residual & $1.59 \mathrm{E}+01$ & $<33.2$ & $1.60 \mathrm{E}+03$ & $2: 61 E+02$ & $8.82 \mathrm{E}+01$ & $3.83 E-01$ \\
\hline & Exchangeable & $5.84 \mathrm{E}+00$ & $<33.2$ & $9.73 \mathrm{E}-01$ & $<0.868$ & $:<0.006$ & $7.08 \mathrm{E}-01$ \\
\hline & Carbonate & $167 E+01$ & $<33.2$ & $6.19 \mathrm{E}-01$ & $<0.868$ & $1.47 \mathrm{E}+01$ & $1.95 E-00$ \\
\hline & Fe. Mn Oxides & $1.15 E+00$ & $<33.2$ & $1.45 E+01$ & $<0.868$ & $5.03 \mathrm{E}+01$ & $2.57 \mathrm{E}-00$ \\
\hline & Organic Matter & $7.96 \mathrm{E}-01$ & $<33.2$ & 2.65E-01 & $<0.868$ & $9.56 \mathrm{E}+01$ & $<0.004$ \\
\hline & Residual & $2.27 \mathrm{E}+01$ & $<33.2$ & $1.42 \mathrm{E}+03$ & $183 E+02$ & $7.89 \mathrm{E}+01$ & $2.03 \mathrm{E}-01$ \\
\hline & Exchangeable & $2.57 \mathrm{E}+00$ & $<33.2$ & $1.77 \mathrm{E}-01$ & $<0.868$ & $1<0.006$ & $<0.004$ \\
\hline & Exchangeable & $6.19 \mathrm{E}-01$ & $<33.2$ & $3.54 \mathrm{E}-0\}$ & $<0.868$ & $1<0.006$ & $5.3 ! E-01$ \\
\hline & Carbonate & $2.65 \mathrm{E}+\infty 0$ & $<33.2$ & $5.31 \mathrm{E}-01$ & $<0.868$ & $2.93 \mathrm{E}+01$ & $<0.004$ \\
\hline & Carbonate & $9.73 \mathrm{E}-01$ & $<33.2$ & $2.12 \mathrm{E}+00$ & $<0.868$ & $1.61 \mathrm{E}+01$ & $<0.004$ \\
\hline & $\mathrm{Fe}, \mathrm{Mn}$ Oxides & $3.54 \mathrm{E}-01$ & $<33.2$ & $4.34 E+\infty$ & $<0.868$ & $1.63 E+01$ & $6.19 \mathrm{E}-0]$ \\
\hline & Fe, Mn Oxides & $3.54 \mathrm{E}-01$ & $<33.2$ & $1.50 \mathrm{E}+00$ & $<0.868$ & $4.87 \mathrm{E}+00$ & $<0.004$ \\
\hline & Organic Matter & $5.3\} \mathrm{E}-01$ & $<33.2$ & $1.00 E+01$ & $<0.868$ & $1.40 E+02$ & $<0.004$ \\
\hline & Organic Matter & $8.85 \mathrm{E}-01$ & $<33.2$ & $6.46 E+00$ & $<0.868$ & $3.03 E+01$ & 7.08E-01 \\
\hline & Residual & $1.65 \mathrm{E}+01$ & $<33.2$ & $1.63 E+03$ & $8.80 \mathrm{E}+01$ & 4.47E+01 & $2.38 E+01$ \\
\hline & Exchangeable & $7.96 \mathrm{E}-01$ & $<33.2$ & $2.65 \mathrm{E}-01$ & $<0.868$ & $1<0.006$ & $<0.004$ \\
\hline & Carbonate & $4.51 \mathrm{E}+00$ & $<33.2$ & $<0.002$ & $<0.868$ & $1.48 E+01$ & $<0.004$ \\
\hline & Fe, Mn Oxides & $7.08 \mathrm{E}-01$ & $<33.2$ & $3.89 \mathrm{E}+00$ & $<0.868$ & $2.59 E+01$ & $4,42 \mathrm{E}-01$ \\
\hline & Organic Matter & $7.96 \mathrm{E}-01$ & $<33.2$ & $7.96 \mathrm{E}-01$ & $<0.868$ & $7.56 \mathbf{E}+01$ & $<0.004$ \\
\hline & Residual & $1.70 E+01$ & $<33.2$ & $1.81 \mathrm{E}+03$ & $9.82 \mathrm{E}+01$ & $7.57 \mathbf{E}+01$ & $2.37 \mathrm{E}+01$ \\
\hline & Exchangeable & $1.50 E+00$ & $<33.2$ & $1.95 \mathrm{E}+00$ & $<0.868$ & $1<0.006$ & $<0.004$ \\
\hline & Carbonate & $6.02 \mathrm{E}+00$ & $<33.2$ & $2.12 \mathrm{E}+00$ & $<0,868$ & $1.44 E+01$ & $<0.004$ \\
\hline & $\mathrm{Fe}, \mathrm{Mn}$ Oxides & $9.73 E-01$ & $9.64 \mathrm{E}+03$ & $3.89 E+00$ & $<0.868$ & $1.48 E+0 !$ & 6. $19 \mathrm{E}-01$ \\
\hline & Organic Matter & $1.15 E+00$ & $<33.2$ & $2.74 \mathrm{E}+00$ & $<0.868$ & $6.85 \mathrm{E}+0 \mathrm{I}$ & $<0.004$ \\
\hline & Residual & $1.88 \mathrm{E}+01$ & $<33.2$ & $1.51 E+03$ & $1.19 \mathrm{E}+02$ & $1.02 E+02$ & $2.54 \mathrm{E}+0 \mathrm{t}$ \\
\hline & Exchangeable & $1,33 \mathrm{E}+00$ & $<33.2$ & $2.39 E+00$ & $<0.868$ & $<0.006$ & $<0.004$ \\
\hline & Carbonate & $6.55 E+00$ & $<33.2$ & $1.33 \mathrm{E}+00$ & $<0.868$ & $1.89 \mathrm{E}+01$ & $<0.004$ \\
\hline & $\mathrm{Fe}, \mathrm{Mn}$ Oxides & $7.96 \mathrm{E}-01$ & $<33.2$ & $3.72 E+00$ & $<0.868$ & $1.89 \mathrm{E}+01$ & 8.85E-0! \\
\hline & Organic Matter & $8.85 \mathrm{E}-01$ & $<33.2$ & $1.06 \mathrm{E}+00$ & $<0.868$ & $7.18 \mathrm{E}+01$ & $<0.004$ \\
\hline & Residual & $1.92 \mathrm{E}+01$ & $<33.2$ & $1.99 \mathrm{E}+03$ & $1.19 \mathrm{E}+02$ & $9.29 \mathrm{E}+01$ & $2.40 E+01$ \\
\hline Core ID & Extraction & Sr & Th & $\mathrm{Ti}$ & $\mathbf{U}$ & $Z_{n}$ & $\mathbf{z r}$ \\
\hline \multirow{30}{*}{ Core S2 } & Exchangeable & $3.19 \mathrm{E}+00$ & $<33.2$ & $2.21 \mathrm{E}+00$ & $<0.868$ & $1.30 \mathrm{E}+01$ & 5.31E-01 \\
\hline & Carbonate & $2.30 E+00$ & $<33.2$ & $1.59 \mathrm{E}+00$ & $<0.868$ & $2.32 \mathrm{E}+01$ & $6.19 \mathrm{E}-01$ \\
\hline & $\mathbf{F e}$, Mn Oxides & $5.31 \mathrm{E}-01$ & $<33.2$ & $3.10 E+00$ & $<0.868$ & $3.70 \mathrm{E}+01$ & $<0.004$ \\
\hline & Organic Matter & $133 \mathrm{E}+00$ & $<33.2$ & $2.04 \mathrm{E}+00$ & $<0.868$ & $2.52 \mathrm{E}+01$ & 6.19E-01 \\
\hline & Residual & $2.05 E+01$ & $<33.2$ & $2.27 E+03$ & $1.50 \mathrm{E}+02$ & $6.57 \mathrm{E}+01$ & $2.43 E+01$ \\
\hline & Exchangeable & $3.10 E+\infty 0$ & $<33.2$ & $2.04 \mathrm{E}+00$ & $<0.868$ & $1.10 \mathrm{E}+01$ & $2.04 \mathrm{E}+00$ \\
\hline & Carbonate & $1.95 \mathrm{E}+00$ & $<33.2$ & $1.86 \mathrm{E}+00$ & $<0.868$ & $2.29 \mathrm{E}+01$ & $<0.004$ \\
\hline & Fe, Mn Oxides & $5.31 \mathrm{E}-01$ & $<33.2$ & $3.80 \mathrm{E}+00$ & $<0.868$ & $4.29 \mathrm{E}+01$ & $6.19 \mathrm{E}-01$ \\
\hline & Organic Matter & $9.73 \mathrm{E} \cdot 01$ & $<33.2$ & $1.86 \mathrm{E}+00$ & $<0.868$ & $2.52 \mathrm{E}+01$ & $<0.004$ \\
\hline & Residual" & $2.01 \mathrm{E}+01$ & $<33.2$ & $1.66 \mathrm{E}+03$ & $1.51 \mathrm{E}+02$ & $6.35 \mathrm{E}+01$ & $2.34 E+01$ \\
\hline & Exchangeable & $1.24 \mathrm{E}+\infty 0$ & $<33.2$ & $4.78 E+00$ & $<0.868$ & $1<0.006$ & $<0.004$ \\
\hline & Carbonate & $6.02 E+\infty 0$ & $<33.2$ & $2.74 E+00$ & $<0.868$ & $2.16 E+01$ & $<0.004$ \\
\hline & $\mathrm{Fe}, \mathrm{Mn}$ Oxides & $7.96 \mathrm{E}-01$ & $<33.2$ & $5.93 \mathrm{E}+00$ & $<0.868$ & $2.61 \mathrm{E}+01$ & $<0.004$ \\
\hline & Organic Matter & $1.06 \mathrm{E}+00$ & $<33.2$ & $1.50 E+00$ & $<0.868$ & $3.49 \mathrm{E}+01$ & $<0.004$ \\
\hline & Residual & $1.91 \mathrm{E}+01$ & $<33.2$ & $2.00 \mathrm{E}+03$ & $1.05 E+02$ & $6.92 \mathrm{E}+01$ & $2.33 \mathrm{E}+01$ \\
\hline & Exchangeable & $1.24 \mathrm{E}+00$ & $<33.2$ & $4.60 \mathrm{E}+00$ & $<0.868$ & $1<0.006$ & 6. $19 \mathrm{E}-01$ \\
\hline & Carbonate & $5.93 \mathrm{E}+00$ & $<33.2$ & $2.74 \mathrm{E}+00$ & $<0.868$ & $1.95 E+01$ & $<0.004$ \\
\hline & Fe, Mn Oxides & $8.85 \mathrm{E}-01$ & $<33.2$ & $1.42 \mathrm{E}+00$ & $<0.868$ & $3.50 \mathrm{E}+01$ & $<0.004$ \\
\hline & Organic Matter & $7.96 \mathrm{E}-01$ & $<33.2$ & $4.87 \mathrm{E}+00$ & $<0.868$ & $2.68 \mathrm{E}+0 \mathrm{t}$ & $7.96 \mathrm{E}-01$ \\
\hline & Residual & $1.77 E+01$ & $<33.2$ & $2.20 \mathrm{E}+03$ & $1.11 E+02$ & $5.92 \mathrm{E}+01$ & $2.09 \mathrm{E}+01$ \\
\hline & Exchangeable & $3.19 E+00$ & $<33.2$ & $1.86 \mathrm{E}+00$ & $<0.868$ & $3.27 \mathrm{E}+00$ & $<0.004$ \\
\hline & Carbonate & $5.31 \mathrm{E}+00$ & $<33.2$ & $1.06 \mathrm{E}+00$ & $<0.868$ & $9.91 E+00$ & 8.85E-0I \\
\hline & $\mathrm{Fe}, \mathrm{Mn}$ Oxides & $7.08 \mathrm{E}-01$ & $<33.2$ & $4.69 \mathrm{E}+00$ & $<0.868$ & $1.18 \mathrm{E}+01$ & 5.31E-01 \\
\hline & Organic Matter & $1.15 \mathrm{E}+00$ & $<33.2$ & $1.15 \mathrm{E}+\infty$ & $<0.868$ & $4.59 \mathrm{E}+01$ & $<0.004$ \\
\hline & Residual & $2.15 E+01$ & $<33.2$ & $2.11 \mathrm{E}+03$ & $1.27 E+02$ & $9.11 E+01$ & $2.51 E+01$ \\
\hline & Exchangeable & $1.42 E+00$ & $<33.2$ & $4.07 \mathrm{E}+00$ & $<0.868$ & $1<0.006$ & $6.19 \mathrm{E}-01$ \\
\hline & Carbonate & $5.57 \mathrm{E}+00$ & $<33.2$ & $3.54 \mathrm{E}-01$ & $<0.868$ & $3.98 \mathrm{E}+00$ & $<0.004$ \\
\hline & Fe. Mn Oxides & $7.08 \mathrm{E}-01$ & $<33.2$ & $5.22 \mathrm{E}+00$ & $<0.868$ & $1.19 \mathrm{E}+01$ & $9.73 \mathrm{E}-01$ \\
\hline & Organic Matter & 8.85E-01 & $<33.2$ & $1.59 \mathrm{E}+00$ & $<0.868$ & $4.90 \mathrm{E}+01$ & $<0.004$ \\
\hline & Residual & $2.52 \mathrm{E}+01$ & $<33.2$ & $1.62 \mathrm{E}+03$ & $1.12 \mathrm{E}+02$ & $1.27 E+02$ & $2.87 \mathrm{E}+01$ \\
\hline Core ID & Extraction & $\mathrm{Sr}$ & Th & $\mathbf{T i}$ & $\mathbf{u}$ & $Z_{n}$ & $\mathbf{Z r}$ \\
\hline \multirow{17}{*}{ Core S3 } & Exchangeable & $3.10 \mathrm{E}+00$ & $<33.2$ & $3.63 \mathrm{E}+00$ & $<0.868$ & $<0.006$ & $7.08 \mathrm{E}-01$ \\
\hline & Exchangeable & $8.85 \mathrm{E}-01$ & $<33.2$ & $2.65 \mathrm{E}+00$ & $<0.868$ & $<0.006$ & $<0.004$ \\
\hline & Carbonate & $1.95 E+00$ & $<33.2$ & $1.59 \mathrm{E}+00$ & $<0.868$ & $3.54 \mathrm{E}+01$ & $<0.004$ \\
\hline & Carbonate & $1.06 \mathrm{E}+00$ & $<33.2$ & $2.92 \mathrm{E}+00$ & $<0.868$ & $2.54 \mathrm{E}+01$ & $<0.004$ \\
\hline & Fe, Mn Oxides & $5.31 \mathrm{E}-01$ & $<33.2$ & $5.31 \mathrm{E}+00$ & $<0,868$ & $4.03 E+01$ & $5.31 \mathrm{E}-01$ \\
\hline & $\mathrm{Fe}, \mathrm{Mn}$ Oxides & $4.42 \mathrm{E}-01$ & $<33.2$ & $4.96 E+00$ & $<0.868$ & $1.43 \mathrm{E}+01$ & $6.19 \mathrm{E}-01$ \\
\hline & Organic Matter & $7.96 \mathrm{E}-01$ & $<33.2$ & $2.71 E+01$ & $<0.868$ & $6.08 \mathrm{E}+01$ & $<0.004$ \\
\hline & Organic Matter & $8.85 \mathrm{E}-0 !$ & $<33.2$ & $6.37 E+00$ & $<0.868$ & $1.50 \mathrm{E}+01$ & $8.85 \mathrm{E}-01$ \\
\hline & Exchangeable & 4.25E+00 & $<33.2$ & $4.42 \mathrm{E}-01$ & $<0.868$ & $1.08 \mathrm{E}+01$ & $<0.004$ \\
\hline & Carbonate & $2.65 \mathrm{E}+00$ & $<33.2$ & $6.19 \mathrm{E}-01$ & $<0.868$ & $4.90 \mathrm{E}+01$ & $6.19 \mathrm{E}-01$ \\
\hline & Fe, Mn Oxides & $8,85 \mathrm{E}-01$ & $<33.2$ & $6.37 \mathrm{E}+00$ & $<0.868$ & $9.03 E+01$ & $8.85 \mathrm{E}-01$ \\
\hline & OTganic Matter & $1.24 \mathrm{E}+00$ & $<33.2$ & $1.33 E+00$ & $<0.868$ & $3.40 \mathrm{E}+01$ & $<0.004$ \\
\hline & Residual & $1.71 E+01$ & $<33.2$ & $9.73 E+02$ & $9.47 E+01$ & $6.57 \mathrm{E}+01$ & $2.72 E+01$ \\
\hline & Exchangeable & $3.89 \mathrm{E}+00$ & $<33.2$ & $1.15 E+00$ & $<0.868$ & $1.78 \mathrm{E}+01$ & $<0.004$ \\
\hline & Carbonate & $1.02 \mathrm{E}+01$ & $<33.2$ & $3.54 \mathrm{E}-01$ & $<0.868$ & $1.75 E+01$ & $<0.004$ \\
\hline & $\mathrm{Fe}, \mathrm{Mn}$ Oxides & $7.08 \mathrm{E}-01$ & $<33.2$ & $3.89 \mathrm{E}+00$ & $<0.868$ & $2.56 \mathrm{E}+01$ & 8.85E-01 \\
\hline & Organic Matter & $1.06 \mathrm{E}+00$ & $<33.2$ & $1.50 \mathrm{E}+00$ & $<0.868$ & $4.72 E+01$ & $<0.004$ \\
\hline
\end{tabular}




\begin{tabular}{|c|c|c|c|c|c|c|c|}
\hline & Residual & $6.11 \mathrm{E}+00$ & $<33.2$ & $1.34 \mathrm{E}+03$ & $1.17 \mathrm{E}+02$ & $7.03 E+01$ & $2.56 \mathrm{E}+01$ \\
\hline & Exchangeable & $1.42 E+00$ & $<33.2$ & $2.21 \mathrm{E}+00$ & $<0.868$ & $<0.006$ & $<0.004$ \\
\hline & Exchangeable & $7.96 \mathrm{E}-01$ & $<33.2$ & $2.57 \mathrm{E}+\infty 0$ & $<0.868$ & $<0.006$ & $<0.004$ \\
\hline & Carbonate & $8.14 E+\infty 0$ & $<33.2$ & $1.24 E+\infty$ & $<0.868$ & $1.77 \mathrm{E}+01$ & $<0.004$ \\
\hline & Carbonate & $1.24 \mathrm{E}+00$ & $<33.2$ & 4. $16 \mathrm{E}+00$ & $<0.868$ & $1.43 \mathrm{E}+01$ & $<0.004$ \\
\hline & $\mathrm{Fe}, \mathrm{Mn}$ Oxides & $2.65 \mathrm{E}-01$ & $<33.2$ & $3.80 \mathrm{E}+00$ & $<0.868$ & $1.17 \mathrm{E}+01$ & $7.96 \mathrm{E}-01$ \\
\hline & $\mathrm{Fe}, \mathrm{Mn}$ Oxides & $3.54 \mathrm{E}-01$ & $<33.2$ & $3.10 E+00$ & $<0.868$ & $4.42 \mathrm{E}+00$ & $<0.004$ \\
\hline & Organic Matter & $4.42 \mathrm{E}-01$ & $<33.2$ & $1.22 \mathrm{E}+01$ & $<0.868$ & $6.01 E+01$ & $<0.004$ \\
\hline & Organic Matter & 4.42E-01 & $<33.2$ & $4.60 \mathrm{E}+00$ & $<0.868$ & $1.67 \mathrm{E}+01$ & $<0.004$ \\
\hline & Residual & $4.78 E+00$ & $<33.2$ & $9.47 \mathrm{E}+02$ & $8.57 \mathrm{E}+01$ & $3.58 \mathrm{E}+01$ & $2.64 E+01$ \\
\hline & Exchangeable & $3.05 E+01$ & $<33.2$ & $6.19 \mathrm{E}-01$ & $<0.868$ & $4.87 \mathrm{E}+00$ & $<0.004$ \\
\hline & Carbonate & $1.45 \mathrm{E}+01$ & $<33.2$ & $<0.002$ & $<0.868$ & $4.02 E+01$ & $<0.004$ \\
\hline & Fe, Mn Oxides & $4.96 \mathrm{E}+00$ & $<33.2$ & 8. $58 \mathrm{E}+00$ & $<0,868$ & $5.32 \mathrm{E}+01$ & $1.95 E+00$ \\
\hline & Organic Matter & $1.95 \mathrm{E}+00$ & $<33.2$ & $2.21 \mathrm{E}+00$ & $<0.868$ & $1.65 \mathrm{E}+02$ & 7.08E-01 \\
\hline & Residual & $1.62 \mathrm{E}+01$ & $<33.2$ & $5.48 \mathrm{E}+02$ & $8.70 E+01$ & $5.27 \mathrm{E}+01$ & $3.45 E+00$ \\
\hline & Exchangeable & $1.08 \mathrm{E}+01$ & $<33.2$ & $1.06 \mathrm{E}+00$ & $<0.868$ & $1<0.006$ & 4.42E-01 \\
\hline & Exchangeable & $3.01 \mathrm{E}+00$ & $<33.2$ & 2.65E-01 & $<0.868$ & $1<0.006$ & 4.42E-0] \\
\hline & Carbonate & $1.62 \mathrm{E}+01$ & $<33.2$ & $6.19 \mathrm{E}-01$ & $<0.868$ & 4. $10 \mathrm{E}+01$ & $9.73 \mathrm{E}-01$ \\
\hline & Carbonate & $2.30 \mathrm{E}+00$ & $<33.2$ & $2.74 \mathrm{E}+00$ & $<0.868$ & $3.69 \mathrm{E}+01$ & $6.19 \mathrm{E}-01$ \\
\hline & Fe, Mn Oxides & $8.85 \mathrm{E}-01$ & $<33.2$ & $1.37 \mathrm{E}+01$ & $<0.868$ & $6.37 \mathrm{E}+01$ & $3.63 E+00$ \\
\hline & Fe, Mn Oxides & $6.19 \mathrm{E}-01$ & $<33.2$ & $6.19 E+\infty 0$ & $<0.868$ & $1.44 E+0 \mid$ & $1.33 E+00$ \\
\hline & Organic Matter & $7.08 \mathrm{E}-01$ & $<33.2$ & $1.30 \mathrm{E}+01$ & $<0.868$ & $2.74 E+02$ & $7.08 \mathrm{E}-01$ \\
\hline & Organic Matter & $7.08 \mathrm{E}-01$ & $<33.2$ & $4.07 \mathrm{E}+00$ & $<0.868$ & $8.52 \mathrm{E}+01$ & $<0.004$ \\
\hline & Residual & $2.01 E+01$ & $<33.2$ & $5.87 \mathrm{E}+02$ & $1.43 E+02$ & $6.55 E+01$ & $3.27 \mathrm{E}+01$ \\
\hline Core ID & Extraction & $\mathbf{s r}$ & Th & $\mathbf{T i}$ & $\mathrm{U}$ & Zn & $\mathbf{Z r}$ \\
\hline Core S4 & Exchangeable & $1.50 \mathrm{E}+00$ & $<33.2$ & $2.39 \mathrm{E}+00$ & $<0.868$ & $1<0.006$ & $7.96 \mathrm{E}-01$ \\
\hline & Carbonate & $6.64 E+00$ & $<33.2$ & $2.30 \mathrm{E}+00$ & $<0.868$ & $5.43 E+01$ & 7.96E-01 \\
\hline & $\mathrm{Fe}$, Mn Oxides & $7.08 \mathrm{E}-01$ & $<33.2$ & $3.89 \mathrm{E}+00$ & $<0.868$ & $2.33 \mathrm{E}+01$ & $5.31 \mathrm{E}-01$ \\
\hline & Organic Matter & $8.85 \mathrm{E}-01$ & $<33.2$ & $3.27 \mathrm{E}+00$ & $<0.868$ & $9.29 \mathrm{E}+01$ & $<0.004$ \\
\hline & Residual & $1.10 \mathrm{E}+01$ & $<33.2$ & $1.40 E+03$ & $126 E+02$ & $7.63 \mathrm{E}+0]$ & $1.83 \mathrm{E}+01$ \\
\hline & Exchangeable & $1.42 \mathrm{E}+00$ & $<33.2$ & $2.74 \mathrm{E}+00$ & $<0.868$ & $1<0.006$ & $4.42 \mathrm{E}-0 !$ \\
\hline & Carbonate & $7.79 E+00$ & $<33.2$ & $2.57 E+00$ & $<0.868$ & $5.03 \mathrm{E}+01$ & $<0.004$ \\
\hline & $\mathrm{Fe}, \mathrm{Mn}$ Oxides & $7.96 \mathrm{E}-01$ & $<33.2$ & $4.25 E+00$ & $<0,868$ & $2.49 \mathrm{E}+01$ & $<0.004$ \\
\hline & Organic Matter & $8.85 E-01$ & $<33.2$ & $4.78 \mathrm{E}+00$ & $<0.868$ & $9.20 \mathrm{E}+01$ & $<0.004$ \\
\hline & Residual & $1.35 \mathrm{E}+01$ & $<33.2$ & $1.66 \mathrm{E}+03$ & $1.30 \mathrm{E}+02$ & $1.06 \mathrm{E}+02$ & $2.25 \mathrm{E}+01$ \\
\hline & Exchangeable & $1.24 \mathrm{E}+00$ & $<33.2$ & 2. $12 \mathrm{E}+00$ & $<0.868$ & $1<0.006$ & $5.31 \mathrm{E}-01$ \\
\hline & Carbonate & $5.31 \mathrm{E}+00$ & $<33.2$ & $3.72 \mathrm{E}+00$ & $<0.868$ & $2.06 \mathrm{E}+01$ & $<0.004$ \\
\hline & $\mathrm{Fe}, \mathrm{Mn}$ Oxides & $7.96 \mathrm{E}-01$ & $<33.2$ & $5.22 \mathrm{E}+00$ & $<0.868$ & $1.04 E+01$ & $7.08 \mathrm{E}-01$ \\
\hline & Organic Matter & $7.96 \mathrm{E}-01$ & $<33.2$ & $6.19 \mathrm{E}+00$ & $<0.868$ & $5.02 \mathrm{E}+01$ & $<0.004$ \\
\hline & Residual & $1.10 \mathrm{E}+01$ & $<33.2$ & $1.25 \mathrm{E}+03$ & $1.04 E+02$ & $7.52 E+01$ & 2.19E+01 \\
\hline & Exchangeable & $1.24 \mathrm{E}+\infty$ & $<33.2$ & $3.63 \mathrm{E}+00$ & $<0.868$ & $1<0.006$ & 4.42E-01 \\
\hline & Carbonate & $5.04 E+00$ & $<33.2$ & $3.72 \mathrm{E}+00$ & $<0.868$ & $2.19 \mathrm{E}+01$ & $5.31 \mathrm{E}-01$ \\
\hline & Fe, Mn Oxides & $7.96 \mathrm{E}-01$ & $<33.2$ & $5.40 \mathrm{E}+00$ & $<0.868$ & $9.64 \mathrm{E}+00$ & $5,31 \mathrm{E} \cdot 01$ \\
\hline & Organic Matter & $7.08 \mathrm{E}-01$ & $<33.2$ & 3. $19 \mathrm{E}+00$ & $<0.868$ & $5.01 E+01$ & $<0.004$ \\
\hline & Residual & $1.30 \mathrm{E}+01$ & $<33.2$ & $1.63 E+03$ & $1.05 E+02$ & $5.95 \mathrm{E}+01$ & $2.35 \mathrm{E}+01$ \\
\hline & Exchangeable & $1.15 E+00$ & $<33.2$ & $2.30 E+00$ & $<0.868$ & $1<0.006$ & $<0.004$ \\
\hline & Carbonate & $4.87 \mathrm{E}+00$ & $<33.2$ & $4.69 E+00$ & $<0.868$ & $1.56 \mathrm{E}+01$ & $5.31 \mathrm{E}-01$ \\
\hline & Fe, Mn Oxides & $7.08 \mathrm{E}-01$ & $<33.2$ & $6.81 \mathrm{E}+00$ & $<0.868$ & $6.55 E+00$ & $1.06 \mathrm{E}+00$ \\
\hline & Organic Matter & $8.85 E-01$ & $<33.2$ & $6.90 E+00$ & $<0.868$ & $6.88 \mathrm{E}+01$ & 4.42E-01 \\
\hline & Residual & $1.04 \mathrm{E}+01$ & $<33.2$ & $1.14 \mathrm{E}+03$ & $1.26 \mathrm{E}+02$ & $5.49 \mathrm{E}+01$ & $2.05 \mathrm{E}+01$ \\
\hline & Exchangeable & $9.73 \mathrm{E}-01$ & $<33.2$ & $1.06 \mathrm{E}+00$ & $<0.868$ & $1<0.006$ & 4.42E-01 \\
\hline & Carbonate & 4. $42 \mathrm{E}+00$ & $<33.2$ & $3.01 E+00$ & $<0.868$ & $1.43 \mathrm{E}+01$ & 6.19E-01 \\
\hline & Fe, Mn Oxides & $7.08 \mathrm{E}-01$ & $<33.2$ & $7.17 \mathrm{E}+00$ & $<0.868$ & $7.26 \mathrm{E}+00$ & $1.06 \mathrm{E}+00$ \\
\hline & Organic Matter & $6.19 \mathrm{E}-01$ & $<33.2$ & $4.60 \mathrm{E}+00$ & $<0.868$ & $2.18 E+01$ & 4.42E-01 \\
\hline & Residual & $1.14 \mathrm{E}+01$ & $<33.2$ & $1.43 E+03$ & $1.21 \mathrm{E}+02$ & $5.04 E+01$ & $2.42 E+01$ \\
\hline & Exchangeable & $1.15 \mathrm{E}+00$ & $<33.2$ & $2.39 \mathrm{E}+00$ & $<0.868$ & $1<0.006$ & $5.31 \mathrm{E}-01$ \\
\hline & Carbonate & $6.28 E+00$ & $<33.2$ & $3.72 \mathrm{E}+00$ & $<0.868$ & $2.13 \mathrm{E}+01$ & $<0.004$ \\
\hline & $\mathrm{Fe}, \mathrm{Mn}$ Oxides & $7.96 \mathrm{E}-01$ & $<33.2$ & $6.72 \mathrm{E}+00$ & $<0.868$ & $8.94 E+\infty 0$ & $4.42 \mathrm{E}-01$ \\
\hline & Organic Matter & $7.96 \mathrm{E}-01$ & $<33.2$ & $2.39 \mathrm{E}+00$ & $<0.868$ & $4.52 \mathrm{E}+01$ & $<0.004$ \\
\hline & Residual & $1.25 \mathrm{E}+01$ & $<33.2$ & $1.27 \mathrm{E}+03$ & $1.11 \mathrm{E}+02$ & $4.23 \mathrm{E}+01$ & $3.06 \mathrm{E}+01$ \\
\hline & Exchangeable & $1.24 \mathrm{E}+00$ & $<33.2$ & $2.39 \mathrm{E}+00$ & $<0.868$ & $1<0.006$ & $<0.004$ \\
\hline & Carbonate & $5.13 \mathrm{E}+00$ & $<33.2$ & $2.12 \mathrm{E}+00$ & $<0.868$ & $1.97 \mathrm{E}+01$ & $<0.004$ \\
\hline & Fe, Mn Oxides & $7.08 E-01$ & $<33.2$ & $6.28 \mathrm{E}+00$ & $<0.868$ & $9.38 \mathrm{E}+00$ & $1.06 \mathrm{E}+00$ \\
\hline & Organic Matter & $7.96 \mathrm{E}-01$ & $<33.2$ & $3.54 \mathrm{E}+00$ & $<0.868$ & $3.41 \mathrm{E}+01$ & $<0.004$ \\
\hline & Residual & $1.42 \mathrm{E}+01$ & $<33.2$ & $1.59 \mathrm{E}+03$ & $1.29 \mathrm{E}+02$ & $6.92 \mathrm{E}+01$ & $2.57 \mathrm{E}+01$ \\
\hline Core ID & Extraction & $\mathrm{Sr}$ & Th & $\mathrm{Ti}$ & $\mathbf{U}$ & $\mathrm{Zn}$ & $\mathbf{Z r}$ \\
\hline Core S5 & Exchangeable & $1.33 \mathrm{E}+00$ & $<33.2$ & $2.48 \mathrm{E}+00$ & $<0.868$ & $1<0.006$ & $6.19 \mathrm{E}-01$ \\
\hline & Carbonate & $5.49 \mathrm{E}+00$ & $<33.2$ & $1.15 \mathrm{E}+00$ & $<0.868$ & $2.12 \mathrm{E}+01$ & $5.31 \mathrm{E}-01$ \\
\hline & $\mathrm{Fe}, \mathrm{Mn}$ Oxides & $7.96 \mathrm{E}-01$ & $<33.2$ & $4.07 \mathrm{E}+00$ & $<0.868$ & $1.34 E+01$ & $<0.004$ \\
\hline & Organic Matter & $1.15 E+00$ & $<33.2$ & $3.54 \mathrm{E}+00$ & $<0.868$ & $6.10 \mathrm{E}+01$ & $<0.004$ \\
\hline & Residual & $1.83 \mathrm{E}+01$ & $<33.2$ & $1.95 \mathrm{E}+03$ & $1.38 E+02$ & $6.65 \mathrm{E}+01$ & $2.56 \mathrm{E}+01$ \\
\hline & Exchangeable & $1.24 \mathrm{E}+00$ & $<33.2$ & $2.21 E+\infty 0$ & $<0.868$ & $1<0.006$ & $7.08 \mathrm{E}-01$ \\
\hline & Carbonate & $5.13 E+00$ & $<33.2$ & $1.59 \mathrm{E}+00$ & $<0.868$ & $2.06 \mathrm{E}+01$ & $7.08 \mathrm{E}-01$ \\
\hline & Fe, Mn Oxides & $7.96 \mathrm{E}-01$ & $<33.2$ & $3.63 E+00$ & $<0.868$ & $1.64 E+01$ & $<0.004$ \\
\hline & Organic Matter & $1.24 \mathrm{E}+00$ & $<33.2$ & $5.75 \mathrm{E}+00$ & $<0.868$ & $7.35 E+01$ & 4.42E-01 \\
\hline & Residual & $1.86 \mathrm{E}+01$ & $<33.2$ & $1.96 \mathrm{E}+03$ & $1.62 \mathrm{E}+02$ & $6.34 E+01$ & $2.71 E+01$ \\
\hline & Exchangeable & $1.06 \mathrm{E}+00$ & $<33.2$ & $2.92 E+00$ & $<0.868$ & $1<0.006$ & $<0.004$ \\
\hline & Carbonate & $6.37 \mathrm{E}+00$ & $<33.2$ & $2.48 \mathrm{E}+00$ & $<0.868$ & $1.42 \mathrm{E}+01$ & $<0.004$ \\
\hline & $\mathrm{Fe}, \mathrm{Mn}$ Oxides & $7.96 \mathrm{E}-01$ & $<33.2$ & $4.96 \mathrm{E}+00$ & $<0.868$ & $9.11 E+00$ & $5.31 \mathrm{E}-01$ \\
\hline & Organic Matter & $8.85 \mathrm{E}-01$ & $<33.2$ & $4.60 E+\infty 0$ & $<0.868$ & $1.02 \mathrm{E}+02$ & $<0.004$ \\
\hline & Exchangeable & $1.24 \mathrm{E}+00$ & $<33.2$ & $2.48 \mathrm{E}+00$ & $<0.868$ & $1<0.006$ & $5.31 E-01$ \\
\hline & Carbonate & $6.28 E+00$ & $<33.2$ & $1.95 E+00$ & $<0.868$ & $1.38 \mathrm{E}+01$ & $<0.004$ \\
\hline & $\mathrm{Fe}, \mathrm{Mn}$ Oxides & $6.19 \mathrm{E}-0 \mathrm{I}$ & $<33.2$ & $5.31 \mathrm{E}+00$ & $<0.868$ & $9.82 \mathrm{E}+00$ & $5.31 \mathrm{E}-01$ \\
\hline & Organic Matter & $7.08 \mathrm{E}-01$ & $<33.2$ & $2.21 E+00$ & $<0.868$ & $1.06 \mathrm{E}+02$ & 4.42E-01 \\
\hline & Residual & $1.49 \mathrm{E}+01$ & $<33.2$ & $1.50 \mathrm{E}+03$ & $1.26 \mathrm{E}+02$ & $8.80 \mathrm{E}+01$ & $1.96 \mathrm{E}+01$ \\
\hline
\end{tabular}




\begin{tabular}{|c|c|c|c|c|c|c|c|}
\hline & Exchangeable & $1.15 E+00$ & $<33.2$ & $2.57 \mathrm{E}+00$ & $<0.868$ & $1<0.006$ & $5.31 \mathrm{E}-01$ \\
\hline & Carbonate & $5.31 E+00$ & $<33.2$ & $2.30 \mathrm{E}+00$ & $<0.868$ & $2.38 E+01$ & 4.42E-0I \\
\hline & Fe, Mn Oxides & $5.31 \mathrm{E}-01$ & $<33.2$ & $4.07 E+00$ & $<0.868$ & $1.27 \mathrm{E}+01$ & $<0.004$ \\
\hline & Organic Matter & $7.96 \mathrm{E}-01$ & $<33.2$ & $3.36 \mathrm{E}+00$ & $<0.868$ & $7.64 E+01$ & $<0.004$ \\
\hline & Residual & $1.40 E+01$ & $<33.2$ & $1.29 \mathrm{E}+03$ & $8.83 \mathrm{E}+01$ & $6.98 \mathrm{E}+01$ & $2.04 \mathrm{E}+01$ \\
\hline & Exchangeable & $1.15 E+00$ & $<33.2$ & $2.30 \mathrm{E}+00$ & $<0.868$ & $:<0.006$ & $<0.004$ \\
\hline & Carbonate & $5.66 \mathrm{E}+00$ & $<33.2$ & 3. $19 \mathrm{E}+00$ & $<0.868$ & $2.73 \mathrm{E}+01$ & $<0.004$ \\
\hline & $\mathrm{Fe}$, Mn Oxides & 5.31E-01 & $<33.2$ & $3.89 \mathrm{E}+00$ & $<0.868$ & $1.39 E+01$ & $<0.004$ \\
\hline & Organic Matter & $7.96 \mathrm{E}-01$ & $<33.2$ & $3.27 E+00$ & $<0.868$ & $7.97 \mathbf{E}+01$ & $<0.004$ \\
\hline & Residual & I. $16 E+01$ & $<33.2$ & $1.18 \mathrm{E}+03$ & $1.33 E+02$ & $8.55 \mathrm{E}+01$ & $1.90 \mathrm{E}+01$ \\
\hline \multicolumn{8}{|c|}{ Total Digestions } \\
\hline Core ID & Extraction & $\mathbf{S r}$ & Th & $\mathrm{Ti}$ & $\mathbf{U}$ & Zn & $\mathbf{Z r}$ \\
\hline \multirow[t]{6}{*}{ Core S1 } & & $2.87 \mathrm{E}+01$ & $<33.2$ & $1.31 E+03$ & $2.35 \mathrm{E}+02$ & $2.82 \mathrm{E}+02$ & $2.75 \mathrm{E}+01$ \\
\hline & & $5.23 E+01$ & $<33.2$ & $2.42 \mathrm{E}+03$ & $4.28 \mathrm{E}+02$ & 4. $37 \mathrm{E}+02$ & $2.06 E+01$ \\
\hline & & $2.97 E+01$ & $<33.2$ & $1.45 \mathrm{E}+03$ & $1.76 \mathrm{E}+02$ & $2.80 E+02$ & $3.06 \mathrm{E}+01$ \\
\hline & & $2.47 \mathrm{E}+01$ & $<33.2$ & $9.19 \mathrm{E}+02$ & $1.63 E+02$ & $2.43 \mathrm{E}+02$ & $2.57 \mathrm{E}+01$ \\
\hline & & $6.96 E+01$ & $<33.2$ & $1.54 E+03$ & $4.46 E+02$ & $6.53 \mathrm{E}+02$ & $7.08 E+01$ \\
\hline & & $6.67 \mathrm{E}+01$ & $<33.2$ & $1.62 \mathrm{E}+03$ & $2.78 \mathrm{E}+02$ & $5.82 \mathrm{E}+02$ & $7.22 E+01$ \\
\hline \multirow[t]{6}{*}{ Core S2 } & & $5.91 \mathrm{E}+01$ & $<33.2$ & $9.07 \mathrm{E}+02$ & $3.09 \mathrm{E}+02$ & $3.57 \mathrm{E}+02$ & $6.28 \mathrm{E}+01$ \\
\hline & & $7.31 E+01$ & $<33.2$ & $8.40 E+02$ & $4.93 E+02$ & $4.36 \mathrm{E}+02$ & $7.78 \mathrm{E}+01$ \\
\hline & & $7.46 \mathrm{E}+01$ & 33.2 & 4. $19 \mathrm{E}+03$ & $3.81 \mathrm{E}+02$ & 4. $70 \mathrm{E}+02$ & $7.24 \mathrm{E}+01$ \\
\hline & & $7.08 E+01$ & $<332$ & $5.28 \mathrm{E}+03$ & $4.03 E+02$ & $4.49 \mathrm{E}+02$ & $6.62 \mathrm{E}+01$ \\
\hline & & $7.97 \mathrm{E}+01$ & $<33.2$ & $1.57 \mathrm{E}+03$ & $3.85 \mathrm{E}+02$ & 4. $62 \mathrm{E}+02$ & $8.47 E+01$ \\
\hline & & $7.80 \mathrm{E}+01$ & $<33.2$ & $3.18 \mathrm{E}+03$ & $3.56 \mathrm{E}+02$ & $4.05 \mathrm{E}+02$ & $7.78 \mathrm{E}+01$ \\
\hline \multirow[t]{7}{*}{ Core S3 } & & $1.60 \mathrm{E}+01$ & $<33.2$ & $1.37 \mathrm{E}+03$ & $9.97 \mathrm{E}+01$ & $4.23 \mathrm{E}+01$ & $2.80 \mathrm{E}+01$ \\
\hline & & $2.54 \mathrm{E}+01$ & $<33.2$ & $7.91 \mathrm{E}+02$ & $1.34 E+02$ & $2.36 \mathrm{E}+02$ & $3.14 E+01$ \\
\hline & & $2.41 \mathrm{E}+01$ & $<33.2$ & $6.46 \mathrm{E}+02$ & $1.28 \mathrm{E}+02$ & $2.30 \mathrm{E}+02$ & $3.07 E+01$ \\
\hline & & $2.31 E+01$ & $<33.2$ & $1.39 \mathrm{E}+03$ & $1.93 \mathrm{E}+02$ & $2.05 \mathrm{E}+02$ & $4.08 E+01$ \\
\hline & & $1.82 \mathrm{E}+01$ & $<33.2$ & $1.25 \mathrm{E}+03$ & $1.31 E+02$ & $1.71 E+02$ & $3.05 E+01$ \\
\hline & & $5.87 \mathrm{E}+01$ & $<33.2$ & $1.23 E+03$ & $1.27 \mathrm{E}+02$ & $3.82 \mathrm{E}+02$ & $3.13 E+01$ \\
\hline & & $8.83 E+01$ & $<33.2$ & $1.59 \mathrm{E}+03$ & $2.65 \mathrm{E}+02$ & $5.61 E+02$ & $4.78 \mathrm{E}+01$ \\
\hline \multirow[t]{8}{*}{ Core S4 } & & $4.61 \mathrm{E}+01$ & $<33.2$ & $3.45 E+03$ & $3.92 \mathrm{E}+02$ & $6.14 E+02$ & $5.30 \mathrm{E}+01$ \\
\hline & & $3.74 \mathrm{E}+01$ & $<33.2$ & $2.69 E+03$ & $2.60 E+02$ & $5.19 E+02$ & $4.04 E+01$ \\
\hline & & $4.62 \mathrm{E}+01$ & $<33.2$ & $3.35 E+03$ & $3.75 E+02$ & 4. $17 \mathrm{E}+02$ & $5.80 E+01$ \\
\hline & & $6.19 \mathrm{E}+01$ & $<33.2$ & $4.22 \mathrm{E}+03$ & $3.91 E+02$ & $5.40 \mathrm{E}+02$ & $8.08 E+01$ \\
\hline & & $4.73 E+01$ & $<33.2$ & $3.64 \mathrm{E}+03$ & $3.31 \mathrm{E}+02$ & $3.71 E+02$ & $6.73 E+01$ \\
\hline & & $4.91 \mathrm{E}+01$ & $<33.2$ & $3.94 \mathrm{E}+03$ & $3.56 \mathrm{E}+02$ & $5.74 \mathrm{E}+02$ & $7.02 \mathrm{E}+01$ \\
\hline & & $4.98 \mathrm{E}+01$ & $<33.2$ & $3.81 E+03$ & $3.14 \mathrm{E}+02$ & $4.04 E+02$ & $7.25 \mathrm{E}+01$ \\
\hline & & $5.02 \mathrm{E}+01$ & $<33.2$ & $3.87 E+03$ & $3.63 \mathrm{E}+02$ & $5.02 E+02$ & $7.57 \mathrm{E}+01$ \\
\hline \multirow[t]{6}{*}{ Core S5 } & & $5.80 \mathrm{E}+01$ & $<33.2$ & $4.06 \mathrm{E}+03$ & $2.68 E+02$ & $4.02 E+02$ & $6.07 E+01$ \\
\hline & & $6.92 \mathrm{E}+01$ & $<33.2$ & $4.67 \mathrm{E}+03$ & 4. $13 E+02$ & $4.78 \mathrm{E}+02$ & $6.78 E+01$ \\
\hline & & $4.47 \mathrm{E}+01$ & $<33.2$ & $3.14 \mathrm{E}+03$ & $2.87 \mathrm{E}+02$ & $5.42 \mathrm{E}+02$ & 4.39E+01 \\
\hline & & $6.37 \mathrm{E}+01$ & $<33.2$ & $4.55 \mathrm{E}+03$ & $4.20 \mathrm{E}+02$ & $5.92 \mathrm{E}+02$ & $6.57 \mathrm{E}+01$ \\
\hline & & $5,04 \mathrm{E}+01$ & $<33.2$ & $3.85 E+03$ & $2.77 \mathbf{E}+02$ & $4.73 \mathrm{E}+02$ & 5. $19 \mathbf{E}+01$ \\
\hline & & $5.66 \mathrm{E}+01$ & $<33.2$ & $3.82 \mathrm{E}+03$ & $2.87 \mathrm{E}+02$ & $5.55 \mathrm{E}+02$ & $6.08 E+01$ \\
\hline
\end{tabular}




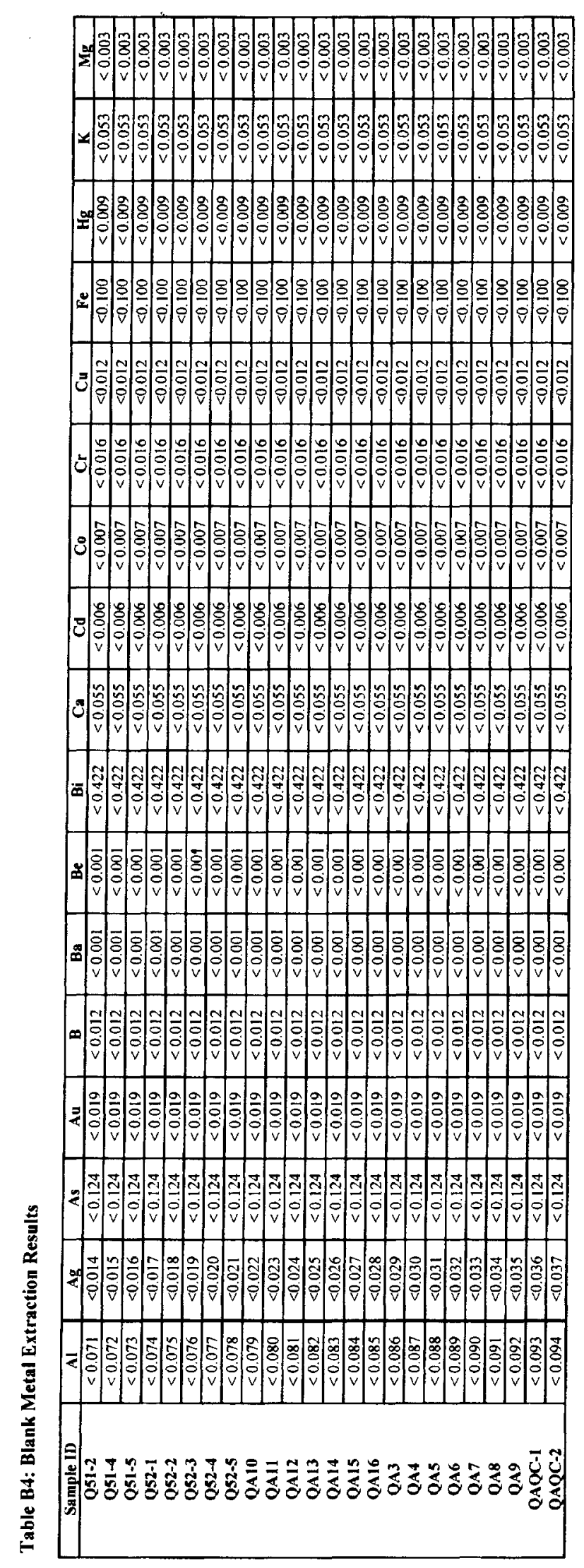




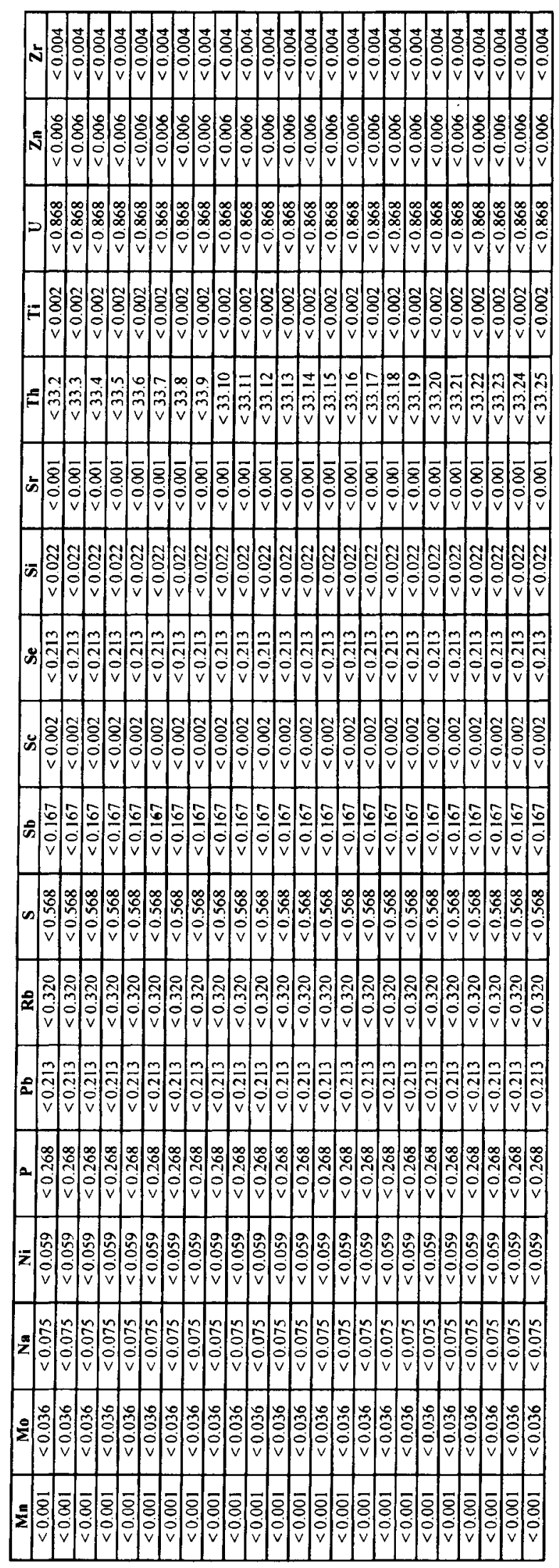


Table B5: Acid Producing Bacteria, Sulfate Reducing Bacteria, and Iron Reducing Bacteria Populations Measured from September 2004 Cores

\begin{tabular}{|cccccccccc|}
\hline Location & Depth $(\mathbf{c m})$ & WC & APB & IRB & SRB & DW $(\mathbf{g})$ & APB & IRB & SRB \\
\hline Core S1 & 25 & 0.295 & $1.10 \mathrm{E}+05$ & $1.70 \mathrm{E}+04$ & $2.20 \mathrm{E}+02$ & 0.705 & $1.56 \mathrm{E}+05$ & $2.41 \mathrm{E}+04$ & $3.12 \mathrm{E}+02$ \\
& 50 & 0.393 & $7.00 \mathrm{E}+06$ & $2.20 \mathrm{E}+04$ & $7.90 \mathrm{E}+05$ & 0.607 & $1.15 \mathrm{E}+07$ & $3.62 \mathrm{E}+04$ & $1.30 \mathrm{E}+06$ \\
& 75 & 0.219 & $3.30 \mathrm{E}+04$ & $1.10 \mathrm{E}+03$ & $1.30 \mathrm{E}+05$ & 0.781 & $4.23 \mathrm{E}+04$ & $1.41 \mathrm{E}+03$ & $1.66 \mathrm{E}+05$ \\
\hline Core S2 & 25 & 0.22 & $4.90 \mathrm{E}+04$ & $1.40 \mathrm{E}+04$ & $2.20 \mathrm{E}+03$ & 0.78 & $6.28 \mathrm{E}+04$ & $1.79 \mathrm{E}+04$ & $2.82 \mathrm{E}+03$ \\
& 50 & 0.201 & $4.90 \mathrm{E}+02$ & $1.70 \mathrm{E}+03$ & $4.90 \mathrm{E}+03$ & 0.799 & $6.13 \mathrm{E}+02$ & $2.13 \mathrm{E}+03$ & $6.13 \mathrm{E}+03$ \\
& 75 & 0.222 & $4.90 \mathrm{E}+03$ & $1.40 \mathrm{E}+02$ & $7.90 \mathrm{E}+02$ & 0.778 & $6.30 \mathrm{E}+03$ & $1.80 \mathrm{E}+02$ & $1.02 \mathrm{E}+03$ \\
\hline Core S3 & 25 & 0.159 & $3.30 \mathrm{E}+04$ & $2.30 \mathrm{E}+04$ & $2.20 \mathrm{E}+05$ & 0.841 & $3.92 \mathrm{E}+04$ & $2.73 \mathrm{E}+04$ & $2.62 \mathrm{E}+05$ \\
& 50 & 0.191 & $1.30 \mathrm{E}+04$ & $4.60 \mathrm{E}+02$ & $3.30 \mathrm{E}+04$ & 0.809 & $1.61 \mathrm{E}+04$ & $5.69 \mathrm{E}+02$ & $4.08 \mathrm{E}+04$ \\
& 75 & 0.652 & $1.30 \mathrm{E}+05$ & $1.10 \mathrm{E}+04$ & $4.90 \mathrm{E}+04$ & 0.348 & $3.74 \mathrm{E}+05$ & $3.16 \mathrm{E}+04$ & $1.41 \mathrm{E}+05$ \\
\hline Core S4 & 25 & 0.146 & $7.90 \mathrm{E}+03$ & $7.90 \mathrm{E}+02$ & $2.20 \mathrm{E}+02$ & 0.854 & $9.25 \mathrm{E}+03$ & $9.25 \mathrm{E}+02$ & $2.58 \mathrm{E}+02$ \\
& 50 & 0.100 & $2.30 \mathrm{E}+04$ & $7.90 \mathrm{E}+02$ & $1.10 \mathrm{E}+02$ & 0.900 & $2.55 \mathrm{E}+04$ & $8.77 \mathrm{E}+02$ & $1.22 \mathrm{E}+02$ \\
& 75 & 0.115 & $4.90 \mathrm{E}+04$ & $1.30 \mathrm{E}+02$ & $2.80 \mathrm{E}+04$ & 0.885 & $5.54 \mathrm{E}+04$ & $1.47 \mathrm{E}+02$ & $3.16 \mathrm{E}+04$ \\
& 100 & 0.171 & $7.90 \mathrm{E}+04$ & $3.30 \mathrm{E}+02$ & $2.30 \mathrm{E}+04$ & 0.829 & $9.53 \mathrm{E}+04$ & $3.98 \mathrm{E}+02$ & $2.77 \mathrm{E}+04$ \\
\hline Core S5 & 25 & 0.239 & $1.30 \mathrm{E}+05$ & $1.80 \mathrm{E}+03$ & $3.50 \mathrm{E}+04$ & 0.761 & $1.71 \mathrm{E}+05$ & $2.37 \mathrm{E}+03$ & $4.60 \mathrm{E}+04$ \\
& 50 & 0.225 & $2.30 \mathrm{E}+03$ & $3.30 \mathrm{E}+02$ & $2.20 \mathrm{E}+03$ & 0.775 & $2.97 \mathrm{E}+03$ & $4.26 \mathrm{E}+02$ & $2.84 \mathrm{E}+03$ \\
& 75 & 0.198 & $7.90 \mathrm{E}+02$ & $1.30 \mathrm{E}+02$ & $2.20 \mathrm{E}+03$ & 0.802 & $9.85 \mathrm{E}+02$ & $1.62 \mathrm{E}+02$ & $2.74 \mathrm{E}+03$ \\
\hline
\end{tabular}

Notes:

WC - Water Content

APB - Acid producing bacteria SRB - Sulfate reducing bacteria IRB - Iron reducing bacteria DW - Dry weight 
Table B6: Acid Volatile Sulfide (AVS) and Chromium Reducible Sulfide (CRS)Sediment Extractions for September 2004 Cores

\begin{tabular}{|cccc|}
\hline Location & Depth $(\mathbf{c m})$ & AVS $(\mathbf{p p m})$ & CRS $(\mathbf{p p m})$ \\
\hline Core S1 & 25 & 2.78 & 56 \\
& 50 & 2.74 & 70.3 \\
& 75 & 2.76 & 46.5 \\
\hline Core S2 & 25 & 2.73 & 55.4 \\
& 50 & 2.76 & 46.2 \\
& 75 & 2.76 & 46.3 \\
\hline Core S3 & 25 & 2.76 & 28.8 \\
& 50 & 2.76 & 46.5 \\
& 75 & 2.76 & 72.2 \\
\hline Core S4 & 25 & 2.74 & 56.3 \\
& 50 & 2.77 & 46.3 \\
& 75 & 2.74 & 28.3 \\
& 100 & 2.94 & 55.8 \\
\hline Core S5 & 25 & 2.82 & 28.7 \\
& 50 & 2.74 & 29.3 \\
& 75 & 3.14 & 56.7 \\
\hline
\end{tabular}




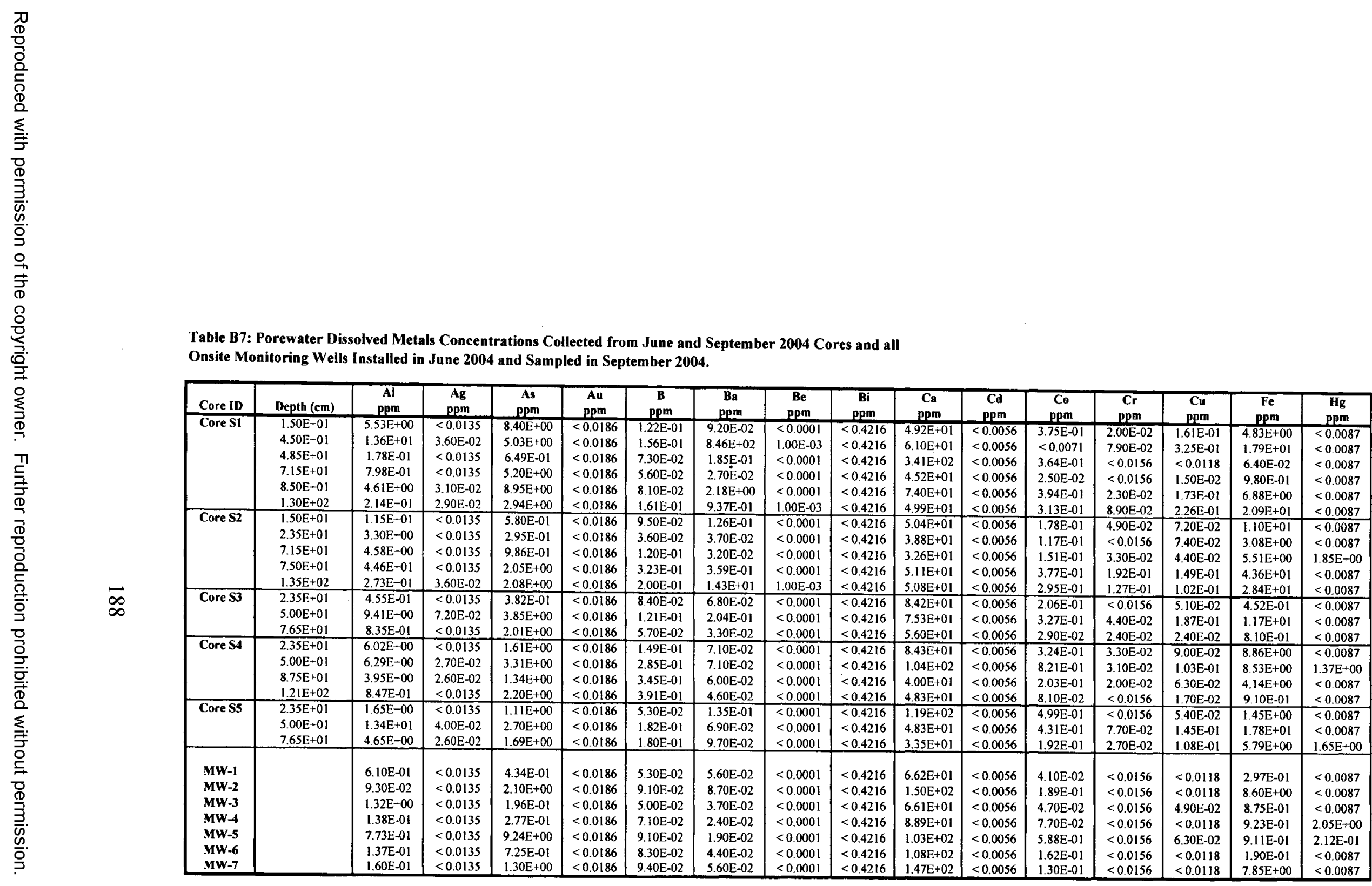




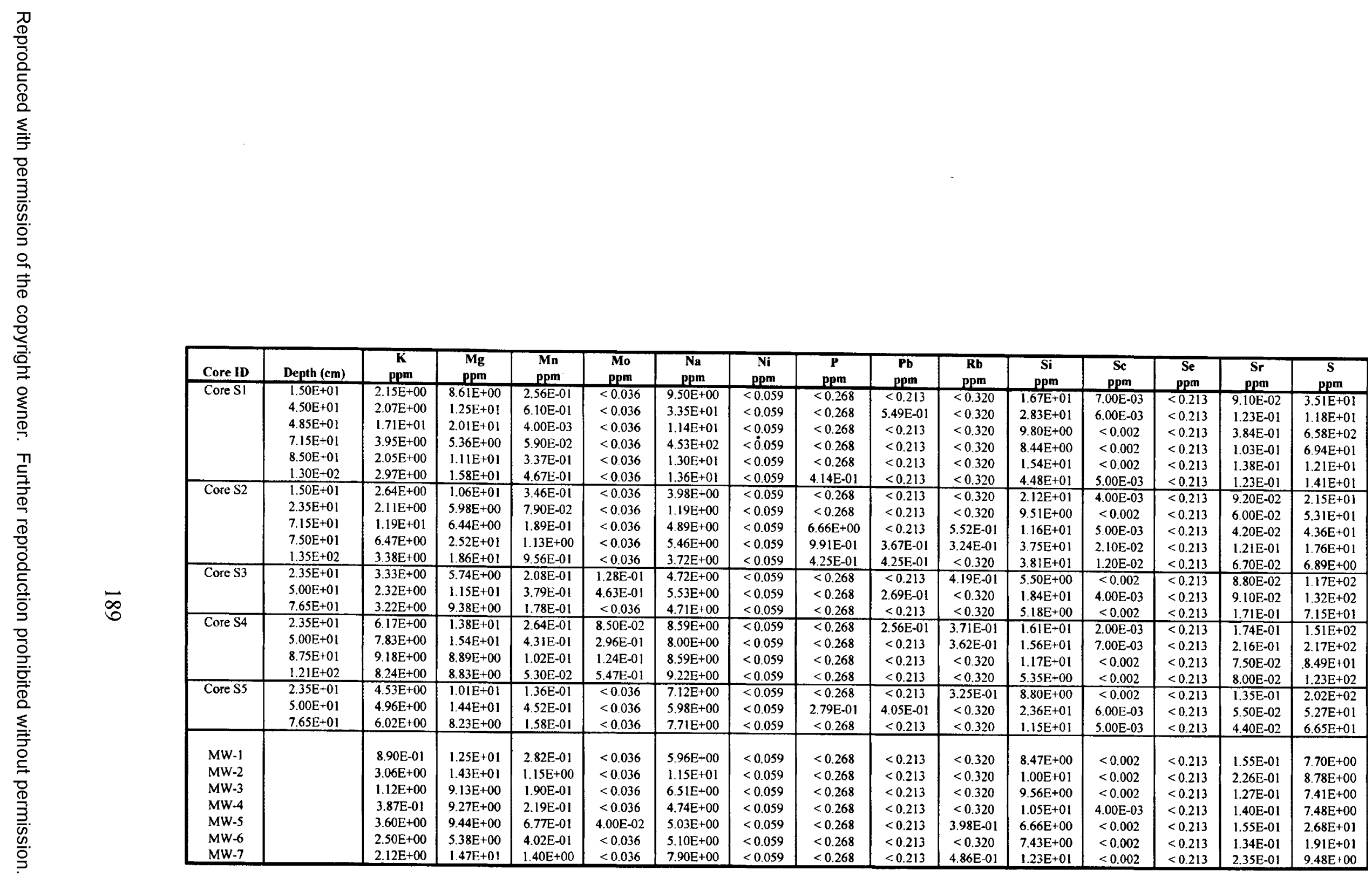




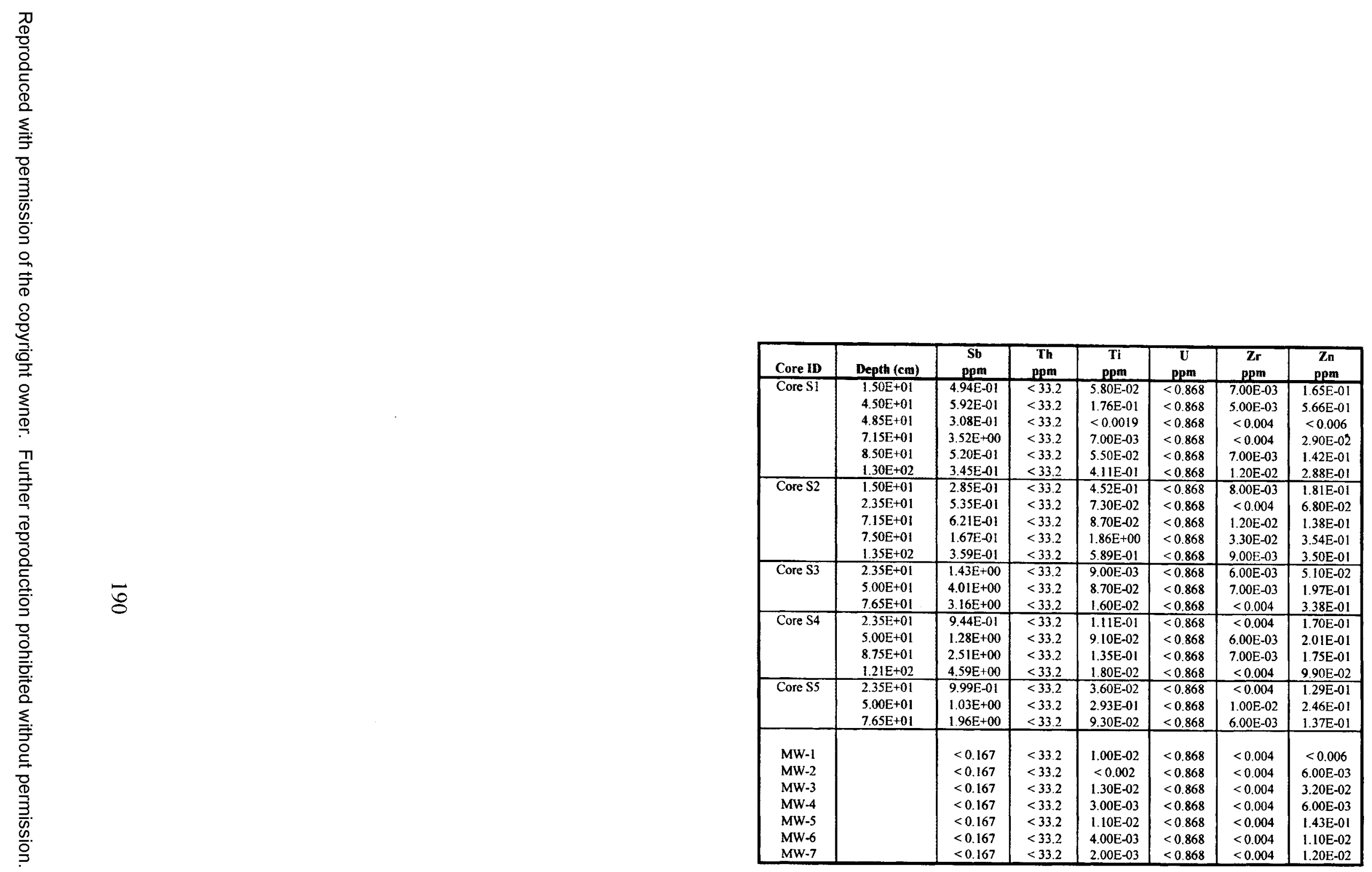


Table B8a: Porewater Field Chemistry Collected from September 2004 Cores

\begin{tabular}{|c|c|c|c|c|c|c|c|c|}
\hline Location & Depth $(\mathrm{cm})$ & $\begin{array}{l}\text { Sulfate } \\
\text { (ppm) }\end{array}$ & $\begin{array}{l}\text { Sulfide } \\
\text { (ppm) }\end{array}$ & $\mathrm{Fe}(\mathrm{II})(\mathrm{ppm})$ & $\begin{array}{c}\text { Alkalinity (mg } \\
\text { H2CO3/L) }\end{array}$ & $\begin{array}{c}\text { Alkalinity (mg } \\
\text { CaCO3/L) }\end{array}$ & $\begin{array}{c}\text { DO } \\
(\mathrm{ppm})\end{array}$ & pH \\
\hline \multirow[t]{3}{*}{ Core S1 } & 25.5 & 125 & 0.10 & 0.10 & $\mathrm{~nm}$ & $\mathrm{~nm}$ & 1.87 & 7.15 \\
\hline & 45.0 & 375 & nd & nd & 10.6 & 17.1 & 2.10 & 7.10 \\
\hline & 75.0 & 250 & nd & nd & 29.1 & 46.8 & 1.90 & 6.80 \\
\hline \multirow[t]{5}{*}{ Core $\mathbf{S 2}$} & 15.0 & 313 & nd & nd & 421 & 679 & 1.95 & 6.18 \\
\hline & 45.0 & 238 & nd & nd & 87.2 & 141 & 2.00 & 7.32 \\
\hline & 75.0 & 213 & 0.10 & nd & 65.2 & 105 & 2.00 & 7.21 \\
\hline & 105 & 200 & nd & nd & 150 & 242 & 2.50 & 7.20 \\
\hline & 130 & 50.0 & nd & nd & 146 & 235 & 1.00 & 7.48 \\
\hline \multirow[t]{4}{*}{ Core S3 } & 15.0 & 325 & 0.20 & nd & 13.1 & 21.1 & 2.00 & 7.70 \\
\hline & 45.0 & 313 & 0.20 & 0.10 & 39.6 & 63.9 & 1.49 & 7.90 \\
\hline & 75.0 & 438 & 0.10 & 0.50 & 76.8 & 123.8 & 0.69 & 7.97 \\
\hline & 105 & 214 & 0.70 & nd & 10.7 & 17.2 & 2.15 & 6.96 \\
\hline \multirow[t]{4}{*}{ Core S4 } & 23.5 & 525 & 0.60 & 0.10 & & & 2.00 & 7.60 \\
\hline & 45.0 & 438 & 0.15 & 0.20 & 16.5 & 26.6 & 1.68 & 7.64 \\
\hline & 75.0 & 588 & 0.10 & 0.10 & 45.8 & 73.8 & 1.49 & 7.78 \\
\hline & 105 & 163 & 0.10 & 0.30 & 15.8 & 25.4 & 1.50 & 7.78 \\
\hline \multirow[t]{4}{*}{ Core $\$ 5$} & 23.5 & 425 & nd & nd & & & 2.00 & 5.36 \\
\hline & 45.0 & 350 & 0.10 & nd & 22.5 & 36.3 & 1.60 & 5.42 \\
\hline & 75.0 & 166 & 0.50 & nd & 8.32 & 13.4 & 0.900 & 5.92 \\
\hline & 105 & 100 & 0.70 & nd & 12.4 & 19.9 & 0.680 & 6.24 \\
\hline
\end{tabular}

Table B8b: Groundwater Field Chemistry Collected from all Onsite Monitoring Wells Intalled in June 2004 and Sampled in September 2004

\begin{tabular}{|c|c|c|c|c|c|c|c|}
\hline MWID & MW1 & MW2 & MW3 & MW4 & MW5 & MW6 & MW7 \\
\hline HS & 0.400 & nd & 0.1 & 0.1 & $\mathrm{~nm}$ & 0.15 & 0.100 \\
\hline $\mathrm{Fe}(\mathrm{II})$ & 1.00 & nd & 0.05 & 2.00 & 0.100 & nd & 0.80 \\
\hline SO4 & 1750 & 100 & 125 & 50.0 & $>\mathbf{2 0 0}$ & 150 & 50.0 \\
\hline DO & 2.23 & 0.34 & 0.25 & 3.52 & 3.68 & 2.92 & 4.98 \\
\hline cond & 349 & 346 & 80 & 53.0 & 198 & 386 & 593 \\
\hline pH & 6.93 & 6.59 & 6.66 & 6.48 & 7.60 & 7.55 & 7.40 \\
\hline temp & 11.3 & 13.5 & 19.5 & 16.9 & 20.5 & 16.2 & 16.3 \\
\hline alk & 230 & 266 & 130 & 423 & $\mathrm{~nm}$ & 178 & $\mathrm{~nm}$ \\
\hline $\mathrm{Cl}$ & $\mathrm{nm}$ & 90 & 15 & 2.20 & 7.5 & 30.0 & $\mathrm{~nm}$ \\
\hline \multicolumn{8}{|l|}{ Notes } \\
\hline $\mathrm{nm}$ & measur & & & & & & \\
\hline
\end{tabular}




\section{Table B9: Monitoring Well Details}

\begin{tabular}{|c|c|c|c|c|}
\hline $\begin{array}{c}\text { MW } \\
\text { ID }\end{array}$ & Total Depth (m) & Screened Interval (m) & Water Elevation (maal) & Vetical Gradient \\
\hline MW1 & 0.65 & $0.341-0.646$ & 97.25 & -1.08 \\
\hline MW2 & 1.02 & $0.719-1.021$ & 98.26 & -0.03 \\
\hline MW3 & 0.96 & $0.657-0.962$ & 98.29 & 0.01 \\
\hline MW4 & 0.85 & $0.238-0.543$ & 98.29 & 0.01 \\
\hline MW5 & 0.43 & $0.127-0.432$ & 101.03 & ND \\
\hline MW6 & 0.79 & $0.184-0.489$ & 98.30 & 0.02 \\
\hline MW7 & 1.21 & $0.901-1.206$ & 98.67 & 0.01 \\
\hline
\end{tabular}




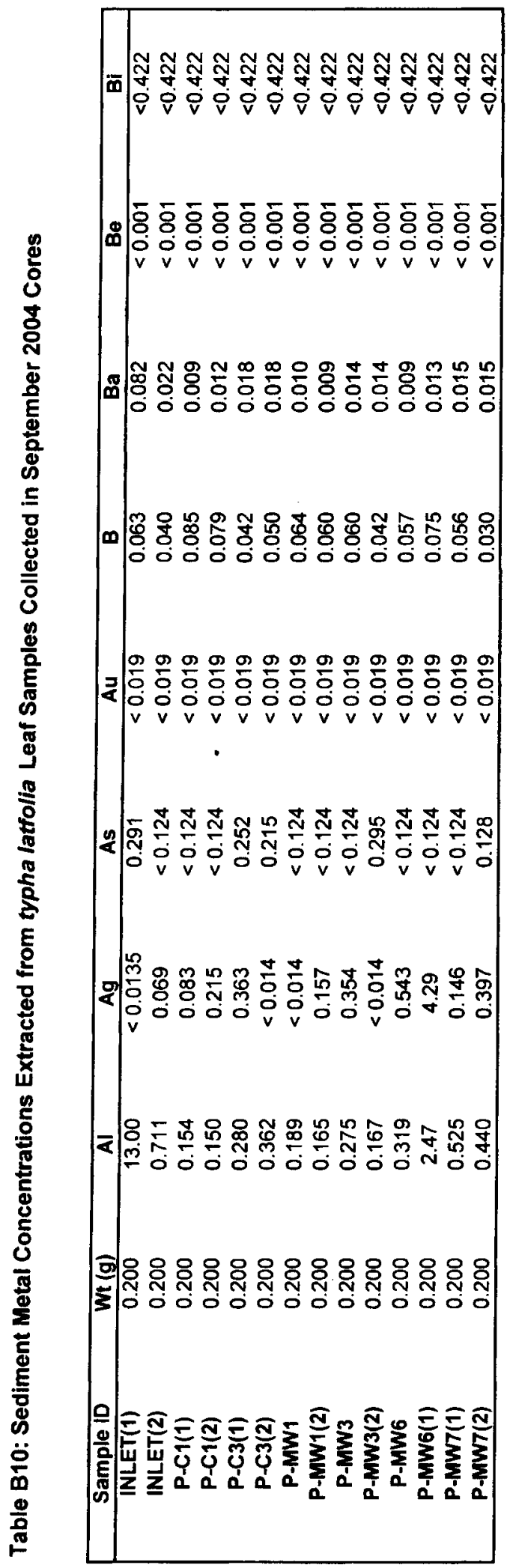

193 


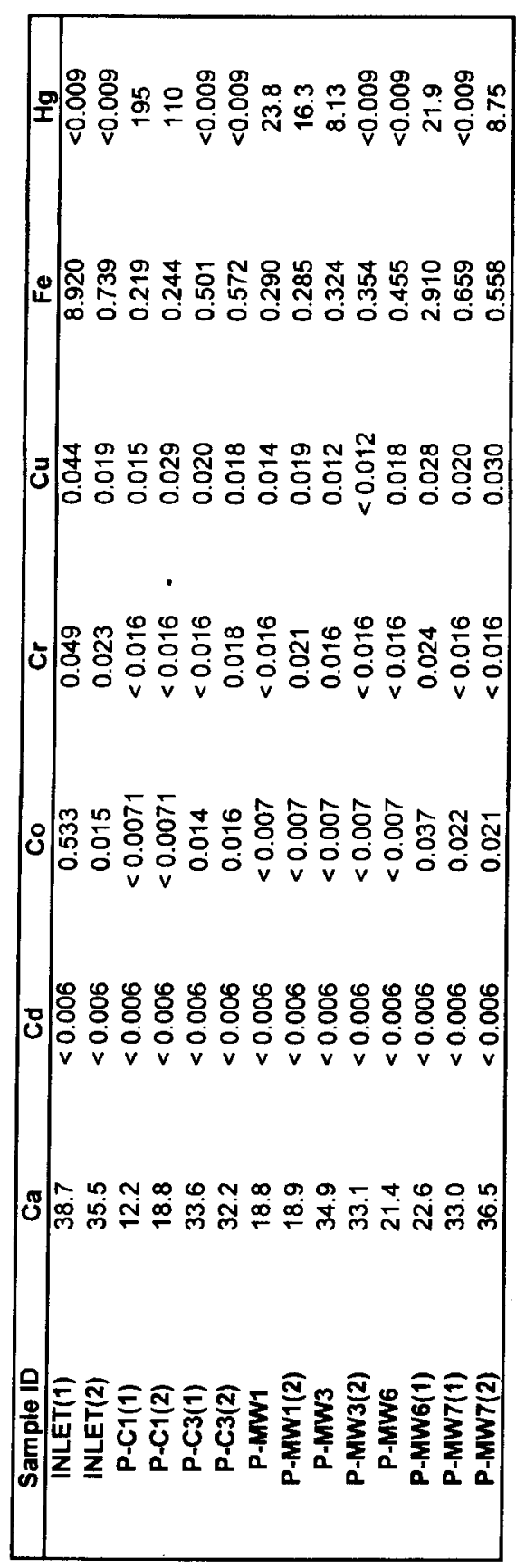




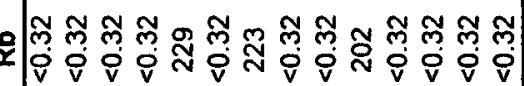
$0 \frac{m}{N} \frac{m}{N} \frac{m}{N} \frac{m}{N} \frac{m}{N} \frac{m}{N} \frac{m}{N} \frac{m}{N} \frac{m}{N} \frac{m}{N} \frac{m}{N} \frac{m}{N} \frac{m}{N}$

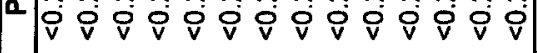

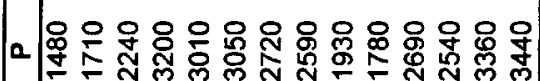

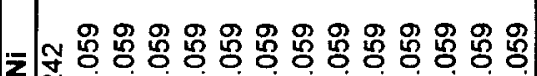

N

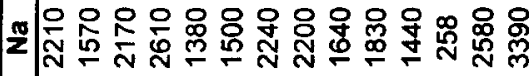

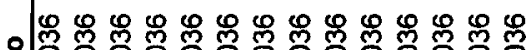

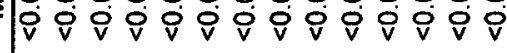

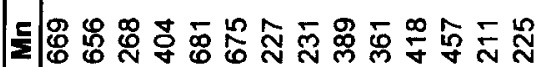

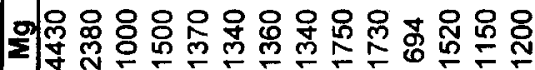

88888880.888

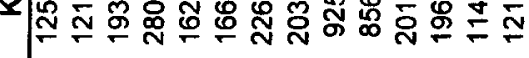

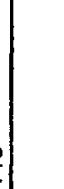




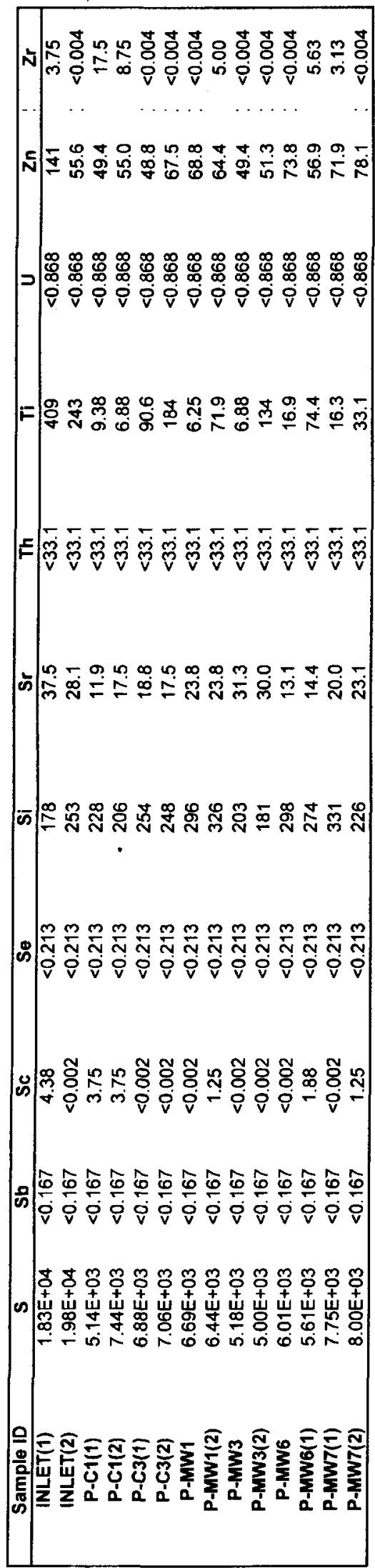


APPENDIX C

\section{MODELLING RESULTS}

RAW DATA 
MW1 - No Adsorption

\section{INPUT DATA BEFORE TYPE MODIFICATIONS}

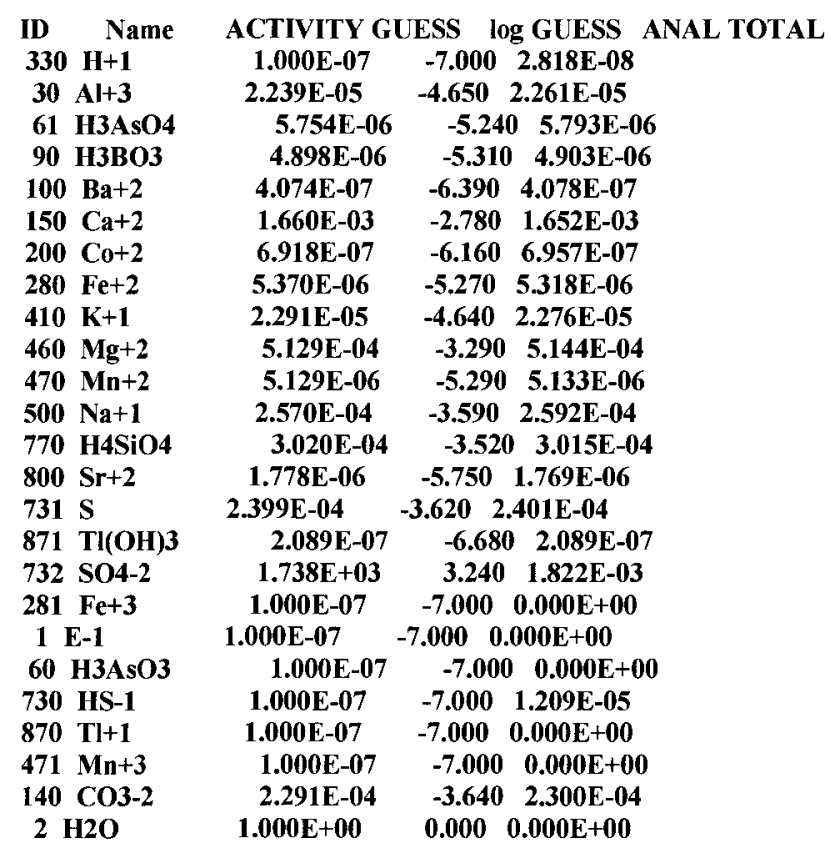

Charge Balance: UNSPECIATED

Sum of CATIONS= 4.709E-03 Sum of ANIONS $=4.116 \mathrm{E}-03$

PERCENT DIFFERENCE $=6.721 \mathrm{E}+00$ (ANIONS - CATIONS) $/($ ANIONS + CATIONS) EQUILIBRATED MASS DISTRIBUTION

$\begin{array}{lllll}\text { IDX Name } & \text { DISSOLVED } & \text { SORBED } & \text { PRECIPITATED } \\ \mathrm{mol} / \mathrm{L} & \text { percent } \mathrm{mol} / \mathrm{L} & \text { percent } \mathrm{mol} / \mathrm{L} & \text { percent }\end{array}$

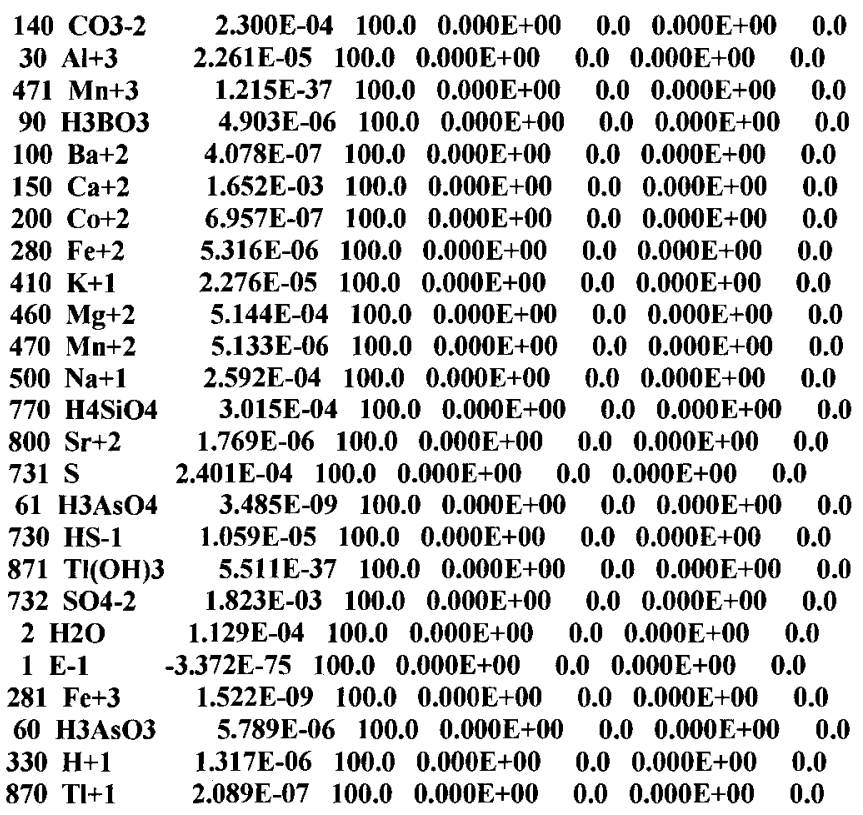

Charge Balance: SPECIATED 
Sum of CATIONS $=4.000 \mathrm{E}-03$ Sum of ANIONS $3.407 \mathrm{E}-03$

PERCENT DIFFERENCE $=8.008 E+00$ (ANIONS - CATIONS) $/($ ANIONS + CATIONS)

EQUILIBRIUM IONIC STRENGTH $(\mathrm{m})=7.116 \mathrm{E}-03$

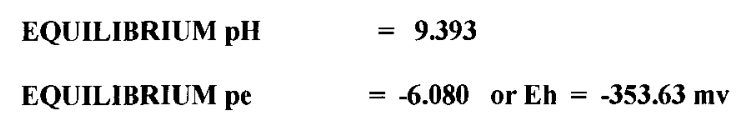

Saturation indices

\begin{tabular}{|c|c|c|}
\hline ID No & Name & SI \\
\hline 1006000 & ORPIMENT & 7.709 \\
\hline 1020001 & CoS (alpha) & 5.109 \\
\hline 1020002 & CoS (beta) & 8.739 \\
\hline 1028000 & FeS (ppt) & 1.598 \\
\hline 1028001 & GREIGITE & 6.962 \\
\hline 1028002 & MACKINAWITE & 2.281 \\
\hline 1028003 & PYRITE & 9.542 \\
\hline 2077002 & QUARTZ & 0.451 \\
\hline 2003001 & BOEHMITE & 0.198 \\
\hline 2003002 & DIASPORE & 1.947 \\
\hline 2003003 & GIBBSITE & 0.552 \\
\hline 2028000 & WUSTITE & 1.405 \\
\hline 2028102 & GOETHITE & 2.584 \\
\hline 3020002 & $\mathrm{CoFe} 2 \mathrm{O4}$ & 21.657 \\
\hline 3028000 & MAGNETITE & 15.589 \\
\hline 3028001 & HERCYNITE & 7.527 \\
\hline 3028100 & HEMATITE & 7.545 \\
\hline 3028101 & MAGHEMITE & \\
\hline 3028102 & LEPIDOCROCITE & 1.885 \\
\hline 3046001 & MAGNESIOFERRI & 4.105 \\
\hline 5047000 & RHODOCHROSITE & \multirow{2}{*}{$0.512^{0.294}$} \\
\hline 5015000 & ARAGONITE & \\
\hline 5015001 & CALCITE & 0.666 \\
\hline 5015002 & DOLOMITE (ordered) & 0.918 \\
\hline \multicolumn{3}{|c|}{5015004 DOLOMITE (disordered) } \\
\hline 6010000 & BARITE & $\mathbf{0 . 5 3 5}$ \\
\hline 7210000 & $\mathrm{Ba3}(\mathrm{AsO4}) 2$ & 9.234 \\
\hline 8603000 & HALLOYSITE & 0.907 \\
\hline 8603001 & KAOLINITE & 3.147 \\
\hline 8628000 & GREENALITE & 11.266 \\
\hline 8646000 & CHRYSOTILE & 5.840 \\
\hline 8646003 & SEPIOLITE & 3.623 \\
\hline 8646004 & SEPIOLITE (A) & 0.944 \\
\hline
\end{tabular}

MW2 - No Adsorption

INPUT DATA BEFORE TYPE MODIFICATIONS

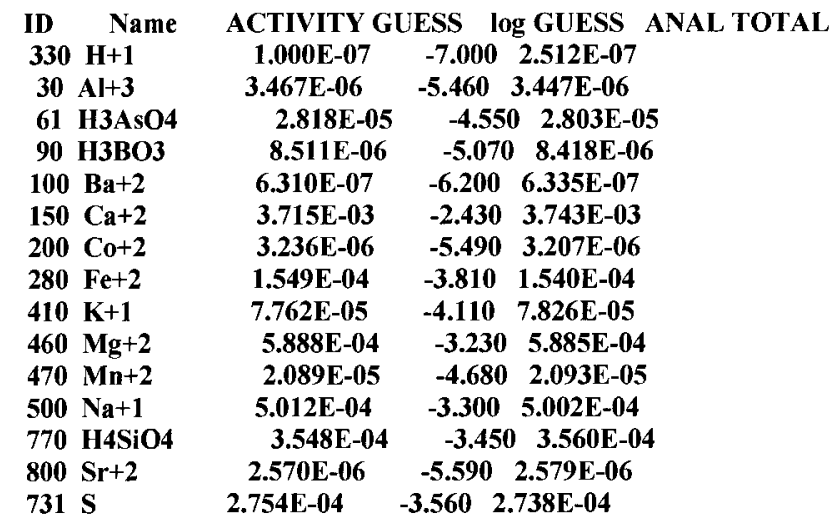




\begin{tabular}{|c|c|c|}
\hline $950 \mathrm{Zn}+2$ & $9.120 \mathrm{E}-08$ & $-7.040 \quad 9.177 E-08$ \\
\hline $732 \mathrm{SO}-2$ & $1.047 \mathrm{E}-03$ & $-2.980 \quad 1.041 \mathrm{E}-03$ \\
\hline $180 \mathrm{Cl}-1$ & $2.512 \mathrm{E}-03$ & $-2.600 \quad 2.539 E-03$ \\
\hline $140 \mathrm{CO} 3-2$ & $2.239 \mathrm{E}-03$ & $-2.650 \quad 2.260 \mathrm{E}-03$ \\
\hline $281 \mathrm{Fe}+3$ & $1.000 E-07$ & $-7.000 \quad 0.000 E+00$ \\
\hline 1 E-1 & $1.000 \mathrm{E}-07$ & $-7.000 \quad 0.000 E+00$ \\
\hline $60 \mathrm{H3AsO3}$ & $1.000 \mathrm{E}-07$ & $-7.000 \quad 0.000 \mathrm{E}+00$ \\
\hline $471 \mathrm{Mn}+3$ & $1.000 \mathrm{E}-07$ & $-7.000 \quad 0.000 \mathrm{E}+00$ \\
\hline 730 HS-1 & 1.000E-07 & $-7.000 \quad 0.000 \mathrm{E}+00$ \\
\hline $201 \mathrm{Co}+3$ & $1.000 \mathrm{E}-07$ & $-7.000 \quad 0.000 E+00$ \\
\hline $2 \mathrm{H} 2 \mathrm{O}$ & $1.000 \mathrm{E}+00$ & $0.000 \quad 0.000 \mathrm{E}+00$ \\
\hline
\end{tabular}

Charge Balance: UNSPECIATED

Sum of CATIONS= 9.615E-03 Sum of ANIONS $=9.141 \mathrm{E}-03$

PERCENT DIFFERENCE $=2.527 \mathrm{E}+00($ ANIONS - CATIONS $) /($ ANIONS + CATIONS $)$

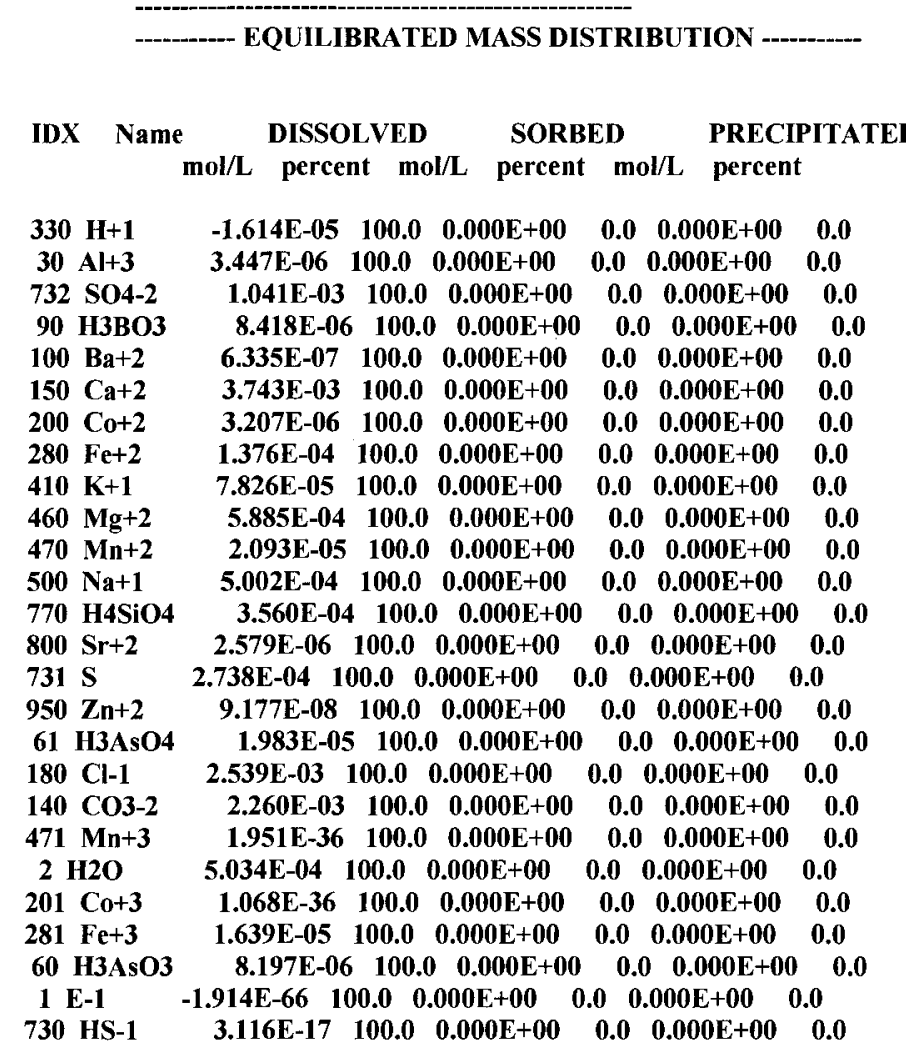

Charge Balance: SPECIATED

Sum of CATIONS $=7.004 \mathrm{E}-03 \mathrm{Sum}$ of ANIONS $6.530 \mathrm{E}-03$

PERCENT DIFFERENCE $=3.501 E+00$ (ANIONS - CATIONS) $/($ ANIONS + CATIONS)

EQUILIBRIUM IONIC STRENGTH (m) $=1.136 \mathrm{E}-02$

EQUILIBRIUM pH $\quad=\mathbf{1 0 . 1 2 6}$

EQUILIBRIUM pe $\quad=-\mathbf{5 . 5 0 2}$ or $\mathrm{Eh}=-\mathbf{3 2 0 . 0 3} \mathrm{mv}$ 
Saturation indices

\begin{tabular}{|c|c|c|}
\hline \multicolumn{3}{|c|}{ SI } \\
\hline 2077002 & QUARTZ & 0.242 \\
\hline 2003002 & DIASPORE & 0.389 \\
\hline 2020002 & $\mathrm{Co}(\mathrm{OH}) 2$ & 0.065 \\
\hline 2028000 & WUSTITE & 3.423 \\
\hline 2028001 & $\mathrm{Fe}(\mathrm{OH}) 2$ & 1.587 \\
\hline 2028100 & FERRIHYDRITE & 3.204 \\
\hline 2028101 & $\mathrm{Fe} 3(\mathrm{OH}) 8$ & 8.158 \\
\hline 2028102 & GOETHITE & \\
\hline 3020002 & $\mathrm{CoFe} 2 \mathrm{O} 4$ & 29.442 \\
\hline 3028000 & MAGNETITE & 24.354 \\
\hline 3028001 & HERCYNITE & 6.460 \\
\hline 3028100 & HEMATITE & 14.262 \\
\hline 3028101 & MAGHEMITE & \\
\hline 3028102 & LEPIDOCROCIT & $\begin{array}{c}6.843 \\
5.244\end{array}$ \\
\hline \multicolumn{3}{|c|}{ 3046001 MAGNESIOFERRITE } \\
\hline 4128100 & $\mathrm{Fe}(\mathrm{OH}) 2.7 \mathrm{Cl} .3$ & 5.824 \\
\hline $\mathbf{5 0 2 8 0 0 0}$ & SIDERITE & 1.662 \\
\hline $\mathbf{5 0 4 7 0 0 0}$ & RHODOCHROSITE & 2.186 \\
\hline $\mathbf{5 0 4 6 0 0 2}$ & MAGNESITE & \\
\hline $\mathbf{5 0 1 5 0 0 0}$ & ARAGONITE & $\begin{array}{l}0.562 \\
2.105\end{array}$ \\
\hline 5015001 & CALCITE & 2.259 \\
\hline 5015002 & DOLOMITE (ordere & 3.828 \\
\hline \multicolumn{3}{|c|}{5015004 DOLOMITE (disordered) } \\
\hline 5015003 & HUNTITE & \\
\hline 6010000 & BARITE & $\begin{array}{l}2.586 \\
0.335\end{array}$ \\
\hline $\mathbf{7 2 4 7 0 0 0}$ & $\mathrm{Mn3}(\mathrm{AsO} \mathrm{O}) 2: 8 \mathrm{H} 2 \mathrm{C}$ & 1.413 \\
\hline 7210000 & Ba3(AsO4)2 & 18.432 \\
\hline 8628000 & GREENALITE & 16.994 \\
\hline 8646000 & CHRYSOTILE & 9.735 \\
\hline 8646003 & SEPIOLITE & 5.872 \\
\hline 8646004 & SEPIOLITE ( & 3.193 \\
\hline
\end{tabular}

MW3 - No Adsorption

INPUT DATA BEFORE TYPE MODIFICATIONS

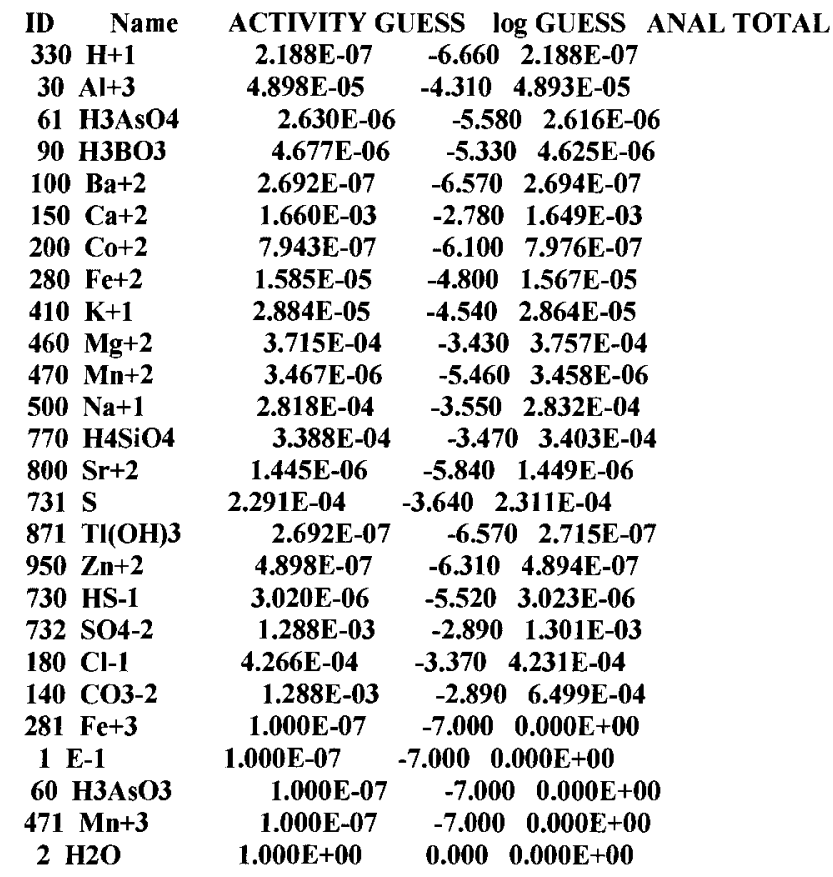

Charge Balance: UNSPECIATED 


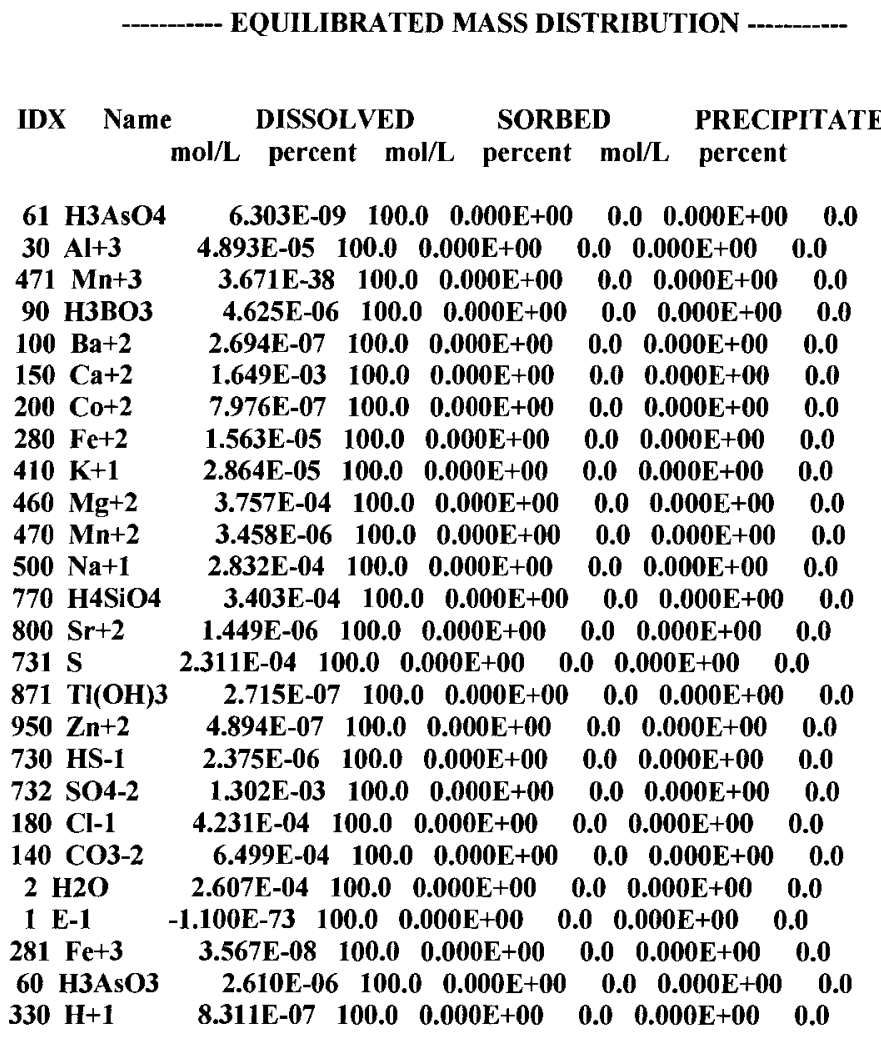

Charge Balance: SPECIATED

Sum of CATIONS $=3.725 \mathrm{E}-03 \mathrm{Sum}$ of ANIONS $3.500 \mathrm{E}-03$

PERCENT DIFFERENCE $=3.108 E+00$ (ANIONS - CATIONS)/(ANIONS + CATIONS)

EQUILIBRIUM IONIC STRENGTH $(\mathrm{m})=6.541 \mathrm{E}-03$

EQUILIBRIUM pH $\quad=9.772$

EQUILIBRIUM pe $\quad=-6.415$ or $\mathrm{Eh}=-373.13 \mathrm{mv}$

Saturation indices

\begin{tabular}{|c|c|}
\hline ID No & SI \\
\hline 1006000 ORPIMENT & 2.795 \\
\hline $1095000 \mathrm{ZnS}(\mathrm{am})$ & 1.829 \\
\hline 1095001 SPHALERITE & 4.271 \\
\hline 1095002 WURTZITE & 1.745 \\
\hline $1020001 \operatorname{CoS}$ (alpha) & 4.218 \\
\hline $1020002 \operatorname{CoS}$ (beta) & 7.848 \\
\hline $1028000 \mathrm{FeS}$ (ppt) & 1.348 \\
\hline 1028001 GREIGITE & 5.054 \\
\hline 1028002 MACKINAWITE & $\mathbf{2 . 0 3 1}$ \\
\hline I028003 PYRITE & 8.134 \\
\hline 2077002 QUARTZ & 0.398 \\
\hline 2003001 BOEHMITE & 0.156 \\
\hline 2003002 DIASPORE & 1.905 \\
\hline
\end{tabular}




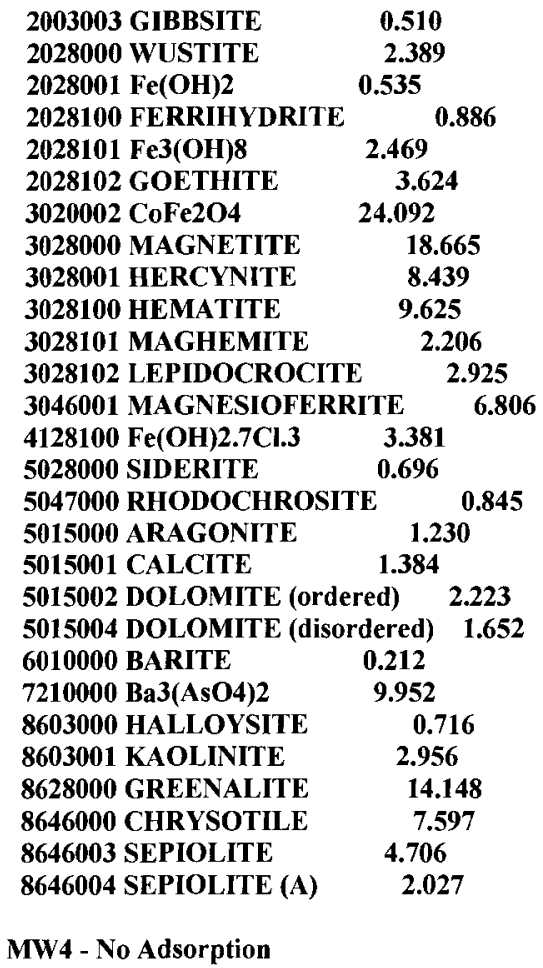

MW4 - No Adsorption

INPUT DATA BEFORE TYPE MODIFICATIONS

\begin{tabular}{|c|c|c|c|}
\hline Name & \multicolumn{3}{|c|}{ ACTIVITY GUESS log GUESS ANAL TOTAL } \\
\hline $330 \mathrm{H}+1$ & 3.311E-07 & $-6.480 \quad 3.311 E-07$ & \\
\hline $30 \mathrm{Al}+3$ & 5.129E-06 & $-5.290 \quad 5.115 E-06$ & \\
\hline $61 \mathrm{H3AsO4}$ & 3.715E-06 & $-5.430 \quad 3.697 \mathrm{E}-06$ & \\
\hline $90 \mathrm{H3BO3}$ & $6.607 \mathrm{E}-06$ & $-5.180 \quad 6.568 E-06$ & \\
\hline $150 \mathrm{Ca}+2$ & $2.239 \mathrm{E}-03$ & $-2.650 \quad 2.218 E-03$ & \\
\hline $200 \mathrm{Co}+2$ & $1.318 \mathrm{E}-06$ & $-5.880 \quad 1.307 \mathrm{E}-06$ & \\
\hline $280 \mathrm{Fe}+2$ & $1.660 \mathrm{E}-05$ & $-4.780 \quad 1.653 E-05$ & \\
\hline $410 K+1$ & $1.000 \mathrm{E}-05$ & $-5.000 \quad 9.898 E-06$ & \\
\hline $460 \mathrm{Mg}+2$ & $3.802 E-04$ & $-3.420 \quad 3.815 E-04$ & \\
\hline $470 \mathrm{Mn}+2$ & 3.981E-06 & $-5.400 \quad 3.986 E-06$ & \\
\hline $500 \mathrm{Na}+1$ & 2.042E-04 & $-3.690 \quad 2.062 \mathrm{E}-04$ & \\
\hline 770 H4SiO4 & $3.715 \mathrm{E}-04$ & $-3.430 \quad 3.738 E-04$ & \\
\hline $800 \mathrm{Sr}+2$ & 1.585E-06 & $-5.800 \quad 1.598 \mathrm{E}-06$ & \\
\hline $731 \mathrm{~S}$ & 2.344E-04 & $-3.630 \quad 2.332 E-04$ & \\
\hline $871 \mathrm{Tl}(\mathrm{OH}) 3$ & $6.310 \mathrm{E}-08$ & $-7.200 \quad 6.266 \mathrm{E}-08$ & \\
\hline $950 Z n+2$ & $9.120 \mathrm{E}-08$ & $-7.040 \quad 9.177 \mathrm{E}-08$ & \\
\hline 730 HS-1 & $3.020 \mathrm{E}-06$ & $-5.520 \quad 3.023 E-06$ & \\
\hline $732 \mathrm{SO4-2}$ & 5.248E-04 & $-3.280 \quad 5.205 E-04$ & \\
\hline $180 \mathrm{Cl}-1$ & $6.166 \mathrm{E}-05$ & $-4.210 \quad 6.206 \mathrm{E}-05$ & \\
\hline $140 \mathrm{CO}-2$ & $4.266 \mathrm{E}-03$ & $-2.370 \quad 2.500 \mathrm{E}-03$ & \\
\hline $281 \mathrm{Fe}+3$ & $1.000 \mathrm{E}-07$ & $-7.000 \quad 0.000 \mathrm{E}+00$ & \\
\hline 1 E-I & $1.000 \mathrm{E}-07$ & $-7.000 \quad 0.000 \mathrm{E}+00$ & \\
\hline $60 \mathrm{H3AsO3}$ & $1.000 \mathrm{E}-07$ & $-7.000 \quad 0.000 E+00$ & \\
\hline $100 \mathrm{Ba}+2$ & 1.738E-07 & $-6.760 \quad 1.748 \mathrm{E}-07$ & \\
\hline $2 \mathrm{H} 2 \mathrm{O}$ & $1.000 \mathrm{E}+00$ & $0.000 \quad 0.000 \mathrm{E}+00$ & \\
\hline
\end{tabular}

Charge Balance: UNSPECIATED

Sum of CATIONS $=5.478 \mathrm{E}-03 \mathrm{Sum}$ of ANIONS $=6.106 \mathrm{E}-03$

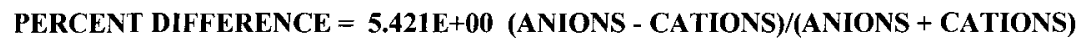




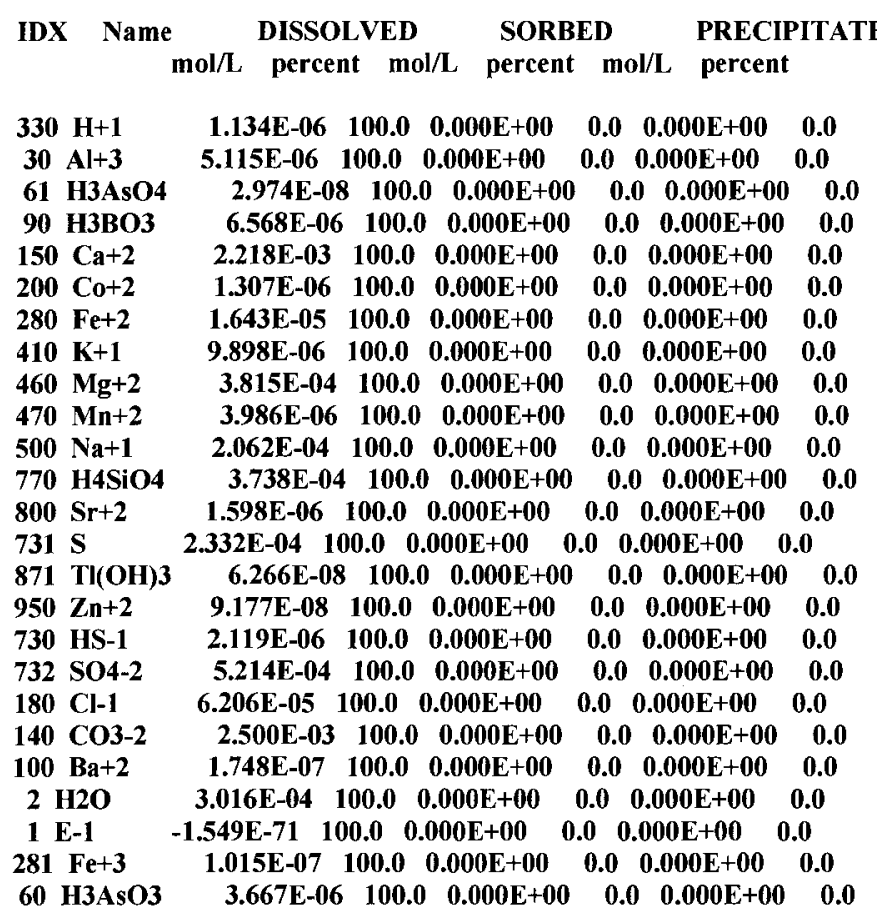

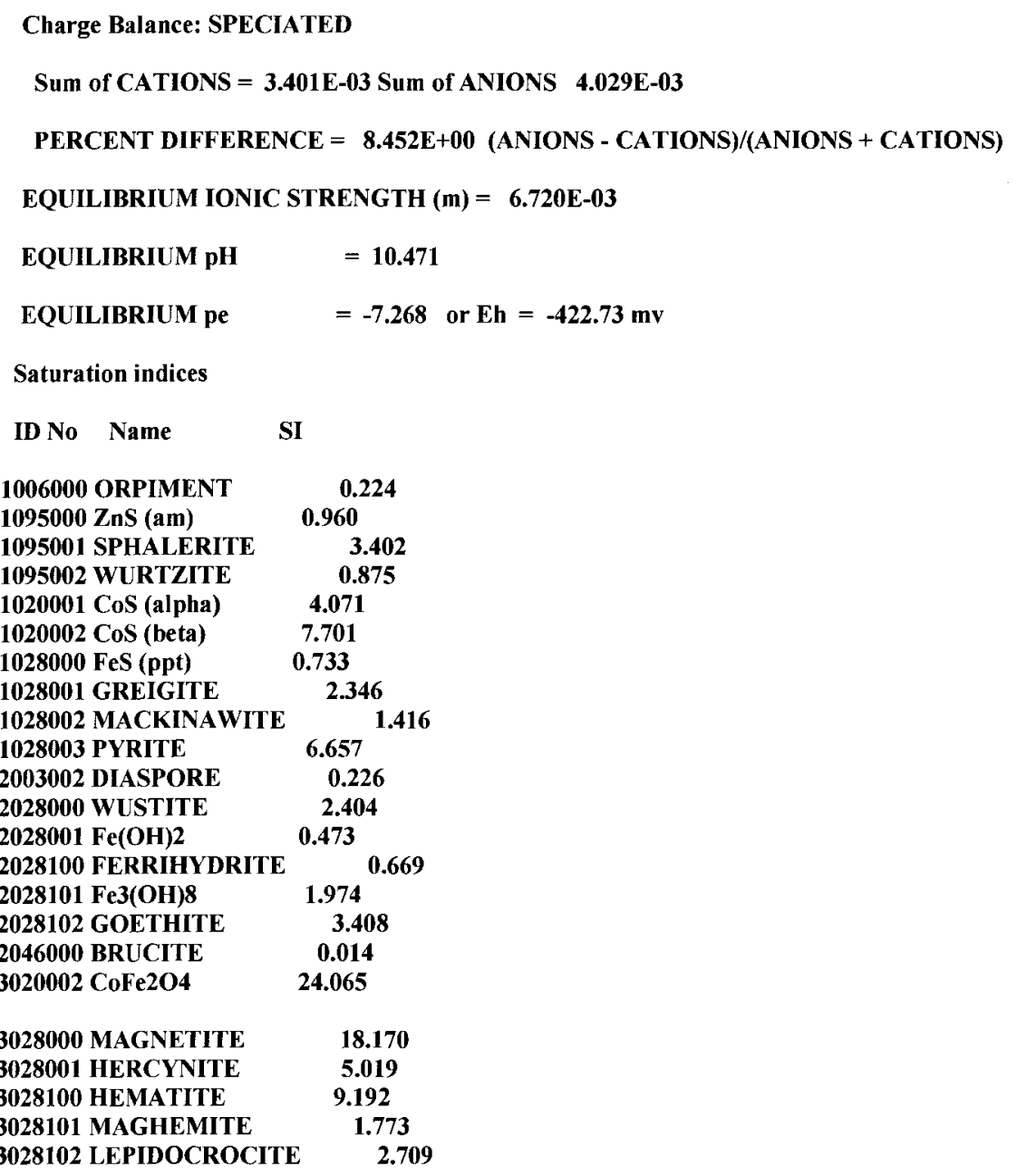




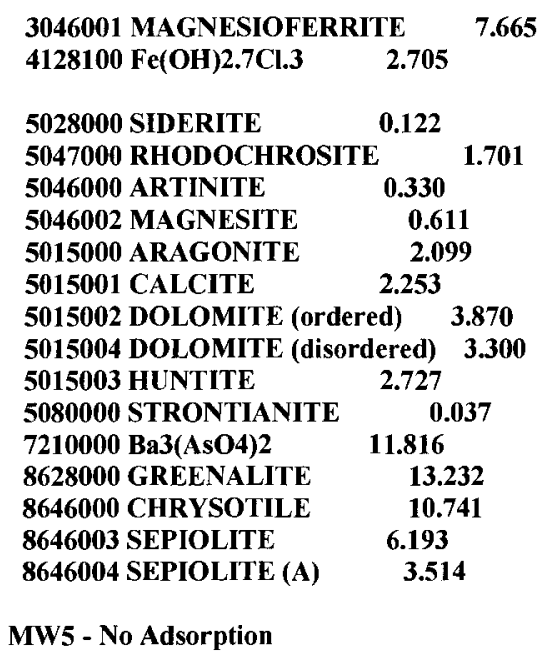

MW5 - No Adsorption

\section{INPUT DATA BEFORE TYPE MODIFICATIONS}

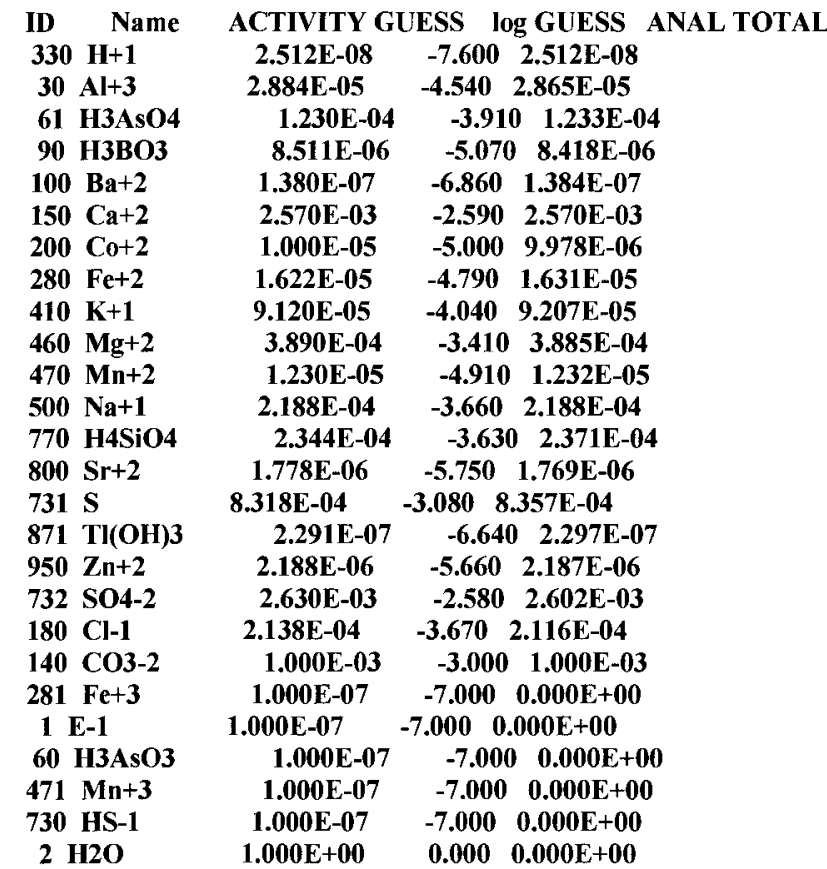

Charge Balance: UNSPECIATED

Sum of CATIONS $=6.399 \mathrm{E}-03 \mathrm{Sum}$ of $\mathrm{ANIONS}=7.416 \mathrm{E}-03$

PERCENT DIFFERENCE $=7.357$ E +00 (ANIONS - CATIONS)/(ANIONS + CATIONS)

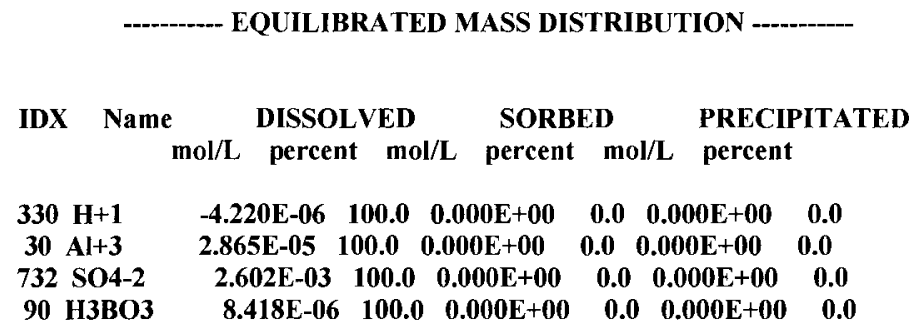




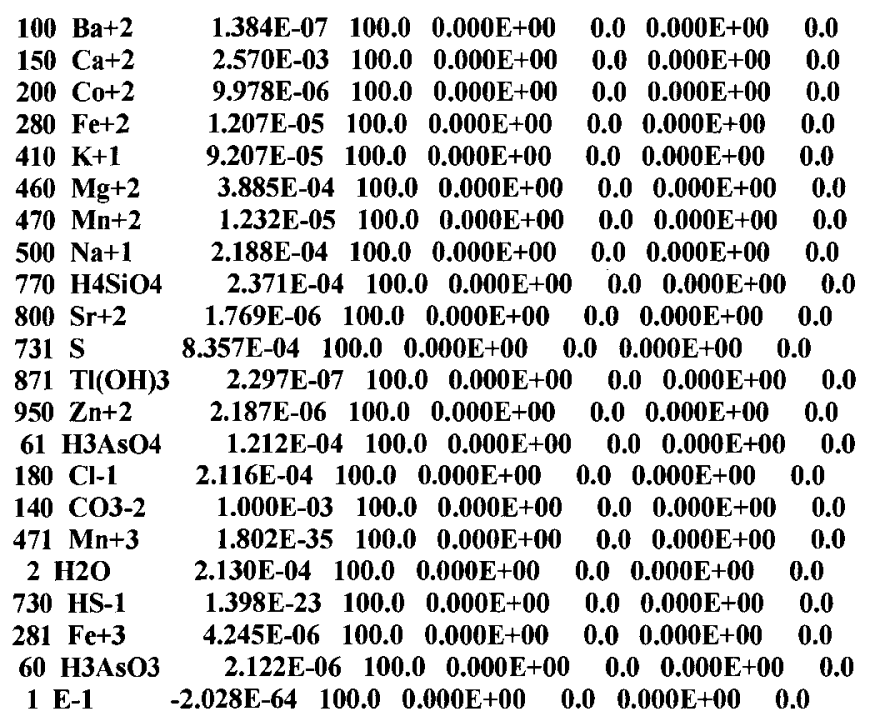

Charge Balance: SPECIATED

Sum of CATIONS $=4.872 \mathrm{E}-03$ Sum of ANIONS $5.889 \mathrm{E}-03$

PERCENT DIFFERENCE $=9.445 E+00$ (ANIONS - CATIONS) $/($ ANIONS + CATIONS)

EQUILIBRIUM IONIC STRENGTH $(\mathrm{m})=1.013 \mathrm{E}-02$

$$
\begin{array}{ll}
\text { EQUILIBRIUM pH } & =9.803 \\
\text { EQUILIBRIUM pe } & =-4.292 \text { or } \mathrm{Eh}=-249.61 \mathrm{mv}
\end{array}
$$

Saturation indices

ID No Name

2077002 QUARTZ

2003002 DIASPORE

2003003 GIBBSITE

SI

0.226

1.634

0.239

$2095003 \mathrm{Zn}(\mathrm{OH}) 2$ (gamma) $\quad 0.203$

$2095004 \mathrm{Zn}(\mathrm{OH}) 2$ (epsilon) $\quad 0.158$

$2095005 \mathrm{ZnO}$ (active) $\quad 0.483$

2095006 ZINCITE $\quad 0.335$

$2020002 \mathrm{Co}(\mathrm{OH}) 2 \quad 0.434$

2028000 WUSTITE $\quad 2.284$

$2028001 \mathrm{Fe}(\mathrm{OH}) 2 \quad 0.421$

2028100 FERRIHYDRITE $\quad 2.926$

$2028101 \mathrm{Fe} 3(\mathrm{OH}) 8 \quad 6.435$

2028102 GOETHITE $\quad 5.664$

$3020002 \mathrm{CoFe2O4} \quad 29.254$

3028000 MAGNETITE $\quad \mathbf{2 2 . 6 3 2}$

3028001 HERCYNITE $\quad \mathbf{7 . 7 8 4}$

3028100 HEMATITE $\quad 13.705$

3028101 MAGHEMITE $\quad 6.287$

3028102 LEPIDOCROCITE $\quad \mathbf{4 . 9 6 5}$

3046001 MAGNESIOFERRITE 10.898

$4128100 \mathrm{Fe}(\mathrm{OH}) 2.7 \mathrm{Cl} .3 \quad \mathbf{5 . 3 2 0}$

$4147000 \mathrm{MnCl}: 4 \mathrm{H} 2 \mathrm{O} \quad-15.370$

4150000 HALITE $\quad \mathbf{- 9 . 0 2 0}$

5095000 SMITHSONITE $\quad-1.596$

5028000 SIDERITE $\quad 0.692$

5047000 RHODOCHROSITE 1.512

5015000 ARAGONITE $\quad 1.522$

5015001 CALCITE $\quad 1.677$

5015002 DOLOMITE (ordered) $\quad \mathbf{2 . 6 3 7}$

5015004 DOLOMITE (disordered) $\mathbf{2 . 0 6 6}$

5015003 HUNTITE $\quad 0.178$ 


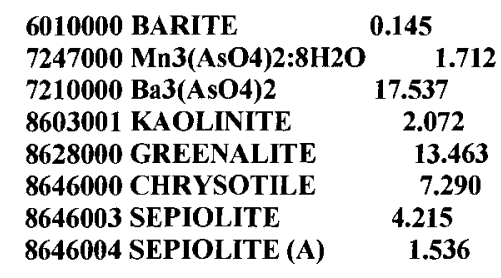

MW6 - No Adsorption

INPUT DATA BEFORE TYPE MODIFICATIONS

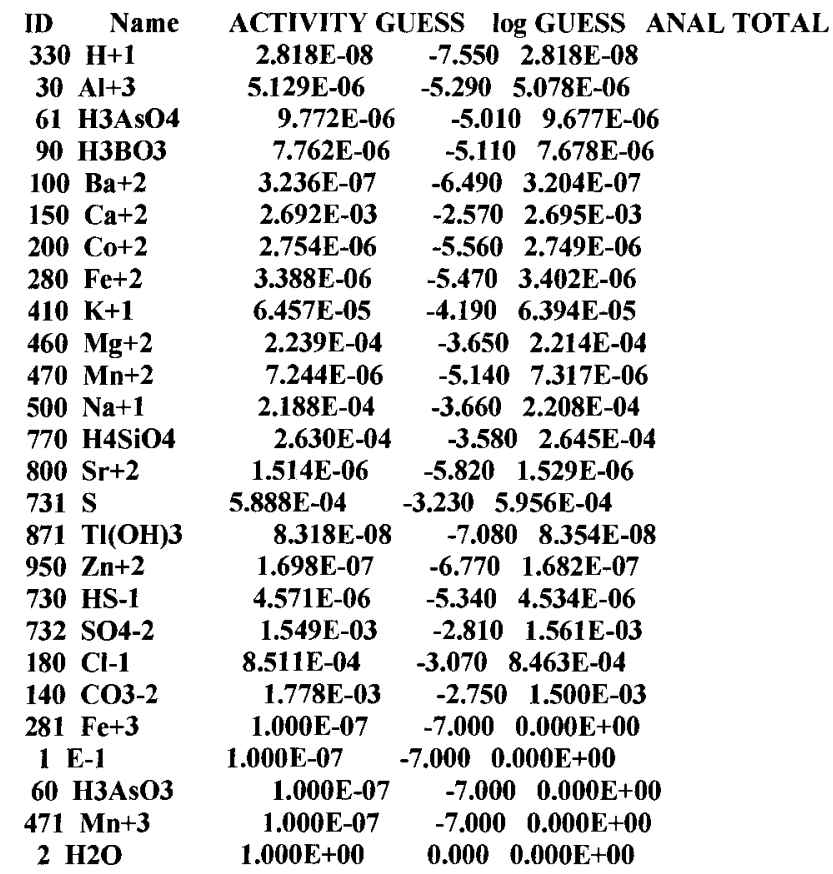

Charge Balance: UNSPECIATED

Sum of CATIONS= 6.164E-03 Sum of ANIONS $=6.973 \mathrm{E}-03$

PERCENT DIFFERENCE $=6.159 E+00$ (ANIONS - CATIONS) $/($ ANIONS + CATIONS)

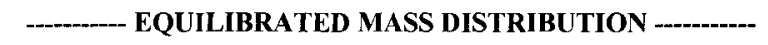

IDX Name DISSOLVED SORBED PRECIPITATED

$\mathrm{mol} / \mathrm{L}$ percent $\mathrm{mol} / \mathrm{L}$ percent $\mathrm{mol} / \mathrm{L}$ percent

\begin{tabular}{|c|c|c|c|c|c|}
\hline $61 \mathrm{H3AsO4}$ & 8.0 & 100.0 & $0.000 \mathrm{E}+00$ & 0.000E & \\
\hline $30 \mathrm{Al}+3$ & $5.078 E-06$ & 100.0 & $0.000 E+00$ & $0.0 \quad 0.000 E+00$ & 0.0 \\
\hline $471 \mathrm{Mn}+3$ & $1.595 \mathrm{E}-38$ & 100.0 & $0.000 \mathrm{E}+00$ & $0.000 E+00$ & 0.0 \\
\hline $90 \mathrm{H3BO3}$ & $7.678 \mathrm{E}-06$ & $6 \quad 100.0$ & $0.000 \mathrm{E}+00$ & $0.00 .000 \mathrm{E}+00$ & 0.0 \\
\hline $100 \mathrm{Ba}+2$ & $3.204 E-07$ & 100.0 & $0.000 \mathrm{E}+00$ & $0.0 \quad 0.000 \mathrm{E}+00$ & 0.0 \\
\hline $150 \mathrm{Ca}+2$ & $2.695 \mathrm{E}-03$ & 100.0 & $0.000 \mathrm{E}+00$ & $0.0 \quad 0.000 \mathrm{E}+00$ & 0.0 \\
\hline $00 \mathrm{Co}+2$ & 2.749E-06 & 100.0 & $0.000 \mathrm{E}+00$ & $\begin{array}{lll}0.0 & 0.00\end{array}$ & 0.0 \\
\hline $280 \mathrm{Fe}+2$ & $3.379 \mathrm{E}-06$ & 100.0 & $0.000 \mathrm{E}+00$ & $0.0 \quad 0.000 \mathrm{E}+00$ & 0.0 \\
\hline $410 \mathrm{~K}+1$ & $6.394 \mathrm{E}-05$ & 100.0 & $0.000 \mathrm{E}+00$ & $0.0 \quad 0.000 \mathrm{E}+00$ & 0.0 \\
\hline $460 \mathrm{Mg}+2$ & 2.214E-04 & 100.0 & $0.000 \mathrm{E}+00$ & $0.0 \quad 0.000 E+00$ & 0.0 \\
\hline $470 \mathrm{Mn}+2$ & 7.31 & 100.0 & $0.000 \mathrm{E}+00$ & $\begin{array}{lll}0.0 & 0.000 \mathrm{E}+00\end{array}$ & 0.0 \\
\hline $500 \mathrm{Na}+1$ & $2.208 E-04$ & 100.0 & $0.000 \mathrm{E}+00$ & $0.0 \quad 0.000 \mathrm{E}+00$ & 0.0 \\
\hline 770 H4SiO & $2.645 \mathrm{E}-04$ & 100.0 & $0.000 \mathrm{E}+00$ & $0.0 \quad 0.000 E+00$ & 0.0 \\
\hline $800 \mathrm{Sr}+2$ & $1.529 \mathrm{E}-06$ & 100.0 & $0.000 \mathrm{E}+00$ & $0.0 \quad 0.000 \mathrm{E}+00$ & 0.0 \\
\hline
\end{tabular}




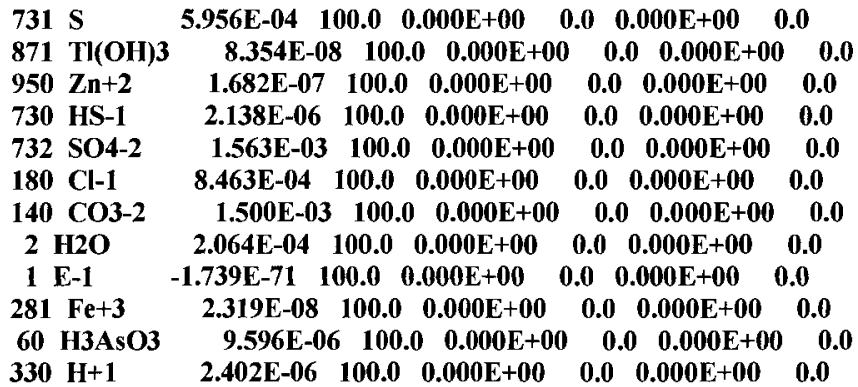

Charge Balance: SPECIATED

Sum of CATIONS $=4.415 E-03$ Sum of ANIONS 5.225E-03

PERCENT DIFFERENCE $=8.393 E+00($ ANIONS - CATIONS $) /($ ANIONS + CATIONS $)$

EQUILIBRIUM IONIC STRENGTH $(\mathrm{m})=8.681 \mathrm{E}-03$

$\begin{array}{ll}\text { EQUILIBRIUM pH } & =10.336 \\ \text { EQUILIBRIUM pe } & =-7.057 \text { or Eh }=-410.44 \mathrm{mv}\end{array}$

Saturation indices

ID No Name SI

1006000 ORPIMENT $\quad 1.601$

$1095000 \mathrm{ZnS}$ (am) $\quad 1.254$

1095001 SPHALERITE $\quad 3.696$

1095002 WURTZITE $\quad 1.170$

1020001 CoS (alpha) $\quad \mathbf{4 . 4 8 5}$

1020002 CoS (beta) $\quad 8.115$

1028000 FeS (ppt) $\quad 0.241$

1028001 GREIGITE $\quad 1.123$

1028002 MACKINAWITE $\quad 0.924$

1028003 PYRITE $\quad 6.417$

2003002 DIASPORE $\quad \mathbf{0 . 3 5 2}$

$2020002 \mathrm{Co}(\mathrm{OH}) 2 \quad 0.073$

2028000 WUSTITE $\quad 1.831$

2028100 FERRIHYDRITE $\quad 0.156$

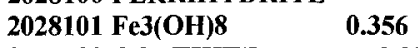

2028102 GOETHITE $\quad 2.894$

$3020002 \mathrm{CoFe} 204 \quad 23.352$

3028000 MAGNETITE $\quad \mathbf{1 6 . 5 5 2}$

3028001 HERCYNITE $\quad 4.682$

3028100 HEMATITE $\quad \mathbf{8 . 1 6 4}$

3028101 MAGHEMITE $\quad 0.746$

3028102 LEPIDOCROCITE $\quad 2.195$

304600I MAGNESIOFERRITE $\quad 6.165$

$4128100 \mathrm{Fe}(\mathrm{OH}) 2.7 \mathrm{Cl.3} \quad 2.571$

5047000 RHODOCHROSITE 1.658

5046002 MAGNESITE 0.103

5015000 ARAGONITE $\quad 1.929$

5015001 CALCITE $\quad 2.083$

5015002 DOLOMITE (ordered) 3.192

5015004 DOLOMITE (disordered) 2.622

5015003 HUNTITE 1.033

6010000 BARITE $\quad 0.288$

7210000 Ba3(AsO4)2 13.266

8628000 GREENALITE $\quad 11.353$

8646000 CHRYSOTILE $\quad 9.220$

8646003 SEPIOLITE $\quad \mathbf{5 . 0 9 0}$

8646004 SEPIOLITE (A) $\quad 2.411$

MW7 - No Adsorption 
INPUT DATA BEFORE TYPE MODIFICATIONS

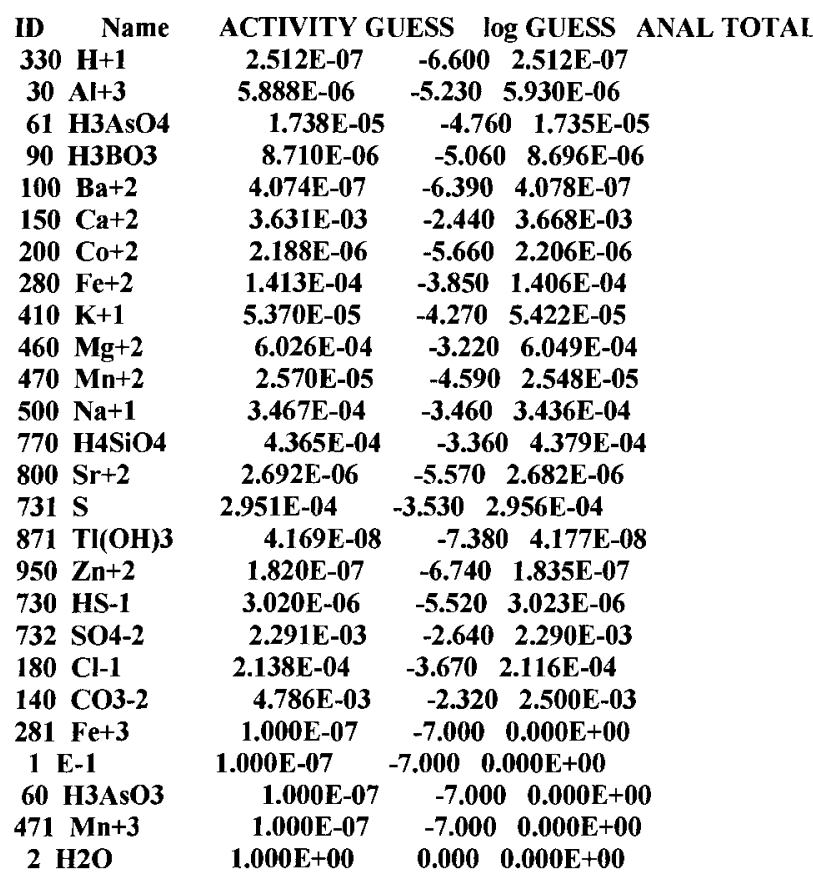

Charge Balance: UNSPECIATED

Sum of CATIONS $=9.305 \mathrm{E}-03$ Sum of ANIONS $=9.795 \mathrm{E}-03$

PERCENT DIFFERENCE $=\mathbf{2 . 5 6 5 E + 0 0}$ (ANIONS - CATIONS)/(ANIONS + CATIONS)

EQUILIBRATED MASS DISTRIBUTION

IDX Name DISSOLVED SORBED PRECIPITATED

$\mathrm{mol} / \mathrm{L}$ percent $\mathrm{mol} / \mathrm{L}$ percent $\mathrm{mol} / \mathrm{L}$ percent

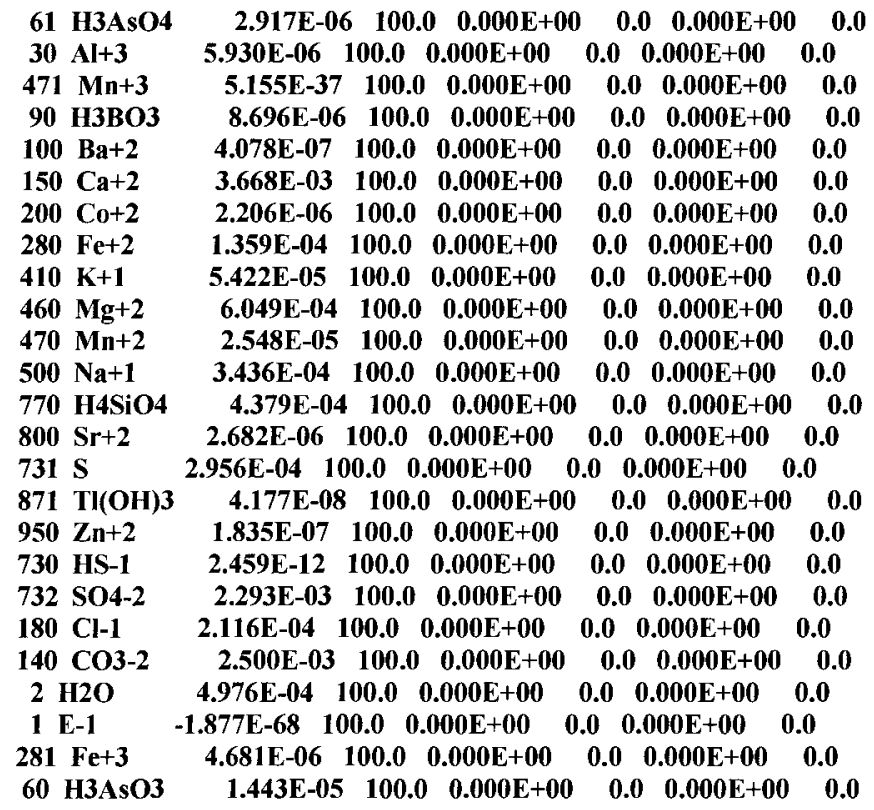


Charge Balance: SPECIATED

Sum of CATIONS $=6.116 \mathrm{E}-03$ Sum of ANIONS $6.606 \mathrm{E}-03$

PERCENT DIFFERENCE $=3.851 \mathrm{E}+00$ (ANIONS - CATIONS)/(ANIONS + CATIONS)

EQUILIBRIUM IONIC STRENGTH $(\mathrm{m})=1.175 \mathrm{E}-02$

$\begin{array}{ll}\text { EQUILIBRIUM pH } & =10.186 \\ \text { EQUILIBRIUM pe } & =-6.138 \text { or } \mathrm{Eh}=-\mathbf{3 5 6 . 9 8} \mathrm{mv}\end{array}$

Saturation indices

\begin{tabular}{|c|c|c|}
\hline No & Name & \\
\hline 1095001 & SPHALERITE & 0.459 \\
\hline 1020002 & CoS (beta) & 2.237 \\
\hline 2077002 & QUARTZ & 0.295 \\
\hline 2003002 & DIASPORE & 0.564 \\
\hline 2028000 & WUSTITE & 3.403 \\
\hline 2028001 & $\mathrm{Fe}(\mathrm{OH}) 2$ & 1.559 \\
\hline 2028100 & FERRIHYDRITE & \multirow{2}{*}{$6.925^{2.601}$} \\
\hline 2028101 & $\mathrm{Fe} 3(\mathrm{OH}) 8$ & \\
\hline 2028102 & GOETHITE & 5.340 \\
\hline 3020002 & $\mathrm{CoFe} 2 \mathrm{O} 4$ & 28.087 \\
\hline 3028000 & MAGNETITE & 23.121 \\
\hline 3028001 & HERCYNITE & 6.783 \\
\hline 3028100 & HEMATITE & 13.056 \\
\hline 3028101 & MAGHEMITE & 5.638 \\
\hline 3028102 & LEPIDOCROCITE & $\begin{array}{c}5.638 \\
4.641\end{array}$ \\
\hline \multicolumn{3}{|c|}{3046001 MAGNESIOFERRITE } \\
\hline 4128100 & $\mathrm{Fe}(\mathrm{OH}) 2.7 \mathrm{Cl} .3$ & \multirow{2}{*}{$\begin{array}{r}4.879 \\
.600\end{array}$} \\
\hline $\mathbf{5 0 2 8 0 0 0}$ & SIDERITE & \\
\hline 5047000 & RHODOCHROSITE & \multirow[b]{2}{*}{0.618} \\
\hline 5046002 & MAGNESITE & \\
\hline $\mathbf{5 0 1 5 0 0 0}$ & ARAGONITE & 2.132 \\
\hline 5015001 & CALCITE & 2.287 \\
\hline 5015002 & DOLOMITE (ordere & red) $\quad 3.911$ \\
\hline \multicolumn{3}{|c|}{5015004 DOLOMITE (disordered) } \\
\hline 5015003 & HUNTITE & \multirow{2}{*}{$\begin{array}{r}2.781 \\
\quad 0.045\end{array}$} \\
\hline 5080000 & STRONTIANITE & \\
\hline 6010000 & BARITE & 0.485 \\
\hline 7247000 & $\mathrm{Mn3(AsO4)2:8H2O}$ & \multirow{2}{*}{$\begin{array}{l}0.008 \\
16.264\end{array}$} \\
\hline 7210000 & Ba3(AsO4)2 & \\
\hline 8603001 & KAOLINITE & 0.070 \\
\hline 8628000 & GREENALITE & 17.017 \\
\hline 8646000 & CHRYSOTILE & 10.112 \\
\hline 8646003 & SEPIOLITE & 6.212 \\
\hline 8646004 & SEPIOLITE (A) & $\mathbf{3 . 5 3 3}$ \\
\hline
\end{tabular}

Core S1 - 45cm Depth - No Adsorption

INPUT DATA BEFORE TYPE MODIFICATIONS

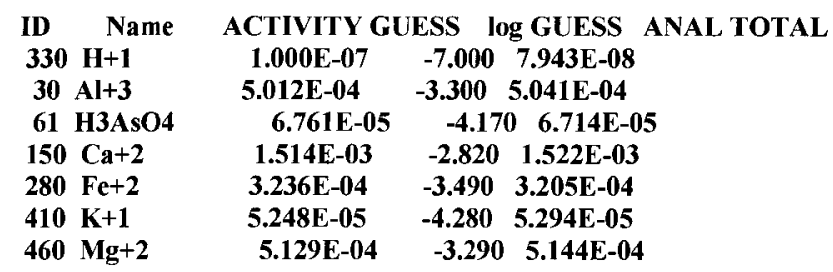




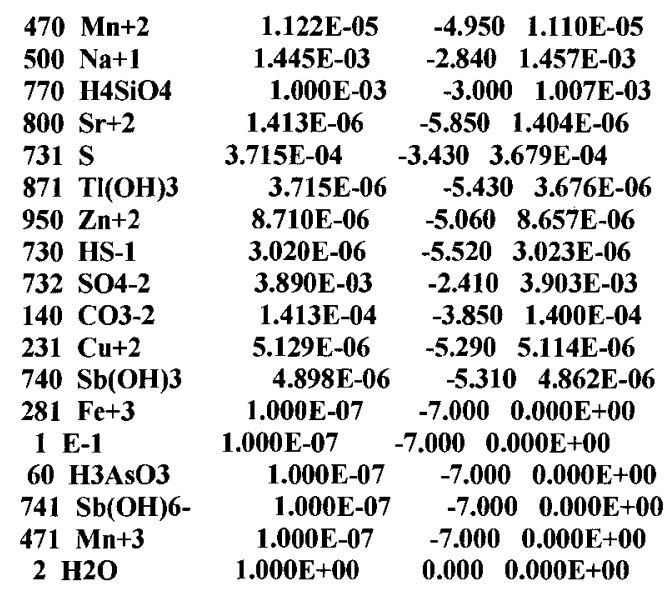

Charge Balance: UNSPECIATED

Sum of CATIONS= 7.789E-03 Sum of ANIONS $=8.089 \mathrm{E}-03$

PERCENT DIFFERENCE $=1.892 \mathrm{E}+00$ (ANIONS - CATIONS) $/($ ANIONS + CATIONS)

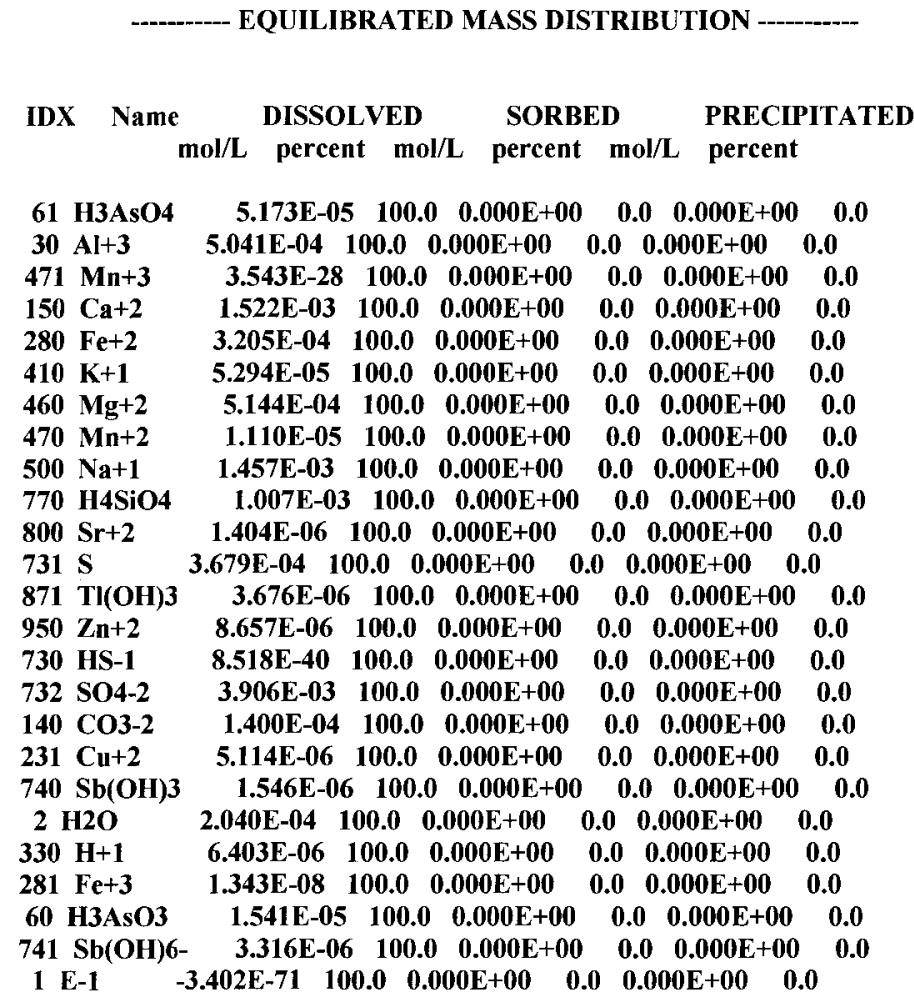

Charge Balance: SPECIATED

Sum of CATIONS $=5.909 E-03$ Sum of ANIONS $6.209 E-03$

PERCENT DIFFERENCE $=2.479 \mathrm{E}+00($ ANIONS - CATIONS) $/($ ANIONS + CATIONS)

EQUILIBRIUM IONIC STRENGTH $(\mathrm{m})=1.122 \mathrm{E}-02$

EQUILIBRIUM pH $\quad \mathbf{5 . 3 0 1}$ 


$$
\text { EQUILIBRIUM pe } \quad=3.027 \text { or Eh }=176.05 \mathrm{mv}
$$

Saturation indices

\begin{tabular}{|c|c|c|}
\hline ID No & Name & SI \\
\hline 2074102 & $\mathrm{SbO} 2$ & 5.736 \\
\hline 2074001 & Sb2O4 & 0.839 \\
\hline 2077000 & CHALCEDONY & 0.613 \\
\hline 2077001 & CRISTOBALITE & 0.414 \\
\hline 2077002 & QUARTZ & 1.071 \\
\hline 2003000 & $\mathrm{Al}(\mathrm{OH}) 3$ (am) & 0.110 \\
\hline 2003001 & BOEHMITE & 2.312 \\
\hline 2003002 & DIASPORE & 4.061 \\
\hline 2003003 & GIBBSITE & 2.666 \\
\hline 2087100 & AVICENNITE & 2.133 \\
\hline 2087101 & $\mathrm{Tl}(\mathrm{OH}) 3$ & 0.007 \\
\hline 2028102 & GOETHITE & 1.303 \\
\hline $\mathbf{3 0 0 3 0 0 0}$ & Al2O3 & 2.059 \\
\hline $\mathbf{3 0 2 8 0 0 0}$ & MAGNETITE & 6.732 \\
\hline 3028001 & HERCYNITE & $\mathbf{5 . 4 6 0}$ \\
\hline $\mathbf{3 0 2 8 1 0 0}$ & HEMATITE & 4.983 \\
\hline 3028102 & LEPIDOCROCITE & 0.604 \\
\hline 3023100 & CUPRIC FERRITE & 2.350 \\
\hline 6003000 & AlOHSO4 & 1.168 \\
\hline 6003001 & Al4(OH)10SO4 & 8.964 \\
\hline 8603000 & HALLOYSITE & 6.375 \\
\hline 86 & KAOLINI & 8.615 \\
\hline
\end{tabular}

Core S1 - 45cm Depth - Adsorption

INPUT DATA BEFORE TYPE MODIFICATIONS

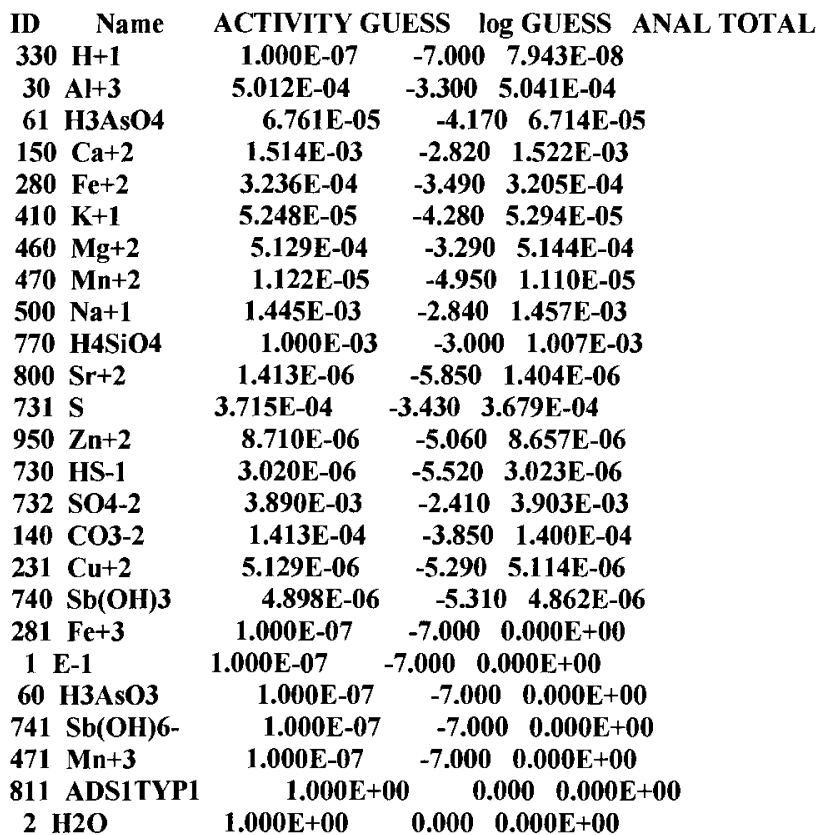

Charge Balance: UNSPECIATED

Sum of CATIONS $=7.789 \mathrm{E}-03$ Sum of ANIONS $=8.089 \mathrm{E}-03$

PERCENT DIFFERENCE $=1.892 \mathrm{E}+00($ ANIONS - CATIONS) $/($ ANIONS + CATIONS) 


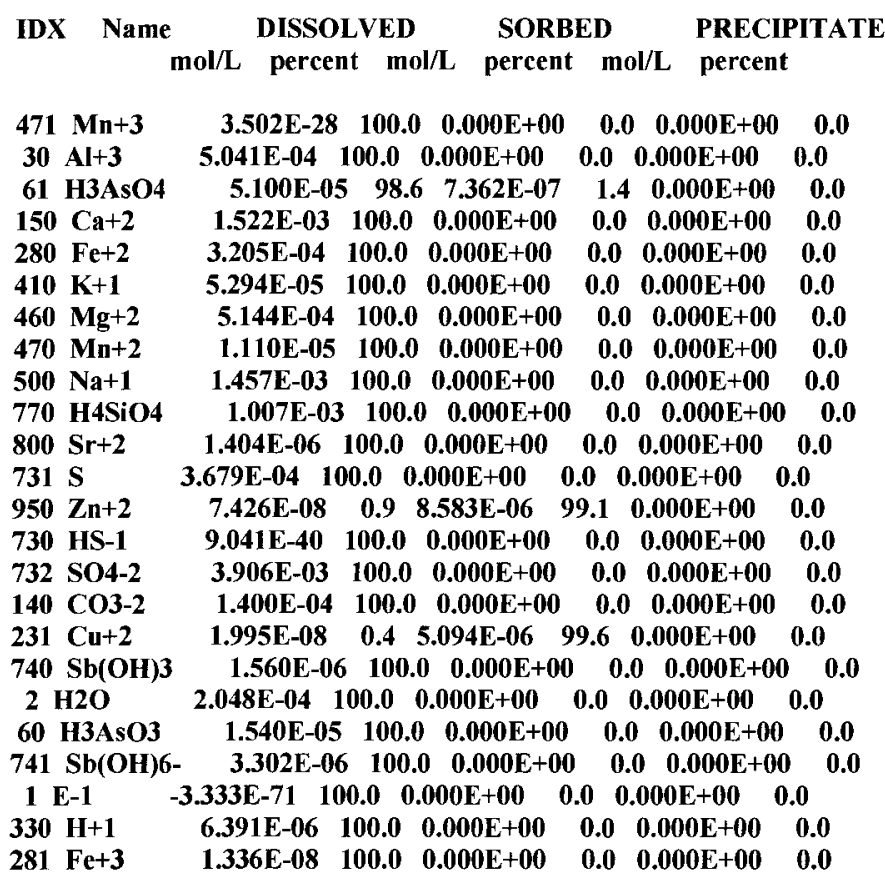

Charge Balance: SPECIATED

Sum of CATIONS $=5.886 \mathrm{E}-03 \mathrm{Sum}$ of ANIONS $6.213 \mathrm{E}-03$

PERCENT DIFFERENCE $=2.708 E+00$ (ANIONS - CATIONS) $/($ ANIONS + CATIONS)

EQUILIBRIUM IONIC STRENGTH $(\mathrm{m})=1.120 \mathrm{E}-02$

EQUILIBRIUM pH $\quad=5.302$

EQUILIBRIUM pe $\quad=3.022$ or $\mathrm{Eh}=175.78 \mathrm{mv}$

Saturation indices

\begin{tabular}{|c|c|c|}
\hline II) No & Name & SI \\
\hline 2074102 & $\mathrm{SbO2}$ & 5.737 \\
\hline 2074001 & Sb2O4 & 0.840 \\
\hline 2074004 & $\mathrm{Sb}(\mathrm{OH}) 3$ & 1.098 \\
\hline 2074006 & SENARMONTITE & \\
\hline 2077000 & CHALCEDONY & 0.613 \\
\hline 2077001 & CRISTOBALITE & 0.414 \\
\hline 2077002 & QUARTZ & 1.071 \\
\hline 20030 & $\mathrm{Al}(\mathrm{OH}) 3$ (am) & 0.113 \\
\hline 2003 & BOF & 2.315 \\
\hline 20030 & DIA & 4.064 \\
\hline 2003 & GIB & 2.669 \\
\hline 2028 & GOETHITE & 1.302 \\
\hline 3003000 & $A 1203$ & 2.065 \\
\hline 3028000 & MAGNETITE & 6.732 \\
\hline 3028001 & HERCYNITE & 5.468 \\
\hline 3028100 & HEMATITE & 4.981 \\
\hline 3028 & CROCITE & 0.6 \\
\hline 6003000 & AlOHSO4 & 1.169 \\
\hline 6003001 & Al4(OH)10SO4 & 8.974 \\
\hline 8603000 & HALLOYSITE & 6.381 \\
\hline
\end{tabular}


Core S1 - 75cm Depth - No Adsorption

\section{INPUT DATA BEFORE TYPE MODIFICATIONS}

\begin{tabular}{|c|c|c|}
\hline Name & ACTIVITY GUESS & $\log$ GUESS AI \\
\hline $330 \mathrm{H}+1$ & $1.585 E-07$ & $-6.800 \quad 1.585 E-07$ \\
\hline $30 \mathrm{Al}+3$ & $2.951 \mathrm{E}-05$ & $-4.530 \quad 2.958 E-05$ \\
\hline $61 \mathrm{H3AsO4}$ & $6.918 E-05$ & $-4.160 \quad 6.941 \mathrm{E}-05$ \\
\hline $150 \mathrm{Ca}+2$ & 1.122E-03 & $-2.950 \quad 1.128 \mathrm{E}-03$ \\
\hline $200 \mathrm{Co}+2$ & $1.000 \mathrm{E}+00$ & $0.000 \quad 4.242 \mathrm{E}-07$ \\
\hline $280 \mathrm{Fe}+2$ & $1.738 E-05$ & $-4.760 \quad 1.755 E-05$ \\
\hline $410 \mathrm{~K}+1$ & $1.000 \mathrm{E}-04$ & $-4.000 \quad 1.010 \mathrm{E}-04$ \\
\hline $460 \mathrm{Mg}+2$ & $2.188 \mathrm{E}-04$ & $-3.660 \quad 2.206 E-04$ \\
\hline $470 \mathrm{Mn}+2$ & 1.072E-06 & $-5.970 \quad 1.074 E-06$ \\
\hline $770 \mathrm{H} 4 \mathrm{SiO} 4$ & $3.020 \mathrm{E}-04$ & $-3.520 \quad 3.005 E-04$ \\
\hline $800 \mathrm{Sr}+2$ & $1.175 E-06$ & $-5.930 \quad 1.176 \mathrm{E}-06$ \\
\hline $731 \mathrm{~S}$ & 2.188E-03 & $-2.660 \quad 2.164 E-03$ \\
\hline $871 \mathrm{Tl}(\mathrm{OH}) 3$ & $1.445 \mathrm{E}-07$ & $-6.840 \quad 1.462 \mathrm{E}-07$ \\
\hline $950 \mathrm{Zn}+2$ & 4.467E-07 & $-6.350 \quad 4.436 E-07$ \\
\hline $732 \mathrm{SO4-2}$ & $2.630 E-03$ & $-2.580 \quad 2.602 \mathrm{E}-03$ \\
\hline $140 \mathrm{CO3}-2$ & $4.677 \mathrm{E}-04$ & $-3.330 \quad 4.667 \mathrm{E}-04$ \\
\hline $231 \mathrm{Cu}+2$ & 2.344E-07 & $-6.630 \quad 2.360 E-07$ \\
\hline $740 \mathrm{Sb}(\mathrm{OH}) 3$ & $2.884 E-05$ & $-4.540 \quad 2.891 E-05$ \\
\hline $281 \mathrm{Fe}+3$ & $1.000 \mathrm{E}-07$ & $-7.000 \quad 0.000 \mathrm{E}+00$ \\
\hline 1 E-1 & $1.000 \mathrm{E}-07$ & $-7.000 \quad 0.000 \mathrm{E}+00$ \\
\hline $60 \mathrm{H3AsO3}$ & 1.000E-07 & $-7.000 \quad 0.000 E+00$ \\
\hline $741 \mathrm{Sb}(\mathrm{OH}) 6-$ & $1.000 \mathrm{E}-07$ & $-7.000 \quad 0.000 E+00$ \\
\hline $471 \mathrm{Mn}+3$ & $1.000 \mathrm{E}-07$ & $-7.000 \quad 0.000 E+00$ \\
\hline 730 HS-1 & $1.000 E-07$ & $-7.000 \quad 0.000 \mathrm{E}+00$ \\
\hline $500 \mathrm{Na}+1$ & $1.950 \mathrm{E}-03$ & $-2.710 \quad 3.000 \mathrm{E}-03$ \\
\hline $90 \mathrm{H3BO3}$ & $5.129 E-06$ & $-5.290 \quad 5.180 \mathrm{E}-06$ \\
\hline $100 \mathrm{Ba}+2$ & $1.950 \mathrm{E}-07$ & $-6.710 \quad 1.966 E-07$ \\
\hline $2 \mathrm{H} 2 \mathrm{O}$ & $1.000 \mathrm{E}+00$ & $0.000 \quad 0.000 \mathrm{E}+00$ \\
\hline
\end{tabular}

Charge Balance: UNSPECIATED

Sum of CATIONS= 5.929E-03 Sum of ANIONS $=6.137 \mathrm{E}-03$

PERCENT DIFFERENCE $=1.725 E+00$ (ANIONS - CATIONS)/(ANIONS + CATIONS)

EOUILIBRATED MASS DISTRIBUTION

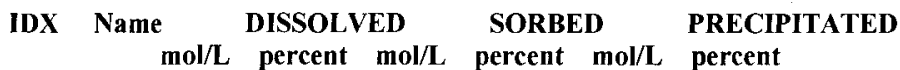

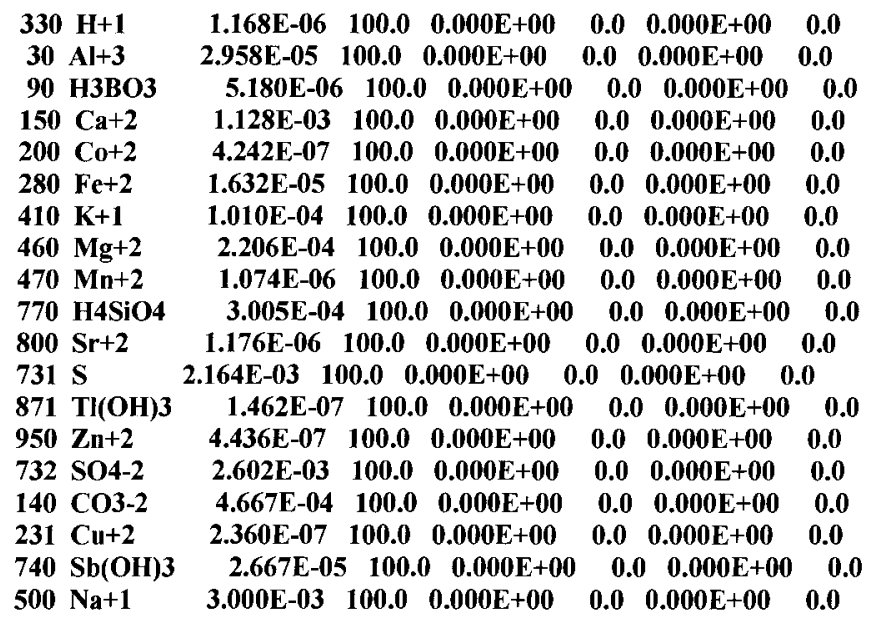




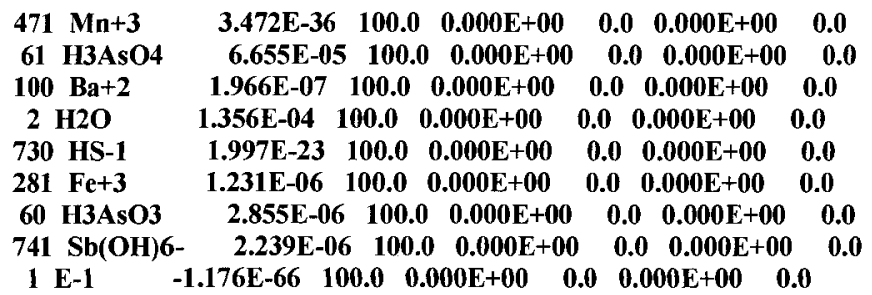

Core S1 - 75cm Depth - Adsorption

INPUT DATA BEFORE TYPE MODIFICATIONS

ID Name ACTIVITY GUESS log GUESS ANAL TOTAL 


\begin{tabular}{|c|c|c|}
\hline $330 \mathrm{H}+1$ & 1.585E-07 & $-6.800 \quad 1.585 E-07$ \\
\hline $30 \mathbf{A l}+3$ & $2.951 \mathrm{E}-05$ & $-4.530 \quad 2.958 E-05$ \\
\hline $61 \mathrm{H3AsO4}$ & $6.918 E-05$ & $-4.160 \quad 6.941 E-05$ \\
\hline $150 \mathrm{Ca}+2$ & $1.122 \mathrm{E}-03$ & $-2.950 \quad 1.128 \mathrm{E}-03$ \\
\hline $200 \mathrm{Co}+2$ & $1.000 \mathrm{E}+00$ & $0.000 \quad 4.242 E-07$ \\
\hline $280 \mathrm{Fe}+2$ & 1.738E-05 & $-4.760 \quad 1.755 E-05$ \\
\hline $410 \mathrm{~K}+1$ & $1.000 \mathrm{E}-04$ & $-4.000 \quad 1.010 \mathrm{E}-04$ \\
\hline $460 \mathrm{Mg}+2$ & $2.188 E-04$ & $-3.660 \quad 2.206 \mathrm{E}-04$ \\
\hline $470 \mathrm{Mn}+2$ & 1.072E-06 & $-5.970 \quad 1.074 \mathrm{E}-06$ \\
\hline $770 \mathrm{H} 4 \mathrm{SiO} 4$ & $3.020 E-04$ & $-3.520 \quad 3.005 E-04$ \\
\hline $800 \mathrm{Sr}+2$ & 1.175E-06 & $-5.930 \quad 1.176 E-06$ \\
\hline $731 \mathrm{~S}$ & 2.188E-03 & $-2.660 \quad 2.164 \mathrm{E}-03$ \\
\hline $950 Z n+2$ & 4.467E-07 & $-6.350 \quad 4.436 E-07$ \\
\hline $732 \mathrm{SO4-2}$ & $2.630 \mathrm{E}-03$ & $-2.580 \quad 2.602 E-03$ \\
\hline $140 \mathrm{CO}-2$ & $4.677 \mathrm{E}-04$ & $-3.330 \quad 4.667 E-04$ \\
\hline $231 \mathrm{Cu}+2$ & 2.344E-07 & $-6.630 \quad 2.360 \mathrm{E}-07$ \\
\hline $740 \mathrm{Sb}(\mathrm{OH}) 3$ & $2.884 \mathrm{E}-05$ & $-4.540 \quad 2.891 \mathrm{E}-05$ \\
\hline $281 \mathrm{Fe}+3$ & $1.000 \mathrm{E}-07$ & 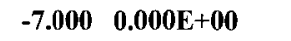 \\
\hline 1 E-1 & $1.000 \mathrm{E}-07$ & $-7.000 \quad 0.000 \mathrm{E}+00$ \\
\hline $60 \mathrm{H3AsO3}$ & $1.000 \mathrm{E}-07$ & $-7.000 \quad 0.000 \mathrm{E}+00$ \\
\hline $741 \mathrm{Sb}(\mathrm{OH}) 6-$ & 1.000E-07 & $-7.000 \quad 0.000 E+00$ \\
\hline $471 \mathrm{Mn}+3$ & $1.000 E-07$ & $-7.000 \quad 0.000 \mathrm{E}+00$ \\
\hline 730 HS-1 & $1.000 \mathrm{E}-07$ & $-7.000 \quad 0.000 E+00$ \\
\hline $500 \mathrm{Na}+1$ & $1.950 \mathrm{E}-03$ & $-2.710 \quad 3.000 E-03$ \\
\hline 90 НЗВОЗ & 5.129E-06 & $-5.290 \quad 5.180 \mathrm{E}-06$ \\
\hline $100 \mathrm{Ba}+2$ & $1.950 \mathrm{E}-07$ & $-6.710 \quad 1.966 \mathrm{E}-07$ \\
\hline 811 ADSITYP1 & $1.000 \mathrm{E}+0$ & $0.000 \quad 0.000 \mathrm{E}+00$ \\
\hline $2 \mathrm{H} 20$ & $1.000 \mathrm{E}+00$ & $0.000 \quad 0.000 \mathrm{E}+00$ \\
\hline
\end{tabular}

Charge Balance: UNSPECIATED

Sum of CATIONS $=5.929 \mathrm{E}-03$ Sum of ANIONS $=6.137 \mathrm{E}-03$

PERCENT DIFFERENCE $=1.725 E+00$ (ANIONS - CATIONS) $/($ ANIONS + CATIONS)

----- EQUILIBRATED MASS DISTRIBUTION ---------

\begin{tabular}{lllll} 
IDX Name & DISSOLVED & \multicolumn{2}{c}{ SORBED } & PRECIPITATED \\
$\mathrm{mol} / \mathrm{L}$ & percent $\mathrm{mol} / \mathrm{L}$ & percent $\mathrm{mol} / \mathrm{L}$ & percent
\end{tabular}

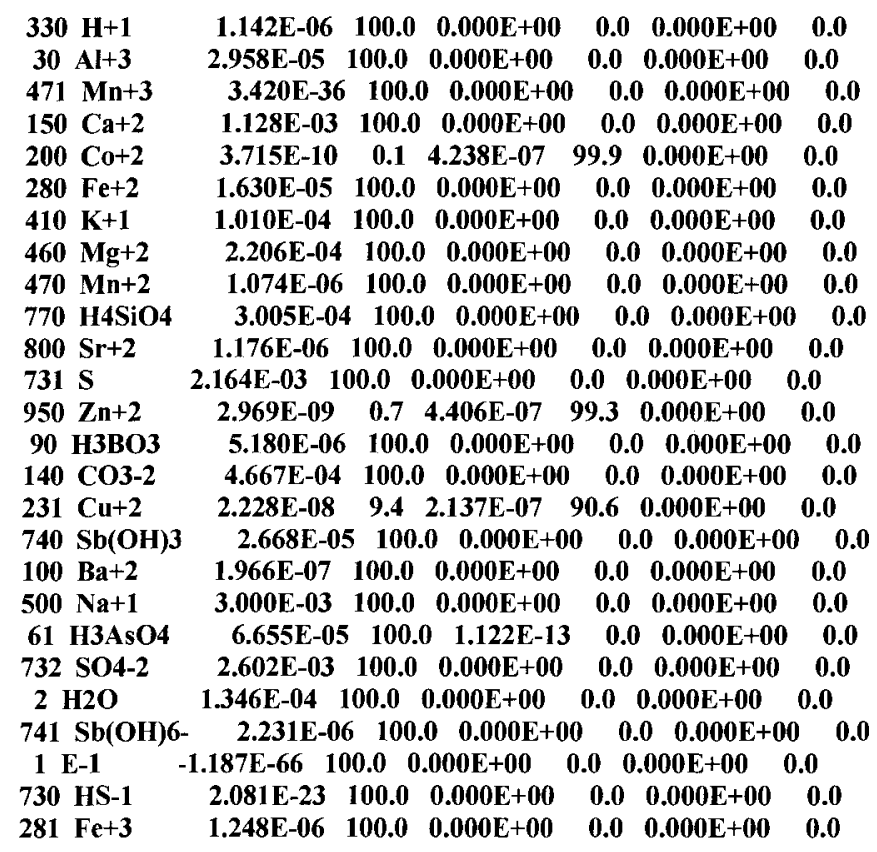


Charge Balance: SPECIATED

Sum of CATIONS $=5.237 \mathrm{E}-03$ Sum of ANIONS $5.447 \mathrm{E}-03$

PERCENT DIFFERENCE $=1.968 \mathrm{E}+00$ (ANIONS - CATIONS)/(ANIONS + CATIONS)

EQUILIBRIUM IONIC STRENGTH $(\mathrm{m})=8.884 \mathrm{E}-03$

$\begin{array}{ll}\text { EQUILIBRIUM pH } & =9.484 \\ \text { EQUILIBRIUM pe } & =\mathbf{- 3 . 9 4 9} \text { or Eh }=-229.68 \mathrm{mv}\end{array}$

Saturation indices

\begin{tabular}{|c|c|c|}
\hline ID No & Name & SI \\
\hline 2074102 & 4.179 & 4.179 \\
\hline 2074004 & $\mathrm{Sb}(\mathrm{OH}) 3$ & 2.330 \\
\hline 2074006 & SENARMONTITE & 2.717 \\
\hline 2077002 & QUARTZ & 0.429 \\
\hline 2003001 & BOEHMITE & 0.221 \\
\hline 2003002 & DIASPORE & 1.969 \\
\hline 2003003 & GIBBSITE & 0.574 \\
\hline 2023101 & TENORITE & 0.475 \\
\hline 2028000 & WUSTITE & 1.996 \\
\hline 2028001 & $\mathrm{Fe}(\mathrm{OH}) 2$ & 0.152 \\
\hline 2028100 & FERRIHYDRITE & 2.681 \\
\hline 2028101 & Fe3(OH)8 & $\mathbf{5 . 6 7 7}$ \\
\hline 2028102 & GOETHITE & 5.419 \\
\hline 3020002 & $\mathrm{CoFe} 2 \mathrm{O} 4$ & 24.104 \\
\hline 3028000 & MAGNETITE & 21.873 \\
\hline 3028001 & HERCYNITE & \multirow{2}{*}{$\begin{array}{r}8.186 \\
13.216\end{array}$} \\
\hline 3028100 & HEMATITE & \\
\hline 3028101 & MAGHEMITE & 5.797 \\
\hline 3028102 & LEPIDOCROCITE & 4.720 \\
\hline 3046001 & MAGNESIOFERRITE & 9.547 \\
\hline 3023100 & CUPRIC FERRITE & 13.879 \\
\hline $\mathbf{5 0 2 8 0 0 0}$ & SIDERITE & 0.564 \\
\hline $\mathbf{5 0 1 5 0 0 0}$ & ARAGONITE & 0.694 \\
\hline 5015001 & CALCITE & 0.848 \\
\hline 5015002 & DOLOMITE (ordered) & 1.087 \\
\hline \multicolumn{3}{|c|}{5015004 DOLOMITE (disordered) 0.51} \\
\hline 7210000 & Ba3(AsO4)2 & 16.934 \\
\hline 8603000 & HALLOYSITE & \multirow{2}{*}{$\begin{array}{c}0.909 \\
3.149\end{array}$} \\
\hline 8603001 & KAOLINITE & \\
\hline 8628000 & GREENALITE & 13.063 \\
\hline 8646000 & CHRYSOTILE & 5.110 \\
\hline 8646003 & SEPIOLITE & \multirow{2}{*}{$\begin{array}{l}3.100 \\
0.421\end{array}$} \\
\hline 8646004 & ? & \\
\hline
\end{tabular}

COre S2 - 15cm depth - No Adsorption

INPUT DATA BEFORE TYPE MODIFICATIONS

\begin{tabular}{|c|c|c|c|}
\hline ID & Name & \multicolumn{2}{|c|}{ ANAL TOTAL } \\
\hline 330 & $\mathrm{H}+\mathbf{1}$ & $1.000 \mathrm{E}-07$ & $-7.000 \quad 6.607 \mathrm{E}-07$ \\
\hline 30 & $\mathbf{A} \mathbf{l}+\mathbf{3}$ & $4.266 \mathrm{E}-04$ & $-3.370 \quad 4.262 \mathrm{E}-04$ \\
\hline 61 & H3AsO4 & $7.762 \mathrm{E}-06$ & $-5.110 \quad 7.742 E-06$ \\
\hline 90 & Н3BO3 & $8.710 \mathrm{E}-06$ & $-5.060 \quad 8.788 \mathrm{E}-06$ \\
\hline 100 & $\mathbf{B a}+2$ & $9.120 \mathrm{E}-07$ & $-6.040 \quad 9.175 E-07$ \\
\hline 150 & $\mathrm{Ca}+2$ & $1.259 \mathrm{E}-03$ & $-2.900 \quad 1.257 \mathrm{E}-03$ \\
\hline 200 & $\mathrm{Co}+2$ & $3.020 \mathrm{E}-06$ & $-5.520 \quad 3.021 E-06$ \\
\hline 231 & $\mathrm{Cu}+2$ & $1.122 \mathrm{E}-06$ & $-5.950 \quad 1.133 E-06$ \\
\hline 280 & $\mathrm{Fe}+2$ & $1.950 \mathrm{E}-04$ & $-3.710 \quad 1.970 \mathrm{E}-04$ \\
\hline
\end{tabular}




\begin{tabular}{|c|c|c|}
\hline $410 \mathrm{~K}+1$ & $6.761 \mathrm{E}-05$ & $-4.170 \quad 6.752 \mathrm{E}-04$ \\
\hline $460 \mathrm{Mg}+2$ & $4.365 E-04$ & $-3.360 \quad 4.362 E-04$ \\
\hline $470 \mathrm{Mn}+2$ & $6.310 \mathrm{E}-06$ & $-5.200 \quad 6.298 \mathrm{E}-06$ \\
\hline $500 \mathrm{Na}+1$ & $1.738 \mathrm{E}-04$ & $-3.760 \quad 5.731 E-04$ \\
\hline $770 \mathrm{H} 4 \mathrm{SiO} 4$ & $7.586 \mathrm{E}-04$ & $-3.120 \quad 7.547 E-04$ \\
\hline $800 \mathrm{Sr}+2$ & $1.047 E-06$ & $-5.980 \quad 1.050 \mathrm{E}-06$ \\
\hline $731 \mathrm{~S}$ & $6.761 \mathrm{E}-04$ & $-3.170 \quad 6.704 E-04$ \\
\hline 871 Tl(OH)3 & $9.333 E-06$ & $-5.030 \quad 9.440 \mathrm{E}-06$ \\
\hline $950 \mathrm{Zn}+2$ & $2.754 \mathrm{E}-06$ & $-5.560 \quad 2.768 E-06$ \\
\hline $732 \mathrm{SO} 4-2$ & $3.236 \mathrm{E}-03$ & $-2.490 \quad 3.253 E-03$ \\
\hline $140 \mathrm{COB}-2$ & $6.761 \mathrm{E}-03$ & $-2.170 \quad 6.770 \mathrm{E}-04$ \\
\hline $740 \mathrm{Sb}(\mathrm{OH}) 3$ & $2.344 E-06$ & $-5.630 \quad 2.341 \mathrm{E}-06$ \\
\hline $281 \mathrm{Fe}+3$ & 1.000E-07 & $-7.000 \quad 0.000 \mathrm{E}+00$ \\
\hline 1 E-1 & $1.000 \mathrm{E}-07$ & $-7.000 \quad 0.000 \mathrm{E}+00$ \\
\hline $60 \mathrm{H3AsO3}$ & 1.000E-07 & $-7.000 \quad 0.000 \mathrm{E}+00$ \\
\hline $741 \mathrm{Sb}(\mathrm{OH}) 6-$ & $1.000 \mathrm{E}-07$ & $-7.000 \quad 0.000 \mathrm{E}+00$ \\
\hline $471 \mathrm{Mn}+3$ & 1.000E-07 & $-7.000 \quad 0.000 \mathrm{E}+00$ \\
\hline 730 HS-1 & 1.000E-07 & $-7.000 \quad 0.000 E+00$ \\
\hline $2 \mathrm{H} 2 \mathrm{O}$ & $1.000 \mathrm{E}+00$ & $0.000 \quad 0.000 \mathrm{E}+00$ \\
\hline
\end{tabular}

Charge Balance: UNSPECIATED

Sum of CATIONS $=6.338 \mathrm{E}-03$ Sum of ANIONS $=7.860 \mathrm{E}-03$

PERCENT DIFFERENCE $=1.072 E+01$ (ANIONS - CATIONS) $/($ ANIONS + CATIONS)

EQUILIBRATED MASS DISTRIBUTION

$\begin{array}{llll}\text { IDX Name } & \text { DISSOLVED } & \text { SORBED } & \text { PRECIPITATED } \\ \text { mol/L } & \text { percent } & \text { mol/L } & \text { percent } \\ \mathrm{mol} / \mathrm{L} & \text { percent }\end{array}$

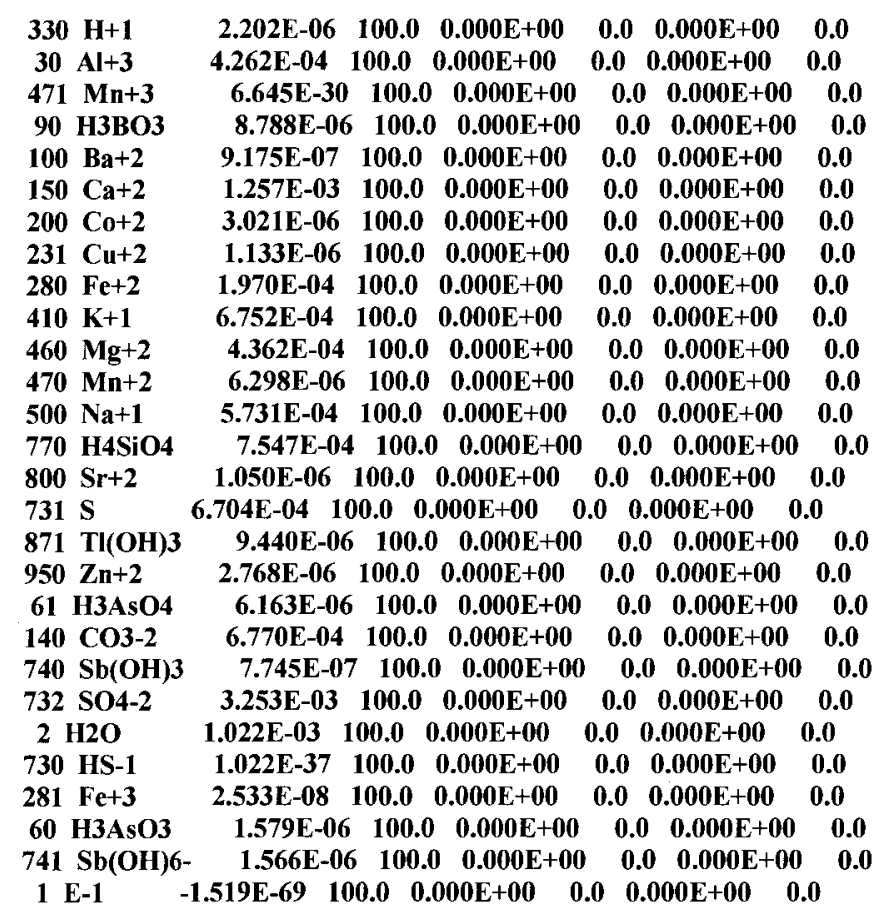

Charge Balance: SPECIATED

Sum of CATIONS $=4.546 \mathrm{E}-03$ Sum of ANIONS $6.068 \mathrm{E}-03$

PERCENT DIFFERENCE $=1.434 E+01$ (ANIONS - CATIONS)/(ANIONS + CATIONS) 
EQUILIBRIUM IONIC STRENGTH $(\mathrm{m})=\mathbf{9 . 6 6 8 \mathrm { E } - 0 3}$

$\begin{array}{ll}\text { EQUILIBRIUM pH } & =6.271 \\ \text { EQUILIBRIUM pe } & =1.560 \text { or } \mathrm{Eh}=90.76 \mathrm{mv}\end{array}$

Saturation indices

\begin{tabular}{lcc} 
ID No Name & \multicolumn{2}{c}{ SI } \\
& \multicolumn{2}{c}{4.940} \\
2074102 SbO2 & 0.794 \\
2074004 Sb(OH)3 & 0.488 \\
2077000 CHALCEDONY & 0.289 \\
2077001 CRISTOBALITE & 0.946 \\
2077002 QUARTZ & 0.96 \\
2003000 AI(OH)3 (am) & 1.582 \\
2003001 BOEHMITE & 3.784 \\
2003002 DIASPORE & 5.533 \\
2003003 GIBBSITE & 4.138 \\
2087100 AVICENNITE & 2.952 \\
2087101 TI(OH)3 & 0.417 \\
2028102 GOETHITE & 2.549 \\
3003000 AI2O3 & 5.003 \\
3020002 COFe2O4 & 16.244 \\
3028000 MAGNETITE & 10.965 \\
3028001 HERCYNITE & 10.146 \\
3028100 HEMATITE & 7.475 \\
3028101 MAGHEMITE & 0.056 \\
3028102 LEPIDOCROCITE & 1.850 \\
3023100 CUPRIC FERRITE & 6.099 \\
6003001 Al4(OH)10SO4 & 12.890 \\
7210000 Ba3(AsO4)2 & 9.107 \\
8603000 HALLOYSITE & 9.069 \\
8603001 KAOLINITE & 11.308
\end{tabular}

Core S2 - 45cm Depth - No Adsorption

INPUT DATA BEFORE TYPE MODIFICATIONS

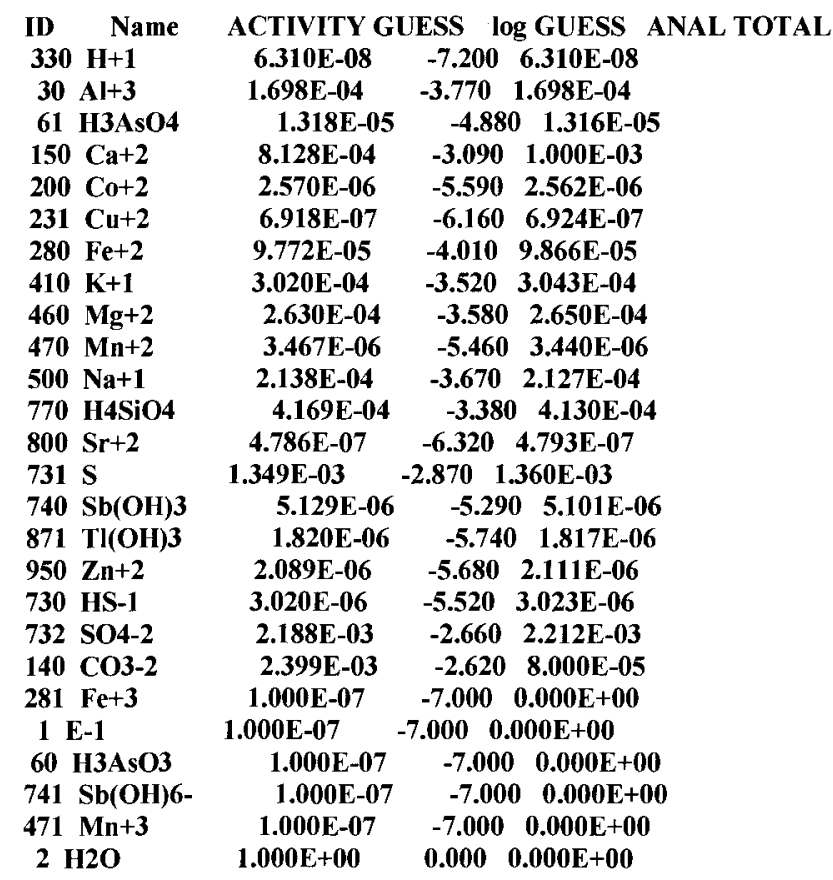


Charge Balance: UNSPECIATED

Sum of CATIONS $=3.772 \mathrm{E}-03 \mathrm{Sum}$ of ANIONS $=4.587 \mathrm{E}-03$

PERCENT DIFFERENCE $=9.746 \mathrm{E}+00$ (ANIONS - CATIONS)/(ANIONS + CATIONS)

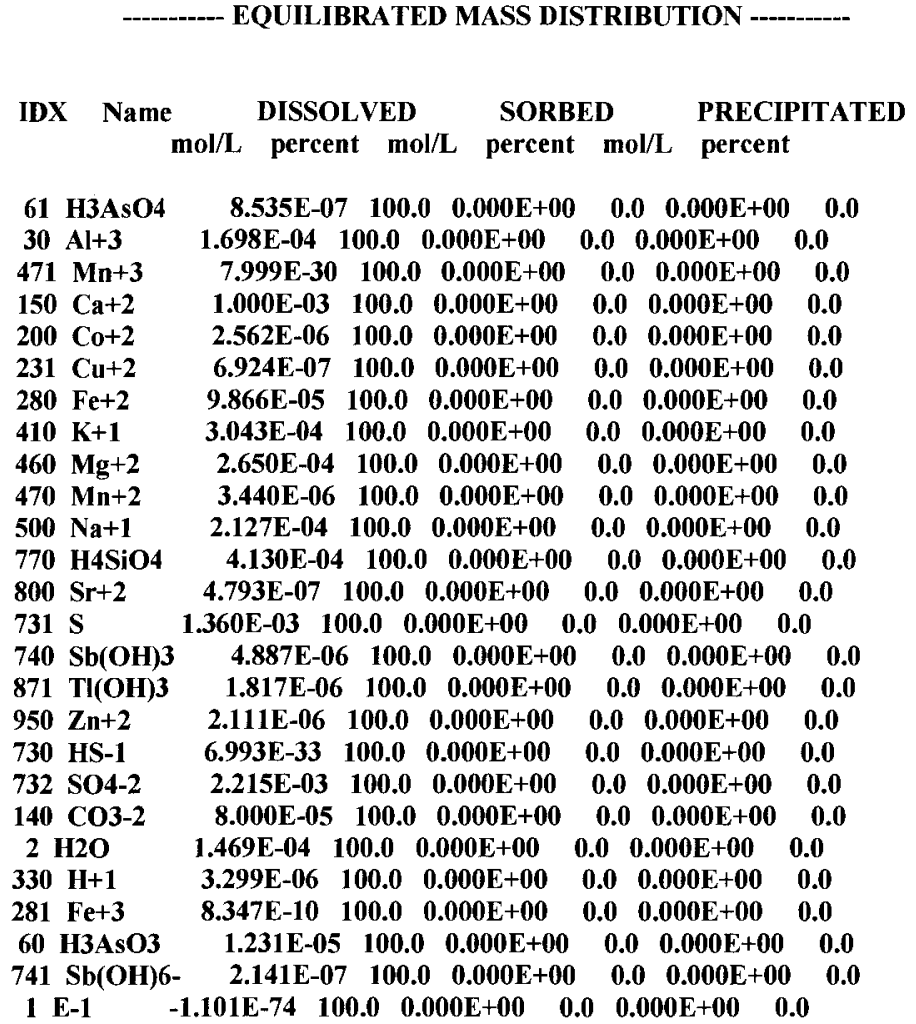

Charge Balance: SPECIATED

Sum of CATIONS $=3.018 \mathrm{E}-03$ Sum of ANIONS 3.832E-03

PERCENT DIFFERENCE $=1.189$ E +01 (ANIONS - CATIONS) $/($ ANIONS + CATIONS)

EQUILIBRIUM IONIC STRENGTH $(\mathrm{m})=6.543 \mathrm{E}-03$

EQUILIBRIUM pH $\quad=\mathbf{5 . 4 8 0}$

EQUILIBRIUM pe $\quad=1.919$ or Eh $=111.62 \mathrm{mv}$

Saturation indices

\begin{tabular}{lcc} 
ID No Name & SI \\
& \multicolumn{2}{c}{5.307} \\
2074102 SbO2 & \multicolumn{2}{c}{1.594} \\
2074004 Sb(OH)3 & \multicolumn{2}{c}{1.244} \\
2074006 SENARMONTITE & \multicolumn{1}{c}{0.226} \\
2077000 CHALCEDONY & \multicolumn{1}{c}{0.026} \\
2077001 CRISTOBALITE & 0.683 \\
2077002 QUARTZ & 0.67 \\
2003000 AI(OH)3 (am) & 0.170 \\
2003001 BOEHMITE & 2.372 \\
2003002 DIASPORE & 4.120
\end{tabular}




$\begin{array}{lc}\text { 2003003 GIBBSITE } & 2.725 \\ \text { 2087100 AVICENNITE } & 1.520 \\ 2028102 \text { GOETIITE } & 0.285 \\ 3003000 \text { Al2O3 } & 2.178 \\ \text { 3020002 CoFe2O4 } & 10.115 \\ \text { 3028000 MAGNETITE } & 4.607 \\ \text { 3028001 HERCYNITE } & 5.490 \\ \text { 3028100 HEMATITE } & 2.947 \\ \text { 6003000 AIOHSO4 } & 0.705 \\ \text { 6003001 AI4(OH)IOSO4 } & 8.679 \\ \text { 8603000 HALLOYSITE } & 5.719 \\ \text { 8603001 KAOLINITE } & 7.959\end{array}$

Core S2 - 45cm Depth - Adsorption

INPUT DATA BEFORE TYPE MODIFICATIONS

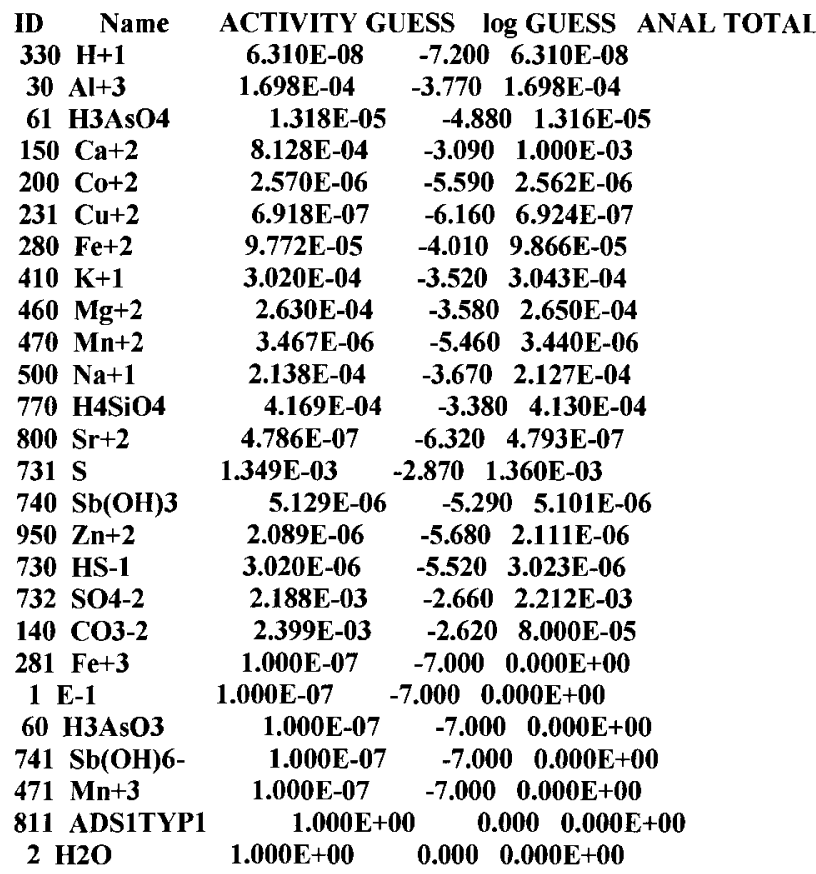

Charge Balance: UNSPECIATED

Sum of CATIONS= 3.772E-03 Sum of ANIONS $=4.587 \mathrm{E}-03$

PERCENT DIFFERENCE $=9.746 E+00$ (ANIONS - CATIONS)/(ANIONS + CATIONS)

EQUILIBRATED MASS DISTRIBUTION

IDX Name DISSOLVED SORBED PRECIPITATED

$\mathrm{mol} / \mathrm{L}$ percent mol/L percent mol/L percent

\begin{tabular}{|c|c|c|c|c|c|c|c|}
\hline & H3AsO4 & $8.238 \mathrm{E}-0$ & 95 & $3.669 \mathrm{E}-08$ & 4. & $0.000 E+00$ & 0.0 \\
\hline 30 & $\mathbf{A l}+\mathbf{3}$ & $1.698 \mathrm{E}-04$ & 100.0 & $0.000 \mathrm{E}+00$ & 0.0 & $0.000 \mathrm{E}+00$ & 0.0 \\
\hline 471 & $M n+3$ & $7.854 \mathrm{E}-30$ & 100.0 & $0.000 E+00$ & 0.0 & $0.000 \mathrm{E}+00$ & 0.0 \\
\hline 150 & $\mathrm{Ca}+2$ & $1.000 \mathrm{E}-03$ & 100.0 & $0.000 \mathrm{E}+00$ & 0.0 & $0.000 \mathrm{E}+00$ & 0.0 \\
\hline 200 & $\mathrm{Co}+2$ & 4.312E-09 & 0.2 & 2.558E-06 & 99.8 & $0.000 \mathrm{E}+00$ & 0.0 \\
\hline 231 & $\mathrm{Cu}+2$ & $4.801 \mathrm{E}-10$ & 0.1 & 6.919E-07 & 99.9 & $0.000 \mathrm{E}+00$ & 0.0 \\
\hline 280 & $\mathrm{Fe}+2$ & $9.866 \mathrm{E}-05$ & 100.0 & $0.000 \mathrm{E}+00$ & 0.0 & $0.000 E+00$ & 0.0 \\
\hline 410 & $\mathbf{K}+\mathbf{1}$ & 3.043E-04 & 100.0 & $0.000 \mathrm{E}+00$ & 0.0 & $0.000 E+00$ & 0.0 \\
\hline 60 & $\mathrm{Mg}+2$ & $2.650 \mathrm{E}-04$ & 100.0 & $0.000 \mathrm{E}+00$ & 0 & $0.000 \mathrm{E}+00$ & .0 \\
\hline
\end{tabular}




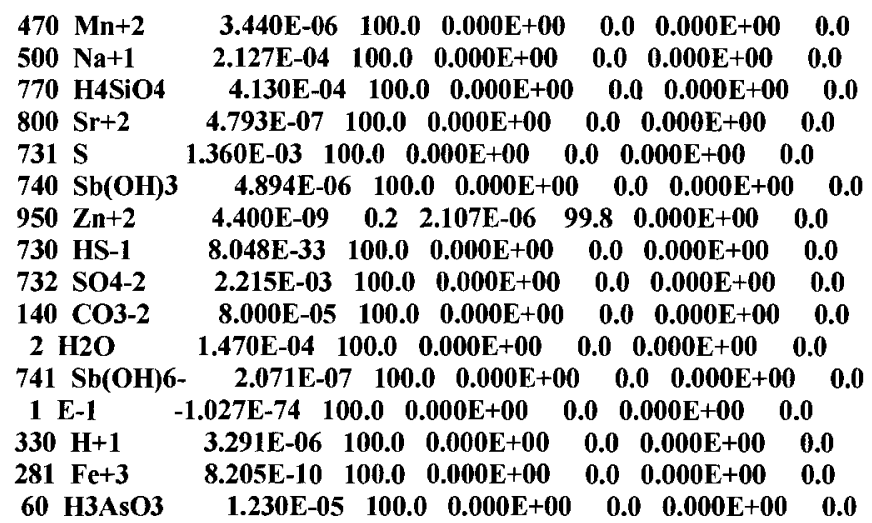

Charge Balance: SPECIATED

Sum of CATIONS $=3.008 \mathrm{E}-03$ Sum of ANIONS $3.834 \mathrm{E}-03$

PERCENT DIFFERENCE $=1.206 E+01$ (ANIONS - CATIONS) $/($ ANIONS + CATIONS)

EQUILIBRIUM IONIC STRENGTH $(\mathrm{m})=6.535 \mathrm{E}-03$

EQUILIBRIUM pH $\quad=\mathbf{5 . 4 8 0}$

EQUILIBRIUM pe $\quad=1.911$ or Eh $=111.16 \mathrm{mv}$

Saturation indices

\begin{tabular}{|c|c|}
\hline ID No & I \\
\hline $2074102 \mathrm{SbO} 2$ & 5.300 \\
\hline $2074004 \mathrm{Sb}(\mathrm{OH}) 3$ & 1.594 \\
\hline 2074006 SENARMONTITE & 1.246 \\
\hline 2077000 CHALCEDONY & 0.226 \\
\hline 2077001 CRISTOBALITE & 0.026 \\
\hline 2077002 QUARTZ & 0.683 \\
\hline $2003000 \mathrm{Al}(\mathrm{OH}) 3$ (am) & 0.170 \\
\hline 2003001 BOEHMITE & 2.372 \\
\hline 2003002 DIASPORE & 4.121 \\
\hline 2003003 GIBBSITE & 2.726 \\
\hline 2028102 GOETHITE & 0.278 \\
\hline 3003000 A12O3 & 2.178 \\
\hline $3020002 \mathrm{CoFe} 2 \mathrm{O} 4$ & 7.327 \\
\hline 3028000 MAGNETITE & 4.593 \\
\hline 3028001 HERCYNITE & 5.491 \\
\hline 3028100 HEMATITE & 2.933 \\
\hline 6003000 AIOHSO4 & 0.705 \\
\hline 6003001 Al4(OH)10SO4 & 8.680 \\
\hline 8603000 HALLOYSITE & 5.720 \\
\hline 8603001 KAOLINITE & 7.960 \\
\hline
\end{tabular}

S2 - $130 \mathrm{~cm}$ Depth - No Adsorption

INPUT DATA BEFORE TYPE MODIFICATIONS

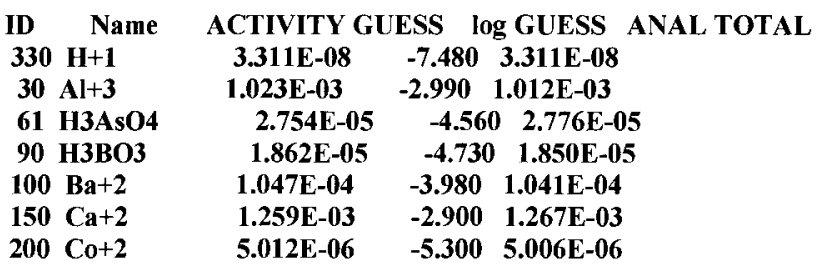




\begin{tabular}{|c|c|c|}
\hline $31 \mathrm{Cu}+2$ & 1.622E-06 & $-5.790 \quad 1.605 E-06$ \\
\hline $80 \mathrm{Fe}+2$ & 5.129E-04 & $-3.290 \quad 5.0$ \\
\hline $0 \mathbf{K}+1$ & 5 & -4.0608 .6 \\
\hline $0 \mathrm{Mg}+2$ & $7.586 E-04$ & $-3.120 \quad 5.650 \mathrm{E}-04$ \\
\hline $0 \mathrm{Mn}+2$ & $1.738 \mathrm{E}$ & -4.7601 .7 \\
\hline $0 \mathrm{Na}+1$ & 1.622E-04 & $-3.790 \quad 1.618 E-04$ \\
\hline $0 \mathrm{H} 4 \mathrm{SiO4}$ & E-03 & $-2.870 \quad 1.356 \mathrm{E}-03$ \\
\hline $00 \mathrm{Sr}+2$ & $7.586 \mathrm{E}-07$ & $-6.1207 .647 \mathrm{E}-07$ \\
\hline & $.138 E-04$ & $-3.670 \quad 2.148 E$ \\
\hline $10 \mathrm{Sb}(\mathrm{OH}) 3$ & $2.951 \mathrm{E}-06$ & $-5.530 \quad 2.949 \mathrm{E}-06$ \\
\hline $1 \mathrm{Tl}(\mathrm{OH}$ & $1.230 \mathrm{E}-05$ & $-4.910 \quad 1.230 \mathrm{E}-05$ \\
\hline $30 \mathrm{Zn}+2$ & $5.370 \mathrm{E}-06$ & $-5.270 \quad 5.353 E-06$ \\
\hline $2 \mathrm{SO4-2}$ & $5.248 \mathrm{E}-04$ & $-3.280 \quad 5.205 E-04$ \\
\hline $140 \mathrm{CO3}-2$ & $2.344 E-03$ & $-2.630 \quad 2.995 E-03$ \\
\hline $81 \mathrm{Fe}+3$ & $1.000 \mathrm{E}-07$ & $-7.000 \quad 0.000 \mathrm{E}+00$ \\
\hline 1 E-1 & $.000 \mathrm{E}-07$ & $-7.000 \quad 0.000 E+00$ \\
\hline $60 \mathrm{H3A}$ & 1.000E-07 & $-7.000 \quad 0.000 \mathrm{E}+00$ \\
\hline $741 \mathrm{Sb}(\mathrm{OH}) 6$ & 1.000E-07 & $-7.000 \quad 0.000 \mathrm{E}+0$ \\
\hline $471 \mathrm{Mn}+3$ & $1.000 E-07$ & $\begin{array}{rl}-7.000 & \mathbf{0 . 0 0 0 E}+00\end{array}$ \\
\hline 730 HS-1 & $1.000 \mathrm{E}-07$ & $-7.000 \quad 0.000 E+00$ \\
\hline $2 \mathrm{H} 2 \mathrm{O}$ & $1.000 \mathrm{E}+00$ & $0.000 \quad 0.000 \mathrm{E}+00$ \\
\hline
\end{tabular}

Charge Balance: UNSPECIATED

Sum of CATIONS $=8.234 \mathrm{E}-03 \mathrm{Sum}$ of $\mathrm{ANIONS}=7.031 \mathrm{E}-03$

PERCENT DIFFERENCE $=7.879 E+00$ (ANIONS - CATIONS) $/($ ANIONS + CATIONS)

EQUILIBRATED MASS DISTRIBUTION

$\begin{array}{lllll}\text { IDX Name } & \text { DISSOLVED } & \text { SORBED } & \text { PRECIPITATED } \\ \mathrm{mol} / \mathrm{L} & \begin{array}{l}\text { percent } \mathrm{mol} / \mathrm{L} \\ \text { percent } \mathrm{mol} / \mathrm{L}\end{array} & \text { percent }\end{array}$

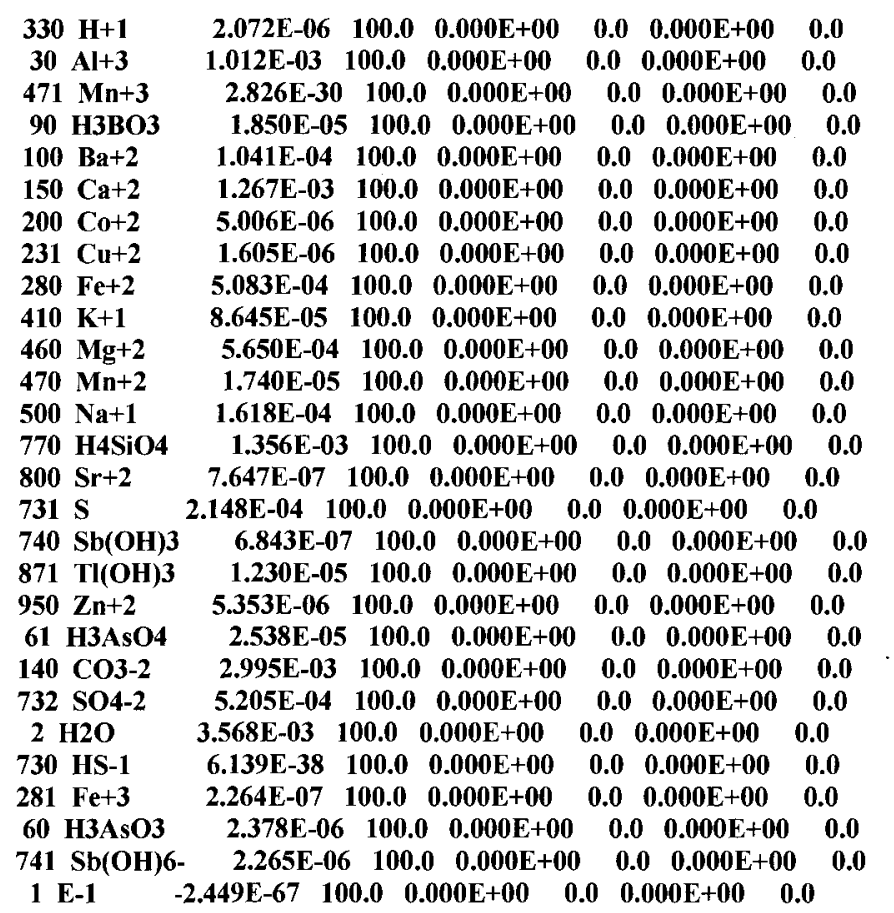

Charge Balance: SPECIATED

Sum of CATIONS $=\mathbf{5 . 0 9 7 E - 0 3 ~ S u m ~ o f ~ A N I O N S ~} 3.894 \mathrm{E}-03$ 
PERCENT DIFFERENCE $=1.338 \mathrm{E}+01$ (ANIONS - CATIONS) $/($ ANIONS + CATIONS $)$

EQUILIBRIUM IONIC STRENGTH $(\mathrm{m})=7.271 \mathrm{E}-03$

$\begin{array}{ll}\text { EQUILIBRIUM pH } & =6.907 \\ \text { EQUILIBRIUM pe } & =0.717 \text { or } \mathrm{Eh}=41.71 \mathrm{mv}\end{array}$

Saturation indices

\begin{tabular}{|c|c|c|}
\hline ID No & Name & \\
\hline 2074004 & $\mathrm{Sb}(\mathrm{OH}) 3$ & 0.740 \\
\hline 2077000 & CHALCEDONY & \\
\hline 2077001 & CRISTOBALITE & $\begin{array}{c}0.742 \\
0.543\end{array}$ \\
\hline 2077002 & QUARTZ & 1.200 \\
\hline 2003000 & $\mathrm{Al}(\mathrm{OH}) 3$ (am) & 1.959 \\
\hline 2003001 & BOEHMITE & 4.161 \\
\hline 2003002 & DIASPORE & 5.910 \\
\hline 2003003 & GIBBSITE & 4.515 \\
\hline 2087100 & AVICENNITE & 3.181 \\
\hline 2087101 & $\mathrm{Tl}(\mathrm{OH}) 3$ & 0.532 \\
\hline 2028100 & FERRIHYDRITE & 1.389 \\
\hline 2028102 & GOETHITE & 4.128 \\
\hline 3003000 & Al2O3 & 5.756 \\
\hline 3020002 & $\mathrm{CoFe} 2 \mathrm{O} 4$ & 20.945 \\
\hline 3028000 & MAGNETITE & 15.909 \\
\hline 3028001 & HERCYNITE & 12.686 \\
\hline 3028100 & HEMATITE & 10.632 \\
\hline 3028101 & MAGHEMITE & 3.214 \\
\hline 3028102 & LEPIDOCROCITE & 3.429 \\
\hline 3046001 & MAGNESIOFERRITE & \multirow{2}{*}{$\begin{array}{c}2.294 \\
10.217\end{array}$} \\
\hline 3023100 & CUPRIC FERRITE & \\
\hline 5023101 & MALACHITE & 0.046 \\
\hline $\mathbf{5 0 2 8 0 0 0}$ & SIDERITE & 0.573 \\
\hline 6003001 & Al4(OH) 10SO4 & 12.321 \\
\hline 6010000 & BARITE & 2.377 \\
\hline 7210000 & Ba3(AsO4)2 & 18.652 \\
\hline 8603000 & HALLOYSITE & 10.330 \\
\hline 8603001 & KAOLINITE & 12.570 \\
\hline 8628000 & GREENALIT & 4.463 \\
\hline
\end{tabular}

Core S3 - 45cm Depth - No Adsorption

INPUT DATA BEFORE TYPE MODIFICATIONS

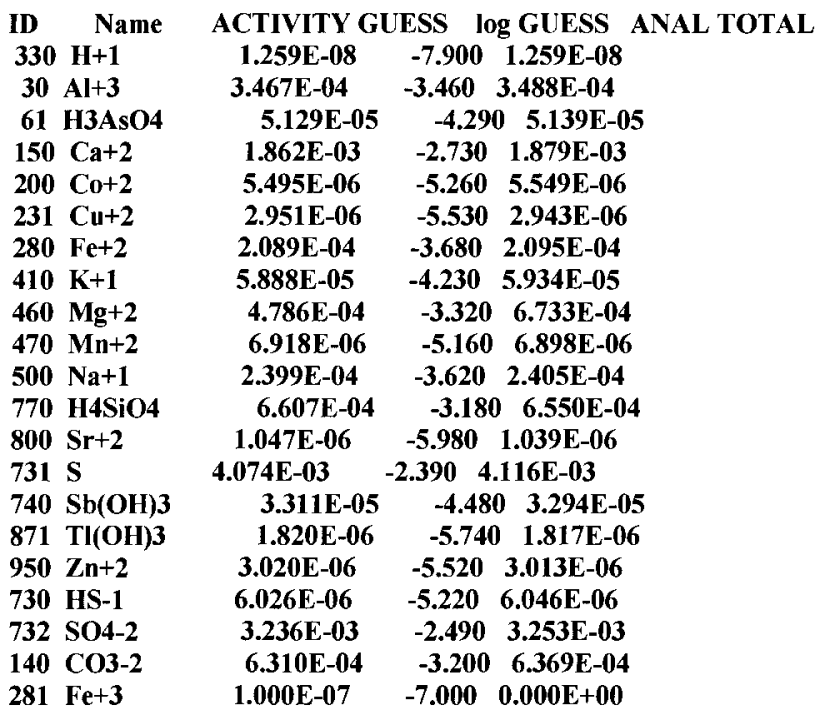




$\begin{array}{llccc}1 & \text { E-1 } & 1.000 E-07 & -7.000 & 0.000 E+00 \\ 60 & \text { H3AsO3 } & 1.000 E-07 & -7.000 & 0.000 E+00 \\ 741 & \mathrm{Sb}(\mathrm{OH}) 6- & 1.000 \mathrm{E}-07 & -7.000 & 0.000 \mathrm{E}+00 \\ 471 & \mathrm{Mn}+3 & 1.000 \mathrm{~B}-07 & -7.000 & 0.000 \mathrm{E}+00 \\ 2 & \mathrm{H} 2 \mathrm{O} & 1.000 \mathrm{E}+00 & 0.000 & 0.000 \mathrm{E}+00\end{array}$

Charge Balance: UNSPECIATED

Sum of CATIONS= $6.909 \mathrm{E}-03 \mathrm{Sum}$ of ANIONS $=7.786 \mathrm{E}-03$

PERCENT DIFFERENCE $=5.969$ E +00 (ANIONS - CATIONS)/(ANIONS + CATIONS)

EQUILIBRATED MASS DISTRIBUTION

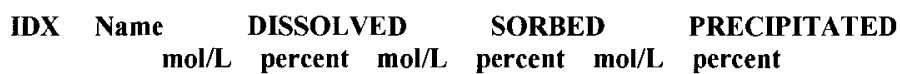

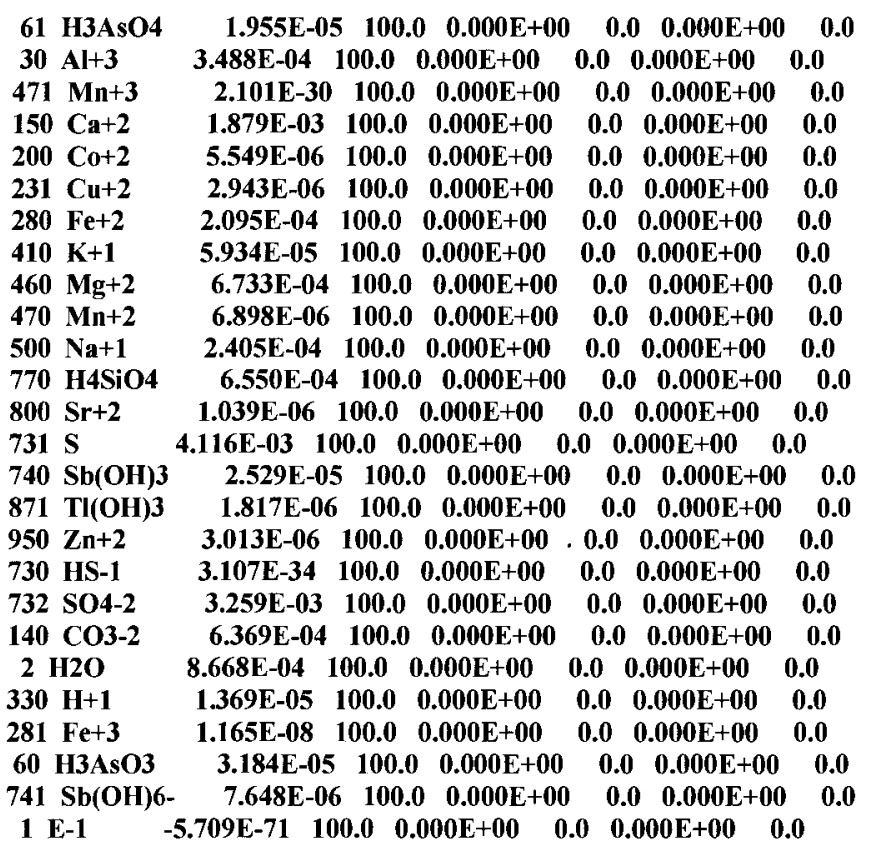

Charge Balance: SPECIATED

Sum of CATIONS $=4.974 \mathrm{E}-03 \mathrm{Sum}$ of ANIONS $5.851 \mathrm{E}-03$

PERCENT DIFFERENCE $=8.103 E+00$ (ANIONS - CATIONS) $/($ ANIONS + CATIONS)

EQUILIBRIUM IONIC STRENGTH $(\mathrm{m})=1.037 \mathrm{E}-02$

EQUILIBRIUM pH $\quad=6.363$

EQUILIBRIUM pe $\quad=1.009$ or Eh $=58.69 \mathrm{mv}$

Saturation indices

\begin{tabular}{lcc}
\multicolumn{1}{|c}{ ID No Name } & SI \\
& & \\
2074102 SbO2 & 5.995 & \\
2074001 Sb2O4 & 1.355 & \\
2074004 Sb(OH)3 & 2.308 & \\
2074006 SENARMONTITE & 2.673 \\
2077000 CHALCEDONY & 0.426
\end{tabular}




$\begin{array}{lc}\text { 2077001 CRISTOBALITE } & 0.227 \\ 2077002 \text { QUARTZ } & 0.884 \\ 2003000 \text { Al(OH)3 (am) } & 1.541 \\ \text { 2003001 BOEHMITE } & 3.743 \\ \text { 2003002 DIASPORE } & 5.492 \\ \text { 2003003 GIBBSITE } & 4.096 \\ \text { 2087100 AVICENNITE } & 1.521 \\ \text { 2028102 GOETHITE } & 2.301 \\ \text { 3003000 AI2O3 } & 4.920 \\ \text { 3020002 CoFe2O4 } & 16.197 \\ \text { 3028000 MAGNETITE } & 10.682 \\ \text { 3028001 HERCYNITE } & 10.275 \\ \text { 3028100 HEMATITE } & 6.980 \\ \text { 3028102 LEPIDOCROCITE } & 1.603 \\ \text { 3023100 CUPRIC FERRITE } & 6.193 \\ \text { 6003000 AIOHSO4 } & 0.428 \\ \text { 6003001 AI4(OH)10SO4 } & 12.515 \\ \text { 8603000 HALLOYSITE } & 8.863 \\ \text { 8603001 KAOLINITE } & 11.102\end{array}$

Core $\$ 33-45 c m$ Depth - Adsorption

\section{INPUT DATA BEFORE TYPE MODIFICATIONS}

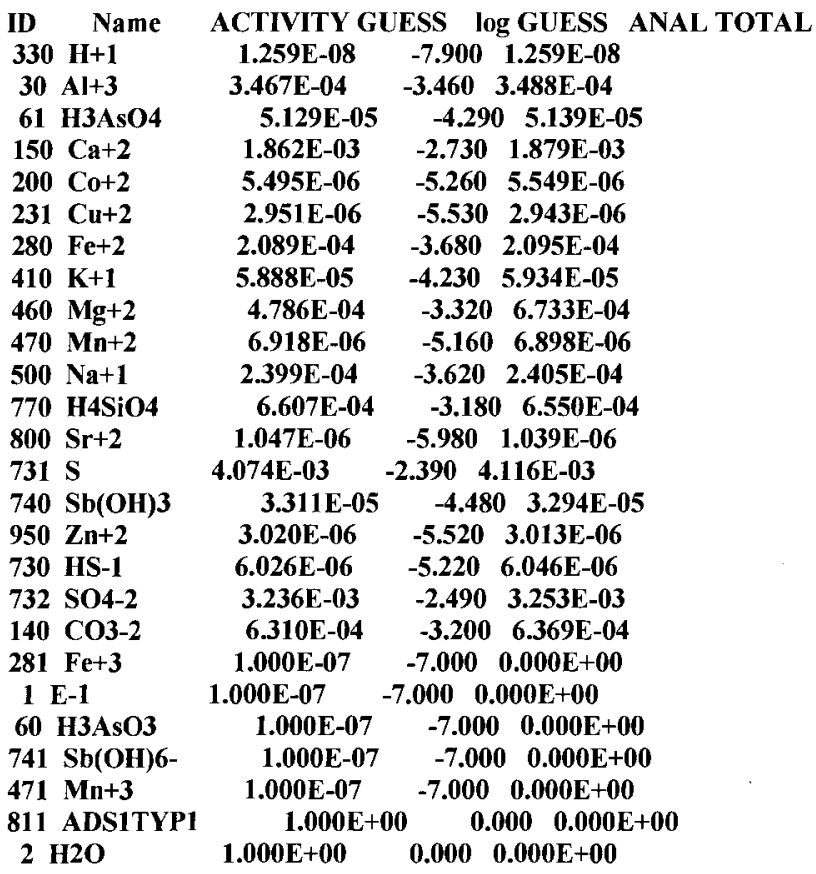

Charge Balance: UNSPECIATED

Sum of CATIONS $=6.909 \mathrm{E}-03$ Sum of ANIONS $=7.786 \mathrm{E}-03$

PERCENT DIFFERENCE $=5.969 \mathrm{E}+00$ (ANIONS - CATIONS) $/($ ANIONS + CATIONS)

EQUILIBRATED MASS DISTRIBUTION

IDX Name DISSOLVED SORBED PRECIPITATED $\mathrm{mol} / \mathrm{L}$ percent $\mathrm{mol} / \mathrm{L}$ percent $\mathrm{mol} / \mathrm{L}$ percent

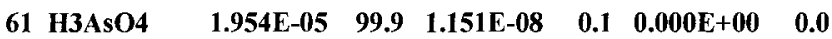




\begin{tabular}{|c|c|}
\hline $30 \mathrm{Al}+3$ & $\begin{array}{llll}3.488 E-04 & 100.0 & 0.000 E+00\end{array}$ \\
\hline $471 \mathrm{Mn}+3$ & $100.0 \quad 0.000 \mathrm{E}+00$ \\
\hline $50 \mathrm{Ca}+2$ & $\begin{array}{lll}1.879 \mathrm{E}-03 & 100.0 & 0.000 \mathrm{E}+00\end{array}$ \\
\hline $00 \mathrm{Co}+2$ & $99.60 .000 \mathrm{E}+00$ \\
\hline $31 \mathrm{Cu}+2$ & $99.70 .000 \mathrm{E}+00$ \\
\hline $30 \mathrm{Fe}+2$ & $\begin{array}{ccc}2.095 E-04 & 100.0 & 0.000 E+00\end{array}$ \\
\hline $10 \mathrm{~K}+1$ & $\begin{array}{lll}5.934 E-05 & 100.0 & 0.000 E\end{array}+00$ \\
\hline $60 \mathrm{Mg}+2$ & 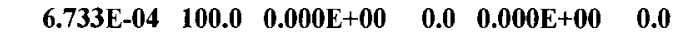 \\
\hline $70 \mathrm{Mn}+2$ & $\begin{array}{llll}6.898 E-06 & 100.0 & 0.000 \mathrm{E}+00\end{array}$ \\
\hline $00 \mathrm{Na}+1$ & 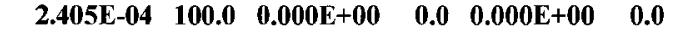 \\
\hline $70 \mathrm{H} 4 \mathrm{SiO} 4$ & $6.550 \mathrm{E}-04 \quad 100.0 \quad 0.000 \mathrm{E}+00$ \\
\hline $00 \mathrm{Sr}+2$ & 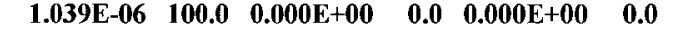 \\
\hline $731 \mathrm{~S}$ & $\begin{array}{llll}4.116 E-03 & 100.0 & 0.000 E & +00\end{array}$ \\
\hline $740 \mathrm{Sb}(\mathrm{OH}) 3$ & $\begin{array}{lll}2.530 \mathrm{E}-05 & 100.0 & 0.000 \mathrm{E}+00\end{array}$ \\
\hline $150 \mathrm{Zn}+2$ & $99.60 .000 \mathrm{E}+00$ \\
\hline 730 HS-1 & $\begin{array}{lll}3.124 \mathrm{E}-34 & 100.0 & 0.000 \mathrm{E}+00\end{array}$ \\
\hline $732 \mathrm{SO4-2}$ & $3.259 \mathrm{E}-03 \quad 100.0 \quad 0.000 \mathrm{E}+00$ \\
\hline $140 \mathrm{CO3}-2$ & $\begin{array}{llll}6.369 \mathrm{E}-04 & 100.0 & 0.000 \mathrm{E}+00\end{array}$ \\
\hline $2 \mathrm{H} 2 \mathrm{O}$ & $\begin{array}{llll}8.670 \mathrm{E}-04 & 100.0 & 0.000 \mathrm{E}+00\end{array}$ \\
\hline $741 \mathrm{Sb}(\mathrm{OH}) 6-$ & $\begin{array}{llll}7.644 E-06 & 100.0 & 0.000 E & +00\end{array}$ \\
\hline 1 E-1 & $\begin{array}{llll}-5.715 E-71 & 100.0 & 0.000 E+00\end{array}$ \\
\hline $330 \mathrm{H}+1$ & 1.369E-05 $100.0 \quad 0.000 E+00$ \\
\hline $281 \mathrm{Fe}+3$ & $\begin{array}{lll}1.165 E-08 & 100.0 & 0.000 E+00\end{array}$ \\
\hline $60 \mathrm{H} 3 \mathrm{AsO3}$ & $100.0 \quad 0.000 \mathrm{E}+00$ \\
\hline
\end{tabular}

Charge Balance: SPECIATED

Sum of CATIONS $=4.955 \mathrm{E}-03 \mathrm{Sum}$ of ANIONS $5.855 \mathrm{E}-03$

PERCENT DIFFERENCE $=8.326 E+00($ ANIONS - CATIONS $) /($ ANIONS + CATIONS)

EQUILIBRIUM IONIC STRENGTH $(\mathrm{m})=1.035 E-02$

$\begin{array}{ll}\text { EQUILIBRIUM pH } & =6.364 \\ \text { EQUILIBRIUM pe } & =1.008 \text { or Eh }=58.64 \mathrm{mv}\end{array}$

Saturation indices

\begin{tabular}{|c|c|c|}
\hline \multicolumn{3}{|c|}{ SI } \\
\hline 2074102 & $\mathrm{SbO2}$ & 5.994 \\
\hline 2074001 & Sb2O4 & 1.355 \\
\hline 2074004 & $\mathrm{Sb}(\mathrm{OH}) 3$ & 2.308 \\
\hline 2074006 & SENARMONTITE & 2.673 \\
\hline 2077000 & CHALCEDONY & 0.426 \\
\hline 2077001 & CRISTOBALITE & 0.227 \\
\hline 2077002 & QUARTZ & 0.884 \\
\hline 2003000 & $\mathbf{A l}(\mathrm{OH}) 3(\mathrm{am})$ & 1.541 \\
\hline 2003001 & ВОЕНМІТЕ & 3.743 \\
\hline 2003002 & DIASPORE & 5.492 \\
\hline 2003003 & GIBBSITE & 4.097 . \\
\hline 2028102 & GOETHITE & 2.302 \\
\hline 3003000 & Al2O3 & 4.920 \\
\hline 3020002 & $\mathrm{CoFe} 2 \mathrm{O} 4$ & 13.823 \\
\hline 3028000 & MAGNETITE & 10.684 \\
\hline 3028001 & HERCYNITE & 10.276 \\
\hline 3028100 & HEMATITE & 6.981 \\
\hline 3028102 & LEPIDOCROCIT & 1.603 \\
\hline 3023100 & CUPRIC FERRITE & \multirow{2}{*}{${ }^{\text {ITE }}{ }_{0.427}^{3.658}$} \\
\hline 6003000 & AlOHSO4 & \\
\hline 6003001 & $\mathrm{Al4}(\mathrm{OH}) 10 \mathrm{SO4}$ & 12.515 \\
\hline $8603000 \mathrm{~J}$ & HALLOYSITE & \\
\hline 8603001 & KAOLINITE & $\begin{array}{r}8.863 \\
11.103\end{array}$ \\
\hline
\end{tabular}

Core S3 - 75cm Depth - No Adsorption 


\section{INPUT DATA BEFORE TYPE MODIFICATIONS}

\begin{tabular}{|c|c|c|}
\hline Name & \multicolumn{2}{|c|}{ ACTIVITY GUESS log GUESS ANAL TOTAL } \\
\hline $330 \mathrm{H}+1$ & $1.072 E-08$ & $-7.970 \quad 1.072 \mathrm{E}-08$ \\
\hline $30 \mathrm{Al}+\mathbf{3}$ & 3.090E-05 & $-4.510 \quad 3.095 \mathrm{E}-05$ \\
\hline $61 \mathrm{H3AsO4}$ & 2.692E-05 & $-4.570 \quad 2.683 \mathrm{E}-05$ \\
\hline $150 \mathrm{Ca}+2$ & 1.413E-03 & $-2.850 \quad 2.687 \mathrm{E}-03$ \\
\hline $200 \mathrm{Co}+2$ & 4.898E-07 & $-6.310 \quad 4.921 E-07$ \\
\hline $231 \mathrm{Cu}+2$ & $3.802 \mathrm{E}-07$ & $-6.420 \quad 3.777 \mathrm{E}-07$ \\
\hline $280 \mathrm{Fe}+2$ & $1.445 \mathrm{E}-05$ & $-4.840 \quad 1.450 \mathrm{E}-05$ \\
\hline $410 \mathrm{~K}+1$ & $8.318 E-05$ & $-4.080 \quad 9.200 \mathrm{E}-05$ \\
\hline $460 \mathrm{Mg}+2$ & $3.890 \mathrm{E}-04$ & $-3.4108 .000 E-04$ \\
\hline $470 \mathrm{Mn}+2$ & $3.236 \mathrm{E}-06$ & $-5.490 \quad 3.240 \mathrm{E}-06$ \\
\hline $500 \mathrm{Na}+1$ & 2.042E-04 & $-3.690 \quad 4.000 \mathrm{E}-04$ \\
\hline $770 \mathrm{H} 4 \mathrm{SiO} 4$ & $1.862 E-04$ & $-3.730 \quad 1.844 E-04$ \\
\hline $800 \mathrm{Sr}+2$ & $1.950 \mathrm{E}-06$ & $-5.710 \quad 1.952 E-06$ \\
\hline $731 \mathrm{~S}$ & $2.239 \mathrm{E}-03$ & $-2.650 \quad 2.229 \mathrm{E}-03$ \\
\hline $740 \mathrm{Sb}(\mathrm{OH}) 3$ & $2.570 \mathrm{E}-05$ & $-4.590 \quad 2.595 E-05$ \\
\hline $871 \mathrm{Tl}(\mathrm{OH}) 3$ & 3.311E-07 & $-6.480 \quad 3.342 E-07$ \\
\hline $950 \mathrm{Zn}+2$ & $5.129 \mathrm{E}-06$ & $-5.290 \quad 5.170 \mathrm{E}-06$ \\
\hline 730 HS-1 & $3.020 \mathrm{E}-06$ & $-5.520 \quad 3.023 E-06$ \\
\hline $732 \mathrm{SO4-2}$ & $4.571 \mathrm{E}-03$ & $-2.340 \quad 3.500 \mathrm{E}-03$ \\
\hline $140 \mathrm{CO} 3-2$ & $1.230 \mathrm{E}-03$ & $-2.910 \quad 1.200 E-04$ \\
\hline $281 \mathrm{Fe}+3$ & $1.000 \mathrm{E}-07$ & $-7.000 \quad 0.000 \mathrm{E}+00$ \\
\hline 1 E-1 & 1.000E-07 & $7.000 \quad 0.000 \mathrm{E}+00$ \\
\hline $60 \mathrm{H3AsO3}$ & $1.000 \mathrm{E}-07$ & $-7.000 \quad 0.000 E+00$ \\
\hline $741 \mathrm{Sb}(\mathrm{OH}) 6-$ & 1.000E-07 & $-7.000 \quad 0.000 \mathrm{E}+00$ \\
\hline $471 \mathrm{Mn}+3$ & $1.000 E-07$ & $-7.000 \quad 0.000 \mathrm{E}+00$ \\
\hline $2 \mathrm{H} 2 \mathrm{O}$ & $1.000 \mathrm{E}+00$ & $0.000 \quad 0.000 \mathrm{E}+00$ \\
\hline
\end{tabular}

Charge Balance: UNSPECIATED

Sum of CATIONS $=7.610 \mathrm{E}-03$ Sum of ANIONS $=7.243 \mathrm{E}-03$

PERCENT DIFFERENCE $=2.473 E+00$ (ANIONS - CATIONS) $/($ ANIONS + CATIONS)

EQUILIBRATED MASS DISTRIBUTION

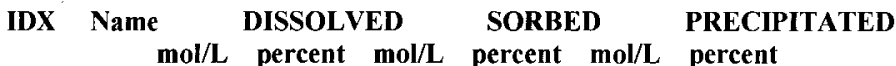

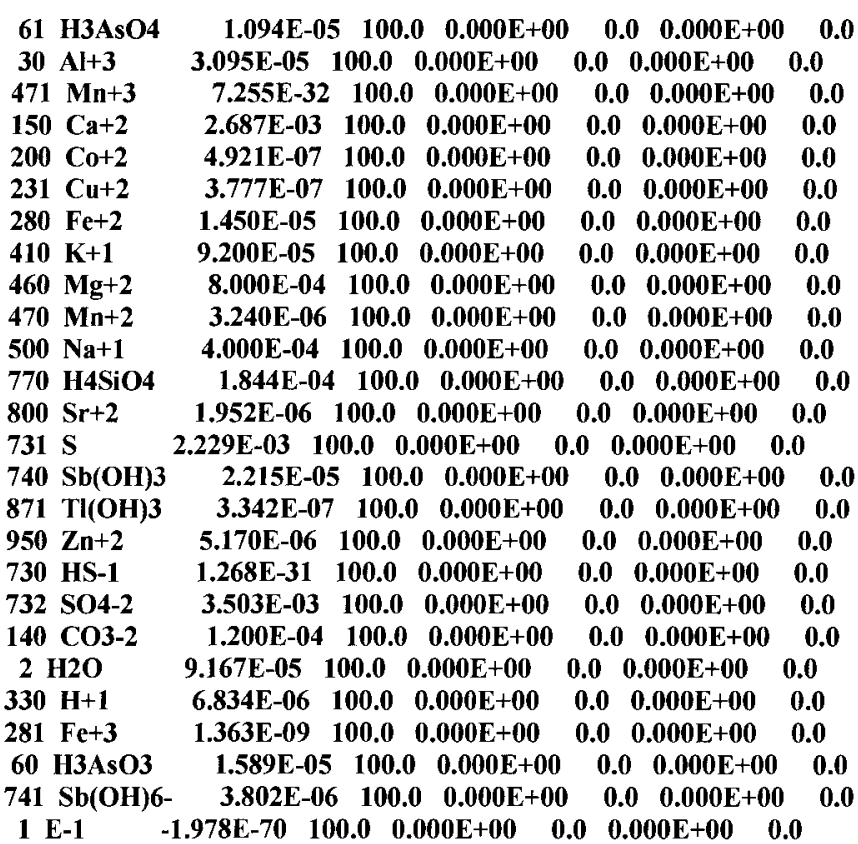




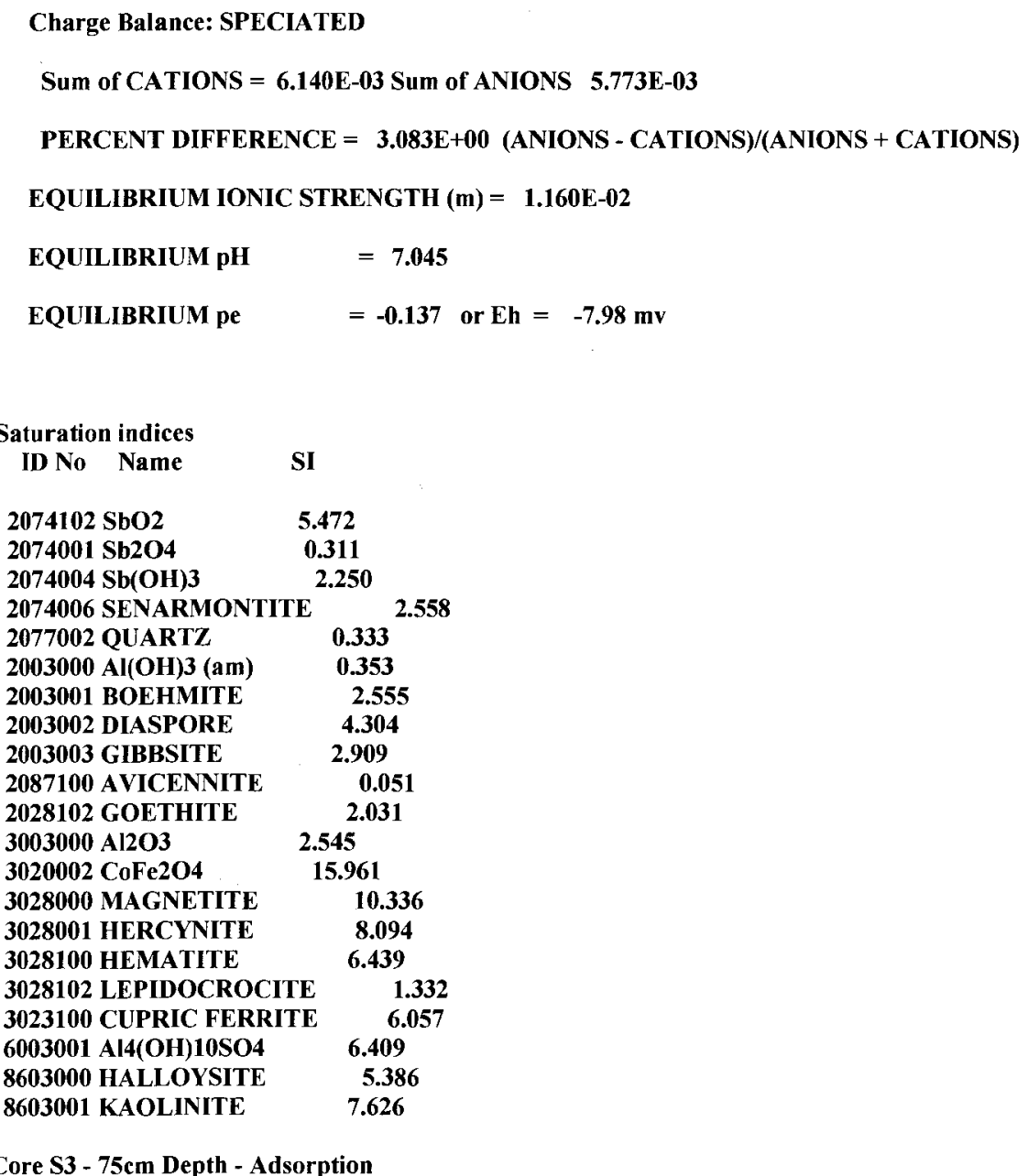

INPUT DATA BEFORE TYPE MODIFICATIONS

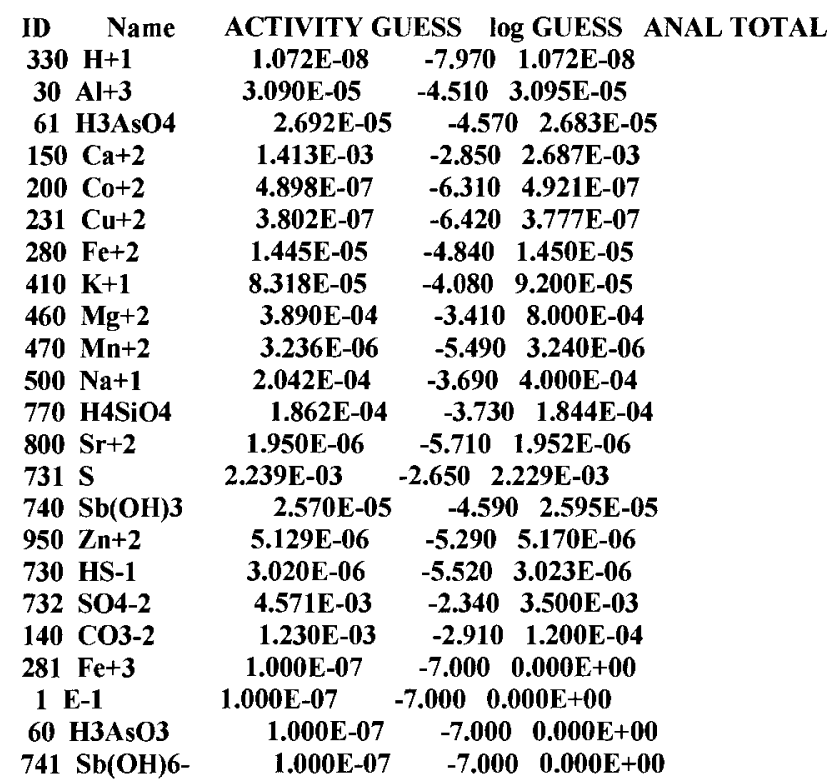




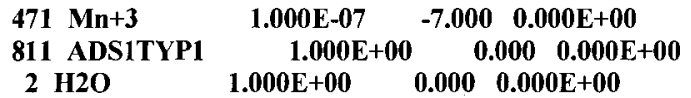

Charge Balance: UNSPECIATED

Sum of CATIONS= 7.610E-03 Sum of ANIONS = 7.243E-03

PERCENT DIFFERENCE $=2.473 E+00$ (ANIONS - CATIONS)/(ANIONS + CATIONS)

IDX Name DISSOLVED SORBED PRECIPITATED

$\mathrm{mol} / \mathrm{L}$ percent mol/L percent $\mathrm{mol} / \mathrm{L}$ percent

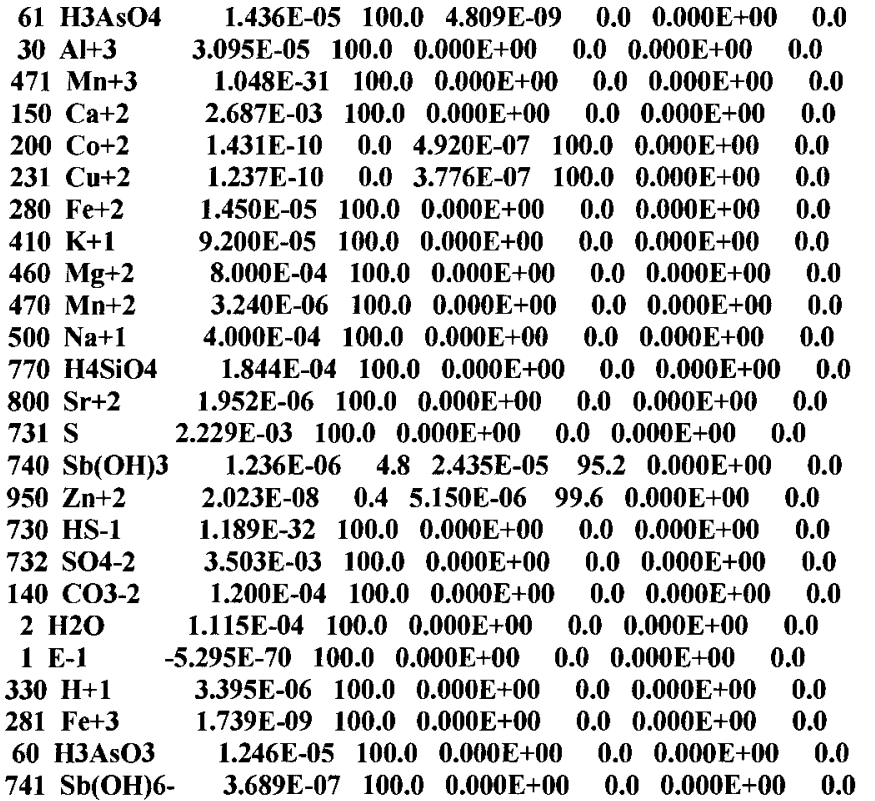

Charge Balance: SPECIATED

Sum of CATIONS $=6.130 \mathrm{E}-03$ Sum of ANIONS $5.775 \mathrm{E}-03$

PERCENT DIFFERENCE $=2.984 \mathrm{E}+00$ (ANIONS - CATIONS)/(ANIONS + CATIONS)

EQUILIBRIUM IONIC STRENGTH $(\mathrm{m})=1.159 \mathrm{E}-02$

$\begin{array}{ll}\text { EQUILIBRIUM pH } & =7.018 \\ \text { EQUILIBRIUM pe } & =0.023 \text { or Eh }=1.31 \mathrm{mv}\end{array}$

Saturation indices

ID No Name SI

\begin{tabular}{lcc} 
2074102 SbO2 & \multicolumn{2}{c}{4.352} \\
2074004 Sb(OH)3 & 0.997 \\
2074006 SENARMONTITE & \multicolumn{2}{c}{0.051} \\
2077002 QUARTZ & 0.333 \\
2003000 AI(OH)3 (am) & 0.371 \\
2003001 BOEHMITE & 2.573 \\
2003002 DIASPORE & 4.322 \\
2003003 GIBBSITE & 2.926
\end{tabular}




$\begin{array}{lc}\text { 2028102 GOETHITE } & 2.112 \\ 3003000 \text { AI2O3 } & 2.580 \\ \text { 3020002 COFE2O4 } & 12.533 \\ \text { 3028000 MAGNETITE } & 10.444 \\ \text { 3028001 HERCYNITE } & 8.077 \\ \text { 3028100 HEMATITE } & 6.600 \\ \text { 3028102 LEPIDOCROCITE } & 1.413 \\ \text { 3023100 CUPRIC FERRITE } & 2.687 \\ \text { 6003001 AI4OH)10SO4 } & 6.533 \\ \text { 8603000 HALLOYSITE } & 5.421 \\ \text { 8603001 KAOLINITE } & 7.661\end{array}$

Core S4 - 23em Depth - No Adsorption

\section{INPUT DATA BEFORE TYPE MODIFICATIONS}

\begin{tabular}{|c|c|c|}
\hline Name & ACTIVITY GUESS & $\log$ GUESS A \\
\hline $330 \mathrm{H}+1$ & 2.512E-08 & $-7.600 \quad 2.512 \mathrm{E}-08$ \\
\hline $30 \mathrm{Al}+3$ & 2.239E-04 & $-3.650 \quad 2.231 E-04$ \\
\hline $61 \mathrm{H3AsO4}$ & 2.138E-05 & $-4.670 \quad 2.149 \mathrm{E}-05$ \\
\hline $150 \mathrm{Ca}+2$ & 2.089E-03 & $-2.680 \quad 2.103 E-03$ \\
\hline $200 \mathrm{Co}+2$ & 5.495E-06 & $-5.260 \quad 5.498 \mathrm{E}-06$ \\
\hline $231 \mathrm{Cu}+2$ & 1.413E-06 & $\begin{array}{cc}-5.850 & 1.416 \mathrm{E}-06\end{array}$ \\
\hline $280 \mathrm{Fe}+2$ & $1.585 \mathrm{E}-04$ & $-3.800 \quad 1.586 E-04$ \\
\hline $410 \mathrm{~K}+1$ & 1.585E-04 & $-3.800 \quad 1.578 E-(04$ \\
\hline $460 \mathrm{Mg}+2$ & 5.623E-04 & $-3.250 \quad 7.700 \mathrm{E}-04$ \\
\hline $470 \mathrm{Mn}+2$ & $4.786 \mathrm{E}-06$ & $-5.320 \quad 4.805 E-06$ \\
\hline $500 \mathrm{Na}+1$ & $3.715 \mathrm{E}-04$ & $-3.430 \quad 3.736 \mathrm{E}-04$ \\
\hline 770 H4SiO4 & 5.754E-04 & $-3.240 \quad 5.732 E-04$ \\
\hline $800 \mathrm{Sr}+2$ & $1.995 \mathrm{E}-06$ & $-5.700 \quad 1.986 E-06$ \\
\hline $731 \mathrm{~S}$ & $4.677 \mathrm{E}-03$ & $-2.330 \quad 4.708 \mathrm{E}-03$ \\
\hline $740 \mathrm{Sb}(\mathrm{OH}) 3$ & $7.762 \mathrm{E}-06$ & $-5.110 \quad 7.754 \mathrm{E}-06$ \\
\hline $871 \mathrm{Tl}(\mathrm{OH}) 3$ & 2.344E-06 & $-5.630 \quad 2.318 E-06$ \\
\hline $950 \mathrm{Zn}+2$ & $2.570 \mathrm{E}-06$ & $\begin{array}{rl}-5.590 & 2.600 \mathrm{E}-06\end{array}$ \\
\hline 730 HS-1 & $1.820 \mathrm{E}-05$ & $-4.740 \quad 1.814 \mathrm{E}-05$ \\
\hline $732 \mathrm{SO} 4-2$ & $5.495 \mathrm{E}-03$ & $-2.260 \quad 3.300 \mathrm{E}-03$ \\
\hline $140 \mathrm{CO3-2}$ & 1.514E-03 & $-2.820 \quad 1.000 \mathrm{E}-04$ \\
\hline $281 \mathrm{Fe}+3$ & $1.000 \mathrm{E}-07$ & $-7.000 \quad 0.000 E+00$ \\
\hline $1 \mathrm{E}-1$ & $1.000 \mathrm{E}-07$ & $-7.000 \quad 0.000 \mathrm{E}+00$ \\
\hline $60 \mathrm{H3AsO3}$ & 1.000E-07 & $-7.000 \quad 0.000 \mathrm{E}+00$ \\
\hline $741 \mathrm{Sb}(\mathrm{OH}) 6-$ & 1.000E-07 & $-7.000 \quad 0.000 \mathrm{E}+00$ \\
\hline $471 \mathrm{Mn}+3$ & 1.000E-07 & $-7.000 \quad 0.000 \mathrm{E}+00$ \\
\hline $2 \mathrm{H} 20$ & $1.000 E+00$ & $0.000 \quad 0.000 E+00$ \\
\hline
\end{tabular}

Charge Balance: UNSPECIATED

Sum of CATIONS $=7.297 \mathrm{E}-03$ Sum of ANIONS $=6.818 \mathrm{E}-03$

PERCENT DIFFERENCE $=3.389 E+00($ ANIONS - CATIONS) $/($ ANIONS + CATIONS)

------ EQUILIBRATED MASS DISTRIBUTION -------

$\begin{array}{lllll}\text { IDX Name } & \text { DISSOLVED } & \text { SORBED } & \text { PRECIPITATED } \\ \mathrm{mol} / \mathrm{L} & \text { percent } \mathrm{mol} / \mathrm{L} & \text { percent } \mathrm{mol} / \mathrm{L} & \text { percent }\end{array}$

\begin{tabular}{|c|c|c|c|c|c|c|}
\hline $61 \mathrm{H3}$ & & 100 & $0 \mathrm{E}+00$ & & 0.0 & \\
\hline $30 \mathrm{Al}+3$ & $2.231 \mathrm{E}-04$ & 100.0 & $0.000 \mathrm{E}+00$ & 0.0 & $0.000 \mathrm{E}+00$ & 0.0 \\
\hline $471 \mathrm{Mn}+3$ & $7.856 \mathrm{E}-33$ & 100.0 & $0.000 \mathrm{E}+00$ & 0.0 & $0.000 \mathrm{E}+00$ & 0.0 \\
\hline $150 \mathrm{Ca}+2$ & $2.103 E-03$ & 100.0 & $0.000 E+00$ & 0.0 & $\mathbf{E}+00$ & 0.0 \\
\hline $200 \mathrm{Co}+2$ & $5.498 \mathrm{E}-06$ & 100.0 & $0.000 \mathrm{E}+00$ & 0.0 & 0.00 & 0.0 \\
\hline $1 \mathrm{Cu}+2$ & $1.416 \mathrm{E}-06$ & 100.0 & 0.00 & 0.0 & 0.0 & 0.0 \\
\hline $30 \mathrm{Fe}+2$ & $1.586 \mathrm{E}-04$ & 100.0 & $0.000 \mathrm{E}+00$ & 0.0 & $0.000 \mathrm{E}+00$ & 0.0 \\
\hline $10 \mathrm{~K}+1$ & $1.578 \mathrm{E}-04$ & 100.0 & $0.000 \mathrm{E}+00$ & 0.0 & $0.000 E+00$ & 0.0 \\
\hline $460 \mathrm{Mg}+2$ & $7.700 \mathrm{E}-04$ & 100.0 & $0.000 \mathrm{E}+00$ & 0.0 & $0.000 \mathrm{E}+00$ & 0.0 \\
\hline H3AsO & 2.149E-05 & 100.0 & $0.000 \mathrm{E}+00$ & 0. & $0.000 E+00$ & 0.0 \\
\hline $500 \mathrm{Na}+1$ & $3.736 \mathrm{E}-04$ & 100.0 & $0.000 \mathrm{E}+00$ & 0.0 & $0.000 \mathrm{E}+00$ & 0.0 \\
\hline
\end{tabular}




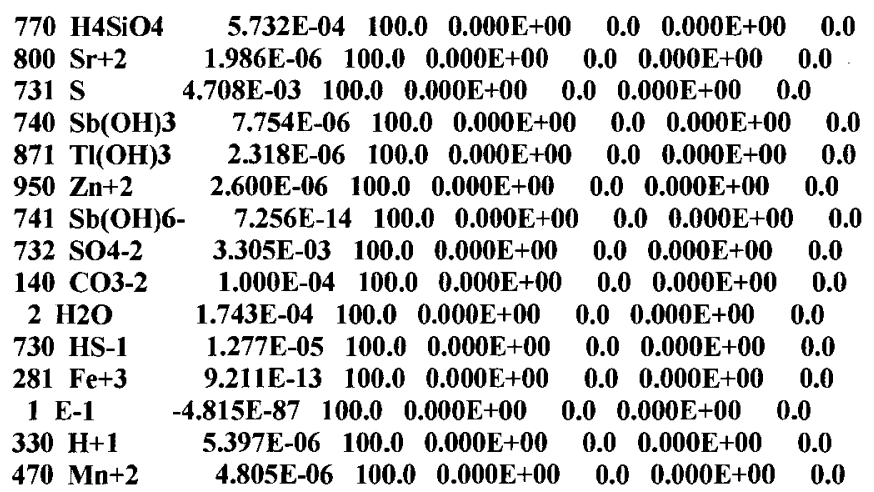

Charge Balance: SPECIATED

Sum of CATIONS $=5.755 E-03$ Sum of ANIONS $5.276 \mathrm{E}-03$

PERCENT DIFFERENCE $=4.337 E+00$ (ANIONS - CATIONS) $/($ ANIONS + CATIONS)

EQUILIBRIUM IONIC STRENGTH $(\mathrm{m})=1.070 \mathrm{E}-02$

$\begin{array}{ll}\text { EQUILIBRIUM pH } & =5.512 \\ \text { EQUILIBRIUM pe } & =-1.269 \text { or Eh }=-73.79 \mathrm{mv}\end{array}$

Saturation indices

ID No Name

SI

1006000 ORPIMENT

$1095000 \mathrm{ZnS}(\mathrm{am})$

1095001 SPHALERITE $\quad 2.804$

1095002 WURTZITE $\quad 0.278$

1023101 COVELLITE $\quad 12.958$

1023102 CHALCOPYRITE 19.127

$1020002 \operatorname{CoS}$ (beta) $\quad 2.671$

1028003 PYRITE 6.295

2074102 SbO2 $\quad 1.951$

$2074004 \mathrm{Sb}(\mathrm{OH}) 3 \quad 1.394$

2074006 SENARMONTITE $\quad 0.845$

2077000 CHALCEDONY $\quad 0.368$

2077001 CRISTOBALITE $\quad 0.169$

2077002 QUARTZ $\quad 0.826$

$2003000 \mathrm{Al}(\mathrm{OH}) 3$ (am) $\quad 0.294$

2003001 BOEHMITE $\quad 2.496$

2003002 DIASPORE $\quad 4.245$

2003003 GIBBSITE $\quad 2.849$

2087100 AVICENNITE $\quad 1.732$

$3003000 \mathrm{Al} 203 \quad \mathbf{2 . 4 2 6}$

3020002 CoFe2O4 $\quad 4.596$

3028001 HERCYNITE $\quad 5.960$

6003000 AlOHSO4 $\quad 0.867$

$6003001 \mathrm{Al} 4(\mathrm{OH}) 10 \mathrm{SO4} \quad 9.213$

8603000 HALLOYSITE $\quad 6.253$

8603001 KAOLINITE $\quad 8.493$

Core S4 - 23cm Depth - Adsorption

INPUT DATA BEFORE TYPE MODIFICATIONS

\begin{tabular}{llccc} 
ID & Name & \multicolumn{2}{c}{ ACTIVITY GUESS log GUESS ANAL TOTAL } \\
$330 \mathrm{H}+1$ & $2.512 \mathrm{E}-08$ & -7.600 & $2.512 \mathrm{E}-08$ \\
$30 \mathrm{Al}+3$ & $2.239 \mathrm{E}-04$ & -3.650 & $2.231 \mathrm{E}-04$ \\
61 $\mathrm{H3AsO4}$ & $2.138 \mathrm{E}-05$ & -4.670 & $2.149 \mathrm{E}-05$
\end{tabular}




\begin{tabular}{|c|c|c|}
\hline $150 \mathrm{Ca}+2$ & $2.089 \mathrm{E}-03$ & $-2.680 \quad 2.103 E-03$ \\
\hline $200 \mathrm{Co}+2$ & 5.495E-06 & $-5.260 \quad 5.498 \mathrm{E}-06$ \\
\hline $231 \mathrm{Cu}+2$ & $1.413 E-06$ & $-5.850 \quad 1.416 \mathrm{E}-06$ \\
\hline $280 \mathrm{Fe}+2$ & $1.585 E-04$ & $-3.800 \quad 1.586 E-04$ \\
\hline $410 K+1$ & 1.585E-04 & $-3.800 \quad 1.578 E-04$ \\
\hline $460 \mathrm{Mg}+2$ & $5.623 \mathrm{E}-04$ & $-3.250 \quad 7.700 \mathrm{E}-04$ \\
\hline $170 \mathrm{Mn}+2$ & $4.786 \mathrm{E}-06$ & $-5.320 \quad 4.805 E-06$ \\
\hline $300 \mathrm{Na}+1$ & $3.715 E-04$ & $-3.430 \quad 3.736 \mathrm{E}-04$ \\
\hline 70 H4SiO4 & $5.754 \mathrm{E}-04$ & $-3.240 \quad 5.732 \mathrm{E}-04$ \\
\hline $800 \mathrm{Sr}+2$ & $1.995 \mathrm{E}-06$ & $-5.700 \quad 1.986 \mathrm{E}-06$ \\
\hline $731 \mathrm{~S}$ & 4.677E-03 & $-2.330 \quad 4.708 \mathrm{E}-03$ \\
\hline $740 \mathrm{Sb}(\mathrm{OH}) 3$ & $7.762 \mathrm{E}-06$ & $-5.110 \quad 7.754 \mathrm{E}-06$ \\
\hline $950 \mathrm{Zn}+2$ & $2.570 \mathrm{E}-06$ & $-5.590 \quad 2.600 E-06$ \\
\hline 730 HS-1 & $1.820 \mathrm{E}-05$ & $-4.740 \quad 1.814 E-05$ \\
\hline $732 \mathrm{SO} 4-2$ & $5.495 E-03$ & $-2.260 \quad 3.300 \mathrm{E}-03$ \\
\hline $140 \mathrm{CO3}-2$ & $1.514 \mathrm{E}-03$ & $-2.820 \quad 5.000 \mathrm{E}-05$ \\
\hline $281 \mathrm{Fe}+3$ & $1.000 \mathrm{E}-07$ & $-7.000 \quad 0.000 E+00$ \\
\hline 1 E-1 & $1.000 \mathrm{E}-07$ & $-7.000 \quad 0.000 E+00$ \\
\hline $60 \mathrm{H3AsO3}$ & $1.000 \mathrm{E}-07$ & $-7.000 \quad 0.000 E+00$ \\
\hline $741 \mathrm{Sb}(\mathrm{OH}) 6-$ & $1.000 \mathrm{E}-07$ & $-7.000 \quad 0.000 E+00$ \\
\hline $471 \mathrm{Mn}+3$ & $1.000 \mathrm{E}-07$ & $-7.000 \quad 0.000 \mathrm{E}+00$ \\
\hline 811 ADS1TYP1 & $1.000 \mathrm{E}+0$ & $0.000 \quad 0.000 E+00$ \\
\hline $2 \mathrm{H} 2 \mathrm{O}$ & $1.000 \mathrm{E}+00$ & $0.000 \quad 0.000 \mathrm{E}+00$ \\
\hline
\end{tabular}

Charge Balance: UNSPECIATED

Sum of CATIONS $=7.297 \mathrm{E}-03$ Sum of ANIONS $=6.718 \mathrm{E}-03$

PERCENT DIFFERENCE $=4.127$ +00 (ANIONS - CATIONS) $/($ ANIONS + CATIONS)

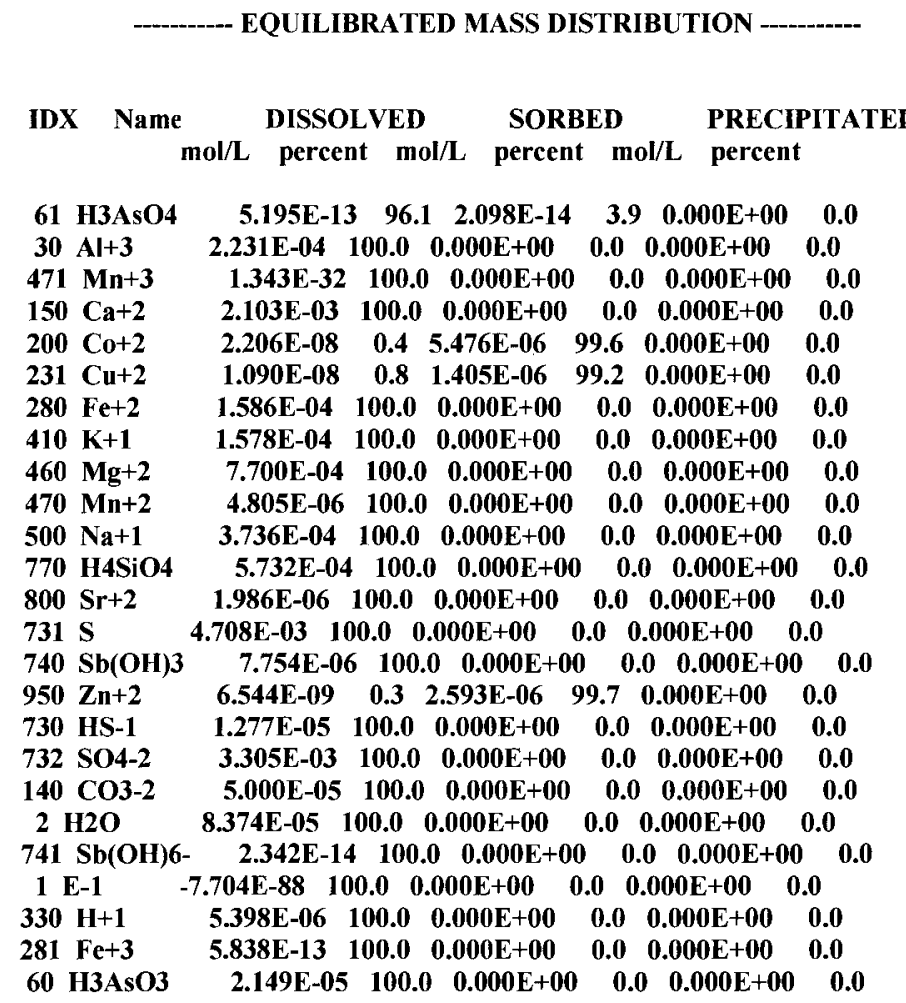

Charge Balance: SPECIATED

Sum of CATIONS $=5.767 \mathrm{E}-03$ Sum of ANIONS $5.207 \mathrm{E}-03$

PERCENT DIFFERENCE $=5.098 E+00$ (ANIONS - CATIONS)/(ANIONS + CATIONS) 
EQUILIBRIUM IONIC STRENGTH $(\mathrm{m})=1.066 \mathrm{E}-02$

$\begin{array}{ll}\text { EQUILIBRIUM pH } & =5.296 \\ \text { EQUILIBRIUM pe } & =-1.036 \text { or Eh }=-60.27 \mathrm{mv}\end{array}$

Saturation indices

ID No Name

SI

1095001 SPHALERITE $\quad 0.067$

1023101 COVELLITE $\quad 10.517$

1023102 CHALCOPYRITE $\quad 16.550$

1020002 CoS (beta) $\quad 0.138$

1028003 PYRITE $\quad 6.485$

$2074102 \mathrm{SbO2} \quad 1.659$

$2074004 \mathrm{Sb}(\mathrm{OH}) 3 \quad 1.085$

$\begin{array}{ll}2074006 & \text { SENARMONTITE } \\ 2 & 0.228\end{array}$

2077000 CHALCEDONY $\quad 0.368$

2077001 CRISTOBALITE $\quad \mathbf{0 . 1 6 9}$

2077002 QUARTZ $\quad 0.826$

2003001 BOEHMITE $\quad 1.990$

2003002 DIASPORE $\quad 3.739$

2003003 GIBBSITE $\quad 2.344$

$3003000 \mathrm{Al} 2 \mathrm{O3} \quad \mathbf{1 . 4 1 4}$

$3020002 \mathrm{CoFe} 2 \mathrm{O} 4 \quad 0.942$

3028001 HERCYNITE $\quad 4.518$

6003000 AlOHSO4 $\quad 0.788$

$6003001 \mathrm{Al}(\mathrm{OH}) 10 \mathrm{SO} 4 \quad 7.617$

8603000 HALLOYSITE $\quad 5.241$

8603001 KAOLINITE $\quad \mathbf{7 . 4 8 1}$

Core S4 - 45cm Depth - No Adsorption

INPUT DATA BEFORE TYPE MODIFICATIONS

\begin{tabular}{|c|c|c|c|}
\hline ID & Name & ACTIVITY GL & UESS log GUESS A \\
\hline 330 & $\mathbf{H}+\mathbf{1}$ & $2.291 \mathrm{E}-08$ & $-7.640 \quad 2.291 \mathrm{E}-08$ \\
\hline 30 & $\mathbf{A} \mathbf{l}+\mathbf{3}$ & $2.344 \mathrm{E}-04$ & $-3.630 \quad 2.331 E-04$ \\
\hline 61 & H3AsO4 & $4.467 \mathrm{E}-05$ & $-4.350 \quad 4.418 E-05$ \\
\hline 150 & $\mathrm{Ca}+2$ & $2.570 \mathrm{E}-03$ & $-2.590 \quad 2.595 E-03$ \\
\hline 200 & $\mathrm{Co}+2$ & $1.380 \mathrm{E}-05$ & $-4.860 \quad 1.393 E-05$ \\
\hline 231 & $\mathrm{Cu}+2$ & $1.622 \mathrm{E}-06$ & $-5.790 \quad 1.621 E-06$ \\
\hline 280 & $\mathrm{Fe}+2$ & 1.514E-04 & $-3.820 \quad 1.527 \mathrm{E}-04$ \\
\hline 410 & $\mathbf{K}+\mathbf{1}$ & $1.995 \mathrm{E}-04$ & $-3.700 \quad 2.003 E-04$ \\
\hline 460 & $\mathrm{Mg}+2$ & $6.310 \mathrm{E}-04$ & $-3.200 \quad 6.337 \mathrm{E}-04$ \\
\hline 470 & $\mathrm{Mn}+2$ & $7.762 \mathrm{E}-06$ & $-5.110 \quad 7.845 \mathrm{E}-06$ \\
\hline 500 & $\mathrm{Na}+1$ & $3.467 E-04$ & $-3.460 \quad 3.480 \mathrm{E}-04$ \\
\hline 770 & H4SiO4 & $5.495 \mathrm{E}-04$ & $-3.260 \quad 5.554 \mathrm{E}-04$ \\
\hline 800 & $\mathrm{Sr}+2$ & $2.455 E-06$ & $-5.610 \quad 2.465 E-06$ \\
\hline 731 & & $6.761 E-03$ & $-2.170 \quad 6.766 \mathrm{E}-03$ \\
\hline 740 & $\mathrm{Sb}(\mathrm{OH}) 3$ & $1.047 \mathrm{E}-05$ & $-4.980 \quad 1.051 \mathrm{E}-05$ \\
\hline 871 & $\mathrm{Tl}(\mathrm{OH}) 3$ & $1.905 \mathrm{E}-06$ & $-5.720 \quad 1.901 E-06$ \\
\hline 950 & $Z n+2$ & $3.090 \mathrm{E}-06$ & $-5.510 \quad 3.074 \mathrm{E}-06$ \\
\hline 730 & HS-1 & $4.571 \mathrm{E}-06$ & $-5.340 \quad 4.534 \mathrm{E}-06$ \\
\hline 732 & SO4-2 & $4.571 \mathrm{E}-03$ & $-2.340 \quad 4.554 \mathrm{E}-03$ \\
\hline 140 & $\mathrm{CO3-2}$ & $2.630 \mathrm{E}-04$ & $-3.580 \quad 2.650 \mathrm{E}-04$ \\
\hline 281 & $\mathbf{F e}+3$ & $1.000 \mathrm{E}-07$ & $-7.000 \quad 0.000 \mathrm{E}+00$ \\
\hline $1 \mathrm{E}$ & $E-1$ & $1.000 \mathrm{E}-07$ & $7.000 \quad 0.000 \mathrm{E}+00$ \\
\hline 601 & H3AsO3 & $1.000 \mathrm{E}-07$ & $-7.000 \quad 0.000 \mathrm{E}+00$ \\
\hline 741 & $\mathrm{Sb}(\mathrm{OH}) 6-$ & $1.000 \mathrm{E}-07$ & $-7.000 \quad 0.000 \mathrm{E}+00$ \\
\hline 471 & $\mathrm{Mn}+3$ & $1.000 \mathrm{E}-07$ & $-7.000 \quad 0.000 \mathrm{E}+00$ \\
\hline & 120 & $1.000 \mathrm{E}+00$ & $\begin{array}{lll}0.000 & 0.000 \mathrm{E}+00\end{array}$ \\
\hline
\end{tabular}

Sum of CATIONS $=8.068 \mathrm{E}-03$ Sum of ANIONS $=9.643 \mathrm{E}-03$ 
PERCENT DIFFERENCE $=8.889 \mathrm{E}+00$ (ANIONS - CATIONS)/(ANIONS + CATIONS)

------- EQUILIBRATED MASS DISTRIBUTION --------

IDX Name DISSOLVED SORBED PRECIPITATED

$\mathrm{mol} / \mathrm{L}$ percent $\mathrm{mol} / \mathrm{L}$ percent $\mathrm{mol} / \mathrm{L}$ percent

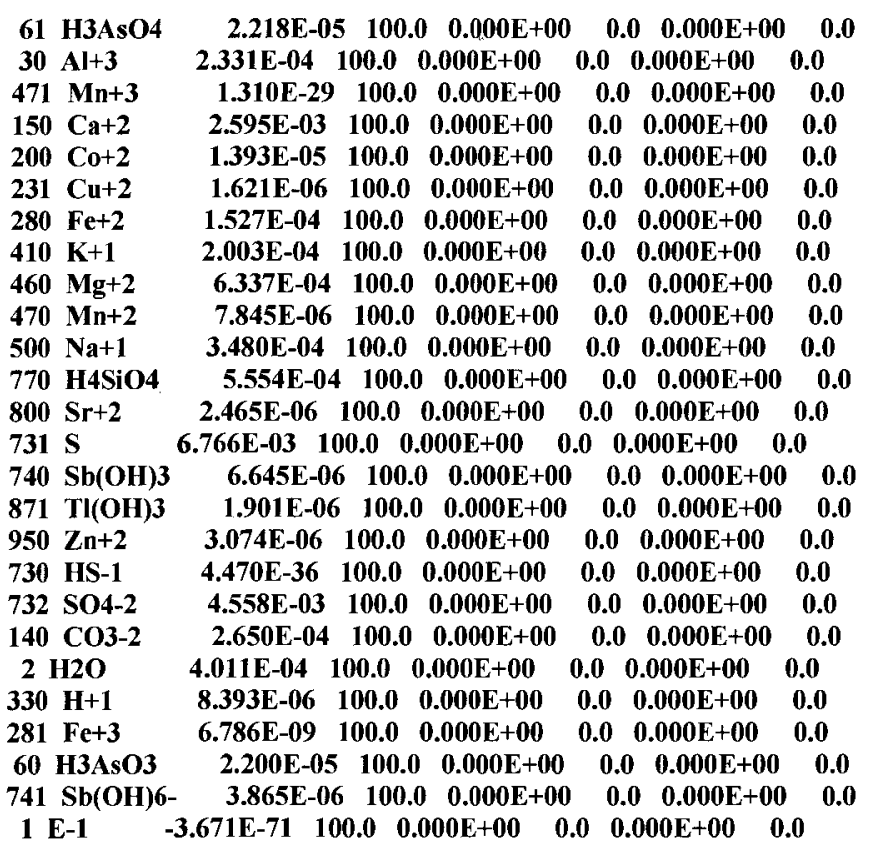

Charge Balance: SPECIATED

Sum of CATIONS $=\mathbf{5 . 9 8 0 E - 0 3 ~ S u m ~ o f ~ A N I O N S ~} 7.554 \mathrm{E}-03$

PERCENT DIFFERENCE $=1.163 E+01$ (ANIONS - CATIONS)/(ANIONS + CATIONS)

EQUILIBRIUM IONIC STRENGTH (m) $=1.312 \mathrm{E}-02$

EQUILIBRIUM pH $\quad=\mathbf{5 . 9 6 9}$

EQUILIBRIUM pe $\quad=1.740$ or Eh $=101.22 \mathrm{mv}$

Saturation indices

\begin{tabular}{lcc} 
ID No $\quad$ Name & SI \\
& \multicolumn{2}{c}{5.751} \\
2074102 SbO2 & 0.868 \\
2074001 Sb2O4 & 1.728 \\
2074004 Sb(OH)3 & \multicolumn{2}{c}{1.513} \\
2074006 SENARMONTITE & 0.355 \\
2077000 CHALCEDONY & 0.156 \\
2077001 CRISTOBALITE & 0.813 \\
2077002 QUARTZ & 0.037 \\
2003000 Al(OH)3 (am) & 1.3 .239 \\
2003001 BOEHMITE & \multicolumn{2}{c}{4.988} \\
2003002 DIASPORE & 3.593 \\
2003003 GIBBSITE & \multicolumn{2}{c}{1.561} \\
2087100 AVICENNITE & \multicolumn{2}{c}{1.670} \\
2028102 GOETHITE & 3.913 \\
3003000 Al2O3 & 14.510 \\
3020002 CoFe2O4 &
\end{tabular}




$\begin{array}{lc}\text { 3028000 MAGNETITE } & 8.452 \\ \text { 3028001 HERCYNITE } & 8.300 \\ \text { 3028100 HEMATITE } & 5.717 \\ \text { 3028102 LEPIDOCROCITE } & 0.971 \\ \text { 3023100 CUPRIC FERRITE } & 3.886 \\ \text { 6003000 AIOHSO4 } & 0.831 \\ \text { 6003001 Al4(OH)1OSO4 } & 11.407 \\ \text { 8603000 HALLOYSITE } & 7.713 \\ \text { 8603001 KAOLINITE } & 9.953\end{array}$

Core S4 - 45cm Depth - Adsorption

\section{INPUT DATA BEFORE TYPE MODIFICATIONS}

\begin{tabular}{|c|c|c|}
\hline Name & \multicolumn{2}{|c|}{ ACTIVITY GUESS log GUESS ANAL TOTAL } \\
\hline $330 \mathrm{H}+1$ & $2.291 \mathrm{E}-08$ & $-7.640 \quad 2.291 \mathrm{E}-08$ \\
\hline $30 \mathbf{A l}+3$ & 2.344E-04 & $-3.630 \quad 2.331 \mathrm{E}-04$ \\
\hline $61 \mathrm{H3AsO4}$ & $4.467 E-05$ & $-4.350 \quad 4.418 E-05$ \\
\hline $150 \mathrm{Ca}+2$ & 2.570E-03 & $-2.590 \quad 2.595 E-03$ \\
\hline $200 \mathrm{Co}+2$ & 1.380E-05 & $-4.860 \quad 1.393 E-05$ \\
\hline $231 \mathrm{Cu}+2$ & $1.622 \mathrm{E}-06$ & $-5.790 \quad 1.621 \mathrm{E}-06$ \\
\hline $280 \mathrm{Fe}+2$ & 1.514E-04 & $-3.820 \quad 1.527 \mathrm{E}-04$ \\
\hline $410 \mathrm{~K}+1$ & $1.995 \mathrm{E}-04$ & $-3.700 \quad 2.003 E-04$ \\
\hline $460 \mathrm{Mg}+2$ & 6.310E-04 & $-3.200 \quad 6.337 \mathrm{E}-04$ \\
\hline $470 \mathrm{Mn}+2$ & $7.762 \mathrm{E}-06$ & $-5.1107 .845 E-06$ \\
\hline $500 \mathrm{Na}+1$ & $3.467 E-04$ & $-3.460 \quad 3.480 E-04$ \\
\hline 770 H4SiO4 & 5.495E-04 & $-3.260 \quad 5.554 \mathrm{E}-04$ \\
\hline $800 \mathrm{Sr}+2$ & 2.455E-06 & $-5.610 \quad 2.465 E-06$ \\
\hline $731 \mathrm{~S}$ & $6.761 \mathrm{E}-03$ & $2.170 \quad 6.766 \mathrm{E}-03$ \\
\hline $740 \mathrm{Sb}(\mathrm{OH}) 3$ & 1.047E-05 & $-4.980 \quad 1.051 \mathrm{E}-05$ \\
\hline $950 \mathrm{Zn}+2$ & $3.090 \mathrm{E}-06$ & $-5.510 \quad 3.074 E-06$ \\
\hline 730 HS-1 & $4.571 \mathrm{E}-06$ & $-5.340 \quad 4.534 \mathrm{E}-06$ \\
\hline $732 \mathrm{SO}-2$ & $4.571 \mathrm{E}-03$ & $-2.340 \quad 4.554 \mathrm{E}-03$ \\
\hline $140 \mathrm{CO3}-2$ & $2.630 \mathrm{E}-04$ & $-3.580 \quad 2.650 \mathrm{E}-04$ \\
\hline $281 \mathrm{Fe}+3$ & 1.000E-07 & $-7.000 \quad 0.000 E+00$ \\
\hline 1 E-1 & 1.000E-07 & $7.000 \quad 0.000 \mathrm{E}+00$ \\
\hline $60 \mathrm{H} 3 \mathrm{AsO3}$ & $1.000 \mathrm{E}-07$ & $-7.000 \quad 0.000 \mathrm{E}+00$ \\
\hline $741 \mathrm{Sb}(\mathrm{OH}) 6-$ & $1.000 \mathrm{E}-07$ & $-7.000 \quad 0.000 \mathrm{E}+00$ \\
\hline $471 \mathrm{Mn}+3$ & $1.000 \mathrm{E}-07$ & $-7.000 \quad 0.000 \mathrm{E}+00$ \\
\hline 811 ADS1TYP1 & $1.000 \mathrm{E}+00$ & $0.000 \quad 0.000 \mathrm{E}+00$ \\
\hline $2 \mathrm{H} 2 \mathrm{O}$ & $1.000 \mathrm{E}+00$ & $0.000 \quad 0.000 E+00$ \\
\hline
\end{tabular}

Charge Balance: UNSPECIATED

Sum of CATIONS $=$ 8.068E-03 Sum of ANIONS $=9.643 E-03$

PERCENT DIFFERENCE $=8.889 E+00$ (ANIONS - CATIONS) $/($ ANIONS + CATIONS)

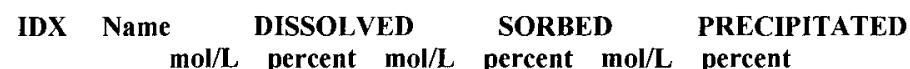

\begin{tabular}{|c|c|c|c|c|c|c|c|}
\hline 61 & H3AsO4 & $2.204 \mathrm{E}-0$ & 99.3 & $1.493 \mathrm{E}-07$ & 0.7 & $0.000 \mathrm{E}+00$ & 0.0 \\
\hline 30 & $\mathbf{A} \mathbf{I}+\mathbf{3}$ & $2.331 \mathrm{E}-04$ & 100.0 & $0.000 \mathrm{E}+00$ & 0.0 & $0.000 \mathrm{E}+00$ & 0.0 \\
\hline 471 & $M n+3$ & $1.303 E-29$ & 100.0 & $0.000 \mathrm{E}+00$ & 0.0 & $0.000 \mathrm{E}+00$ & 0.0 \\
\hline 150 & $\mathrm{Ca}+2$ & $2.595 \mathrm{E}-03$ & 100.0 & $0.000 \mathrm{E}+00$ & 0.0 & $0.000 \mathrm{E}+00$ & 0.0 \\
\hline 200 & $\mathrm{Co}+2$ & $6.143 E-08$ & 0.41 & $1.387 \mathrm{E}-05$ & 99.6 & $0.000 \mathrm{E}+00$ & 0.0 \\
\hline 231 & $\mathrm{Cu}+2$ & $2.416 \mathrm{E}-09$ & 0.11 & 1.619E-06 & 99.9 & $0.000 \mathrm{E}+00$ & 0.0 \\
\hline 80 & $\mathrm{Fe}+2$ & 1.527E-04 & 100.0 & $0.000 \mathrm{E}+00$ & 0.0 & $0.000 \mathrm{E}+00$ & 0.0 \\
\hline 410 & $\mathbf{K}+1$ & 2.003E-04 & 100.0 & $0.000 \mathrm{E}+00$ & 0.0 & $0.000 \mathrm{E}+00$ & 0.0 \\
\hline 460 & $\mathrm{Mg}+2$ & $6.337 \mathrm{E}-04$ & 100.0 & $0.000 \mathrm{E}+00$ & 0.0 & $0.000 E+00$ & 0.0 \\
\hline 470 & $\mathbf{M n}+2$ & $7.845 E-06$ & 100.0 & $0.000 \mathrm{E}+00$ & 0.0 & $0.000 \mathrm{E}+00$ & 0.0 \\
\hline 500 & $\mathrm{Na}+1$ & $3.480 \mathrm{E}-04$ & 100.0 & $0.000 \mathrm{E}+00$ & 0.0 & $0.000 E+00$ & 0.0 \\
\hline 770 & $\mathrm{H} 4 \mathrm{SiO} 4$ & $5.554 \mathrm{E}-04$ & 100.0 & $0 \quad 0.000 \mathrm{E}+00$ & 0 . & $0.000 \mathrm{E}+00$ & 0.0 \\
\hline 800 & $\mathbf{S r}+\mathbf{2}$ & $2.465 \mathrm{E}-06$ & 100.0 & $0.000 E+00$ & 0.0 & $0.000 \mathrm{E}+00$ & 0.0 \\
\hline
\end{tabular}




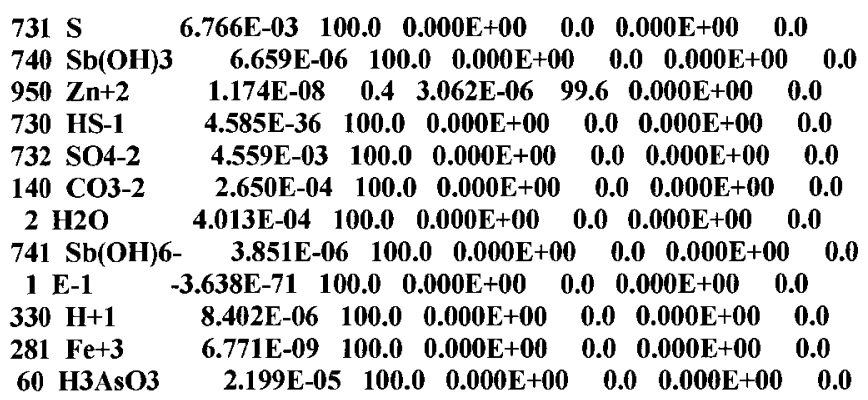

Core S5 - 23cm Depth - No Adsorption

\section{INPUT DATA BEFORE TYPE MODIFICATIONS}

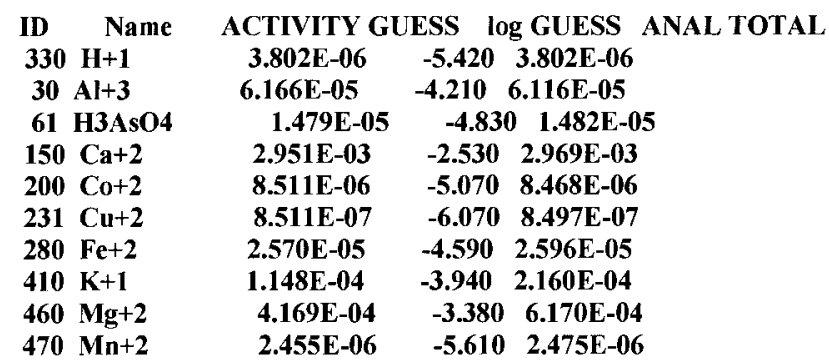




\begin{tabular}{|c|c|c|}
\hline $500 \mathrm{Na}+1$ & $3.090 \mathrm{E}-04$ & $-3.510 \quad 3.097 \mathrm{E}-04$ \\
\hline 770 H4SiO4 & 3.162E-04 & $-3.500 \quad 3.133 E-04$ \\
\hline $800 \mathrm{Sr}+2$ & $1.549 \mathrm{E}-06$ & $-5.810 \quad 1.541 E-06$ \\
\hline $731 \mathrm{~S}$ & $6.310 \mathrm{E}-03$ & $-2.200 \quad 6.299 \mathrm{E}-03$ \\
\hline $740 \mathrm{Sb}(\mathrm{OH}) 3$ & 8.128E-06 & $-5.090 \quad 8.205 E-06$ \\
\hline 871 Tl(OH)3 & $7.586 \mathrm{E}-07$ & $-6.120 \quad 7.519 E-07$ \\
\hline $950 Z n+2$ & $1.995 \mathrm{E}-06$ & $-5.700 \quad 1.973 E-06$ \\
\hline $732 \mathrm{SO}-2$ & 4.467E-03 & $-2.350 \quad 3.400 E-03$ \\
\hline $140 \mathrm{CO3-2}$ & $3.631 E-04$ & $-3.440 \quad 3.612 \mathrm{E}-04$ \\
\hline $281 \mathrm{Fe}+3$ & $1.000 E-07$ & $-7.000 \quad 0.000 E+00$ \\
\hline 1 E-1 & 1.000E-07 & $-7.000 \quad 0.000 \mathrm{E}+00$ \\
\hline $60 \mathrm{H} 3 \mathrm{AsO3}$ & $1.000 \mathrm{E}-07$ & $-7.000 \quad 0.000 \mathrm{E}+00$ \\
\hline $741 \mathrm{Sb}(\mathrm{OH}) 6-$ & $1.000 \mathrm{E}-07$ & $-7.000 \quad 0.000 \mathrm{E}+00$ \\
\hline $471 \mathrm{Mn}+3$ & 1.000E-07 & $-7.000 \quad 0.000 \mathrm{E}+00$ \\
\hline 730 HS-1 & 1.000E-07 & $-7.000 \quad 0.000 \mathrm{E}+00$ \\
\hline $2 \mathrm{H} 2 \mathrm{O}$ & $1.000 \mathrm{E}+00$ & $0.000 \quad 0.000 E+00$ \\
\hline
\end{tabular}

Charge Balance: UNSPECIATED

Sum of CATIONS $=7.968 \mathrm{E}-03$ Sum of ANIONS $=7.522 \mathrm{E}-03$

PERCENT DIFFERENCE $=2.874 \mathrm{E}+00($ ANIONS - CATIONS $) /($ ANIONS + CATIONS)

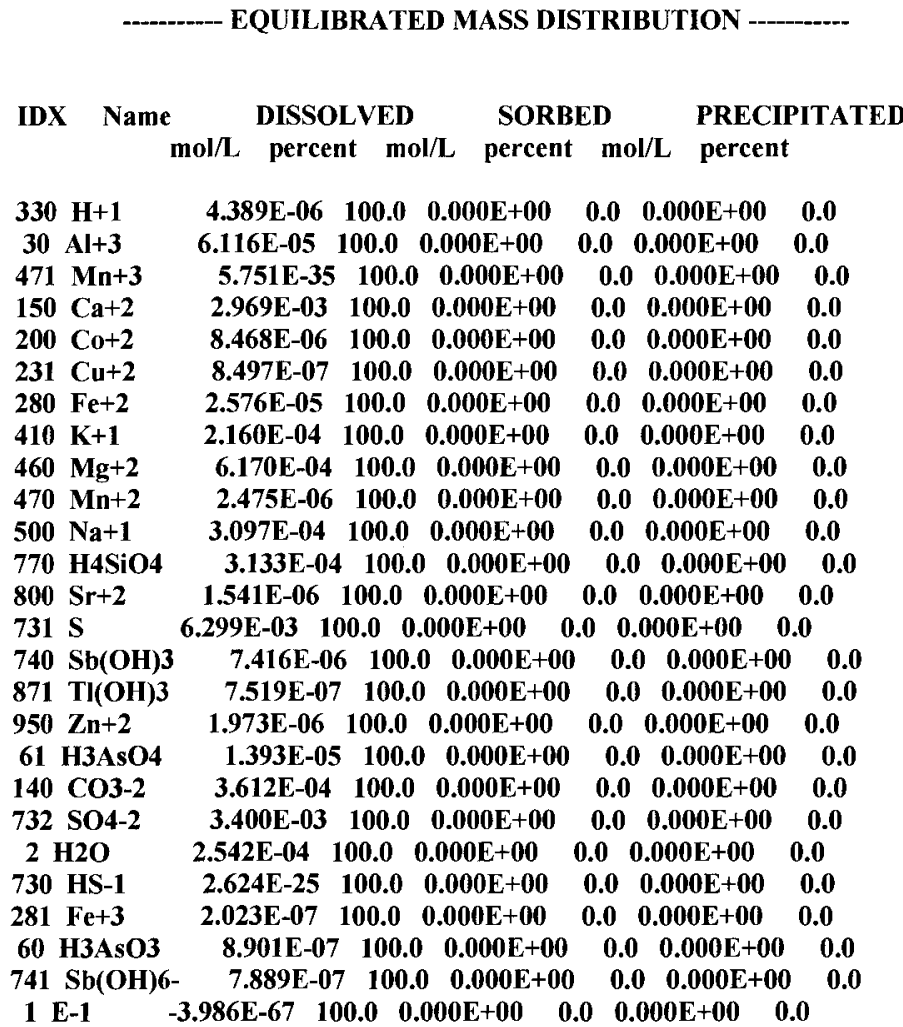

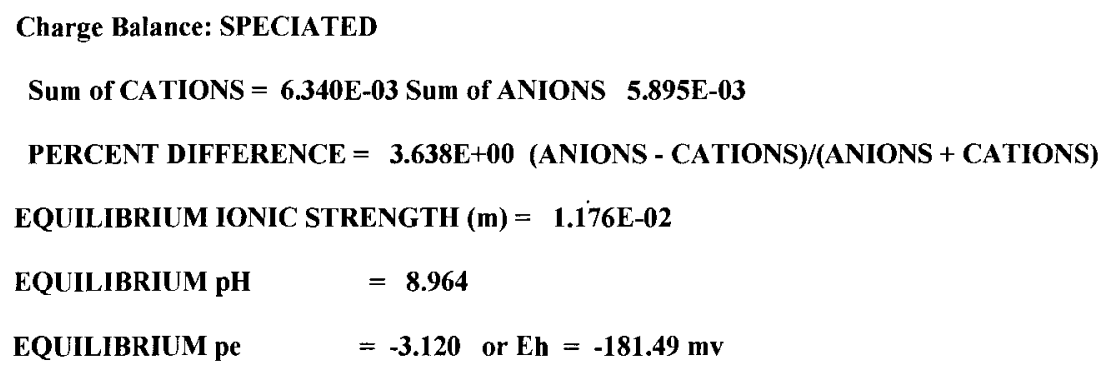


Saturation indices

\begin{tabular}{|c|c|c|}
\hline \multicolumn{3}{|c|}{ SI } \\
\hline 2074102 & $\mathbf{3 . 9 3 3}$ & 3.933 \\
\hline 2074004 & $\mathrm{Sb}(\mathrm{OH}) 3$ & 1.775 \\
\hline 2074006 & SENARMONTITE & 1.607 \\
\hline 2077000 & CHALCEDONY & 0.067 \\
\hline 2077002 & QUARTZ & 0.525 \\
\hline 2003001 & BOEHMITE & 1.050 \\
\hline 2003002 & DIASPORE & 2.798 \\
\hline 2003003 & GIBBSITE & 1.403 \\
\hline 2087100 & AVICENNITE & 0.753 \\
\hline 2095005 & ZnO (active) & 0.099 \\
\hline 2023100 & $\mathrm{Cu}(\mathrm{OH}) 2$ & 0.840 \\
\hline 2023101 & TENORITE & 1.845 \\
\hline 2028000 & WUSTITE & 1.251 \\
\hline 2028100 & FERRIHYDRITE & 2.262 \\
\hline 2028101 & $\mathrm{Fe} 3(\mathrm{OH}) 8$ & 4.109 \\
\hline 2028102 & GOETHITE & 5.000 \\
\hline 3020002 & $\mathrm{CoFe} 2 \mathrm{O} 4$ & 26.867 \\
\hline $\mathbf{3 0 2 8 0 0 0}$ & MAGNETITE & 20.306 \\
\hline 3028001 & HERCYNITE & 9.115 \\
\hline 3028100 & HEMATITE & 12.376 \\
\hline 3028101 & MAGHEMITE & 4.958 \\
\hline 3028102 & LEPIDOCROCITE & 4.301 \\
\hline 3046001 & MAGNESIOFERRITE & \multirow{2}{*}{$\begin{array}{lc}\text { TE } & 8.097 \\
14.410\end{array}$} \\
\hline 3023100 & CUPRIC FERRITE & \\
\hline 5023101 & MALACHITE & 2.006 \\
\hline $\mathbf{5 0 2 8 0 0 0}$ & SIDERITE & 0.286 \\
\hline 5015000 & ARAGONITE & 0.509 \\
\hline 5015001 & CALCITE & 0.663 \\
\hline 5015002 & DOLOMITE (ordered) & \\
\hline 5015004 & DOLOMITE (disordered & d) 0.171 \\
\hline 6023101 & BROCHANTITE & 2.215 \\
\hline 6023102 & LANGITE & 0.060 \\
\hline 8603000 & HALLOYSITE & 2.758 \\
\hline 8603001 & KAOLINITE & 998 \\
\hline 8628000 & GREENALITE & 1.070 \\
\hline 8646000 & CHRYSOTILE & 3.470 \\
\hline 8646003 & SEPIOLITE & \\
\hline
\end{tabular}

Core S5 - 23cm Depth - Adsorption

\section{INPUT DATA BEFORE TYPE MODIFICATIONS}

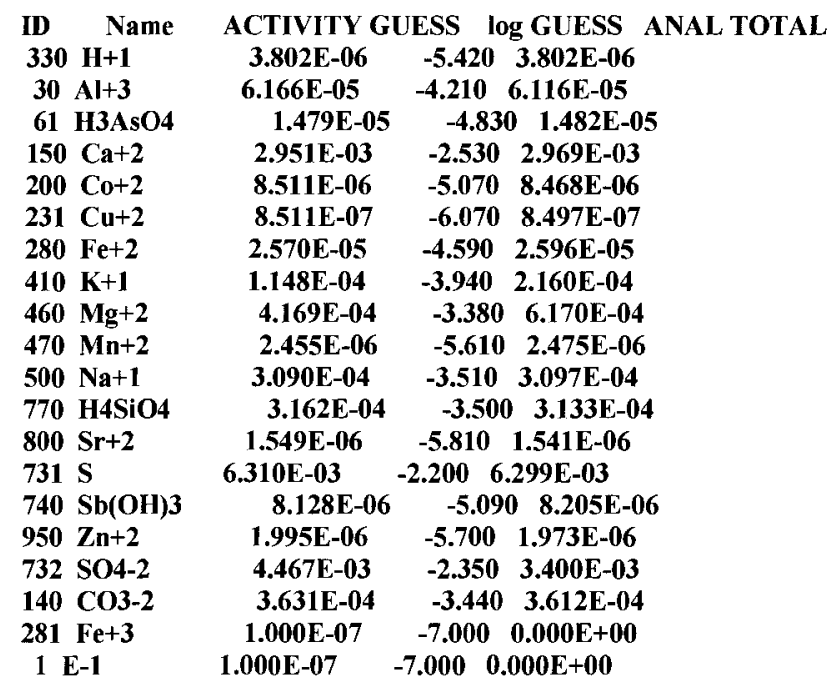




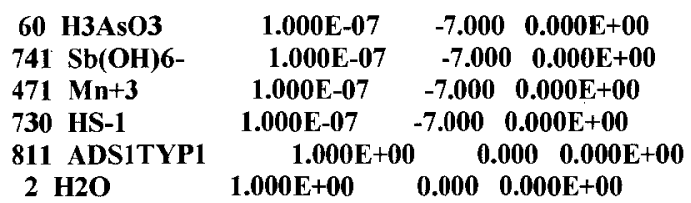

Charge Balance: UNSPECIATED

Sum of CATIONS= 7.968E-03 Sum of ANIONS $=7.522 \mathrm{E}-03$

PERCENT DIFFERENCE $=2.874 E+00$ (ANIONS - CATIONS)/(ANIONS + CATIONS)

IDX Name DISSOLVED SORBED PRECIPITATED $\mathrm{mol} / \mathrm{L}$ percent $\mathrm{mol} / \mathrm{L}$ percent $\mathrm{mol} / \mathrm{L}$ percent

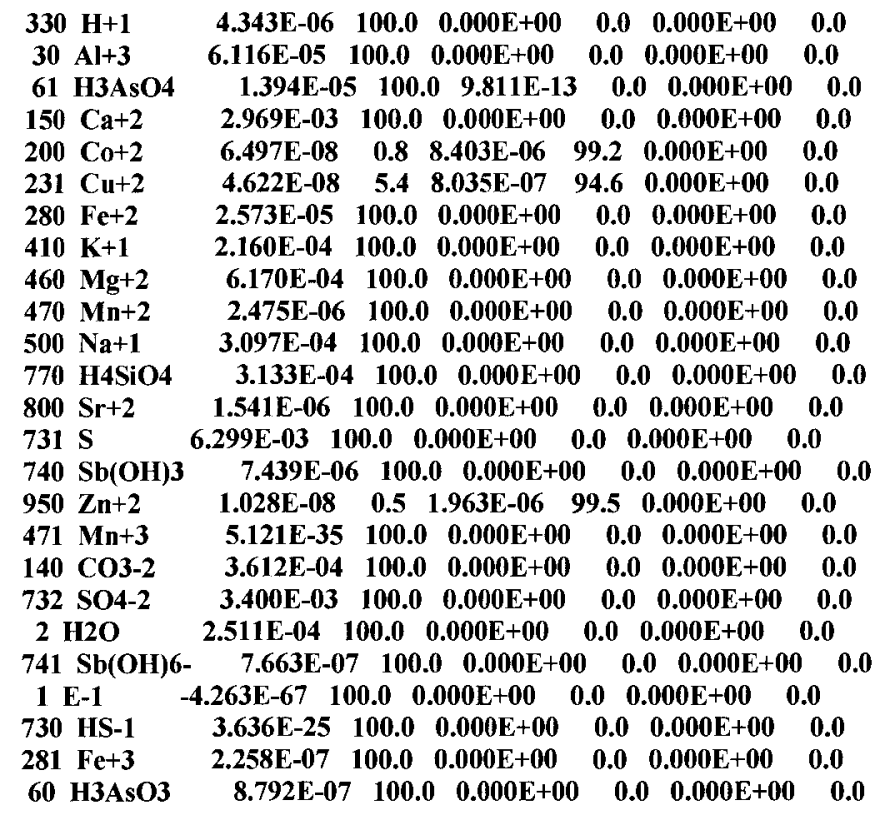

Charge Balance: SPECIATED

Sum of CATIONS $=6.323 \mathrm{E}-03$ Sum of ANIONS $5.900 \mathrm{E}-03$

PERCENT DIFFERENCE $=3.459 E+00$ (ANIONS - CATIONS)/(ANIONS + CATIONS)

EQUILIBRIUM IONIC STRENGTH $(\mathrm{m})=1.175 \mathrm{E}-02$

$\begin{array}{ll}\text { EQUILIBRIUM pH } & =8.993 \\ \text { EQUILIBRIUM pe } & =-3.170 \text { or } \mathrm{Eh}=-184.39 \mathrm{mv}\end{array}$

Saturation indices

\begin{tabular}{llc}
\multicolumn{1}{|c}{ ID No Name } & SI \\
& \multicolumn{2}{c}{3.913} \\
2074102 SbO2 & \multicolumn{2}{c}{1.776} \\
2074004 Sb(OH)3 & \multicolumn{1}{c}{1.610} \\
2074006 SENARMONTITE & \multicolumn{2}{c}{0.065} \\
2077000 CHALCEDONY & \multicolumn{2}{c}{0.523} \\
2077002 QUARTZ & 0.523
\end{tabular}




\begin{tabular}{|c|c|c|}
\hline 2003001 BOEHMITE & \multicolumn{2}{|c|}{1.021} \\
\hline 2003002 DIASPORE & \multicolumn{2}{|c|}{2.770} \\
\hline 2003003 GIBBSITE & \multicolumn{2}{|l|}{$\mathbf{1 . 3 7 5}$} \\
\hline 2023101 TENORITE & \multicolumn{2}{|c|}{0.599} \\
\hline 2028000 WUSTITE & \multicolumn{2}{|c|}{1.304} \\
\hline 2028100 FERRIHYDRITE & \multicolumn{2}{|c|}{2.293} \\
\hline $2028101 \mathrm{Fe} 3(\mathrm{OH}) 8$ & \multicolumn{2}{|l|}{4.226} \\
\hline 2028102 GOETHITE & \multicolumn{2}{|c|}{5.032} \\
\hline $3020002 \mathrm{CoFe} 2 \mathrm{O} 4$ & \multicolumn{2}{|c|}{24.865} \\
\hline 3028000 MAGNETITE & \multicolumn{2}{|c|}{20.422} \\
\hline 3028001 HERCYNITE & \multicolumn{2}{|c|}{9.111} \\
\hline 3028100 HEMATITE & \multicolumn{2}{|c|}{12.440} \\
\hline 3028101 MAGHEMITE & \\
\hline 3028102 LEPIDOCROCITE & \multicolumn{2}{|c|}{$\begin{array}{r}5.021 \\
4.333\end{array}$} \\
\hline 3046001 MAGNESIOFERRI & \multicolumn{2}{|r|}{8.218} \\
\hline 3023100 CUPRIC FERRITE & \multicolumn{2}{|r|}{13.228} \\
\hline 5028000 SIDERITE & \multicolumn{2}{|l|}{0.309} \\
\hline 5015000 ARAGONITE & \multicolumn{2}{|c|}{0.536} \\
\hline 5015001 CALCITE & \multicolumn{2}{|l|}{0.690} \\
\hline 5015002 DOLOMITE (ordere & red) & 0.796 \\
\hline 5015004 DOLOMITE (disord & \multirow{2}{*}{\multicolumn{2}{|c|}{$\begin{array}{c}\text { rdered) } 0.225 \\
2.696\end{array}$}} \\
\hline 8603000 HALLOYSITE & & \\
\hline 8603001 KAOLINITE & \multicolumn{2}{|c|}{4.936} \\
\hline 8628000 GREENALITE & \multicolumn{2}{|c|}{11.224} \\
\hline 8646000 CHRYSOTILE & \multicolumn{2}{|c|}{$\mathbf{3 . 6 3 7}$} \\
\hline 8646003 SEPIOLITE & \multicolumn{2}{|c|}{2.274} \\
\hline
\end{tabular}

Core $\mathbf{S 5}-\mathbf{7 5} \mathrm{cm}$ Depth - No Adsorption

\section{INPUT DATA BEFORE TYPE MODIFICATIONS}

\begin{tabular}{|c|c|c|}
\hline Name & \multicolumn{2}{|c|}{ ACTIVITY GUESS log GUESS ANAL TOTAL } \\
\hline $330 \mathrm{H}+1$ & $1.202 \mathrm{E}-06$ & $-5.9201 .202 \mathrm{E}-06$ \\
\hline $30 \mathbf{A l}+\mathbf{3}$ & $1.738 \mathrm{E}-04$ & $-3.760 \quad 1.723 E-04$ \\
\hline $61 \mathrm{H3AsO4}$ & 2.239E-05 & $-4.650 \quad 2.256 \mathrm{E}-05$ \\
\hline $150 \mathrm{Ca}+2$ & 8.318E-04 & $-3.080 \quad 8.358 E-04$ \\
\hline $200 \mathrm{Co}+2$ & $3.236 \mathrm{E}-06$ & $-5.490 \quad 3.258 E-06$ \\
\hline $231 \mathrm{Cu}+2$ & $1.698 \mathrm{E}-06$ & $-5.770 \quad 1.699 \mathrm{E}-06$ \\
\hline $280 \mathrm{Fe}+2$ & $1.047 \mathrm{E}-04$ & $-3.980 \quad 1.037 \mathrm{E}-04$ \\
\hline $410 \mathrm{~K}+1$ & 1.549E-04 & $-3.810 \quad 1.540 E-04$ \\
\hline $460 \mathrm{Mg}+2$ & 3.388E-04 & $-3.470 \quad 3.387 \mathrm{E}-04$ \\
\hline $470 \mathrm{Mn}+2$ & $2.884 \mathrm{E}-06$ & $-5.540 \quad 2.876 \mathrm{E}-06$ \\
\hline $500 \mathrm{Na}+1$ & $3.388 \mathrm{E}-04$ & $-3.470 \quad 3.354 E-04$ \\
\hline 770 H4SiO4 & $4.074 \mathrm{E}-04$ & $-3.390 \quad 4.094 \mathrm{E}-04$ \\
\hline $800 \mathrm{Sr}+2$ & 5.012E-07 & $-6.300 \quad 5.022 E-07$ \\
\hline $731 \mathrm{~S}$ & 2.089E-03 & $-2.680 \quad 2.074 \mathrm{E}-03$ \\
\hline $740 \mathrm{Sb}(\mathrm{OH}) 3$ & $1.622 \mathrm{E}-05$ & $-4.790 \quad 1.610 \mathrm{E}-05$ \\
\hline $871 \mathrm{TI}(\mathrm{OH}) 3$ & $1.950 \mathrm{E}-06$ & $-5.710 \quad 1.942 \mathrm{E}-06$ \\
\hline $950 \mathrm{Zn}+2$ & 2.089E-06 & $-5.680 \quad 2.095 \mathrm{E}-06$ \\
\hline 730 HS-1 & $1.514 E-05$ & $-4.820 \quad 1.511 \mathrm{E}-05$ \\
\hline $732 \mathrm{SO4-2}$ & $1.738 \mathrm{E}-03$ & $-2.760 \quad 1.727 \mathrm{E}-03$ \\
\hline $140 \mathrm{CO3}-2$ & 1.349E-04 & $-3.870 \quad 1.336 \mathrm{E}-04$ \\
\hline $281 \mathrm{Fe}+3$ & $1.000 \mathrm{E}-07$ & $-7.000 \quad 0.000 E+00$ \\
\hline $1 \mathrm{E}-1$ & 1.000E-07 & $-7.000 \quad 0.000 \mathrm{E}+00$ \\
\hline $60 \mathrm{H3AsO3}$ & $1.000 \mathrm{E}-07$ & $-7.000 \quad 0.000 \mathrm{E}+00$ \\
\hline $741 \mathrm{Sb}(\mathrm{OH}) 6-$ & $1.000 \mathrm{E}-07$ & $-7.000 \quad 0.000 \mathrm{E}+00$ \\
\hline $471 \mathrm{Mn}+3$ & $1.000 \mathrm{E}-07$ & $-7.000 \quad 0.000 \mathrm{E}+00$ \\
\hline $2 \mathrm{H} 2 \mathrm{O}$ & $1.000 \mathrm{E}+00$ & $0.000 \quad 0.000 \mathrm{E}+00$ \\
\hline
\end{tabular}

Sum of CATIONS $=3.585 \mathrm{E}-03 \mathrm{Sum}$ of $\mathrm{ANIONS}=3.736 \mathrm{E}-03$

PERCENT DIFFERENCE $=2.070 \mathrm{E}+00$ (ANIONS - CATIONS) $/($ ANIONS + CATIONS) 


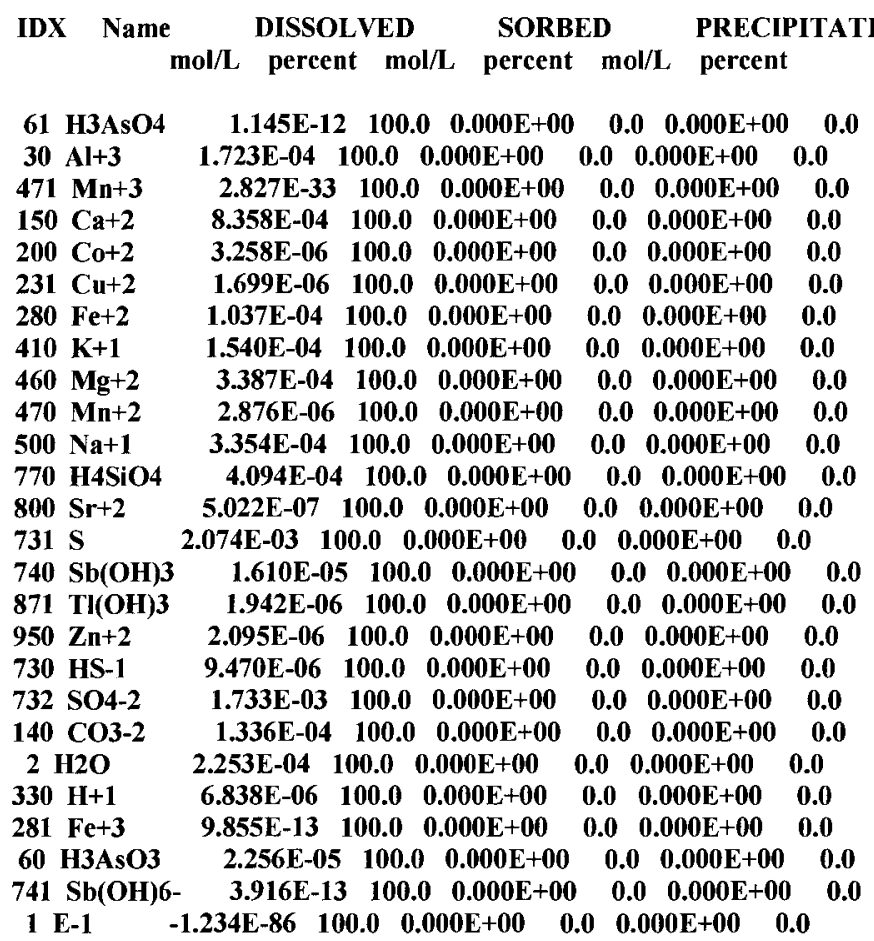

Charge Balance: SPECIATED

Sum of CATIONS $=2.902 \mathrm{E}-03$ Sum of ANIONS $3.053 \mathrm{E}-03$

PERCENT DIFFERENCE $=2.545 E+00$ (ANIONS - CATIONS)/(ANIONS + CATIONS)

EQUILIBRIUM IONIC STRENGTH $(\mathrm{m})=5.645 \mathrm{E}-03$

$\begin{array}{ll}\text { EQUILIBRIUM pH } & =5.681 \\ \text { EQUILIBRIUM pe } & =-1.454 \text { or Eh }=-84.54 \mathrm{mv}\end{array}$

Saturation indices

\begin{tabular}{|c|c|c|}
\hline ID No & Name & I \\
\hline 1095000 & $\mathrm{ZnS}$ (am) & 0.275 \\
\hline 1095001 & SPHALERITE & 2.716 \\
\hline 1095002 & WURTZITE & 0.190 \\
\hline 1023101 & COVELLITE & 13.431 \\
\hline 1023102 & CHALCOPYRITE & 19.421 \\
\hline 1020002 & CoS (beta) & 2.446 \\
\hline 1028003 & PYRITE & 5.680 \\
\hline 2074102 & Sb02 & .542 \\
\hline 2074004 & $\mathrm{Sb}(\mathrm{OH}) 3$ & 2.001 \\
\hline 2074006 & SENARMONTITE & 2.059 \\
\hline 2077000 & CHALCEDONY & 0.222 \\
\hline 2077001 & CRISTOBALITE & 0.023 \\
\hline 2077002 & QUARTZ & 0.680 \\
\hline 2003000 & $\mathrm{~A} \mathbf{l}(\mathrm{OH}) 3(\mathrm{am})$ & 0.582 \\
\hline 2003001 & BOEHMITE & 2.784 \\
\hline 2003002 & DIASPORE & 4.533 \\
\hline 2003003 & GIBBSITE & 3.137 \\
\hline 2087100 & AVICENNITE & 1.578 \\
\hline 3003000 & $\mathrm{~A} 1203$ & 3.002 \\
\hline 3020002 & $\mathrm{CoFe} 2 \mathrm{O} 4$ & 5.193 \\
\hline
\end{tabular}




\begin{tabular}{|lc} 
3028001 HERCYNITE & 6.761 \\
6003000 AIOHSO4 & 0.623 \\
6003001 Al4(OH)10SO4 & 9.833 \\
8603000 HALLOYSITE & 6.536 \\
8603001 KAOLINITE & $\mathbf{8 . 7 7 5}$
\end{tabular}

Core S5 - 75cm Depth - Adsorption

\section{INPUT DATA BEFORE TYPE MODIFICATIONS}

\begin{tabular}{|c|c|c|c|}
\hline ID & Name & \multicolumn{2}{|c|}{ ACTIVITY GUESS $\log$ GUESS ANAL TOTAL } \\
\hline 330 & $\mathbf{H}+\mathbf{1}$ & $1.202 E-06$ & $-5.920 \quad 1.202 E-06$ \\
\hline 30 & $\mathbf{A l}+\mathbf{3}$ & 1.738E-04 & $-3.760 \quad 1.723 E-04$ \\
\hline 61 & H3AsO4 & $2.239 \mathrm{E}-05$ & $-4.650 \quad 2.256 \mathrm{E}-05$ \\
\hline 150 & $\mathrm{Ca}+2$ & 8.318E-04 & $-3.080 \quad 8.358 E-04$ \\
\hline 200 & $\mathrm{Co}+2$ & $3.236 \mathrm{E}-06$ & $-5.490 \quad 3.258 E-06$ \\
\hline 231 & $\mathrm{Cu}+2$ & 1.698E-06 & $-5.770 \quad 1.699 E-06$ \\
\hline 280 & $\mathrm{Fe}+2$ & $1.047 \mathrm{E}-04$ & $-3.980 \quad 1.037 \mathrm{E}-04$ \\
\hline 410 & $\mathbf{K}+\mathbf{1}$ & 1.549E-04 & $-3.810 \quad 1.540 \mathrm{E}-04$ \\
\hline 460 & $\mathbf{M g}+2$ & $3.388 \mathrm{E}-04$ & $-3.470 \quad 3.387 \mathrm{E}-04$ \\
\hline 470 & $\mathrm{Mn}+2$ & 2.884E-06 & $-5.540 \quad 2.876 \mathrm{E}-06$ \\
\hline 500 & $\mathbf{N a}+\mathbf{1}$ & 3.388E-04 & $-3.470 \quad 3.354 E-04$ \\
\hline 770 & H4SiO4 & 4.074E-04 & $-3.390 \quad 4.094 \mathrm{E}-04$ \\
\hline 800 & $\mathrm{Sr}+2$ & 5.012E-07 & $-6.300 \quad 5.022 E-07$ \\
\hline 731 & $\mathbf{S}$ & $2.089 E-03$ & $-2.680 \quad 2.074 E-03$ \\
\hline 740 & $\mathrm{Sb}(\mathrm{OH}) 3$ & $1.622 \mathrm{E}-05$ & $-4.790 \quad 1.610 \mathrm{E}-05$ \\
\hline 950 & $\mathrm{Zn}+2$ & $2.089 \mathrm{E}-06$ & $-5.680 \quad 2.095 E-06$ \\
\hline 730 & HS-1 & 1.514E-05 & $-4.820 \quad 1.511 \mathrm{E}-05$ \\
\hline 732 & SO4-2 & $1.738 E-03$ & $-2.760 \quad 1.727 E-03$ \\
\hline 140 & $\mathrm{CO}-2$ & 1.349E-04 & $-3.870 \quad 1.336 \mathrm{E}-04$ \\
\hline 281 & $\mathrm{Fe}+3$ & $1.000 \mathrm{E}-07$ & $-7.000 \quad 0.000 E+00$ \\
\hline $1 \mathrm{I}$ & $\mathrm{E}-1$ & $1.000 \mathrm{E}-07$ & $7.000 \quad 0.000 \mathrm{E}+00$ \\
\hline 60 & H3AsO3 & $1.000 \mathrm{E}-07$ & $-7.000 \quad 0.000 \mathrm{E}+00$ \\
\hline & $\mathrm{Sb}(\mathrm{OH}) 6-$ & 1.000E-07 & $-7.000 \quad 0.000 \mathrm{E}+00$ \\
\hline 471 & $\mathbf{M n}+3$ & 1.000E-07 & $-7.000 \quad 0.000 \mathrm{E}+00$ \\
\hline 811 & ADS1TYP1 & $1.000 \mathrm{E}+0$ & $0.000 \quad 0.000 \mathrm{E}+00$ \\
\hline 21 & $\mathrm{H} 2 \mathrm{O}$ & $1.000 \mathrm{E}+00$ & $0.000 \quad 0.000 \mathrm{E}+00$ \\
\hline
\end{tabular}

Charge Balance: UNSPECIATED

Sum of CATIONS $=3.585 \mathrm{E}-03 \mathrm{Sum}$ of $\mathrm{ANIONS}=3.736 \mathrm{E}-03$

PERCENT DIFFERENCE $=2.070 E+00$ (ANIONS - CATIONS) $/($ ANIONS + CATIONS)

EQUILIBRATED MASS DISTRIBUTION

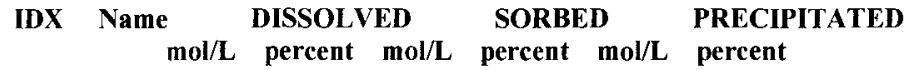

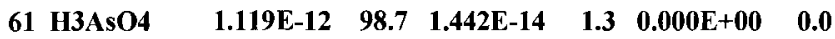

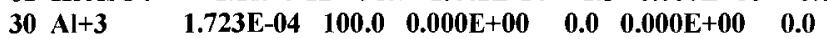

$\begin{array}{llllllll}471 & \mathrm{Mn}+3 & 2.766 \mathrm{E}-33 & 100.0 & 0.000 \mathrm{E}+00 & 0.0 & 0.000 \mathrm{E}+00 & 0.0\end{array}$

$\begin{array}{lllllll}150 \mathrm{Ca}+2 & 8.358 \mathrm{E}-04 & 100.0 & 0.000 \mathrm{E}+00 & 0.0 & 0.000 \mathrm{E}+00 & 0.0\end{array}$

$\begin{array}{llllllll}200 & \mathrm{C} 0+2 & 6.659 \mathrm{E}-09 & 0.2 & 3.251 \mathrm{E}-06 & 99.8 & 0.000 \mathrm{E}+00 & 0.0\end{array}$

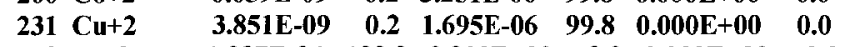

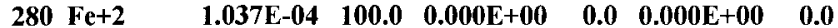

$\begin{array}{llllllll}410 & \mathrm{~K}+1 & 1.540 \mathrm{E}-04 & 100.0 & 0.000 \mathrm{E}+00 & 0.0 & 0.000 \mathrm{E}+00 & 0.0\end{array}$

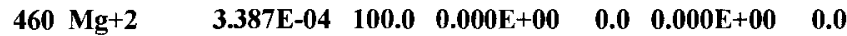

$\begin{array}{lllllll}470 \mathrm{Mn}+2 & 2.876 \mathrm{E}-06 & 100.0 & 0.000 \mathrm{E}+00 & 0.0 & 0.000 \mathrm{E}+00 & 0.0\end{array}$

$\begin{array}{lllllll}500 \mathrm{Na}+1 & 3.354 \mathrm{E}-04 & 100.0 & 0.000 \mathrm{E}+00 & 0.0 & 0.000 \mathrm{E}+00 & 0.0\end{array}$

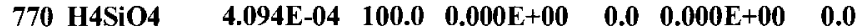

$\begin{array}{llllllll}800 \mathrm{Sr}+2 & 5.022 \mathrm{E}-07 & 100.0 & 0.000 \mathrm{E}+00 & 0.0 & 0.000 \mathrm{E}+00 & 0.0\end{array}$

$\begin{array}{lllllll}731 \mathrm{~S} & 2.074 \mathrm{E}-03 & 100.0 & 0.000 \mathrm{E}+00 & 0.0 & 0.000 \mathrm{E}+00 & 0.0\end{array}$

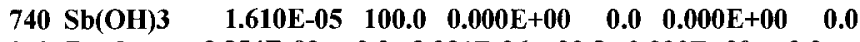

$\begin{array}{llllllll}950 \mathrm{Zn}+2 & 3.854 \mathrm{E}-09 & 0.2 & 2.091 \mathrm{E}-06 & 99.8 & 0.000 \mathrm{E}+00 & 0.0\end{array}$

$\begin{array}{llllllll}730 & \text { HS-1 } & 9.470 \mathrm{E}-06 & 100.0 & 0.000 \mathrm{E}+00 & 0.0 & 0.000 \mathrm{E}+00 & 0.0\end{array}$

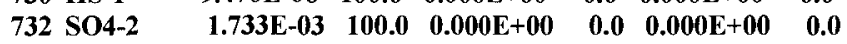




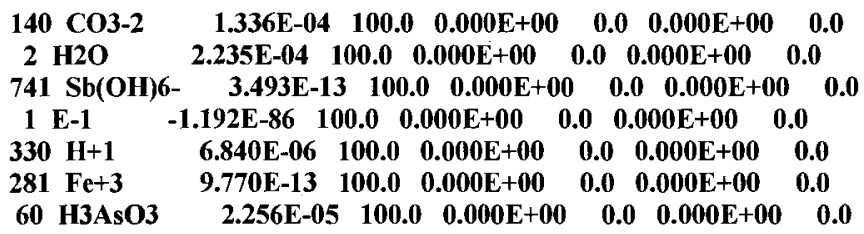

Charge Balance: SPECIATED

Sum of CATIONS $=2.890 \mathrm{E}-03$ Sum of ANIONS $3.056 \mathrm{E}-03$

PERCENT DIFFERENCE $=2.785 E+00$ (ANIONS - CATIONS) $/($ ANIONS + CATIONS)

EQUILIBRIUM IONIC STRENGTH $(\mathrm{m})=\mathbf{5 . 6 3 6 E - 0 3}$

EQUILIBRIUM pH $\quad=5.683$

EQUILIBRIUM pe $\quad=-1.463$ or $\mathrm{Eh}=-85.08 \mathrm{mv}$

Saturation indices

\begin{tabular}{lc} 
ID No Name & SI \\
& \\
1006000 ORPIMENT & 10.067 \\
1095001 SPHALERITE & 0.033 \\
1023101 COVELLITE & 10.769 \\
1023102 CHALCOPYRITE & 16.812 \\
1028003 PYRITE & 5.766 \\
2074102 SbO2 & 2.496 \\
2074004 Sb(OH)3 & 1.961 \\
2074006 SENARMONTITE & 1.980 \\
2077000 CHALCEDONY & 0.222 \\
2077001 CRISTOBALITE & 0.023 \\
2077002 QUARTZ & 0.680 \\
2003000 AI(OH)3 (am) & 0.586 \\
2003001 BOEHMITE & 2.788 \\
2003002 DIASPORE & 4.537 \\
2003003 GIBBSITE & 3.142 \\
3003000 Al2O3 & 3.011 \\
3020002 CoFe2O4 & 2.507 \\
3028001 HERCYNITE & 6.775 \\
6003000 AIOHSO4 & 0.622 \\
6003001 AI4(OH)10SO4 & 9.846 \\
8603000 HALLOYSITE & 6.544 \\
8603001 KAOLINITE & 8.784 \\
\hline
\end{tabular}

